\title{
DIREITOS DE PROPRIEDADE INTELECTUAL E O CONTROLE DAS PRÁTICAS RESTRITIVAS DA CONCORRÊNCIA À LUZ DO ACORDO TRIPS/OMC
}

\author{
Tese de Doutorado
}

Orientadora: Professora Associada Doutora Maristela Basso

FACULDADE DE DIREITO DA UNIVERSIDADE DE SÃO PAULO

São Paulo

Janeiro de 2013 


\section{DIREITOS DE PROPRIEDADE INTELECTUAL E O CONTROLE DAS PRÁTICAS RESTRITIVAS DA CONCORRÊNCIA À LUZ DO ACORDO TRIPS/OMC}

Tese apresentada na Faculdade de Direito da Universidade de São Paulo, como requisito parcial à obtenção do título de Doutor em Direito.

Área de Concentração: Direito Internacional e Comparado

Orientadora: Professora Associada Doutora Maristela Basso

São Paulo

Janeiro de 2013 
Banca Examinadora:

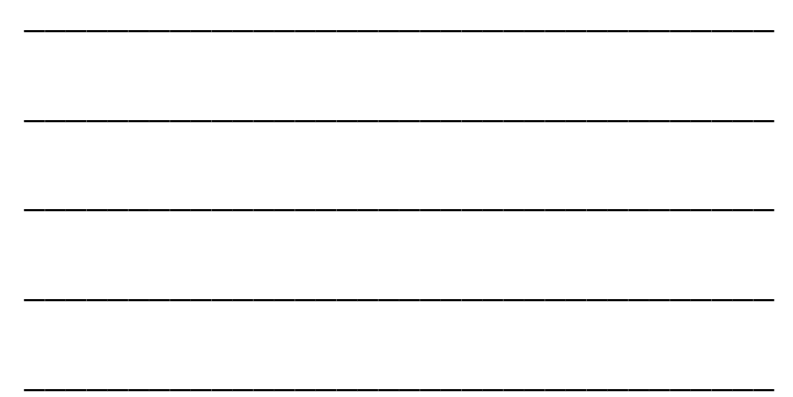


Dedico esta tese de doutorado ao meu pai, Fábio Lilla, por todo apoio durante o desenvolvimento deste trabalho e inestimável orientação ao longo da minha formação acadêmica e profissional. 


\section{AGRADECIMENTOS}

Agradeço a Deus, por ser a razão de tudo para mim.

À Professora Dra. Maristela Basso, agradeço imensamente pela valorosa orientação, sobretudo pelos excelentes comentários e contribuições ao longo do desenvolvimento deste trabalho, bem como por sua atenção e disponibilidade.

Agradeço também aos Professores Dr. José Marcelo Martins Proença e Dr. Newton Silveira, membros da banca de qualificação, pelas valiosas contribuições e recomendações que foram indispensáveis para a pesquisa e delimitação do tema. Ao Professor Dr. Calixto Salomão Filho, agradeço pelas sugestões e críticas que também foram de extrema relevância para a realização deste trabalho. Agradeço também ao Professor José Carlos de Magalhões, que foi meu orientador no Mestrado, pelos inestimáveis conselhos, ensinamentos e incentivo.

Ao Professor Mark Lemley, agradeço imensamente por ter me aceitado como Visiting Scholar na Stanford Law School, como também pelas valiosas contribuições e recomendações. Agradeço também ao Professor Mitchell Polinsky pelo apoio do Stanford Program in the Law and Economics of Intellectual Property and Antitrust e também ao Professor Charles Koob pelo valioso material que disponibilizou para a minha pesquisa.

Por fim, agradeço aos meus familiares pelo incentivo, paciência e compreensão durante a pesquisa e elaboração da tese, em especial ao meu pai, Fábio Lilla, a quem dedico este trabalho, minha mãe Esther, minha avó Glorinha, e a minha querida Angela. 


\section{RESUMO}

A presente tese de doutorado tem como objetivo a análise da interface entre propriedade intelectual e direito da concorrência no contexto do enquadramento jurídico oferecido pelo Acordo sobre Aspectos de Direitos de Propriedade Intelectual Relacionados ao Comércio Acordo TRIPS - da Organização Mundial do Comércio - OMC. As disposições relevantes sobre concorrência foram incluídas no Artigo 8.2, que autoriza os Membros a adotarem medidas apropriadas para evitar abusos dos direitos de propriedade intelectual e práticas que restrinjam o comércio e a transferência internacional de tecnologia; no Artigo 40, que dispõe sobre o controle das práticas restritivas em acordos de licenciamento; e no Artigo 31(k), que trata do licenciamento compulsório de patentes para remediar práticas anticoncorrenciais. Essas disposições acabaram sendo incluídas no Acordo TRIPS como resultado de concessões feitas pelos países desenvolvidos aos países em desenvolvimento, em troca do fortalecimento dos padrões mínimos de proteção dos direitos de propriedade intelectual, podendo, portanto, ser consideradas no contexto das "flexibilidades" constantes no Acordo. No entanto, ainda que essas disposições representem um elemento essencial de equilíbrio, também deixaram importantes questões sem resposta. Além de serem vagas, não fornecem diretrizes adequadas para os países em desenvolvimento implementarem políticas públicas nacionais para coibir práticas restritivas da concorrência relacionadas à exploração de direitos de propriedade intelectual. Assim, enquanto os países mais industrializados possuem autoridades antitruste e tribunais com sólida experiência e recursos necessários para lidar com questões envolvendo a interface entre propriedade intelectual e direito da concorrência, os países em desenvolvimento, em sua maioria, mesmo possuindo leis antitruste nacionais, ainda não adquiriram a experiência e capacitação para tratar de tema tão complexo. Desse modo, a tese deverá abordar as circunstâncias nas quais eventuais abusos de direitos de propriedade intelectual podem restringir a livre concorrência nos mercados, com ênfase nas práticas restritivas em acordos de licenciamento, pools de patentes e licenças cruzadas, bem como nas condutas unilaterais de exclusão relacionadas à exploração desses direitos. Para tanto, propõe-se a interpretação dos dispositivos do TRIPS sobre concorrência a partir da experiência prática das autoridades antitruste e tribunais dos Estados Unidos e da União Europeia. Será também abordada a relação entre propriedade intelectual e direito da concorrência no contexto do ordenamento jurídico-constitucional brasileiro, especialmente a partir da Lei n. ${ }^{\text {o }}$ 12.529/2011, nova lei antitruste que altera e define o Sistema Brasileiro de Defesa da 
Concorrência (SBDC), e de casos recentes julgados pelo Conselho Administrativo de Defesa Econômica (CADE). Ao final, serão analisadas as possíveis abordagens que poderiam ser adotadas pelos países em desenvolvimento na implementação de políticas de concorrência nacionais, que sejam eficazes e compatíveis com o Acordo TRIPS, de modo a contribuir com eventuais discussões futuras sobre o tema em foros internacionais.

Palavras-chave: Direitos de propriedade intelectual; direito da concorrência; antitruste; Acordo TRIPS/OMC. 


\section{SUMMARY}

The purpose of this thesis is to assess the interface between intellectual property and competition law in light of the Agreement on Trade-Related Aspects of Intellectual Property Rights - TRIPS Agreement - of the World Trade Organization - WTO. The provisions regarding competition were included in Article 8.2, which authorizes the Members to adopt appropriated measures to prevent abuses of intellectual property rights by right holders or practices which restrain trade and international transfer of technology; in the Article 40, which deals with the control of anti-competitive practices in contractual licenses; and Article 31(k), which deals with the compulsory licensing of patents to remedy a practice considered to be anti-competitive. These provisions were included in the TRIPS Agreement as a result of concessions made by the developed countries to the developed countries, in exchange for the strengthening of the minimal standards for the protection of intellectual property rights. Therefore, these provisions can be considered within the context of the "flexibilities" set forth in the Agreement. However, even if such provisions represent an essential element of balance, they also left important issues unanswered. Besides being vague, they do not provide adequate guidance for emerging countries to implement national public policies to prevent restrictive practices related with the exploitation of intellectual property rights. As a consequence, whereas the most industrialized countries already have antitrust authorities and courts with strong experience and the necessary resources to deal with issues related with the interface between intellectual property and competition law, most of the emerging countries, even those which have national antitrust laws, have not yet acquired experience and technical capacity to deal with such a complex matter. Thus, the thesis should tackle the circumstances in which possible abuses of intellectual property rights might restrain competition, especially with regard to restrictive practices in licensing agreements, cross-licenses and patent pools, and unilateral exclusionary abuses related with the exploitation of such rights. In this sense, it is proposed to interpret the provisions of TRIPS on competition from the practical experience of the antitrust authorities and courts of the United States and the European Union. We should also tackle the relationship between intellectual property and competition laws in the ambit of the Brazilian legal and constitutional system, especially with regard to Law No. 12.529/2011, the new Brazilian antitrust law, which alters and defines the Brazilian Defense of Competition System - SBDC (Sistema Brasileiro de Defesa da Concorrência - SBCD), as well as with regard to recent cases judged by the 
Administrative Counsel of Economic Defense - CADE (Conselho Administrativo de Defesa Econômica - CADE). Finally, it will be examined possible approaches that could be adopted by developing countries in implementing national competition policies, effective and compatible with the TRIPS Agreement, so as to contribute to future discussions on the issue in international fora.

Keywords: Intellectual property rights, competition law, antitrust, WTO TRIPS Agreement. 


\section{RIASSUNTO}

Lo scopo della presente tesi di dottorato è l'analisi dell'interface tra proprietà intellettuale e diritto della concorrenza nell'ambito dell'inquadramento giuridico offerto dall'Accordo sugli Aspetti di Diritti di Proprietà Intellettuale Riferenti al Commercio - Accordo TRIPS - dell'Organizzazione Mondiale del Commercio - OMC. Le disposizioni attinenti alla concorrenza vi sono state incluse nell'Articolo 8.2 che autorizza i Membri ad adottare dei provvedimenti adatti affinché si evitino gli abusi dei diritti di proprietà intellettuale e delle eventuali pratiche che restringano il commercio ed il trasferimento internazionale di tecnologia; nell' Articolo 40, il cui oggetto è il controllo delle pratiche restrittive in accordi di concessione di licenza; e nell'Articolo $31(\mathrm{~K})$ che tratta della concessione di licenza coercitiva di marchio o brevetti per rimediare le pratiche anticoncorrenziali. Alla fine, tali disposizioni sono state richiamate a far parte dell'accordo TRIPS come risultato delle concessioni elargite dai paesi sviluppati ai paesi in via di sviluppo, essendo che, in cambio, i primi pretendevano il rinforzamento dei livelli minimi di salvaguardia dei diritti di proprietà intellettuale; cosicché tali disposizioni possono essere valutate nel contesto delle "flessibilità" presenti all'interno dell'Accordo. Tuttavia, benché tali disposizioni siano un elemento nodale di equilibrio, non sono state in grado di rispondere a delle importanti questioni. Oltre al fatto che la loro natura è di carattere piuttosto generico, non forniscono le direttrici adatte affinché i paesi in via di sviluppo possano implementare delle politiche pubbliche nazionali il cui scopo sia limitare le pratiche restrittive della concorrenza per quanto riguarda lo sfruttamento di diritti di proprietà intellettuale. Così, mentre i paesi più sviluppati possono contare sulle autorità antitrust e sui tribunali dalla vasta esperienza e risorse necessarie di fronte alle questioni attinenti all'interface fra proprietà intellettuale e diritto concorrenza, i paesi in via di sviluppo, nella loro maggioranza, anche nei casi in cui hanno delle leggi antitrust nazionali, non hanno ancora acquisito dell'esperienza e dell'abilità necessarie perché tale tema, così complesso, venga trattato in modo ottimale. Cosicché, la tesi dovrà occuparsi delle circostanze nelle quali eventuali abusi di diritti di proprietà intellettuale possono restringere la libera concorrenza nei mercati, speciale enfasi sarà rivolta alle pratiche restrittive tanto in accordi di concessione di licenza, pools di brevetti e licenze incrociate quanto nelle condotte unilaterali di esclusione attinenti allo sfruttamento di tali diritti. Si propone, dunque, l'interpretazione dei dispositivi del TRIPS sulla concorrenza, partendo dall'esperienza pratica delle autorità antitrust e tribunali tanto degli Stati Uniti quanto dell'Unione Europea. Sarà pure oggetto di studio il rapporto 
esistente fra proprietà intellettuale e diritto della concorrenza nell'ambito dell'ordinamento giuridico costituzionale brasiliano, soprattutto a partire dalla Legge n. ${ }^{\circ}$ 12.529/2011, la nuova legge antitrust che altera e definisce il Sistema Brasiliano di Difesa della Concorrenza (SBDC), e di casi recenti giudicati dal Consiglio Amministrativo di Difesa Economica (CADE). Alla fine, si analizzeranno ancora i possibili modi di abbordaggio della questione e che potrebbero essere adottati dai paesi in via di sviluppo nell'impianto di politiche di concorrenze nazionali; una volta collaudata la loro efficacia e compatibilità con l'Accordo TRIPS potrebbero certamente contribuire alle eventuali discussioni future sul tema in sedi internazionali.

Parole chiavi: Diritto di proprietà intellettuale; diritto della concorrenza; antitrust; Accordo TRIPS/OMC. 


\section{SUMÁRIO}

Introdução 16

1. Propriedade intelectual e direito da concorrência: uma relação de conflito ou complementaridade? .23

1.1. Fundamentos jurídicos e econômicos da propriedade intelectual ..........................23

1.1.1. Propriedade física e propriedade intelectual: pressupostos econômicos distintos.. 30

1.1.2. Os custos sociais resultantes da proteção da propriedade intelectual ...........34

1.1.3. Equilíbrio entre interesses públicos e privados: as limitações e exceções à

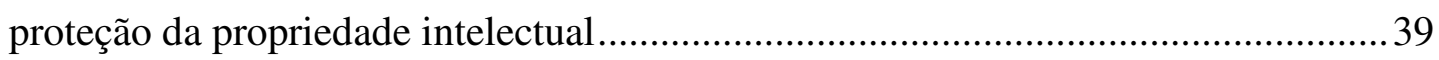

1.2. A interface entre propriedade intelectual e direito de concorrência .....................49

1.2.1. Propriedade intelectual e poder de mercado .............................................58

1.2.2. Barreiras à entrada em mercados dinâmicos: o problema das externalidades positivas de redes. 65

1.3. Intervenção antitruste na exploração de direitos de propriedade intelectual e a proteção aos incentivos à inovação. 70

2. Interface entre propriedade intelectual e direito da concorrência no acordo TRIPS/OMC 80

2.1. Origens da inclusão do tema da interface entre propriedade intelectual e direito da concorrência na agenda internacional. 81

2.2. As disposições do Acordo TRIPS sobre concorrência.......................................... 86

2.2.1. Interpretação do Artigo 8.2 ................................................................ 87

2.2.1.1. Abuso de direitos de propriedade intelectual.............................89

2.2.1.2. Práticas que limitam de maneira injustificável o comércio .........91

2.2.1.3. Práticas que afetam adversamente a transferência internacional de

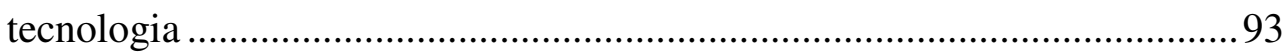

2.2.1.4. Limites a serem observados pelos Membros da OMC: as exigências de proporcionalidade e consistência...........................................94

2.2.2. Interpretação do Artigo 40 do TRIPS ....................................................... 97

2.2.2.1. Regras substantivas contidas nos Artigos 40.1 e 40.2: práticas restritivas da concorrência em acordos de licenciamento 
2.2.2.2. Regras procedimentais contidas nos Artigos 40.3 e 40.4: obrigações de consultas e cooperação antitruste. 106

2.2.3. Artigo 31(k): licenças compulsórias para remediar práticas anticoncorrenciais.

2.3. Ausência de diretrizes suficientes aos países em desenvolvimento para a implementação das normas do TRIPS sobre concorrência.....

3. Formas de abuso de direitos de propriedade intelectual capazes de restringir a concorrência: experiência dos Estados Unidos e da União Europeia 119

3.1. Breves considerações sobre a interface entre propriedade intelectual e direito da concorrência nos Estados Unidos

3.2. Breves considerações sobre a interface entre propriedade intelectual e direito da concorrência na União Europeia

3.3. Práticas restritivas em acordos de licenciamento e transferência de tecnologia.133 3.3.1. Elementos para a análise antitruste de acordos de licenciamento e transferência de tecnologia 136

3.3.1.1. Identificação da natureza da relação entre as partes do acordo de licenciamento e definição dos mercados relevantes.................................. 138

3.3.1.2. As zonas de segurança ......................................................... 142

3.3.1.3. Ilícitos per se ou restrições hard-core ....................................... 144

3.3.1.4. Análise antitruste das práticas restritivas sob a regra da razão.. 147

3.3.2. Tratamento de práticas restritivas específicas em acordos de licenciamento .......151

3.3.2.1. Restrições de preço ................................................................. 152

3.3.2.2. Licenças exclusivas e restrições territoriais............................... 155

3.3.2.3. Exclusividade e não concorrência ............................................. 161

3.3.2.4. Licenças casadas e pacotes de licenças .................................... 164

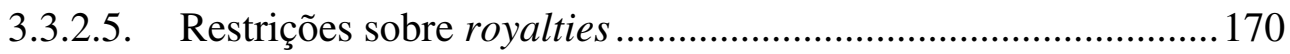

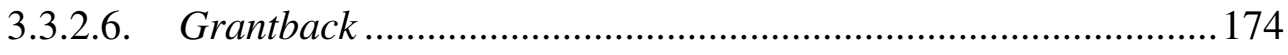

3.3.2.7. Cláusulas de não impugnação (“non-challenge clauses")......... 177

3.4. Licenças cruzadas e pools de patentes ............................................................. 180

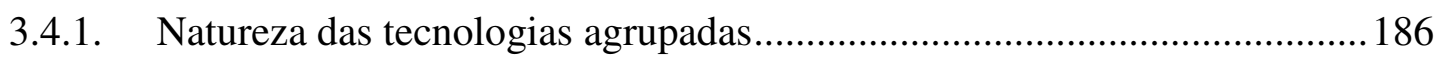

3.4.2. Existência de restrições individuais impostas a terceiros ........................... 190

3.4.3. Enquadramento institucional que rege o pool de patentes ......................... 192 
3.5. Condutas unilaterais de exclusão a partir da exploração de direitos de propriedade intelectual

3.5.1. Recusa de licenciar direitos de propriedade intelectual ...........................202

3.5.1.1. Estados Unidos ..................................................................... 203

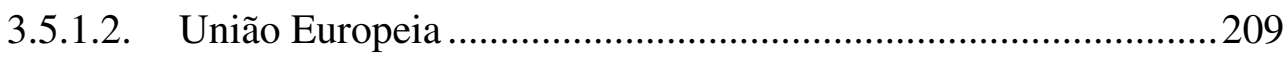

3.5.2. Abusos na imposição de direitos de propriedade intelectual ......................221

3.5.3. Abusos em processos de padronização tecnológica: "patent ambush" e o

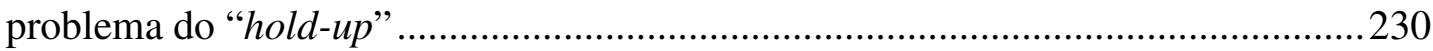

3.5.4. Aquisição e acumulação de patentes: a supressão unilateral de tecnologias .......2238

4. A experiência brasileira na repressão ao abuso do poder econômico a partir da exploração de direitos de propriedade intelectual ...............................................248

4.1. Interface entre propriedade intelectual e concorrência no ordenamento jurídico brasileiro

4.1.1. Enquadramento jurídico das práticas restritivas da concorrência na Lei $\mathrm{n}^{\circ}{ }^{\circ}$ 12.529/2011: especial referência aos direitos de propriedade intelectual 253

4.1.2. O licenciamento compulsório de direitos de propriedade intelectual para remediar práticas restritivas da concorrência .........................................................260

4.2. Análise de casos selecionados julgados pelo CADE .........................................265

4.2.1. Licenciamento de direitos de propriedade intelectual..............................266

4.2.2. Condutas unilaterais de exclusão na exploração de direitos de propriedade intelectual 274

4.2.1.1. O caso Philips - DVD ….....................................................2 275

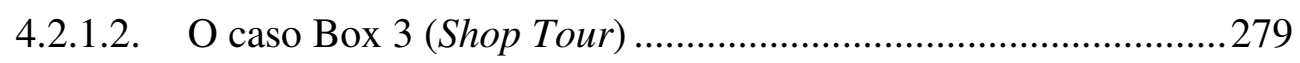

4.2.1.3. O caso Alcoa - perfis de alumínio...........................................285

5. As diretrizes do TRIPS sobre concorrência no contexto global e suas implicações para os países em desenvolvimento .......................................................290

5.1. Possíveis abordagens para a implementação de normas de concorrência compatíveis com as disposições do Acordo TRIPS

5.1.1. Abordagem orientada pela disseminação e transferência de tecnologia ....295

5.1.2. Abordagem orientada pela inovação ..................................................... 302

5.2. Limites da intervenção antitruste e a importância dos princípios concorrenciais na formulação das leis de propriedade intelectual 
Conclusões

316

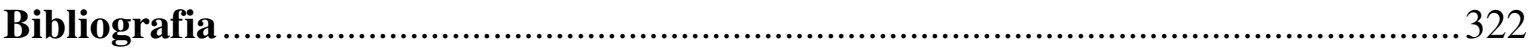




\section{INTRODUÇÃO}

A relação entre a propriedade intelectual e o direito da concorrência (ou direito antitruste) tem estado no centro do debate nos últimos anos, constituindo um dos temas de maior relevância e complexidade no que concerne aos seus aspectos jurídicos e econômicos. Durante algum tempo, muitos acreditavam que haveria um conflito entre esses dois ramos do direito, já que partiam da premissa simplista de que a exclusividade temporária conferida ao titular de um direito de propriedade intelectual seria um monopólio. ${ }^{1}$ Nesse contexto, a propriedade intelectual era vislumbrada como antagônica ao direito da concorrência, sob o argumento de que o titular de um direito exclusivo poderia fazer uso de seu "monopólio" para excluir seus concorrentes do mercado e aumentar os preços, em detrimento do bem-estar dos consumidores.

Contudo, essa abordagem tem sido cada vez mais contestada nas últimas décadas. Atualmente, a propriedade intelectual e o direito antitruste são vistos como instrumentos complementares de promoção da concorrência, da inovação e do crescimento econômico, gerando eficiências econômicas - estáticas e dinâmicas. Prevalece o entendimento de que a exclusividade conferida ao titular de direitos de propriedade intelectual não cria um monopólio no sentido econômico. Pelo contrário, esse "direito de excluir" constitui a função essencial da propriedade intelectual, consubstanciada na promoção dos incentivos necessários para que agentes econômicos invistam em atividades de pesquisa, desenvolvimento e criação de novos produtos, serviços e tecnologias, resultando ao final no aumento das possibilidades de escolha em benefício dos consumidores. $^{2}$

\footnotetext{
${ }^{1}$ BARBOSA afirma que a construção dos direitos exclusivos como monopólios tem origem no direito inglês e no direito norte-americano. O autor explica que essa construção teve início com o Estatuto dos Monopólios de 1635, única lei de patentes existente no Reino Unido até meados do século XIX, e que continua sendo invocado como elemento da Constituição Inglesa, tendo influenciado outros sistemas jurídicos, não apenas dos países da Commonwealth, mas também de vários outros países, como o Brasil. O autor prossegue afirmando que a classificação dos direitos exclusivos como monopólios tem sido uma constante na história da Suprema Corte dos Estados Unidos, e também em outros tribunais constitucionais, como a Câmara dos Lordes, o tribunal máximo da Índia, o do Canadá e a Corte Suprema da Austrália. BARBOSA, Denis Borges. A Criação de um Ambiente Competitivo no Campo da Propriedade Intelectual: O Caso Sul Americano, in: Centre for Trade and Sustainable Development, nov. 2005, p. 16-17.

${ }^{2}$ Relatório elaborado pelo Department of Justice (DOJ) em conjunto com a Federal Trade Commission (FTC), dos Estados Unidos, em abril de 2007, corrobora esse entendimento: "The property rights promote innovation by allowing intellectual property owners to prevent others from appropriating much of the value derived from their inventions or original expressions. (...) Antitrust laws, in turn, ensure that new proprietary technologies, products and services are bought, sold, traded, and licensed in a competitive environment. In today's dynamic marketplace, new technological improvements are constantly replacing those that came before, as competitors are driven to improve their existing products in order to maintain their market share".
} 
Por outro lado, é inegável que situações de conflito podem decorrer de práticas restritivas $^{3}$ a partir da exploração de direitos de propriedade intelectual, capazes de produzir efeitos adversos sobre a concorrência nos mercados. Tais condutas podem ser colocadas em prática por meio de restrições em acordos de licenciamento e transferência de tecnologia, ou até mesmo por meio de estratégias unilaterais impostas por agentes econômicos dominantes visando à exclusão de seus rivais do mercado. Essas práticas podem vir a ser objeto de intervenção por parte das autoridades da concorrência na medida em que os titulares de direitos de propriedade intelectual detenham poder de mercado, em conjunto ou isoladamente, além da presença de outras circunstâncias de mercado, tais como a presença de barreiras à entrada que facilitem a imposição dessas estratégias anticoncorrenciais. $^{4}$

As jurisprudências norte-americana e europeia oferecem uma variedade de casos envolvendo a aplicação do direito da concorrência para coibir o exercício abusivo de direitos de propriedade intelectual. Nos países em desenvolvimento, essa questão ainda não recebeu uma análise mais acurada, provavelmente em razão da inexistência de legislações adequadas sobre a matéria, da fraca implementação das normas antitruste existentes, ou até mesmo pela ausência de políticas voltadas especificamente para a interface entre propriedade intelectual e direito da concorrência. ${ }^{5}$ No Brasil, o tema tem despertado o interesse da comunidade acadêmica, dos advogados e das autoridades antitruste, sendo

U.S. Dep't of Justice \& Fed. Trade Comm'n. Antitrust Enforcement and Intellectual Property Rights: Promoting Innovation and Competition, 2007, p. 01.

${ }^{3}$ Práticas restritivas e abusos de direitos de propriedade intelectual serão tratados como sinônimos na medida em que estiverem ligados a questões concorrenciais. Abuso de direito de propriedade intelectual é um conceito amplo que pode tanto se referir a abuso do poder econômico relacionado à exploração de direitos de propriedade intelectual, como a condutas abusivas que, embora violem a legislação de propriedade intelectual, não produzem efeitos anticoncorrenciais nos mercados.

${ }^{4}$ De acordo com Mark LEMLEY: "There is room, therefore, for the patent and antitrust laws to coexist in the service of long-run, dynamic efficiencies. In this scheme, IP and antitrust sometimes do not overlap at all. Most copyright and trademark cases, for example, don't involve even a credible allegation of market power or anticompetitive conduct. Similarly, most antitrust cases don't involve IP. This doesn't mean, however, that antitrust law does not or should not constrain the scope of IP rights. Just as it was too facile to assume that IP rights confer monopolies, it is also wrong to equate IP with real property and therefore to assume that it can never confer market power. IP rights are granted in unique goods, and in some respects patent law in particular gives patent owners rights far greater than any that would be granted by real property law. It is possible to use an IP right to obtain unwarranted market power or interfere with competition in a variety of ways, and antitrust law properly addresses conduct of that sort”. LEMLEY, Mark A. A New Balance Between IP and Antitrust (Apr. 1, 2007). Southwestern Journal of Law and Trade in the Americas, v. 13, p. 237, 2007; Stanford Law and Economics Olin Working Paper n. 340. Disponível em SSRN: http://ssrn.com/abstract=980045.

${ }^{5}$ Cf. CorreA, Carlos M. Intellectual Property and Competition Law: Exploring Some Issues of Relevance to Developing Countries, ICTSD IPRs and Sustainable Development Program Issue Paper n. 21, International Centre for Trade and Sustainable Development. Geneva, Switzerland, p. 01. 
crescente nos últimos anos a atividade dos órgãos brasileiros de defesa da concorrência nessa área.

No plano internacional, o Acordo TRIPS $^{6}$ da Organização Mundial do Comércio (OMC), que estabelece padrões mínimos de proteção aos direitos de propriedade intelectual, trata do assunto a partir de uma abordagem direcionada à repressão ao abuso de direitos de propriedade intelectual e às práticas anticoncorrenciais capazes de restringir o comércio e a transferência de tecnologia. As disposições relevantes do TRIPS sobre concorrência foram incluídas nos Artigos 8.2 e 40 do Acordo TRIPS, que, em termos gerais, autorizam os membros a adotar medidas apropriadas para evitar abusos de direitos de propriedade intelectual e práticas restritivas em acordos de licenciamento, bem como no Artigo $31(\mathrm{k})$, que trata especificamente do licenciamento compulsório de patentes para remediar práticas anticoncorrenciais. ${ }^{7}$

Essas disposições acabaram sendo incluídas no Acordo TRIPS como resultado de concessões feitas pelos países desenvolvidos aos países em desenvolvimento, em troca

\footnotetext{
${ }^{6}$ Sigla em inglês para Trade-Related Intellectual Property Rights (Acordo sobre Aspectos de Direito de Propriedade Intelectual Relacionados ao Comércio). O referido Acordo entrou em vigor no Brasil em $1^{\circ}$ de janeiro de 1995 e é um dos diversos anexos ao Acordo Constitutivo da OMC constante da Ata Final que Incorpora os Resultados da Rodada Uruguai de Negociações Comerciais Multilaterais do GATT, assinada em Marraqueche, em 15 de abril de 1994. As tensões entre países desenvolvidos e em desenvolvimento marcaram todas as discussões para a criação de um acordo de propriedade intelectual durante a Rodada Uruguai. Mesmo assim, após longa negociação e troca de concessões entre os países desenvolvidos e em desenvolvimento, o Acordo TRIPS foi implementado como um dos acordos abrangidos pela OMC, podendo ser objeto de disputa entre os Países-Membros no âmbito do Órgão de Solução de Controvérsias (OSC), que possui jurisdição sobre todos os acordos multilaterais da organização. O Acordo TRIPS estabelece padrões mínimos de proteção para diversos direitos de propriedade intelectual, tais como direitos autorais, marcas, patentes, indicações geográficas, desenhos industriais, circuitos integrados e informações confidenciais. Imperioso destacar que o Acordo não possui aplicação imediata nos ordenamentos jurídicos internos dos países, uma vez que, na qualidade de "tratado-contrato", os destinatários das suas normas são os Membros da OMC, que assumiram o compromisso de implementar em suas legislações nacionais os padrões mínimos de proteção. De acordo com a Professora Maristela BASSO: "O TRIPS é um 'tratado-contrato', não só devido aos seus aspectos relacionados ao comércio, mas porque através dele, bem como dos demais acordos que compõem a OMC, os Estados-Partes, realizando uma operação jurídica, criaram uma situação jurídica subjetiva. (...) Os Estados-Partes do TRIPS assumiram, reciprocamente, o compromisso de implementar, em seus sistemas de direito nacional, os padrões mínimos de proteção fixados em comum. São livres para determinar a forma mais apropriada de cumprir esse compromisso de acordo com as regras vigentes em seus sistemas de direito e com a prática reinante. Caracterizará violação ao Acordo TRIPS se os Estados partes não o fizerem, se, ao fazerem, não observarem os padrões mínimos ou, se esses forem observados, houver descumprimento". BASSO, Maristela. O Direito Internacional da Propriedade Intelectual. Porto Alegre: Livraria do Advogado, 2000, p. 169.

${ }^{7}$ São escassos os trabalhos acadêmicos que versem especificamente sobre os Artigos 8.2, 31(k) e 40 do Acordo TRIPS/OMC. No Brasil, destacamos os seguintes: PADILHA, Alexandre Garcia. A Influência do Direito da Concorrência na Proteção Internacional dos Direitos de Propriedade Intelectual: Especial Referência aos Artigos 8.2 e 40 do Acordo TRIPS, Dissertação de Mestrado - Faculdade de Direito da Universidade de São Paulo, São Paulo, 2012; e ROSENBERG, Barbara. Patentes de Medicamentos e Comércio Internacional: Os Parâmetros do TRIPS e do Direito Concorrencial para a Outorga de Licenças Compulsórias, Tese de Doutorado - Faculdade de Direito da Universidade de São Paulo, São Paulo, 2004.
} 
do fortalecimento dos padrões mínimos de proteção dos direitos de propriedade intelectual. ${ }^{8} \mathrm{O}$ caráter amplo e vago dessas normas, somado à ausência de um acordo multilateral no âmbito da OMC sobre concorrência, é apontado como um dos desafios dos Membros, visando ao aprimoramento do sistema de proteção internacional da propriedade intelectual, uma vez que práticas anticoncorrenciais relacionadas à exploração de direitos exclusivos podem resultar em prejuízos consideráveis ao comércio, à inovação e à transferência de tecnologia nos países em desenvolvimento. ${ }^{9}$

A despeito do amplo debate atualmente existente sobre o tema, ainda não há consenso quanto aos limites da intervenção antitruste nesses casos e quanto aos critérios que devem ser utilizados na análise de condutas anticoncorrenciais relacionadas à propriedade intelectual. Essa ausência de consenso decorre do fato de que, normalmente, estratégias comerciais envolvendo a exploração de direitos de propriedade intelectual são lícitas e totalmente legítimas, ainda que possam reduzir de certo modo a concorrência no mercado. Diante desse quadro, as próprias características da propriedade intelectual, consubstanciadas no direito de excluir terceiros, tornam mais complexa, em determinados casos, a tarefa das autoridades antitruste de distinguir de forma precisa condutas legítimas baseadas na concorrência por méritos - mesmo que resultem na exclusão de concorrentes do mercado - de condutas abusivas cuja finalidade ou efeito é meramente a eliminação da concorrência. Assim, pode-se afirmar que o grande desafio é estabelecer critérios

\footnotetext{
${ }^{8}$ Como se pode observar no preâmbulo e em diversos dispositivos do TRIPS, as tensões Norte-Sul que marcaram as negociações do Acordo durante a Rodada Uruguai foram direcionadas de modo a acomodar as divergentes posições, resultando num texto jurídico equilibrado no qual são estabelecidos padrões mínimos de proteção da propriedade intelectual a serem observados pelos Membros da OMC como forma de reduzir distorções e obstáculos ao comércio internacional, ao mesmo tempo em que se reconhecem os objetivos legítimos de política pública relacionados à proteção desses direitos e as necessidades especiais dos países em desenvolvimento. Nesse sentido, de acordo com a Professora Maristela BASSO: "O TRIPS representa, portanto, um documento fundamental na consolidação da proteção dos direitos de propriedade intelectual na sociedade internacional contemporânea, e a vinculação definitiva desses direitos ao comércio internacional. Com ele, as partes ganharam e perderam e os interesses contrapostos acabaram chegando ao consenso. Certamente, o texto ficou aquém das expectativas dos países desenvolvidos, que buscavam no GATT patamares superiores de proteção dos direitos de propriedade intelectual. Por outro lado, os países em desenvolvimento, que buscavam assegurar a difusão da tecnologia, destacando as assimetrias Norte-Sul, comprometeram-se a implementar medidas eficazes e apropriadas para a aplicação das normas de proteção desses direitos relacionadas ao comércio na perspectiva da cooperação internacional". BASSO, Maristela. $O$ Direito Internacional da Propriedade Intelectual. Porto Alegre: Livraria do Advogado, 2000, p. 169.

${ }^{9}$ De acordo com COTTIER e FOLTEA: "Today, the main challenges in the agreement relate to the absence of international disciplines in anti-trust and competition law and policy within and without the WTO". COTTIER, Thomas; FOLTEA, Marina. Global Governance in Intellectual Property Protection, NCCR Trade Regulation, Working Paper n. 2011/45, June 2011, p. 13-14.
} 
econômicos objetivos e limites para intervenção antitruste que permitam às autoridades preservar a concorrência sem prejudicar os incentivos à inovação. ${ }^{10}$

Feitas as considerações acima, a presente tese de doutorado tem como objetivo a análise da interface entre propriedade intelectual e política de concorrência no contexto do enquadramento jurídico oferecido pelas disposições do Acordo TRIPS. Mais especificamente, a tese deverá abordar as circunstâncias em que eventuais abusos de direitos de propriedade intelectual podem restringir a livre concorrência nos mercados. Para tanto, propõe-se a interpretação dos dispositivos do TRIPS sobre concorrência a partir da experiência prática das autoridades antitruste e tribunais dos Estados Unidos e da União Europeia, que são as jurisdições mais avançadas nessa área, de modo a possibilitar a formulação de diretrizes que poderiam ser adotadas pelos países em desenvolvimento na implementação de políticas públicas eficazes para coibir condutas anticoncorrenciais relacionadas à exploração de direitos de propriedade intelectual. A escolha do tema devese à carência de estudos sobre a interação entre propriedade intelectual e política antitruste no Brasil, somada à ausência de uma jurisprudência consolidada capaz de imprimir a visão das autoridades brasileiras sobre o assunto.

O estudo será concentrado nas condutas anticoncorrenciais relacionadas à exploração de criações intelectuais protegidas por direitos de propriedade industrial, tais como patentes, modelos de utilidade e desenhos industriais, bem como por direitos autorais e softwares. Dentro do conceito amplo de "criações intelectuais", incluem-se as tecnologias e conhecimentos técnicos (know-how), que, embora não sejam suscetíveis de proteção, são tratados como segredos industriais ou informações confidenciais, normalmente protegidos por cláusulas de confidencialidade em acordos de licenciamento e transferência de tecnologia. Assim, não serão analisadas as questões antitruste relacionadas às marcas, que, além de serem fundadas em pressupostos jurídicos e econômicos próprios, envolvem discussões muito específicas, normalmente ligadas ao controle concorrencial de concentrações econômicas, tais como fusões e incorporações, tema que está fora do escopo deste trabalho. ${ }^{11}$

${ }^{10}$ PITOFSKI, Robert. Antitrust and Intellectual Property: Unresolved Issues at the Heart of the New Economy, 16 Berkeley Tech. L.J. 535-559 (2001). Disponível em: http://scholarship.law.georgetown.edu/facpub/315, p. 539.

${ }^{11}$ Como bem ressaltado pelo Professor Newton SILVEIRA, enquanto o fundamento jurídico da proteção às criações intelectuais é o estímulo a novas criações por meio do monopólio legal conferido pelo Estado, o fundamento da proteção aos sinais distintivos é a prevenção da concorrência desleal por meio de atos 
Inicialmente, a Seção 1 abordará os principais elementos da interface entre propriedade intelectual e direito da concorrência, de modo a possibilitar a identificação dos elementos de convergência e tensão resultantes da relação entre as duas disciplinas. Para tanto, analisamos os fundamentos jurídicos e econômicos da propriedade intelectual, para então tratarmos dos elementos para a intervenção antitruste em casos de abuso de direitos de propriedade intelectual.

$\mathrm{Na}$ Seção 2, serão analisadas as origens do tema no direito internacional, além de buscar uma interpretação adequada para os Artigos 8.2, 31(k) e 40 do Acordo TRIPS, que tratam especificamente dos abusos de direitos de propriedade intelectual e de restrições em acordos de licenciamento capazes de produzir efeitos adversos sobre o comércio, a transferência de tecnologia e a concorrência nos mercados. Ademais, será abordada a perspectiva para um maior detalhamento do tema em foros internacionais, tendo em vista a ausência de diretrizes suficientes nas disposições do Acordo TRIPS.

Em seguida, a Seção 3 tratará das formas de abuso de direitos de propriedade intelectual capazes de restringir a concorrência, de modo a conferir aplicação prática às disposições do TRIPS sobre o tema. Para tanto, será realizada uma análise comparada da experiência dos Estados Unidos e da União Europeia no controle e repressão de práticas restritivas da concorrência relacionadas à exploração de direitos de propriedade intelectual. Nesse contexto, serão examinados os casos julgados pelas autoridades antitruste e tribunais norte-americanos e europeus para identificar as abordagens adotadas na análise econômica de ilícitos antitruste relacionados à propriedade intelectual. Ênfase será dada para os seguintes tipos de condutas: (i) práticas restritivas em acordos de licenciamento e transferência de tecnologia; (ii) restrições em pools de patentes e licenças cruzadas; e (iii) condutas unilaterais de exclusão. A análise da experiência das duas jurisdições mais avançadas em termos de direito antitruste pode servir para embasar a formulação de normas nacionais compatíveis com as disposições do Acordo TRIPS sobre concorrência nos países em desenvolvimento.

A Seção 4 tratará da relação entre propriedade intelectual e concorrência no contexto do ordenamento jurídico-constitucional brasileiro, especialmente a partir da Lei n..$^{\circ}$ 12.529/2011, a nova lei antitruste que altera e define o Sistema Brasileiro de Defesa da 
Concorrência (SBDC), e de casos recentes julgados pelo Conselho Administrativo de Defesa Econômica (CADE). Embora a matéria seja ainda incipiente no Brasil, é inegável que a experiência dos órgãos brasileiros de defesa da concorrência também poderia servir de modelo para outros países em desenvolvimento que desejem implementar normas antitruste nacionais para lidar com abusos de direitos de propriedade intelectual.

Por fim, a partir da experiência dos Estados Unidos, da União Europeia e do Brasil, a Seção 5 tratará das diretrizes do TRIPS sobre concorrência no contexto global e suas implicações para os países em desenvolvimento. Para tanto, serão analisadas as possíveis abordagens que poderiam ser adotadas pelos países em desenvolvimento na implementação de políticas de concorrência nacionais eficazes e compatíveis com o Acordo TRIPS, de modo a contribuir com eventuais discussões futuras sobre o tema em foros internacionais.

Não é objetivo desta tese buscar uma resposta definitiva à questão sobre quais diretrizes ou abordagens são mais adequadas para a implementação de políticas de concorrência nacionais para coibir abusos de direitos de propriedade intelectual. A ideia é apenas contribuir com o desenvolvimento do tema no Brasil a partir da análise comparada da experiência dos Estados Unidos e da União Europeia, examinando possíveis abordagens que poderiam ser utilizadas pelos países em desenvolvimento com vistas ao enquadramento institucional do tema em seus respectivos ordenamentos jurídicos nacionais. 


\section{PROPRIEDADE INTELECTUAL E DIREITO DA CONCORRÊNCIA: UMA RELAÇÃO DE CONFLITO OU COMPLEMENTARIDADE?}

Nesta Seção, analisamos os principais elementos da interface entre propriedade intelectual e direito da concorrência, de modo a possibilitar a identificação dos pontos de convergência e tensão resultantes dessa relação. Na primeira parte desta Seção, abordaremos os fundamentos jurídicos e econômicos da propriedade intelectual, para então examinarmos os elementos essenciais da interface entre propriedade intelectual e direito antitruste, inclusive no que concerne ao papel de ambos na promoção dos incentivos à inovação.

\subsection{Fundamentos jurídicos e econômicos da propriedade intelectual}

A propriedade intelectual pode ser compreendida, em termos gerais, como o conjunto dos direitos relativos às obras literárias, artísticas e científicas, às invenções, desenhos e modelos industriais, às marcas, firmas comerciais e denominações comerciais, à proteção contra a concorrência desleal e todos os outros direitos inerentes à atividade intelectual nos domínios industrial, científico, literário e artístico. ${ }^{12}$ Tradicionalmente, a propriedade intelectual é dividida em direitos de propriedade industrial (patentes, modelos de utilidade, desenhos industriais e marcas) e direitos autorais (direitos de autor, direitos conexos e a proteção dos programas de computador), muito embora existam atualmente outros tipos de direitos de propriedade intelectual que não se enquadram necessariamente na dicotomia direito industrial e autoral. ${ }^{13}$

Os direitos de propriedade intelectual existem de forma independente em relação ao suporte físico no qual possam estar incorporados, além de possuírem valor econômico para indivíduos e agentes econômicos, bem como para o sistema econômico como um todo. ${ }^{14}$ Destaca-se o papel dos bens intelectuais para os agentes econômicos por constituírem ativos valiosos e estratégicos que lhes permitem diferenciar seus produtos e

\footnotetext{
${ }^{12}$ Cf. Convenção da Organização Mundial da Propriedade Intelectual (OMPI).

${ }^{13}$ Em termos gerais, a propriedade intelectual é disciplinada no Brasil pelas Leis 9.279/96 (Propriedade Industrial), 9.456/97 (Cultivares), 9.609/98 (Software) e 9.610/98 (Direitos Autorais), além de constituir preceito constitucional arrolado entre os Direitos e Garantias Fundamentais, com previsão nos incisos XXVII, XXVIII e XXIX, em consonância aos incisos XXII e XXIII, do artigo $5^{\circ}$ da Constituição Federal.

${ }^{14}$ Ressalte-se que muitas vezes o valor intrínseco desses direitos supera o valor do suporte físico no qual estejam incorporados.
} 
serviços e obter vantagens competitivas que os bens tangíveis muitas vezes não são capazes de conferir. ${ }^{15}$ Assim, por possuírem valor econômico, é possível constatar que os bens intelectuais podem ser livremente transacionados no mercado.

Nesse contexto, Gustavo GHIDINI lembra que a estrutura econômica da propriedade intelectual concentra-se muito mais nas empresas do que nas pessoas físicas (autores e inventores), uma vez que as empresas são encarregadas de produzir e ofertar em larga escala no mercado os bens e serviços fruto da criação humana e objeto de proteção, sejam eles invenções, tecnologias ou expressões do conhecimento. ${ }^{16}$ Por outro lado, ainda que o foco da propriedade intelectual esteja nas empresas, não se pode esquecer que sua justificativa encontra fundamentos na promoção do desenvolvimento econômico e do progresso científico e tecnológico dos países.

A despeito da existência de diversas teorias jurídico-filosóficas fundadas em preceitos de direito moral e natural para justificar a propriedade intelectual, para fins desta tese interessa apenas a análise dos seus fundamentos jurídicos e econômicos. ${ }^{17}$

Nesse contexto, é possível afirmar que a abordagem econômica tem sido cada vez mais utilizada por juristas e economistas para delinear as justificativas da propriedade intelectual. A nosso ver, a Análise Econômica do Direito, ou "Law and Economics", oferece as melhores ferramentas para a compreensão da propriedade intelectual como

\footnotetext{
${ }^{15}$ Nesse sentido, Juliana L. B. VIEGAS aponta que: “(...) cada vez mais o valor de uma empresa é representado não pelos seus bens tangíveis, mas pelos intangíveis: conhecimento das tecnologias de ponta, ideias, design e o valor estratégico criado pelo desenvolvimento da informação e pela criatividade, tais como novas tecnologias, marcas, patentes, segredos de indústria e de negócios, serviços, software e entretenimento". VIEGAS, Juliana L. B. Aspectos Legais de Contratação na Área da Propriedade Industrial, in: PEREIRA DOS SANTOS, Manoel J.; JABUR, Wilson Pinheiro. Contratos de Propriedade Industrial e Novas Tecnologias. São Paulo: Saraiva, 2007 (Série GVlaw), p. 4.

${ }^{16}$ GHIDINI, Gustavo. Innovation, Competition and Consumer Welfare in Intellectual Property Law. UK: Edward Elgar, 2010, p. 06.

${ }^{17}$ Destacam-se a tese da recompensa, inspirada nas ideias de LOCKE, no sentido de que o autor ou inventor tem o direito de perceber os frutos de seu trabalho intelectual, assim como a tese do direito natural, com fundamento na filosofia hegeliana do espírito, que estabelece que o autor ou inventor possui um direito natural à propriedade sobre suas próprias ideias, devendo esse direito moral de propriedade ser devidamente reconhecido pela sociedade. Abordagens com base na moral e no direito natural são amplamente reconhecidas e estão expressamente referidas no âmbito da Organização das Nações Unidas (ONU), tanto na Declaração de Direitos Humanos de 1948 como no Pacto Internacional dos Direitos Econômicos, Sociais e Culturais de 1966, que estabelecem que "toda pessoa tem direito à proteção dos interesses morais e materiais decorrentes de qualquer produção científica, literária ou artística da qual seja autor". Para uma análise mais aprofundada dessas abordagens, cf. MERGES, Robert P.; MENELL, Peter S.; LEMLEY, Mark A. Intellectual Property in the New Technological Age. New York: Aspen Publishers. 4th ed. 2006, p. 2-22; e FISHER, Matthew. Fundamentals of Patent Law: Interpretation and Scope of Protection. Oxford: Hart Publishing, 2007, p. 65-85.
} 
instrumento eficiente de incentivo à produção de novas ideias, inovações e tecnologias, denominadas genericamente pelos economistas de "informação". ${ }^{18}$

Assim, as justificativas econômicas da propriedade intelectual, fundadas em preceitos utilitaristas, têm como pressuposto fundamental a necessidade de resolução do problema do bem público "informação", com o objetivo de criar incentivos para a atividade inventiva e intelectual, permitindo o desenvolvimento de inovações técnicas e culturais. Se não vejamos.

Uma das principais características da informação é sua "inapropriabilidade", ou seja, uma vez criada não pode ser apropriada pelo seu criador. Isso ocorre porque a informação pode ser qualificada como “bem público”. Para a economia, bens públicos são definidos como bens não rivais e não excludentes, de modo que a informação, objeto da proteção da propriedade intelectual, possui essas características. ${ }^{19}$

Os bens tangíveis, em geral, são rivais, uma vez que seu uso ou consumo por alguém impede que terceiros o utilizem ou consumam simultaneamente. ${ }^{20} \mathrm{~A}$ informação, ao contrário, é um bem não rival, pois, uma vez divulgada, poderá ser utilizada por milhares de pessoas ao mesmo tempo, sem alteração de suas características, ou seja, o uso da informação por alguém não diminui ou restringe seu uso por todos os demais. ${ }^{21}$ Tomando como exemplo invenções, obras literárias ou programas de computador, todos são bens não rivais, pois podem ser utilizados ao mesmo tempo por milhares de pessoas, ainda que estejam incorporados em bens tangíveis rivais.

Os bens tangíveis são excludentes, uma vez que seus proprietários podem impedir seu acesso por terceiros. Já a informação, por seu turno, é um bem não excludente, pois, uma vez divulgada, é praticamente impossível impedir que terceiros a utilizem sem autorização, a não ser que seja mantida em segredo. ${ }^{22}$ Dessa forma, assim que a

\footnotetext{
18 Sobre o tema da propriedade intelectual como "informação", cf. BARBOSA, Cláudio R. Propriedade Intelectual: Introdução à Propriedade Intelectual como Informação. Rio de Janeiro: Elsevier, 2009.

${ }^{19}$ Para o Direito, bem público (res publicae) pode tanto designar bens de uso comum do povo, como bens pertencentes às pessoas jurídicas de direito público interno.

${ }^{20}$ Por exemplo, duas pessoas não podem dirigir um carro ao mesmo tempo.

${ }^{21}$ Cf. ARROW, Kenneth J. Economic Welfare and the Allocation of Resources for Innovation, in The Rate and Direction of Inventive Activity. National Bureau of Economic Research ed. (1962), p. 614-616.

${ }^{22}$ Nesse sentido, BLAIR e COTTER esclarecem que: “(...) most goods are excludable, in the sense that you can take precautions - locks, guards, fences - to prevent other people from having access to them. But the only way to exclude others from having access to your idea for a new invention is to keep the idea to yourself.
} 
informação for incorporada a um bem tangível - por exemplo, uma invenção embutida numa máquina - e posteriormente comercializada, terceiros poderão utilizar essa informação para fabricar cópias da invenção a custos marginais baixos e concorrer de igual para igual com o inventor, sem, contudo, ter inicialmente contribuído para sua criação.

Assim, por apresentar características de bem público (não rival e não excludente), a informação é, em princípio, “inapropriável”, ou seja, impede seu criador de apropriar-se do seu valor econômico. A criação de informações úteis e valiosas muitas vezes requer elevados investimentos, que podem ser considerados custos fixos por serem invariáveis em relação à produção. Entretanto, uma vez criada a informação, os custos marginais $^{23}$ para sua reprodução e distribuição aos usuários serão baixos, algumas vezes muito próximos de zero, como ocorre, por exemplo, com os softwares e músicas disponíveis para download pela internet.

Nesse caso, o criador da informação somente conseguirá recuperar seus investimentos se vier a cobrar um preço superior ao custo marginal. ${ }^{24}$ Por outro lado, ao terem acesso à informação já criada, terceiros terão incentivos para adotar comportamentos oportunistas (prática comumente denominada de "free riding"), pois poderão concorrer no mercado praticando preços muito baixos, próximos ou equivalentes ao custo marginal, impedindo que aquele que originalmente criou a informação recupere seus investimentos e seja recompensado por seus esforços. ${ }^{25}$ A consequência disso é a falta de motivação para investir tempo e dinheiro no desenvolvimento de criações intelectuais, tendo em vista que há muito incentivo para a cópia e pouquíssimo incentivo para a criação.

Portanto, a "inapropriabilidade" do bem público "informação", assim como a consequente falta de motivação para sua produção, resultam no que os economistas chamam de "falha de mercado", pois na ausência de uma intervenção do Estado, o

Once you disclose the idea to someone else, there may be no way to prevent that person from using it, assuming that he has the technical skill to do so. (...) Once you embody your idea in a tangible object (say, a computer chip) and make copies of that object available to others (for example, by selling to them), the cat may be out of the bag. If the invention is valuable enough, someone will try to reverse-engineer it". BLAIR, Roger D.; COTTER, Thomas F. Intellectual Property: Economics and legal Dimensions of Rights and Remedies. Cambridge, UK: Cambridge University Press, 2005, p. 13 e 14.

${ }^{23}$ Custo marginal corresponde ao acréscimo dos custos totais de produção quando se aumenta a quantidade produzida em uma unidade.

${ }^{24}$ No mercado farmacêutico, por exemplo, os custos fixos incorridos na pesquisa e desenvolvimento de novos medicamentos tendem a ser elevadíssimos em comparação aos custos marginais de reprodução.

25 Cf. POSNER, Richard A. Intellectual Property: The Law and Economics Approach, in: Journal of Economic Perspectives - v. 19, n. 2 - Spring 2005, p. 58. 
mercado será incapaz de prover à sociedade um nível ótimo de bens intelectuais, traduzidos em informações e conhecimentos úteis e valiosos. Portanto, com o objetivo de corrigir essa "falha de mercado", são atribuídos direitos de exclusividade sobre a informação, permitindo aos autores e inventores apropriarem-se do valor econômico de suas criações intelectuais. ${ }^{26}$

Dessa forma, os direitos de exclusividade conferidos pela propriedade intelectual permitem que autores e inventores recuperem os custos fixos incorridos na criação intelectual e sejam recompensados pelos esforços empregados nesse objetivo, uma vez que poderão cobrar preços acima dos custos marginais, sem o risco de sofrerem a concorrência de cópias fornecidas por terceiros ("free riders") sobre as quais não incorreram os respectivos custos da criação. Em última instância, é a perspectiva de vantagens competitivas e de obtenção de lucros considerados "supranormais" que estimula os investimentos e esforços para a criação intelectual. ${ }^{27}$

Entretanto, nem sempre a criação de direitos exclusivos sobre a exploração da informação é uma resposta social e economicamente eficiente. Isso porque o conteúdo e valor da informação passível de ser transacionada no mercado somente serão conhecidos após sua criação, conforme pode ser constatado no chamado "Paradoxo de Arrow". ${ }^{28}$ Nesse sentido, é o mercado que determina o valor econômico das criações intelectuais, independentemente dos custos incorridos na criação. Ainda que os custos sejam elevados, como ocorre em segmentos como o farmacêutico e de alta tecnologia, o valor da

\footnotetext{
${ }^{26}$ Cláudio R. BARBOSA esclarece que “(...) bens públicos acarretam um problema específico que é a falta de motivação para produzi-los, pois não é eficiente despender tempo e esforço para a produção de um bem não rival e não excludente. Essa situação na qual a oferta não consegue atender a demanda sem uma intervenção externa é denominada, em economia, uma 'falha de mercado' ('market failure') e, para contorná-la, é necessária uma intromissão: atribui-se ao bem público uma exclusividade, transformando-o em bem privado sob o ponto de vista econômico". BARBOSA, Cláudio R. Propriedade Intelectual: Introdução à Propriedade Intelectual como Informação. Rio de Janeiro: Campus Jurídico, 2008, p. 02.

27 Nesse contexto, comparando a propriedade física e a propriedade intelectual, LEMLEY afirma que: "Intellectual property, then, is not a response to allocative distortions resulting from scarcity, as real property is. Rather, it is a conscious decision to create scarcity in a type of good in which it is ordinarily absent in order to artificially boost the economic returns to innovation". LEMLEY, Mark. Property, Intellectual Property, and Free Riding. Stanford Law School, John M. Olin Program in Law and Economics, Working Paper n. 291, August 2004, p. 9.

${ }^{28}$ De acordo com ARROW, "there is a fundamental paradox in the determination of demand for information; its value for the purchaser is not known until he knows the information, but then he has in effect acquired it without cost. Of course, if the seller can retain property rights in the use of information, this would be no problem, but given incomplete appropriability, the potential demander will base his decision to purchase information on less than optimal criteria. (...) If any particular item of information has differing values for different economic agents, this procedure will lead both to a suboptimal purchase of information at any given
} 
informação somente poderá ser determinado após sua criação e dependerá de fatores como a estrutura do mercado (grau de concorrência, disponibilidade e preço de produtos substitutos), características da demanda (aceitação e utilidade do produto para os usuários), bem como da extensão e duração da proteção (escopo e prazo da proteção são definidos pela legislação de propriedade intelectual). ${ }^{29}$

Dessa forma, mesmo na presença de um sistema eficiente de propriedade intelectual, nem sempre será possível estabelecer incentivos adequados para a criação de informação, uma vez que seu valor econômico pode vir a ser inferior ao esperado pelo titular do bem intelectual. ${ }^{30}$ Ainda assim, a exclusividade conferida pela propriedade intelectual permite maiores incentivos à criação da informação do que num eventual cenário de completa ausência de proteção, ou até mesmo de proteção insuficiente.

De qualquer modo, é inegável que, mesmo na ausência da propriedade intelectual, haveria espaço para alguma atividade inventiva e intelectual, tendo em vista a existência de incentivos alternativos. Por exemplo, mesmo na ausência de patentes, invenções que não impliquem elevados custos fixos de pesquisa e desenvolvimento certamente seriam desenvolvidas. É possível compensar esses custos aproveitando-se da vantagem de ser o primeiro a ingressar no mercado ("first move advantages"), principalmente se for difícil para os concorrentes fabricar a invenção por meio de engenharia reversa ou se os custos de reprodução da invenção forem muito elevados. Alternativamente, é possível manter a invenção em segredo, especialmente processos

price and also to a suboptimal allocation of the information purchased". ARROW, Kenneth J., Economic Welfare and the Allocation of Resources for Invention. California: The Rand Corporation, p. 10.

${ }^{29}$ Esses fatores podem impedir o titular do direito de propriedade intelectual de praticar preços monopolísticos que lhe permitiriam recuperar o investimento e lucrar com a informação criada. Nesse sentido, HETTINGER afirma que: "Market value is a socially created phenomenon, depending on the activity (or nonactivity) of other producers, the monetary demand of purchasers, and the kinds of property rights, contracts, and markets the state has established and enforced. The market value of the same fruits of labor will differ greatly with variations in these social factors. Consider the market value of a new drug formula. This depends on the length and the extent of the patent monopoly the state grants and enforces, on the level of affluence of those who need the drug, and on the availability and price of substitutes". HETTINGER, Edwin C. Justifying Intellectual Property, in: Philosophy and Public Affairs, v. 18, n. 1 (Winter, 1989), p. 3839.

${ }^{30}$ As constatações de SHAVEL parecem corroborar esse entendimento: "It may be noted, however, that property rights do not engender socially perfect incentives to create information, for monopoly profits will generally fall short of the full social value of products; sellers will typically be unable to identify and to extract from each buyer an amount equal to his particular valuation. Thus, the incentive to generate information is not socially ideal under property rights, even though it exceeds that in the absence of property rights". SHAVEL, Steven. Foundations of Economic Analysis of Law. Cambridge, Massachusetts: Harvard University Press, 2004, p. 143. 
industriais, pelo menos por certo tempo, e aproveitar-se de eventuais vantagens competitivas momentâneas decorrentes da curva de aprendizado. ${ }^{31}$

Contudo, na ausência da proteção conferida pela propriedade intelectual ainda que existam variadas formas de incentivos alternativos -, é provável que, nesse cenário hipotético, o nível de criação de informações úteis e valiosas seria inferior ao socialmente desejável. ${ }^{32}$

Pelo exposto, pode-se afirmar que, ao conferir exclusividade para a exploração de direitos de propriedade intelectual, o Estado cria incentivos para os agentes privados investirem no desenvolvimento de novos produtos, serviços e expressões do conhecimento, permitindo que sejam remunerados pelos seus esforços, uma vez que terceiros serão impedidos de explorar comercialmente tais direitos sem autorização, evitando-se, assim, comportamentos oportunistas daqueles que desejam apropriar-se indevidamente do esforço alheio.

Por outro lado, a exclusividade conferida pela propriedade intelectual, também denominada de "monopólio legal" por restringir o acesso aos bens intelectuais a terceiros, poderá resultar em custos sociais que em determinadas situações poderão sobrepor-se às eficiências decorrentes da inovação, uma vez que o titular desses direitos terá condições de cobrar preços supracompetitivos ou recusar transacionar esses bens com seus concorrentes.

Portanto, é exatamente nesse tradeoff entre incentivo e acesso que reside o ponto de partida da análise econômica da propriedade intelectual. Um sistema ótimo de propriedade intelectual deverá permitir que autores e inventores apropriem-se ao máximo do valor da informação criada, conferindo proteção tão somente àquelas informações que agreguem valor à sociedade, isto é, que efetivamente contribuam com o patrimônio literário, científico ou tecnológico do país.

\footnotetext{
${ }^{31}$ Cf. BLAIR, Roger D.; COTTER, Thomas F. Intellectual Property: Economics and Legal Dimensions of Rights and Remedies. Cambridge, UK: Cambridge University Press, 2005, p.15-16.

32 Sobre o assunto, SHAVEL afirma que: "Property rights are necessary for there to be any incentive for information creation - and it is simply a moot point that, were information generated in the absence of property rights, the level of production of the associated goods would be higher. Realistically, though, creators of information can often obtain positive profits in the absence of property tights, so that there will be a positive incentive to produce information in the absence of property rights, meaning that the answer to the question of the social desirability of property rights in information becomes ambiguous. Nevertheless, and perhaps with justification, economics tend to assert that the added incentive to generate information under property rights outweighs their drawbacks, at least in a broad sense". SHAVEL, Steven. Foundations of Economic Analysis of Law. Cambridge, Massachusetts: Harvard University Press, 2004, p. 144.
} 


\subsubsection{Propriedade física e propriedade intelectual: pressupostos econômicos distintos}

Muitos autores, especialmente os norte-americanos, buscam utilizar os pressupostos econômicos da propriedade sobre bens tangíveis como justificativa para a proteção da propriedade intelectual. Entretanto, a propriedade física e a propriedade intelectual possuem fundamentos econômicos distintos que devem ser levados em consideração na formulação de políticas públicas.

COOTER e UlEN definem a propriedade como um conjunto de direitos ("bundle of rights") que descrevem o que as pessoas podem, ou não, fazer com os recursos que possuem. ${ }^{33}$ Podemos citar de forma exemplificativa os direitos de usar, gozar, dispor, transformar, transferir, além do direito de excluir terceiros, impedindo que utilizem ou tenham acesso à sua propriedade. ${ }^{34}$ Assim, o direito de excluir, somado ao direito de dispor, permite que os bens sejam alocados ao seu melhor uso, proporcionando maximização de riqueza e bem-estar.

Essa alocação eficiente de recursos somente será possível se os direitos de propriedade forem bem definidos e assegurados pelo Estado. É a garantia da propriedade privada e a segurança de sua conservação que permitem que as pessoas concentrem os seus esforços na produção de riqueza, em vez de gastarem tempo e recursos na defesa daquilo que possuem. ${ }^{35}$ Portanto, a estabilidade e segurança dos direitos de propriedade, bem como a possibilidade de transferência desses direitos, criam incentivos para que os indivíduos maximizem a utilidade de seus bens, uma vez que terão a certeza de retorno sobre aquilo que produzirem.

\footnotetext{
${ }^{33}$ COOTER, Robert; ULEN, Thomas. Law and Economics, Addison Wesley, 5th ed., 2008, p. 77.

${ }^{34}$ No mesmo sentido, a Professora Rachel SZTAJN esclarece que a propriedade deve ser considerada sob dois aspectos: "a atribuição e a garantia de conservação. Conviria, talvez, analisar a propriedade como direito e sua função econômica. No plano do direito a propriedade é compreendida como um feixe de poderes, que vem acompanhado de algumas restrições. Os poderes - usar, gozar e dispor - desenham o que as pessoas podem, ou não, fazer, com seus bens (recursos), como usá-los, transformá-los, transferir ou excluir outrem de sua propriedade. A regra é que os poderes são imutáveis ao longo de gerações, mas sempre servem para explicar como são estabelecidos, que bens podem ser objeto de apropriação privada, o que os proprietários podem fazer com seus bens e que remédios existem para casos de violação de um direito de propriedade". SZTAJN, Rachel. Externalidades e Custos de Transação: A Redistribuição de Direitos no Código Civil, in: Revista de Direito Privado, n. 22, p. 256, abr./jun. 2005.

${ }^{35}$ Cf. PINHEIRO, Armando Castelar; SADDI, Jairo. Direito, Economia e Mercados. Rio de Janeiro: Elsevier, 2005, p. 95.
} 
Nesse contexto, é importante ressaltar que o fundamento econômico primordial da propriedade é a necessidade de internalização das externalidades negativas, compreendidas como custos, ou efeitos negativos, impostos a terceiros em decorrência da utilização dos bens tangíveis. ${ }^{36}$ Ao discorrer sobre a propriedade como solução para a questão das externalidades negativas, muitos juristas e economistas fazem menção ao conhecido problema da "Tragédia dos Comuns", teoria elaborada por Garrett HARDIN em 1968 para exemplificar a ineficiência dos recursos ou bens comuns. ${ }^{37}$

A ideia central da teoria tem como pressuposto um bem comum utilizado por um número ilimitado de pessoas sem qualquer restrição, o que é ineficiente dada a ausência de incentivos para que seus usuários cuidem desse bem comum de forma devida, levando à sua "superutilização", sem que ninguém se esforce para evitar impor custos sobre os demais. O exemplo clássico utilizado por HARDIN é o do pasto comum, dividido por diversos pastores para cultivar seus rebanhos. Cada pastor, como ser racional, buscará maximizar seus ganhos e não hesitará em incluir um animal a mais no pasto, já que aproveitará integralmente os benefícios resultantes da venda desse animal adicional. Por outro lado, se cada pastor raciocinar dessa forma e seguir adicionando animais ao pasto, o resultado será a diminuição correspondente do espaço da propriedade comum até seu completo esgotamento, impondo custos a todos os usuários.

Assim, o argumento central é que, ao dividir o bem comum em propriedades privadas, resolve-se o problema da Tragédia dos Comuns, pois cada proprietário será responsável pelos efeitos negativos resultantes da utilização de seus respectivos bens, arcando com os custos eventualmente impostos sobre os demais. Em outras palavras, a atribuição de direitos de propriedade permite a internalização das externalidades negativas decorrentes da utilização dos bens. ${ }^{38}$

\footnotetext{
${ }^{36}$ Externalidades podem ser definididas como os efeitos positivos ou negativos - em termos de custos ou de benefícios - gerados pelas atividades de produção ou consumo exercidas por um agente econômico e que atingem os demais agentes, sem que haja incentivos econômicos para que seu causador produza ou consuma a quantidade referente ao custo de oportunidade social. Uma externalidade pode ser negativa quando gera custos para os demais agentes, como, por exemplo, uma fábrica que polui o ar afetando a comunidade próxima. Pode ser positiva, quando os demais agentes se beneficiam involuntariamente, a exemplo dos investimentos governamentais em infraestrutura e equipamentos públicos.

${ }^{37}$ HARDIN, Garrett. The Tragedy of the Commons. Science, New Series, v. 162, Dec., 1968, p. 1243-1244 .

${ }^{38}$ Cf. LEMLEY, Mark. Property, Intellectual Property, and Free Riding. Stanford Law School, John M. Olin Program in Law and Economics, Working Paper n. 291, August 2004, p. 9.
} 
Essa conclusão nos permite constatar que a atribuição clara de direitos de propriedade permitirá a internalização de externalidades negativas e, consequentemente, a redução dos custos de transação ${ }^{39}$, facilitando o processo de barganha, o que levará a uma alocação eficiente dos recursos, já que os bens serão alocados para aqueles que mais os valorizam. ${ }^{40}$ Partindo-se da premissa de que o mercado possui fricções que impedem que os bens sejam negociados a custo zero, a atribuição clara da propriedade pelo Estado permite que as externalidades negativas sejam internalizadas de forma eficiente pelo proprietário, facilitando o processo de barganha e, consequentemente, a circulação dos bens no mercado. ${ }^{41}$

Nesse sentido, COOTER e UlEN afirmam que as normas jurídicas são capazes de "lubrificar" o processo de barganha, reduzindo custos de transação, ao definirem claramente a atribuição dos direitos de propriedade, permitindo, assim, uma alocação eficiente desses direitos. ${ }^{42} \mathrm{O}$ mesmo pode ser afirmado sobre as normas que regulam os contratos, não apenas por "lubrificar" a barganha pela redução dos custos de transação, mas também por minimizar as perdas resultantes de negociações malsucedidas. ${ }^{43}$

Pode-se concluir, então, que a proteção jurídica dos direitos de propriedade cria incentivos para que os recursos sejam utilizados de maneira eficiente e que circulem de

\footnotetext{
${ }^{39}$ Em termos gerais, os custos de transação são aqueles custos que oneram a celebração de acordos, incluindo os custos de procura dos bens no mercado e obtenção de informações sobre preço e especificações técnicas e qualitativas, os custos da negociação e elaboração dos instrumentos contratuais, bem como os custos de monitoramento e implementação ("enforcement") do acordo, o que pode incluir medidas judiciais que eventualmente sejam necessárias para forçar seu cumprimento. Raquel SZTAJN acrescenta que "incertezas criam, representam, custos de transação. Quanto maiores forem tais incertezas no que diz respeito ao bom resultado da operação (transação) visada pelos agentes, maiores serão os custos de transação que as partes a ela - incerteza ou insegurança - imputarão. SZTAJN, Raquel. Externalidades e Custos de Transação: A Redistribuição de Direitos no Código Civil. Revista de Direito Privado, n. 22, p. 253, abr./jun. 2005.

${ }^{40}$ Cf. DEMETZ, Harold. Toward a Theory of Property Rights. American Economic Review Papers \& Proc., v. 57, p. $347-348,1967$.

${ }^{41}$ Nesse contexto, indispensável invocar a contribuição de Ronald Coase a partir de seu trabalho "The Problem of Social Cost", publicado em 1960, para o reconhecimento da enorme influência que a propriedade exerce sobre os resultados do mercado. O "Teorema de Coase" pressupõe que, quando os custos de transação forem nulos ou irrisórios, a alocação inicial de direitos, efetuada pelo ordenamento jurídico, não influirá sobre o resultado da disputa em torno das externalidades, pois os agentes afetados acabarão por encontrar uma forma de resolvê-la por intermédio de um processo de autocomposição (barganha), no sentido de distribuição mais eficiente dos recursos existentes na economia. Portanto, quando as partes podem negociar sem custos e com possibilidade de obter benefícios mútuos, o resultado das transações será eficiente, independentemente de como estejam determinados os direitos de propriedade. O Teorema de Coase permite constatar que, para corrigir alocações ineficientes de recursos, os governos devem criar instituições capazes de minimizar os custos de transação, prestigiando mecanismos simples, flexíveis e baratos que facilitem o processo de barganha, permitindo, assim, que os recursos sejam alocados ao seu uso mais eficiente.

${ }^{42}$ COOTER, Robert; ULEN, Thomas. Law and Economics. Addison Wesley, 5th ed., 2008, p. 97.

${ }^{43}$ Id. ibid.
} 
modo a permitir que sejam alocados ao seu melhor uso. Daí a constatação de que a propriedade constitui o fundamento para a alocação de recursos e distribuição de riqueza na sociedade.

Essas premissas constituem os fundamentos econômicos do direito da propriedade sobre bens tangíveis. Entretanto, muitos passaram a adotar esses fundamentos, em especial o problema da "Tragédia dos Comuns", como justificativa também para a propriedade intelectual. Nesse sentido, LANDES e POSNER afirmam que a análise econômica não pode perder de vista a relação de continuidade entre propriedade física e intelectual, e a utilidade em recorrer aos pressupostos econômicos daquela para facilitar a compreensão desta. ${ }^{44}$

No entanto, ainda que os bens intelectuais possam ser considerados direitos subjetivos patrimoniais privados, passíveis de ser transacionados no mercado, a propriedade intelectual possui justificativas econômicas distintas em relação à propriedade física. Enquanto o fundamento econômico primordial da propriedade física é permitir a internalização das externalidades negativas, de modo a resolver um problema essencialmente alocativo, a principal justificativa econômica da propriedade intelectual é a necessidade de resolver o problema do bem público "informação", permitindo que o criador de novas invenções, tecnologias ou expressões do conhecimento possa apropriar-se do valor econômico de sua criação, isto é, estabelecendo incentivos razoáveis à criação de novas informações socialmente úteis e valiosas.

Conforme ensina Mark LEMLEY, ao contrário do que ocorre com a propriedade física, na propriedade intelectual todas as externalidades são em geral positivas, o que torna ilógico, para não dizer absurdo, cogitar da possibilidade de uma "tragédia da informação comum". Ora, a ideia da teoria da "Tragédia dos Comuns" tem como pressuposto o esgotamento de um recurso natural escasso em consequência de sua exploração ou utilização excessiva, enquanto a informação, por ser um bem público não rival, jamais poderá exaurir-se em razão de seu consumo excessivo. Em outras palavras, a utilização da informação não impõe custos sobre os demais. E justamente pelo fato de seu consumo ser não rival, a informação não apresenta qualquer risco de que ocorra algo semelhante à tragédia descrita por HARDIN. Pelo contrário, a utilização, cópia e

\footnotetext{
${ }^{44}$ LANDES, William M.; POSNER, Richard A. Economic Structure of Intellectual Property, p. 11.
} 
disseminação da informação só faz beneficiar a coletividade, estando muito longe de ser uma tragédia. ${ }^{45}$

Assim, pode-se afirmar que enquanto a propriedade física pressupõe a necessidade de internalização das externalidades negativas, a propriedade intelectual envolve somente a internalização de externalidades positivas, de modo a permitir que o autor ou inventor aproprie-se do valor econômico da informação criada, não apenas recuperando os custos fixos incorridos na criação, mas também sendo remunerado por sua contribuição ao patrimônio científico, tecnológico e cultural da sociedade. ${ }^{46}$

Por fim, deve-se destacar que, ao contrário da propriedade física, a propriedade intelectual implica custos sociais significativos que devem ser levados em consideração na formulação de políticas públicas. O objetivo da propriedade intelectual não é apenas a proteção do autor e inventor mediante a criação de incentivos à inovação técnica e cultural, mas principalmente o desenvolvimento econômico e social resultante do progresso científico, tecnológico e cultural.

Com essa ideia em mente, analisamos a seguir como as normas de propriedade intelectual lidam com os conflitos de interesses públicos e privados decorrentes da proteção conferida pelas patentes e direitos autorais, bem como com os valores afetados direta ou indiretamente por essa proteção legal.

\subsubsection{Os custos sociais resultantes da proteção da propriedade intelectual}

Ao contrário da propriedade física em geral, os direitos de propriedade intelectual tendem a resultar na criação de informações socialmente úteis e economicamente valiosas, o que torna a necessidade de difusão dessas informações e de acesso pela coletividade, em especial consumidores e concorrentes, uma questão de

\footnotetext{
${ }^{45}$ Nas palavras de LEMLEY, “(...) copying information actually multiplies the available resources, not only by making a new physical copy but spreading the idea and therefore permitting others to use and enjoy it. The result is that rather than a tragedy, an information commons is a 'comedy' in which everyone benefits. The notion that information will be depleted by overuse simply ignores basic economics". LEMLEY, Mark A. Property, Intellectual Property, and Free Riding. Stanford Law School, John M. Olin Program in Law and Economics, Working Paper n. 291, August 2004, p. 26.

46 Nesse contexto, é interessante destacar o entendimento de MAGGIOLINO, que afirma que as patentes e direitos autorais são ferramentas de alocação e apropriação ("allocative and apropriability tools"). São ferramentas alocativas porque a mera existência da propriedade sobre a informação permite que seu titular lhe atribua um valor e a negocie no mercado. E são ferramentas de apropriação porque permitem que os agentes econômicos capturem o valor econômico e social dos bens intelectuais. MAGGIOLINO,
} 
interesse público. Por outro lado, a exclusividade conferida pelos direitos de propriedade intelectual restringe o acesso de terceiros aos bens objeto de proteção, já que possibilita que sejam cobrados preços acima do custo marginal como forma de retribuição ao titular desses direitos. Esses custos sociais podem ser ainda mais elevados quando as leis de propriedade intelectual são excessivamente protecionistas em favor dos titulares de direitos exclusivos, desviando a finalidade social para a qual a proteção das criações intelectuais foi originalmente concebida, qual seja, estimular a inovação em benefício do desenvolvimento econômico e do progresso científico, tecnológico e cultural.

São diversos os custos sociais decorrentes da proteção dos direitos de propriedade intelectual, podendo ser maiores ou menores a depender da extensão e escopo desses direitos, assim como do prazo legal de proteção, dentre outros fatores. Ressalte-se que as patentes de invenção tendem a resultar em custos sociais mais significativos do que os direitos autorais, dado o seu escopo naturalmente mais amplo. ${ }^{47}$

Deve-se destacar, primeiramente, o custo de administração de um sistema de propriedade intelectual, o que no caso das patentes tende a ser elevado, não apenas pelo tempo e recursos humanos e financeiros despendidos no exame técnico de pedidos de patentes pelos órgãos competentes, mas também no que concerne aos custos de transação resultantes das incertezas sobre a delimitação do escopo da invenção protegida, levando, muitas vezes, a longas disputas judiciais, tanto no que concerne aos casos de infração, como de anulação de patente. $^{48}$

Mariateresa. Intellectual Property and Antitrust: A Comparative Economic Analysis of US and EU Law. Celtenham: Edward Elgar, 2011, p. 33.

${ }^{47}$ Isso porque as patentes protegem ideias inventivas consubstanciadas na solução de problemas técnicos, enquanto os direitos autorais, ao contrário, protegem obras intelectuais, expressões originais decorrentes da criação do espírito humano que estejam fixadas em algum suporte, excluindo a possibilidade de proteção das ideias que são de uso comum. Desse modo, é possível constatar que o escopo de proteção das patentes tende a ser mais amplo do que o escopo de proteção conferido pelo direito autoral, pois enquanto as patentes protegem as ideias contidas no relatório descritivo e reivindicações, os direitos autorais protegem apenas expressões originais, permitindo que diversas obras intelectuais explorem uma mesma ideia ou tema.

${ }^{48}$ Como se sabe, a descrição contida no relatório e nas reivindicações constantes de um pedido de patente muitas vezes pode não ser precisa, não definindo claramente os limites exatos da proteção conferida pela patente. Essa deficiência pode gerar incertezas, na medida em que terceiros nem sempre saberão o que podem e o que não podem fazer diante da existência de uma invenção patenteada. Diversos são os casos em que o titular de uma patente ingressa com ação de infração por simplesmente suspeitar que o produto lançado por seu concorrente no mercado viola sua patente. Se a violação ocorreu ou não, dependerá sempre de uma análise muito cuidadosa, com a participação de técnicos e peritos no assunto, bem como da sensibilidade e expertise da autoridade julgadora em matéria de propriedade industrial. Uma ação como essa, além de custosa, pode ser demorada, principalmente se envolver aspectos complexos e excessivamente técnicos. Da mesma forma, uma ação de nulidade de patente pode gerar o mesmo nível de incerteza, uma vez que a discussão sobre ausência ou não de requisitos de patenteabilidade, principalmente no que concerne ao 
Destacam-se também os custos sociais decorrentes da duplicação de esforços entre concorrentes para a obtenção de patentes, o que os economistas chamam de "patent races". A possibilidade de obtenção de um "monopólio" conferido pela patente para a exploração de uma determinada invenção, somada à vantagem competitiva que esse "monopólio" pode ser capaz de conferir ao titular do direito patentário, induz a uma corrida para ser o primeiro a inovar, tendo em vista que somente o primeiro que depositar o pedido de patente junto ao órgão responsável será beneficiado pela concessão da patente. Essa corrida pode resultar em substanciais desperdícios de recursos, uma vez que os esforços daqueles que perderam a corrida não terão, em princípio, retorno social.

Por outro lado, a teoria econômica da "patent race" é questionável, na medida em que os esforços empregados pelos "perdedores" da corrida não devem ser considerados desperdício de recursos, uma vez que as informações obtidas por meio da atividade de pesquisa poderão ser aplicadas no desenvolvimento de invenções alternativas, ou até mesmo empregadas em outras invenções. ${ }^{49}$ A corrida pela inovação gera mais externalidades positivas do que negativas, uma vez que permite uma aceleração no desenvolvimento de novas tecnologias, levando ao acirramento da concorrência pela diferenciação de produtos. ${ }^{50}$

Há também os custos sociais resultantes das atividades de lobby por parte de grupos de pressão organizados, com o objetivo de interferir diretamente no âmbito do Poder Legislativo para a aprovação de leis favoráveis aos interesses privados de determinados setores industriais ou empresariais, geralmente representados por associações

requisito da atividade inventiva, geralmente envolve aspectos excessivamente técnicos que requerem análise cuidadosa, tornando o processo custoso e demorado.

${ }^{49}$ Nesse contexto, LANDES e POSNER afirmam que: "Two qualifications to the economic criticism of patent races should be noted. First, the research expenditure by the losers of the race may not be wasted even if the race does not accelerate the inventive process by a day, for the expenditures will generate information that the losers may be able to use in other projects. Second, patent races need not produce any social waste at all in cases, which are particularly common in the pharmaceutical drug industry, in which there are as it were multiple prizes and hence more than one winner. For example, SSRIs (selective serotonin reuptake inhibitors), such as Prozac, Zoloft, and Paxil, are competing antidepressant drugs, but they are based on different chemicals and so are separately patentable”. LANDES, William M.; POSNER, Richard A. Economic Structure of Intellectual Property, p. 303. No mesmo sentido, SCOTCHEMER afirma que: “(...) patent races can increase the probability of innovation when inventors have different ideas for how to solve a targeted problem". SCOTCHEMER, Suzanne. Innovation and Incentives. Cambridge, Massachusetts: MIT Press, 2006, p. 112.

${ }^{50}$ Segundo BLAIR e COTTER, “(...) patent races may speed up the development of new technology and may have unintended, but beneficial, spillover effects: on the way to discovering one thing, a researcher may discover something else that was unforeseen. In light of these conflicting effects, the theoretical literature on patent races remains equivocal". BLAIR, Roger D.; COTTER, Thomas F. Intellectual Property: Economics and legal Dimensions of Rights and Remedies. Cambridge University Press, 2005, p.18. 
de classe ou sindicatos. Desse modo, essas atividades de "rent seeking" em diversos países e geralmente resultam na ampliação do escopo e na duração dos direitos de propriedade intelectual, acompanhadas da redução recíproca da esfera de liberdade normalmente conferida pela legislação a terceiros (consumidores, concorrentes, pesquisadores etc.) para o uso legítimo dos bens objeto de proteção. ${ }^{52}$

É importante apontar também os potenciais custos associados ao "monopólio" resultante dos direitos de propriedade intelectual. Primeiramente, é necessário fazer as devidas distinções terminológicas. Monopólio no sentido econômico é uma estrutura de mercado em que há apenas um agente econômico ofertante de bens e serviços. O monopolista detém poder de mercado suficiente para restringir a produção e provocar aumento nos preços aos consumidores, resultando no que os economistas chamam de perda de eficiência alocativa e, consequentemente, prejuízos ao bem-estar social, conforme veremos mais adiante. ${ }^{53}$

Contudo, cumpre ressaltar que uma patente ou direito autoral, por si só, não é capaz de conferir monopólio no sentido econômico. A exclusividade concedida pelo Estado ao titular de um direito de propriedade intelectual pode ser compreendida como um

51 O termo rent seeking pode ser definido como busca de privilégios especiais à custa da sociedade. TOLLISON define rent seeking da seguinte forma: "Rent seeking is the expenditure of scarce resources to capture an artificially created transfer". TOLLISON, Robert D. Rent-Seeking: a Survey, in: TOLLISON, Robert D.; CONGLETON, Roger D. (Ed.). The Economic Analysis of Rent Seeking. Aldershoot, England: Edward Elgar Publishing Ltd., 1995, p. 77. No mesmo sentido, BUCHANAN afirma que: "The term rent seeking is designed to describe behavior in institutional settings where individual efforts to maximize value generate social waste rather than social surplus". BUCHANAN, James M. Rent Seeking and Profit Seeking, in: TOLLISON, Robert D.; CONGLETON, Roger D. (Ed.). The economic analysis of rent seeking. Aldershoot, England: Edward Elgar Publishing Ltd., 1995, p. 47.

52 Segundo LEMLEY: "This sort of legislative rent-seeking has proven to be a real problem in intellectual property, particularly in the copyright field, where Congress of late seems willing to give copyright owners whatever they ask for, at least as long as there is no large vested interest making demands on the other side. This rent-seeking is a cost of government-granted intellectual property rights. Indeed, economic theory suggests that private parties will spend up to the total value of the benefit seeking to capture it. LEMLEY, Mark A. Property, Intellectual Property, and Free Riding. Stanford Law School, John M. Olin Program in Law and Economics, Working Paper n. 291, August 2004, p. 42.

53 Eficiência alocativa ou eficiência de Pareto é alcançada quando os recursos escassos da sociedade são alocados ao seu melhor uso, isto é, quando os bens são alocados, por meio do sistema de preços no mercado, para aqueles que os valorizam mais e que estão dispostos a pagar pelo bem. Nesse cenário hipotético de equilíbrio, os preços desses bens no mercado são equivalentes aos seus custos marginais de produção e distribuição, de modo que a soma de todos os agentes econômicos em determinado setor industrial produz a quantidade exatamente correspondente às necessidades e preferências da soma de todos os consumidores, de modo que nenhuma troca ou barganha adicional mutualmente vantajosa poderá ser feita, já que nenhum dos players, vendedores ou compradores, poderá melhorar sua situação sem piorar a situação dos demais. Cf. MOTTA, Massimo. Competition Policy: Theory and Practice. Cambridge University Press, 2004, p. 40; WHISH, Richard. Competition Law. Oxford University Press. 6th ed. 2009, p. 4; GoldBERG, Daniel. Poder de Compra e Política Antitruste. São Paulo: Singular, 2006, p. 28-29. 
monopólio legal sobre a exploração da invenção ou trabalho intelectual protegido, o que não significa necessariamente domínio sobre o mercado. Aliás, raríssimas são as situações em que um direito de propriedade intelectual efetivamente confere monopólio no sentido econômico ao seu titular, conforme veremos mais adiante.

De qualquer modo, a função da propriedade intelectual é essencialmente conferir ao titular do direito exclusivo certo grau de poder de mercado que lhe permita impor preços acima do custo marginal e, assim, internalizar o valor econômico de sua criação intelectual. Em todo caso, esses preços supracompetitivos podem resultar em perdas de eficiência alocativa, já que nem todos os consumidores estarão dispostos a pagar mais do que o custo marginal da cópia do bem intelectual protegido. Numa perspectiva estática da concorrência, conforme veremos mais adiante, essa perda de eficiência implica custos sociais significativos, a depender das características do mercado relevante em questão. $^{54}$

Por essa mesma razão, a propriedade intelectual também pode implicar custos sociais associados a perdas de eficiência dinâmica ${ }^{55}$, uma vez que, conforme já mencionado, o titular de uma patente ou direito autoral poderá negar a terceiros (seus concorrentes) acesso à sua criação intelectual para desenvolverem inovações cumulativas ou incrementais, ou até mesmo melhorias ou aperfeiçoamento dos produtos e tecnologias já existentes (follow-on innovations). Afinal, nenhuma inovação surge do nada, de modo que o processo criativo é naturalmente cumulativo. As informações conhecidas, estejam elas protegidas por direitos de propriedade intelectual ou em domínio público, constituem importante fonte ou insumo para a criação de novas informações que agregam valor social. $^{56}$

\footnotetext{
${ }^{54}$ Nesse sentido, vale a pena citar o entendimento de LEMLEY: “(...) the intellectual property system permits owners to raise price above marginal cost, creating deadweight losses by raising the price to consumers. If it doesn't do that, it isn't working. This does not mean that all intellectual property rights are monopolies in the antitrust sense, of course. Indeed, few are. But it does not mean that consumers who are willing to pay more than it costs to make a copy of a work will be denied access to that work". LEMLEY, Mark A. Property, Intellectual Property, and Free Riding. Stanford Law School, John M. Olin Program in Law and Economics, Working Paper n. 291, August 2004, p. 36.

${ }^{55}$ A eficiência dinâmica é associada à inovação e se refere à possibilidade de os agentes econômicos introduzirem novos produtos, e processos e tecnologias no mercado.

${ }^{56}$ Nesse sentido, STIGLITZ afirma que: "Initial knowledge is a key input into the production of further knowledge, and thus the design of the patent system can dramactically affect the overall pace of innovation. An excessively broad patent system (for example, with long-lived patents of broad scope) can raise the price of one of the most vital imputs into innovative process and thus reduce the pace of follow-on innovations, even as it may provide returns to those making the original innovation". STIGLITZ, Joseph E. Knowledge as a Global Public Good, in: KAUL, Inge; GRUNBERG, Isabelle; STERN, Marc A. (Coord.). Global Public
} 
Esse "controle" sobre inovações cumulativas pode levar a situações típicas conhecidas da jurisprudência antitruste norte-americana, tais como "hold-ups" e "patent thickets", que, como veremos mais adiante, são associadas à enorme quantidade de patentes detidas por diferentes titulares, o que impede um terceiro de ingressar no mercado sem a obtenção de diversas licenças junto aos respectivos titulares, o que muitas vezes se torna uma tarefa quase impossível. O Professor SALOMÃo FILHO também menciona estratégias de "patentes defensivas", que assim define:

As patentes defensivas são parte de estratégias anticoncorrenciais bastante comuns. Através das táticas chamadas blocking e fencing, as empresas procuram - através, respectivamente, da compra sistemática de todas as novas patentes e sua não utilização ou, então, através do pedido de patenteamento de todas as possíveis alternativas a serem utilizadas pelos concorrentes - impedir o acesso de novos concorrentes ao mercado $^{57}$

Como se pode observar, são diversos os custos sociais associados à proteção conferida pelo Estado à propriedade intelectual. Por essa razão, os direitos de propriedade intelectual normalmente sofrem limitações normativas intrínsecas, inerentes ao próprio sistema, conforme veremos a seguir.

\subsubsection{Equilíbrio entre interesses públicos e privados: as limitações e exceções à proteção da propriedade intelectual}

Como bem lembra LEMLEY, a teoria econômica ensina que, para garantir equilíbrio e eficiência, os direitos de propriedade intelectual devem ser conferidos apenas nos estritos limites necessários a permitir que autores e inventores recuperem seus custos

Goods: International Cooperation in the 21st Century, United Nations Development Program (UNDP), Oxford University Press, 1999, p. 312. MAGGIOLINO acrescenta o seguinte: “(...) consider that historically IPRs resulted from balancing two opposing interests: the interest to incentivize and protect first generations of inventors and creators through granting them exclusive rights, and the interest to spur further generation of innovators and creators by enlarging the public domain. Especially in industries characterized by cumulative knowledge and/or overlapping cross-markets knowledge, it is likely that patents and copyrights on first innovations can decrease R\&D incentives and block future innovations. Indeed, if one conceives of innovative output as a natural outcome of complex process, then strengthening pioneer patents and copyrights and, hence, protecting initial innovators the option to monopolize subsequent innovations, can have a surprisingly depressing effect over subsequent R\&D investments". MAGGIOLINO, Mariateresa. Intellectual Property and Antitrust: A Comparative Economic Analysis of US and EU Law. Celtenham: Edward Elgar, 2011, p. 36-37.

${ }^{57}$ SALOMÃO FILHO, Calixto. Direito Industrial, Direito Concorrencial e Interesse Público, in: Revista de Direito Público da Economia. Belo Horizonte, ano 2, n. 7, p. 43, jul./set. 2004. 
fixos médios incorridos na criação intelectual. ${ }^{58}$ Essa ideia de equilíbrio nos permite afirmar que a propriedade intelectual não é um fim em si mesmo, mas um meio para atender ao interesse público, ou seja, um instrumento de estímulo para a criação de informações úteis que tenham valor econômico para o seu criador e também para a coletividade.

Nesse sentido, REMÉDIO MARQUES ensina que:

Em termos de política legislativa, há que procurar estabelecer um frágil equilíbrio entre o interesse público na utilização livre das inovações tecnológicas, das obras (e das demais prestações empresariais e intelectuais protegidas por direitos de propriedade intelectual, com o que assim se assegura o acesso à ciência, à tecnologia e à cultura) e o interesse privado (egoístico) do titular do direito em manter um exclusivo que mais facilmente o pode colocar numa posição monopolista em termos económicos, contanto que o seu direito industrial tenha como objeto $o$ conhecimento tecnológico (v.g., soluções técnicas vazadas em produtos ou processos), informações (v.g., armazenadas em bases de dados) ou esquemas para acção (v.g., programas de computador) relacionados com a produção de bens ou serviços que sejam objeto de procura no mercado económico.

Por esse motivo, os tratados internacionais sobre a matéria, assim como a maioria das legislações nacionais, estabelecem limites e exceções à aquisição e ao exercício dos direitos de propriedade intelectual, possibilitando que os benefícios sociais decorrentes da inovação do progresso científico, tecnológico e cultural se sobreponham aos eventuais custos sociais decorrentes da exclusividade conferida aos titulares desses direitos. ${ }^{59}$ Trata-se de mecanismos que visam conferir um equilíbrio mais eficiente ao sistema de propriedade intelectual.

\footnotetext{
${ }^{58}$ LEMLEY, Mark A. Property, Intellectual Property, and Free Riding. Stanford Law School, John M. Olin Program in Law and Economics, Working Paper n. 291, August 2004, p. 43.

${ }^{59}$ Ao discorrer especificamente sobre os problemas estruturais das patentes em setores socialmente sensíveis, Calixto SALOMÃo FILHO destaca que os limites ao seu exercício são plenamente justificáveis: “(...) les problèmes structurels spécifiques aux brevets ne doivent pas être négligés. Ces problèmes sont d'autant plus importants lorsque les secteurs concernés sont socialement sensibles. Dans ces secteurs, les consequences negatives du fait des restrictions de l'information et de l'accèss aux biens (produits du monopole protégé par les brevets) sont décisives. Les limites structuralles imposes aux brevets sont alors justifies". SALOMÃO FILHO, Calixto. Histoire Critique des Monopoles: Une Perspective Juridique et Économique, Paris: LGDJ, Collection Droit \& Économie, 2010, p. 99.
} 
No plano internacional, esse equilíbrio pode ser encontrado em diversos dispositivos do Acordo TRIPS/OMC, com base no princípio insculpido no Artigo $7^{\circ}$, que determina que "a proteção e a aplicação de normas de proteção dos direitos de propriedade intelectual devem contribuir para a promoção da inovação tecnológica e para a transferência e difusão da tecnologia, em benefício mútuo de produtores e usuários de conhecimento tecnológico e de uma forma conducente ao bem-estar social e econômico e a um equilíbrio entre direitos e obrigações". (grifo nosso)

No Brasil, o art. 5, XXIX, da Constituição Federal determina que "a lei assegurará aos autores de inventos industriais privilégio temporário para sua utilização, bem como proteção às criações industriais, à propriedade das marcas, aos nomes de empresas e a outros signos distintivos, tendo em vista o interesse social $e \quad o$ desenvolvimento tecnológico e econômico do país". (grifo nosso) Soma-se esse dispositivo à limitação constitucional imposta pela função social da propriedade, prevista nos arts. $5^{\circ}$, XXIII, e 170 da Carta Magna. ${ }^{60}$

Dispositivo semelhante consta na Constituição Federal dos Estados Unidos, que estabelece que "o Congresso deverá ter o poder para promover o progresso da ciência e das artes úteis, garantindo, por tempo limitado, aos autores e inventores o direito exclusivo aos seus escritos ou descobertas" (Artigo 1, Seção 8, da Constituição Federal dos Estados Unidos). (grifo nosso)

A partir da análise dos dispositivos legais acima citados, nota-se que a proteção conferida aos direitos de propriedade intelectual é sempre condicionada ao atendimento de um interesse social maior, como a promoção da inovação, a transferência de tecnologia, o desenvolvimento tecnológico e econômico, o progresso das ciências e das artes, traduzindo uma ideia de equilíbrio e ponderação dos interesses públicos e privados envolvidos. Nesse contexto, é possível afirmar que os limites e exceções impostos pelas normas de proteção da propriedade intelectual funcionam como filtros normativos a proteger as informações

60 Embora o art. 5, XXVII, preveja que "aos autores pertence o direito exclusivo de utilização, publicação ou reprodução de suas obras, transmissível aos herdeiros pelo tempo que a lei fixar", sem a mesma cláusula finalística prevista no inciso XXIX para as criações industriais, BARBOSA entende que "no que for objeto de propriedade (ou seja, no alcance dos direitos patrimoniais), o direito autoral também está sujeito às limitações constitucionalmente impostas em favor do bem comum - a função social da propriedade de que fala o Art. $5^{\circ}$, XXIII". BARBOSA, Denis Borges. A Criação de um Ambiente Competitivo no Campo da Propriedade Intelectual: O Caso Sul-Americano, in: Centre for Trade and Sustainable Development, nov. 2005, p. 25. 
que estão em domínio público, assim como a garantir o incentivo adequado e eficiente à inovação, sem restringir desnecessariamente a concorrência.

A principal limitação aos direitos de propriedade intelectual é temporal. Tanto as patentes como os direitos autorais conferem exclusividade apenas durante determinado prazo, após o qual todos os conhecimentos assim criados ingressam no domínio público, podendo ser livremente aproveitados por toda a coletividade. ${ }^{61}$ A limitação do escopo da proteção também é de extrema importância, já que define a extensão da exclusividade conferida pelo direito de propriedade intelectual. No caso das patentes, a extensão da proteção conferida depende das reivindicações, interpretadas com base no relatório descritivo. ${ }^{62}$ Dessa forma, o escopo da patente poderá ser mais amplo ou mais restrito, a depender das próprias características da invenção e da forma como suas reivindicações forem redigidas. Já o escopo do direito autoral é mais limitado do que o das patentes, pois não admite a proteção das ideias, apenas expressões originais do conhecimento que estejam fixadas em algum suporte material. ${ }^{63}$ Por outro lado, o escopo mais limitado do direito autoral é compensado pelo seu prazo maior de proteção (70 anos após o falecimento do autor), enquanto o escopo mais amplo das patentes é compensado pelo seu prazo menor (20 anos contados do depósito do pedido). ${ }^{64}$

\footnotetext{
${ }^{61} \mathrm{O}$ Acordo TRIPS estabelece para os direitos autorais um prazo de proteção de no mínimo 50 anos contados da publicação ou elaboração da obra, enquanto que, para as patentes, determina um prazo mínimo de 20 anos contados a partir da data de depósito do pedido de patente. No Brasil, enquanto o prazo de proteção das patentes é de 20 anos (art. 40 da Lei n. ${ }^{\circ}$ 9.279/96), o prazo de proteção dos direitos patrimoniais do autor é de 70 anos contados de $1^{\circ}$ de janeiro do ano subsequente ao falecimento do autor (art. 41 da Lei n. ${ }^{\circ}$ 9.610/98). Para os programas de computador tutelados sob o regime de direito autoral o prazo de proteção é fixado em 50 anos contados a partir de $1^{\circ}$ de janeiro do ano subsequente ao de sua publicação ou, na ausência desta, da sua criação (art. $2^{\circ}, \S^{\circ}{ }^{\circ}$ da Lei n. $\left.{ }^{\circ} 9.609 / 1998\right)$.

${ }^{62}$ Cf. No Brasil, essa regra está expressamente prevista no art. 41 da Lei n. ${ }^{\circ}$ 9.279/96.

${ }^{63}$ Por essa razão, é plenamente possível a elaboração de diversas obras intelectuais originais que explorem uma mesma ideia ou tema, pois o que importa é tão somente a forma como essa ideia ou tema é trabalhado pelo autor.

${ }^{64}$ Sobre o assunto, Claudio R. BARBOSA afirma com muita propriedade que a relação entre escopo e duração opera como uma compensação que visa garantir equilíbrio na proteção: “(...) o escopo e o tempo de proteção são variáveis inversamente proporcionais, ou seja, quanto maior o escopo da proteção, menor o tempo de exclusividade da informação. Como visto, o direito autoral tem escopo limitado, acarretando inclusive problemas para proteger (com eficiência) os programas de computador; todavia o direito autoral confere exclusividade por um longo período (por exemplo, no Brasil os direitos patrimoniais perduram por setenta anos após o falecimento do autor). A proteção às criações industriais, por outro lado, tem escopo mais amplo de proteção, delimitada pelas reinvindicações. Isto implica um prazo menor, que em linhas gerais, no Brasil, tem uma duração de quinze anos para as patentes de modelo de utilidade, e de vinte anos para as patentes de invenção)". BARBOSA, Cláudio R. Propriedade Intelectual: Introdução à Propriedade Intelectual como Informação. Rio de Janeiro: Campus Jurídico, 2008, p. 197-198.
} 
Além das limitações de escopo e duração, destacam-se também outras limitações e exceções que permitem conferir maior equilíbrio ao sistema, especialmente no que concerne à possibilidade de filtrar o que pode e o que não pode ser objeto de proteção. No que concerne às patentes, uma invenção somente será protegida se cumprir os requisitos de patenteabilidade, quais sejam: (i) novidade; (ii) atividade inventiva; e (iii) aplicação industrial (Artigo 27.1 do Acordo TRIPS). ${ }^{65}$ Esses requisitos funcionam como um filtro que premia tão somente invenções úteis e com mérito inovador, decorrentes dos esforços e investimentos empregados nas atividades de pesquisa e desenvolvimento, eliminando o patenteamento de inventos menores ou sem utilidade, incapazes de agregar valor social e enriquecer o patrimônio científico e tecnológico. ${ }^{66}$

Além dos requisitos de patenteabilidade, há normas que permitem excluir determinadas matérias da possibilidade de serem patenteadas, seja por imperativos de ordem pública, moralidade, para permitir a proteção da vida ou da saúde humana, animal ou vegetal ou para evitar sérios prejuízos ao meio ambiente (Artigo 27.2 do Acordo TRIPS). ${ }^{67}$ É possível, ainda, excluir a patenteabilidade de determinadas matérias por não poderem ser consideradas como invenções (Artigo 27.3 do Acordo TRIPS), tais como as descobertas, teorias científicas, métodos comerciais, obras literárias, arquitetônicas, artísticas e científicas ou quaisquer criações estéticas, técnicas e métodos operatórios ou cirúrgicos, métodos terapêuticos ou de diagnóstico, o todo ou parte de seres vivos naturais e materiais biológicos encontrados na natureza, dentre outros. ${ }^{68}$

Há também outras limitações normativas de extrema importância para minimizar os custos sociais das patentes, como: (i) a doutrina da exaustão de direitos; (ii) a licença compulsória; e (iii) a obrigatoriedade de divulgação do relatório descritivo das reivindicações.

\footnotetext{
${ }^{65}$ Cf. art. $8^{\circ}$ da Lei n. ${ }^{\circ} 9.279 / 96$.

${ }^{66} \mathrm{O}$ primeiro requisito, da novidade, impede a concessão de patente sobre algo que já tenha sido inventado anteriormente e, portanto, esteja compreendido no estado da técnica, independentemente de ainda estar protegido por patente ou em domínio público. $\mathrm{O}$ requisito da atividade inventiva condiciona a concessão de patente a invenções que efetivamente tenham mérito inovador, constituindo um passo adiante em relação ao estado da técnica, impedindo a proteção de invenções triviais ou excessivamente óbvias. Já o requisito da aplicação industrial tem como finalidade estimular o desenvolvimento de invenções úteis e investimentos em pesquisa aplicada, excluindo a possibilidade de proteção à pesquisa básica. Cf. arts. 11 a 15 da Lei n. ${ }^{\circ}$ $9.279 / 96$.

${ }^{67}$ Cf. art. 18 da Lei n. ${ }^{\circ} 9.279 / 96$.

${ }^{68}$ Cf. art. 10 da Lei n. ${ }^{\circ} 9.279 / 96$.
} 
A doutrina da exaustão prevê que, uma vez que o titular da patente tenha auferido o benefício econômico da exclusividade por meio da comercialização do produto objeto de proteção, não poderá controlar as vendas subsequentes do mesmo produto. ${ }^{69}$ Essa limitação é importante para permitir a livre circulação de produtos protegidos por patentes no mercado. ${ }^{70}$

Já a licença compulsória constitui instrumento complementar de política pública, particularmente importante para os países em desenvolvimento. O Artigo 31 do Acordo TRIPS prevê as circunstâncias nas quais poderá ser determinado o licenciamento compulsório de patentes, permitindo que terceiros explorem seu objeto de forma temporária e não exclusiva, sem prejuízo dos direitos do respectivo titular, a quem será devida a justa remuneração, e respeitadas as condicionantes estabelecidas pelo Acordo. ${ }^{71}$ Dentre as hipóteses que autorizam o licenciamento compulsório, destacamos: (i) situações emergência nacional e interesse público (Artigo 31(b) $)^{72}$; (ii) quando restar caracterizada situação de dependência de uma patente em relação a outra, na hipótese em que o objeto da patente dependente constituir substancial progresso técnico em relação à patente anterior e o titular não realizar acordo com o titular da patente dependente para exploração daquela patente anterior (Artigo 31(1) $)^{73}$; e (iii) para remediar práticas anticompetitivas após o devido processo administrativo ou judicial (Artigo $31(\mathrm{k}))^{74}$. No Brasil, além dessas hipóteses, há possibilidade de licenciamento compulsório em caso de não exploração do

\footnotetext{
${ }^{69}$ Cf. art. 43, IV, da Lei n. ${ }^{\text {9 } 9.279 / 96 . ~}$

${ }^{70}$ Para um estudo mais aprofundado do tema, com ênfase na exaustão internacional de direitos e importação paralela, cf. BASSO, Maristela. Propriedade Intelectual e Importação Paralela. São Paulo: Atlas, 2011.

71 De acordo com José Carlos Vaz e DiAs: "Licença compulsória pode ser definida como a outorga de direitos de utilização de uma patente a um terceiro, por determinação governamental e sem autorização prévia do titular da patente, conforme o procedimento de concessão descrito pela lei de direito da propriedade industrial e direito antitruste". DIAS, José Carlos Vaz e. Licença Compulsória de Patentes e o Direito Antitruste, in: Revista da ABPI n. 54, São Paulo: ABPI, p. 03, 2001.

72 No Brasil, cf. art. 72 da Lei n. 9.279/96, que estabelece que "nos casos de emergência nacional ou interesse público, declarados em ato do Poder Executivo Federal, desde que o titular da patente ou seu licenciado não atenda a essa necessidade, poderá ser concedida, de ofício, licença compulsória, temporária e não exclusiva, para a exploração da patente, sem prejuízo dos direitos do respectivo titular".

${ }^{73}$ Nos termos do art. 70 da Lei n. 9 9.279/96: "A licença compulsória será ainda concedida quando, cumulativamente, se verificarem as seguintes hipóteses:

I - ficar caracterizada situação de dependência de uma patente em relação a outra;

II - o objeto da patente dependente constituir substancial progresso técnico em relação à patente anterior; $e$ III - o titular não realizar acordo com o titular da patente dependente para exploração da patente anterior".

${ }^{74}$ Nos termos do art. 68, caput, da Lei n. ${ }^{\circ}$ 9.279/96, “o titular ficará sujeito a ter a patente licenciada compulsoriamente se exercer os direitos dela decorrentes de forma abusiva, ou por meio dela praticar abuso de poder econômico, comprovado nos termos da lei, por decisão administrativa ou judicial".
} 
objeto da patente, falta de uso integral do processo patenteado, bem como a comercialização que não satisfizer às necessidades do mercado. ${ }^{75}$

A obrigatoriedade de divulgação da informação contida no relatório e reivindicações constantes do pedido de patente, de forma clara e suficiente, também constitui importante contrapartida social, já que permite que todos tenham acesso à informação contida na invenção, ainda que não possam explorá-la comercialmente durante o prazo de proteção. $^{76}$ Essa contrapartida permite a automática circulação do conhecimento, fazendo com que a patente cumpra uma função social informacional tripla: (i) impedir os custos sociais decorrentes da duplicação de esforços para o desenvolvimento de novas invenções; (ii) permitir que terceiros utilizem esses conhecimentos para fins de pesquisa (uso experimental), possibilitando o pronto ingresso de cópias da invenção no mercado após a expiração da patente e o consequente aumento da concorrência; e (iii) permitir que terceiros utilizem esses conhecimentos para a pesquisa e desenvolvimento de outras invenções alternativas ou incrementais, mitigando eventual poder de mercado que a patente possa conferir ao seu titular. ${ }^{77}$

Finalmente, é imperioso mencionar as diretrizes estabelecidas pelo Acordo TRIPS para os Membros da OMC estabelecerem em suas legislações nacionais exceções legítimas à exploração de direitos de propriedade intelectual, como pode se observar nos

\footnotetext{
${ }^{75}$ Conforme o disposto no art. $68, \S 1^{\circ}$, incisos I e II da Lei n. ${ }^{\circ}$ 9.279/96: "ensejam, igualmente, licença compulsória: (i) a não exploração do objeto da patente no território brasileiro por falta de fabricação ou fabricação incompleta do produto, ou, ainda, a falta de uso integral do processo patenteado, ressalvados os casos de inviabilidade econômica, quando será admitida a importação; ou (ii) a comercialização que não satisfizer às necessidades do mercado".

${ }^{76}$ Nos termos do art. 24 da Lei n. ${ }^{\circ}$ 9.279/96: "O relatório deverá descrever clara e suficientemente o objeto, de modo a possibilitar sua realização por técnico no assunto e indicar, quando for o caso, a melhor forma de execução".

${ }^{77}$ Do ponto de vista econômico, essa contrapartida social é uma resposta aos problemas inerentes ao segredo industrial e ao poder de mercado que uma patente poderia ser capaz de conferir ao seu titular. Isso porque, na ausência de um sistema de patentes, inventores envidariam esforços na tentativa de manter suas invenções em segredo, provocando uma redução no estoque de informações e conhecimentos disponíveis para a sociedade. Ademais, a publicação do relatório descritivo e reivindicações inibe o eventual poder de mercado conferido ao titular da patente, na medida em que seus concorrentes poderão utilizar essa informação como base para a pesquisa e desenvolvimento de outras invenções alternativas ou incrementais (atividade conhecida como "inventing around"), sem violar a patente. A divulgação da informação, portanto, permite reduzir os custos para que outros agentes econômicos ingressem no mesmo mercado com soluções técnicas distintas, permitindo um aumento potencial da concorrência. Nesse sentido, REMÉDIO MARQUES afirma que: “(...) a exigência de as invenções deverem ser descritas e reivindicadas de forma clara, concisa e suficiente (de jeito a que um perito na especialidade as possa razoavelmente executar), a par do dever de o requerente de direitos sobre desenhos e modelos juntar os desenhos das características bidimensionais ou tridimensionais cuja protecção visa alcançar, são mecanismos indutores do enriquecimento do patrimônio técnico-cultural existente num dado momento". REMÉDIO MARQUES, J. P. Propriedade Intelectual e Interesse Público, in: Boletim da Faculdade de Direito da Universidade de Coimbra, n. ${ }^{\circ}$ 79, 2003, p. 338.
} 
Artigos 13, 26 e 30 do Acordo, aplicáveis respectivamente aos direitos autorais, desenhos industriais e patentes de invenção. Esses dispositivos tratam da regra geral do chamado "teste dos três passos" (three-step test), que estabelece exceções à proteção dos direitos de propriedade intelectual, permitindo a utilização legítima desses direitos por terceiros, sem implicar violação. Assim, com base no "teste dos três passos", as exceções aos direitos de propriedade intelectual serão legítimas desde que: (i) não conflitem injustificadamente com a exploração normal do direito protegido; (ii) nem prejudiquem injustificadamente o legítimo interesse de seu titular; (iii) devendo-se levar em conta o legítimo interesse de terceiros. $^{78}$

Portanto, é a partir desse "teste dos três passos", estabelecido pelo TRIPS e previsto também em outros tratados internacionais, que as legislações nacionais dos Membros da OMC adotam exceções à exploração de direitos de propriedade intelectual. No caso dos direitos autorais, há exceções que permitem a reprodução de obras intelectuais, em determinadas circunstâncias, sem autorização do detentor dos direitos. A regra do uso legítimo, também conhecida como "fair use" no sistema anglo-americano, permite cópias de obras intelectuais protegidas por direitos autorais, sem autorização dos seus detentores, para determinadas finalidades previstas nas legislações internas dos países. ${ }^{79} \mathrm{Na}$ ausência dessas exceções, os custos de transação para obter autorizações para esses tipos de uso legítimo de obras literárias e artísticas e de programas de computador seriam proibitivos, transformando a proteção aos direitos autorais em entrave à educação, às ciências, à tecnologia e, acima de tudo, à concorrência e à difusão do conhecimento.

\footnotetext{
78 Para uma análise mais aprofundada do teste dos três passos, cf. BASSO, Maristela. As Exceções e Limitações aos Direitos de Autor e a Observância da Regra dos Três Passos (Three Step Test), in: Eduardo Salles Pimenta (Coord.). Direitos Autorais: Estudos em Homenagem a Afonso dos Santos. São Paulo: Revista dos Tribunais, p. 258, 2008.

${ }^{79}$ Ressalte-se que a exceção de uso legítimo é plenamente prevista nos principais tratados sobre a matéria e nas legislações nacionais da grande maioria dos países. No Brasil, essas exceções estão previstas no art. 46 da Lei n. ${ }^{\circ}$ 9.610/98 (Lei de Direitos Autorais), que, por exemplo, prevê que não constitui infração aos direitos autorais a reprodução, em um só exemplar, de pequenos trechos da obra, para uso privado do copista, desde que feita por este, sem intuito de lucro (art. 46, II), bem como a citação em livros, jornais, revistas ou qualquer outro meio de comunicação, de passagens de qualquer obra, para fins de estudo, crítica ou polêmica, na medida justificada para o fim a atingir, indicando-se o nome do autor e a origem da obra (art. 46, III). Da mesma forma, a Lei n ${ }^{\circ}$ 9.610/98 (Lei de Proteção de Programas de Computador) também estabelece exceções de uso legítimo de programas de computador por terceiros, sem resultar em infração, cruciais para permitir uma maior concorrência nesse setor. Tais exceções estão previstas no art. 6 da referida lei que, por exemplo, prevê que não constitui ofensa aos direitos do titular de programa de computador a ocorrência de semelhança de programa a outro, preexistente, quando se der por força das características funcionais de sua aplicação, da observância de preceitos normativos e técnicos, ou de limitação de forma alternativa para a sua expressão (art. $6^{\circ}$, III).
} 
Disposições semelhantes sobre "uso legítimo" podem ser encontradas nas normas que regulam as patentes. ${ }^{80}$ Cite-se como exemplo a exceção de uso experimental, também conhecida como "Exceção Bolar", que permite que terceiros utilizem as informações contidas na patente, mesmo sem autorização do seu titular, meramente para fins de pesquisa científica e tecnológica. Essa exceção é particularmente importante no setor farmacêutico, pois permite que os fabricantes de medicamentos genéricos antecipem os testes sanitários exigidos para fins de aprovação de registro de comercialização, viabilizando o pronto ingresso de genéricos no mercado tão logo expire a patente do medicamento de referência, levando ao aumento da concorrência e à consequente redução dos preços, em benefício da população, que terá mais acesso aos medicamentos. ${ }^{81}$

Como se pode observar, são diversas as limitações e exceções legais, que variam conforme a estrutura, o escopo e as esferas de aplicação de cada um dos direitos de propriedade intelectual, contribuindo para o equilíbrio necessário entre interesses públicos e privados para garantir a eficiência do sistema.

Pelo exposto, pode-se afirmar que as instituições da propriedade intelectual serão eficazes somente se permitirem que o valor econômico das informações seja devidamente apropriado pelos agentes privados que tenham investido na sua criação, com a contrapartida de que essas informações contribuam efetivamente para o enriquecimento do patrimônio científico, tecnológico, literário ou artístico, minimizando os custos sociais decorrentes da restrição temporária ao seu livre acesso e disseminação. Assim, conclui-se que uma proteção excessiva ou exagerada, sem os filtros normativos adequados, seria ineficiente por restringir injustificadamente a concorrência e retirar do domínio público

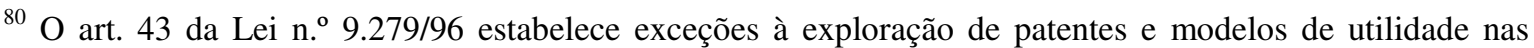
seguintes hipóteses: (i) aos atos praticados por terceiros não autorizados, em caráter privado e sem finalidade comercial, desde que não acarretem prejuízo ao interesse econômico do titular da patente; (ii) aos atos praticados por terceiros não autorizados, com finalidade experimental, relacionados a estudos ou pesquisas científicas ou tecnológicas; (iii) à preparação de medicamento de acordo com prescrição médica para casos individuais, executada por profissional habilitado, bem como ao medicamento assim preparado; (iv) a produto fabricado de acordo com patente de processo ou de produto que tiver sido colocado no mercado interno diretamente pelo titular da patente ou com seu consentimento; (v) a terceiros que, no caso de patentes relacionadas com matéria viva, utilizem, sem finalidade econômica, o produto patenteado como fonte inicial de variação ou propagação para obter outros produtos; (vi) a terceiros que, no caso de patentes relacionadas com matéria viva, utilizem, ponham em circulação ou comercializem um produto patenteado que haja sido introduzido licitamente no comércio pelo detentor da patente ou por detentor de licença, desde que o produto patenteado não seja utilizado para multiplicação ou propagação comercial da matéria viva em causa; e (vii) aos atos praticados por terceiros não autorizados, relacionados à invenção protegida por patente, destinados exclusivamente à produção de informações, dados e resultados de testes, visando à obtenção do registro de comercialização, no Brasil ou em outro país, para a exploração e comercialização do produto objeto da patente, após a expiração do prazo legal de proteção.
} 
informações que poderiam ser utilizadas para a criação de bens intelectuais novos, capazes de agregar valor social. ${ }^{82}$ Da mesma forma, uma proteção frágil ou insuficiente não atenderia ao interesse público, na medida em que não haveria estímulos suficientes para a criação intelectual, implicando redução do bem-estar econômico e social.

Entretanto, a teoria econômica não oferece uma resposta segura sobre quais são os limites e exceções necessários para garantir esse equilíbrio, ou sobre qual o nível ótimo de proteção (escopo e duração) para garantir um sistema eficiente de propriedade intelectual, ou seja, que o valor das inovações supere os custos sociais da proteção. Por essa razão, os sistemas de propriedade intelectual normalmente apresentam falhas, possibilitando tanto situações de proteção excessiva como de proteção insuficiente. ${ }^{83} \mathrm{~A}$ despeito das diferentes teorias econômicas e argumentos empíricos sobre o tema, MAGGIOLINO acredita que a distribuição dos incentivos para inovar e criar é mais do que uma questão de fato ou de teorias: trata-se de uma questão de opinião e ideologia e, dessa forma, uma questão política. ${ }^{84}$

Por fim, é imperioso destacar que nem sempre os filtros normativos constantes da legislação de propriedade intelectual serão suficientes, já que são incapazes de evitar o exercício abusivo desses direitos pelos seus titulares, visando ampliar artificialmente o escopo da proteção conferida ou mesmo restringir o acesso de seus concorrentes ao mercado, o que pode ser extremamente prejudicial à livre concorrência. Em outras palavras, os limites e as exceções legais acima mencionados são muitas vezes insuficientes para impedir que titulares de direitos de propriedade intelectual se aproveitem de lacunas

\footnotetext{
${ }^{81}$ Cf. art. 43, II e VII, da Lei n. ${ }^{\circ}$ 9.279/96.

${ }^{82}$ Nesse sentido, Cláudio R. BARBOSA afirma que "a ineficiência da propriedade intelectual ocorre quando proteções rígidas e amplas são concedidas a bens intelectuais que não agregaram valor e, ao mesmo tempo, representam um grande custo para novas criações de produtos ou serviços”. BARBOSA, Cláudio R. Propriedade Intelectual: Introdução à Propriedade Intelectual como Informação. Rio de Janeiro: Elsevier, 2009, p. 02.

${ }^{83}$ De acordo com HovenKAMP: "At least some IP protection is necessary to encourage innovation. Up to a point the trade-off is positive - that is, as protection increases, the marginal social gains from innovation are greater than the marginal losses from enforcement of exclusionary rights and the transaction costs of negotiating licenses. The problem is that no one knows what the optimal length of time is, or how broad the protection should be. Furthermore, it seems clear that the correct duration for patents and copyrights varies considerably depending on the technology or the market. The term should probably be much shorter in fastmoving industries like software design, and longer in slower-moving industries for durable goods where technology tends to stay in place for long periods". HOVENKAMP, Herbert. The Antitrust Enterprise: Principle and Execution. Harvard University Press, p. 251.

${ }^{84}$ MAgGiolino, Mariateresa. Intellectual Property and Antitrust: A Comparative Economic Analysis of US and EU Law. Celtenham: Edward Elgar, 2011, p. 43.
} 
ou imperfeições constantes na legislação para adotar estratégias anticoncorrenciais com o objetivo de dominar mercados e eliminar a concorrência.

Desse modo, a política de defesa da concorrência passa a servir como espécie de "filtro externo" a disciplinar as condutas de agentes econômicos que abusam de seus direitos de propriedade intelectual como estratégia para restringir ou eliminar a concorrência. Evidentemente, as leis antitruste não interferem na concessão e exercício dos direitos de propriedade intelectual, mas apenas impõem condições para o exercício desses direitos com o objetivo de evitar os efeitos negativos decorrentes de estratégias anticoncorrenciais. ${ }^{85}$ É nesse contexto que as leis de defesa da concorrência servem como instrumentos de política pública complementares às leis de proteção da propriedade intelectual, conforme veremos a seguir.

\subsection{A interface entre propriedade intelectual e direito de concorrência}

A política de defesa da concorrência, ou simplesmente política antitruste, tem como pressuposto fundamental a proteção da concorrência por meio da repressão do abuso do poder econômico, de modo a promover o bem-estar econômico e social. Em outras palavras, é possível afirmar que a política da concorrência refere-se ao conjunto de normas e instituições voltadas à implementação de políticas públicas que visam à competitividade e eficiência dos mercados. ${ }^{86}$ Massimo MotTA faz referência expressa ao conceito de "bem-

${ }^{85}$ De acordo com Gustavo GHIDINI: “(...) antitrust law does not in itself hinder the granting and enjoyment of IPRs, but simply conditions the manner of their exercise so that the monopolistic effect that such exercise implies does not exceed the level necessary to satisfy their essential function of granting a chance of differential remuneration in order to foster innovation and creativity, or protection of trade identity". GHIDINI, Gustavo. Innovation, Competition and Consumer Welfare in Intellectual Property Law. UK: Edward Elgar, 2010, p. 15.

${ }^{86}$ Imperioso destacar que o conceito de direito da concorrência é mais restrito do que o conceito de política da concorrência. Direito da concorrência corresponde essencialmente ao regramento da concorrência, seja por meio da edição de normas de defesa da concorrência no âmbito do Poder Legislativo, seja por meio da interpretação e aplicação dessas normas pelas autoridades antitruste e tribunais. Sobre essa distinção, Daniel GOLDBERG destaca que “(...) o conceito política de concorrência é distinto do de regramento da concorrência. Nos termos deste texto, denominamos política de concorrência a conjunção de: (i) a prática das autoridades da concorrência e tribunais que, interpretando e aplicando o conjunto de normas vigentes para perseguir determinado objetivo, confere um caráter dinâmico às regras antitruste, (ii) a edição de normas em abstrato que tenham impacto sobre mercados livres ou regulados (i.e. política legislativa) e, por último, (iii) os critérios governamentais que pautam a alocação de recursos a uma ou a outra prioridade, sobre as quais, discricionariamente, pode dispor qualquer autoridade de concorrência. Nesse contexto, define-se a política de concorrência como espécie de política pública. E, como tal, há de ter um objetivo”. GOLDBERG, Daniel. Poder de Compra e Política Antitruste. São Paulo: Singular, 2006, p. 28. No mesmo sentido, HOVENKAMP explica a distinção entre política antitruste e direito da concorrência no ordenamento jurídico norte-americano: "Competition policy refers to the full range of public rules and sanctions designed to ensure that markets are as competitive as they can realistically be, consistent with these other policies. In the United States the term 'competition policy' certainly includes the antitrust laws as a central component, but 
estar econômico" ("economic welfare") ao definir a política de concorrência como o "conjunto de políticas e leis que têm como objetivo garantir que a concorrência no mercado não seja restringida de modo a reduzir o bem-estar econômico". ${ }^{87}$

Assim, o direito antitruste, como elemento central desse conjunto de normas e instituições que forma a política de concorrência, pode ser definido simplesmente como a prática dos órgãos de defesa da concorrência na interpretação e aplicação das normas antitruste. Nessa perspectiva, o objetivo do direito antitruste é disciplinar as condutas dos agentes econômicos no mercado, de modo a proteger a concorrência e, consequentemente, a liberdade de escolha dos consumidores. É imperioso destacar que a proteção do bemestar dos consumidores tem sido apontada como o fim último a ser perseguido pelo direito da concorrência. ${ }^{88}$

Dadas as premissas acima, a atuação dos órgãos de defesa da concorrência assume pelo menos duas vertentes principais, quais sejam: (i) controle preventivo das estruturas de mercado, por meio da análise de operações de concentração econômica, tais como fusões e aquisições de empresas, joint ventures, dentre outras; e (ii) repressão das condutas anticoncorrenciais ou acordos restritivos por agentes econômicos visando à dominação dos mercados e à eliminação da concorrência.

Nesse contexto, o conceito de poder de mercado assume papel central na análise antitruste, já que as condutas de agentes econômicos somente terão relevância do ponto de vista do direito da concorrência se tais agentes detiverem poder de mercado no

competition policy is in fact much broader. For example, many regulatory agencies including the Federal Communications Commission and the Securities Exchange Commission operate under mandates that require them to take concerns for competition into account in making regulatory decisions. Well established rules within Intellectual Property policy, such as the doctrines of patent and copyright 'misuse', or the first sale doctrine serve to protect competition by applying the policies of those statutes as a kind of substitute for the antitrust laws. And some our concerns about competition are addressed through the common law tort system, in particular the law of business torts". HOVENKAMP, Hebert J. Innovation and the Domain of Competition Policy, University of Iowa Legal Studies Research Paper, n. 08-07, March 2008. Disponível no website da Social Science Research Network electronic library: http://ssrn.com/abstract=1091488. Acesso em: 24 de outubro de 2009.

${ }^{87}$ MOTTA, Massimo. Competition Policy: Theory and Practice. Cambridge University Press, 2004, p. 30.

${ }^{88}$ De acordo com Calixto SALOMÃo FILHO: “(...) toda a teorização econômica do direito da concorrência baseia-se na proteção do consumidor". Entretanto, o autor ressalta que: "O fato de o consumidor ser o destinatário econômico final das normas concorrenciais não o transforma em destinatário jurídico direto das mencionadas normas. Muitas vezes é apenas através da proteção da 'instituição' concorrência que seu interesse será protegido”. SALOMÃO FILHO, Calixto. Direito Concorrencial - As Condutas. São Paulo: Malheiros Editores, 2003, p. 81. 
mercado relevante em questão, seja individual ou coletivamente. ${ }^{89}$ Poder de mercado pode ser definido como a capacidade dos agentes econômicos de restringir a produção e aumentar os preços acima do custo marginal - acima dos níveis em que seriam cobrados num mercado competitivo -, de forma estável e lucrativa, sem levar em consideração as pressões competitivas, ou seja, atuando de modo independente e indiferente em relação a seus concorrentes ou consumidores. ${ }^{90}$

A teoria econômica desenvolveu uma série de ferramentas analíticas para explicar que mercados competitivos oferecem melhores resultados em termos de bem-estar social do que mercados concentrados ou monopolizados, conforme se depreende dos modelos econômicos neoclássicos. ${ }^{91}$ Nesse contexto, o modelo de concorrência perfeita ${ }^{92}$ é

\footnotetext{
${ }^{89}$ Neste trabalho, os termos "poder de mercado", "poder de monopólio" e "posição dominante" serão tratados como sinônimos, muito embora seja possível afirmar que a configuração de poder de monopólio ou de posição dominante requer um grau substancial de poder de mercado. Para Sérgio Varella BRUNA: “(...) as expressões poder de mercado e posição dominante não parecem ser exatamente sinônimas. Com efeito, como já exposto, a avaliação do poder de mercado é, sobretudo, uma questão de grau, podendo ocorrer que níveis moderados de poder econômico, muito comuns de serem encontrados nos mercados reais, sejam absolutamente irrelevantes à tutela da concorrência e à repressão dos abusos de poder econômico. (...) podese dizer que posição dominante é aquela que confira a seu detentor quantidade substancial de poder econômico ou de mercado, a ponto de que possa ele exercer influência determinante sobre a concorrência, principalmente no que se refere ao processo de formação de preços, quer atuando sobre o volume da oferta, quer sobre o da procura, e que lhe proporcione elevado de independência em relação aos demais agentes econômicos do mercado relevante". BRUNA, Sérgio Varella. O Poder Econômico e a Conceituação do Abuso em seu Exercício, São Paulo: Editora Revista dos Tribunais, 1997, p. 115.

${ }^{90}$ MotTA define poder de mercado como: “(...) the ability of a firm to raise prices above some competitive level - the benchmark price - in a profitable way". MOTTA, Massimo. Competition Policy: Theory and Practice, Cambridge University Press, 2004, p. 40. No mesmo sentido, com foco no bem-estar dos consumidores, WHISH traz a seguinte definição: "market power presents undertakings with the possibility of limiting output, raising price and depriving consumers of choice, which are clearly inimical to consumer welfare". WHISH, Richard. Oxford University Press. 6th ed. 2009, p. 25. A Suprema Corte dos Estados Unidos definiu poder de mercado da seguinte forma: "Market power is the power to force a purchaser to do something that he would not do in a competitive market. It has been defined as the ability of a single seller to raise price and restrict output". Eastman Kodak Co. v. Image Technical Servs., 504 U.S. 451, 464 (1992), citando Jefferson Parish Hosp. Dist. n. 2 v. Hyde, 466 U.S. 2, 14 (1984).

${ }^{91}$ A economia clássica foi elaborada e sistematizada nas obras dos economistas políticos Adam Smith e J.S. Mill. Além de Smith e Mill, os principais responsáveis pela formação da economia clássica foram o francês Jean-Baptiste Say (1767-1832), David Ricardo (1772-1823) e Robert Malthus (1766-1834). A ideia central da economia clássica é a de concorrência. Embora os indivíduos ajam apenas em proveito próprio, os mercados em que vigora a concorrência funcionam espontaneamente, de modo a garantir (por um mecanismo abstrato designado por Smith como "a mão invisível" que ordena o mercado) a alocação mais eficiente dos recursos e da produção, sem que haja excesso de lucros. Por essa razão, o único papel econômico do governo (além do básico, que é garantir a lei e a ordem) é a intervenção na economia quando o mercado não existe ou quando deixa de funcionar em condições satisfatórias, ou seja, quando não há livre concorrência. Segundo a teoria clássica, na economia concorrencial a oferta de cada bem e de cada fator de produção tende sempre a igualar a procura. Em todos os mercados, o elemento que determina esse equilíbrio entre oferta e procura são os preços. A escola neoclássica do pensamento econômico caracterizou-se pelas suas contribuições ao conhecimento da utilidade de um bem e da sua escassez. Caracterizou-se igualmente pela abordagem microeconômica e pelo forte instrumentário matemático com que revestia a exposição e fundamentação das suas teorias visando o equilíbrio da economia.
} 
vislumbrado como o ponto de partida para a análise antitruste, já que é essa estrutura de mercado que garante o equilíbrio necessário para se alcançar a eficiência alocativa ${ }^{93}$ e produtiva $^{94}$, e consequentemente o bem-estar dos produtores ${ }^{95}$, o bem-estar dos consumidores $^{96}$ e, enfim, o bem-estar agregado ou total da economia ${ }^{97}$.

Assim, na medida em que o mercado se distancia da concorrência perfeita e se aproxima do monopólio, ou seja, quanto maior o poder de mercado detido pelos agentes econômicos, maiores serão os efeitos líquidos negativos sobre o bem-estar social, representados pela transferência do excedente do consumidor para o produtor. ${ }^{98}$ A partir dessas premissas, as autoridades antitruste intervêm para impedir que agentes econômicos fortaleçam seu poder de mercado por meio de contratos, operações de concentração econômica, práticas abusivas de exclusão, dentre outras, capazes de conduzir o mercado à

${ }^{92} \mathrm{O}$ modelo de concorrência perfeita descreve uma estrutura de mercado na qual há um grande número de ofertantes e compradores, de modo que nenhum agente, isoladamente, tem capacidade para influenciar o nível da oferta (quantidade de bens ofertados) e nem os preços de equilíbrio. Nessas condições, os preços no mercado obedecem à correlação perfeita entre oferta e demanda, sem a influência individual quer dos ofertantes quer dos compradores. Seus pressupostos são: (i) a existência de grande número de produtores e compradores; (ii) a homogeneidade dos produtos, ou seja, eles são substitutos perfeitos, não havendo diferenciação entre eles; (iii) o conhecimento generalizado das informações sobre lucros, preços etc.; (iv) acesso igual à tecnologia e aos fatores de produção, tanto por parte das empresas instaladas na indústria, como por parte das que planejam entrar nela; e (v) a inexistência de barreiras à entrada ou saída do mercado.

${ }^{93}$ Para o conceito de eficiência alocativa, vide nota 53.

94 Eficiência produtiva ocorre quando bens são produzidos ao menor custo possível, tendo em vista a tecnologia disponível e os preços dos fatores produtivos. Em outras palavras, tendo em conta a tecnologia disponível e os preços dos fatores produtivos, determinada firma produz o máximo de bens com o mínimo de fatores produtivos. Cf. WHISH, Richard. Competition Law. Oxford University Press. 6th ed. 2009, p. 5.

${ }^{95} \mathrm{O}$ bem-estar (excedente) de um produtor individual é medido pela diferença entre o preço pelo qual ele vende o produto e os custos que incorreu para produzi-lo, de modo que o bem-estar dos produtores nada mais é do que a soma dos lucros de todos os produtores em determinado setor industrial.

96 O bem-estar (ou excedente) de um consumidor individual resulta da diferença entre o valor que esse consumidor atribui a determinado bem - ou seja, o quanto está disposto a pagar pelo bem - e o preço que efetivamente será obrigado a pagar pelo bem. Assim, o bem-estar dos consumidores é meramente a soma do excedente individual de todos os consumidores. Cf. MOTTA, Massimo. Competition Policy: Theory and Practice. Cambridge University Press, 2004, p. 18.

97 Bem-estar agregado da economia pode ser definido pela soma do bem-estar dos consumidores e dos produtores. Esse bem-estar agregado da economia - soma dos excedentes dos consumidores e produtores - é considerado o padrão de análise econômica da performance dos mercados, embora seja dada ênfase ao bemestar dos consumidores.

98 De acordo com SCHUARTZ: "De uma perspectiva teórica, é sem dúvida o quantum de poder de mercado detido por um agente econômico a variável fundamental. É essa quantificação, com efeito, que permite estimar variações nos excedentes do consumidor e do produtor, e mensurar a 'perda de peso morto' (deadweight loss) associada ao exercício do correspondente poder, bem como a magnitude da redução de custos eventualmente necessária para compensá-la”. SCHUARTZ, Luiz Fernando. Ilícito Antitruste e Acordos entre Concorrentes, in: POSSAS, Mário (Coord.). Ensaios sobre Economia e Direito da Concorrência, São Paulo: Singular, 2002, p. 104. 
concorrência imperfeita e, consequentemente, à ineficiência alocativa (perda de bem-estar social ou perda de peso morto - "deadweight loss" - no sentido de Pareto). ${ }^{99}$

Entretanto, estruturas de mercado semelhantes às situações hipotéticas da concorrência perfeita ou do monopólio dificilmente serão observadas na prática. $\mathrm{O}$ modelo da concorrência perfeita é tão somente uma base de comparação, um benchmark, para a análise econômica de estruturas mais realistas de mercado, nas quais geralmente predomina a concorrência imperfeita. ${ }^{100}$ Além de ser excessivamente simplista, o modelo de concorrência perfeita é baseado apenas nas variáveis preço e produção, sendo aplicável apenas a bens homogêneos, ignorando o papel da inovação e da concorrência pela diferenciação de produtos, que conduzem à eficiência dinâmica. ${ }^{101}$ Afinal, os consumidores certamente estarão dispostos a pagar mais por produtos inovadores do que por produtos obsoletos a preços mais próximos do custo marginal.

Ademais, a partir dessa visão estática da concorrência baseada no modelo neoclássico de concorrência perfeita, poder-se-ia afirmar que a propriedade intelectual, por conferir "monopólios" aos titulares de direitos exclusivos como forma de incentivar a inovação e criação intelectual, estaria em conflito com o direito antitruste, cujo objetivo central é disciplinar condutas de agentes econômicos capazes de levar à dominação ou monopolização dos mercados.

No entanto, em oposição ao modelo estático da concorrência perfeita, que pressupõe completo equilíbrio de mercado, o economista austríaco SCHUMPETER aborda a concorrência como processo dinâmico no qual os agentes econômicos buscam constantemente a inovação e diferenciação de produtos, de modo a garantir maiores fatias do mercado e, consequentemente, a obtenção de lucros extraordinários. ${ }^{102}$ Assim, novas

${ }^{99} \mathrm{O}$ exercício de poder de mercado por agentes econômicos pode resultar na chamada "perda de peso morto", no sentido de Pareto, caracterizada pela redução do bem-estar agregado ou total por meio da redução da produção e aumento dos preços, permitindo que tais agentes econômicos beneficiem-se da transferência de bem-estar dos consumidores. Essa situação leva, consequentemente, à redução da qualidade e variedade de produtos ofertados no mercado, diminuindo as possibilidades de escolha dos consumidores.

${ }^{100}$ Ou seja, estruturas de mercado intermediárias, entre concorrência perfeita e monopólio.

101 Cf. MAGgiolinO, Mariateresa. The Economics of Antitrust and Intellectual Property Rights, in: ANDERMAN, Steven; EZRACHI, Ariel. Intellectual Property and Competition Law: New Frontiers, Oxford University Press, 2010, p. 78.

102 Joseph A. SCHUMPETER, em sua clássica obra Capitalism, Socialism, and Democracy, publicada em 1942, propôs uma visão acerca do processo concorrencial distinta do então modelo tradicional neoclássico. Para Schumpeter, o traço marcante do sistema capitalista é a busca constante pela inovação, compreendida como a introdução de novos produtos, novos processos produtivos, novos mercados e novas estruturas de organização da empresa, concorrência pela diferenciação de produtos (ou pela qualidade), como se pode 
tecnologias são rapidamente substituídas por outras mais inovadoras, tornando aquelas obsoletas, levando a um ciclo tecnológico que pressiona os agentes econômicos a investirem cada vez mais para incrementar as tecnologias existentes ou até mesmo a introduzir novos produtos que as substituam por completo. Esse processo dinâmico, que SCHUMPETER convencionou chamar de "destruição criativa", contribui para o progresso tecnológico e científico, beneficiando o bem-estar econômico e social, uma vez que esses novos produtos e serviços serão aproveitados por toda a coletividade. ${ }^{103}$

De acordo com SCHUMPETER, as eficiências dinâmicas resultantes do progresso técnico e científico, promovidas por esse processo de "destruição criativa", são mais importantes, no que concerne aos níveis de bem-estar econômico e social, do que as eficiências estáticas resultantes do modelo neoclássico de concorrência perfeita, que pressupõe equilíbrio na alocação e utilização dos recursos, isto é, eficiências associadas às condições de equilíbrio de Pareto. ${ }^{104}$ Por essa razão, o poder de mercado, conquistado por meio de inovações bem sucedidas, ainda que leve o agente econômico inovador a dominar o mercado - pelo menos durante um período limitado de tempo -, não deve ser objeto de intervenção antitruste, a não ser em caso de abuso desse poder visando à manutenção desse poder de mercado e à eliminação da concorrência.

Desse modo, na perspectiva da análise antitruste, o exame desse tradeoff entre eficiência estática e eficiência dinâmica é fundamental. O poder de mercado conquistado

observar do seguinte trecho: "in capitalist reality as distinguished from its textbook Picture, it is not that kind of competition [concorrência em matéria de preços] which counts but the competition from the new type of organization (the largest-scale unit of control for instance) - competition which commands a decisive cost or quality advantage and which strikes not at the margins of the profits and the outputs of the existing firms but at their foundations and their very lives. This kind of competition is as much more effective than the other as a bombardment is in comparison with forcing a door, and so much more important that it becomes a matter of comparative indifference whether competition in the ordinary sense functions more or less promptly; the powerful lever in the long run expands output and brings down prices is in any case made of other stuff". SCHUMPETER, Joseph A. Capitalism, Socialism and Democracy, New York: Harper Perennial Modern Thought, nova edição publicada em 2008, p. 84-85.

103 Para SCHUMPETER, a inovação estaria na origem da "destruição criativa", indispensável ao sistema capitalista: "The opening up of new markets, foreign or domestic, and the organizational development from the craft shop and factory to such concerns as U.S. Steel illustrate the same process of industrial mutation - if I may use the biological term - that incessantly revolutionizes the economic structure from within, incessantly destroying the old one, incessantly creating a new one. This process of Creative Destruction is the essential fact about capitalism. It is what capitalism consists in and what every capitalist concern has got to live in". Ibid., p. 83.

104 De acordo com FAGUNDES: "Schumpeter descartou a eficiência de Pareto estática como critério particularmente relevante para o bem-estar social, uma vez que seu foco está colocado sobre as propriedades dinâmicas da concorrência e dos mercados, cujo impacto alocativo, e respectivas implicações normativas, deve ser visto pela ótica da geração, filtragem seletiva e difusão das inovações no bojo do progresso técnico". 
por meio da inovação deve ser vislumbrado como incentivo para que agentes econômicos invistam na criação e desenvolvimento de novos produtos, processos e tecnologias valorizados pelos consumidores. Assim, os preços considerados supracompetitivos e os consequentes lucros supranormais associados ao exercício do poder mercado, na perspectiva do modelo de concorrência perfeita, são tidos como a remuneração ou recompensa pela contribuição ao progresso técnico, científico e cultural que leva ao crescimento econômico, servindo como incentivos ex ante para que agentes econômicos assumam os custos e riscos inerentes à inovação. ${ }^{105}$

Portanto, as vantagens competitivas conquistadas mediante esforços empregados nas atividades de inovação, ainda que resultem em perdas de eficiência alocativa (estática), acarretam aumento de bem-estar social em perspectiva dinâmica, pois estimulam a concorrência pela diferenciação de produtos (ou pela superação). Evitar que essas vantagens competitivas sejam rapidamente exauridas pela cópia, imitação e difusão precoce, é fundamental para assegurar o retorno econômico dos investimentos na produção intelectual, além dos benefícios dinâmicos decorrentes da inovação. ${ }^{106}$

Nesse contexto, ao permitir que os agentes econômicos apropriem-se do valor econômico de suas criações intelectuais, a propriedade intelectual ajuda a fortalecer os incentivos ex ante para o dispêndio de recursos nas atividades de pesquisa, desenvolvimento e criação de novas invenções, tecnologias e expressões do conhecimento. A partir dessa perspectiva dinâmica, a propriedade intelectual encontra plena convergência com o direito antitruste, uma vez que ambos visam à eficiência econômica dos mercados por meio da concorrência pela inovação e diferenciação de produtos e serviços, em oposição à tradicional concorrência por preços. A exclusividade conferida ao titular de direitos de propriedade intelectual estimula a inovação e promove a concorrência, na medida em que os agentes econômicos são forçados a investir em qualidade e inovação para diferenciar seus produtos em relação aos de seus concorrentes e, assim, maximizar seus lucros e garantir maiores fatias do mercado. Essa dinâmica da concorrência pela inovação e superação, que constitui o ponto de convergência entre a propriedade

FAGUNDES, Jorge. Concorrência, Eficiência Dinâmica e Análise Antitruste. Revista do IBRAC, v. 11, n. 4, 2004, p. 29-30.

${ }^{105}$ Cf. GLADER, Marcus. Innovation Markets and Competition Analysis: EU Competition Law and US Antitrust Law. Edward Elgar Publishing, 2009, p. 26.

${ }^{106}$ Cf. POSSAS, Mario L. Concorrência Schumpteriana, in: KUPFER, David; HASENCLEVER, Lia. Economia Industrial: Fundamentos Teóricos e Práticos no Brasil. Rio de Janeiro: Elsevier, 2002, p. 426. 
intelectual e o direito antitruste, contribui para o progresso técnico e crescimento econômico, em benefício dos consumidores, que terão maiores opções de escolha no mercado. $^{107}$

O reconhecimento da relação de complementaridade entre a propriedade intelectual e o direito antitruste está expressamente indicado nas guidelines publicadas em 1995 pelas autoridades antitruste norte-americanas, Department of Justice (DOJ) e Federal Trade Commission (FTC), para orientar a análise de acordos de licenciamento de direitos de propriedade intelectual:

The intellectual property laws and the antitrust laws share the common purpose of promoting innovation and enhancing consumer welfare. The intellectual property laws provide incentives for innovation and its dissemination and commercialization by establishing enforceable property rights for the creators of new and useful products, more efficient processes, and original works of expression. In the absence of intellectual property rights, imitators could more rapidly exploit the efforts of innovators and investors without compensation. Rapid imitation would reduce the commercial value of innovation and erode incentives to invest, ultimately to the detriment of consumers. The antitrust laws promote innovation and consumer welfare by prohibiting certain actions that may harm competition with respect to either existing or new ways of serving consumers. $^{108}$

De forma semelhante, as diretrizes sobre acordos de transferência de tecnologia, publicadas pela Comissão Europeia, manifestam entendimento no sentido de que a propriedade e o direito da concorrência promovem a inovação e o bem-estar dos consumidores:

\footnotetext{
${ }^{107}$ Nesse sentido, Maristela BASSO ensina que: “(...) a propriedade intelectual e o direito concorrencial compartilham um propósito comum de assegurar os níveis de inovação nos mercados e a proteção do consumidor. Os direitos de propriedade intelectual oferecem incentivos para a inovação e sua disseminação nos mercados, a partir de 'direitos' que podem ser exercidos pelos titulares-criadores/inventores de novos produtos, processos mais eficientes e obras dotadas de originalidade - todos eles diretamente destinados aos consumidores. O direito concorrencial, por seu turno, promove a inovação e o bem-estar do consumidor a partir da aplicação de normas proibitivas de condutas restritivas à concorrência no mercado, buscando uma política corretiva e preventiva". BASSO, Maristela. Propriedade Intelectual e Importação Paralela. São Paulo: Atlas, 2011, p. 206.

${ }^{108}$ DOJ; FTC. Antitrust Guidelines for the Licensing of Intellectual Property, 1995, item 1.
} 
The fact that intellectual property laws grant exclusive rights of exploitation does not imply that intellectual property rights are immune from competition law intervention. Articles 81 and 82 are in particular applicable to agreements whereby the holder licenses another undertaking to exploit his intellectual property rights. Nor does it imply that there is an inherent conflict between intellectual property rights and the Community competition rules. Indeed, both bodies of law share the same basic objective of promoting consumer welfare and an efficient allocation of resources. Innovation constitutes an essential and dynamic component of an open and competitive market economy. Intellectual property rights promote dynamic competition by encouraging undertakings to invest in developing new or improved products and processes. So does competition by putting pressure on undertakings to innovate. Therefore, both intellectual property rights and competition are necessary to promote innovation and ensure a competitive exploitation thereof. ${ }^{109}$

Todavia, ainda que sejam instrumentos complementares de estímulo à inovação e bem-estar, é equivocado e simplista negar a possibilidade de situações de conflito e tensão, o que se dá nos casos de exploração abusiva de direitos de propriedade intelectual capaz de restringir a concorrência em determinado mercado relevante. É possível afirmar que essas situações de conflito e tensão resultam das diferenças intrínsecas entre a propriedade intelectual e o direito antitruste no que concerne aos meios pelos quais ambos incentivam a inovação. Enquanto o direito antitruste estimula a inovação ao promover a concorrência, coibindo o exercício abusivo do poder de mercado, a propriedade intelectual incentiva a inovação restringindo a concorrência, já que o direito de exclusividade pode levar o seu titular a obter poder de mercado, permitindo-lhe cobrar preços supracompetitivos para obter o retorno de seus investimentos na criação intelectual. ${ }^{110}$

\footnotetext{
${ }^{109}$ Commission Notice. Guidelines on the application of Article 81 of the EC Treaty to technology transfer agreements (2004/C 101/02), parágrafo 7.

${ }^{110}$ Nesse sentido, LEMLEY afirma que: "Identifying complementary goals for the two laws does not end the inquiry, however. The opposite argument - that there is no tension between IP and antitrust law - is equally facile. Bowman is best understood as saying that both patent law and antitrust law are tools to be used in promoting wealth maximization. They are designed to be used together to achieve certain result. However, they strive towards that result in ways that are often in tension. Antitrust law seeks to maximize efficiency by preventing monopolization or other forms of anticompetitive conduct. IP, while it does not generally create a monopoly, may in some cases permit or even encourage monopoly in order to give incentives for invention. That invention, in turn, may generate longer-term wealth gains to society". LEMLEY, Mark A. A New Balance between IP and Antitrust (April 1, 2007). Southwestern Journal of Law and Trade in the Americas, v. 13, p. 237, 2007; Stanford Law and Economics Olin Working Paper n. 340. Disponível em SSRN: http://ssrn.com/abstract $=980045$
} 
Desse modo, há casos conhecidos de abuso de direitos de propriedade intelectual por meio dos quais o titular desses direitos abusa de seu poder de mercado para ampliar o escopo da proteção conferida por patentes ou direitos autorais e excluir rivais do mercado ou impedir sua entrada. Tais condutas podem ser colocadas em prática por meio de cláusulas contratuais impostas em contratos de licenciamento, acordos entre concorrentes para aumentar preços, reduzir a produção ou dividir o mercado, ou até mesmo por meio de práticas restritivas unilaterais.

Essas práticas podem vir a ser objeto de intervenção antitruste desde que os titulares de patentes ou direitos autorais em questão detenham poder de mercado, em conjunto ou isoladamente, devendo ser observadas outras circunstâncias de mercado, como a presença de barreiras à entrada que facilitem a prática dessas estratégias anticoncorrenciais, como veremos a seguir.

\subsubsection{Propriedade intelectual e poder de mercado}

A análise antitruste de atos de concentração e condutas anticoncorrenciais depende da verificação da presença de poder de mercado. Afinal, conforme já mencionado, condutas anticoncorrenciais somente terão relevância do ponto de vista antitruste se os agentes econômicos em questão detiverem certo grau de poder de mercado que lhes possibilite o aumento lucrativo de preços acima do custo marginal e a consequente redução da produção, sem levar em conta as pressões competitivas no mercado. Em outras palavras, essa posição de domínio sobre o mercado é verificada sempre que uma empresa ou grupo de empresas for capaz de alterar unilateral ou coordenadamente as condições de mercado ou detiver percentual elevado de market share. ${ }^{111}$

No entanto, para se verificar a existência de poder de mercado - e a possibilidade de seu exercício efetivo -, deve-se, em primeiro lugar, delimitar o mercado relevante afetado pelo ato de concentração ou conduta em questão, tanto em sua dimensão material, atinente ao produto envolvido, quanto em sua dimensão geográfica, que corresponde à menor área possível na qual um "monopolista hipotético" poderia impor um

\footnotetext{
${ }^{111}$ No Brasil, conforme disposto no art. $36, \S 2^{\circ}$ da Lei n. ${ }^{\circ} 12.529 / 2011$, "presume-se posição dominante sempre que uma empresa ou grupo de empresas for capaz de alterar unilateral ou coordenadamente as condições de mercado ou quando controlar $20 \%$ (vinte por cento) ou mais do mercado relevante, podendo este percentual ser alterado pelo Cade para setores específicos da economia".
} 
pequeno, porém significativo e não transitório, aumento de preços. ${ }^{112}$ É preciso incluir no mesmo mercado relevante todos os agentes econômicos que ofereçam produtos substitutos, de modo que a variação no preço de um desses produtos, dentro de uma área geográfica, possa afetar a concorrência. A existência de poder de mercado será observada a partir do momento em que um agente econômico for capaz de aumentar seus preços sem levar em consideração a reação dos concorrentes e consumidores dentro do mercado relevante em questão. ${ }^{113}$ Por essa razão, deve-se verificar a presença de barreiras à entrada que facilitem a manutenção desse domínio sobre o mercado, caso contrário, outros agentes econômicos terão condições de ingressar no mercado em resposta a esse eventual aumento de preços. ${ }^{114}$

\footnotetext{
112 A aplicação do "teste do monopolista hipotético" na definição do mercado relevante envolve um exercício hipotético de avaliação de possível efeito anticompetitivo, expresso em termos de poder de mercado sobre preços, em decorrência de operações de concentração econômica ou de condutas anticoncorrenciais praticadas por agentes econômicos que detenham esse poder. Nesse contexto, teste do monopolista hipotético consiste em observar se um pequeno, porém significativo e não transitório, aumento de preços (variando entre $5 \%$ a $10 \%$ ) levaria um significante número de consumidores a migrar para outros produtos substitutos. Em outras palavras, o teste procura analisar se esse aumento de preços seria lucrativo (hipótese em que haverá poder de mercado) ou, ao contrário, se induziria à substituição (hipótese em que não haverá poder de mercado). Sobre a relação entre mercado relevante e poder de mercado, cf. POSSAS, Mário Luiz. Os Conceitos de Mercado Relevante e de Poder de Mercado no Âmbito da Defesa da Concorrência, in: POSSAS, Mário (Coord.). Ensaios sobre Economia e Direito da Concorrência, São Paulo: Singular, 2002.

${ }^{113}$ Para a configuração de poder de mercado, tanto a demanda pelo produto quanto a sua oferta devem ter elasticidades suficientemente baixas, de modo a assegurar que um aumento de preços seja lucrativo ao monopolista hipotético que exerce poder de mercado. Essa análise é realizada por meio da identificação ampla dos possíveis produtos substitutos à disposição do consumidor (elasticidade da demanda), bem como da possibilidade de concorrentes efetivos ampliarem a oferta rapidamente sem maiores investimentos mediante o reaproveitamento de uma capacidade produtiva já existente -, em resposta ao aumento de preços (elasticidade da oferta).

114 A possibilidade de entrada de novos competidores no mercado pode ser um fator a inibir o exercício efetivo de poder de mercado. Se a entrada for fácil e suficiente, dentro de um prazo razoável (2 anos), a probabilidade de exercício do poder de mercado será considerada praticamente nula. Por outro lado, quanto maiores forem as barreiras à entrada, menores serão as possibilidades de entrada capaz de contestar o exercício de poder de mercado. Desse modo, a análise do efeito da entrada sobre as condições de concorrência em determinado mercado relevante requer o exame das extensões das barreiras à entrada nesse mercado. De acordo com o Guia de Análise de Atos de Concentração, publicado pela Secretaria de Acompanhamento Econômico - SEAE (Portaria n. ${ }^{\circ}$ 39, de 29 de junho de 1999), barreiras à entrada podem ser definidas como qualquer fator em um mercado que ponha um potencial competidor eficiente em desvantagem com relação aos agentes econômicos estabelecidos. Os seguintes fatores constituem importantes barreiras à entrada: (a) custos irrecuperáveis (sunk costs), ou seja, que não podem ser recuperados quando a empresa decide sair do mercado; (b) barreiras legais ou regulatórias, compreendidas como exigências impostas pelo governo para a instalação e funcionamento de uma empresa, como, por exemplo, autorizações e licenças exigidas para o desempenho de uma atividade; (c) recursos de propriedade das empresas instaladas, tais como insumos de produção, exclusividade de uso da rede de distribuidores, ou mesmo patentes e direitos de propriedade intelectual; (d) economias de escala (economias físicas de insumos derivados do aumento do volume de produção final) e/ou de escopo (economias derivadas da produção conjunta de dois ou mais bens); (e) o grau de integração da cadeia produtiva; (f) fidelidade dos consumidores às marcas estabelecidas; e (g) a ameaça de reação dos competidores instalados, na medida em que essas empresas sejam capazes de baixar seus preços a níveis inferiores aos vigentes antes da concentração e mantêlos nesses níveis por no mínimo um ano.
} 
Como se pode observar, a definição do mercado relevante e a verificação de poder de mercado suficiente para impor preços sem levar em consideração as pressões competitivas de concorrentes e consumidores constituem o primeiro passo em qualquer análise antitruste. Sob essa perspectiva, quaisquer estratégias potencialmente abusivas conduzidas por agentes econômicos que não detenham determinado grau de poder de mercado seriam irrelevantes do ponto de vista antitruste, tendo em vista a impossibilidade de produzirem efeitos sobre o mercado. Afinal, o papel do direito antitruste é proteger a concorrência no mercado, e não os concorrentes. ${ }^{115}$

Passamos a verificar as implicações desses conceitos no que diz respeito às condutas anticoncorrenciais a partir da exploração abusiva de direitos de propriedade intelectual. Era comum no passado afirmar que direitos de propriedade intelectual conferiam "monopólios", no sentido econômico, aos seus titulares. Ou seja, costumava-se presumir que a mera obtenção de uma patente seria capaz de conferir ao seu titular uma posição de domínio sobre o mercado. Esse entendimento prevaleceu nos tribunais norteamericanos durante a primeira metade do século XIX. ${ }^{116}$ Eram frequentes naquela época os casos de patent misuse nos quais a questão era verificar se o titular de uma patente estendia de forma indevida o monopólio conferido pela patente a produtos não patenteados, oferecidos como condição para a aquisição do produto patenteado. ${ }^{117}$

No entanto, conforme já mencionado anteriormente, a exclusividade conferida pelo Estado ao titular de um direito de propriedade intelectual pode ser compreendida como um monopólio legal sobre a exploração da invenção ou trabalho intelectual protegido, o que não significa necessariamente monopólio no sentido econômico. Pelo

\footnotetext{
${ }^{115}$ Conforme bem ressaltado por Calixto SALOMÃo FILHO: "A defesa do sistema da concorrência, entendida como a defesa da existência da concorrência, não pode ser confundida com a proteção da existência de um tipo particular de concorrente ou de uma estrutura específica do mercado". SALOMÃO FILHO, Calixto. Direito Concorrencial: As Estruturas. 2 ed., São Paulo: Malheiros, 2002, p. 37

${ }^{116}$ A partir da segunda metade do século XX esse entendimento foi sendo gradualmente modificado. Nas décadas de 1980 e 90, as autoridades antitruste e tribunais dos Estados Unidos consolidaram a ideia de que os direitos de propriedade intelectual não conferem, necessariamente, poder de mercado aos seus titulares. Para uma análise do histórico da jurisprudência norte-americana sobre o assunto, confira ROSEMBERG, Bárbara. Considerações sobre Direito da Concorrência e os Direitos de Propriedade Intelectual, in: ZANOTTA, Pedro; BRANCHER, Paulo. Desafios Atuais do Direito da Concorrência. São Paulo: Singular, p. 169-189, e ANDRADE, Gustavo Piva de. A Interface entre a Propriedade Intelectual e o Direito Antitruste, in: Revista da Associação Brasileira de Propriedade Intelectual - ABPI, n. 91, p. 29-49, nov./dez., 2007.

${ }^{117}$ Vale citar como exemplo os seguintes casos: (i) Henry v. A.B. Dick Co., 224 U.S. 1, 32S.Ct. 364, 56 L.Ed. 645 (1912); (ii) Motion Pictures Patents Co. v. Universal Film Manufacturing Co, 243 U.S. 502 (1917); (iii) International Business Machines Corporation (IBM) v. United States, 298 U.S. 131 (1936); e (iv) International Salt Co. v. United States, 332 U.S. 392 (1947).
} 
contrário, são raras as situações em que um direito de propriedade intelectual efetivamente confere poder de monopólio ao seu titular. ${ }^{118}$

De fato, um direito de propriedade intelectual não é capaz de garantir, por si só, ao seu titular o poder de impor os preços que bem entender, ignorando as eventuais pressões competitivas. Primeiramente, é necessário verificar se há produtos substitutos capazes de desviar a demanda em caso de aumento de preços. Ademais, pelo lado da oferta, dada a dinâmica dos mercados, sabe-se que há sempre novos produtos mais inovadores sendo desenvolvidos e lançados, tornando rapidamente obsoletos os produtos e tecnologias anteriores. Finalmente, na medida em que a vigência dos direitos de propriedade intelectual se aproxima do fim, a tendência será a redução progressiva dos preços em consequência da entrada iminente de novos concorrentes no mercado. ${ }^{119}$

Além disso, nem sempre os direitos de propriedade intelectual permitirão o retorno dos investimentos incorridos na criação intelectual, devido ao já mencionado Paradoxo de Arrow, pelo qual o conteúdo e valor da informação passível de ser transacionada no mercado somente serão conhecidos após sua criação, e nunca ex ante, o que aumenta significativamente os riscos das atividades de pesquisa e desenvolvimento, especialmente em alguns setores da economia, tais como os setores farmacêutico e biotecnológico. Portanto, é o mercado que determina o valor econômico das criações intelectuais, independentemente dos custos incorridos na atividade inventiva ou intelectual. Ainda que esses custos sejam elevados, o valor dos bens objeto de proteção dependerá de fatores como a estrutura do mercado (grau de concorrência, disponibilidade e preço de produtos substitutos), características da demanda (aceitação e utilidade do produto para os

\footnotetext{
${ }^{118}$ Sobre a confusão entre monopólio e propriedade intelectual, LANDES e POSNER afirmam que: "Most copyrights, trademarks, and trade secrets confer little in the way of monopoly power. The situation is less clear regarding patents (...), and so it is not surprising that courts in the early patent tie-in cases tended to confuse patent 'monopolies' with monopolies that have economic consequences grave enough to warrant the invocation of antitrust prohibitions. This confusion led judges to suppose that there is an inherent tension between intellectual property law, because it confers 'monopolies', and antitrust law, which is dedicated to overthrowing monopolies. That was a mistake. At one level it is a confusion of a property right with a monopoly. One does not say that the owner of a parcel of a land has a monopoly because he has the right to exclude others from using the land. But a patent or a copyright is a monopoly in the same sense. It excludes other people from using some piece of intellectual property without consent. That in itself has no antitrust significance. (...) Talk of patent and copyright 'monopolies' is conventional; we have used this terminology ourselves in this book. The usage is harmless as long as it is understood to be different from how the same word is used in antitrust analysis". LANDES, William M.; POSNER, Richard A. The Economic Structure of Intellectual Property Law. The Belknap Press of Harvard University Press, Cambridge, Massachusetts, e London, England, 2003, p. 374.

${ }^{119}$ Cf. KITCH, Edmund W. Patents: Monopolies or Property Rights? Research in Law and Economics, v. 8, 1986, p. 31.
} 
usuários), bem como da extensão e duração da proteção (escopo e prazo da proteção são definidos pela legislação sobre propriedade intelectual). ${ }^{120}$

No caso específico das patentes, há margem de discussão sobre a possibilidade de seu titular adquirir certo grau de poder de mercado, podendo ser maior ou menor a depender das circunstâncias do mercado. Como se sabe, ao titular da patente é conferido o direito de impedir terceiros, sem o seu consentimento, de produzir, usar, vender, licenciar ou importar a invenção protegida. ${ }^{121}$ No entanto, esse poder de excluir é limitado ao escopo da invenção protegida, o que significa que a extensão da proteção conferida pela patente limita-se à solução técnica específica para um problema técnico, conforme descrito no relatório descritivo e nas reivindicações. ${ }^{122}$

Denis Borges BARBOSA lembra que o "monopólio" conferido pela patente é instrumental, já que: "a exclusividade recai sobre um meio de se explorar o mercado, sem evitar que, por outras soluções técnicas diversas, terceiros explorem a mesma oportunidade de mercado". ${ }^{123}$ Por esse motivo, o titular de uma patente não poderá impedir que terceiros ingressem no mercado com produtos e processos alternativos que concorram com a invenção protegida sem violar a patente.

Nesse contexto, GHIDINI afirma que a missão institucional da patente é conferir aos inventores um "micromonopólio", limitado a determinada solução técnica específica, e não um "macromonopólio" sobre o setor industrial como um todo, já que não impede que concorrentes do titular da patente lancem no mercado soluções técnicas alternativas que tenham a mesma função, ou seja, que resolvam o mesmo problema técnico. Nas palavras do autor:

\footnotetext{
${ }^{120}$ Como bem colocado por MOURA E SILVA, "em última análise, é o mercado que define qual o verdadeiro valor das inovações". MOURA E SILVA, Miguel. Inovação, Transferência de Tecnologia e Concorrência: Estudo Comparado dos Direito da Concorrência dos Estados Unidos e da União Europeia. Coimbra: Almedina, 2003, p. 71.

${ }^{121}$ Nos termos do Artigo 28 do Acordo TRIPS: "Uma patente conferirá a seu titular os seguintes direitos exclusivos: (a) quando o objeto da patente for um produto, o de evitar que terceiros sem seu consentimento produzam, usem, coloquem à venda, vendam, ou importem com esses propósitos aqueles bens; (b) quando o objeto da patente for um processo, o de evitar que terceiros sem seu consentimento usem o processo e usem, coloquem à venda, vendam, ou importem com esses propósitos pelo menos o produto obtido diretamente por aquele processo". Nos termos do art. 42 da Lei n. ${ }^{\circ}$ 9.279/96: "A patente confere ao seu titular o direito de impedir terceiros, sem o seu consentimento, de produzir, usar, colocar à venda, vender ou importar com esses propósitos: I - produto objeto de patente; II - processo ou produto obtido diretamente por processo patenteado".

${ }^{122}$ Vide art. 41 da Lei n. ${ }^{\circ} 9.279 / 96$.
} 
This assumption is supported by the indisputable principle that patents cannot prevent competitors from developing and marketing (and indeed patenting, if novel and inventive) any different competitive solution aimed at the same function, even if the first patented solution had happened to be, at the date of filing, the first and only to satisfy that specific function/usefulness. More than that: subsequent competitive innovation is indeed fostered by several built-in mechanisms of the patent paradigm itself, in particular the public disclosure of a full and exact description of the invention. ${ }^{124}$

Esse entendimento de que uma patente é incapaz de conferir poder de mercado tem sido confirmado em diversos casos julgados nos Estados Unidos e na Europa. Na célebre decisão proferida pela Suprema Corte norte-americana no caso Illinois Tool Works Inc., constata-se a síntese do entendimento atual predominante sobre o assunto: "Congress, the antitrust enforcement agencies, and most economists have all reached the conclusion that a patent does not necessarily confer market power upon the patentee. Today we reach the same conclusion, and therefore hold that, in all cases involving a tying arrangement, the plaintiff must prove that the defendant has market power in the tying product". ${ }^{125}$

Não obstante o entendimento acima exposto, é possível vislumbrar situações em que o titular de uma patente venha a deter posição dominante no mercado. Isso pode ocorrer em mercados caracterizados por baixa substituibilidade pelo lado da demanda, como os segmentos de medicamentos e de alta tecnologia, ou quando a tecnologia patenteada constitui o padrão de produção de toda uma indústria. ${ }^{126}$ Nesse contexto, pelo menos enquanto tecnologias alternativas não forem lançadas no mercado por potenciais concorrentes, o titular da patente poderá ter poder de mercado suficiente para reduzir a

${ }^{123}$ BARBOSA, Denis Borges. A Criação de um Ambiente Competitivo no Campo da Propriedade Intelectual: O Caso Sul-Americano, in: Centre for Trade and Sustainable Development, nov. 2005, p. 20.

${ }^{124}$ GHIDINI, Gustavo. Innovation, Competition and Consumer Welfare in Intellectual Property Law. UK: Edward Elgar, 2010, p. 222.

${ }^{125}$ Cf. Illinois Tool Works Inc. et. al. v. Independent Ink, Inc., 547 U.S. 28 (2006).

${ }^{126}$ Em geral, a ausência de produtos substitutos pode ser observada, sobretudo, em mercados caracterizados pela presença de elevadas barreiras à entrada, tais como: (i) presença de economias de escalas estáticas reais e pecuniárias (grandes custos fixos de entrada e escala ótima de planta com custos decrescentes); (ii) economias de escalas dinâmicas (curvas de aprendizado - custos de produção se reduzem com o tempo); (iii) reputação de qualidade (necessidade de investimentos em propaganda para a fixação da marca); e (vi) assimetria de informações. Alguns mercados de medicamentos, por exemplo, apresentam as características acima descritas. 
produção e aumentar o preço do produto objeto da proteção, obtendo os chamados "lucros de monopólio". 127

Isso não significa que as autoridades de defesa da concorrência devam intervir para impedir o eventual poder de mercado resultante da patente, já que o objetivo da política antitruste não é garantir a manutenção de mercados perfeitamente competitivos. Ainda que um direito de propriedade intelectual venha a conferir poder de mercado ao seu titular, a eventual perda de eficiência alocativa (estática) em curto prazo poderá ser compensada pelos ganhos de eficiência dinâmica em longo prazo, consubstanciada na inovação tecnológica e científica, que resultará ao final no aumento das possibilidades de escolha em benefício dos consumidores. É importante lembrar que a concorrência potencial, representada pela possibilidade de ingresso de invenções ou tecnologias alternativas no mercado, sempre cumpre papel extremamente relevante.

Se a patente confere um "micromonopólio" ao seu titular, limitado a determinada solução técnica, os direitos autorais são incapazes de conferir qualquer grau de poder de mercado aos seus titulares, uma vez que a proteção é conferida tão somente a expressões originais e não a ideias. Desse modo, sempre haverá uma infinidade de trabalhos originais substitutos ou alternativos explorando uma mesma ideia ou tema, o que torna praticamente impossível a obtenção de poder de mercado e, consequentemente, qualquer preocupação do ponto de vista antitruste. A situação é mais complexa quando a proteção autoral se estende a tecnologias, como ocorre no caso dos programas de computador, já que sua forma de expressão é geralmente conduzida por um objetivo funcional. ${ }^{128}$ Nesse contexto, são comuns os casos em que determinado software torna-se um "quase padrão" na indústria, como ocorre, por exemplo, com o Sistema Operacional Windows, da Microsoft, o que requer que as informações de interoperabilidade sejam disponibilizadas a terceiros que pretendem desenvolver softwares e aplicativos, de modo a

\footnotetext{
${ }^{127}$ Quanto mais baixa a elasticidade da demanda, menores serão as possibilidades de que os consumidores venham a migrar para produtos substitutos diante de um aumento de preços praticado pelo monopolista, sendo, portanto, maiores as possibilidades de exercício abusivo de poder de mercado. Se a elasticidade da demanda for baixa no curto prazo, mas alta no longo prazo, o titular do direito de propriedade intelectual poderá, nesse breve período, garantir o retorno de seus custos fixos incorridos na pesquisa e desenvolvimento do produto objeto da proteção, aproveitando-se de sua posição dominante no mercado. Alternativamente, poderá aproveitar-se da curva de aprendizado que lhe permitiria gozar de uma vantagem competitiva em relação aos seus rivais quando estes entrarem no mercado com produtos alternativos.

${ }^{128}$ Cf. GHIDINI, Gustavo. Innovation, Competition and Consumer Welfare in Intellectual Property Law. UK: Edward Elgar, 2010, p. 225.
} 
permitir a interface ou compatibilidade necessária entre os programas, como veremos mais adiante. $^{129}$

O fato é que dificilmente a mera titularidade de patentes e direitos autorais, por si só, será capaz de conferir domínio sobre o mercado. Na maioria das vezes, a posição dominante detida por titulares de direitos de propriedade intelectual é facilitada pelas circunstâncias do próprio mercado, em especial em razão da presença de barreiras à entrada, tais como externalidades de redes ("network effects") nos mercados dinâmicos de tecnologias da informação, como veremos a seguir.

De qualquer modo, na presença de poder de mercado, seja por consequência da titularidade de direitos de propriedade intelectual em si, seja pelas características do próprio mercado, agentes econômicos serão capazes de adotar estratégias anticoncorrenciais com o objetivo de excluir seus rivais ou impedir o ingresso de concorrentes potenciais, permitindo-lhes dominar o mercado de bens e serviços. Na ausência de eficiências econômicas capazes de justificar essas condutas, os agentes econômicos envolvidos poderão vir a ser penalizados pelos órgãos de defesa da concorrência, como veremos ao longo deste trabalho.

\subsubsection{Barreiras à entrada em mercados dinâmicos: o problema das externalidades positivas de redes}

Mercados dinâmicos, como os de tecnologia da informação, comumente denominados de "nova economia", são caracterizados pela presença de elevadas barreiras à entrada, provocadas pelas externalidades positivas de rede, que fortalecem o poder de

\footnotetext{
${ }^{129}$ O termo "interoperabilidade" possui diferentes conceitos a depender do contexto. De acordo com a Diretiva 91/250/EEC sobre proteção legal de softwares, publicada pelo Conselho de União Europeia, interoperabilidade foi definida como "a capacidade de trocar informações e de reciprocamente utilizar as informações trocadas", de modo que as interfaces seriam "as partes do programa que permitem tal interconexão e interação entre os componentes de um sistema". Diretiva 91/250/EEC do Conselho, de 14 de maio de 1991, relativa à proteção jurídica dos programas de computador. Leandro SAITO esclarece que: “(...) podemos definir interoperabilidade como a possibilidade de dois ou mais programas estabelecerem trocas mútuas de informação, de modo que ambos possam utilizar a informação trocada. Estas trocas, por sua vez, são realizadas por meio das interfaces, que podem ser definidas como as partes do programa (trechos de código-fonte) responsáveis pela operação de troca de informações entre elementos do software e do hardware. A interoperabilidade não requer uma similaridade completa entre os dois sistemas, mas apenas que estes possam trocar e utilizar a informação trocada. Nestes termos, a interoperabilidade nada mais é do que um requisito essencial para o uso normal de um computador". SAITO, Leandro. A propriedade intelectual como barreira à entrada de novos players no mercado de softwares. São Paulo: Ibpi - Instituto Brasileiro de Propriedade Intelectual, 2012, p. 91.
} 
mercado dos agentes econômicos dominantes, facilitando práticas anticoncorrenciais a partir da exploração de direitos de propriedade intelectual.

As externalidades positivas de rede ocorrem quando a utilidade ou valor de um bem para um usuário deriva da quantidade de outros usuários que optem pelo mesmo bem. Desse modo, quanto mais usuários optarem pelo produto em questão, mais valioso ele será e, consequentemente, mais difícil para os rivais atraírem demanda por meio da oferta de produtos alternativos ou substitutos. ${ }^{130}$ Esse efeito de rede, também conhecido pelos economistas como "economia de escala no consumo", faz com que o valor ou utilidade do produto em questão seja diretamente proporcional à quantidade de usuários que a ele aderem. $^{131}$

As externalidades de rede podem ser diretas (físicas) ou indiretas (virtuais). Exemplo clássico de efeitos de rede diretos, ou físicos, é o do telefone, cuja utilidade no consumo aumenta diretamente na medida em que outras pessoas passam a utilizar o telefone como meio de comunicação. Quanto maior o número de usuários de telefone, mais úteis serão os serviços de telefonia. Um exemplo mais atual pode ser ilustrado pelo fenômeno das redes sociais. $\mathrm{O}$ valor de uma rede social aumenta diretamente na medida em que mais pessoas passam a fazer parte dessa rede, como ocorre no caso do Facebook e do Twitter. Por outro lado, os efeitos poderão ser indiretos, ou virtuais, na medida em que a expansão da rede leva ao aumento da disponibilidade de bens e serviços complementares. Nessa hipótese, os usuários são indiretamente, ou virtualmente, beneficiados pela adesão de outros usuários. Um bom exemplo é o do cartão de crédito. Os consumidores que utilizam cartão de crédito de determinada bandeira não se beneficiam diretamente quando outros consumidores adquirem o mesmo cartão, mas sim indiretamente, em razão do aumento da aceitação do cartão pelos estabelecimentos comerciais. ${ }^{132}$ Outro exemplo é o do sistema operacional utilizado em computadores: quanto mais consumidores usam determinado software de sistema operacional, mais softwares de aplicativos são programados para interagir com esse sistema operacional.

\footnotetext{
130 KATZ, Michael L.; SCHAPIRO, Carl. Network Externalities, Competition, and Compatibility, in American Economics Review, 1985, p. 424.

131 Cf. EVANS, David S.; SCHMALENSEE, Richard. Some Economic Aspects of Antitrust Analysis in Dynamically Competitive Industries, in: National Bureau of Economic Research, Working Paper 86268, issued on May 2001. Disponível em: http://www.nber.org/chapters/c10784.pdf.

${ }^{132}$ MOTTA, Massimo. Competition Policy: Theory and Practice. Cambridge University Press, 2004, p. 82.
} 
Os mercados nos quais há presença de efeitos de redes apresentam duas características específicas que os diferenciam dos mercados convencionais. ${ }^{133}$ Primeiramente, esses mercados são propensos ao domínio de uma tecnologia de rede específica, que acaba se tornando uma espécie de "padrão de facto" ("de facto standard") após atrair uma grande quantidade de consumidores. Cada consumidor adicional que adere a essa tecnologia de rede padrão contribui para o aumento proporcional de seu valor, atraindo ainda mais consumidores. Ao mesmo tempo, a tecnologia de rede que perde consumidores para uma rede rival torna-se menos atrativa para os consumidores remanescentes. Esses consumidores serão então induzidos a acompanhar os demais consumidores, migrando para a outra rede. Assim, esses mercados são considerados como "winner takes all" ou "winner takes most", já que um agente econômico que seja bem sucedido no lançamento de uma nova tecnologia de rede poderá atrair uma grande quantidade de consumidores, fazendo com que sua tecnologia torne-se o "padrão" no segmento, pelo menos durante certo período. ${ }^{134}$

A segunda característica diz respeito às barreiras à entrada resultantes do domínio da rede "padrão" sobre o mercado. Isso porque, na presença de externalidades de redes, os consumidores tornam-se familiarizados com o uso da tecnologia escolhida inicialmente e acabam "capturados" por ela em razão dos custos de mudança ("switching costs") e do "lock-in effect". Explica-se: os custos inicialmente incorridos, incluindo o custo do produto ou da tecnologia em si, o custo de aprendizado e os custos na aquisição de bens complementares, desencorajam os consumidores a trocarem o produto ou tecnologia em questão por outros, resultando no que se convencionou chamar de "lock-in effect", já que os consumidores acabam "trancados" nessa tecnologia. Além desses custos de mudança, o efeito "lock-in" também decorre das incertezas sobre o sucesso de uma nova tecnologia de rede, uma vez que os consumidores levarão em consideração os riscos de migrar para uma nova rede que ainda não tenha atraído uma grande quantidade de usuários. ${ }^{135}$ Assim, esses custos de mudança e efeitos de "lock-in", alimentados pelos

${ }^{133}$ MACKENRODT, Mark-Oliver. Assessing the Effects of Intellectual Property Rights in Network Standards, in: DREXL, Josef (Ed.). Research Handbook on Intellectual Property and Competition Law. Cheltenham: Edward Elgar, 2008, p. 88-89.

${ }^{134} \mathrm{Na}$ medida em que uma tecnologia de rede atrai para si uma grande quantidade de usuários, o mercado acaba sendo dominado por essa rede "padrão", de modo que as redes rivais acabam saindo do mercado ou buscando estratégias de diferenciação, que na maioria das vezes são insuficientes para garantir uma maior fatia do mercado.

${ }^{135}$ Esse "lock-in effect" pode ser ainda maior, considerando a aversão ao risco de ser o primeiro consumidor a migrar para a nova rede, já que sempre haverá incerteza quanto ao seu sucesso, ou seja, será difícil prever se 
efeitos de rede, acabam se tornando uma poderosa barreira ao lançamento de novos produtos no mercado, ainda que de tecnologia superior.

Essas barreiras à entrada são ainda mais fortalecidas tendo em vista que a tecnologia de rede padrão é protegida por patentes ou direitos autorais, possibilitando que seu titular explore esses direitos de propriedade intelectual de forma estratégica com o objetivo de tornar seu domínio sobre o mercado ainda mais estável e duradouro, dificultando a entrada de tecnologias rivais. Além disso, em razão dos efeitos indiretos de rede, os concorrentes do agente econômico dominante terão dificuldades de acesso a bens e serviços complementares, já que estes acabam sendo desenvolvidos para ter maior interface ou interoperabilidade com a tecnologia padrão dominante. ${ }^{136}$

A exploração estratégica de direitos de propriedade intelectual é normalmente implementada por meio da criação de incompatibilidades entre a tecnologia padrão dominante e as tecnologias complementares desenvolvidas por rivais. Nos setores de tecnologia da informação, a concorrência entre produtos complementares que sejam compatíveis com o produto padrão dominante leva à criação de nichos de mercado que antes não existiam, ou que não foram originalmente vislumbrados pelo agente econômico dominante. ${ }^{137}$ Cite-se como exemplo desse tipo de estratégia um sistema operacional dominante no mercado primário que tenha interface ou interoperabilidade apenas com os softwares aplicativos desenvolvidos pela mesma empresa, ou por terceiros que não sejam seus rivais no mercado primário ou nos mercados secundários. Claro que um sistema operacional será mais valioso para os consumidores se for compatível com uma ampla variedade de softwares aplicativos, o que evidencia que nem sempre esse tipo de estratégia será uma alternativa eficaz para o agente econômico titular de direitos de propriedade

os demais consumidores também acabarão aderindo a ela. Sobre o assunto, MACKEDRODT afirma que: “(...) for the entirety of consumers it is socially desirable for a superior network technology to become established in the market. However, it is rational for an individual consumer who is adverse to risk not to be the first to switch to the new network standard. An early switcher initially loses network effects and has to bear the risk that the new technology will fail to achieve a critical mass of consumers. In this case the new network technology will have to exit the market, and an early switcher become stranded with his investments in that technology. Consequently, an individual consumer will be reluctant to switch away from an incumbent network until the new technology has achieved a critical mass and until the market is close to tipping". MACKENRODT, Mark-Oliver. Assessing the Effects of Intellectual Property Rights in Network Standards, in: DREXL, Josef (Ed.). Research Handbook on Intellectual Property and Competition Law. Cheltenham: Edward Elgar, 2008, p. 88-89.

${ }^{136}$ Cf. PITOFSKI, Robert. Antitrust and Intellectual Property: Unresolved Issues at the Heart of the New Economy, 16 Berkeley Tech. L.J. 535-559 (2001), p. 539.

${ }^{137}$ GHIDINI, Gustavo. Innovation, Competition and Consumer Welfare in Intellectual Property Law. UK: Edward Elgar, 2010, p. 232. 
intelectual sobre a tecnologia padrão dominante. Por outro lado, a estratégia poderá ser eficaz após a tecnologia padrão dominante atrair uma grande quantidade de consumidores que, em razão dos custos de mudança e efeitos "lock-in", terão menores incentivos para migrar para uma rede rival em resposta a essa estratégia de incompatibilidade, resultando em perdas consideráveis de bem-estar social. ${ }^{138}$

Assim, se a tecnologia de rede padrão é protegida por direitos de propriedade intelectual, seu titular poderá negar o acesso de determinados rivais, impedindo a desejada interface ou interoperabilidade de bens e serviços complementares, de modo a criar incompatibilidades capazes de levar ao fechamento do mercado para esses potenciais concorrentes que, sem acesso à tecnologia padrão, acabam em situação de extrema desvantagem. Como bem ressaltado por Paulo BRANCHER:

Considerando a necessidade de os vários equipamentos, produtos e serviços se comunicarem entre si, a forma como isso ocorre é por meio da chamada interoperabilidade dos padrões existentes. O que cada usuário deseja é que seu novo produto ou serviço seja "plugado", conectado, à base preexistente, ou mesmo que fale a mesma linguagem, sem a necessidade de procurar formas extraordinárias de adaptação que permitam a interoperabilidade do sistema. Uma falha ou bloqueio nessa possibilidade fará que o produto ou serviço, ainda que de boa qualidade, mas não compatível com os padrões dominantes, tenha chance diminuída de entrar nesse mercado. Tal como acontece com o problema dos custos de mudança, somente um produto não compatível que traga grande transformação no mercado, ou que tenda a criar um novo mercado, fará que a ausência de interoperabilidade deixe de ser um problema. ${ }^{139}$

Assim, considerando a presença de externalidades de redes diretas e indiretas, custos de mudança e a necessidade de interface ou interoperabilidade entre os diversos produtos e serviços complementares, estratégias anticoncorrenciais bem-sucedidas poderão reduzir a probabilidade de ingresso de concorrentes no mercado, facilitando a manutenção do poder de mercado do agente econômico dominante titular dos direitos de propriedade

\footnotetext{
${ }^{138}$ MACKENRODT, Mark-Oliver. Assessing the Effects of Intellectual Property Rights in Network Standards, in: DREXL, Josef (Ed.). Research Handbook on Intellectual Property and Competition Law. Cheltenham: Edward Elgar, 2008, p. 90.

139 BRANCHER, Paulo. Direito da Concorrência e Propriedade Intelectual: Da Inovação Tecnológica ao Abuso de Poder. São Paulo: Singular, 2010, p. 98.
} 
intelectual sobre o produto ou tecnologia padrão. ${ }^{140}$ Assim, veremos que os efeitos dessas estratégias são especialmente prejudiciais à eficiência dinâmica, uma vez que a criação de dificuldades à entrada no mercado poderá reduzir os incentivos à inovação por parte de agentes econômicos potencialmente inovadores, resultando em perdas substanciais ao bemestar econômico e social, representadas pela redução da inovação agregada na indústria ou segmento em questão. ${ }^{141}$

\subsection{Intervenção antitruste na exploração de direitos de propriedade intelectual e a proteção aos incentivos à inovação}

Há quem sustente que a aplicação das leis antitruste para remediar abusos de direitos de propriedade intelectual poderia ser prejudicial aos incentivos à inovação, servindo como fator de ampliação dos riscos associados aos investimentos em pesquisa e desenvolvimento, especialmente em segmentos sensíveis como o setor farmacêutico e os mercados dinâmicos de tecnologia.

De acordo com essa abordagem, considerando as eficiências dinâmicas associadas à inovação, conforme o processo de "destruição criativa" descrito por SCHUMPETER, as autoridades antitruste deveriam ser mais lenientes na aplicação das leis de defesa da concorrência. Isso porque, segundo esses autores, os modelos econômicos normalmente aplicados na análise antitruste partem de pressupostos estáticos, baseados na análise de market share para a aferição de poder de mercado, o que seria inadequado, já que, para garantir eficiências dinâmicas, o poder de mercado, pelo menos durante certo tempo, é condição para o retorno dos investimentos em pesquisa e desenvolvimento, servindo como estímulo para a inovação. Assim, a intervenção antitruste nesses mercados

\footnotetext{
${ }^{140}$ Sobre o assunto, GHIDINI afirma que: “(...) in high-tech sectors, in the absence of compatibility between the standard product and a competing product which is trying to enter the market (the standard owner, thanks to IPR protection, will be able to hinder such compatibility in order to prevent her customers from migrating to a competing product), and in the presence of network effects, the probability of changeover by customers to the second product is minimal if not actually nil, even if it is technically superior to the first. All this related to aforesaid (direct and indirect) network effects - entails great risks for competition well beyond the degree of restriction normally inherent in the proprietary paradigm (that is, exclusion from a market, not only form a technological advancement). It also entails risk for innovation, whose dynamic process can be blocked, or at any rate slowed". GHIDINI, Gustavo. Innovation, Competition and Consumer Welfare in Intellectual Property Law. UK: Edward Elgar, 2010, p. 232.

${ }^{141}$ Nesse contexto, vale destacar as conclusões de Robert PITOFSKY: “The exclusionary rights granted by intellectual property protection, coupled with trends toward standardization due to network effects, threaten to diminish market competition, Where this result in monopoly or near-monopoly, there can be negative effects not only on price and output, but also on innovation, as the diversity of competing research and development programs and the pressure on the incumbent to innovate and stay ahead of competition are
} 
afetaria negativamente a estrutura de incentivos criada no âmbito do sistema de propriedade intelectual, tendo em vista que as perdas de eficiência dinâmica causadas pela redução da inovação seriam superiores a eventuais perdas de eficiência alocativa, representada pelo aumento dos preços. ${ }^{142}$

Ademais, esses autores também afirmam que os custos de condenação de práticas pró-competitivas nos setores em que há inovação seriam maiores do que os custos de não condenar práticas anticoncorrenciais. Em outras palavras, os riscos de decisões equivocadas, capazes de prejudicar o próprio processo competitivo, seriam maiores na hipótese de intervenção, já que colocariam em risco eficiências dinâmicas. ${ }^{143}$

De acordo com DREXL, há duas visões antagônicas sobre como promover a eficiência dinâmica no âmbito dos sistemas de propriedade intelectual e de defesa da concorrência. De acordo com a primeira visão, representada pelos neo-schumpterianos, as autoridades antitruste devem ser lenientes nesses casos, conforme acima descrito, já que os riscos da intervenção são maiores em termos de eficiência dinâmica do que os riscos da não intervenção. Já a segunda visão advoga pela complementaridade do direito da concorrência e da propriedade intelectual na promoção da eficiência dinâmica, o que requer a intervenção antitruste para garantir as pressões competitivas no mercado e impedir estratégias abusivas de exclusão, que seriam prejudiciais não apenas à eficiência alocativa, como também à eficiência dinâmica. ${ }^{144}$

Esse conflito de abordagens reflete um amplo e tradicional debate entre economistas sobre qual a estrutura de mercado mais favorável à inovação. Seriam mercados monopolizados ou concentrados mais conducentes à inovação? Ou, por outro lado, seriam as pressões de mercado garantidas pela concorrência mais adequadas para

lost". PITOFSKI, Robert. Antitrust and Intellectual Property: Unresolved Issues at the Heart of the New Economy. 16 Berkeley Tech. L.J. 535-559 (2001), p. 539.

142 Cf. GERADIN, Damien; AHLBORN, Christian; DENICOLÓ, Vincenzo; PADILLA, A. Jorge. DG Comp's Discussion Paper on Article 82: Implications of the Proposed Framework and Antitrust Rules for Dynamic Competitive Industries (2006). Disponível em:

http://papers.ssrn.com/sol3/papers.cfm?abstract_id=894466.

${ }^{143}$ EVANS, David S.; PADILLA, A. Jorge. Designing Antitrust Rules for Assessing Unilateral Practices: A Neo-Chicago Approach, in: University of Chicago Law Review, p. 72-73.

${ }^{144}$ DREXL, Josef. Is there a "More Economic Approach" to Intellectual Property and Competition Law ? , in: DREXL, Josef (Ed.), Research Handbook on Intellectual Property and Competition Law. Cheltenham: Edward Elgar, 2008, p. 36. 
essa finalidade? Em geral, as teses sobre a relação entre concorrência e inovação têm origem nas teorias de Joseph SCHUMPETER e nos modelos econômicos de Kenneth ARROW.

SCHUMPETER estabeleceu uma teoria no sentido de que mercados concentrados, normalmente dominados por firmas de grande porte, seriam mais favoráveis à inovação. ${ }^{145}$ De acordo com sua teoria, as firmas de grande porte seriam fornecedoras mais eficientes de inovação por terem maiores condições de obter recursos financeiros necessários para investir em atividades custosas e arriscadas de pesquisa e desenvolvimento, garantindo importantes economias de escala nessas atividades. Ademais, com linhas de produtos diversificadas, essas firmas poderiam explorar resultados inesperados advindos das atividades de pesquisa e desenvolvimento, o que as firmas menores seriam incapazes de fazer. Finalmente, firmas de grande porte em mercados monopolizados teriam maiores condições de apropriar-se dos resultados da inovação, utilizando esses "lucros de monopólio" para investir continuamente em atividades de pesquisa e desenvolvimento de novos produtos e processos. Nesse contexto, quanto maiores os retornos da inovação, maiores os incentivos para que essas firmas empreguem esses recursos para gerar mais inovação.

Kenneth ARROw, por outro lado, enfatizou o papel da concorrência como fator de incentivo à inovação. ${ }^{146} \mathrm{O}$ economista procurou demonstrar que um monopolista que não esteja exposto à concorrência efetiva ou potencial terá menores incentivos para investir em pesquisa e desenvolvimento do que firmas em mercados competitivos. Apesar de o monopolista e uma firma que opere sob concorrência terem os mesmos incentivos para inovar, o monopolista terá mais a perder, já que seu retorno líquido será menor. Isso porque, se o monopolista investir para lançar um novo produto, parte dos retornos resultantes dessa inovação servirá tão somente para substituir os lucros que o monopolista já obteve com produto anterior. Por outro lado, uma firma que não detenha poder de mercado e que venha a lançar esse mesmo produto inovador, poderá ter um retorno líquido superior, representado pelo incremento substancial de sua participação no mercado. Em consequência, os ganhos incrementais do monopolista resultantes da inovação serão inferiores aos ganhos líquidos da uma firma que opere sob concorrência.

${ }^{145}$ SCHUMPETER, Joseph A. Capitalism, Socialism and Democracy. New York: Harper Perennial Modern Thought, nova edição publicada em 2008, p. 102-103.

146 ARROW, Kenneth J. Economic Welfare and the Allocation of Resources for Invention. California: The Rand Corporation, p. 619. 
Todavia, o modelo de ARROW ignora a possibilidade da concorrência potencial, como se o monopolista não enfrentasse a possibilidade de ingresso iminente de um rival no mercado com produto similar ou alternativo. ${ }^{147}$ Conforme demonstram os modelos de organização industrial, o monopolista, diante desse cenário de concorrência potencial, não terá menores incentivos para inovar do que uma empresa que opere num mercado competitivo. Pelo contrário, o monopolista poderá ter até maiores incentivos para investir em inovação, caso esses investimentos sejam capazes de desencorajar a entrada de seus potenciais rivais. ${ }^{148}$

As teses de SCHUMPETER e ARROW estimularam uma série de estudos econômicos sobre os efeitos da concorrência sobre a inovação e, consequentemente, sobre a relação entre eficiência estática e dinâmica. ${ }^{149}$ Dados empíricos demonstram que, dependendo das condições de mercado, tanto situações de concorrência, como de maior concentração, são capazes de conduzir à inovação. Há quem sustente que mercados oligopolizados (poucas firmas de grande porte competindo entre si) seriam mais conducentes à inovação. ${ }^{150}$ Nesse contexto, os dados empíricos apresentados por SCHERER demonstram haver uma relação não linear entre concorrência e inovação, em formato de letra "U” invertida: o grau de inovação seria baixo quando os níveis de competição fossem elevados, alcançando seu ponto máximo em níveis intermediários de concentração (quando as quatro maiores firmas controlam aproximadamente $50 \%$ do mercado), e caindo à medida que a estrutura de mercado aproxima-se do monopólio. ${ }^{151}$ Assim, o grau de inovação seria baixo tanto em situações de concorrência excessiva, como em situações de monopólio, alcançando o ponto ótimo em mercados oligopolizados.

No entanto, os estudos empíricos sobre a relação entre concorrência e inovação são questionáveis e não apresentam respostas conclusivas. Isso porque esses estudos ignoram que fatores alheios à concorrência, tais como as diferenças entre indústrias e a

147 Cf. GREENSTEIN, Shane; RAMEY, Garey. Market Structure, Innovation, and Vertical Product Differentiation, in: 16 International Journal of Industrial Organization (1988), p. 285.

${ }^{148}$ Sobre o papel da concorrência potencial e as estratégias de inovação preventiva, cf. GILBERT, Richard J.; NEWBERRY, David M.G. Preemptive Patenting and the Persistence of Monopoly, in: 75 American Economic Review (1982), p. 514.

${ }^{149}$ Para um estudo aprofundado sobre o tema, cf. GILBERT, Richard J. Looking for Mr. Schumpeter: Where Are We in the Competition-Innovation Debate?, in: 6 Innovation Policy and the Economy (2006), p. 159.

${ }^{150}$ Cf. BAULMOL, William J. The Free-Market Innovation Machine: Analyzing the Growth Miracle of Capitalism. Princeton University Press, 2002, p. 32.

${ }^{151}$ SCHERER, F. M. Market Structure and the Employment of Scientists and Engineers, in: 57 American Economic Review (1967), p. 524-531. 
oportunidade tecnológica, cumprem papel mais determinante para a inovação do que a estrutura de mercado propriamente dita. Como bem ressaltado por KATZ e SHELANSKI, a estrutura de mercado é a consequência dos incentivos à inovação, e não a causa:

Many empirical studies fail to account for the fact that market structure itself might be affected by the perceived possibilities for innovation and that market structure might therefore be a result, rather than a cause, of innovation incentives. The literature addressing how market structure affects innovation (and vice versa) in the end reveals an ambiguous relationship in which factors unrelated to competition play an important role. $^{152}$

Portanto, não há qualquer fundamento econômico que sustente o argumento dos autores neo-schumpeterianos no sentido de que órgãos de defesa da concorrência deveriam abster-se de aplicar as normas antitruste contra agentes econômicos inovadores detentores de poder de mercado, ou serem mais lenientes nesses casos, como forma de não prejudicar seus incentivos à inovação e, consequentemente, a eficiência dinâmica. Estão equivocados também ao sugerir que o direito antitruste promove apenas a eficiência estática (alocativa), enquanto a propriedade intelectual promove a eficiência dinâmica.

Ao contrário do que sustentam esses autores, os estudos econômicos demonstram que a concorrência cumpre papel fundamental na promoção da inovação. De acordo com Jonathan BAKER, a partir desses estudos econômicos, quatro princípios importantes podem ser apontados na relação entre concorrência e inovação: (i) primeiro princípio: a concorrência ou corrida para desenvolver um novo produto encoraja a inovação (como se observa na teoria do "patent race"); (ii) segundo princípio: a concorrência entre rivais que fabricam um produto já existente encoraja essas firmas a investirem na redução de custos de produção, aprimoramento da qualidade, ou desenvolvimento de novos produtos, como forma de "escaparem da concorrência" (maior concorrência pré-inovação encoraja investimentos em inovação - concorrência pela superação ou substituição); (iii) terceiro princípio: empresas que tenham expectativa de enfrentar maior concorrência pós-inovação terão menores incentivos para investir ex ante em pesquisa e desenvolvimento; e (iv) quarto princípio: uma empresa terá incentivos

152 KATZ, Michael L.; SHELANSKI, Howard A. "Schumpeterian" Competition and Antitrust Policy in High-Tech Markets (2005), p. 17. Disponível em SSRN: http://ssrn.com/abstract=925707. 
adicionais para inovar se essa inovação desencorajar os investimentos em pesquisa e desenvolvimento por parte de rivais potenciais ("inovação preventiva"). ${ }^{153}$

Desse modo, a concorrência pela superação ou substituição pressiona os agentes econômicos a buscarem alternativas de diferenciação ("escape competition"), seja por meio da redução de custos de produção, aumento da qualidade, lançamento de novos produtos ou de aperfeiçoamentos aos produtos existentes, como demonstra o segundo princípio. Sob esse prisma, o direito antitruste cumpriria um papel relevante ao preservar essa concorrência pré-inovação. Por outro lado, maior concorrência pós-inovação poderá ser prejudicial em termos de incentivos, já que a perspectiva de obtenção de poder de mercado constitui um dos fatores a induzir investimentos em atividades de inovação, conforme indica o terceiro princípio. Sob esse aspecto, a propriedade intelectual cumpre papel relevante, já que permite que o autor ou inventor internalize o valor econômico das criações intelectuais, possibilitando o retorno dos investimentos em inovação ao impedir a concorrência pela imitação. Essa função da propriedade intelectual está em consonância com o terceiro princípio.

Ademais, é fato que o monopolista que vive numa situação cômoda, sem ser ameaçado por rivais, não terá qualquer incentivo para investir em inovação. Como bem ressaltado pelo economista John HICKS, "the best of all monopoly profits is a quiet life" 154 Somente diante da concorrência potencial de novos produtos e tecnologias mais avançadas, o monopolista terá incentivos para inovar, se seus investimentos em pesquisa e desenvolvimento forem capazes de deter a entrada ou reduzir os incentivos à inovação por parte de seus rivais ("preemptive innovation”), conforme demonstra o quarto princípio. ${ }^{155}$

Portanto, o direito antitruste cumpre papel central na promoção da inovação e da eficiência dinâmica, ainda que este fim seja alcançado de forma indireta, por meio da promoção da concorrência, seja ela efetiva ou potencial.

\footnotetext{
${ }^{153}$ BAKER, Jonathan B. Beyond Schumpeter vs. Arrow: How Antitrust Fosters Innovation (2007), p. 6-10. Disponível em SSRN: http://ssrn.com/abstract=962261 ou http://dx.doi.org/10.2139/ssrn.962261.

${ }^{154}$ HICKS, John R. Annual Survey of Economic Theory: The Theory of Monopoly. Econometrica 3, 1-8 (1955).

155 A despeito do que afirmam os neo-schumpterianos, ainda que SCHUMPETER acreditasse que mercados concentrados, dominados por firmas de grande porte, seriam mais conducentes à inovação, em nenhum momento negou a importância da concorrência potencial. O próprio conceito de "destruição criativa" de SCHUMPETER pressupõe que, nesse processo dinâmico de inovação, a iminência da concorrência pela diferenciação de produtos pressiona as firmas a inovarem.
} 
No entanto, os neo-schumpterianos estão certos ao afirmar que modelos econômicos estáticos, baseados essencialmente na verificação de participações de mercado para auferir a existência de poder de mercado, podem não ser adequados para a análise antitruste de mercados caracterizados por atividades de inovação. Dadas as características desses mercados, caberia às autoridades antitruste desenvolver instrumentos de análise que levassem em consideração a importância das eficiências dinâmicas (aumento da inovação pela introdução de novos produtos) para o bem-estar social, e não apenas eficiências estáticas (redução dos preços e aumento da produção). ${ }^{156}$

O grande problema é que a análise antitruste dos efeitos econômicos de determinadas condutas ou estratégias comerciais sobre a inovação é uma tarefa praticamente impossível, já que exigiria dos órgãos de defesa da concorrência avaliar ex ante se determinada conduta resultará em eficiências dinâmicas, representadas pelo aumento da inovação a médio ou longo prazo. A situação fica ainda mais complicada se a conduta ou estratégia em questão resultar em perdas de eficiência alocativa (estática) em curto prazo, como aumento de preços e exclusão de rivais do mercado, mesmo que seja capaz de gerar ganhos de eficiência dinâmica, mediante a introdução de novos produtos desejados e valorizados pelos consumidores. As ferramentas econômicas disponíveis para análise de condutas anticoncorrenciais (e de atos de concentração) permite a verificação dos efeitos dessas condutas sobre o bem-estar social, mediante aumento de preços e redução da produção no curto prazo. Contudo, essas ferramentas não permitem uma avaliação de seus efeitos sobre o bem-estar em longo prazo, consubstanciados no aumento da inovação e no consequente crescimento econômico. ${ }^{157}$

\footnotetext{
${ }^{156}$ Sabe-se que os agentes econômicos competem entre si a partir de múltiplas dimensões, que não apenas preço e produção, mas também inovação, qualidade, reputação, redução de custos, dentre outros. O que complica o trabalho das autoridades antitruste é o fato de que essas dimensões são muitas vezes negativamente relacionadas. Ao favorecer a dimensão inovação e qualidade, as autoridades poderão sacrificar as dimensões preço e produção, e vice-versa. Saber fazer o tradeoff entre os diferentes "mix" de dimensões competitivas em cada mercado e em cada caso concreto é um dos grandes desafios da política antitruste. Sobre o tema, cf. WRIGHT, Joshua D. Antitrust, Multi-Dimensional Competition, and Innovation: Do We Have an Antitrust-Relevant Theory of Competition Now? (Aug. 28, 2009). George Mason Law \& Economics Research Paper n. 09-44. Disponível em SSRN: http://ssrn.com/abstract=1463732.

${ }^{157}$ HovENKAMP exprime com clareza a questão: “(...) in antitrust economic analysis we tend to look at the price and output effects of practices. We evaluate them by asking whether they tend toward increased or decreased output, higher or lower prices, or whether they injure consumers over a testable time period, which is typically quite short. We do not try to show more, because for the most part we cannot answer second order questions about long run welfare implications. In the short run a practice may destroy a rival, produce monopoly, and even may appear to impair consumer welfare. But in the longer run, it may be part of the process of creative destruction that Schumpeter believed to be the bedrock of economic progress. Or to say it differently, it may be quite easy for an antitrust economist to predict that a particular exclusionary practice will tend to produce lower market wide output and higher prices. But it is very likely impossible to predict
} 
Desse modo, a análise antitruste de condutas e estratégias comerciais a partir da exploração de direitos de propriedade intelectual pode acabar resultando num dilema para os órgãos de defesa da concorrência. Sabe-se que, por um lado, muitas dessas condutas são lícitas e totalmente pró-competitivas, ainda que façam parte de um esquema de competição agressiva capaz de limitar a concorrência no mercado em curto prazo, podendo levar ao aumento de preços e redução de oferta. Isso porque essas estratégias incrementam as pressões competitivas no mercado, forçando os agentes econômicos a investir em inovação, qualidade e redução de custos de produção para tornarem-se mais competitivos e conquistarem as preferências dos consumidores. Mas, por outro lado, também é fato que muitas dessas condutas ou estratégias podem ser prejudiciais não apenas à eficiência alocativa (bem-estar social no curto prazo), mas também à eficiência dinâmica, já que são capazes de resultar na exclusão de rivais potencialmente inovadores ou no fechamento do mercado para novos produtos ou serviços lançados por potenciais entrantes, diminuindo as perspectivas de inovação no mercado como um todo.

Na impossibilidade de avaliar ex ante os efeitos dessas condutas sobre o bemestar em longo prazo, mais fácil e seguro seria evitar a aplicação das leis antitruste nesses casos ou simplesmente adotar uma postura mais leniente, como sugerem os neoschumpeterianos, o que não é adequado.

Tendo em vista as dificuldades de eventual análise antitruste ex ante sobre os resultados de condutas e estratégias capazes de conduzir à inovação, DREXL sugere que as autoridades antitruste adotem o conceito de "concorrência dinâmica" em vez de eficiência dinâmica. De acordo com o autor, a intervenção antitruste não deve servir para garantir a eficiência dinâmica, pois não há como prever que essa intervenção resultará em mais inovação a médio ou longo prazo. A intervenção antitruste deve salvaguardar as pressões competitivas necessárias para a manutenção das estruturas de incentivos à inovação presentes no mercado, sendo suficientes as ferramentas econômicas de análise normalmente utilizadas. ${ }^{158}$ Para tanto, seria necessário permitir que o sistema de propriedade intelectual exclua a possibilidade de concorrência pela imitação, enquanto o

whether some inchoate innovation that is part of the monopolist's scheme might produce long term gains that greatly outweigh these short term losses". HOVENKAMP, Herbert J. Schumpeterian Competition and Antitrust (Oct. 01, 2008), in: University of Iowa Legal Studies Research Paper n. 08-43. Disponível em SSRN: http://ssrn.com/abstract=1275986 ou http://dx.doi.org/10.2139/ssrn.1275986.

${ }^{158}$ DREXL, Josef. Is there a 'More Economic Approach' to Intellectual Property and Competition Law?, in: DREXL, Josef (Ed.), Research Handbook on Intellectual Property and Competition Law, Cheltenham: Edward Elgar, 2008, p. 40. 
direito da concorrência concentraria esforços na proteção da concorrência pela superação ou substituição, que é justamente o que caracteriza a concorrência dinâmica. Dessa forma, a intervenção antitruste seria cabível quando agentes econômicos abusassem de seus direitos de propriedade intelectual para inviabilizar essa concorrência dinâmica, seja pelo fechamento do mercado para novos entrantes potencialmente inovadores ou por meio da exclusão de rivais efetivos capazes de desenvolver produtos mais inovadores. ${ }^{159}$

Jonathan BAKER sugere que a política antitruste deveria concentrar esforços em setores industriais específicos e em determinados tipo de condutas anticoncorrenciais. ${ }^{160}$ Por meio dessa "seleção", a intervenção antitruste contribuiria para o aumento da concorrência pré-inovação - concorrência dinâmica pela superação ou substituição - sem ampliar a concorrência pós-inovação - concorrência pela imitação, evitada pela propriedade intelectual -, assegurando os incentivos adequados aos investimentos em pesquisa e desenvolvimento.

De fato, vimos que determinados setores industriais, como os segmentos de alta tecnologia, em especial os de tecnologia da informação, são marcados pela presença de elevadas barreiras à entrada provocadas pelas externalidades positivas de redes, que facilitam o recurso a práticas anticoncorrenciais de exclusão a partir de direitos de propriedade intelectual, visando à manutenção de posições de domínio sobre o mercado. Cite-se como exemplo as práticas do tipo "cheap exclusion", definidas como práticas de exclusão fáceis de serem implementadas pelos agentes econômicos dominantes e que normalmente não possuem justificativas econômicas plausíveis. Essas práticas possibilitam a criação de incompatibilidades entre bens e serviços complementares ao impedir que rivais tenham acesso a insumos essenciais, normalmente protegidos por direitos de propriedade intelectual, que lhes permitiriam lançar produtos e tecnologias complementares mais inovadores no mercado, ou até mesmo tecnologias substitutas ou alternativas à tecnologia ofertada pelo agente econômico dominante. ${ }^{161}$

\footnotetext{
${ }^{159}$ Ibid., p. 47.

${ }^{160}$ BAKER vê a política antitruste como instrumento importante de incentivo à inovação por meio da preservação da concorrência. Concentrar esforços em setores e condutas específicos seria uma forma de ir além do debate Schumpeter vs. Arrow. BAKER, Jonathan B. Beyond Schumpeter vs. Arrow: How Antitrust Fosters Innovation (2007), p. 20. Disponível em: SSRN: http://ssrn.com/abstract=962261 ou http://dx.doi.org/10.2139/ssrn.962261.

${ }^{161}$ BAKER, Jonathan B. Dynamic Competition Does Not Excuse Monopolization (Oct. 15, 2008), p. 11. Disponível em SSRN: http://ssrn.com/abstract=1285223 ou http://dx.doi.org/10.2139/ssrn.1285223.
} 
A intervenção antitruste nesses casos, normalmente por meio da imposição de um dever de licenciar ou de permitir o acesso de rivais à tecnologia padrão protegida por direitos de propriedade intelectual, ainda que pudesse reduzir as possibilidades de retorno que o agente econômico dominante poderia extrair do mercado - o que representaria uma potencial redução de seus incentivos à inovação -, certamente permitiria salvaguardar as pressões competitivas, especialmente no que concerne à preservação da concorrência potencial por meio da eliminação de barreiras artificiais ao ingresso de novos produtos ou tecnologias no mercado. Em outras palavras, ao preservar as pressões competitivas no mercado, a intervenção antitruste abriria caminho para a concorrência dinâmica pela superação ou substituição, permitindo o aumento dos incentivos à inovação da indústria como um todo. ${ }^{162}$

Essas questões serão aprofundadas ao longo deste trabalho, especialmente quando analisarmos a experiência dos Estados Unidos e da União Europeia no controle das práticas restritivas da concorrência a partir da exploração de direitos de propriedade intelectual.

\footnotetext{
${ }^{162}$ Nas palavras de BAKER: “(...) the increased product market competition that results from antitruste enforcement may provide strong encouragement to R\&D by the dominant firm's rivals, and consequently generate a substantial increase in rival prospects for innovation success. If so, the greater competition resulting from antitrust enforcement against monopolization would increase the aggregate odds of innocation success in the market as a whole". Id., ibid..
} 


\section{INTERFACE ENTRE PROPRIEDADE INTELECTUAL E DIREITO DA CONCORRÊNCIA NO ACORDO TRIPS/OMC}

As negociações do Acordo TRIPS/OMC durante a Rodada Uruguai foram marcadas por profundas divergências de interesses entre, de um lado, os países desenvolvidos interessados no fortalecimento dos padrões internacionais de proteção aos direitos de propriedade intelectual e, de outro, os países em desenvolvimento, receosos de que a inclusão do tema na OMC poderia dificultar a transferência internacional de tecnologias, além de fortalecer a proteção patentária em setores de interesse público, como os de saúde e nutrição. ${ }^{163}$

Mesmo assim, após longa negociação e troca de concessões entre os países desenvolvidos e em desenvolvimento, o Acordo TRIPS foi implementado como um dos acordos abrangidos pela OMC. Como se pode observar no preâmbulo e em diversos dispositivos do Acordo, as tensões Norte-Sul que marcaram as negociações foram direcionadas de modo a acomodar as divergentes posições, resultando num texto jurídico equilibrado, no qual foram estabelecidos padrões mínimos de proteção da propriedade intelectual a serem observados pelos Membros da OMC como forma de reduzir distorções e obstáculos ao comércio internacional. Em contrapartida, foram reconhecidos os objetivos legítimos de política pública, relacionados à proteção desses direitos, e as necessidades especiais dos países em desenvolvimento. ${ }^{164}$

\footnotetext{
${ }^{163}$ Sobre as negociações do Acordo TRIPS e o direito internacional da propriedade intelectual, cf. BASSO, Maristela. O Direito Internacional da Propriedade Intelectual. Porto Alegre: Livraria do Advogado, 2000.

${ }^{164}$ O TRIPS apresenta diversas flexibilidades, limitações e exceções à proteção da propriedade intelectual, como se pode observar, sobretudo, nos seguintes dispositivos: (i) Artigo 8, que autoriza os Membros a adotarem medidas de preservação de questões de interesse público e repressão ao abuso de direitos de propriedade intelectual; (ii) Artigos, 13, 17, 26.2 e 30, que estabelecem limitações e exceções à proteção conferida, respectivamente, aos direitos autorais, marcas, desenhos industriais e patentes; (iii) Artigo 27.2, que se refere ao não patenteamento de invenções cuja exploração no território seja necessário evitar para proteger a ordem pública ou a moralidade, inclusive para proteger a vida ou a saúde humana, animal ou vegetal ou para evitar sérios prejuízos ao meio ambiente; (iv) no Artigo 31, que trata das hipóteses que autorizam os Membros a decretarem o licenciamento compulsório de patentes; e (v) no Artigo 40, que permite que os Membros adotem medidas para o controle de práticas restritivas da concorrência em acordos de licenciamento de direitos de propriedade intelectual. Ademais, o TRIPS leva em consideração os Membros com diferentes estágios em desenvolvimento econômico, uma vez que, enquanto para os países desenvolvidos foi conferido um prazo até 1996 para o cumprimento das obrigações contidas no Acordo, para os países em desenvolvimento o prazo foi estendido até 2000 e, para os menos desenvolvidos, até 2006. Após a Conferência de Doha, em 2001, esses prazos foram estendidos até 2005 para os países em desenvolvimento, e até 2016 para os países menos desenvolvidos. O objetivo desses períodos de transição é oferecer a esses países prazos suficientes para a implementação, em suas legislações nacionais, de todos os padrões de proteção aos direitos de propriedade intelectual conforme determinados pelo TRIPS.
} 
Essa ideia de equilíbrio pode ser observada na redação do Artigo 7, que estabelece os objetivos do Acordo TRIPS: “A proteção e a aplicação de normas de proteção dos direitos de propriedade intelectual devem contribuir para a promoção da inovação tecnológica e para a transferência e difusão da tecnologia, em benefício mútuo de produtores e usuários de conhecimento tecnológico e de uma forma conducente ao bemestar social e econômico e a um equilíbrio entre direitos e obrigações" (grifo nosso).

Desse modo, é possível afirmar que as normas do TRIPS sobre a concorrência resultaram de concessões dos países desenvolvidos aos países em desenvolvimento em troca do fortalecimento dos padrões mínimos de proteção da propriedade intelectual, devendo, portanto, ser consideradas no contexto das "flexibilidades" constantes no Acordo.

Feitas as observações gerais sobre o Acordo TRIPS, nesta Seção analisamos as origens do tratamento do tema da interface entre propriedade intelectual e concorrência no direito internacional, além de buscar uma interpretação adequada aos Artigos 8.2, 31(k) e 40 do Acordo TRIPS/OMC, que tratam do tema numa abordagem direcionada à repressão ao abuso de direitos de propriedade intelectual e às práticas restritivas da concorrência capazes de restringir o comércio e a transferência internacional de tecnologia. ${ }^{165}$

\subsection{Origens da inclusão do tema da interface entre propriedade intelectual e direito da concorrência na agenda internacional}

Os primeiros esforços para a criação de regras internacionais sobre concorrência remontam à Carta de Havana de 1948, que incorporou o resultado final da Conferência sobre Comércio e Emprego das Nações Unidas para a criação da Organização Internacional do Comércio (OIC). ${ }^{166} \mathrm{O}$ Artigo 46 da Carta de Havana, intitulado "Práticas Comerciais Restritivas", continha um compromisso expresso dos países no sentido de adotar medidas apropriadas e cooperar com a OIC para coibir práticas comerciais que

\footnotetext{
165 Trabalhos acadêmicos que versem especificamente sobre os Artigos 8.2, 31(k) e 40 do TRIPS são escassos. No Brasil, destacamos os seguintes: PADILHA, Alexandre Garcia. A Influência do Direito da Concorrência na Proteção Internacional dos Direitos de Propriedade Intelectual: Especial Referência aos Artigos 8.2 e 40 do Acordo TRIPS, Dissertação de Mestrado - Faculdade de Direito da Universidade de São Paulo, São Paulo, 2012; e ROSENBERG, Barbara. Patentes de Medicamentos e Comércio Internacional: Os Parâmetros do TRIPS e do Direito Concorrencial para a Outorga de Licenças Compulsórias, Tese de Doutorado - Faculdade de Direito da Universidade de São Paulo, São Paulo, 2004.

166 Embora nunca tenha sido implementada, a OIC era uma das instituições econômicas idealizadas no famoso Encontro de Bretton Woods, havido em 1945, que, juntamente com o Fundo Monetário Internacional (FMI) e o Banco Mundial, constituiriam os pilares da Nova Ordem Econômica Mundial. A Carta de Havana é o resultado da Conferência sobre Comércio e Emprego das Nações Unidas realizada em Havana, Cuba, de 21 de novembro de 1947 a 24 de março de 1948.
} 
restrinjam a concorrência, o acesso a mercados, ou que possibilitem um controle monopolizador, sempre que essas práticas produzirem efeitos danosos sobre a expansão da produção, do comércio e do desenvolvimento dos Membros da organização. ${ }^{167}$

De acordo com o dispositivo em comento, qualquer membro da OIC poderia até mesmo acionar o mecanismo de solução de controvérsias da organização com objetivo de questionar a omissão de qualquer outro membro em adotar as medidas necessárias para reprimir práticas restritivas. Dentre as diversas práticas citadas, duas merecem destaque por tratar especificamente de práticas restritivas da concorrência relacionadas à exploração de direitos de propriedade intelectual e tecnologias: (i) impedir por meio de contrato o desenvolvimento ou aplicação de tecnologia ou invenção, seja patenteada ou não (Artigo 26.3(e)); e (ii) estender o uso de patentes, marcas ou direitos autorais concedidos por qualquer Membro a matérias as quais, de acordo com suas leis e regulamentos, não estejam dentro do escopo de proteção de tais direitos, ou a produtos ou condições de produção, uso ou venda que, da mesma forma, não constituam objeto de tais direito (Artigo 26.3(f)). Contudo, a OIC jamais chegou a ser implementada, muito embora o GATT-1947, acordo provisório que se originou de um dos capítulos da Carta de Havana, tenha constituído o instrumento que, de fato, regulamentou o comércio internacional durante décadas até a criação da OMC.

Muito anos depois, em 1980, a Assembleia Geral da ONU adotou uma espécie de "código de conduta" denominado "Set of Multilateral Agreed Equitable Principles and Rules for the Control of Restrictive Business Practices", cujo principal objetivo era assegurar que práticas comerciais restritivas não impedissem a concretização dos benefícios que resultariam da liberalização do comércio internacional, especificamente aquelas que prejudicavam o comércio e o desenvolvimento dos países emergentes. ${ }^{168}$ Como não se tratava de um documento vinculativo, o documento não resultou em maiores repercussões no cenário internacional.

Durante a Rodada Uruguai, foi proposto o chamado Projeto de Código Antitruste Internacional ("Draft International Antitrust Code"), que visava à criação de um regime jurídico de concorrência internacional, baseado em regras mínimas, substantivas e

167 Cf. Artigo 46 da Carta de Havana, cujo texto está disponível no site da OMC: http://www.wto.org/english/docs_e/legal_e/havana_e.pdf. Acesso em: 5 jun. 2012.

${ }^{168}$ Cf. Documento das Nações Unidas TD/RBP/CONF/10/Rev.2 (1980). Disponível em: http://unctad.org/en/docs/tdrbpconf10r2.en.pdf. Acesso em: 5 jun. 2012. 
procedimentais, com aplicação centralizada e utilização de um órgão de solução de controvérsias. O regime antitruste internacional deveria ser administrado por uma autoridade internacional de concorrência que teria competência para tomar medidas contra autoridades antitruste nacionais, instaurar painéis para resolução de disputas, assistir as partes na aplicação do Código Antitruste Internacional, dentre outras medidas. O Projeto de Código continha o reconhecimento de que a exploração de direitos de propriedade intelectual, dentro dos seus limites legais, não resulta em restrições à concorrência e que o conteúdo de um direito de propriedade intelectual permite ao seu titular conceder, durante o prazo legal de proteção, licenças passíveis de serem restringidas territorialmente, além de impor ao licenciado obrigações e restrições "justificáveis". ${ }^{169}$ Não obstante mais esse esforço, o Projeto de Código Antitruste Internacional acabou não sendo incluído no sistema multilateral da OMC devido à sua natureza extremamente ambiciosa. ${ }^{170}$ De fato, seria difícil imaginar a criação de um marco antitruste internacional considerando que naquela época a maioria dos países sequer possuía normas nacionais de defesa da concorrência.

Após a criação da OMC, durante a Conferência Ministerial de Cingapura, em 1996, vários países passaram a considerar relevante a criação de um acordo multilateral de cooperação antitruste, o que resultou na criação do Grupo de Trabalho sobre a Interação entre Comércio e Política de Concorrência. Após alguns anos de discussão, os trabalhos forram encerrados em decorrência da ausência de consenso entre os Membros da OMC na Conferência Ministerial de Cancún, realizada em 2003, que daria início às negociações do acordo multilateral. Por outro lado, o tema da interface entre propriedade intelectual e política de concorrência foi bastante discutido em algumas reuniões do Grupo de Trabalho sobre a Interação entre Comércio e Política de Concorrência, constituindo importante referência para pesquisa. ${ }^{171}$

Não há dúvidas de que a tentativa mais ambiciosa de criação de normas internacionais relacionadas à interface entre propriedade intelectual e direito da concorrência decorreu das negociações do Código Internacional de Conduta sobre

\footnotetext{
${ }^{169}$ Cf. International Anti-trust Code Worling Group, "Draft International Antitrust Code", Antitrust and Trade Regulation Report, v. 65, n. 1628 (19 August 1993).

${ }^{170}$ Cf. MONTINI, Massimiliano. Globalization and International Antitrust Cooperation. International Conference - Trade and Competition in the WTO and Beyond - Veneza, 4 e 5 dez. 1998, p. 6.

${ }^{171}$ Cf. Working Group on the Interface between Trade and Competition Policy (WGTCP) Annual Report of 2003, WTO document WT/WGTCP/7.
} 
Transferência de Tecnologia, sob os auspícios da Conferência das Nações Unidas sobre Comércio e Desenvolvimento (UNCTAD). As negociações para a criação desse Código de Conduta tiveram início em 1976 e perduraram até meados de 1985, quando o projeto foi definitivamente abandonado em razão da total ausência de consenso entre países desenvolvidos e em desenvolvimento. ${ }^{172}$

De fato, as tensões Norte-Sul em relação a diversos temas relacionados à transferência internacional de tecnologia marcaram todo o período de negociação. Segundo Juliana VIEGAS, os governos da maioria dos países em desenvolvimento, tradicionalmente mais dependentes de tecnologia internacional, chegaram à conclusão de que empresas multinacionais de países desenvolvidos utilizavam a transferência de tecnologia como um instrumento de evasão de divisas, causando prejuízos consideráveis ao desenvolvimento econômico e tecnológico dos países emergentes. ${ }^{173}$ Diversas normas e regulamentos foram aprovados nesses países entre o fim da década de 1960 e início da década de 1970 com o objetivo de reduzir as condições desiguais e discriminatórias impostas por empresas multinacionais em acordos de transferência de tecnologia celebrados com empresas receptoras locais. Nesse contexto, as discussões sobre o Código de Conduta no âmbito da UNCTAD seriam uma tentativa dos países em desenvolvimento de legitimar suas políticas nacionais intervencionistas nesse campo e garantir a proteção necessária contra pressões de investidores estrangeiros e de governos de países industrializados. ${ }^{174}$

De acordo com RofFe e Spennemann, os países em desenvolvimento, extremamente dependentes de tecnologia estrangeira, entendiam que o Código de Conduta deveria ter como principais objetivos: (i) estabelecer padrões gerais e equitativos entre as partes de acordos de transferência de tecnologia; (ii) permitir o equilíbrio nas relações contratuais entre as partes, de modo a prevenir abusos praticados pela parte que possuísse maior poder de barganha; (iii) ampliar a capacitação técnica e científica por meio da

\footnotetext{
${ }^{172}$ UNCTAD. Draft International Code of Conduct on the Transfer of Technology as of 5 June 1985's (TD/CODE/TOT/47) (1985). Para a última versão da minuta, cf. ILM 1980, v. XIX, n. 3, May, p. 773-812.

${ }^{173}$ De acordo com a autora: “(...) países como a Argentina, o Brasil, a Índia, o México e os países do Pacto Andino (Colômbia, Peru, Bolívia, Equador e Chile - que se desligou do Pacto em 1976) chegaram à conclusão - não sem razão - de que muitas vezes os fornecedores de tecnologia (na maioria empresas multinacionais) exploravam as receptoras de tecnologia nos países em desenvolvimento mediante a cobrança excessiva de royalties, por períodos longos, por tecnologia obsoleta ou não de ponta, e mediante cláusulas restritivas à liberdade de comercialização das receptoras". VIEGAS, Juliana L. B. Aspectos Legais de Contratação na Área da Propriedade Industrial, in: PEREIRA DOS SANTOS, Manoel J.; JABUR, Wilson Pinheiro. Contratos de Propriedade Industrial e Novas Tecnologias. São Paulo: Saraiva, 2007 (Série GVlaw), p. 06.
} 
transferência internacional de tecnologia; (iv) melhorar a contribuição da tecnologia para a identificação e solução de problemas sociais e econômicos; e (v) formular, adotar e implementar políticas nacionais e normas sobre transferência de tecnologia. Os países desenvolvidos, em sua maioria exportadores de tecnologia, viam a iniciativa com suspeita e previam que o projeto de código acabaria se tornando um instrumento excessivamente intervencionista que certamente dificultaria a transferência internacional de tecnologia ao invés de promovê-la. ${ }^{175}$

A versão do projeto de Código de Conduta publicada em 1985 continha em seu capítulo 4 uma lista com quatorze práticas restritivas que, segundo os países em desenvolvimento, deveriam ser expressamente proibidas em acordos de transferência de tecnologia. São elas: cláusulas de grantback com exclusividade; proibição de questionamento da validade de patentes ("non-challenge clauses"); cláusulas de não concorrência ("exclusive dealing"); restrições de pesquisa; restrições sobre uso de pessoal; fixação de preços; restrições sobre adaptações; vendas exclusivas em acordos de representação; licenças casadas ("tying arrangements"); restrições a exportações; licenças cruzadas e pool de patentes; restrições sobre publicidade; pagamento de royalties após a expiração dos direitos de propriedade intelectual; e restrições impostas após o término do contrato. $^{176}$

Os países industrializados, por seu turno, firmaram o entendimento no sentido de que as práticas restritivas listadas deveriam ser analisadas caso a caso e com base em critérios de razoabilidade, de modo a verificar se produzem ou não efeitos adversos sobre a concorrência. Seguindo a experiência das jurisdições mais avançadas em matéria de aplicação de normas antitruste, esses países buscaram deixar claro que somente em casos muito limitados práticas comerciais restritivas poderiam ser consideradas ilícitas per se. De acordo com esse entendimento, muitas das práticas consideradas restritivas poderiam ser justificadas com base em critérios de eficiência, podendo inclusive ser benéficas à economia. Essa abordagem demonstra claramente uma tentativa dos países desenvolvidos

\footnotetext{
${ }^{174}$ Ibid., p. 07.

175 ROFFE, Pedro; SPENNEMANN, Christoph. Control of Anti-competitive Practices in Contractual Licenses under the TRIPS Agreement, in: CORREA, Carlos M.; YUSUF, Abdulqawi A. (Ed.). Intellectual Property and International Trade: The Trips Agreement. 2nd ed. Wolters Kluwer, 2008, p. 309.

176 Capítulo 4 da versão de 1985 do Transfer of Technology International Code, in: UNCTAD (2001), Compendium of International Arrangements on Technology Transfer: Selected Instruments. Geneva: UNCTAD, p. 266-269.
} 
de vincular o tema das práticas restritivas em acordos de transferência de tecnologia a critérios de análise antitruste, conforme a experiência norte-americana e europeia sobre a matéria. ${ }^{177}$

Todavia, os países em desenvolvimento insistiram numa abordagem que levasse em consideração a proibição per se de práticas restritivas que limitem de maneira injustificável o comércio ou que afetem adversamente a transferência internacional de tecnologia, tendo em vista seus potenciais efeitos negativos sobre o desenvolvimento econômico e tecnológico dos países emergentes receptores de tecnologia. De acordo com essa abordagem, todas as práticas listadas na minuta de código seriam desleais e prejudiciais ao desenvolvimento, independentemente de serem ou não anticoncorrenciais. Assim, houve um claro conflito entre a "abordagem tecnológica", defendida pelos países emergentes, e a "abordagem concorrencial", proposta pelos países industrializados, o que foi crucial para o insucesso das negociações. ${ }^{178}$

Apesar de não ter sido concluído, o projeto de Código Internacional de Conduta sobre Transferência de Tecnologia acabou servindo de referência para as negociações dos Artigo 8.2 e 40 do Acordo TRIPS, que tratam de abusos de direitos de propriedade intelectual e práticas restritivas em acordos de licenciamento, permitindo a composição entre os países desenvolvidos e em desenvolvimento no que concerne às diferentes abordagens propostas para o tema.

\subsection{As disposições do Acordo TRIPS sobre concorrência}

Durante as negociações do Acordo TRIPS, os países em desenvolvimento manifestaram preocupação com o fato de que o fortalecimento da proteção da propriedade intelectual poderia resultar no aumento da incidência de práticas restritivas capazes de prejudicar o comércio e a transferência internacional de tecnologia. As principais preocupações eram com práticas e condições restritivas inseridas em acordos de licenciamento de direitos de propriedade intelectual, o que já havia sido objeto de intensos debates por ocasião das negociações do Código Internacional de Conduta sobre Transferência de Tecnologia. Os países desenvolvidos estavam concentrados em fortalecer

${ }^{177}$ Cf. UNCTAD, The Basic Objectives and Main Provisions of Competition Laws and Policies, (UNCTAD/ITD/15), 11 Oct. 1995. 
os padrões mínimos de proteção dos direitos de propriedade intelectual e não tinham interesse em incluir o tema nas negociações, mesmo porque já possuíam sólida experiência interna no controle de práticas de restritivas a partir da exploração de direitos de propriedade intelectual. ${ }^{179}$

Após a insistência dos países em desenvolvimento, regras sobre concorrência acabaram sendo incluídas no Acordo TRIPS, como resultado de concessões feitas pelos países desenvolvidos em troca do fortalecimento dos padrões mínimos de proteção dos direitos de propriedade intelectual. Assim, as disposições sobre concorrência podem ser compreendidas no contexto das flexibilidades que foram incluídas no Acordo como forma de estabelecer um equilíbrio entre promoção da inovação e transferência e difusão da tecnologia. É importante ressaltar que o TRIPS não trata diretamente do tema, deixando essa tarefa para legislações nacionais dos Membros da OMC, que possuem ampla discricionariedade para implementar medidas visando ao controle de práticas restritivas da concorrência a partir da exploração de direitos de propriedade intelectual.

As disposições relevantes do TRIPS sobre concorrência foram incluídas no Artigo 8.2, que autoriza os Membros a adotarem medidas apropriadas para evitar abusos dos direitos de propriedade intelectual e práticas que restrinjam o comércio e a transferência internacional de tecnologia, no Artigo 40, que dispõe sobre o controle das práticas restritivas em acordos de licenciamento de direitos de propriedade intelectual, e no Artigo $31(\mathrm{k})$, que trata do licenciamento compulsório de patentes para remediar práticas anticoncorrenciais.

\subsubsection{Interpretação do Artigo 8.2}

Ao tratar dos princípios do Acordo TRIPS, o Artigo 8.2 dispõe que:

Medidas apropriadas, desde que consistentes com o disposto neste Acordo, poderão ser necessárias para evitar o abuso dos direitos de propriedade intelectual por seus titulares ou para evitar o recurso a

\footnotetext{
${ }^{178}$ ROFFE, Pedro ; SPENNEMANN, Christoph. Control of Anti-competitive Practices in Contractual Licenses under the TRIPS Agreement, in: CORREA, Carlos M.; YUSUF, Abdulqawi A. (Ed.). Intellectual Property and International Trade: The Trips Agreement. 2nd ed. Wolters Kluwer, 2008, p. 310.

${ }^{179}$ Cf. UNCTADE \& ICTSD, TRIPS and Development - Resource Book, Part Three: Intellectual Property Rights and Competition. Cambridge University Press, 2005, p. 542.
} 
práticas que limitem de maneira injustificável o comércio ou que afetem adversamente a transferência internacional de tecnologia.

O dispositivo não estabelece um regramento específico sobre a matéria, muito menos um padrão que obrigatoriamente deva ser seguido pelos Membros da OMC em suas legislações nacionais para coibir práticas abusivas. Ao contrário, o objetivo do Artigo 8.2 é tão somente estabelecer uma regra geral reconhecendo o direito dos Membros de implementar medidas internas de políticas públicas, por meio de leis e regulamentos, voltadas para a repressão a práticas que constituam abuso de direitos de propriedade intelectual, que restrinjam o comércio ou que prejudiquem a transferência internacional de tecnologia, sob a condição de que tais medidas sejam "apropriadas" e "necessárias", além de "consistentes" com as demais disposições do Acordo TRIPS. ${ }^{180}$

O caráter amplo do dispositivo permite concluir que os Membros estão autorizados a adotar medidas para coibir quaisquer práticas restritivas decorrentes da exploração dos direitos de propriedade intelectual cobertos pelo TRIPS, podendo incluir tanto condutas abusivas unilaterais, como restrições contratuais constantes de acordos de licenciamento e transferência de tecnologia.

Nesse contexto, o Artigo 8.2 aplica-se somente a abusos ou práticas restritivas, excluindo-se as operações de concentração econômica que normalmente estão sujeitas ao controle preventivo por parte de autoridades antitruste nacionais, tais como fusões e aquisições de empresas, que muitas vezes envolvem, indiretamente, a cessão de direitos de propriedade intelectual e tecnologias, ou mesmo a inclusão de acordos ancilares de licenciamento. Pelo mesmo motivo, estão fora do escopo do dispositivo as joint ventures e acordos de cooperação, tais como aqueles voltados à pesquisa e desenvolvimento, que também são normalmente considerados como operações de concentração econômica. ${ }^{181}$

\footnotetext{
${ }^{180}$ Nesse sentido, HEINEMANN esclarece que: “O Acordo TRIPS não obriga os Estados-Membros a tomarem medidas contra o abuso de direitos de propriedade intelectual, mas permite tais medidas. Tal constatação resulta de uma leitura cuidadosa do Art. 8(2) do Acordo, que prevê que 'medidas apropriadas poderão ser necessárias', bem como de sua função de cláusula de exceção. Não se trata de estabelecer um standard mínimo para o direito concorrencial; apenas esclarece que o direito antitruste, sob certas condições, não deve violar as normas estabelecidas no âmbito do sistema de proteção da propriedade intelectual”. HEINEMANN, Andrea. Antitruste Internacional e Propriedade Intelectual, in: RODRIGUES JR., Edson Beas; POLIDO, Fabrício (Orgs.). Propriedade Intelectual: Novos Paradigmas Internacionais, Conflitos e Desafios. Rio de Janeiro: Elsevier, 2007, p. 440.

${ }^{181}$ Cf. UNCTADE \& ICTSD, TRIPS and Development - Resource Book, Part Three: Intellectual Property Rights and Competition. Cambridge University Press, 2005, p. 546.
} 
Com efeito, o Artigo 8.2 do TRIPS poderá ser levado em consideração somente quando práticas restritivas estiverem diretamente relacionadas à exploração de direitos de propriedade intelectual, cabendo às legislações nacionais dos Membros estabelecer a forma pela qual tais práticas poderão ser coibidas. O Artigo 8.2 lista três tipos de práticas que podem ser objeto de repressão ou controle: (i) abusos de direitos de propriedade intelectual; (ii) práticas que limitem de maneira injustificável o comércio; e (iii) práticas que afetem adversamente a transferência internacional de tecnologia. $\mathrm{O}$ dispositivo também estabelece limites à liberdade dos Membros para regular a matéria em suas legislações nacionais, uma vez que as medidas que poderão ser adotadas devem ser "apropriadas" e "necessárias" para evitar abusos, além de "consistentes" com os dispositivos contidos no Acordo TRIPS. Passamos a analisar a seguir os tipos de práticas mencionadas no dispositivo, bem como as limitações impostas aos Membros.

\subsubsection{Abuso de direitos de propriedade intelectual}

O conceito de abuso de direitos de propriedade intelectual é amplo, não se limitando apenas à esfera do direito antitruste. Em geral, abuso de direito ocorre quando o titular desse direito o exerce de modo a extrapolar seus limites jurídicos, desviando das finalidades sociais e econômicas para as quais o direito foi conferido. ${ }^{182}$ Nesse contexto, é possível afirmar que abuso de direitos de propriedade intelectual, seja no caso de patentes ou de direitos autorais, pressupõe a exploração irregular de tais direitos, para além dos seus limites legais, de modo a contrariar suas funções sociais e econômicas, conforme referidas no Artigo 7 do TRIPS, quais sejam, promover a inovação tecnológica e a transferência e difusão da tecnologia, em benefício mútuo de produtores e usuários de conhecimento tecnológico e de uma forma conducente ao bem-estar social e econômico. ${ }^{183}$

182 De acordo com AMARAL: "Há abuso de direito sempre que o titular o exerce fora dos seus limites intrínsecos, próprios de suas finalidades sociais e econômicas". AMARAL, Francisco. Direito Civil: Introdução, 7. ed. Rio de Janeiro: Renovar, 2008, p. 243. Segundo VENOSA: “Ocorre abuso quando se atua aparentemente dentro da esfera jurídica, daí ser seu conteúdo aplicável em qualquer esfera jurídica, ainda que isso no direito público possa ter diferente rotulação. (...) No abuso de direito, pois, sob a máscara de ato legítimo esconde-se uma ilegalidade. Trata-se de ato jurídico aparentemente lícito, mas que, levado a efeito sem a devida regularidade, ocasiona resultado tido como ilícito. (...) Conclui-se, portanto, que o titular da prerrogativa jurídica, de direito subjetivo, que atua de modo tal que sua conduta contraria a boa-fé, a moral, os bons costumes, os fins econômicos e sociais da norma, incorre no ato abusivo". VENOSA, Silvio de Salvo. Direito Civil: Parte Geral, 10. ed. São Paulo: Atlas, 2010, p. 552-554.

183 Nesse sentido, GALLEGO afirma que: “(...) the TRIPS Agreement is not only concerned with the production of knowledge, but also with its diffusion and with the fact that this knowledge gets used. Moreover, as users of IP-protected goods are both end users as well as producers of goods and services that incorporate an existing invention while developing it, the TRIPS Agreement is also very much concerned with the continuous improvement of existing knowledge and as a precondition for this, with preserving 
Há formas variadas de abusos que podem resultar da exploração de direitos de propriedade intelectual. A Convenção da União de Paris (CUP) já tratava do tema em seu Artigo 5(A), que autoriza os países da União "a adotarem providências legislativas permitindo a concessão de licenças compulsórias para prevenir os abusos que poderiam resultar do exercício do direito exclusivo conferido pela patente, como, por exemplo, a falta de exploração". Embora o dispositivo não ofereça uma diretriz detalhada sobre as hipóteses de abuso de patentes, o exemplo mencionado - não exploração local do objeto da patente - pode configurar abuso sujeito ao licenciamento compulsório, conforme previsto nas legislações internas de diversos Membros da OMC, especialmente em países em desenvolvimento como o Brasil, uma vez que a não utilização efetiva da patente impede o atendimento de sua função social e econômica. ${ }^{184}$

Nos Estados Unidos, a doutrina da patent misuse é uma boa referência para o estudo do abuso de direitos de propriedade intelectual. De acordo com essa doutrina, misuse ou abuso pode ser compreendido como uma tentativa de estender o escopo da patente para além de seus limites legais. O exemplo mais marcante é o da licença casada (ou venda casada), que ocorre quando o titular de uma patente estende de forma indevida a exclusividade conferida pela patente a produtos não patenteados, oferecidos como condição para o licenciamento do produto patenteado. ${ }^{185}$ Outras práticas restritivas em acordos de licenciamento também podem ser consideradas no contexto da doutrina do patent misuse, tais como a cobrança de royalties após a expiração da patente ou sobre a totalidade das vendas que incluam produtos não protegidos. Embora a doutrina do patent misuse tenha se desenvolvido de forma independente em relação ao direito antitruste norteamericano, houve uma aproximação entre os dois conceitos, de modo que muitos tribunais entendem que a configuração de uma hipótese de misuse requer a demonstração de que o

access to this knowledge by third parties. Coming back to the concept of abuse, a use of the IP right that runs counter to the goals of promoting the diffusion of knowledge and of preserving access to it would definitely defeat its purpose. Likewise, as was pointed out above in the introduction, IP protection can only effectively contribute to the goal of promoting innovation if the operability of the mechanism of dynamic competition is guaranteed. Thus, a use of the IP right directed at restricting or excluding the possibility of competing firms to offer substitutive goods would also qualify as an abuse of the right". GALLEGO, Beatriz Conde. Intellectual Property Rights and Competition Policy, in: CORREA, Carlos (Ed.). Research Handbook on the Protection of Intellectual Property under WTO Rules. Intellectual Property in the WTO v. I, Edward Elgar, 2010, p. 234-235.

${ }^{184}$ De acordo com BARBOSA, "a questão do uso efetivo das patentes é a do equilíbrio dos interesses do titular do privilégio e do público em geral, que necessita que as novas tecnologias sejam usadas em benefício da produção nacional”. BARBOSA, Denis Borges. Tratado da Propriedade Intelectual, Tomo I. Rio de Janeiro: Lumen Juris Editora, p. 981.

${ }^{185}$ Cf. Illinois Tool Works Inc. et al. v. Independent Ink, Inc., 547 U.S. 28 (2006). 
titular da patente possui poder de mercado e que a conduta em questão produz efeitos anticoncorrenciais em determinado mercado relevante. ${ }^{186}$

De qualquer modo, é possível afirmar que a redação do Artigo 8.2 confere ampla discricionariedade aos Membros da OMC para adotarem medidas a fim de coibir todas as formas de abuso por parte de titulares de direitos exclusivos, independentemente de serem ou não anticoncorrenciais, desde que resultem em desvio de suas finalidades sociais e econômicas. Por outro lado, é certo que, quando o abuso resultar em prejuízos sobre a concorrência em determinado mercado relevante, poderá haver violação das normas antitruste nacionais. Nesse sentido, conclui-se que o uso anticoncorrencial de direitos de propriedade intelectual será sempre abusivo, mas nem todo abuso será capaz de produzir efeitos adversos sobre a concorrência, a justificar a aplicação de normas antitruste.

No que concerne especificamente aos abusos de direitos de propriedade intelectual que produzem efeitos adversos sobre a concorrência, poderão ser levadas em consideração pelos Membros práticas restritivas em acordos de licenciamento, tema especificamente abordado no Artigo 40 do TRIPS, bem como condutas abusivas unilaterais de exclusão, que levam ao fechamento do mercado para concorrentes efetivos ou potenciais, causando prejuízos, sobretudo à concorrência dinâmica, em detrimento do bemestar dos consumidores.

\subsubsection{Práticas que limitam de maneira injustificável o comércio}

De acordo com o Artigo 8.2, os Membros também podem adotar medidas contra práticas que limitem de maneira injustificável o comércio a partir da exploração de direitos de propriedade intelectual. Tal como ocorre com o conceito de abuso, práticas que limitam o comércio são normalmente associadas a práticas restritivas da concorrência. De fato, é possível encontrar referências a práticas que prejudicam o comércio nas legislações antitruste norte-americana e europeia, conforme se observa na Seção 1 do Sherman Act, que considera ilegal os contratos, combinações ou conspirações "para restringir o comércio entre os diversos estados ou com nações estrangeiras", bem como no Artigo 101 do Tratado sobre Funcionamento da União Europeia, que utiliza expressão semelhante ao

${ }^{186}$ Cf. USM Corp. v. SPS Techs., 694 F.2d 505, 510-14 (7 $7^{\text {th }}$ Cir. 1982); Windsurfing Int'l, v. AMF, Inc., 782 F,2d 995, 1001-02 (Fed. Cir. 1986); e Mallinckrodt, Inc. v. Medipart, Inc., 976 F.2d 700 (Fed. Cir. 1992). 
dispor serem incompatíveis com o mercado único os acordos "suscetíveis de afetar o comércio entre os Estados-Membros".

Contudo, o termo "práticas que restrinjam de maneira injustificada o comércio", conforme redação do Artigo 8.2, não se restringe apenas a questões concorrenciais, devendo ser interpretado de maneira mais ampla, em consonância com os objetivos do Acordo Constitutivo da OMC, dentre eles a redução substancial das barreiras tarifárias e não tarifárias ao comércio internacional, e no contexto do Preâmbulo do Acordo TRIPS, que menciona o desejo dos Membros de reduzir as "distorções e obstáculos ao comércio internacional" ${ }^{187}$ De qualquer modo, é certo que a natureza ampla do Artigo 8.2 engloba também as práticas anticoncorrenciais suscetíveis de limitar o comércio, conforme expressamente abordado em algumas legislações nacionais, como a norte-americana e a europeia.

Ademais, deve-se destacar que somente as práticas restritivas que restrinjam de maneira "injustificável" o comércio poderão ser coibidas. A inclusão da expressão “injustificável” traduz a intenção dos Membros de inserir critérios de razoabilidade na análise dessas práticas, impedindo que sejam consideradas ilícitas quando puderem ser devidamente justificadas. Numa leitura breve do dispositivo, a referência à expressão "injustificável" parece remeter ao conceito de "regra da razão" (rule of reason), conforme desenvolvido pelo direito antitruste norte-americano e aplicado atualmente em diversas jurisdições. A análise de práticas restritivas da concorrência com base na "regra da razão" exige que as autoridades antitruste ou tribunais levem em consideração possíveis eficiências pró-competitivas capazes de compensar os eventuais efeitos líquidos negativos causados pela prática em questão. ${ }^{188}$ Assim, somente após sopesar os efeitos anticompetitivos e os efeitos pró-competitivos, será possível determinar se a prática restritiva deve ser considerada ilícita.

No entanto, a referência à expressão “injustificável” não deve ser confundida com o padrão de análise antitruste com base na regra da razão. Admitir essa hipótese impediria os Membros de considerar determinadas práticas restritivas como ilícitos per se, dada a impossibilidade de produzirem qualquer efeito pró-competitivo, como ocorre, por

\footnotetext{
${ }^{187}$ Ibid., p. 201.

${ }^{188}$ Cite-se como exemplo os casos National Society of Professional Engineers v. United States, 435 U.S. 679, 687-692 (1978) e Arizona v. Maricopa County Medical Society, 457 U.S. 332, 342-343 (1982).
} 
exemplo, com os cartéis e práticas colusivas, que são acordos restritivos entre concorrentes para fixação de preços, redução da produção e divisão de mercados. . Desse modo, a expressão "injustificável" tem sido interpretada como uma forma de impedir que os Membros proibam práticas que, embora sejam suscetíveis de restringir de alguma forma o comércio, facilitam o uso produtivo de direitos de propriedade intelectual, tais como cláusulas de confidencialidade em acordos de licenciamento ou de transferência mútua de segredos de negócios, ou mesmo que condicionem o sublicenciamento ao consentimento do titular do direito exclusivo. ${ }^{189}$

\subsubsection{Práticas que afetam adversamente a transferência internacional de tecnologia}

A terceira categoria de práticas restritivas são aquelas suscetíveis de prejudicar a transferência internacional de tecnologia. A inclusão de referência a esse tema remete às negociações do Código Internacional de Conduta sobre Transferência de Tecnologia no âmbito da UNCTAD e aos interesses dos países em desenvolvimento de adotarem instrumentos regulatórios internos para coibir esse tipo de prática. Ademais, é certo que as práticas restritivas em questão não são limitadas apenas a condutas anticoncorrenciais, podendo incluir qualquer forma de restrição que prejudique a transferência de tecnologia em si, independentemente de seus efeitos sobre determinado mercado relevante. ${ }^{190}$ Nesse contexto, o dispositivo autoriza os Membros a adotarem quaisquer medidas para coibir tais práticas, seja por intermédio da intervenção antitruste ou por meio de regulamentação específica, desde que tais medidas sejam apropriadas e consistentes com os demais dispositivos do Acordo TRIPS. ${ }^{191}$

\footnotetext{
189 “(...) practices which 'unreasonable' restrain trade are not only those, which, under a given concept of 'rule of reason' of antitrust law, would be held to be anti- rather than pro-competitive, but any practice which 'reasonably' may be held 'unreasonable'. What Article 8.2 seeks to avoid is that Members outlaw practices that are inherently beneficial, such as contractual clauses facilitating the productive use of the intellectual property." UNCTADE \& ICTSD, TRIPS and Development - Resource Book, Part Three: Intellectual Property Rights and Competition. Cambridge University Press, 2005, p. 548-549.

${ }^{190}$ Dentre as práticas suscetíveis de prejudicar a transferência de tecnologia, sem necessariamente violar as normas de defesa da concorrência, cite-se a cobrança de royalties após a expiração da patente, ou mesmo a cobrança de royalties excessivos em acordos de transferência de tecnologia, sobretudo quando as partes forem empresas do mesmo grupo econômico, restrições à fabricação, comercialização ou exportação de produtos cobertos pela tecnologia licenciada, dentre outras práticas. Cf. CORREA, Carlos M. Trade Related Aspects of Intellectual Property Rights - A Commentary on the TRIPS Agreement. Oxford University Press, 2007, p. 112.

${ }^{191}$ Cf. UNCTADE \& ICTSD, TRIPS and Development - Resource Book, Part Three: Intellectual Property Rights and Competition. Cambridge University Press, 2005, p. 549.
} 
É imperioso destacar também que a categoria de práticas aqui mencionada não se limita apenas a cláusulas restritivas contidas em acordos de licenciamento e transferência de tecnologia - tema abordado de forma específica no Artigo 40 -, podendo incluir também condutas unilaterais ou mesmo quaisquer formas de transferência de tecnologia, independentemente de serem ou não objeto de contratos formais. ${ }^{192}$ Afinal, o conceito de "transferência de tecnologia" é amplo, englobando qualquer processo por meio do qual uma tecnologia é disseminada. ${ }^{193}$

2.2.1.4. Limites a serem observados pelos Membros da OMC: as exigências de proporcionalidade e consistência

O Artigo 8.2 autoriza a adoção de quaisquer medidas para coibir abusos de direitos de propriedade intelectual e práticas restritivas, desde que tais medidas sejam "apropriadas" e "necessárias", além de "consistentes" com o Acordo TRIPS. Dessa forma, pode-se afirmar que as medidas a serem adotadas pelos Membros em seus ordenamentos jurídicos nacionais para remediar práticas restritivas ou anticoncorrenciais estão sujeitas a importantes limitações consubstanciadas em exigências de proporcionalidade e consistência, necessárias não apenas para garantir a observância dos padrões mínimos de proteção da propriedade intelectual previstas no TRIPS, mas também para conferir segurança e previsibilidade a cada um dos Membros no que concerne às normas e regulamentos nacionais adotados pelos demais Membros.

Ao referir-se a medidas "apropriadas" e "necessárias", o Artigo 8.2 submete a aplicação das normas antitruste nacionais a critérios de proporcionalidade. Nesse contexto, é importante ressaltar que o princípio da proporcionalidade está presente em diversos ordenamentos jurídicos domésticos, tendo sido incluído em alguns acordos abrangidos pela OMC. ${ }^{194}$ Contudo, a exigência de proporcionalidade não deve ser interpretada como uma

\footnotetext{
192 Cf. WTO - Trade Related Aspects of Intellectual Property Rights (Max Planck Commentaries on World Trade Law). Editado por Peter-Tobias Stoll, Jan Busche e Katrin Arend. Max Planck Institute for Comparative Public Law and International Law, 2009, p. 202.

193 “'Technology transfer' is the process by which commercial technology is disseminated. This takes the form of a technology transfer transaction, which may or may not be covered by a legally binding contract (...), but which involves the communication, by the transferor, of the relevant knowledge to the recipient". UNCTAD Series on Issues in International Investment Agreements. "Transfer of Technology". UNCTAD/ITE/IIT/28, United Nations, New York and Geneva, 2001, p. 6.

${ }^{194}$ Cf. Artigos 3.2, 8, 27.2 e 40.2 do Acordo TRIPS; Artigos IV, XII e XIV do General Agreement on Trade and Services (GATS); Artigos XI e XX do GATT-1994; Artigo 2 do Artigo sobre Barreiras Técnicas ao Comércio (TBT); Artigos 2 e 5 do Acordo sobre Medidas Sanitárias e Fitossanitárias (SPS). De acordo com Tu Thanh NGUYEN: 'In WTO agreements, the terms 'appropriate', 'necessary' and 'reasonable' are often
} 
interferência sobre a estrutura ou formato das medidas que poderão ser adotadas. Pelo contrário, o Artigo 8.2 confere ampla discricionariedade aos Membros para adotarem quaisquer instrumentos normativos e regulatórios em seus ordenamentos jurídicos nacionais com o objetivo de remediar práticas abusivas ou restritivas, estando livres, portanto, para estabelecer procedimentos administrativos ou judiciais, seja na esfera cível ou criminal, para a prevenção e repressão dessas práticas, incluindo a possibilidade de imposição de penalidades, tais como multas, licenciamento compulsório de patentes, reparação de danos, dentre outras. ${ }^{195}$

De fato, na qualidade de tratado-contrato estabelecendo padrões mínimos de proteção à propriedade intelectual, não cabe ao TRIPS interferir nessas questões de direito interno que dizem respeito à soberania dos Membros. Assim, a exigência de proporcionalidade deve ser interpretada como a imposição de uma limitação negativa sobre as legislações nacionais que tratam das práticas restritivas a partir da exploração de direitos de propriedade intelectual. Essa limitação tem como objetivo evitar punições excessivas ou incompatíveis em relação aos fins a serem alcançados, tendo em vista que eventuais excessos poderiam causar insegurança jurídica, além de colocar em risco a proteção da propriedade intelectual. Desse modo, a exigência de proporcionalidade não deve ser interpretada como uma forma de controle sobre as medidas efetivamente adotadas em casos específicos, uma vez que estas devem ficar a critério das autoridades judiciais ou administrativas nacionais. ${ }^{196}$

Já a exigência de consistência exige que as normas antitruste nacionais sejam coerentes com os padrões mínimos de proteção da propriedade intelectual e princípios gerais previstos no Acordo TRIPS. O objetivo dessa limitação é impedir que a aplicação da legislação antitruste nacional resulte na submissão do exercício regular dos direitos de propriedade intelectual - conforme os padrões mínimos de proteção assegurados pelo TRIPS - ao controle das autoridades nacionais. Em outras palavras, as medidas a serem

used where Members are given a right to decide an issue as an exception to WTO obligations. They aim at: (i) reflecting a balance in WTO agreements between preserving the freedom of Members to determine and achieve regulatory objectives through measures chosen by themselves; and (ii) discouraging Members from adopting and maintaining measures that unduly restrict trade". NGUYEN, Tu Thanh. Competition Law, Technology Transfer and the TRIPS Agreement. Cheltenham: Edward Elgar, 2010, p. 50.

${ }^{195}$ Cf. WTO - Trade Related Aspects of Intellectual Property Rights (Max Planck Commentaries on World Trade Law). Editado por Peter-Tobias Stoll, Jan Busche e Katrin Arend. Max Planck Institute for Comparative Public Law and International Law, 2009, p. 203.

${ }^{196}$ Cf. UNCTADE \& ICTSD, TRIPS and Development - Resource Book, Part Three: Intellectual Property Rights and Competition. Cambridge University Press, 2005, p. 554. 
adotadas para coibir abusos e práticas restritivas a partir da exploração de direitos de propriedade intelectual não podem constituir mero pretexto para subverter os padrões mínimos de proteção resguardados pelo Acordo. ${ }^{197}$ Esse dever de consistência reflete a preocupação manifestada pelos países desenvolvidos durante a fase de negociações, no sentido de que alguns países em desenvolvimento mais avançados poderiam fazer uso de suas leis e regulamentos nacionais sobre concorrência com vistas a limitar ou enfraquecer os padrões de proteção estabelecidos no Acordo TRIPS. ${ }^{198}$

Assim, o dever de consistência contido no Artigo 8.2 estabelece uma limitação negativa sobre as legislações nacionais que tratam da matéria, impedindo que venham a ser proibidos métodos de exploração de direitos de propriedade intelectual que são normalmente aceitos, além de serem expressamente reconhecidos pelo TRIPS ao estabelecer os padrões mínimos de proteção. ${ }^{199}$ Desse modo, cabe às legislações antitruste nacionais proteger a concorrência e coibir abusos e práticas restritivas a partir da exploração de direitos de propriedade intelectual, dentro dos limites de suas finalidades, sem intervir no exercício regular dos direitos de propriedade intelectual.

Da mesma forma, a exigência de consistência determina que as normas antitruste nacionais não devem ser aplicadas de forma discriminatória, contrariando os princípios gerais do tratamento nacional ${ }^{200}$ e do tratamento da nação mais favorecida ${ }^{201}$,

\footnotetext{
${ }^{197}$ Cf. NGUYEN, Tu Thanh. Competition Law, Technology Transfer and the TRIPS Agreement. Cheltenham: Edward Elgar, 2010, p. 49.

198 Nesse sentido, GALLEGO esclarece que: “(...) Article 8(2) was introduced on the insistence of (some major) developing countries which were concerned about the possible negative effects of introducing broad standards of IP protection. While stating a concession to the interests of developing countries, industrialized countries also made sure that the system of IP protection established in the TRIPS Agreement would be maintained as such. The consistency clause therefore fulfills a clarifying function: Article 8(2) merely allows the prevention of individual excess within the system. As far as national competition rules are concerned, the consistency requirement thus precludes an excessive application of these rules that would outlaw uses and forms of IPRs guaranteed by the TRIPS Agreement”. GALLEGO, Beatriz Conde. Intellectual Property Rights and Competition Policy, in: CORREA, Carlos (Ed.). Research Handbook on the Protection of Intellectual Property under WTO Rules. Intellectual Property in the WTO v. I, Edward Elgar, 2010, p. 237.
}

199 A exigência de consistência impediria, por exemplo, que as legislações antitruste nacionais estabelecessem proibições genéricas e sistemáticas a todo e qualquer tipo de cláusula restritiva em acordos de licenciamento, sem uma análise circunstancial dos casos concretos.

${ }^{200}$ De forma geral, o princípio do tratamento nacional, nos termos do Artigo 3 do Acordo TRIPS, prevê que cada Membro concederá aos nacionais dos demais Membros tratamento não menos favorável que o outorgado a seus próprios nacionais com relação à proteção da propriedade intelectual, salvo as exceções já previstas, respectivamente, na Convenção de Paris (1967), na Convenção de Berna (1971), na Convenção de Roma e no Tratado sobre a Propriedade Intelectual em Matéria de Circuitos Integrados, bem como as demais exceções previstas no próprio Artigo 3.

${ }^{201}$ Em termos gerais, o princípio do tratamento da nação mais favorecida previsto no Artigo 4 do Acordo TRIPS, estabelece que toda vantagem, favorecimento, privilégio ou imunidade que um Membro conceda aos 
que constituem, juntamente com o princípio da transparência, a essência do sistema multilateral do comércio estabelecido pela OMC, além de estarem expressamente previstos no Acordo TRIPS. ${ }^{202}$

\subsubsection{Interpretação do Artigo 40 do TRIPS}

O Artigo 40 do Acordo TRIPS trata especificamente do controle das práticas restritivas da concorrência nos acordos de licenciamento de direitos de propriedade intelectual. Não há dúvidas de que o Artigo 40 é, de longe, o mais compreensivo e detalhado dispositivo sobre concorrência constante no Acordo TRIPS. Comparado ao Artigo 8.2, o Artigo 40 é mais específico e minucioso, além de concentrar-se exclusivamente no licenciamento de direitos de propriedade intelectual.

Ademais, a inclusão do Artigo 40 no Acordo TRIPS remete aos esforços para a criação do Código de Conduta sobre Transferência de Tecnologia da UNCTAD, além de corroborar a observação de que, no contexto internacional, a propriedade intelectual e o direito da concorrência têm sido considerados no âmbito das políticas de promoção da transferência de tecnologia dos países desenvolvidos para os países em desenvolvimento. Enquanto estes sempre vislumbraram o desenvolvimento econômico e tecnológico como o elemento central a justificar o controle das práticas restritivas em acordos de licenciamento, os países industrializados sempre insistiram numa abordagem concorrencial para o tratamento dessas práticas. Nesse contexto, o Artigo 40 adota claramente essa abordagem concorrencial ao controle das práticas e condições de licenciamento de direitos de propriedade intelectual. Destarte, os "efeitos adversos sobre a concorrência" constituem o elemento central na definição das práticas restritivas cobertas pelo dispositivo. ${ }^{203}$

nacionais de qualquer outro país será outorgada imediata e incondicionalmente aos nacionais de todos os demais Membros da OMC, ressalvadas as exceções previstas no Acordo.

202 No que concerne ao princípio da transparência, o Artigo 63.1 do TRIPS trata especificamente da necessidade de publicação de legislações, regulamentos ou decisões judiciais ou administrativas que tratem de abusos de direitos de propriedade intelectual: "As leis e regulamentos e as decisões judiciais e administrativas finais de aplicação geral, relativas à matéria objeto deste Acordo (existência, abrangência, obtenção, aplicação de normas de proteção e prevenção de abuso de direitos de propriedade intelectual) que forem colocadas em vigor por um Membro serão publicadas ou, quando essa publicação não for conveniente, serão tornadas públicas, num idioma nacional, de modo a permitir que Governos e titulares de direitos delas tomem conhecimento. Os Acordos relativos a matéria objeto deste Acordo que estejam em vigor entre o Governo ou uma Agência Governamental de um Membro e o Governo ou uma Agência Governamental de um outro Membro também serão publicados" (grifo nosso).

203 Cf. GALLEGO, Beatriz Conde. Intellectual Property Rights and Competition Policy, in: CORREA, Carlos (Ed.). Research Handbook on the Protection of Intellectual Property under WTO Rules. Intellectual Property in the WTO v. I, Edward Elgar, 2010, p. 239. 
Sob esse prisma concorrencial, é imperioso destacar que os acordos de licenciamento de direitos de propriedade intelectual são normalmente benéficos para a concorrência, uma vez que possibilitam a integração da propriedade licenciada com fatores complementares de produção, conduzindo a uma exploração mais eficiente desses direitos e beneficiando os consumidores por meio da redução de custos de produção e introdução de novos produtos no mercado. ${ }^{204}$ Ademais, o licenciamento pode aumentar a expectativa de retorno da propriedade intelectual, ampliando os incentivos para a criação intelectual e a consequente disseminação de tecnologias, em benefício da livre concorrência. ${ }^{205}$

Por outro lado, ainda que práticas e condições restritivas em acordos de licenciamento possam, na maioria das vezes, ser pró-competitivas, como se pode constatar pela experiência dos Estados Unidos e da União Europeia no tratamento do tema, tais práticas podem resultar em preocupações do ponto de vista antitruste, a depender do grau de poder de mercado detido pelos agentes econômicos envolvidos, da estrutura do mercado e das características dos bens ou tecnologias objeto do licenciamento.

Feitas essas considerações iniciais, cumpre-nos ressaltar que os dois primeiros parágrafos do Artigo 40 (Artigos 40.1 e 40.2) estabelecem regras substantivas a orientar os Membros da OMC na adoção de regras nacionais voltadas para a repressão de práticas restritivas à concorrência nos contratos de licenciamento de direitos de propriedade intelectual. Já os dois últimos parágrafos (Artigos 40.3 e 40.4) estabelecem regras procedimentais de consultas e cooperação antitruste a serem adotadas entre os Membros nas situações em que práticas restritivas da concorrência venham a produzir efeitos extraterritoriais. Passaremos a examinar a seguir as regras substantivas e procedimentais que compõem o Artigo 40 do TRIPS.

\footnotetext{
${ }^{204}$ De acordo com o item 2.3 das Antitrust Guidelines for the Licensing of Intellectual Property, publicadas pelas autoridades antitruste norte-americanas (FTC e DOJ): "Licensing, cross-licensing, or otherwise transferring intellectual property (hereinafter 'licensing') can facilitate integration of the licensed property with complementary factors of production. This integration can lead to more efficient exploitation of the intellectual property, benefiting consumers through the reduction of costs and the introduction of new products. Such arrangements increase the value of intellectual property to consumers and to the developers of the technology. By potentially increasing the expected returns from intellectual property, licensing also can increase the incentive for its creation and thus promote greater investment in research and development".

${ }^{205}$ É nesse sentido que o parágrafo 4 do Preâmbulo do Regulamento da Comissão Europeia n. ${ }^{\circ} 772 / 2004$ sobre acordos de transferência de tecnologia dispõe que: "Technology transfer agreements concern the licensing of technology. Such agreements will usually improve economic efficiency and be pro-competitive as they can reduce duplication of research and development, strengthen the incentive for the initial research and development, spur incremental innovation, facilitate diffusion and generate product market competition.
} 
2.2.2.1. Regras substantivas contidas nos Artigos 40.1 e 40.2: práticas restritivas da concorrência em acordos de licenciamento

As regras substantivas contidas nos dois primeiros parágrafos do Artigo 40 do TRIPS dispõem que:

1. Os Membros concordam que algumas práticas ou condições de licenciamento de direitos de propriedade intelectual que restrinjam a concorrência podem afetar adversamente o comércio e impedir a transferência e disseminação de tecnologia.

2. Nenhuma disposição deste Acordo impedirá que os Membros especifiquem em suas legislações condições ou práticas de licenciamento que possam, em determinados casos, constituir um abuso dos direitos de propriedade intelectual que tenha efeitos adversos sobre a concorrência no mercado relevante. Conforme estabelecido acima, um Membro pode adotar, de forma compatível com as outras disposições deste Acordo, medidas apropriadas para evitar ou controlar tais práticas, que podem incluir, por exemplo, condições de cessão exclusiva, condições que impeçam impugnações da validade e pacotes de licenças coercitivos, à luz das leis e regulamentos pertinentes desse Membro.

A interpretação dos Artigos 40.1 e 40.2 impõe diversas questões desafiadoras em relação ao escopo de aplicação e natureza desses dispositivos. Não há uma definição clara do que seriam práticas ou condições de licenciamento. Além disso, a referência a efeitos adversos sobre o comércio e sobre a transferência e disseminação da tecnologia, contida no Artigo 40.1, é completamente omitida no Artigo 40.2. Além dessas ambiguidades, também não há clareza sobre a relação entre ambos os dispositivos, o que dificulta ainda mais sua interpretação.

Ao analisar o Artigo 40.1, é possível notar que o dispositivo não estabelece qualquer obrigação afirmativa para que os Membros imponham suas normas antitruste nacionais para remediar práticas restritivas em acordos de licenciamento de direitos de propriedade intelectual. Trata-se apenas de uma declaração dos Membros reconhecendo 
que algumas práticas e condições de licenciamento podem produzir efeitos restritivos sobre a concorrência. $^{206}$

Todavia, o dispositivo não deve ser compreendido como uma mera declaração política sem qualquer efeito vinculativo. De fato, o Artigo 40.1 tem sido interpretado como uma norma que impõe a cada um dos Membros uma "obrigação mínima" de agir. ${ }^{207}$ É nesse aspecto que reside a principal diferença entre o Artigo 40.1 e o Artigo 8.2 do TRIPS, embora ambos contenham linguagem semelhante. ${ }^{208}$ Nesse sentido, enquanto o Artigo 8.2 apenas reconhece que pode ser necessário coibir certos abusos e práticas restritivas, deixando a critério dos Membros a opção de agir ou não, o Artigo 40.1 vai além, afirmando claramente a concordância expressa dos Membros no sentido de que algumas práticas ou condições de licenciamento que restrinjam a concorrência podem prejudicar o comércio e impedir a transferência e disseminação de tecnologia. ${ }^{209}$ Ora, se há o reconhecimento expresso de que certas práticas deveriam ser objeto de intervenção antitruste, é difícil imaginar por que o TRIPS permitiria a total inércia dos Membros em relação a tais práticas. Admitir essa hipótese seria não apenas uma afronta aos objetivos contidos no Artigo 7, que faz referência expressa à difusão e transferência de tecnologia, como também contrariaria o disposto no Artigo 1.1, por meio do qual os membros se comprometeram a colocar em vigor o disposto no Acordo. ${ }^{210}$

\footnotetext{
206 "Art. 40.1 is not a classical legal norm containing an example of conduct and a suitable legal remedy, but it constitutes a declaration of the Member's shared opinion on the detrimental consequences of certain licensing practices." WTO - Trade Related Aspects of Intellectual Property Rights (Max Planck Commentaries on World Trade Law). Editado por Peter-Tobias Stoll, Jan Busche e Katrin Arend. Max Planck Institute for Comparative Public Law and International Law, 2009, p. 665.

${ }^{207}$ Cf. UNCTADE \& ICTSD, TRIPS and Development - Resource Book, Part Three: Intellectual Property Rights and Competition. Cambridge University Press, 2005, p. 555.

208 "The relationship between Article 40 and Article 8.2 is not self-evident. Whilst some authors hold the view that Article 8.2 contains a policy statement, which is implemented by Article 40, a more consistent interpretation seems to be that Article 40 represents lex specialis provision. This is so, first, because Article 40 has a narrower scope of application than Article 8.2; second, Article 8.2 is a rule of treaty law, not merely a policy statement. Third, Article 40 contains rules which, with regard only to some of the conduct of IPRholders listed in Article 8.2, may establish obligations on Members that are not mandated by Article 8.2." UNCTADE \& ICTSD, TRIPS and Development - Resource Book, Part Three: Intellectual Property Rights and Competition. Cambridge University Press, 2005, p. 555

${ }^{209}$ Cf. WTO - Trade Related Aspects of Intellectual Property Rights (Max Planck Commentaries on World Trade Law). Editado por Peter-Tobias Stoll, Jan Busche e Katrin Arend. Max Planck Institute for Comparative Public Law and International Law, 2009, p. 665; e UNCTADE \& ICTSD, TRIPS and Development - Resource Book, Part Three: Intellectual Property Rights and Competition. Cambridge University Press, 2005, p. 555.
}

${ }^{210}$ Nesse sentido, ROFFE e SPENNEMANN esclarecem que: "The consensus expressed in Article 40.1, TRIPS Agreement, that some licensing practices may impede the transfer and dissemination of technology, which is one of the objectives of IP protection and enforcement (Article 7, TRIPS Agreement), has been interpreted as imposing on Members a 'minimum obligation' to address certain forms of anti-competitive practices in 
Sob esse prisma, práticas restritivas da concorrência que afetem adversamente o comércio e impeçam a transferência e disseminação de tecnologia podem frustrar os objetivos da proteção aos direitos de propriedade intelectual, conforme determinados pelo TRIPS, de modo que a completa ausência de normas nacionais de concorrência para coibir tais práticas, e a consequente omissão dos Membros a esse respeito, pode não ser consistente com as demais disposições do TRIPS, conforme determinado na segunda parte do Artigo 40.2. De qualquer modo, os Membros possuem ampla discricionariedade para implementar e definir essas normas em seus ordenamentos jurídicos internos. ${ }^{211}$

Apesar de não definirem o conceito de "práticas e condições de licenciamento", os Artigos 40.1 e 40.2 cobrem todo e qualquer tipo de conduta abusiva em acordos de licenciamento de direitos de propriedade intelectual que seja capaz de produzir efeitos anticoncorrenciais, tais como licenças casadas, cláusulas de exclusividade, restrições territoriais, proibições de impugnação da validade dos direitos, cláusulas de grantback, dentre outras. ${ }^{212}$ Embora tais práticas sejam normalmente associadas às patentes, os dispositivos abrangem todas as categoriais de direitos de propriedade intelectual disciplinadas pelo TRIPS, incluindo know-how e segredos de negócios, além de direitos autorais e softwares. O caráter amplo do termo "práticas e condições de licenciamento" nos permite concluir que os dispositivos também englobam práticas restritivas nas licenças cruzadas e pools de patentes, além de condutas abusivas unilaterais

licensing agreements. Such obligation would be disregarded if a Member systematically refused to take any action against anti-competitive licensing practices". ROFFE, Pedro; SPENNEMANN, Christoph. Control of Anti-competitive Practices in Contractual Licenses under the TRIPS Agreement, in: CORREA, Carlos M. \& YUSUF, Abdulqawi A. (Ed.). Intellectual Property and International Trade: The Trips Agreement. 2nd ed. Wolters Kluwer, 2008, p. 318.

${ }^{211}$ WTO - Trade Related Aspects of Intellectual Property Rights (Max Planck Commentaries on World Trade Law). Editado por Peter-Tobias Stoll, Jan Busche e Katrin Arend. Max Planck Institute for Comparative Public Law and International Law, 2009, p. 666; e UNCTAD \& ICTSD, TRIPS and Development - Resource Book, Part Three: Intellectual Property Rights and Competition. Cambridge University Press, 2005, p. 555.

212 Os Artigos 40.1 e 40.2 tratam apenas de práticas restritivas em acordos de licenciamento, estando fora do escopo dos dispositivos a cessão de direitos de propriedade intelectual, operações de fusões e aquisições que incluam o acordos ancilares de licenciamento, joint ventures de pesquisa e desenvolvimento, subcontratação e terceirização, dentre outros que envolvam indiretamente o licenciamento. Nesse contexto, vale citar o Resource Book da UNCTAD \& ICTSD, TRIPS and Development: "As licensing may occur in the context of some of the transactions referred to, the necessary distinction must be made in accordance with the overall nature of the arrangement as a business transaction and the centre of gravity of the transaction in question. Nonetheless, the fact that an abusive licensing practice takes place within the context of a transaction with a larger scope would not insulate that practice from being addressed by a Member. It is customary for competition authorities to address particular anti-competitive elements of large-scale arrangements such as mergers and acquisitions without necessarily seeking to prevent the conclusion of the arrangement". UNCTAD \& ICTSD, TRIPS and Development - Resource Book, Part Three: Intellectual Property Rights and Competition. Cambridge University Press, 2005, p. 556. 
relacionadas ao licenciamento, tais como a recusa de licenciar e a imposição de licenças discriminatórias por parte de titulares de direitos de propriedade intelectual, desde que estes detenham poder de mercado suficiente para restringir a concorrência em determinado mercado relevante. ${ }^{213}$

Conforme já mencionado, a relação entre os Artigos 40.1 e 40.2 é ambígua. Apesar de ambos tratarem de práticas restritivas da concorrência em acordos de licenciamento de direitos de propriedade intelectual, esses dispositivos apresentam diferenças consideráveis entre si que não se limitam apenas à linguagem utilizada em sua redação, muito embora ambos devam, necessariamente, ser interpretados conjuntamente. ${ }^{214}$

Nos termos do Artigo 40.1, os Membros da OMC concordam que certas práticas restritivas da concorrência em acordos de licenciamento podem prejudicar o comércio e a transferência e disseminação de tecnologia. Desse modo, é possível observar que o dispositivo trata de duas categorias de práticas anticoncorrenciais (i) que restringem o comércio; e (ii) que afetam a transferência de tecnologia. ${ }^{215}$ Quanto à primeira categoria, é possível citar como exemplo restrições territoriais em acordos de licenciamento, tais como exclusividade de território, alocações de clientes e limitações de vendas que inviabilizem importações paralelas. ${ }^{216}$ A segunda categoria faz referência a práticas que

${ }^{213}$ Cf. GALLEGO, Beatriz Conde. Intellectual Property Rights and Competition Policy, in: CORREA, Carlos (Ed.). Research Handbook on the Protection of Intellectual Property under WTO Rules. Intellectual Property in the WTO v. I, Edward Elgar, 2010, p. 240.

${ }^{214}$ Cf. UNCTAD \& ICTSD, TRIPS and Development - Resource Book, Part Three: Intellectual Property Rights and Competition. Cambridge University Press, 2005, p. 556.

215 "Art. 40.1 covers only such licensing practices or conditions which have an adverse effect on trade or which constitute an impediment to technology transfer. This wording needs to be read restrictively in respect of two criteria. First, the licensing practices or conditions do not have to have an adverse effect on trade and technology transfer. These negative criteria are meant to apply alternatively, not cumulatively. The reason is that Art. 40.1 clearly relates to licensing of intellectual property which is not related to technology transfer, too. WTO - Trade Related Aspects of Intellectual Property Rights (Max Planck Commentaries on World Trade Law). Editado por Peter-Tobias Stoll, Jan Busche e Katrin Arend. Max Planck Institute for Comparative Public Law and International Law, 2009, p. 666.

${ }^{216}$ Cláusulas de exclusividade de território em acordos de licenciamento são aquelas que restringem o direito do licenciante de conferir licenças a terceiros, ou de explorar o direito exclusivo por si só, no território de atuação do licenciado. Veremos que a Comissão Europeia, assim como os tribunais europeus, costumam vedar restrições territoriais absolutas que impeçam importações paralelas nos territórios exclusivos dos licenciados, uma vez que a proteção do comércio no mercado único constitui um dos objetivos da integração regional da União Europeia. 
envolvam apenas a exploração de direitos sobre tecnologias, excluindo-se, portanto, direitos autorais ou outros bens intelectuais que não sejam tecnológicos. ${ }^{217}$

Já o Artigo 40.2, por outro lado, é mais específico. Na primeira parte do dispositivo, há o reconhecimento expresso do direito dos Membros de estabelecer e definir regras nacionais visando ao controle de práticas e condições de licenciamento que, em determinados casos, possam constituir abuso de direitos de propriedade intelectual que tenha efeitos adversos sobre a concorrência no mercado relevante. Nota-se que não há qualquer referência aos impactos das práticas restritivas sobre o comércio e à transferência de tecnologia, mas apenas menção genérica a abuso de direitos de propriedade intelectual. Conforme já mencionado em nossa análise sobre o Artigo 8.2, abuso pressupõe a exploração irregular de direitos de propriedade intelectual, para além dos seus limites legais, contrariando suas funções sociais e econômicas. Contudo, o conceito de abuso no Artigo 40.2 é mais específico do que no Artigo 8.2, já que possui uma conotação eminentemente concorrencial, compreendendo qualquer tipo de prática abusiva decorrente do licenciamento de direitos de propriedade intelectual que seja capaz de restringir a concorrência em determinado mercado relevante. Assim, não basta a constatação de abuso, devendo haver também comprovação dos seus efeitos anticoncorrenciais. ${ }^{218}$

Ademais, o dispositivo deixa claro que somente "em determinados casos" práticas restritivas em acordos de licenciamento poderão constituir abuso de direito de propriedade intelectual. Essa ressalva contida no Artigo 40.2 traduz o reconhecimento implícito de que práticas e condições restritivas em acordos de licenciamento são geralmente pró-competitivas e plenamente justificáveis, uma vez que incentivam à inovação e a transferência de tecnologia, além de possibilitarem uma exploração mais eficiente dos direitos de propriedade intelectual. Nesse contexto, a expressão "em determinados casos" parece refletir a intenção dos Membros de que práticas restritivas em

\footnotetext{
${ }^{217}$ Cf. GALLEGO, Beatriz Conde. Intellectual Property Rights and Competition Policy, in: CORREA, Carlos (Ed.). Research Handbook on the Protection of Intellectual Property under WTO Rules. Intellectual Property in the WTO v. I. Edward Elgar, 2010, p. 242.

218 "Members may take measures subject to two conditions. There must be an abuse of intellectual property rights and this abuse must have adverse effects on competition ('2-step analysis'). During the negotiations in the Uruguay Round, it was discussed at length whether these requirements need to met cumulatively or alternatively. The fact that it was decided to use an 'and' instead of 'or' - as it was still the case in the Brussels Draft - indicates that both requirements have to be met simultaneously." WTO - Trade Related Aspects of Intellectual Property Rights (Max Planck Commentaries on World Trade Law). Editado por PeterTobias Stoll, Jan Busche e Katrin Arend. Max Planck Institute for Comparative Public Law and International Law, 2009, p. 668.
} 
acordos de licenciamento sejam analisadas pelas autoridades nacionais de defesa da concorrência com base na chamada "regra da razão". 219

Assim, pode-se afirmar que o objetivo do dispositivo é assegurar que os Membros não especifiquem práticas ou condições restritivas da concorrência em acordos de licenciamento de modo genérico ou abstrato, mas com base nas circunstâncias de cada caso concreto, examinando seus reais efeitos sobre a concorrência nos respectivos mercados relevantes. ${ }^{220}$

Por outro lado, é importante ressaltar que essa preferência pela "regra da razão" não deve ser interpretada como um impedimento para que algumas práticas restritivas sejam consideradas ilícitas per $s e .{ }^{221}$ Conforme já mencionado, tanto nos Estados Unidos como na União Europeia, algumas práticas restritivas são tão prejudiciais à concorrência, que são tratadas pelas autoridades antitruste e tribunais como ilícitos per se, sem a necessidade de análise mais aprofundada de seus efeitos sobre a concorrência no mercado relevante, tal como ocorre com os cartéis de preços e outras práticas colusivas entre concorrentes. ${ }^{222}$ Assim, na medida em que práticas restritivas em acordos de licenciamento servirem apenas para mascarar condutas desse tipo, nada impede que os Membros as tratem como ilícitos per se em suas legislações internas sobre concorrência. ${ }^{223}$

\footnotetext{
${ }^{219}$ De acordo com Carlos CORREA: "The need to examine the effects of licensing practices and conditions 'in each particular case' evokes the so called 'rule of reason' developed under US antitrust law. In accordance with this rule, the competent authority must weigh all circumstances of the case to determine whether a practice unreasonably restrains competition". CORREA, Carlos M. Trade Related Aspects of Intellectual Property: A Commentary on the TRIPS Agreement. Oxford University Press, 2007, p. 402.

${ }^{220}$ Cf. UNCTAD \& ICTSD, TRIPS and Development - Resource Book, Part Three: Intellectual Property Rights and Competition. Cambridge University Press, 2005, p. 559.

${ }^{221}$ Nesse sentido, de acordo com RofFe e SPENNEMANN: “(...) TRIPS adopts the requirement for an evaluation of the practices and for the determination when they constitute an abuse. The Agreement, therefore, does not favor a per se approach to the control of abusive practices. At the same time, however, the rule of reason approach under Article 40 does not prevent Members from adopting in their domestic laws some per se prohibitions, provided these are open to a rule of reason analysis". ROFFE, Pedro; SPENNEMANN, Christoph. Control of Anti-competitive Practices in Contractual Licenses under the TRIPS Agreement, in: CORREA, Carlos M.; YUSUF, Abdulqawi A. (Ed.). Intellectual Property and International Trade: The Trips Agreement. 2nd ed. Wolters Kluwer, 2008, p. 318.

${ }^{222}$ Veremos, por exemplo, que o Artigo 4 do Regulamento da Comissão Europeia (EC) n. ${ }^{\circ} 772 / 2004$ sobre acordos de transferência de tecnologia contém uma lista das proibições hard-core em acordos de licenciamento que não podem beneficiar-se da isenção em bloco.

223 "This particular understanding of Article 40.2 (first sentence) is confirmed by both the history of the provision and by the literature. It does not mean that Members may not, by their sovereign judgment, define what constitutes an abuse. Article 40.2 expressly refers to their national legislation. But they must do so on the competition merits of a practice as they see them. Nor does the provision exclude the establishment or the development of well defined per se prohibitions of licensing practices or conditions that have no redeeming virtues, i.e. which, as such, are a priori and under all foreseeable circumstances anticompetitive". UNCTAD
} 
Na segunda parte do Artigo 40.2, além da imposição da obrigação de cumprimento das exigências de proporcionalidade e coerência, tal como ocorre no Artigo 8.2, há referência expressa a exemplos de práticas restritivas da concorrência suscetíveis de serem coibidas pelos Membros em suas legislações nacionais, quais sejam, condições de cessão exclusiva ${ }^{224}$, condições que impeçam impugnações da validade e pacotes de licenças coercitivos ${ }^{225}$. Ressalte-se que, durante as negociações do TRIPS, versões anteriores do Acordo continham uma lista com diversos exemplos de práticas restritivas em acordos de licenciamento, o que pode ser explicado pela influência do projeto de Código de Conduta sobre Transferência de Tecnologia da UNCTAD, que continha uma lista de quatorze práticas restritivas. É provável que os três exemplos contidos no Artigo 40.2 reflitam o consenso de que tais práticas são potencialmente abusivas do ponto de vista antitruste, merecendo especial deferência por parte das autoridades da concorrência nacionais, ainda que na maioria das vezes possam ser justificáveis e pró-competitivas, conforme se observa nas jurisprudências norte-americana e europeia. ${ }^{226}$

Em suma, a despeito das diferenças entre as redações dos Artigos 40.1 e 40.2, ambos são complementares entre si e devem ser interpretados em conjunto e à luz dos objetivos constantes no Artigo 7 e do princípio insculpido no Artigo 8.2 do TRIPS. Desse modo, os Membros da OMC possuem ampla liberdade, ressalvadas as exigências de proporcionalidade e consistência, para coibirem práticas e condições de licenciamento que constituam abuso de direitos de propriedade intelectual, capazes de produzir efeitos adversos sobre a concorrência em determinado mercado relevante, podendo causar prejuízos ao comércio, à transferência e disseminação de tecnologia, e à inovação tecnológica. Nesse contexto, cabe aos Membros especificarem em suas legislações

\& ICTSD, TRIPS and Development - Resource Book, Part Three: Intellectual Property Rights and Competition . Cambridge University Press, 2005, p. 559.

${ }^{224}$ O termo "condições de cessão exclusiva" contido na tradução oficial do Acordo TRIPS, conforme promulgado pelo Decreto Presidencial n. ${ }^{\circ} 1.355$, de 30 de dezembro de 1994, não parece ser a tradução mais adequada para o termo original em inglês "exclusive grantback conditions". O mais correto seria "condições de retrolicenciamento exclusivo".

${ }^{225} \mathrm{O}$ termo "pacotes de licenças coercitivos" pode ser associado à prática de "licença casada".

${ }^{226}$ Sobre o tema, CORREA esclarece que: "It would be interesting to clarify the reasons that the drafters of the commented text had to select the three mentioned examples. Previous versions of the document included a significantly longer list where restrictions on research and on use of personnel, price fixing, exclusive sales on representation agreements, tying agreements, export restrictions, and other practices were mentioned. The list of practices negotiated by the UN Conference on a Code of Conduct on Transfer of Technology was even longer. (...) One possible explanation for the choice of examples in Article 40.2 is that there may exist some consensus to consider the exemplified clauses, under certain conditions, as anti-competitive". CORREA, Carlos M. Trade Related Aspects of Intellectual Property: A Commentary on the TRIPS Agreement. Oxford University Press, 2007, p. 403-404. 
nacionais os critérios para intervenção antitruste nesses casos e os elementos regulatórios e normativos para a análise econômica dessas práticas anticoncorrenciais por parte das autoridades e tribunais competentes.

2.2.2.2. Regras procedimentais contidas nos Artigos 40.3 e 40.4: obrigações de consultas e cooperação antitruste

As regras procedimentais contidas nos dois últimos parágrafos do Artigo 40 do TRIPS dispõem que:

3. Cada Membro aceitará participar de consultas quando solicitado por qualquer outro Membro que tenha motivo para acreditar que um titular de direitos de propriedade intelectual, que seja nacional ou domiciliado no Membro ao qual o pedido de consultas tenha sido dirigido, esteja adotando práticas relativas à matéria da presente Seção, em violação às leis e regulamentos do Membro que solicitou as consultas e que deseja assegurar o cumprimento dessa legislação, sem prejuízo de qualquer ação legal e da plena liberdade de uma decisão final por um ou outro Membro. O Membro ao qual tenha sido dirigida a solicitação dispensará consideração plena e receptiva às consultas com o Membro solicitante, propiciará adequada oportunidade para sua realização e cooperará mediante o fornecimento de informações não confidenciais, publicamente disponíveis, que sejam de relevância para o assunto em questão, e de outras informações de que disponha o Membro, sujeito à sua legislação interna e à conclusão de acordos mutuamente satisfatórios relativos à salvaguarda do seu caráter confidencial pelo Membro solicitante.

4. Um Membro, cujos nacionais ou pessoas nele domiciliadas estejam sujeitas a ações judiciais em outro Membro, relativas à alegada violação de leis e regulamentos desse outro Membro em matéria objeto desta Seção, terá oportunidade, caso assim o solicite, para efetuar consulta nas mesmas condições previstas no parágrafo $3^{\circ}$.

Como se pode observar, os parágrafos $3^{\circ}$ e $4^{\circ}$ do Artigo 40 preveem regras procedimentais para consultas e cooperação relacionadas à aplicação das normas antitruste nacionais visando ao controle das práticas restritivas da concorrência nos acordos de licenciamento de direitos de propriedade intelectual. O parágrafo $3^{\circ}$ (Artigo 40.3) estabelece a obrigação básica de consultas e cooperação caso um Membro tenha motivos 
para acreditar que suas leis de defesa da concorrência estejam sendo violadas por nacionais ou domiciliados de outro Membro, no que concerne ao licenciamento de direitos de propriedade intelectual. O Membro que recebe a solicitação de consultas deverá cooperar fornecendo informações não confidenciais que possam auxiliar o Membro solicitante nas eventuais investigações conduzidas pelas autoridades antitruste locais.

Já o parágrafo $4^{\circ}$, por seu turno, tem como finalidade permitir que sejam conduzidas consultas quando práticas restritivas ocorridas no território de um Membro, bem como investigações e/ou processos judiciais ou administrativos conduzidos por autoridades desse mesmo país, sejam do interesse do outro Membro, ou afetem de alguma forma seus nacionais ou domiciliados. Assim, o Membro que recebe a solicitação tem apenas a obrigação de iniciar procedimento de consultas com o Membro solicitante, nas mesmas condições previstas no parágrafo $3^{\circ}$.

Tais regras procedimentais de consultas e cooperação nada mais são do que a consagração do princípio da transparência, que constitui uma das pedras angulares do sistema multilateral de comércio estabelecido pela OMC, além de refletirem a preocupação dos Membros em estabelecer maior convergência entre os diferentes sistemas antitruste existentes em cada jurisdição. De fato, a globalização econômica resultou no aumento da incidência de práticas restritivas transnacionais capazes de produzir efeitos danosos sobre a concorrência em várias jurisdições ao mesmo tempo. ${ }^{227}$ Desse modo, práticas consideradas ilícitas em determinado país podem ser consideradas lícitas em outros países, levando a situações de conflitos de jurisdições em matéria antitruste. ${ }^{228}$ A ausência de convergência entre os diferentes sistemas antitruste decorre, entre outros motivos, das diferentes culturas de concorrência entre os países, bem como dos diferentes critérios e instrumentos de investigação e repressão de condutas anticoncorrenciais de alcance global, o que acaba prejudicando a ação das autoridades de concorrência de um país afetado por uma prática

\footnotetext{
${ }^{227}$ Os exemplos mais claros de práticas restritivas com efeitos transnacionais são os cartéis hard-core internacionais. Essa prática colusiva, além dos prejuízos causados aos consumidores por meio da fixação de preços e redução da produção, é caracterizada pela imposição de elevadas barreiras à entrada de novos competidores nos mercados dos países de atuação do cartel. As poucas empresas multinacionais que participam de um cartel internacional podem acordar em dividir mercados entre si, limitando ou impedindo a participação de outros agentes econômicos concorrentes que não são membros do acordo colusivo. Sobre o tema, cf. OMC - Grupo de Trabalho sobre Interação entre Comércio e Política de Concorrência Communication from the European Community and its Member States - WT/WGTCP/W160 - documento publicado em 14 mar. 2001.

${ }^{228}$ Sobre o tema, cf. GUZMAN, Andrew T. The Case for International Antitrust, in: EPSTEIN Richard A.; GREVE, M.S. (Ed.). Competition Laws in Conflict: Antitrust Jurisdiction in the Global Economy, Washington DC: AEI Press, 2004, p. 101.
} 
ocorrida em outro território. Essas divergências podem ser ainda maiores em razão dos diferentes níveis de desenvolvimento econômico entre os países. Pode-se afirmar que foram essas dificuldades que impossibilitaram a celebração de um acordo multilateral sobre concorrência no âmbito da OMC.

Diante desse quadro, que já era vislumbrado quando das negociações do Acordo TRIPS, a cooperação antitruste internacional é vista como a maneira mais eficaz de atingir maior convergência, desenvolvimento e harmonização das regras sobre concorrência em âmbito global. Ressalte-se que a experiência dos acordos bilaterais de cooperação antitruste, em especial aquele celebrado entre os Estados Unidos e a União Europeia em 1991, serviu como exemplo para a criação das normas de consultas e cooperação contidas nos Artigos 40.3 e 40.4 do TRIPS.

O acordo bilateral de cooperação celebrado entre o governo dos Estados Unidos e a Comissão Europeia, autoridade de concorrência da União Europeia, tem como objetivo a cooperação e coordenação entre as partes, de modo a diminuir os efeitos negativos resultantes de suas diferentes normas nacionais, abordagens e culturas de concorrência. $^{229} \mathrm{O}$ acordo prevê que cada uma das partes notifique a outra quando a aplicação de suas respectivas legislações nacionais de concorrência afetar os interesses da outra parte. ${ }^{230}$ Não há dúvidas de que a maior inovação trazida por esse acordo foram os chamados positive comity e negative comity, compreendidos como princípios de "cortesia negativa" e "cortesia positiva". Por meio da cortesia negativa, uma das partes leva em consideração os interesses da outra, antes de aplicar sua legislação nacional antitruste para remediar uma conduta anticoncorrencial praticada por agentes econômicos localizados no território dessa outra parte. ${ }^{231}$ Desse modo, sempre que uma das partes for iniciar uma investigação, deverá notificar a outra para que tome as devidas precauções. A cortesia positiva, por seu turno, pressupõe que, quando uma das partes sentir-se prejudicada por

\footnotetext{
${ }^{229}$ Agreement Between the Government of the United States of America and the Commission of the European Communities Regarding the Application of their Competition Laws (Acordo CE-EUA de 1991). Disponível em: $\quad \underline{\text { http://ec.europa.eu/competition/international/legislation/usa01.pdf } \quad \mathrm{e}}$ http://www.justice.gov/atr/public/international/docs/0525.htm.

${ }^{230}$ Os EUA também firmaram acordos bilaterais de cooperação antitruste com alguns outros países, tais como Austrália, Canadá e Brasil. Os acordos bilaterais de cooperação firmados com o governo dos Estados Unidos podem ser encontrados no seguinte link: http://www.justice.gov/atr/public/international/intarrangements.html.

${ }^{231}$ Cf. artigo IV do Acordo CE-EUA de 1991.
} 
condutas anticoncorrenciais praticadas no território da outra, poderá notificá-la para que tome as medidas cabíveis em cada caso. ${ }^{232}$

Em 1998, os Estados Unidos e a União Europeia ampliaram seu acordo de cooperação antitruste com o objetivo de tornar mais abrangente o conceito de cortesia positiva. ${ }^{233}$ A versão aprimorada do princípio da cortesia positiva estabelece que qualquer das partes tem o dever de abrir uma investigação contra condutas praticadas em seu território, sempre que for solicitada pela outra parte. Assim, uma parte deve atender ao pedido da outra, mesmo que não haja qualquer violação de sua legislação antitruste interna. $^{234}$

No entanto, as obrigações de consultas e cooperação antitruste contidas nos Artigos 40.3 e 40.4 possuem escopo extremamente limitado, o que dificulta sua aplicação prática. Isso porque um pedido de consultas formulado por um Membro não obriga o outro a impor suas normas antitruste internas ou a tomar qualquer providência com relação a práticas restritivas em acordos de licenciamento que não prejudiquem a concorrência em seu mercado interno, embora possam produzir efeitos negativos no território do Membro solicitante. Os dispositivos em comento se limitam a impor uma obrigação de iniciar procedimentos de consultas em resposta à solicitação de um Membro e de trocar informações relevantes, não confidenciais, quando uma prática restritiva de licenciamento estiver supostamente produzindo efeitos negativos no território do Membro solicitante. ${ }^{235}$ Isso significa que, após o início das consultas, nada impede que o Membro para o qual foi

\footnotetext{
${ }^{232}$ Cf. artigo V do Acordo CE-EUA de 1991.

${ }^{233}$ Agreement Between the Government of the United States of America and the European Communities on the Application of Positive Comity Principles in the Enforcement of their Competition Laws (Acordo CEEUA de 1998). Disponível em: http://www.justice.gov/atr/public/international/docs/1781.htm.

${ }^{234}$ Cf. artigo III do Acordo CE-EUA de 1998.

235 "Article 40.3 is of limited scope (...). All it establishes is a basic obligation of consultation and cooperation. The obligation exists only if Member A has reason to believe that its competition laws and regulations regarding licensing practices or conditions have been violated by a national or domiciliary of Member B. (...) The obligation of cooperation of the Member to which the request has been addressed is limited to an obligation to supply information to the Member making the request. This obligation in turn is limited to information which is relevant to the matter, which is non-confidential and publicly available or which is not publicly available and/or confidential, but available to Member B (...)". UNCTADE \& ICTSD, TRIPS and Development - Resource Book, Part Three: Intellectual Property Rights and Competition. Cambridge University Press, 2005, p. 562.
} 
dirigido o pedido de consultas abandone os procedimentos e cesse o fornecimento de informações relevantes. ${ }^{236}$

Nesse contexto, as disposições contidas nos Artigos 40.3 e 40.4 estão longe de constituir obrigações de cortesia negativa ou positiva, conhecidas dos acordos bilaterais de cooperação antitruste. De qualquer modo, apesar das limitações dos dispositivos, deve-se levar em consideração o fato de que se trata das primeiras normas de direito internacional público a instituir obrigações de cooperação antitruste em âmbito multilateral, além de refletir a intenção dos Membros da OMC de estabelecer mecanismos para o efetivo controle de práticas restritivas da concorrência em acordos de licenciamento de direitos de propriedade intelectual.

\subsubsection{Artigo 31(k): licenças compulsórias para remediar práticas anticoncorrenciais}

O Artigo 31 do Acordo TRIPS dispõe sobre licenciamento compulsório de patentes, cuja concessão possibilita que terceiros produzam, usem ou vendam a invenção patenteada sem autorização de seu titular. Trata-se de uma das mais importantes flexibilidades do TRIPS, pois permite que os Membros, especialmente países em desenvolvimento, concedam essas licenças ditas "não voluntárias" em circunstâncias diversas, embora excepcionais, tais como situações de emergência nacional e interesse público, bem como para coibir práticas anticoncorrenciais, dentre outras hipóteses. Pode-se afirmar que o Artigo 31 do TRIPS complementa o disposto no Artigo 5(A) da CUP que, conforme já mencionado, autoriza a concessão de licenças compulsórias para prevenir os abusos de patente, como a falta de exploração local de seu objeto. ${ }^{237}$

Todas as hipóteses de licenciamento compulsório estão sujeitas às condições previstas nos diversos incisos do Artigo 31, dentre elas a necessidade de negociação prévia para obtenção de uma licença voluntária, a exigência de remuneração adequada ao titular

\footnotetext{
${ }^{236}$ ROFFE, Pedro e SPENNEMANN, Christoph. Control of Anti-competitive Practices in Contractual Licenses under the TRIPS Agreement, in: CORREA, Carlos M.; YUSUF, Abdulqawi A. (Ed.). Intellectual Property and International Trade: The Trips Agreement. 2nd ed. Wolters Kluwer, 2008, p. 319.

${ }^{237}$ Nesse sentido, ROFFE e SPENNEMANN afirmam que: "Taken together, the provisions of the TRIPS Agreement preserve and expand exceptions that Article 5(A) of the Paris Convention has long recognized, and explicitly entitle Members to take measures to prevent recourse to practices that 'adversely affect the international transfer of technology'. Even forfeiture or revocation of a patent becomes technically feasible under the TRIPS Agreement, subject to an opportunity for judicial review. Therefore, the standard form of remedial action remains compulsory licensing, as mentioned under Article 5(A) of the Paris Convention, subject to the conditions introduced by Article 31 of the TRIPS Agreement. In principle, both the public interest exception and measures to prevent abuse, stipulated in Article 8 of the TRIPS Agreement, would justify resorting to compulsory licensing”. Ibid., p. 314.
} 
da patente, o caráter não exclusivo e intransferível da licença compulsória, a restrição a exportações do produto objeto da patente licenciada, dentre outras limitações. ${ }^{238}$ São previstas hipóteses de licenciamento compulsório também nos casos de recusa de licenciar após tentativas fracassadas de obtenção de licença voluntária junto ao titular da patente, em termos e condições comerciais razoáveis (Artigo 31(b)), bem como para viabilizar a exploração de patentes dependentes, isto é, quando uma segunda patente que envolva um avanço técnico importante não puder ser explorada sem violar a primeira patente (Artigo $31(1))$.

O Artigo 31(k) trata especificamente da hipótese de licenciamento compulsório para corrigir práticas anticoncorrenciais unilaterais a partir da exploração de patentes, estabelecendo que, nesses casos, não serão aplicáveis algumas das condições impostas para a concessão da licença compulsória:

(...) os Membros não estão obrigados a aplicar as condições estabelecidas nos subparágrafos "b" e "f" quando esse uso for permitido para remediar um procedimento determinado como sendo anticompetitivo ou desleal após um processo administrativo ou judicial. A necessidade de corrigir práticas anticompetitivas ou desleais pode ser levada em conta na determinação da remuneração em tais casos. As autoridades competentes terão o poder de recusar a terminação da autorização se e quando as condições que a propiciaram forem tendentes a ocorrer novamente.

Dessa forma, se após uma decisão judicial ou administrativa a conduta do titular de uma patente for considerada anticoncorrencial, as autoridades competentes nacionais poderão autorizar o licenciamento compulsório sem a necessidade de (i) negociar previamente com o titular da patente (Artigo 31(b)); e (ii) de cumprir a condição que estabelece que a licença compulsória será autorizada predominantemente para o uso no

\footnotetext{
${ }^{238}$ As condições impostas ao licenciamento compulsório de patentes são: (i) a autorização do uso deve ser considerada com base em seu mérito individual; (ii) somente será permitida se houver prévia negociação com o titular da patente para obter uma licença voluntária ou redução do preço do produto patenteado; (iii) o alcance e a duração da licença compulsória será restrito ao objetivo para o qual foi autorizada; (iv) a licença não poderá ser exclusiva e nem transferida; (v) a licença será autorizada predominantemente para suprir o mercado interno do Membro que a autorizou; (vi) a licença compulsória deverá ser revogada se e quando as circunstâncias que a propiciaram deixarem de existir e se for improvável que venham a existir novamente; e (vi) o titular da patente deverá ser adequadamente remunerado nas circunstâncias de cada uso, levando-se em conta o valor econômico da licença; e (vii) a decisão sobre o licenciamento compulsório e sobre sua remuneração poderá ser submetida a recurso judicial ou administrativo a uma autoridade superior àquela que autorizou a licença.
} 
mercado doméstico (Artigo 31(f)). Ademais, apesar de o Artigo 31(k) não eliminar o direito do titular da patente de ser remunerado em contrapartida ao licenciamento compulsório, o valor dessa remuneração poderá ser reduzido para refletir a necessidade de remediar a prática anticoncorrencial em questão, o que pode ocorrer, por exemplo, em casos de reincidência, ou mesmo para viabilizar o ingresso de um novo concorrente no mercado. $^{239}$

Mesmo limitado ao campo das patentes, o Artigo 31(k) confirma que a licença compulsória pode ser um remédio útil a ser utilizado pelas autoridades antitruste nacionais. Assim, é possível concluir que, ao submeter o licenciamento compulsório em casos de práticas anticoncorrenciais a condições menos rigorosas do que em outros casos previstos no Artigo 31, resta evidente que o Acordo TRIPS reconhece a importância da proteção da concorrência nos sistemas nacionais dos Membros da OMC.

\subsection{Ausência de diretrizes suficientes aos países em desenvolvimento para a implementação das normas do TRIPS sobre concorrência}

As disposições sobre concorrência contidas no Acordo TRIPS, conforme descritas e interpretadas nesta Seção, conferem aos Membros da OMC ampla discricionariedade para adotar e aplicar leis e regulamentos internos voltados ao controle e prevenção de práticas anticoncorrenciais resultantes da exploração abusiva de direitos de propriedade intelectual, desde que as exigências de proporcionalidade e consistência sejam observadas. $^{240}$

\footnotetext{
${ }^{239}$ Pode-se citar como exemplo a decisão do Federal Trade Commission (FTC) norte-americano, que condenou a Rambus por condutas enganosas de concorrência desleal no âmbito de um organismo de padronização técnica, com o objetivo de monopolizar os mercados de quatro tecnologias, que foram incluídas na tecnologia padronizada após a empresa esconder das demais participantes o fato de que possuía pedidos de patentes pendentes para essas tecnologias. Como forma de remediar a conduta anticoncorrencial, a FTC estabeleceu os percentuais máximos de royalties que a Rambus poderia cobrar das empresas que desejassem implementar os padrões técnicos que continham tecnologias protegidas por suas patentes. Assim, mesmo após a Rambus alegar que os percentuais deveriam variar entre $1 \%$ e $2 \%$, a FTC determinou que os percentuais não poderiam exceder $0,25 \%$ a $0,5 \%$ durante três anos, sendo zerados após esse período. A FTC justificou sua decisão afirmando que: "Royalty rates unquestionably are better set in the marketplace, but Rambus's deceptive conduct has made that impossible. Although we do not relish imposing a compulsory licensing remedy, the facts presented make that relief appropriate and indeed necessary to restore competition". In the Matter of Rambus Inc., Docket n. 9302, Feb. 5, 2007, "Opinion of the Commission on Remedy", da Chairman Deborah Platt Majoras. No entanto, o DC Circuit Court, no caso Rambus Inc. v. FTC, 522 F.3d 456 (DC Cir. 2008), cert. denied, 129 S.Ct 1318 (2009), considerou que a FTC não logrou êxito ao demonstrar o caráter exclusionário da conduta da Rambus, conforme exigido pela Seção 2 do Sherman Act. Assim, o caso foi reenviado à FTC.

${ }^{240}$ A linguagem ampla e genérica utilizada na redação dos dispositivos em comento reflete as dificuldades dos Membros, durante as negociações do Acordo, para obter consenso sobre um tema tradicionalmente
} 
Frederick M. Аввотт entende que a ampla discricionariedade conferida aos Membros da OMC pelas normas de concorrência do TRIPS serve tanto aos interesses dos países desenvolvidos como dos países em desenvolvimento, não havendo a necessidade de qualquer modificação no texto do Acordo. ${ }^{241}$ Nesse contexto, é inegável que os Membros possuem flexibilidade para implementar essas normas internamente conforme suas necessidades, interesses e prioridades de política pública, respeitando-se as diferentes realidades e características intrínsecas pertinentes aos sistemas jurídicos de cada um desses países.

Por outro lado, tais normas, da forma como estão redigidas, não fornecem diretrizes adequadas para que os países em desenvolvimento possam incorporá-las de forma eficaz em seus ordenamentos jurídicos internos. Nesse sentido, Robert D. ANDERSON afirma que as normas do TRIPS sobre concorrência, ainda que representem um elemento essencial de equilíbrio, deixam importantes questões sem resposta. Em primeiro lugar, não definem os padrões de análise antitruste necessários para determinar as hipóteses em que práticas comerciais a partir da exploração de direitos de propriedade intelectual poderiam ser consideradas anticoncorrenciais. Em segundo lugar, não estabelecem quais práticas deveriam ser coibidas, além dos três exemplos contidos no Artigo 40.2. Mais importante, o TRIPS não estabelece diretrizes adequadas para a implementação das medidas que poderiam ser adotadas em casos específicos, limitando-se a afirmar que estas devem ser consistentes e apropriadas. Para o autor, na ausência de diretrizes suficientes, muitos países em desenvolvimento certamente terão dificuldades para formular políticas de concorrência adequadas nessa área. ${ }^{242}$

A esse respeito, é imperioso destacar que, embora a inclusão das disposições sobre concorrência no TRIPS tenha sido uma concessão dos países desenvolvidos aos

marcado por fortes divergências entre os países desenvolvidos e em desenvolvimento, principal razão pela qual foram frustradas as negociações no âmbito da UNCTAD para a implementação do Código de Conduta sobre Transferência de Tecnologia, assim como as discussões travadas na OMC sobre um possível acordo multilateral sobre concorrência. Desse modo, as normas do TRIPS sobre concorrência, da forma como foram redigidas, é o máximo que foi possível alcançar em nível multilateral, dadas as dificuldades encontradas para a obtenção de consenso sobre o tema. Por outro lado, o caráter genérico dessas normas conferem uma margem maior de flexibilidade aos Membros para implementá-las internamente.

${ }^{241}$ ABBOTT, Frederick M. Are the Competition Rules in the WTO Agreement on Trade-Related Aspects of Intellectual Property Rights Adequate?, in: PETERSMAN, Ernst-Ulrich (Ed.). Reforming the World Trading System: Legitimacy, Efficiency, and Democratic Governance. Oxford: OUP, p. 333-334.

242 ANDERSON, Robert D. Competition Policy and Intellectual Property in the WTO: More Guidance Needed?, in: DREXL, Josef (Ed.). Research Handbook on Intellectual Property and Competition Law. Cheltenham: Edward Elgar, 2008, p. 452. 
países em desenvolvimento durante a fase de negociações, sendo consideradas por muitos no contexto das flexibilidades contidas no Acordo, é paradoxal o fato de que a maioria dos países em desenvolvimento e de menor desenvolvimento relativo sequer possuía, à época, legislações nacionais de defesa da concorrência, tampouco mecanismos institucionais adequados para lidar com as complexas questões que normalmente envolvem a análise antitruste de abusos de direitos de propriedade intelectual. ${ }^{243}$

É bem verdade que essa realidade vem mudando sensivelmente ao longo dos últimos anos, já que boa parte dos países em desenvolvimento, especialmente aqueles que alcançaram níveis mais elevados de industrialização, têm buscado implementar ou aprimorar seus sistemas nacionais de defesa da concorrência. ${ }^{244}$ Mesmo assim, enquanto os países mais industrializados, em especial os Estados Unidos e os da União Europeia, possuem normas e instituições sólidas de concorrência, incluindo autoridades antitruste e tribunais com experiência e recursos necessários para lidar com questões envolvendo a interface entre propriedade intelectual e concorrência, os países em desenvolvimento, em sua maioria, mesmo possuindo leis antitruste nacionais, ainda não adquiriram experiência e capacitação necessárias para tratar de tema tão complexo. De fato, os órgãos de defesa da concorrência dos países em desenvolvimento ainda enfrentam inúmeros problemas, como a carência de recursos humanos, financeiros e de mecanismos de investigação adequados, o que lhes possibilitaria uma efetiva aplicação de suas normas de defesa da concorrência para corrigir práticas anticoncorrenciais, especialmente nas hipóteses em que elas resultem de abusos de direitos de propriedade intelectual. ${ }^{245}$

\footnotetext{
${ }^{243}$ De acordo com ROFFE e SPENNEMANN: “(...) domestic implementation of the TRIPS provisions on anticompetitive practices in any case poses a serious challenge to many developing countries, particularly the least developed among them, given the lack of competition culture in those countries. In particular, when formulating an intellectual property-related competition policy, WTO Members will face a complex task to the extent that the areas that may have to be covered are rather broad and heterogeneous". ROFFE, Pedro; SPENNEMANN, Christoph. Control of Anti-competitive Practices in Contractual Licenses under the TRIPS Agreement, in: CORREA, Carlos M. ; YUSUF, Abdulqawi A. (Ed.). Intellectual Property and International Trade: The Trips Agreement. 2nd ed. Wolters Kluwer, 2008, p. 324.

${ }^{244}$ De acordo com CORREA: "Until 1990 only 16 developing countries had formal competition legislation. With technical assistance from international institutions, particularly the United Nations Conference on Trade and Development (UNCTAD), around 50 countries completed legislation for competition in the 1990s and many others were in the process thereafter". CORREA, Carlos M. Intellectual Property and Competition Law: Exploring Some Issues of Relevance to Developing Countries. ICTSD IPRs and Sustainable Development Program Issue Paper n. 21. International Centre for Trade and Sustainable Development, Geneva, Switzerland, 2007, p. 01.

${ }^{245}$ Nesse sentido, NGUYEN: “(...) the existence of IPR-related competition legislation in developing and leastdeveloped countries does not mean that competent authorities in those countries can deal with complicated IPR-related anti-competitive practices efficiently. This is for many reasons, especially their limited capacity
} 
Conforme bem ressaltado por Carlos M. CORREA, essas disparidades entre os países desenvolvidos e em desenvolvimento impõem desafios consideráveis à comunidade internacional, na medida em que a proteção à propriedade intelectual foi fortalecida e ampliada em escala global. Para ele, em consequência da implementação do Acordo TRIPS, os países em desenvolvimento foram obrigados a fortalecer e expandir suas legislações de propriedade intelectual, mesmo na ausência de instituições sólidas de concorrência. Em contraste, a introdução de níveis mais elevados de proteção a esses direitos nos países desenvolvidos ocorreu em contextos nos quais já havia normas e instituições sólidas de concorrência. Como resultado, os países em desenvolvimento ficaram em situação desvantajosa, pois a ausência de instituições adequadas de concorrência e de experiência para lidar com práticas anticoncorrenciais envolvendo direitos de propriedade intelectual pode resultar no aumento da incidência desses comportamentos abusivos, causando prejuízos consideráveis à inovação, ao comércio e à transferência de tecnologia, que são elementos essenciais para o desenvolvimento econômico e o bem-estar social. ${ }^{246}$

Mesmo os países em desenvolvimento que possuem instituições sólidas de defesa da concorrência, como o Brasil, possuem dificuldades em estabelecer políticas públicas adequadas nessa área, tendo em vista a complexidade do tema e a ausência de concordância entre os diferentes países em relação aos padrões de análise antitruste a serem adotados para examinar abusos de direitos de propriedade intelectual, assim como

to monitor and discourage such practices". NGUYEN, Tu Thanh. Competition Law, Technology Transfer and the TRIPS Agreement. Cheltenham: Edward Elgar, 2010, p. 53.

${ }^{246}$ Nas palavras de CORREA: "The relationship between intellectual property (IP) and disciplines regulating competition has attracted growing attention, particularly as a result of the expansion and strengthening of IP protection at the global scale. While IP law deliberately subjects intellectual assets to the exclusive control of right owners, competition law seeks to avoid market barriers and benefit consumers by encouraging competition among a multiplicity of suppliers of goods, services and technologies. Dealing with such a relationship poses unique analytical challenges to policy-makers (...). Such challenges are particularly complex in developing countries, the majority of which have little or no tradition in the application of competition law and policies. In fact, in most of these countries IPRs have been broadened and strengthened in the absence an operative body of competition law, in contrast to developed countries where the introduction of higher levels of IP protection has taken place in normative contexts that provide strong defenses against anti-competitive practices". CORREA, Carlos M. Intellectual Property and Competition Law: Exploring Some Issues of Relevance to Developing Countries, ICTSD IPRs and Sustainable Development Program Issue Paper n. 21, International Centre for Trade and Sustainable Development, Geneva, Switzerland, 2007, p. 01. No mesmo sentido, COTTIER e MEITINGER sustentam que: "We submit that the national or regional approach to competition rules within the scope of the TRIPs Agreement is likely to bring about an unbalanced situation in many countries, and it will undermine, in the long run, the legitimacy of IPR protection and the TRIPs Agreement as no efficient tools to deal with abuses are available". COTTIER, Thomas; MEITINGER, Ingo. The Trips Agreement without a Competition Agreement?, Fondazione Eni Enrico Mattei. Trade and Competition in the WTO and Beyond, Venice, Dec. 4th-5th, 1998, p. 7. 
em relação aos limites da intervenção das autoridades de defesa da concorrência nesses casos.

Desse modo, na ausência de um acordo de cooperação antitruste multilateral no âmbito da OMC, o que seria válido para possibilitar a assistência técnica aos países menos desenvolvidos, sobretudo em questões envolvendo a interface entre propriedade intelectual e direito da concorrência ${ }^{247}$, alguns autores sugerem a possibilidade de formulação de diretrizes internacionais não vinculativas, elaboradas com a participação de autoridades de defesa da concorrência de países desenvolvidos e em desenvolvimento. Essas diretrizes trariam padrões de análise antitruste aplicáveis às práticas restritivas da concorrência em acordos de licenciamento e transferência de tecnologia, bem como às condutas abusivas unilaterais a partir da exploração de direitos de propriedade intelectual, podendo ser voluntariamente adotadas pelas autoridades de concorrência dos países em desenvolvimento. ${ }^{248}$

Contudo, é improvável, neste momento, a obtenção de consenso em relação a padrões comuns de análise antitruste, tendo em vista as diferenças consideráveis de cultura da concorrência entre os países, além dos diferentes níveis de desenvolvimento econômico, sendo inviável a definição de um modelo único que não levasse em consideração essas disparidades. Além disso, é importante ressaltar que ainda pairam divergências substanciais entre as jurisdições mais tradicionais em matéria de política de concorrência os Estados Unidos e a União Europeia -, sobretudo no que concerne às abordagens utilizadas por suas respectivas autoridades antitruste na análise de casos específicos envolvendo direitos de propriedade intelectual. ${ }^{249}$ Se por um lado há certa coerência entre

\footnotetext{
${ }^{247}$ Um acordo de cooperação antitruste multilateral no âmbito da OMC possibilitaria a assistência técnica aos países em desenvolvimento e menos desenvolvidos para a elaboração de leis e estabelecimento de autoridades de concorrência, capacitação de pessoal, ou mesmo viabilizar a troca de informações entre autoridades antitruste dos diferentes países em casos específicos.

248 ANDERSON, Robert D. Competition Policy and Intellectual Property in the WTO: More Guidance Needed?, in: DREXL, Josef (Ed.), Research Handbook on Intellectual Property and Competition Law. Cheltenham: Edward Elgar, 2008, p. 452.

${ }^{249}$ Para BRADFORD, foram justamente as divergências entre as duas principais potências, Estados Unidos e União Europeia, que levaram ao fracasso do tema concorrência na OMC, ao contrário do que ocorreu com o TRIPS, já que as duas principais potências estavam alinhadas quanto aos padrões mínimos de proteção da propriedade intelectual: "In contrast to the great power consensus over international IP regime, one of the primary obstacles to a binding international antitrust agreement has been a longstanding disagreement between the US and the EU regarding the content and institutional form of the international antitrust cooperation. The US has repeatedly stated its opposition to the WTO antitrust rules, while the EU has been their strongest advocate. The US and EU positions on how to protect IPRs are more closely aligned than their views on how to protect their markets from anti-competitive practices. Even as the US and EU antitrust laws are gradually converging, disagreement on the optimal content of antitrust laws remains. This disagreement
} 
as duas potências no que concerne à análise antitruste de acordos de licenciamento, como se pode observar nas guidelines sobre o tema que foram publicadas pelas autoridades antitruste das duas jurisdições ${ }^{250}$, o mesmo não se pode afirmar com relação às abordagens adotadas para coibir condutas abusivas unilaterais. Enquanto os Estados Unidos adotam uma postura mais liberal nesses casos, as autoridades e tribunais europeus tendem a ser mais intervencionistas, sendo frequente o recurso ao licenciamento compulsório para remediar tais condutas, como pode ser claramente observado em casos de recusa de licenciar direitos de propriedade intelectual. ${ }^{251}$

Destarte, considerando a impossibilidade de se estabelecer padrões internacionais comuns nessa área num futuro próximo, é certo que as autoridades de defesa da concorrência dos países em desenvolvimento podem beneficiar-se das discussões informais e trocas de experiências havidas no âmbito do Comitê sobre Direito e Política da Concorrência da Organização para Cooperação e Desenvolvimento Econômico - OCDE, bem como do Grupo Intergovernamental de Especialistas em Direito e Política da Concorrência da UNCTAD, que resultaram na publicação de relatórios substanciais que constituem rica fonte de informação sobre o tema. ${ }^{252} \mathrm{Da}$ mesma forma, alguns relatórios

stems from a different belief on when and how a government should intervene when market fail. In general, the EU is considered to be more interventionist and less tolerant of market power. Consequently, the EU is more likely to challenge mergers and pursue the conduct of a dominant corporation. The divergent outcomes in the Microsoft case and GE/Honeywell merger are often cited as most prominent examples of the remaining transatlantic differences". BRADFORD, Anu. International Antitrust Regime, TRIPs and Different Paths to Regulatory Convergence, in: PIPES: The Program on International Politics, Economics, and Security, 2009, p. 11. Disponível em: http://cas.uchicago.edu/workshops/pipes/2009/02/26/archive-bradford-feb-26-2009international-antitrust-regime-trips-and-different-paths-to-regulatory-convergence/. Acesso em: 22 jul. 2012.

${ }^{250}$ Cf. U.S. DEPARTMENT OF JUSTICE \& FEDERAL. TRADE COMMISSION. Antitrust Guidelines for the Licensing of Intellectual Property, $1995 . \quad$ Disponível em: http://www.justice.gov/atr/public/guidelines/0558.htm. Acesso em: 22 jul. 2012; e Commission Notice Guidelines on the application of Article 81 of the EC Treaty to technology transfer agreements n. ${ }^{\circ}$ 2004/C 101/02. Disponível em: http://eurlex.europa.eu/LexUriServ/LexUriServ.do?uri=OJ:C:2004:101:0002:0042:EN:PDF. Acesso em: 22 jul. 2012.

${ }^{251}$ Sobre o assunto, ANDERSON afirma que: “(...) even if it is deemed desirable to provide additional guidance for WTO Member regarding these questions, it may not be possible to agree on appropriate standards to govern all practices in all situations. Although approaches to the competition policy-intellectual property interface in major developed jurisdiction have undergone a degree of convergence in recent years and a number of useful guidelines on national enforcement policies are available for reference, there remain important residual differences even between the US and the European Community. In the past, even greater divergences have been evident between developed and developing countries regarding issues in this area". ANDERSON, Robert D. Competition Policy and Intellectual Property in the WTO: More Guidance Needed?, in: DREXL, Josef (Ed.), Research Handbook on Intellectual Property and Competition Law. Cheltenham: Edward Elgar, 2008, p. 453.

252 Cf. OECD, Committee on Competition Law and Policy (1998), Competition Policy and Intellectual Property Rights, DAFFE/CLP(98)18. Disponível em: http://www.oecd.org/dataoecd/34/57/1920398.pdf. Acesso em: 22 jul. 2012; e UNCTAD, Intergovernmental Group of Experts on Competition Law and Policy, Competition Policy and the Exercise of Intellectual Property Rights, TD/B/COM.2/CLP/22/Rev.1. Disponível em: http://unctad.org/en/docs/c2clp22r1.en.pdf. Acesso em: 22 jul. 2012. 
elaborados no âmbito da OMC pelo Grupo de Trabalho sobre Comércio e Política da Concorrência, atualmente inativo, também podem servir como referência, já que o tema da relação entre política de concorrência e propriedade intelectual foi discutido em algumas ocasiões. $^{253}$

Por fim, tendo em vista a limitada experiência dos países em desenvolvimento e menos desenvolvidos na implementação de políticas de concorrência efetivas, sobretudo nos casos em que há discussão sobre propriedade intelectual, não há dúvidas de que a experiência das duas jurisdições mais avançadas em matéria de direito antitruste - Estados Unidos e União Europeia - poderia servir como modelo para a formulação de normas e diretrizes adequadas e consistentes com as disposições do TRIPS sobre concorrência. Nesse contexto, podem ser extremamente úteis, como referência para a formulação de políticas públicas nessa área, não apenas as guidelines sobre análise antitruste de acordos de licenciamento e transferência de tecnologia publicadas pelas autoridades antitruste dessas duas jurisdições, como também os precedentes administrativos e judiciais, que trazem uma variedade de casos envolvendo a aplicação do direito da concorrência para coibir o exercício abusivo de direitos de propriedade intelectual. Baseando-se na experiência de jurisdições mais avançadas em relação ao tema, e na ampla discricionariedade conferida pelas disposições do TRIPS sobre concorrência, os países em desenvolvimento podem formular normas e mecanismos internos adaptados às suas próprias realidades, necessidades e prioridades de política pública. ${ }^{254}$

\footnotetext{
${ }^{253}$ Cf. World Trade Organization - WTO (1998), Report of the WTO Working Group on the Interaction between Trade and Competition Policy, WT/WGTCP/M/6, November 16, 1998. Disponível em: http://www.wto.org/english/tratop_e/comp_e/wgtcp_docs_e.htm. Acesso em: 22 jul. 2012.

${ }^{254}$ A esse respeito, NGUYEN afirma que: "There is certainly no one-size-fits-all approach concerning technology transfer-related competition law. However, studying and profiting from the experience of developed countries and other advanced developing countries in this area are very important. Based on such experience, developing country Members may find a suitable answer for themselves as they seek to balance the rights and obligations of right holders from the competition perspective in order to serve national interests and consumer welfare". NGUYEN, Tu Thanh. Competition Law, Technology Transfer and the TRIPS Agreement. Cheltenham: Edward Elgar, 2010, p. 58.
} 


\section{FORMAS DE ABUSO DE DIREITOS DE PROPRIEDADE INTELECTUAL CAPAZES DE RESTRINGIR A CONCORRÊNCIA: EXPERIÊNCIA DOS ESTADOS UNIDOS E DA UNIÃO EUROPEIA}

Nesta Seção, passamos a analisar as formas de abuso de direitos de propriedade intelectual capazes de restringir a concorrência, de modo a conferir aplicação prática às disposições do TRIPS que tratam do tema. Para tanto, analisamos os casos julgados nos Estados Unidos e na União Europeia, que são as jurisdições mais avançadas em matéria de aplicação do direito da concorrência. Conforme mencionado na Seção anterior, a jurisprudência norte-americana e europeia oferece uma variedade de casos envolvendo a aplicação do direito da concorrência para coibir o exercício abusivo de direitos de propriedade intelectual, sobretudo no que concerne aos ilícitos atinentes aos acordos de licenciamento de direitos de propriedade intelectual e transferência de tecnologia. A análise desses casos pode auxiliar os países em desenvolvimento a estabelecer normas nacionais coerentes com as disposições do Acordo TRIPS sobre concorrência e, assim, implementar políticas públicas efetivas para lidar com abusos de direitos de propriedade intelectual que tenham efeitos anticoncorrenciais.

Não é objetivo desta Seção a análise pormenorizada dos sistemas de propriedade intelectual e de defesa da concorrência dos Estados Unidos e da União Europeia, mas simplesmente examinar as abordagens utilizadas pelas autoridades da concorrência e tribunais norte-americanos e europeus na análise antitruste de casos envolvendo a exploração abusiva de direitos de propriedade intelectual. Para tanto, é necessário inicialmente apontar alguns aspectos do desenvolvimento da relação entre propriedade intelectual e direito da concorrência nessas duas jurisdições.

Para facilitar a compreensão do tema, a análise das práticas restritivas ligadas à exploração de direitos de propriedade intelectual será dividida de acordo com a seguinte classificação: (i) cláusulas restritivas em acordos de licenciamento; (ii) restrições em licenças cruzadas e pool de patentes; e (iii) condutas unilaterais de exclusão. ${ }^{255}$

\footnotetext{
${ }^{255}$ SALOMÃO FILHO desenvolve uma classificação semelhante para o que chama de "abuso de patentes": "No campo das condutas, os abusos de patentes podem ser agrupados em três grandes grupos: (i) contratos de licenciamento; (ii) pool de patentes e (iii) patentes fraudulentas e defensivas". SALOMÃO FILHO, Calixto. Direito Industrial, Direito Concorrencial e Interesse Público, in: Revista de Direito Público da Economia, Belo Horizonte, ano 2, n. 7, p. 33, jul./set. 2004.
} 


\subsection{Breves considerações sobre a interface entre propriedade intelectual e direito da concorrência nos Estados Unidos}

Os Estados Unidos foram os pioneiros em matéria de direito da concorrência, ao aprovarem em 1890 o Sherman Act que, como bem definido pela Suprema Corte daquele país, foi estruturado para ser uma carta compreensiva de liberdade econômica com o objetivo de preservar a livre e irrestrita concorrência como regra de comércio, de modo a assegurar uma melhor alocação dos recursos, menores preços, mais qualidade e maior progresso material. ${ }^{256} \mathrm{O}$ Sherman Act é, portanto, o primeiro estatuto legal da defesa da concorrência a obter relevância. Foi aprovado em resposta ao crescente descontentamento popular com a formação de trustes, que era uma forma de organização empresarial que se caracterizava pela concentração do controle econômico das atividades produtivas num pequeno grupo de pessoas. $^{257}$

A Seção 1 do Sherman Act visa ao controle de acordos e contratos capazes de restringir a concorrência, ao dispor que: "Todo contrato, combinação em forma de truste ou qualquer outra forma, ou conspiração para restringir o comércio entre os diversos estados ou com nações estrangeiras é declarado ilegal". ${ }^{258}$ Já a Seção 2 do Sherman Act tem o objetivo de coibir as práticas restritivas unilaterais tendentes à monopolização dos mercados e tentativa de monopolização, ao dispor que: "Toda a pessoa que monopolize ou tente monopolizar, ou combine ou conspire com outra pessoa ou pessoas para monopolizar qualquer ramo da indústria ou do comércio entre os diversos estados ou com

256 "The Sherman Act was designed to be a comprehensive charter of economic liberty aimed at preserving free and unfettered competition as the rule of trade. It rests on the premise that the unrestrained interaction of competitive forces will yield the best allocation of our economic resources, the lowest prices, the highest quality and the greatest material progress, while at the same time providing an environment conductive to the preservation of our democratic political and social institutions. But even were that premise open to question, the policy unequivocally laid down by the Act is competition". Northern Pacific Railroad v. U.S., 356 U.S. 1 (1958), p. 4.

${ }^{257}$ Ao comentar a aprovação do Sherman Act como resposta à concentração econômica causada pelos trustes, Miguel Moura E SiLva afirma que: "Por diversos motivos, essa concentração de poder económico era extremamente impopular, em especial junto dos pequenos e médios empresários e dos agricultores; os primeiros por serem obrigados a concorrer com verdadeiros gigantes comerciais que nem sempre se comportavam segundo os usos honestos do comércio; os segundos, por se verem obrigados a pagar elevados preços pelo transporte ferroviário dos seus produtos, sendo discriminados em relação aos grandes criadores de gado". MourA E SILVA, Miguel. Inovação, Transferência de Tecnologia e Concorrência: Estudo Comparado dos Direito da Concorrência dos Estados Unidos e da União Europeia. Coimbra: Almedina, 2003, p. 117.

258 Tradução livre de: "Every contract, combination in the form of trust or otherwise, or conspiracy, in restraint of trade or commerce among the several States, or with foreign nations, is declared to be illegal". 


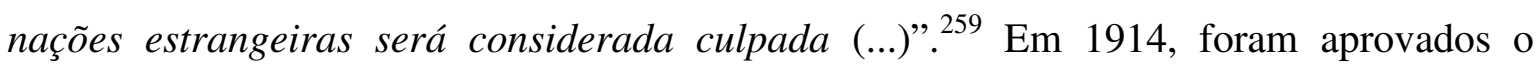
Clayton Act e o Federal Trade Commission Act. O primeiro instituiu o controle antitruste de práticas específicas, tais como discriminação de preços, contratos de exclusividade, vendas casadas e fusões e aquisições capazes de reduzir a concorrência, enquanto o segundo passou a proibir genericamente o que seriam "métodos de concorrência desleal" capazes de causar danos aos consumidores. A partir desses diplomas legais e suas alterações posteriores, os tribunais norte-americanos construíram uma série de doutrinas e regras que formam o atual sistema antitruste dos Estados Unidos.

É importante ressaltar que nem todas as condutas restritivas ao comércio, conforme linguagem contida nas Seções 1 e 2 do Sherman Act, serão consideradas ilícitas. Os tribunais norte-americanos reconhecem que determinadas práticas potencialmente anticoncorrenciais podem ser justificadas dentro de critérios de razoabilidade. ${ }^{260}$ Por outro lado, há práticas tão restritivas por natureza que não requerem maior análise para constatar seus prováveis efeitos anticoncorrenciais. Desse modo, enquanto algumas práticas devem ser analisadas sob a égide da rule of reason ("regra da razão" ou "regra da razoabilidade"), tendo em vista a possibilidade de serem justificadas por imperativos de eficiência econômica $^{261}$, outras são tão restritivas à luz da experiência adquirida pelos tribunais que devem ser consideradas como ilícitos per se, sem a necessidade de qualquer análise mais aprofundada. ${ }^{262}$ Exemplo de ilícitos antitruste per se, como já mencionado, são os acordos restritivos entre concorrentes para fixação de preços, redução da produção e divisão de mercados. $^{263}$

\footnotetext{
${ }^{259}$ Tradução livre de: "Every person who shall monopolize, or attempt to monopolize, or combine or conspire with any other person or persons, to monopolize any part of the trade or commerce among the several States, or with foreign nations, shall be deemed guilty of a felony (...)".

${ }^{260}$ Nesse contexto, a Suprema Corte norte-americana manifestou-se da seguinte forma num dos primeiros casos em que critérios de razoabilidade foram utilizados na análise de práticas restritivas da concorrência: "The true test of legality is whether the restraint imposed is such as merely regulates and perhaps thereby promotes competition or whether it is such as may suppress or even destroy competition. To determine that question the court must ordinarily consider the facts peculiar to the business to which the restraint is applied; its condition before and after the restraint was imposed; the nature of the restraint and its effect, actual or probable". Chicago Board of Trade v. United States, 246 U.S. 231 (1918), p. 238.

${ }^{261}$ Cite-se como exemplo os casos National Society of Professional Engineers v. United States, 435 U.S. 679, 687-692 (1978) e Arizona v. Maricopa County Medical Society, 457 U.S. 332, 342-343 (1982).

262 Vale mencionar como exemplo os casos Northern Pacific Railway Co. v. United States, 356 U.S. 1,5 (1958) e National Society of Professional Engineers v. United States, 435 U.S. 679, 692 (1978).

${ }^{263}$ A Suprema Corte norte-americana rejeita uma abordagem meramente formal ao determinar se uma conduta é per se ilícita. Para determinar se uma conduta deve ser considerada um ilícito per se, os tribunais devem levar em consideração as peculiaridades do caso concreto.
} 
A análise de práticas restritivas pela regra da razão requer um exame detalhado de seus efeitos econômicos em determinado mercado relevante, se os agentes econômicos envolvidos possuem poder de mercado, se há barreiras à entrada, dentre outros elementos. Caso se constate que a prática em questão produz efeitos negativos líquidos sobre a concorrência, deve-se verificar se há eficiências econômicas capazes de justificá-la, por exemplo, se leva à redução de custos de produção, se permite ganhos de escala, ou se beneficia a inovação (eficiência dinâmica). Após sopesar os efeitos anticompetitivos e os efeitos pró-competitivos, será possível constatar se a prática restritiva sob análise constitui ilícito antitruste.

As autoridades antitruste competentes para investigar condutas anticoncorrenciais e instaurar medidas administrativas e judiciais são o Department of Justice (DOJ) e a Federal Trade Commission (FTC), que possuem competências exclusivas e concorrentes, a depender da matéria em questão e de outros fatores específicos, embora atuem de forma coordenada em algumas situações, especialmente na análise de fusões e aquisições. A despeito dos processos administrativos que podem ser instaurados no âmbito da FTC e da competência do DOJ para ingressar com ações criminais por violação das normas antitruste, qualquer pessoa pode promover ações judiciais perante os tribunais federais norte-americanos para questionar práticas anticoncorrenciais. ${ }^{264}$

Conforme já ressaltado, durante algum tempo, mais precisamente nas primeiras décadas de vigência do Sherman Act, prevaleceu o entendimento dos tribunais norteamericanos de que haveria um conflito entre o direito de propriedade intelectual e o direito da concorrência, mais precisamente entre a legislação de patentes e a legislação antitruste. Além disso, em caso de conflito, prevaleciam as normas atinentes às patentes, já que os tribunais se recusavam a condenar práticas a partir da exploração do "monopólio" legítimo

\footnotetext{
${ }^{264}$ Deve-se ressaltar que os tribunais federais norte-americanos possuem jurisdição exclusiva sobre questões pertinentes à legislação federal antitruste, sem prejuízo da jurisdição das cortes estaduais para aplicar as normas antitruste do respectivo estado. Além dos processos administrativos que podem ser instaurados pela FTC, cuja decisão permite apelação direta aos tribunais de apelação ("US Courts of Appeals"), qualquer pessoa pode ingressar com ação judicial perante os tribunais federais locais ("district courts"). Das decisões dos district courts cabe recurso aos tribunais de apelação, normalmente denominados "circuit courts", com exceção do D.C. Circuit Court, situado em Washington D.C., ao qual compete exclusivamente apreciar recursos de apelação das decisões administrativas das agências federais. A Suprema Corte norte-americana é a última instância de apelação, mas possui discricionariedade para a escolha dos casos que deseja apreciar. Cf. ELHAUGE, Einer; GERADIN, Damien. Global Competition Law and Economics. 2nd ed. Oxford and Portland: Hart Publishing, 2011, p. 12-15.
} 
conferido por uma patente. ${ }^{265}$ Mesmo casos em que o titular de uma patente condicionasse o licenciamento do direito à aquisição de outros produtos não patenteados, prática conhecida como venda casada ou licença casada ("tying arrangement"), eram considerados exploração legítima da patente. ${ }^{266}$

Posteriormente, diante de práticas abusivas por parte de titulares de direitos de propriedade intelectual, a legislação antitruste passou a prevalecer sobre a legislação de patentes, embora os tribunais continuassem a considerar não apenas que havia conflito entre as duas áreas do direito, mas também que uma patente conferia monopólio no sentido econômico ao seu titular. No célebre caso Motion Picture, de 1917, a Suprema Corte considerou ilícita a conduta de licenciar o uso de projetores patenteados sob a condição de que somente fossem utilizados para a exibição dos filmes por ela produzidos. ${ }^{267} \mathrm{~A}$ Suprema Corte entendeu que o titular da patente utilizou uma estratégia de venda casada para estender de forma injustificada o escopo da proteção conferida pela patente para abarcar também os filmes que, embora devessem ser utilizados nos projetores, não faziam parte da invenção patenteada.

Esse caso deu origem à doutrina da "patent misuse" (ou "abuso de patentes"), mecanismo de defesa processual disponível ao réu de uma ação de infração de patente. Se um argumento de "misuse" for aceito pelo tribunal, o titular da patente não poderá impor seu direito contra o suposto infrator. ${ }^{268}$ Os primeiros casos de patente misuse envolveram argumentos de venda casada, ou seja, situações em que o titular de uma patente estendia de forma indevida o "monopólio" conferido pela patente a produtos não patenteados,

\footnotetext{
${ }^{265}$ A decisão da Suprema Corte no caso National Harrow é um bom exemplo dessa visão: “(...) the general rule is absolute freedom in the use or sale of rights under the patente laws of the United States. The very object of these laws is monopoly, and the rule is, with legal exceptions, that any conditions which are not in their very nature illegal with regard to this kind of property, imposed by the patentee and agreed to by the licensee for the right to manufacture or use or sell the article, will be upheld by the courts. The fact that the conditions in the contracts keep up the monopoly of fix prices does not render them illegal". E. Bemet \& Sons v. National Harrow Co., 186 U.S. 70, $72-73$ (1902).

${ }^{266}$ Cf. decisão da Suprema Corte no caso Henry v. A.B. Dick Co., 224 U.S. 1 (1912).

${ }^{267}$ Motion Pictures Patents Co. v. Universal Film Manufacturing Co., 243 U.S. 502 (1917).

${ }^{268}$ Sobre o tema, HovenKAMP afirma que: "The misuse claim typically arises when the patent holder sues another firm, claiming that its patent rights or contract rights under a licensing arrangement have been violated. The defense raised is that the patent has been misused, which is tantamount to a defense that the way the patent's owner used the patent violates patent law, antitrust law, or perhaps some less clearly articulated policy. If the misuse defense prevails, the patent is generally held to be unenforceable". HOVENKAMP, Herbert. Federal Antitrust Policy: The Law of Competition and its Practice. 3rd ed. Thomson West, 2005, p. 242.
} 
oferecidos como condição para a aquisição do produto patenteado. ${ }^{269}$ Mais tarde, a doutrina do patente misuse passou a ser aplicável a uma série de práticas restritivas da concorrência, especialmente em contratos de licenciamento de direitos de propriedade intelectual. Embora a doutrina do patent misuse tenha se desenvolvido de forma independente em relação ao direito antitruste, atualmente entende-se que a configuração de uma hipótese de misuse requer a demonstração de que a conduta em questão produz efeitos anticoncorrenciais em determinado mercado relevante. ${ }^{270} \mathrm{Em}$ todo o caso, ainda existe debate na doutrina e jurisprudência sobre a relação entre patent misuse e ilícito antitruste. $^{271}$ Atualmente, os tribunais norte-americanos também aceitam argumentos de "copyright misuse" (ou "abuso de direitos autorais"). ${ }^{272}$

Seguindo essa linha mais rígida contra práticas restritivas relacionadas à exploração de direitos de propriedade intelectual, o DOJ divulgou em 1970 um conjunto de cláusulas contratuais em contratos de licenciamento que deveriam ser consideradas como ilícitos per se. Assim, nove tipos de cláusulas restritivas seriam proibidas, de modo que essa política passou a ser chamada de "Nine No-Nos". 273

Entre a década de 1980 e início da década de 1990, o DOJ e a FTC passaram a adotar uma abordagem mais flexível em matéria de exploração de direitos de propriedade intelectual, o que culminou com a publicação, em 1995, do Antitrust Guidelines for the Licensing of Intellectual Property ("Diretrizes de 1995”), guia para análise antitruste de contratos de licenciamento de direitos de propriedade intelectual. De acordo com esse guia práticas restritivas contidas nesses acordos deveriam, em sua maioria, ser analisadas sob a égide da regra da razão. Além disso, o DOJ e a FTC deixam claro que a propriedade

\footnotetext{
269 Cf. International Business Machines Corporation (IBM) v. United States, 298 U.S. 131 (1936) e International Salt Co. v. United States, 332 U.S. 392 (1947).

${ }^{270}$ Cf. USM Corp. v. SPS Techs., 694 F.2d 505, 510-14 ( $7^{\text {th }}$ Cir. 1982); Windsurfing Int'l, Inc v. AMF, Inc., 782 F,2d 995, 1001-02 (Fed. Cir. 1986); e Mallinckrodt, Inc. v. Medipart, Inc., 976 F.2d 700 (Fed. Cir. 1992).

${ }^{271}$ Cf. HOVENKAMP, Herbert. Federal Antitrust Policy: The Law of Competition and its Practice. 3rd ed. Thomson West, 2005, p. 242.

${ }^{272}$ Cf. Assessment Technologies v. WIREdata, Inc., 350 F.3d 640 (7 $7^{\text {th }}$ Cir. 2003); 361 F.3d 434 ( $7^{\text {th }}$ Cir. 2004).

${ }^{273}$ As cláusulas em questão eram: (i) condicionar o licenciamento de uma patente à aquisição de bens não patenteados (licença casada); (ii) determinar ao licenciado a cessão exclusiva de patentes subsequentes (grantback com exclusividade); (iii) restrições aos direitos do comprador na revenda de produtos protegidos; (iv) restrições à liberdade do licenciado de comercializar produtos fora do escopo da patente licenciada ("tieout"); (v) proibição ao licenciante de conceder licenças adicionais; (vi) imposição de pacote de licenças obrigatório; (vii) royalties não relacionados às vendas de produtos protegidos por patentes; (viii) restrições às
} 
intelectual e o direito antitruste são instrumentos complementares de promoção da inovação e do bem-estar dos consumidores. A partir dessa abordagem, as autoridades antitruste passaram a considerar os efeitos pró-competitivos dos acordos de licenciamento de direitos de propriedade intelectual, já que facilitam a integração da propriedade licenciada com fatores complementares de produção, levando à exploração mais eficiente de direitos de propriedade intelectual, beneficiando consumidores por meio da redução de custos de produção e introdução de novos produtos. ${ }^{274}$

As Diretrizes de 1995 também passaram a adotar expressamente a premissa de que as autoridades antitruste não presumirão que uma patente, um direito autoral ou um segredo industrial conferem necessariamente poder de mercado ao seu titular. E ainda acrescentam que: "Although the intellectual property right confers the power to exclude with respect to specific product, process, or work in question, there will often be sufficient actual or potential close substitutes for such product, process, or work to prevent the exercise of market power". ${ }^{275}$ A mesma premissa passou também a ser observada pelos tribunais norte-americanos e confirmada em recente decisão proferida pela Suprema Corte dos Estados Unidos no caso Illinois Tools Works, no qual foi expressamente refutada a hipótese de que a existência de poder de mercado seja presumida em razão da titularidade de um direito de propriedade intelectual. ${ }^{276}$

Por outro lado, as Diretrizes de 1995 reconhecem que determinadas práticas restritivas em contratos de licenciamento de direitos de propriedade intelectual podem levantar preocupações do ponto de vista antitruste, particularmente quando uma cláusula contratual prejudica a competição entre agentes econômicos que, na ausência da licença, poderiam ser concorrentes efetivos ou potenciais em determinado mercado relevante. ${ }^{277}$ Analisaremos mais adiante as principais cláusulas restritivas em contratos de licenciamento e a abordagem adotada pelas autoridades antitruste e tribunais norte-americanos nesses casos.

vendas de produtos não patenteados fabricados a partir de processo patenteado; e (ix) fixação de preço de revenda de produtos protegidos pelas patentes licenciadas.

${ }^{274}$ De acordo com as Diretrizes de 1995: "Licensing, cross-licensing, or otherwise transfering intelectual property (...) can facilitate integration of the license property with complementary factors of production. This integration can lead to more efficient exploitation of the intellectual property, benefiting consumers through the reduction of costs and the introduction of new products" (item 2.3 das Diretrizes de 1995).

${ }^{275}$ Item 2.2. das Diretrizes de 1995.

${ }^{276}$ Illinois Tool Works Inc. et. al. v. Independent Ink, Inc., 547 U.S. 28 (2006).

${ }^{277}$ Item 3.1 das Diretrizes de 1995. 
Seguindo a classificação das categorias de práticas restritivas proposta nesta Seção, é certo que as condutas anticoncorrenciais em acordos de licenciamento de tecnologia, os pools de patentes e licenças cruzadas e os acordos de licenciamento, são em geral analisados no âmbito da Seção 1 do Sherman Act, enquanto as práticas restritivas unilaterais são normalmente analisadas no contexto da Seção 2 do mesmo estatuto legal. Nada impede, no entanto, que uma prática restritiva seja analisada como ilicitude coberta tanto pela Seção 1 como pela Seção 2 do Sherman Act, como muitas vezes acontece.

\subsection{Breves considerações sobre a interface entre propriedade intelectual e direito da concorrência na União Europeia}

Com o objetivo de preservar o livre comércio e a integração econômica entre os Estados-Membros da Comunidade Europeia, foram introduzidas normas de defesa da concorrência no Tratado de Roma de 1957. Com a entrada em vigor do Tratado de Lisboa em dezembro de 2009, o Tratado de Roma foi modificado e passou a se denominar Tratado sobre o Funcionamento da União Europeia (TFUE), resultando na renumeração dos seus dispositivos. ${ }^{278}$ Atualmente, o direito da concorrência europeu é regulado pelos artigos 101 a 109 do TFUE, enquanto o Artigo 101 proíbe os acordos e práticas concertadas que restrinjam o comércio e a livre concorrência e o Artigo 102 proíbe práticas que constituam abuso de posição dominante. ${ }^{279}$

O Artigo 101 do TFUE apresenta uma estrutura mais complexa do que a Seção 1 do Sherman Act. O Parágrafo $1^{\circ}$ do Artigo 101 enumera tipos de acordos entre empresas e seus efeitos anticoncorrenciais ${ }^{280}$, enquanto o Parágrafo $2^{\circ}$ trata da nulidade desses

\footnotetext{
278 O Tratado de Lisboa foi assinado pelos Estados-Membros da União Europeia em 13 de dezembro de 2007, entrando em vigor em $1^{\circ}$ de dezembro de 2009. Esse Tratado alterou o Tratado da União Europeia (Tratado de Maastricht de 1992) e o Tratado de Roma, de 1957, que estabeleceu a Comunidade Europeia.

${ }^{279}$ Os atuais Artigos 101 e 102 do TFUE correspondem aos Artigos 81 e 82 do Tratado de Roma.

280 “1. São incompatíveis com o mercado interno e proibidos todos os acordos entre empresas, todas as decisões de associações de empresas e todas as práticas concertadas que sejam susceptíveis de afectar o comércio entre os Estados-Membros e que tenham por objectivo ou efeito impedir, restringir ou falsear a concorrência no mercado interno, designadamente as que consistam em:

a) Fixar, de forma directa ou indirecta, os preços de compra ou de venda, ou quaisquer outras condições de transacção;

b) Limitar ou controlar a produção, a distribuição, o desenvolvimento técnico ou os investimentos;

c) Repartir os mercados ou as fontes de abastecimento;

d) Aplicar, relativamente a parceiros comerciais, condições desiguais no caso de prestações equivalentes colocando-os, por esse facto, em desvantagem na concorrência;
} 
acordos. A flexibilização da proibição contida no Parágrafo $1^{\circ}$ se dá por meio da possibilidade de isenção conferida pelo Parágrafo $3^{\circ}$ do mesmo Artigo 101 do TFUE ${ }^{281}$, desde que sejam obedecidos os critérios contidos nesse dispositivo, que permitem uma ponderação entre os efeitos negativos e positivos dos acordos em questão. ${ }^{282}$ Para satisfazer os critérios de isenção do Parágrafo $3^{\circ}$ do Artigo 101, os acordos restritivos devem cumprir quatro requisitos: (i) apresentar ganhos de eficiência na produção e distribuição de produtos ou resultar em progresso técnico ou econômico; (ii) permitir que uma parte equitativa desses ganhos de eficiência seja aproveitada pelos consumidores ${ }^{283}$; (iii) não impor restrições que não sejam indispensáveis para a obtenção dos ganhos de eficiência em questão; e (iv) não conferir às empresas envolvidas a possibilidade de eliminar a concorrência relativamente a uma parte substancial dos produtos em questão. ${ }^{284}$

Assim, a análise dos acordos restritivos da concorrência nos termos do Artigo 101 do TFUE consiste em duas etapas: (i) análise dos efeitos anticoncorrenciais do acordo para verificar seu eventual enquadramento no Parágrafo $1^{\circ}$ do Artigo 101; e (ii) equilíbrio entre efeitos positivos e negativos do acordo sobre a concorrência, nos termos do Parágrafo $3^{\circ}$ do Artigo 101. Por outro lado, para facilitar a aplicação do Parágrafo $3^{\circ}$ do Artigo 101, as autoridades europeias costumam editar regulamentos de isenção em bloco, ou seja, por categoria de acordos, permitindo uma espécie de "zona de segurança" (safe harbour) com o objetivo de conferir segurança e previsibilidade aos agentes econômicos na celebração de

e) Subordinar a celebração de contratos à aceitação, por parte dos outros contraentes, de prestações suplementares que, pela sua natureza ou de acordo com os usos comerciais, não têm ligação com o objecto desses contratos."

281 “3. As disposições no inciso 1 podem, todavia, ser declaradas inaplicáveis:

- a qualquer acordo, ou categoria de acordos, entre empresas,

- a qualquer decisão, ou categoria de decisões, de associações de empresas, e

- a qualquer prática concertada, ou categoria de práticas concertadas, que contribuam para melhorar a produção ou a distribuição dos produtos ou para promover o progresso técnico ou económico, contanto que aos usuários se reserve uma parte equitativa do lucro daí resultante, e que:

a) Não imponham às empresas em causa quaisquer restrições que não sejam indispensáveis à consecução desses objectivos;

b) Nem deem a essas empresas a possibilidade de eliminar a concorrência relativamente a uma parte substancial dos produtos em questão.” C 115/88 PT Jornal Oficial da União Europeia 9.5.2008.

282 Cf. MOURA E SILVA, Miguel. Inovação, Transferência de Tecnologia e Concorrência: Estudo Comparado dos Direito da Concorrência dos Estados Unidos e da União Europeia. Coimbra: Almedina, 2003, p. 137.

283 Os efeitos positivos gerados pelo acordo restritivo em questão deve, no mínimo, compensar os consumidores pelo eventual impacto negativo, efetivo ou potencial, que a restrição da concorrência nos termos do inciso 1 do artigo 101 teve para esses consumidores.

${ }^{284}$ Cf. Diretrizes da Comissão relativas à aplicação do inciso 3 do Artigo 81 [atual Artigo 101] do Tratado (OJ 2004/C 101/08). 
acordos potencialmente restritivos à concorrência nos termos do Parágrafo $1^{\circ}$ do Artigo 101 do TFUE. ${ }^{285}$

Já o Artigo 102, à semelhança da Seção 2 do Sherman Act, trata da repressão ao abuso de posição dominante, ao assim dispor: "É incompatível com o mercado interno e proibido, na medida em que tal seja susceptível de afetar o comércio entre os EstadosMembros, o fato de uma ou mais empresas explorarem de forma abusiva uma posição dominante no mercado interno ou numa parte substancial deste". Esse abuso pode consistir nas seguintes hipóteses: (a) impor, de forma direta ou indireta, preços de compra ou de venda ou outras condições de transação não equitativas; (b) limitar a produção, a distribuição ou o desenvolvimento técnico em prejuízo dos consumidores; (c) aplicar, relativamente a parceiros comerciais, condições desiguais no caso de prestações equivalentes colocando-os, por esse fato, em desvantagem na concorrência; e (d) subordinar a celebração de contratos à aceitação, por parte dos outros contratantes, de prestações suplementares que, pela sua natureza ou de acordo com os usos comerciais, não possuem ligação com o objeto desses contratos.

A Comissão Europeia (Comissão) é a autoridade supranacional responsável pela aplicação das normas de proteção da concorrência no âmbito comunitário, sem prejuízo das autoridades nacionais de cada um dos Estados-Membros. Das decisões da Comissão, cabe recurso ao Tribunal Geral (nova denominação dada ao Tribunal de Primeira Instância). Das decisões do Tribunal Geral, por sua vez, cabe recurso ao Tribunal de Justiça da União Europeia (TJUE), última instância judicial. ${ }^{286}$

Ao contrário do que ocorre nos Estados Unidos e em outras jurisdições, o direito da concorrência aplicado pela União Europeia tem como um de seus principais objetivos a proteção do mercado único ("single market") e a eliminação das barreiras ao comércio entre os Estados-Membros, de modo a promover a utilização eficiente e disseminação de bens e serviços. ${ }^{287}$ É exatamente essa a linguagem utilizada no artigo 101 do TFEU: "São incompatíveis com o mercado único e proibidos todos os acordos entre

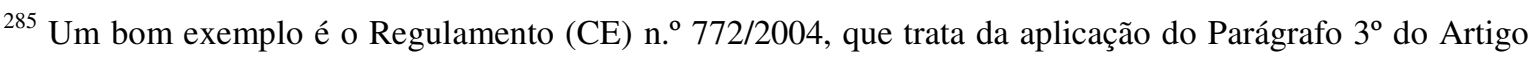
101 aos acordos de transferência de tecnologia.

${ }^{286}$ ELHAUGE, Einer; GERADIN, Damien. Global Competition Law and Economics. 2nd ed. Oxford and Portland: Hart Publishing, 2011, p. 50.

${ }^{287}$ Nos termos do artigo 26 do TFEU, "o mercado interno compreende um espaço sem fronteiras internas no qual a livre circulação das mercadorias, das pessoas, dos serviços e dos capitais é assegurada de acordo com as disposições dos Tratados".
} 
empresas, todas as decisões de associações de empresas e todas as práticas concertadas que sejam suscetíveis de afetar o comércio entre os Estados-Membros e que tenham por objetivo ou efeito impedir, restringir ou falsear a concorrência no mercado único". Nesse contexto, o direito comunitário da concorrência sempre foi vislumbrado como instrumento de promoção da integração econômica, consubstanciada nas quatro liberdades - livre circulação de mercadorias, pessoas, serviços e capitais -, e não apenas de proteção da livre concorrência no mercado. ${ }^{288}$

Essa característica do direito da concorrência da União Europeia explica a hostilidade contra qualquer prática restritiva da concorrência capaz de dividir o mercado único em torno das fronteiras nacionais, como se pode observar no rigor da Comissão e dos tribunais europeus na apreciação de restrições verticais, como, por exemplo, as cláusulas de exclusividade de território, que, embora restrinjam a concorrência intramarcas ${ }^{289}$, são normalmente justificadas eficiências econômicas. ${ }^{290}$ Mesmo a proteção da propriedade intelectual, garantida por meio de legislações nacionais, está sujeita às limitações impostas para salvaguardar o mercado único. Nesse contexto, o artigo 36 do TFUE é claro ao determinar que a propriedade intelectual, assim como outros direitos e restrições legais, não pode constituir "um meio de discriminação arbitrária nem qualquer restrição dissimulada ao comércio entre os Estados-Membros". Por essa razão, aplica-se o princípio da "exaustão de direitos", que proíbe que direitos de propriedade intelectual sejam impostos de forma a impedir a importação paralela, isto é, a livre comercialização do bem

\footnotetext{
${ }^{288}$ Ao comparar as finalidades da política de concorrência na União Europeia e nos Estados Unidos, Miguel MOURA E SILVA esclarece que: "A finalidade da integração econômica é um dos aspectos que mais diferencia a política de concorrência da União Europeia da política correspondente dos Estados Unidos. Com efeito, embora a génese do direito da concorrência nos Estados Unidos esteja intrinsecamente ligada à criação de uma economia continental nas últimas décadas do séc. XIX, ele configura-se como uma reação aos efeitos dessa mesma integração no tecido empresarial. Ele surge como contrapeso às forças que, combinadas com a industrialização, levavam a uma maior integração das atividades económicas sob formas cada vez mais concentradas de gestão. Em suma, ele procura regular o resultado espontâneo da integração econômica dos Estados Unidos. Pelo contrário, o direito comunitário da concorrência foi originariamente concebido como instrumento de promoção dessa mesma integração económica, a qual dava ainda os seus primeiros passos. A ilustração clássica dessa diferença é-nos dada pelo tratamento dado às concentrações de empresas. Enquanto nos Estados Unidos surge logo em 1914 uma regulamentação específica, ainda que com lacunas graves, na Comunidade Europeia esse fenómeno só ocorre durante o processo de criação do mercado único e a adopção do Regulamento n. ${ }^{\circ}$ 4064/89". MOURA E SILVA, Miguel. Inovação, Transferência de Tecnologia e Concorrência: Estudo Comparado dos Direito da Concorrência dos Estados Unidos e da União Europeia. Coimbra: Almedina, 2003, p. 132.

${ }^{289}$ Concorrência intramarcas corresponde àquela que se opera entre distribuidores ou revendedores de uma mesma marca. Já a concorrência intermarcas opera-se entre revendedores de marcas distintas.

${ }^{290}$ MOURA E SILVA, Miguel. Inovação, Transferência de Tecnologia e Concorrência: Estudo Comparado dos Direito da Concorrência dos Estados Unidos e da União Europeia. Coimbra: Almedina, 2003, p. 132.
} 
objeto de proteção em um Estado-Membro após esse mesmo bem ter sido comercializado em outro Estado-Membro, com ou sem a autorização do seu titular.

Se, por um lado, a Comissão e os tribunais comunitários adotaram inicialmente uma postura mais flexível na apreciação de acordos de licença de direitos de propriedade intelectual $^{291}$, não demorou para que as cláusulas de exclusividade de território contidas nesses acordos logo passassem a ser objeto de análise rigorosa, dado o receio de que esse tipo de prática restritiva pudesse ser capaz de isolar os mercados nacionais em detrimento dos objetivos do mercado único, como pode ser observado na decisão do TJUE no caso Consten \& Grunding v. Commission, julgado em meados da década de $1960 .^{292}$ Nesse caso, o TJUE considerou que um contrato que previa a licença de uso de direito de propriedade intelectual seria uma tentativa de isolar um mercado nacional e distorcer a concorrência no mercado único, recaindo, portanto, na proibição constante no artigo do Tratado de Roma equivalente ao atual artigo 101(1) do TFUE. Para o TJUE, o direito de propriedade intelectual em questão poderia contribuir com a infração, já que permitiria ao distribuidor gozar de absoluta proteção em seu território exclusivo de atuação, permitindolhe impedir as importações paralelas advindas de outros Estados-Membros.

Por outro lado, a distinção feita nesse caso pelo TJUE entre a existência de direitos de propriedade intelectual (concessão) e o exercício desses direitos (exploração), constitui um dos pilares da interface entre propriedade intelectual e direito de concorrência na União Europeia. Assim, enquanto a mera existência de direitos de propriedade intelectual não deve sofrer qualquer intervenção no âmbito do direito da concorrência, a exploração desses direitos pode resultar em violação dos artigos 101 e 102 do TFUE. ${ }^{293}$

Assim, a Comissão passou a adotar um posicionamento muito mais restritivo na análise de práticas restritivas em acordos de licenciamento de direitos de propriedade intelectual e transferência de tecnologia ao abrigo do Parágrafo $1^{\circ}$ do Artigo 85 do Tratado de Roma [equivalente ao atual Parágrafo $1^{\circ}$ do Artigo 101 do TFUE], especialmente no

\footnotetext{
${ }^{291}$ No início da década de 1960, a Comissão adotou o posicionamento no sentido de que a maioria das cláusulas restritivas contidas em contratos de licenciamento de patentes não violariam o artigo 101(1) do TFUE, uma vez que as restrições à concorrência intramarcas simplesmente emanam da exclusividade conferida ao titular da patente. Essa visão ficou muito clara no documento elaborado pela Comissão com o nome de Notice on Patent Licensing Agreements de 1962 - OJ [1962] 139/2922.

${ }^{292}$ Casos 56/84 e 58/64 [1966] ECR 299, [1966] CMLR 418.

${ }^{293}$ Cf. WHISH, Richard. Competition Law. 6th ed. Oxford University Press, 2009, p. 763; e NGUYEN, Tu Thanh. Competition Law, Technology Transfer and the TRIPS Agreement. Cheltenham: Edward Elgar, 2010, p. 65.
} 
que concerne às restrições territoriais, normalmente estabelecidas por meio de cláusulas de exclusividade territorial, como pode ser observado em uma série de casos julgados pela Comissão e pelos tribunais comunitários ao longo das décadas de 1970 e 80, e nos regulamentos de isenção em bloco para determinadas categorias de restrições em contratos de licenciamento de patentes [Regulamento n. ${ }^{0}$ 2349/84/EEC sobre a aplicação do Parágrafo $3^{\circ}$ do Artigo 85, equivalente ao atual Artigo 101 do TFEU] e em contratos de licenciamento de know-how [Regulamento n. ${ }^{\circ}$ 556/89/EEC sobre a aplicação do Parágrafo $3^{\circ}$ do Artigo 85, equivalente ao atual Artigo 101 do TFUE]. Ainda que algumas restrições pudessem ser isentas de intervenção, a maioria dos casos julgados nesse período evidencia uma abordagem extremamente intervencionista por parte da Comissão e do TJUE.

Vale ressaltar que essa política intervencionista foi fortemente influenciada pela política norte-americana do "Nine No-Nos", adotada pelo DOJ em 1970, que considerava diversas práticas restritivas em contratos de licenciamento como ilícitos per se, a partir de uma abordagem essencialmente formalista. Mais tarde, após a publicação das Diretrizes de 1995 pelo DOJ e pela FTC nos Estados Unidos, a Comissão adotou o Regulamento sobre Transferência de Tecnologia, conferindo isenção em bloco para determinadas categorias de restrições em contratos de transferência de tecnologia [Regulamento (EC) n. ${ }^{\circ}$ 240/96 sobre a aplicação do artigo 85(3)], incluindo patentes e know-how. Ressalte-se que a abordagem conferida pela Comissão nesse novo regulamento continuava excessivamente formalista, ao contrário das Diretrizes de $1995 .{ }^{294}$

Mais recentemente, no contexto da modernização do direito comunitário da concorrência ${ }^{295}$, a Comissão adotou o Regulamento (CE) n. ${ }^{\circ}$ 772/2004, novo Regulamento sobre Transferência de Tecnologia ("Regulamento de 2004"), relativo à aplicação do

\footnotetext{
${ }^{294}$ Esse formalismo podia ser observado na própria estrutura do Regulamento, que dividia as restrições em quatro categorias: (i) cláusulas isentas; (ii) "lista branca", contendo cláusulas que não violariam o artigo 101(1) do TFUE e poderiam ser utilizadas livremente; (iii) "cláusulas proibidas", que certamente violariam o artigo 101(1) e jamais poderiam ser beneficiadas pela isenção em bloco; e (iv) "lista cinza", contendo cláusulas que, embora não pudessem ser isentas, também não poderiam ser proibidas per se, devendo ser analisadas caso a caso. Nesse contexto, a forma era mais importante do que os efeitos econômicos das cláusulas restritivas. Cf. ANDERMAN, Steven. The New EC Competition Law Framework for Technology Transfer and IP Licensing, in: DREXL, Josef (Ed.). Research Handbook on Intellectual Property and Competition Law. Cheltenham: Edward Elgar, 2008, p. 109; e NGUYEN, Tu Thanh. Competition Law, Technology Transfer and the TRIPS Agreement. Cheltenham: Edward Elgar, 2010, p. 67.

${ }^{295}$ A modernização do direito da concorrência da União Europeia ocorreu a partir da adoção do Regulamento do Conselho n. ${ }^{\circ}$ 1/2003 e consistiu em uma série de reformas processuais, incluindo: (i) o fim da notificação prévia de contratos à Comissão; (ii) descentralização da aplicação de isenções ao abrigo do inciso 3 do Artigo 101 pela Comissão, que passou a dividir essa competência com as autoridades de concorrência e tribunais nacionais; e (iii) a modernização dos poderes de investigação e de decisão da Comissão.
} 
Parágrafo $3^{\circ}$ do Artigo 81 [equivalente ao atual Artigo 101 do TFUE] a certas categorias de acordos, acompanhado das Diretrizes n. ' 2004/C 101/02 (“Diretrizes de 2004”). Na esteira da modernização, as partes de um acordo de transferência de tecnologia não mais necessitariam notificar o acordo para obter isenção da Comissão nos termos do Parágrafo $3^{\circ}$ do Artigo 101, de modo que o novo sistema pressupõe que as próprias partes e seus advogados avaliem se o acordo em questão se enquadra nos critérios de isenção, tendo em vista o disposto no Artigo 101, além dos precedentes da Comissão e dos tribunais comunitários. ${ }^{296} \mathrm{O}$ fato é que o Regulamento de 2004 representa uma clara mudança de uma abordagem essencialmente formalista para uma abordagem mais flexível, consubstanciada na análise dos efeitos econômicos dos acordos de licenciamento e transferência de tecnologia em determinado mercado relevante. ${ }^{297}$

O Regulamento de 2004 foi ampliado para incluir, além de patentes e knowhow, o licenciamento de direitos autorais sobre programas de computador. ${ }^{298}$ Ao contrário do regulamento anterior, que fazia uma divisão entre categorias permitidas e proibidas de restrições, o Regulamento de 2004 apenas determina uma lista limitada de restrições hardcore, proibidas per se, que não podem ser analisadas de forma independente em relação ao acordo, além de uma lista limitada de restrições excluídas, que podem ser analisadas de forma independente, não prejudicando a aplicação do Regulamento às demais cláusulas do acordo. ${ }^{299}$ Todas as demais restrições em acordos de transferência de tecnologia poderão beneficiar-se da isenção por categoria, na medida em que as participações de mercado das partes envolvidas no acordo não excedam os limites estabelecidos (20\% para acordos entre concorrentes e $30 \%$ para acordos entre não concorrentes), participações essas no mercado de tecnologia ou no mercado do produto fabricado com a tecnologia licenciada. ${ }^{300}$

De qualquer modo, o Regulamento de 2004 deixa claro que não haverá presunção de que, acima dos limites de participação de mercado, os acordos de transferência de tecnologia serão considerados abrangidos pelo Parágrafo $1^{\circ}$ do Artigo 101 do TFUE, da mesma forma que não haverá presunção de que os acordos abrangidos pelo

\footnotetext{
${ }^{296}$ Cf. ANDERMAN, Steven. The New EC Competition Law Framework for Technology Transfer and IP Licensing, in: DREXL, Josef (Ed.). Research Handbook on Intellectual Property and Competition Law. Cheltenham: Edward Elgar, 2008, p. 110.

${ }^{297}$ Cf. parágrafo 4 do Preâmbulo do Regulamento de 2004.

${ }^{298}$ Cf. Artigo 1.1(b) do Regulamento de 2004.

${ }^{299}$ Artigos 4.1, 4.2 e 5 do Regulamento de 2004.

${ }^{300}$ Artigo 3 do Regulamento de 2004.
} 
Parágrafo $1^{\circ}$ do Artigo 101 não satisfazem as condições de isenção, nos termos do Parágrafo $3^{\circ}$ do Artigo 101 do TFEU. ${ }^{301}$ Ademais, é imperioso destacar que o Regulamento de 2004 evidencia uma preocupação muito maior com práticas restritivas horizontais (entre concorrentes), do que com práticas restritivas verticais (entre não concorrentes). ${ }^{302}$

Como se pode observar, o Regulamento de 2004 é muito mais simples do que o anterior, permitindo uma maior segurança jurídica para as partes em contratos de transferência de tecnologia, além de estar em linha com as Diretrizes de 1995 adotadas pelo DOJ e pela FTC nos Estados Unidos, embora persistam algumas divergências importantes, como veremos mais adiante.

\subsection{Práticas restritivas em acordos de licenciamento e transferência de tecnologia}

Conforme já mencionado ao longo deste trabalho, os acordos de licenciamento de direitos de propriedade intelectual e de transferência de tecnologia são essenciais para o desenvolvimento técnico e econômico, já que criam incentivos para a inovação e disseminação dos bens e tecnologias objeto de proteção. Inventores ou titulares de direitos de propriedade intelectual podem não possuir a infraestrutura necessária para a fabricação e distribuição desses bens e tecnologias em larga escala, de modo que o licenciamento para empresas especializadas passa a ser a melhor alternativa para permitir uma alocação mais eficiente dos bens e tecnologias objeto de proteção. Ademais, os acordos de licenciamento possibilitam a integração de tecnologias complementares para o desenvolvimento de novos produtos, já que os direitos de propriedade intelectual constituem insumos relevantes para as atividades de inovação e criação intelectual, ampliando a concorrência dinâmica e permitindo o aumento da competitividade das empresas no comércio internacional. ${ }^{303}$

É imperioso destacar que os acordos de licenciamento e transferência de tecnologia apresentam características peculiares que devem ser levadas em consideração. Em primeiro lugar, o licenciamento de direitos de propriedade intelectual dá-se mediante o pagamento de royalties (por unidade vendida ou por receita líquida de vendas). Em

\footnotetext{
${ }^{301}$ Cf. parágrafo 12 do Preâmbulo do Regulamento de 2004.

${ }^{302}$ Cf. Artigos 4.1, 4.2, 5.1 e 5.2 do Regulamento de 2004.

303 Nesse sentido, o parágrafo 4 do Preâmbulo do Regulamento de 2004 da Comissão afirma que: "Technology transfer agreements concern the licensing of technology. Such agreements will usually improve economic efficiency and be pro-competitive as they can reduce duplication of research and development, strengthen the incentive for the initial research and development, spur incremental innovation, facilitate diffusion and generate product market competition".
} 
contrapartida a esse pagamento, o licenciado adquire o direito de fabricar os bens objeto de proteção ou mesmo de empregar a tecnologia licenciada como insumo na fabricação de produtos. Essa característica implica a necessidade de o licenciante exercer certo controle sobre as atividades do licenciado, de modo a proteger seus direitos de propriedade intelectual. Em segundo lugar, os acordos de licenciamento diferem da cessão de direitos de propriedade intelectual, por meio da qual o titular transfere o direito de propriedade intelectual como um todo, e não apenas o seu exercício, como no caso da licença. $\mathrm{Na}$ cessão, a transferência se dá mediante pagamento único de quantia previamente determinada (em geral calculada com base no valor de mercado dos ativos intangíveis em questão). ${ }^{304} \mathrm{E}$ como a transferência é definitiva, não há em geral a necessidade de o cedente ou vendedor controlar ou restringir o uso dos direitos de propriedade intelectual pelo cessionário ou adquirente, como ocorre geralmente no licenciamento. Em terceiro lugar, o licenciamento permite a disseminação de ideias e conhecimentos que podem ser utilizados pelo licenciado no desenvolvimento de inovações incrementais ou de novos produtos e tecnologias, permitindo seu licenciamento para terceiros ou para o licenciante original (em geral quando há cláusulas de "grantback" ou de licenciamento cruzado).

Tendo em vista as características específicas acima descritas, é frequente a elaboração de cláusulas contratuais restritivas em acordos de licenciamento e transferência de tecnologia, com o objetivo de salvaguardar os interesses legítimos das partes. Por um lado, o licenciado poderá não ter incentivos necessários para investir na fabricação e distribuição de um novo produto, sem a proteção de uma cláusula de exclusividade territorial que o proteja da concorrência direta do próprio licenciante e de outros licenciados em sua área de atuação. Por outro, o licenciante poderá não aceitar a cláusula de exclusividade sem que o licenciado, em contrapartida, aceite cláusulas restritivas que protejam a integridade e o valor do direito de propriedade intelectual licenciado, tais como: (i) cláusulas de exclusividade e não concorrência que proíbam o licenciado de explorar bens ou tecnologias concorrentes: (ii) pagamento de valor mínimo de royalties; (iii)

\footnotetext{
${ }^{304}$ Denis Borges BARBOSA esclarece bem a distinção: "Da licença há que se distinguir a cessão de patentes, contrato em que o titular transfere o direito de exclusividade (ou o direito de pedir patente, ou sobre o pedido de patente), como um todo, e não só seu exercício - como no caso da licença 104. Pela licença, o titular do direito exclusivo autoriza o uso e o gozo do objeto de sua patente e sinal distintivo, ou, como o quer parte da doutrina, compromete-se a não exercer o seu poder de proibir o uso. Pela cessão, por sua vez, repassa a titularidade do direito, como ato voluntário inter vivos. (...) A licença é a autorização concedida para a exploração do direito (como no caso de locação de bens físicos), enquanto a cessão é negócio jurídico que afeta o direito em si (como a venda de um apartamento)". BARBOSA, Denis Borges. Contratos em Propriedade Intelectual. Disponível em: http://www.denisbarbosa.addr.com/arquivos/apostilas/ufrj/contratos_propriedade_intelectual.pdf, p. 74.
} 
confidencialidade sobre know-how transferido; (iv) controle de qualidade sobre os recursos utilizados na fabricação dos bens objeto de proteção; (v) limites ao sublicenciamento dos direitos licenciados; (vi) limites ao uso dos direitos; (vii) obrigação de licenciamento cruzado de melhorias ou aprimoramentos efetuados na tecnologia licenciada; dentre outras cláusulas. De fato, muitas dessas restrições podem ser comercialmente indispensáveis para induzir o licenciante a efetivamente licenciar seus direitos de propriedade intelectual ou tecnologias. ${ }^{305}$

Embora possam ser na maioria das vezes pró-competitivas, essas cláusulas restritivas podem resultar em preocupações do ponto de vista antitruste, a depender do grau de poder de mercado detido pelas partes, da estrutura do mercado e das características dos bens ou tecnologias objeto do contrato em questão. Há casos em que cláusulas restritivas são incluídas em acordos de licenciamento com o objetivo de mascarar esquemas de colusão entre agentes econômicos concorrentes, seja por meio da fixação de preços, de restrição da produção ou divisão de mercados. Outras cláusulas possibilitam a ampliação do domínio do mercado da tecnologia licenciada, o fechamento de mercados a jusante e o aumento dos custos dos rivais.

Para lidar com essas situações, vimos que as autoridades de defesa da concorrência dos Estados Unidos e da União Europeia publicaram diretrizes e regulamentos para a análise antitruste de acordos de licenciamento e transferência de tecnologia. Esses instrumentos legais trazem elementos semelhantes, embora restem alguns aspectos conflitantes que refletem as diferenças conceituais e culturais entre as duas jurisdições em matéria de política de concorrência. Assim, antes de analisarmos as abordagens utilizadas nessas jurisdições para análise antitruste de cláusulas restritivas específicas, examinaremos a seguir os principais elementos presentes nas Diretrizes de 1995, implementadas pelo DOJ e pela FTC nos Estados Unidos, e no Regulamento de 2004, acompanhado das Diretrizes de 2004, ambos implementados pela Comissão Europeia.

\footnotetext{
${ }^{305}$ Cf. ANDERMAN, Steve. The New EC Competition Law Framework for Technology Transfer and IP Licensing, in: DREXL, Josef (Ed.). Research Handbook on Intellectual Property and Competition Law. Cheltenham: Edward Elgar, 2008, p. 111-112.
} 


\subsubsection{Elementos para a análise antitruste de acordos de licenciamento e transferência de tecnologia}

Tanto as Diretrizes de 1995 como o Regulamento de 2004 reconhecem que o direito antitruste e a propriedade intelectual são instrumentos complementares de promoção da inovação e da concorrência. Ademais, a análise antitruste dos acordos de licenciamento e transferência de tecnologia é concentrada nos seus efeitos econômicos, e não nos seus aspectos formais. ${ }^{306}$

As Diretrizes de 1995 estabelecem três princípios fundamentais pertinentes à análise antitruste de acordos de licenciamento: (i) para fins de análise antitruste, direitos de propriedade intelectual serão considerados comparáveis a qualquer outra forma de propriedade; (ii) direitos de propriedade intelectual não criam por si só poder de mercado; e (iii) acordos de licenciamento de direitos de propriedade intelectual são geralmente prócompetitivos. $^{307}$

A intenção do primeiro princípio é assegurar que as autoridades antitruste norte-americanas não deverão conferir tratamento diferenciado aos direitos de propriedade intelectual, mesmo reconhecendo que a propriedade intelectual possui características específicas em comparação com a propriedade física. Ainda que as autoridades levem em consideração essas características especiais na análise antitruste de práticas restritivas em acordos de licenciamento - tal como fazem ao analisar circunstâncias específicas de mercado em determinados setores industriais -, o fato é que não adotarão padrões de análise diferenciados (mais flexíveis ou mais rigorosos) em razão da presença de diretos de propriedade intelectual. $^{308}$

Já o segundo princípio vai ao encontro da tendência da jurisprudência norteamericana no sentido de não presumir poder de mercado pela mera titularidade de direitos de propriedade intelectual, conforme a decisão da Suprema Corte no caso Illinois Tool Works v. Independent Ink.. As Diretrizes de 1995 vão além ao considerar que, mesmo no

\footnotetext{
${ }^{306}$ Cf. item 3.1 das Diretrizes de 1995 e parágrafo 4 do Preâmbulo do Regulamento de 2004.

${ }^{307}$ Item 2 das Diretrizes de 1995.

${ }^{308}$ Vale conferir o item 2.1 das Diretrizes de 1995: "The Agencies apply the same general antitrust principles to conduct involving intellectual property that they apply to conduct involving any other form of tangible or intangible property. That is not to say that intellectual property is in all respects the same as any other form of property. Intellectual property has important characteristics, such as ease of misappropriation, that distinguish it from many other forms of property. These characteristics can be taken into account by standard antitrust analysis, however, and do not require the application of fundamentally different principles".
} 
caso em que um direito de propriedade intelectual vier a conferir poder de mercado ao seu titular, esse fato não será por si só suficiente para constituir uma violação das normas antitruste, nem mesmo uma obrigação de licenciar sua propriedade para terceiros. ${ }^{309}$ Por outro lado, as autoridades reconhecem que o poder de mercado resultante da propriedade intelectual adquirido de forma indevida ou fraudulenta, ou mesmo adquirido de forma lícita, mas exercido de forma indevida, poderá ser levado em consideração na análise de condutas anticoncorrenciais a partir da exploração de direitos exclusivos. ${ }^{310}$

Finalmente, o terceiro princípio reconhece os benefícios do licenciamento de direitos de propriedade intelectual para a concorrência, uma vez que pode facilitar a integração da propriedade licenciada com fatores complementares de produção, conduzindo a uma exploração mais eficiente desses direitos e beneficiando os consumidores por meio da redução de custos e introdução de novos produtos no mercado. $^{311}$ Ademais, o licenciamento pode aumentar a expectativa de retorno da propriedade intelectual, ampliando os incentivos para a criação intelectual e, assim, promover maiores investimentos em pesquisa e desenvolvimento.

De forma semelhante, as Diretrizes de 2004 aprovadas pela Comissão levam em consideração os aspectos dinâmicos da concessão de licenças de tecnologia, não havendo presunção de que os direitos de propriedade intelectual e os acordos de licença suscitam problemas de natureza concorrencial. Há o reconhecimento de que esses acordos, em sua maioria, não restringem a concorrência e, pelo contrário, criam eficiências prócompetitivas, uma vez que conduzem à disseminação de tecnologias e promoção da inovação. Ademais, mesmo os acordos de licença que restringem a concorrência podem frequentemente resultar em ganhos de eficiência favoráveis à concorrência, devendo ser apreciados ao abrigo do Parágrafo $3^{\circ}$ do Artigo 101 do TFUE, permitindo que os eventuais efeitos negativos sejam compensados pelos efeitos positivos. ${ }^{312}$

\footnotetext{
${ }^{309}$ Essa abordagem das autoridades no que concerne a não imposição de obrigação de licenciar (licença compulsória) vai ao encontro do item 3.1 das Diretrizes de 1995, que determina que as autoridades não obrigarão o titular de direitos de propriedade intelectual a criar concorrência sobre sua própria tecnologia. Por outro lado, veremos que essa abordagem conflita com aquela adotada pela Comissão e tribunais comunitários, que entendem que em "circunstâncias excepcionais", o titular de direito de propriedade intelectual poderá ser compelido a licenciar seu direito para terceiros.

${ }^{310}$ Cf. item 2.2 das Diretrizes de 1995.

${ }^{311}$ Fatores complementares de produção incluem instalações para fabricação e distribuição, mão de obra, logística, tecnologias complementares, dentre outros fatores que muitas vezes o titular do direito de propriedade intelectual não possui, dificultando a exploração eficiente de seu direito.

${ }^{312}$ Cf. item 2.1.9 das Diretrizes de 2004.
} 
3.3.1.1. Identificação da natureza da relação entre as partes do acordo de licenciamento e definição dos mercados relevantes

A análise antitruste de acordos de licenciamento e transferência de tecnologia depende, inicialmente, da determinação da natureza da relação entre partes (se horizontal ou vertical) e da definição dos mercados relevantes afetados pelo acordo. Somente a partir dessas definições será possível avaliar os efeitos de determinadas práticas restritivas sobre a concorrência.

Primeiramente, é imprescindível identificar se a relação jurídica entre as partes do acordo é horizontal, isto é, entre concorrentes, ou vertical, entre não concorrentes, ou ainda se há aspectos substanciais de ambos. Em geral, acordos de licenciamento entre concorrentes suscitam maior preocupação por parte das autoridades antitruste norteamericanas e europeias, tendo em vista seus potenciais efeitos negativos sobre a concorrência em determinado mercado relevante. ${ }^{313}$ Por outro lado, as restrições verticais são normalmente consideradas lícitas, sobretudo nos Estados Unidos, devendo ser analisadas sob a regra da razão, embora a abordagem adotada pela Comissão seja mais rigorosa em relação às restrições dessa natureza, tendo em vista as já mencionadas preocupações com a proteção do mercado único e do comércio entre os EstadosMembros. $^{314}$

De acordo com as Diretrizes de 1995, um acordo será vertical quando fatores complementares de produção são combinados pelas partes que não sejam concorrentes, como: (i) quando o negócio do licenciante limita-se a atividades de pesquisa e desenvolvimento, o licenciado, na qualidade de fabricante, poderá adquirir a licença para utilizar a tecnologia desenvolvida pelo licenciante; (ii) quando o licenciante é titular de direitos de propriedade intelectual e fabricante de um componente utilizado pelo licenciado para a fabricação de um produto que combine esse componente com outros insumos; ou (iii) quando o licenciante fabrica o produto enquanto o licenciado atua na sua distribuição e comercialização. Por outro lado, as autoridades deverão tratar uma relação entre licenciante e licenciado, ou entre licenciados, como horizontal quando as partes em questão

\footnotetext{
${ }^{313}$ Práticas restritivas em contratos de licenciamento podem facilitar esquemas de colusão para divisão de mercados e fixação de preços entre concorrentes.

314 Essa característica pode ser claramente observada na abordagem adotada pela Comissão para a identificação de restrições verticais do tipo hard-core e para a análise dos efeitos anticoncorrenciais de
} 
puderem ser consideradas concorrentes efetivas ou potenciais na ausência do acordo de licenciamento. ${ }^{315}$

A determinação da relação como horizontal ou vertical é normalmente mais complexa do que em outros casos, já que as partes podem ser ao mesmo tempo concorrentes e não concorrentes, a depender dos mercados relevantes afetados pelo acordo de licenciamento, devendo ser considerados, conforme o caso: (i) o mercado do produto; (ii) o mercado de tecnologia; e/ou (iii) o mercado de inovação. ${ }^{316}$

De acordo com as Diretrizes de 1995, uma restrição em acordo de licenciamento poderá produzir efeitos em mercados finais ou intermediários de produtos fabricados a partir da tecnologia ou direito de propriedade intelectual licenciado, ou ainda em mercados a montante de bens ou serviços utilizados como insumo, juntamente com os direitos de propriedade intelectual, para a fabricação de outros produtos (nesses casos, considera-se a definição de mercado relevante do produto e geográfico). ${ }^{317}$ Em geral, para definir o mercado relevante do produto e mensurar as participações de mercado, as autoridades norte-americanas aplicarão o clássico "teste do monopolista hipotético", conforme a abordagem adotada no US DOJ and FTC Horizontal Merger Guidelines. ${ }^{318}$

Quando os direitos de propriedade intelectual forem comercializados de forma separada em relação aos produtos nos quais são utilizados, as autoridades norte-americanas poderão analisar os efeitos do acordo no mercado da tecnologia licenciada e seus substitutos próximos, isto é, as tecnologias alternativas capazes de impor pressões

práticas restritivas sobre a concorrência intratecnologia (entre concorrentes que utilizam uma mesma tecnologia). Abordaremos esse assunto mais adiante.

${ }^{315}$ Esse critério para identificação de relações horizontais pode ser difícil de ser analisado, especialmente se as partes tiverem optado pela licença como alternativa à eventual ação de infração de direitos de propriedade intelectual. A ação de infração resulta justamente da incerteza sobre a possibilidade ou não de o licenciado concorrer de forma lícita com o licenciante, isto é, sem violar seu direito de propriedade intelectual. Questões relevantes para a definição da relação como horizontal incluem: (i) o licenciado possui a capacidade técnica e recursos necessários para ingressar no mercado sem o acordo de licenciamento? (ii) Há alguma evidência de que o licenciado teria tido qualquer intenção de ingressar no mercado relevante na ausência do acordo de licenciamento em questão? (iii) Poderia o licenciado ter sido impedido de ingressar no mercado relevante pelo licenciante titular do direito de propriedade intelectual?

316 Cf. item 3.2 das Diretrizes de 1995. O Regulamento de 2004 concentra-se apenas nos mercados do produto e da tecnologia licenciada.

${ }^{317}$ Cf. item 3.2.1 das Diretrizes de 1995.

318 US DOJ and FTC Horizontal Merger Guidelines, revised on August 19, 2010. Disponível em: http://www.justice.gov/atr/public/guidelines/hmg-2010.pdf. Sobre a aplicação do teste do monopolista hipotético, cf. comentário constante na nota de rodapé n. ${ }^{\circ} 112$. 
competitivas significativas sobre o exercício de poder de mercado com relação ao direito de propriedade intelectual licenciado. ${ }^{319}$

As autoridades também poderão levar em consideração os efeitos sobre o "mercado de inovação" (innovation market), que consiste na atividade de pesquisa e desenvolvimento dirigida a bens ou processos novos ou melhorados, bem como os seus substitutos próximos, que podem incluir esforços de pesquisa e desenvolvimento, tecnologias e bens que limitem significativamente o exercício de poder de mercado relativamente à pesquisa e desenvolvimento em questão, por exemplo, limitando a capacidade e o incentivo de um monopolista de retardar o ritmo da atividade de pesquisa e desenvolvimento. ${ }^{320}$

Enquanto a definição de "mercados de inovação" tem sido aplicada na análise antitruste de fusões e aquisições, especialmente no setor farmacêutico ${ }^{321}$, as autoridades antitruste norte-americanas têm utilizado amplamente as definições de mercado relevante de produto e de tecnologia no exame dos efeitos econômicos de acordos de licenciamento e transferência de tecnologia. Assim, na análise de acordos de licenciamento, é possível que as partes sejam concorrentes no mercado do produto, mas não concorrentes no mercado da tecnologia licenciada, e vice-versa, o que torna mais complexa a definição da relação como horizontal ou vertical.

Na União Europeia, a abordagem adotada pela Comissão no Regulamento de 2004 é semelhante, embora se concentre apenas nos mercados relevantes do produto e da tecnologia licenciada. De acordo com a alínea “j” do item 1 do Regulamento de 2004, partes concorrentes no mercado da tecnologia relevante são empresas que concedem licenças relativas a tecnologias concorrentes sem infringir os direitos de propriedade intelectual da outra parte (concorrentes efetivos no mercado da tecnologia). No mercado relevante da tecnologia, são incluídas as tecnologias consideradas substituíveis pela tecnologia licenciada. Portanto, somente concorrentes efetivos são levados em consideração na definição do mercado da tecnologia, ao contrário da definição do mercado

\footnotetext{
${ }^{319}$ Cf. item 3.2.2 das Diretrizes de 1995.

${ }^{320}$ Cf. item 3.2.3 das Diretrizes de 1995.

321 Cf. ROSCH, Thomas. Antitrust Regulation of Innovation Markets, in: ABA Antitrust Intellectual Property Conference, Berkeley, CA (February 5, 2002). Disponível em:

http://www.ftc.gov/speeches/rosch/090205innovationspeech.pdf
} 
relevante do produto, que leva em consideração tanto concorrentes efetivos, como potenciais. $^{322}$

Assim, concorrentes no mercado relevante do produto são definidos como as empresas que, na ausência do acordo de transferência de tecnologia, operam ambas em mercados relevantes do produto e geográficos em que os produtos objeto do acordo são vendidos sem infringir os direitos de propriedade intelectual da outra parte (concorrentes efetivos no mercado do produto) ou que, com base em premissas realistas, poderiam realizar os investimentos adicionais necessários ou suportar custos de mudança para ingressar prontamente no mercado relevante em questão (do produto e geográfico), sem infringir os direitos de propriedade intelectual da outra parte, em resposta a um pequeno, porém significativo, aumento dos preços (concorrentes potenciais no mercado do produto). Ademais, na definição do mercado relevante do produto, devem ser incluídos os produtos considerados pelos compradores como substituíveis pelos produtos objeto do acordo.

É importante ressaltar que o Regulamento de 2004 confere segurança jurídica ao determinar que a definição das partes como concorrentes ou não concorrentes leva em consideração o momento da assinatura do acordo. Desse modo, mesmo que o licenciado venha a tornar-se concorrente do licenciante ao longo da vigência do acordo, o que pode ocorrer, por exemplo, na hipótese de o licenciado aplicar a tecnologia licenciada no desenvolvimento de um novo produto que venha a competir com o produto fabricado pelo licenciante, as partes continuarão sendo consideradas como não concorrentes, a não ser que o acordo seja materialmente modificado. ${ }^{323}$

A determinação da natureza da relação entre partes como horizontal ou vertical e a identificação dos mercados relevantes afetados pelo acordo de licenciamento são fundamentais, não apenas por possibilitar a avaliação dos efeitos de determinado acordo sobre o mercado, mas também por permitir verificar: (i) se as partes poderão beneficiar-se da zona de segurança; e (ii) se alguma cláusula restritiva incluída no acordo pode ser considerada no bojo das restrições hard-core, consideradas ilícitas per se.

${ }^{322}$ Regulamento de 2004, item 1, “j”. 


\subsubsection{As zonas de segurança}

Tanto as Diretrizes de 1995, como o Regulamento de 2004, estabelecem "zonas de segurança" (safety zone ou safe harbour), isto é, limites de participação de mercado dentro dos quais as autoridades de defesa da concorrência comprometem-se a não intervir, tendo em vista a baixa probabilidade de que acordos de licenciamento produzam efeitos prejudiciais à concorrência nessas circunstâncias. A finalidade desses limites de participação de mercado é conferir maior grau de certeza sobre as situações nas quais os efeitos anticoncorrenciais são tão improváveis que os acordos podem ser considerados lícitos per se, sem qualquer análise mais aprofundada. A adoção de zonas de segurança corrobora o entendimento de que as autoridades de defesa da concorrência adotam uma abordagem favorável à celebração de acordos de licenciamento de direitos de propriedade intelectual e que somente deverão intervir em circunstâncias específicas de mercado. ${ }^{324}$

Para beneficiar-se da zona de segurança, primeiramente é preciso ter a certeza de que o acordo de licenciamento não inclui práticas restritivas evidentemente anticompetitivas, ou seja, práticas consideradas ilícitas per se, para usar a linguagem adotada nos Estados Unidos pelas Diretrizes de 1995, ou que sejam restrições do tipo hardcore, conforme definidas pela Comissão no Regulamento de $2004 .^{325}$

Não havendo quaisquer restrições ilícitas per se do tipo hard-core, o segundo passo será verificar se os percentuais de participações de mercado dos agentes econômicos estão dentro dos limites previamente definidos. De acordo com as Diretrizes de 1995, para que seja aplicável a zona de segurança, o licenciante e seus licenciados coletivamente deverão deter não mais do que $20 \%$ de cada mercado relevante afetado pela restrição. A aplicabilidade desse limite é determinada apenas para mercados relevantes de produtos, a não ser que a análise do mercado do produto seja inadequada para avaliar os efeitos de determinado acordo de licenciamento sobre a concorrência entre tecnologias ou na pesquisa e desenvolvimento. A definição precisa do mercado do produto pode ser difícil

\footnotetext{
${ }^{323}$ Cf. parágrafo $3^{\circ}$ do Artigo 4 do Regulamento de 2004.

${ }^{324}$ De acordo com o item 4.3 das Diretrizes de 1995: "The safety zone is designed to provide owners of intellectual property with a degree of certainty in those situations in which anticompetitive effects are so unlikely that the arrangements may be presumed not to be anticompetitive without an inquiry into particular industry circumstances".

${ }^{325}$ Veremos em seguida as práticas consideradas ilícitas per se ou restrições do tipo hard-core.
} 
em determinadas circunstâncias ${ }^{326}$, já que a participação de mercado conjunta das partes pode ser extremamente elevada após o lançamento de um novo produto ou tecnologia, caindo gradualmente à medida que outros agentes econômicos vão ingressando no mercado.

Assim, na indisponibilidade de dados sobre participação de mercado, ou caso esses dados não sejam seguros ou significativos, as Diretrizes de 1995 permitem a aplicação de outros critérios, que não os de participação de mercado, para a determinação da zona de segurança em mercados de tecnologia e de inovação. Para mercados de tecnologia, a zona de segurança se aplica quando: (i) os acordos não contenham restrições consideradas ilícitas per se; e (ii) houver pelo menos quatro ou mais tecnologias independentes, além da tecnologia controlada pelas partes do acordo, que possam ser consideradas substituíveis em relação à tecnologia licenciada, a custos comparáveis para o usuário. $^{327}$

É importante ressaltar que as Diretrizes de 1995 deixam claro que não haverá qualquer presunção de ilegalidade para acordos que não possam beneficiar-se da zona de segurança, os quais serão analisados com base na regra da razão. Conforme indicado no item 3.3, é provável que os acordos de licenciamento que não alcancem os critérios de isenção sejam, em sua maioria, lícitos e pró-competitivos.

$\mathrm{Na}$ União Europeia a zona de segurança é tratada como isenção em bloco. O Regulamento de 2004 adota critérios diferentes de isenção, conforme a relação das partes seja horizontal ou vertical. Assim, restrições contidas em acordos de licenciamento entre concorrentes estarão isentas da aplicação do Parágrafo $1^{\circ}$ do Artigo 101 quando a participação de mercado agregada das partes não exceder $20 \%$ dos mercados relevantes da tecnologia e do produto afetados. ${ }^{328}$ Já no caso de restrições contidas em acordos celebrados entre não concorrentes, a isenção será aplicável quando a participação de mercado agregada das partes não exceder $30 \%$ dos mercados relevantes da tecnologia e do

\footnotetext{
${ }^{326}$ Cf. item 4.3 das Diretrizes de 1995.

${ }^{327}$ O critério é o mesmo para mercados de inovação, já que, além de não poder haver restrições que sejam ilícitas per se, deverá haver pelo menos quatro ou mais entidades independentes, além das partes do acordo de licenciamento, que possuam os ativos e características necessários, além dos incentivos para se dedicarem a atividades de pesquisa e desenvolvimento que sejam substitutas próximas das atividades de pesquisa e desenvolvimento das partes do acordo de licenciamento.

${ }^{328}$ Cf. parágrafo $1^{\circ}$ do Artigo 3 do Regulamento de 2004.
} 
produto afetados. ${ }^{329}$ Nota-se que o limite de participação de mercado para acordos entre não concorrentes é maior, em razão de apresentarem menores riscos para a concorrência em comparação com acordos entre concorrentes. ${ }^{330}$

Entretanto, ao contrário das Diretrizes de 1995, o Regulamento de 2004 não é flexível em relação às situações em que a identificação das participações de mercado das partes não for possível, ou for inadequada diante das circunstâncias do mercado. Se as participações de mercado excederem os limites da zona de segurança durante a vigência do acordo de transferência de tecnologia, as partes perderão o benefício da isenção, o que pode resultar em insegurança jurídica para as partes em mercados voláteis de tecnologia, caracterizados por mudanças drásticas e repentinas de market shares, e em desincentivo para o licenciamento da tecnologia. ${ }^{331}$

Por outro lado, mesmo que o acordo perca o benefício da isenção em bloco nos termos do Regulamento de 2004, não significa que será automaticamente proibido nos termos do Parágrafo $1^{\circ}$ do Artigo 101. No caso, o acordo poderá ser individualmente isento por meio da análise do Parágrafo $3^{\circ}$ do Artigo 101, aplicável conforme indicado nas Diretrizes de 2004 e nas decisões da Comissão e dos tribunais comunitários. E essa análise deve ser feita pelas próprias partes e seus advogados no sistema "self-assessment", não havendo a obrigatoriedade de notificação do acordo à Comissão.

\subsubsection{3. $\quad$ Ilícitos per se ou restrições hard-core}

Algumas práticas restritivas em acordos de licenciamento e transferência de tecnologia são tratadas como ilícitos per se, tendo em vista seus evidentes efeitos anticoncorrenciais, dispensando-se uma análise econômica mais elaborada. As Diretrizes de 1995 apontam cinco categorias de restrições ilícitas per se, quais sejam, fixação de preços, restrições de produção e divisão de mercado entre concorrentes em relação

\footnotetext{
${ }^{329}$ Cf. parágrafo $2^{\circ}$ do Artigo 3 do Regulamento de 2004.

${ }^{330}$ Cf. parágrafo 68 e seguintes das Diretrizes de 2004.

${ }^{331}$ Sobre o assunto, Steven ANDERMAN ressalta que: "Under the guise of giving greater recognition to the economic realities of IP licensing, the TTBER [Regulamento de 2004] creates legal uncertainty for the parties in volatile new technology markets. (...) An innovative product can break through to a market, replacing other products, or it can flop. High market shares can occur suddenly and unexpectedly. If success meets with automatic disqualification from the block exemption because of market-share limits, there will be a disincentive to license in the first place". ANDERMAN, Steve. The New EC Competition Law Framework for Technology Transfer and IP Licensing, in: DREXL, Josef (Ed.). Research Handbook on Intellectual Property and Competition Law. Cheltenham: Edward Elgar, 2008, p. 117-118.
} 
horizontal, assim como alguns boicotes coletivos e a fixação de preços de revenda. ${ }^{332} \mathrm{Na}$ ausência de eventuais eficiências capazes de justificar essas restrições, as autoridades antitruste norte-americanas deverão presumir sua ilicitude per se, sem uma análise mais aprofundada sobre as circunstâncias de mercado ou da indústria. ${ }^{333}$

O Regulamento de 2004 estabelece uma lista limitada de restrições proibidas do tipo hard-core, que, além de não poderem beneficiar-se da isenção em bloco, tornam nulos e inexequíveis os acordos de licenciamento nos quais estiverem inseridas, nos termos do Artigo 101 do TFUE. As restrições hard-core são quase sempre anticoncorrenciais, correspondendo ao conceito de ilícito per se adotado nos Estados Unidos, e dificilmente poderão ser justificadas com base no Parágrafo $3^{\circ}$ do Artigo 101 do TFUE. As restrições hard-core são definidas de formas diferentes, dependendo de as partes do acordo serem ou nãoconcorrentes .

Nos casos de acordos de licenciamento celebrados entre concorrentes, o Regulamento de 2004 contém a proibição de quatro restrições hard-core: (i) fixação de preços, compreendida como a restrição da capacidade do licenciado de determinar os preços de venda dos produtos a terceiros ${ }^{334}$; (ii) limitações recíprocas de produção ${ }^{335}$; (iii) alocação ou divisão de mercados, ressalvadas algumas exceções ${ }^{336}$; e (iv) práticas que restrinjam a capacidade do licenciado de explorar a sua própria tecnologia ou que restrinjam a capacidade de qualquer das partes no acordo de praticar atividades de pesquisa

332 Ressalte-se que a prática de fixação de preço de revenda tem sido analisada pelos tribunais norteamericanos sob a regra da razão.

${ }^{333}$ Cf. item 3.4 das Diretrizes de 1995.

${ }^{334}$ Artigo 4.1(a) do Regulamento de 2004.

${ }^{335}$ Artigo 4.1(b) do Regulamento de 2004.

${ }^{336}$ A proibição de alocação ou divisão de mercados entre concorrentes está sujeita às seguintes exceções: (i) a obrigação imposta ao licenciado de fabricar com a tecnologia licenciada apenas no âmbito de um ou mais domínios técnicos de utilização ou de um ou mais mercados do produto; (ii) a obrigação imposta ao licenciante e/ou ao licenciado, num acordo não recíproco, de não fabricar com a tecnologia licenciada no âmbito de um ou mais domínios técnicos de utilização ou de um ou mais mercados do produto ou de um ou mais territórios exclusivos reservados à outra parte; (iii) a obrigação imposta ao licenciante de não conceder qualquer licença da tecnologia a outro licenciado num determinado território; (iv) a restrição, num acordo não recíproco, de vendas ativas e/ou passivas pelo licenciado e/ou pelo licenciante no território exclusivo ou ao grupo de clientes exclusivo reservado à outra parte; (v) a restrição, num acordo não recíproco, de vendas ativas pelo licenciado no território exclusivo ou ao grupo de clientes exclusivo atribuído pelo licenciante a outro licenciado, desde que este último não seja uma empresa concorrente do licenciante no momento da conclusão da sua própria licença; (vi) a obrigação de o licenciado fabricar os produtos objeto do acordo para sua utilização exclusiva, desde que o licenciado não tenha restrições de venda dos produtos, ativa e passivamente, a título de peças sobressalentes para os seus próprios produtos; e (vii) a obrigação imposta ao licenciado, num acordo não recíproco, de fabricar os produtos contratuais apenas para um cliente específico, quando a licença foi concedida para criar uma fonte alternativa de abastecimento para esse cliente. Cf. Artigo 4.1(c) do Regulamento de 2004. 
e desenvolvimento, exceto se esta última restrição for indispensável para impedir a divulgação a terceiros de um know-how licenciado ${ }^{337}$.

Para acordos de licenciamento entre não concorrentes, as hipóteses de restrições hard-core são: (i) fixação de preços mínimos de revenda, compreendida como a restrição sobre a capacidade de uma parte para determinar seus preços de venda de produtos a terceiros, sem prejuízo da possibilidade de impor um preço de venda máximo ou de sugerir um preço de venda ${ }^{338}$; e (ii) alocação de mercados ou de consumidores, compreendida como a restrição do território no qual, ou dos clientes aos quais, o licenciado pode vender de forma passiva ${ }^{339}$ os produtos objeto do acordo, ressalvadas algumas exceções $^{340}$; e (iii) a restrição de vendas ativas ou passivas a usuários finais por um licenciado que seja membro de um sistema de distribuição seletiva ${ }^{341}$ (rede de distribuidores autorizados) e que opere no varejo, sem prejuízo da possibilidade de um membro desse sistema ser proibido de operar a partir de um local de estabelecimento não autorizado $^{342}$.

Nota-se que, ao contrário da abordagem adotada pelas autoridades norteamericanas, a Comissão é rigorosa com práticas restritivas verticais em acordos de licenciamento, especialmente no que concerne à exclusividade territorial e outras restrições territoriais de vendas. Embora restrições verticais dessa natureza em acordos de

337 Essa exceção se justifica em razão do know-how consistir muitas vezes em segredos de negócios protegidos por cláusulas de confidencialidade nos acordos de licenciamento. Cf. Artigo 4, parágrafo $1^{\circ}$, alínea "d" do Regulamento de 2004.

${ }^{338}$ Artigo 4.2(a) do Regulamento de 2004.

${ }^{339}$ Venda passiva é aquela realizada sem a participação ativa do licenciado, como em resposta a encomendas, ou por meio da internet, a consumidores localizados no território exclusivo de outro licenciado.

${ }^{340}$ As exceções à proibição de alocação de mercados e clientes são: (i) a restrição de vendas passivas num território exclusivo ou a um grupo de clientes exclusivo reservado ao licenciante; (ii) a restrição de vendas passivas num território exclusivo ou a um grupo de clientes exclusivo atribuído pelo licenciante a outro licenciado, durante os dois primeiros anos que esse outro licenciado vender os produtos objeto do acordo nesse território ou a esse grupo de clientes; (iii) a obrigação de fabricar os produtos objeto do acordo para sua utilização exclusiva, desde que o licenciado não tenha restrições de venda dos produtos contratuais, ativa e passivamente, a título de peças sobressalentes para os seus próprios produtos; (iv) a obrigação de fabricar os produtos contratuais apenas para um cliente específico, quando a licença foi concedida para criar uma fonte alternativa de abastecimento para esse cliente; (v) a restrição de vendas a usuários finais por um licenciado que opere no atacado; e (vi) a restrição de vendas a distribuidores não autorizados pelos membros de um sistema de distribuição seletiva. Cf. Artigo 4.2(b) do Regulamento de 2004.

${ }^{341}$ Sistema de distribuição seletiva é definido no Regulamento de 2004 como um sistema de distribuição em que o licenciante se compromete a conceder licenças relativas à fabricação dos produtos objeto do acordo apenas a licenciados selecionados com base em critérios específicos, comprometendo-se esses licenciados a não vender tais produtos a distribuidores não autorizados.

${ }^{342}$ Artigo 4.1(c) do Regulamento de 2004. 
licenciamento sejam normalmente justificáveis com base em critérios de eficiência ${ }^{343}$, a abordagem da Comissão é coerente com a política comunitária contrária a restrições territoriais que resultem no isolamento dos Estados-Membros em detrimento do mercado único. Por outro lado, deve-se ressaltar que, ao estabelecer as exceções, a Comissão reconhece como indispensáveis algumas restrições territoriais de venda em acordos de licenciamento, uma vez que os licenciados podem não ter incentivos para celebrar esses acordos sem uma proteção temporária (de pelo menos dois anos) contra vendas passivas em seu território exclusivo por outros licenciados.

O Regulamento de 2004 inclui também algumas "restrições excluídas", que, embora não possam beneficiar-se da isenção em bloco, também não serão consideradas como restrições hard-core proibidas e, assim, sua eventual ilicitude não torna nulas as demais cláusulas do acordo. Essas restrições podem ser isentas individualmente, caso atendam os requisitos contidos no Parágrafo $3^{\circ}$ do Artigo 101 do TFUE..$^{344}$

\subsubsection{Análise antitruste das práticas restritivas sob a regra da razão}

As práticas restritivas em acordos de licenciamento são analisadas em sua maioria sob a regra da razão. Tanto nos Estados Unidos como na União Europeia, essa análise é realizada em dois passos. Primeiramente, deve-se verificar se a restrição produz efeitos anticoncorrenciais em determinado mercado relevante. Caso a resposta seja afirmativa, deve-se verificar se a restrição pode ser justificada com base em critérios de eficiência, isto é, se os efeitos pró-competitivos compensam seus efeitos anticoncorrenciais.

O item 3.4 das Diretrizes de 1995 reconhece que a aplicação da regra da razão geralmente envolve uma investigação ampla sobre as condições de mercado. Entretanto,

\footnotetext{
343 Cláusulas de exclusividade de território são normalmente consideradas eficientes por induzir os licenciados a investir em ativos complementares e atividades necessárias para promover a nova tecnologia. Licenciados muitas vezes necessitam de garantias de que os benefícios resultantes de seus investimentos não serão diluídos pelas vendas de terceiros (free riders) que não incorreram nos mesmos custos.

344 As "restrições excluídas" estão previstas no Artigo 5 do Regulamento de 2004. São elas: (i) obrigação direta ou indireta imposta ao licenciado de ceder ou de conferir uma licença exclusiva ao licenciante relativa a melhoramentos dissociáveis por ele introduzidos (isto é, melhoramentos que possam ser explorados de forma independente em relação à tecnologia licenciada) ou a novas aplicações da tecnologia licenciada por ele desenvolvidas ("grantback" exclusivo); (ii) obrigação direta ou indireta imposta ao licenciado de não impugnar a validade dos direitos de propriedade intelectual de que o licenciante seja titular ("non-challenge clause"); e (iii) num acordo de licenciamento vertical, qualquer obrigação direta ou indireta que limite a capacidade do licenciado para explorar a sua própria tecnologia ou que limite a capacidade de qualquer das
} 
caso seja improvável que um acordo de licenciamento produza efeitos restritivos sobre a concorrência, as autoridades antitruste norte-americanas poderão valer-se de uma análise simplificada sob a regra da razão (truncated rule of reason), sem a necessidade de exame mais aprofundado sobre o poder de mercado das partes ou justificativas econômicas para a restrição. $^{345}$

Por outro lado, nos casos mais complexos em que essa abordagem simplificada não seja possível, as autoridades deverão seguir a metodologia de análise padrão sob a regra da razão, isto é, ponderando efeitos anticoncorrenciais e benefícios prócompetitivos. 346

A análise dos efeitos anticoncorrenciais requer uma investigação ampla da estrutura de mercado, do risco de colusão ou coordenação e de fechamento do mercado, conforme se observa no item 4.1.1 das Diretrizes de 1995. Conforme já mencionado, os efeitos das práticas restritivas em acordos de licenciamento variam conforme a relação entre as partes seja horizontal ou vertical. Práticas restritivas horizontais em acordos de licenciamento podem aumentar os riscos de fixação coordenada de preços, restrições na produção, aquisição ou manutenção de poder de mercado, ou ainda retardamento ou restrição do desenvolvimento de novos produtos ou tecnologias. Os potenciais danos sobre a concorrência dependem, em parte, do grau de concentração do mercado, de barreiras à entrada e da elasticidade da oferta e da demanda. ${ }^{347}$

Já as práticas restritivas verticais em acordos de licenciamento podem resultar no fechamento do mercado ao impedir ou dificultar o acesso de concorrentes a insumos importantes, bem como facilitar esquemas de colusão e atuação coordenada entre concorrentes. De acordo com as Diretrizes de 1995, o risco do fechamento do mercado nesses casos depende da proporção dos mercados afetados pela restrição, do grau de concentração dos mercados relevantes, da presença de barreiras à entrada, do grau de

partes no acordo para praticar atividades de pesquisa e desenvolvimento, exceto se esta última restrição for indispensável para impedir a divulgação a terceiros do know-how licenciado.

${ }^{345}$ A metodologia de análise sob a regra da razão simplificada é semelhante à adotada para determinar se uma prática restritiva deve ser considerada ilícita per se. A análise sob a regra da razão simplificada parte do pressuposto de que é tão improvável que o acordo em questão produza efeitos anticoncorrenciais, que ele deve ser considerado lícito per se.

346 De acordo com o item 3.4 das Diretrizes de 1995: "The Agencies' general approach in analyzing a licensing restraint under the rule of reason is to inquire whether the restraint is likely to have anticompetitive effects and, if so, whether the restraint is reasonably necessary to achieve procompetitive benefits that outweigh those anticompetitive effects". 
elasticidade da oferta e da demanda, bem como da duração da restrição. ${ }^{348}$ Ademais, práticas restritivas verticais em acordos de licenciamento podem facilitar a atuação coordenada entre concorrentes para a fixação de preços ou redução da produção. Por exemplo, agentes econômicos titulares de direitos de propriedade intelectual sobre tecnologias concorrentes podem impor restrições similares aos seus licenciados, facilitando a coordenação para a fixação de seus preços. ${ }^{349} \mathrm{O}$ risco da coordenação entre concorrentes, tanto no nível do licenciante, como no nível do licenciado, será maior na medida em que os mercados relevantes forem concentrados e houver elevadas barreiras à entrada. ${ }^{350}$

Uma vez constatado que a prática restritiva investigada produz efeitos anticoncorrenciais, as autoridades norte-americanas passarão para a segunda etapa, qual seja, analisar as eficiências e justificativas econômicas capazes de compensar os efeitos nocivos sobre a concorrência. De acordo com as Diretrizes de 1995, as autoridades deverão primeiramente averiguar se a restrição é razoavelmente necessária para que as eficiências visadas sejam atingidas, devendo levar em consideração a disponibilidade de alternativas práticas e significantemente menos restritivas do que a restrição investigada. ${ }^{351} \mathrm{Em}$ seguida, caso se constate que a restrição em questão é razoavelmente necessária, as autoridades deverão ponderar as eficiências pró-competitivas e efeitos anticoncorrenciais, de modo a determinar seu provável efeito líquido (positivo ou negativo) sobre a concorrência no mercado relevante. ${ }^{352}$

A abordagem adotada pela Comissão, a partir do Regulamento de 2004 e das Diretrizes de 2004, é semelhante. A análise de acordos de transferência de tecnologia é realizada em dois passos: (i) determinar se o acordo contém restrições da concorrência nos

\footnotetext{
${ }^{347}$ Cf. item 4.1.1 das Diretrizes de 1995.

${ }^{348}$ Ibid.

${ }^{349}$ Da mesma forma, licenciados que sejam concorrentes podem encontrar facilidade em coordenar seus preços se estiverem sujeitos a restrições comuns impostas por um licenciante ou por licenciantes concorrentes.

${ }^{350}$ Cf. item 4.1.1 das Diretrizes de 1995.

${ }^{351}$ De acordo com o item 4.2 das Diretrizes de 1995: "The existence of practical and significantly less restrictive alternatives is relevant to a determination of whether a restraint is reasonably necessary. If it is clear that the parties could have achieved similar efficiencies by means that are significantly less restrictive, then the Agencies will not give weight to the parties' efficiency claim. In making this assessment, however, the Agencies will not engage in a search for a theoretically least restrictive alternative that is not realistic in the practical prospective business situation faced by the parties".

${ }^{352}$ Nessa análise, outros fatores também são levados em consideração, como a duração da restrição e circunstâncias específicas de mercado.
} 
termos do Parágrafo $1^{\circ}$ do Artigo 101 do TFUE ${ }^{353}$; e (ii) determinar se a restrição em questão possui benefícios pró-competitivos capazes de compensar os efeitos anticoncorrenciais, conforme os critérios estabelecidos pelo Parágrafo $3^{\circ}$ do Artigo 101 do TFUE. ${ }^{354}$ Desse modo, se uma prática restritiva em acordo de transferência de tecnologia recai sobre qualquer das hipóteses do Parágrafo $1^{\circ}$ do Artigo 101 do TFUE, uma análise sob a regra da razão será aplicável com base no Parágrafo $3^{\circ}$ do Artigo 101 do TFUE. ${ }^{355}$

Ressalte-se que ao analisar se um acordo de licenciamento restringe a concorrência, nos termos do Parágrafo $1^{\circ}$ do Artigo 101 do TFUE, a Comissão levará em consideração o impacto provável do acordo sobre a concorrência intertecnologias (isto é, a concorrência entre empresas que utilizam tecnologias concorrentes) e sobre a concorrência intratecnologia (isto é, a concorrência entre empresas que utilizam a mesma tecnologia). ${ }^{356}$

Ao dar ênfase também às práticas que restrinjam a concorrência intratecnologia, a Comissão adota uma abordagem oposta à das autoridades norteamericanas. Isso porque as Diretrizes de 1995 dão ênfase à concorrência intertecnologias ao afirmar expressamente que as autoridades não deverão obrigar o titular de um direito de propriedade intelectual a criar concorrência a partir de sua própria tecnologia. ${ }^{357}$ Mesmo quando analisam restrições verticais, as autoridades norte-americanas focam em seus

\footnotetext{
${ }^{353}$ Na aplicação do Parágrafo $1^{\circ}$ do Artigo 101 do TFUE, o objetivo é verificar se o acordo como um todo, ou se determinada cláusula, poderá eliminar a concorrência real ou potencial que haveria existido na ausência do acordo ou da cláusula em questão. Nesse sentido, de acordo com o parágrafo $6^{\circ}$ do preâmbulo do Regulamento de 2004: "The likelihood that such efficiency-enhancing and procompetitive effects will outweigh any anti-competitive effects due to restrictions contained in technology transfer agreements depends on the degree of market power of the undertakings concerned and, therefore, on the extent to which those undertakings face competition from undertakings owning substitute technologies or undertakings producing substitute product".

${ }^{354}$ Nesse caso, deve-se verificar se a restrição atende aos quatro requisitos constantes no Parágrafo $3^{\circ}$ do Artigo 101 do TFUE.

${ }^{355} \mathrm{Cf}$. item 3.2, supra.

${ }^{356}$ De acordo com o item 2 parágrafo 11 das Diretrizes de 2004: "The assessment of whether a license agreement is restrictive of competition must be made within the actual context in which competition would occur in the absence of the agreement with its alleged restrictions. In making this assessment, it is necessary to take account of the likely impact of the agreement on inter-technology completion (i.e. competition between undertakings using competing technologies) and on intra-technology competition (i.e. competition between undertakings using the same technology). Article 81(1) prohibits restrictions of both intertechnology competition and intra-technology competition”. Para possibilitar essa análise, duas perguntas devem ser feitas. A primeira é: (a) $\mathrm{O}$ acordo de licença restringe a concorrência real ou potencial que teria existido sem o acordo previsto? Em caso afirmativo, o acordo pode ser abrangido pelo Parágrafo $1^{\circ}$ do artigo 101 do TFUE. A segunda pergunta é: (b) O acordo restringe a concorrência real ou potencial que teria existido na ausência da ou das restrições contratuais? Em caso afirmativo, o acordo pode ser abrangido pelo Parágrafo $1^{\circ}$ do artigo 101 do TFUE. Cf. item 2, parágrafos 11e 12 das Diretrizes de 2004.

357 "The Agencies will not require the owner of intellectual property to create competition in its own technology". Cf. item 3.1 das Diretrizes de 1995.
} 
efeitos sobre a concorrência intertecnologias, por exemplo, ao examinar a possibilidade de tais restrições levarem ao fechamento do mercado (impedindo ou dificultando a entrada de rivais que ofertem tecnologias alternativas ou substitutas), bem como facilitarem esquemas de colusão e atuação coordenada entre concorrentes. ${ }^{358}$

A Comissão, por seu turno, concentra sua análise não apenas nos efeitos de determinadas práticas restritivas sobre a concorrência entre o licenciante e seus rivais que ofertam tecnologias alternativas ou substitutas (concorrência intertecnologias), como também nos efeitos dessas práticas sobre a concorrência entre licenciados que utilizam a mesma tecnologia (concorrência intratecnologia), como ocorre com as restrições territoriais, a despeito das eficiências normalmente associadas a esse tipo de restrição. ${ }^{359}$ Conforme já ressaltado, essa abordagem mais rigorosa contra práticas restritivas verticais é reflexo da política comunitária contrária a restrições territoriais que resultem no isolamento dos Estados-Membros em detrimento do mercado único. ${ }^{360}$

\subsubsection{Tratamento de práticas restritivas específicas em acordos de licenciamento}

Passaremos a analisar as seguintes práticas restritivas específicas em acordos de licenciamento e transferência de tecnologia: (i) restrições de preços; (ii) exclusividade e restrições territoriais; (iii) cláusulas de exclusividade e não concorrência; (iv) licenças casadas e pacotes de licenças; (v) restrições sobre royalties; (vi) grantback; e (vii) cláusulas de não impugnação.

\footnotetext{
${ }^{358}$ De acordo com o item 3.1 das Diretrizes de 1995, o foco está na concorrência real ou potencial que haveria existido na ausência do acordo de licenciamento, ou seja, na concorrência entre diferentes tecnologias alternativas ou substitutas. .

359 O Regulamento de 2004 concentra-se tanto na concorrência real ou potencial que haveria existido na ausência do acordo (concorrência intertecnologias), como ocorre, por exemplo, quando um licenciante impõe aos seus licenciados uma obrigação de não utilização de tecnologias concorrentes e esta obrigação exclui as tecnologias de terceiros; bem como na concorrência real ou potencial que haveria existido na ausência da cláusula restritiva em si (concorrência intratecnologias), tal como a fixação vertical de preços e restrições de vendas territoriais ou a clientes entre licenciados. Tanto que algumas práticas restritivas verticais são consideradas restrições hard-core, como vimos no item 3.3.1.3.

${ }^{360}$ Sobre as diferentes abordagens na análise antitruste de práticas restritivas em acordos de licenciamento entre os Estados Unidos e a União Europeia, cf. GILBERT, Richard J. Converging Doctrines? US and EU Antitrust Policy for the Licensing of Intellectual Property (Feb. 2004). University of California, Berkeley, Competition Policy Working Paper. Disponível em SSRN: http://ssrn.com/abstract=527762 ou http://dx.doi.org/10.2139/ssrn.527762.
} 


\subsubsection{Restrições de preço}

Alguns acordos de licenciamento e transferência de tecnologia podem conter cláusulas fixando os preços que os licenciados devem cobrar na venda de produtos que contenham o direito de propriedade intelectual ou tecnologia licenciada. Nesses casos, o licenciado poderá ser obrigado a vender o produto pelo preço fixado pelo licenciante, ou dentro de limites de preços mínimos ou máximos determinados pelo licenciante.

Práticas de fixação pura de preços (naked price restrictions) em acordos de licenciamento entre concorrentes são consideradas ilícitas per se pelas autoridades antitruste e tribunais norte-americanos, especialmente se forem acompanhadas por restrições de produção ou fornecimento, já que podem servir para acobertar esquemas de colusão entre concorrentes. ${ }^{361}$ A fixação de preços de revenda em acordos verticais também foi, durante muito tempo, considerada ilícita per se quando "as commodities houverem passado pelos canais de comércio e já forem detidas pelos distribuidores". ${ }^{362}$ Esse trecho da decisão da Suprema Corte no caso Dr. Miles foi até mesmo inserido no item 5.2 das Diretrizes de 1995.

Contudo, o tratamento das restrições de preço nos acordos de licenciamento é um tema controverso nos Estados Unidos em razão do caso US v. General Electric, julgado em 1926 pela Suprema Corte, que entendeu ser lícito um acordo de licenciamento no qual o licenciante fixou o preço a ser praticado pelo licenciado na comercialização do produto patenteado, sendo ambas as empresas as únicas concorrentes no mercado relevante. ${ }^{363}$

De acordo com a Suprema Corte, a General Electric, titular de patentes sobre lâmpadas incandescentes, poderia ter mantido para si o direito exclusivo de fabricar e comercializar as lâmpadas em questão, cobrando preços de monopólio. Em vez disso, optou por licenciar esse direito para sua única concorrente, no caso a Westinghouse, sob a condição de que também cobrasse esse mesmo preço de monopólio. ${ }^{364}$ A Suprema Corte considerou que quando o titular da patente opta por conceder uma licença de venda a um concorrente, mas também continua vendendo o produto, seria apropriado permitir ao

\footnotetext{
${ }^{361}$ Cf. itens 3.4 e 5.1 das Diretrizes de 1995. Cf. também o caso United States v. Trenton Potteries Co., 273 U.S. 392, 397-398 (1927).

${ }^{362}$ Dr. Miles Medical Co. v. John D. Park \& Sons Co., 220 U.S. 373 (1911).

${ }^{363}$ United States v. General Electric Co., 272 U.S. 476, 47 S.Ct 192 (1926).

${ }^{364}$ Naquela época, as duas empresas eram as maiores fabricantes de lâmpadas nos Estados Unidos.
} 
licenciante impedir que o licenciado praticasse preços capazes de prejudicar os lucros de monopólio decorrentes da exclusividade conferida pela patente. ${ }^{365}$ Em outras palavras, o titular da patente possui o direito de impor restrições razoáveis com o objetivo de maximizar os retornos de seu direito de propriedade intelectual, incluindo o direito de controlar os preços pelos quais seus produtos patenteados são comercializados. ${ }^{366}$

Embora permaneça sendo precedente válido nos Estados Unidos, essa decisão foi objeto de muitas críticas, o que levou à limitação de seu escopo pela própria Suprema Corte, como também pelos tribunais inferiores. ${ }^{367}$ Primeiramente, a regra estabelecida no caso US v. General Electric não se aplica aos casos em que os titulares de patentes de bloqueio (blocking patents) ${ }^{368}$, que sejam parte de acordos de licença cruzada, fixem o preço pelo qual os produtos protegidos por essas patentes podem ser comercializados. ${ }^{369}$ Pela mesma lógica, um acordo de licenciamento não pode permitir que o licenciante, titular da patente, estabeleça uma fixação concertada de preços com seus licenciados. ${ }^{370}$ Assim, qualquer forma de fixação concertada de preços que envolva toda uma indústria deverá ser tratada como ilícito per se, não sendo beneficiada pela regra estabelecida no caso US v.

\footnotetext{
${ }^{365}$ De acordo com a decisão: "When the patentee licenses another to make and vend and retains the right to continue to make and vend on his own account, the price at which his licensee will sell will necessarily affect the price at which he can sell his own patented goods. It would seem entirely reasonable that he should say to the licensee, 'Yes, you may make and sell articles under my patent, but not so as to destroy the profit that I wish to obtain by making them and selling them myself.' He does not thereby sell outright to the licensee the articles the latter may make and sell, or vest absolute ownership in them. He restricts the property and interest the licensee has in the goods he makes and proposes to sell". United States v. General Electric Co., 272 U.S. 476, 47 S.Ct 192 (1926), p. 490.

${ }^{366}$ Ao abordar os precedentes Dr. Miles Medical Co. v. Park \& Sons Co., 220 U. S. 373 e Standard Sanitary Manufacturing Co. v. United States, 226 U.S. 20 (1912), a Suprema Corte ressaltou que a fixação dos preços a serem praticados pelo licenciado seria lícita desde que aplicável apenas à primeira venda do produto patenteado, sendo vedado o controle sobre os preços praticados pelos adquirentes do produto nas vendas subsequentes (fixação de preços de revenda). United States v. General Electric Co., 272 U.S. 476, 47 S.Ct 192 (1926), p. 485-91.

${ }^{367}$ O DOJ questionou sem sucesso a regra estabelecida na decisão do caso US v. General Electric, conforme pode ser observado nos casos United States v. Line Material Co., 333 U.S. 287, 320-321 (1948) e United States v. Huck Manufacturing Co., 382 U.S. 197 (1965), embora o escopo da regra tenha sofrido limitações.

${ }^{368}$ Patentes de bloqueio são aquelas não podem ser exploradas sem violar outras patentes. Por exemplo, uma patente que proteja uma melhoria em relação à tecnologia já patenteada poderá levar à situação de bloqueio, já que o titular da patente incremental não poderá explorá-la sem infringir a patente original, a não ser que obtenha uma licença de uso desta última.

${ }^{369}$ Cf. United States v. Line Material Co., 333 U.S. 287, 320-321 (1948). Nesse caso, os titulares das patentes necessárias para a fabricação de um produto firmaram acordos de licença cruzada fixando os preços que seus licenciados e sublicenciados poderiam cobrar pelo produto coberto por essas patentes. A Suprema Corte considerou essa prática como ilícita per se, não sendo aplicável a regra estabelecida no caso US v. General Electric, que envolvia apenas um licenciante e um licenciado.

${ }^{370}$ Cf. United States v. United States Gypsum Co., 333 U.S. 364, 389 (1948). Nesse caso, a Suprema Corte entendeu que: "The industry-wide license agreements, entered into with knowledge on the part of licensor
} 
General Electric. ${ }^{371}$ Deve-se ressaltar que alguns tribunais inferiores chegaram a limitar essa regra aos casos envolvendo um único licenciante e um único licenciado. ${ }^{372}$

Finalmente, é imperioso destacar que a regra também está sujeita às seguintes exceções: (i) a fixação de preços não pode ser estendida a produtos não cobertos pelo direito de propriedade intelectual ou tecnologia licenciada ${ }^{373}$; (ii) a fixação de preços deve limitar-se ao preço cobrado pelo licenciado na primeira venda, ou seja, o licenciante não pode restringir os preços de revenda praticados por terceiros que adquiriram o produto do licenciado, tendo em vista a aplicação da "doutrina da primeira venda" (first sale doctrine $)^{374}$; e (iii) caso o licenciado opte por sublicenciar o direito de propriedade intelectual ou tecnologia, não poderá fixar o preço de venda a ser praticado pelo sublicenciado. ${ }^{375}$

No que concerne às práticas de fixação de preços máximos ou mínimos de revenda em acordos verticais, antes consideradas ilícitas per se, atualmente têm sido analisadas sob a regra da razão, tendo em vista as recentes decisões da Suprema Corte nos casos State Oil v. Khan e Leeging. ${ }^{376}$ Ainda que práticas de fixação de preços mínimos ou máximos em acordos verticais possam facilitar esquemas de colusão, em muitos casos essas restrições produzem efeitos pró-competitivos. A fixação de preços máximos de venda ou revenda em acordos verticais de licenciamento pode ser uma forma eficiente de impedir

and licensees of the adherence of others, under which control was exercised over prices and methods of distribution, were sufficient to establish a prima facie case of conspiracy", p. 388-389.

${ }^{371}$ Cf. United States v. New Wrinkle, Inc., 342 U.S. 371, 379 (1952).

${ }^{372}$ Cf. Newburgh Moire Co. v. Superior Moire Co., 237 F.2d 283 (3d Cir. 1976). O tribunal considerou que: “(...) we think that the patent laws were not intended to empower a patentee to grant a plurality of licenses, each containing provisions fixing the price at which the licensee might sell the product or process to the company, and that, if a plurality of licenses are granted, such provisions therein are prohibited by the antitrust laws", p. 293-294.

373 Cummer-Graham Co. v. Straight Side Basket Corp., 142 F.2d 646, 647 (5 ${ }^{\text {th }}$ Cir.), cert. denied, 323 U.S. 726, 65 S. Ct. 60 (1944).

${ }^{374}$ United States v. Univis Lens Co., 316 U.S. 241 (1942) e Ethyl Gasoline Corp. v. United States, 309 U.S. 436 (1940).

375 United States v. Line Material Co., 333 U.S. 287, 320-321 (1948).

${ }^{376}$ No caso State Oil v. Khan, a Suprema Corte reverteu sua decisão no caso Albrecht v. Herald e considerou que a fixação de preços máximos de revenda não mais seria considerada ilícita per se, devendo ser analisada sob a regra da razão [State Oil Co. v. Khan, 522 U.S. 3, 18-19 (1997)]. No que concerne à fixação de preços mínimos de revenda, a Suprema Corte manteve durante décadas seu entendimento no caso Dr. Miles, julgado em 1911, no sentido de que a prática deve ser tratada como ilícito per se. [Dr. Miles Medical Co. v. John D. Park \& Sons Co., 220 U.S. 373 (1911)]. Contudo, a partir de sua recente decisão no caso Leeging, julgado em 2007, a Suprema Corte passou a considerar que a fixação de preços mínimos pode ser justificada com base em critérios de eficiência, devendo ser analisada sob a regra da razão [Leegin Creative Leather Products, Inc. v. PSKS, Inc., 127 S.Ct. 2705, 2712 (2007)]. 
que o licenciado eleve demasiadamente seus preços, especialmente se tiver exclusividade em seu território de atuação. Da mesma forma, a fixação de preços mínimos pode permitir que o distribuidor (ou licenciado) obtenha uma margem mínima de lucros, servindo como um incentivo para que amplie seus investimentos com o objetivo de atrair novos consumidores. $^{377}$

A Comissão adota uma abordagem um pouco mais rígida na análise de restrições de preços. De acordo com o Regulamento de 2004, qualquer prática de fixação de preços em acordos de licenciamento celebrados entre concorrentes será considerada como restrição do tipo hard-core, não podendo beneficiar-se da isenção prevista no Parágrafo $3^{\circ}$ do Artigo 101 do TFUE. ${ }^{378}$ Caso as partes não sejam concorrentes, a fixação de preços máximos de venda e a simples recomendação ou sugestão de preços poderão beneficiar-se da isenção, enquanto a fixação de preços mínimos é considerada restrição do tipo hard-core. ${ }^{379}$

\subsubsection{Licenças exclusivas e restrições territoriais}

Licenças exclusivas em acordos de licenciamento são aquelas que restringem o direito do licenciante de conferir licenças a terceiros e, possivelmente, de explorar por si próprio o direito de propriedade intelectual ou tecnologia objeto do acordo. ${ }^{380}$ Ao conferir uma licença exclusiva para determinado licenciado, o licenciante abdica dos seus direitos de explorar o direito de propriedade intelectual e de conferir licenças adicionais, hipótese em que a exclusividade será total. ${ }^{381}$ Por outro lado, caso o licenciante opte por resguardar seu direito de explorar a invenção ou tecnologia licenciada, mas abrindo mão do direito de conferir licenças adicionais, a exclusividade será parcial. Ressalte-se que o titular do direito de propriedade intelectual poderá conferir licenças exclusivas limitadas a um território

\footnotetext{
${ }^{377}$ Leegin Creative Leather Products, Inc. v. PSKS, Inc., 127 S.Ct. 2705, 2728-2733 (2007).

${ }^{378}$ Artigo 4.1(a) do Regulamento de 2004.

${ }^{379}$ Artigo 4.2(2) do Regulamento de 2004.

${ }^{380}$ Cf. item 4.1.2 das Diretrizes de 1995.

381 De acordo com ANDERMAN, uma licença exclusiva pode conferir diferentes níveis de proteção ao licenciado. O primeiro nível de proteção seria contra o próprio licenciante, que, além de não poder vender no território do licenciado, também não poderia conferir licenças adicionais nesse mesmo território. O segundo nível de proteção também inclui a proteção contra vendas diretas de outros licenciados. Essa proibição contra vendas diretas pode ser limitada a vendas "ativas" no sentido de que outros licenciados serão proibidos de promover vendas ou estabelecer canais de distribuição no território. Essa proibição pode estender-se à restrição de vendas "passivas", que proíbem um licenciado de atender encomendas enviadas por consumidores localizados no território exclusivo de outro licenciado. ANDERMAN, Steve. The New EC
} 
específico (restrição territorial), a determinado do grupo de consumidores ${ }^{382}$ (alocação de consumidores), ou a determinado campo de aplicação técnica ${ }^{383}$ (field of use restriction).

As Diretrizes de 1995 deixam claro que as várias formas de licenças exclusivas e restrições territoriais (incluindo alocação de consumidores e restrições de campo de aplicação) produzem efeitos pró-competitivos ao permitir que o licenciante explore seus direitos de propriedade intelectual de forma mais eficiente e efetiva, protegendo-o, por exemplo, contra a concorrência resultante de sua própria tecnologia em determinado nicho de mercado que desejaria manter para si. $^{384}$ Ademais, essas formas de licenciamento exclusivo e restrições territoriais conferem incentivos para que o licenciado invista na comercialização de produtos protegidos pela propriedade intelectual licenciada, impedindo que seus investimentos sejam dissipados em consequência de comportamentos oportunistas de outros licenciados (free-riders), que poderiam aproveitar-se dos clientes por ele conquistados sem arcarem com os respectivos custos. ${ }^{385}$

O Patent Act norte-americano permite expressamente a concessão de licenças exclusivas em relação à totalidade ou qualquer parte específica do território dos Estados Unidos $^{386}$, o que está em consonância com a jurisprudência norte-americana sobre o tema. ${ }^{387}$ Além disso, a decisão da Suprema Corte norte-americana no caso Sylvania estabeleceu que todas as restrições verticais não relacionadas com preço (non-price

Competition Law Framework for Technology Transfer and IP Licensing, in: DREXL, Josef (Ed.). Research Handbook on Intellectual Property and Competition Law. Cheltenham: Edward Elgar, 2008, p. 123.

${ }^{382}$ Licenças por meio das quais o licenciado é autorizado a vender os produtos para determinado grupo de consumidores com exclusividade, permitindo que o licenciante reserve para si outras classes ou grupos de consumidores. Caso as partes estejam em relação horizontal, esse tipo de restrição poderá suscitar preocupações do ponto de vista antitruste. Em acordos verticais, a restrição será analisada sob a regra da razão, sendo normalmente considerada pró-competitiva. Cf. Westinghouse Elec. \& Mfg. v. Cutting \& Washington Radio Corp., 294 F. 671-73 (2d Cir. 1923).

383 Trata-se de licenças por meio das quais o licenciante limita o uso do direito de propriedade intelectual pelo licenciado a certos domínios de aplicação técnica, a determinado tipo de produto ou a um nicho específico de mercado. No caso General Talking Pictures v. Western Electric, a Suprema Corte norteamericana considerou lícita uma restrição desse tipo. A AT\&T licenciava sua patente para uma subsidiária para utilização na fabricação de amplificadores para uso em teatros e resolveu licenciar sua patente a um terceiro, mas com uso limitado à fabricação de amplificadores para aparelhos de rádio para uso pessoal. 304 U.S. 175, aff'd on reh'g, 305 U.S. 124 (1938).

384 Por exemplo, poderá reservar para si um território, um grupo específico de consumidores ou um determinado campo de aplicação técnica.

${ }^{385}$ Cf. item 4.1.2 das Diretrizes de 1995.

38635 U.S.C. 261.

${ }^{387}$ Cf. Waterman v. Mackenzie, 138 U.S. 252, 255 (1891) e Zenith Radio Corp. v. Hazeltine Research, 395 U.S. 100, 135-36 (1969). 
restrictions) devem ser analisadas sob a regra da razão. ${ }^{388}$ Assim, de acordo com essa interpretação, as diversas formas de licenciamento exclusivo (restrições territoriais, alocação de clientes e restrições de campo de aplicação) para e entre licenciados, são similares a quaisquer outras restrições verticais que estejam fora do contexto de um licenciamento. ${ }^{389}$ Mesmo no caso em que as partes estejam em relação horizontal, a mera concessão de licença exclusiva não constitui, por si só, violação das normas antitruste. ${ }^{390}$

Por outro lado, licenças exclusivas podem, em determinadas circunstâncias, vir a ser objeto de intervenção antitruste, especialmente se as partes do acordo de licenciamento forem concorrentes efetivos ou potenciais. ${ }^{391}$ Restrições territoriais entre concorrentes podem facilitar esquemas de colusão para divisão de mercados entre os licenciados, ou entre o licenciante e seus licenciados. Exemplo desse tipo de situação é o caso Palmer v. BRG of Georgia, julgado pela Suprema Corte norte-americana. ${ }^{392}$ Nesse caso, o licenciante e o licenciado ofertavam cursos preparatórios para o exame da ordem dos advogados. O licenciante conferiu ao licenciado uma licença exclusiva de direitos autorais para comercializar os materiais do curso no estado da Geórgia. Ambos acordaram que o licenciante não poderia concorrer com o licenciado na Geórgia, enquanto o licenciado não poderia concorrer com o licenciante fora desse estado. A Suprema Corte considerou essa licença exclusiva como ilícito per se, já que servia meramente para facilitar um esquema de divisão de mercados entre concorrentes. ${ }^{393}$

Na União Europeia, o tratamento dado a cláusulas de exclusividade de território em acordos de licenciamento é sensivelmente diferente. Vimos que a Comissão e os tribunais comunitários sempre foram rigorosos com restrições territoriais, dado o receio

\footnotetext{
${ }^{388}$ Continental TV Inc. v. G. T. E. Sylvania Inc., 433 U.S. 36 (1977).

${ }^{389}$ Cf. item 4.1.2. das Diretrizes de 1995.

${ }^{390}$ Cf. Virtue v. Cremery Package Mfg, 227 U.S. 8, 36-37 (1913); United States v. E.I. DuPont de Nemours \& Co., 118 F. Supp. 41, 224 (D. Del. 1953); SCM Corp. v. Xerox Corp., 463 F. Supp. 983, 1005-06 (D. Conn. 1978); United States v. Studiengesellschaft Kohle, 670 F.2d 1122, 1127 (D.C. Cir. 1981); United States v. Westinghouse Elec., 648 F.2d 1122, 1127 (D.C. Cir. 1981); Levi Case Co. v. ATS Produs., 788 F. Supp.428, 431-32 (N.D. Cal. 1992); Genentech, Inc. v. Eli Lilly \& Co., 998 F. 2d 931, 949 (Fed. Cir. 1993); Baxter Int'l v. Abbott Labs., 315 F.3d 829, 830-31 ( $7^{\text {th }}$ Cir. 2003);

${ }^{391}$ Licenças exclusivas podem ser problemáticas do ponto de vista antitruste se os licenciados por si só, ou mesmo o licenciante e seus licenciados, estiverem em relação horizontal. As Diretrizes de 1995 destacam, como exemplo de licenças exclusivas horizontais capazes de prejudicar a concorrência, o licenciamento cruzado entre partes que detenham poder de mercado, grantback e aquisições de direitos de propriedade intelectual.

${ }^{392}$ Palmer v. BRB of Georgia, 498 U.S. 46, 111 S.Ct. 401 (1990).

${ }^{393}$ Cf. também A.\&E. Plastik Pak v. Monsanto Co., 396 F.2d $710\left(9^{\text {th }}\right.$ Cir. 1968) e International Wood Processors v. Power Dry Inc., 792 F2d. 416 ( $4^{\text {th }}$ Cir. 1986).
} 
de que pudessem levar ao isolamento dos mercados nacionais em detrimento dos objetivos do mercado único, como pode ser observado na decisão do TJUE no caso Consten \& Grunding v. Commission. ${ }^{394}$ Desse modo, licenças exclusivas e outras formas de restrições territoriais eram normalmente proibidas nos termos do Parágrafo $1^{\circ}$ do Artigo 101 do TFUE.

Essa abordagem rígida e formalista começou a ser flexibilizada no início dos anos 1980, a partir da decisão do TJUE no caso Nungesser, mais conhecido como Maize Seeds, que tratava de uma licença exclusiva de direitos de obtenção vegetal sobre uma nova variedade de milho. ${ }^{395}$ Nesse caso, o TJUE fez uma distinção entre licença exclusiva aberta, por meio da qual o licenciante se obriga apenas a não conceder outras licenças no território do licenciado e a não concorrer diretamente nesse território, e licenças exclusivas que garantiriam uma proteção absoluta ao licenciado em sua área de atuação, isto é, que eliminavam totalmente a concorrência nesse território ao proibir as importações paralelas por parte de terceiros dentro desse território (adquirindo de licenciados localizados em outros territórios). O TJUE considerou que o licenciado poderia não aceitar assumir os riscos incorridos para cultivar e comercializar o novo produto em seu território, a não ser que lhe fosse conferida alguma forma de exclusividade. Desse modo, o TJUE considerou que uma licença exclusiva aberta que não afetasse as importações paralelas de terceiros, não teria como objetivo restringir a concorrência, não recaindo, por si só, nas proibições contidas no Parágrafo $1^{\circ}$ do Artigo 101 do TFUE. ${ }^{396}$

Nos anos que se seguiram após a decisão do caso Maize Seeds, a abordagem favorável às licenças exclusivas abertas de direitos de propriedade intelectual passou a ser aplicada de forma restrita pelo TJUE, limitada aos casos que apresentassem as mesmas circunstâncias daquele caso, ou seja, a presença de um produto verdadeiramente inovador e riscos para o licenciado fabricar e comercializar o produto, caso não houvesse proteção territorial. ${ }^{397}$ Por outro lado, houve casos em que a Comissão e o TJUE aceitaram restrições territoriais absolutas, como no caso Coditel v Ciné Vog Films, referente ao licenciamento

\footnotetext{
${ }^{394}$ Casos 56/84 e 58/64 [1966] ECR 299, [1966] CMLR 418.

${ }^{395}$ Caso 258/78 [1982] ECR 2015, [1983] 1 CMLR 278.

396 Ao contrário da restrição territorial absoluta, que por si só seria proibida nos termos do Parágrafo $1^{\circ}$ do Artigo 101 do TFUE, sem poder beneficiar-se da isenção nos termos do Parágrafo $3^{\circ}$ do mesmo dispositivo. Cf. Caso 258/78 [1982] ECR 2015, [1983] 1 CMLR 278, parágrafos 53-63.
} 
de direitos autorais de radiodifusão. ${ }^{398}$ Nesse caso, o TJUE aceitou a proteção territorial absoluta conferida ao licenciado em razão dos elevados riscos assumidos por investidores na indústria cinematográfica e a necessidade de aumentar as receitas relativas aos filmes com maior sucesso para compensar os prejuízos sofridos com outros filmes. No caso Louis Erauw-Jacquery Sprl v La Hesbignonne Société, o TJUE entendeu que a proibição de exportações de sementes de base ("basic seeds") não violava o Parágrafo $1^{\circ}$ do Artigo 101, já que era necessária para a proteção dos direitos de obtenção vegetal contra a manipulação indevida das variedades vegetais protegidas. ${ }^{399}$

Assim, é certo que as restrições territoriais em acordos de licenciamento nem sempre serão consideradas proibidas nos termos do Parágrafo $1^{\circ}$ do Artigo 101 do TFUE, especialmente no caso das licenças abertas, e mesmo as proteções territoriais absolutas poderão ser justificadas em determinadas circunstâncias. ${ }^{400}$

No Regulamento de 2004, acompanhado das Diretrizes de 2004, a Comissão distingue entre: (i) licenças exclusivas e licenças únicas, compreendidas como restrições sobre a produção dentro do território exclusivo; e (ii) restrições de venda, isto é, proibições de venda de produtos que incorporem a tecnologia licenciada em determinado território ou a determinado grupo de consumidores. Vejamos.

Uma licença é considerada exclusiva se o licenciado for o único autorizado a produzir com base na tecnologia licenciada num determinado território. O licenciante compromete-se assim a não produzir ele próprio nem a conceder licenças a outros para produzir num determinado território. Já a licença única é limitada à obrigação do licenciante de não conferir licenças adicionais a terceiros no território do licenciado, resguardando para si o direito de explorar a tecnologia nesse mesmo território. ${ }^{401} \mathrm{Se}$ essas licenças forem celebradas entre não concorrentes (em relação vertical), poderão beneficiarse da isenção prevista no Parágrafo $3^{\circ}$ do Artigo 101 do TFUE, caso recaiam na proibição

\footnotetext{
${ }^{397}$ Cf. Velcro/Aplix, OJ [1985] L233/22, [1989] 4 CMLR 157, parágrafos 43, 44 e 60; Tetra Pak I (BTG Licence), OJ [1988] L272/27, [1990] 4 CMLR 47, que manteve em sede de apelação a decisão no caso T41/89 Tetra Pak Rausing AS v Commission [1990] ECR II-309, [1991] 4 CMLR 334.

${ }^{398}$ Caso 262/81 [1982] ECR 3381, [1983] 1 CMLR 49.

${ }^{399}$ Caso 27/87 [1988] ECR 1919, [1988] 4 CMLR 576.

${ }^{400}$ Cf. WHISH, Richard. Competition Law. 6th ed. Oxford University Press, 2009, p. 765-766.

${ }^{401}$ Cf. Diretrizes de 2004, parágrafo 162.
} 
contida no Parágrafo $1^{\circ}$ do mesmo dispositivo. ${ }^{402}$ Essa isenção pode ser aplicável dentro ou fora da zona de segurança, desde que a tecnologia licenciada não alcance uma posição dominante no mercado relevante. ${ }^{403}$

Da mesma forma, uma licença exclusiva conferida por um licenciante por meio de um acordo de licenciamento não recíproco entre concorrentes (que é em essência um acordo vertical), poderá beneficiar-se da isenção em bloco contida no Regulamento de 2004, desde que o percentual de participação de mercado das partes não exceda o limite de $20 \%$ no mercado relevante. Acima desse limite, deverão ser analisados os efeitos anticoncorrenciais do acordo e possíveis eficiências para eventual isenção nos termos do Parágrafo $3^{\circ}$ do Artigo 101 do TFUE. Finalmente, a licença exclusiva em acordo recíproco entre concorrentes é considerada restrição do tipo hard-core, nos termos do Artigo 4.1(c) do Regulamento de 2004, por se tratar de divisão pura de mercado entre concorrentes. Por outro lado, uma licença única em acordo recíproco entre concorrentes (por meio do qual as partes comprometem-se mutuamente a não conceder licenças das suas tecnologias concorrentes a terceiros) poderá ser beneficiada pela isenção em bloco se as participações de mercado das partes atenderem ao limite de $20 \%$ do mercado relevante. Acima desse patamar, as Diretrizes de 2004 deixam claro que esses acordos podem facilitar a colusão ao garantir que as partes são as únicas fontes de produção no mercado com base nas tecnologias licenciadas. ${ }^{404}$

No que concerne às restrições territoriais de venda, as Diretrizes de 2004 também fazem a distinção entre acordos de licenciamento entre concorrentes e entre não concorrentes. Nos acordos de licenciamento entre não concorrentes, restrições de vendas poderão ser beneficiadas pela isenção em bloco, até o limite de participação de mercado de 30\% no mercado relevante. Mesmo acima desse limite, restrições sobre todas as vendas do licenciado para grupos de consumidores ou territórios reservados ao licenciante poderão

\footnotetext{
${ }^{402}$ A Comissão reconhece expressamente os possíveis efeitos pró-competitivos de licenças exclusivas ou únicas em acordos verticais: "the right to grant an exclusive licence is generally necessary in order to induce the licensee to invest in the licensed technology and to bring the products to Market in a timely manner. This is particularly the case where the licensee must make large investments in further developing the licensed technology. To intervene against the exclusivity once the licensee has made a commercial success of the licensed technology would deprive the licensee of the fruits of his success and would be detrimental to competition, the dissemination of technology and innovation". Diretrizes de 2004, parágrafo 165.

${ }^{403}$ Cf. ANDERMAN, Steve. The New EC Competition Law Framework for Technology Transfer and IP Licensing, in: DREXL, Josef (Ed.). Research Handbook on Intellectual Property and Competition Law. Cheltenham: Edward Elgar, 2008, p. 125.

${ }^{404}$ Cf. Diretrizes de 2004, parágrafo 163.
} 
não recair sobre as proibições do Parágrafo $1^{\circ}$ do Artigo 101 do TFEU, já que é reconhecido o direito do licenciante de não criar concorrência para si mesmo a partir de sua própria tecnologia. ${ }^{405}$ Por outro lado, as Diretrizes de 2004 estabelecem que acima dos limites de participação de mercado, restrição das vendas ativas entre territórios e grupos de clientes exclusivos dos licenciados limita a concorrência intratecnologia e é suscetível de ser abrangida pelo âmbito de aplicação do Parágrafo $1^{\circ}$ do Artigo 101 do TFUE, caso o licenciado detenha poder de mercado significativo. ${ }^{406}$ Mesmo assim, essas restrições podem ser beneficiadas pela isenção contida no Parágrafo $3^{\circ}$ do mesmo dispositivo, caso efetivamente sejam necessárias para inibir o "free-riding" e estimular os investimentos dos licenciados. ${ }^{407}$

Em caso de acordos não recíprocos entre concorrentes, restrições ativas e passivas pelo licenciado ou licenciante no território exclusivo (ou para um grupo de consumidores exclusivo) de outro licenciado também poderão beneficiar-se da isenção em bloco. Mesmo acima do limite de participação de mercado de $20 \%$, tais restrições podem ser indispensáveis para a difusão das tecnologias, podendo ser isentas nos termos do Parágrafo $3^{\circ}$ do Artigo 101 do TFUE. Já no caso de acordos recíprocos entre concorrentes, quaisquer restrições sobre vendas ativas e passivas para consumidores ou territórios alocados ao licenciado serão consideradas restrições do tipo hard-core nos termos do Artigo 4.1(c) do Regulamento de 2004, uma vez que podem facilitar esquemas de divisão de mercados entre concorrentes.

\subsubsection{Exclusividade e não concorrência}

As cláusulas de exclusividade ("exclusive dealing") em acordos de licenciamento e transferência de tecnologia, também chamadas de obrigações de não concorrência, são aquelas que impedem o licenciado de explorar tecnologias concorrentes. ${ }^{408}$ Desse modo, o licenciado fica proibido de utilizar tecnologias de terceiros que se encontrariam em concorrência com a tecnologia licenciada. Essas obrigações são normalmente consideradas pró-competitivas, uma vez que: (i) incentivam à transferência

\footnotetext{
405 Cf. Diretrizes de 2004, parágrafo 172.

${ }^{406}$ Cf. Diretrizes de 2004, parágrafo 174.

${ }^{407}$ Vimos que restrições sobre vendas passivas pelos licenciados são permitidas apenas durante dois anos, de modo que além desse período serão consideradas restrições do tipo hard-core.

${ }^{408}$ De acordo com o item 5.4 das Diretrizes de 1995: “(...) exclusive dealing, arises when a license prevents or restrains the licensee from licensing, selling, distributing, or using competing technologies".
} 
de tecnologia ao assegurar ao licenciante que o licenciado não utilizará a tecnologia licenciada para explorar tecnologias concorrentes em benefício de seus rivais; (ii) incentivam o licenciado a investir na tecnologia licenciada e a explorá-la de forma mais eficiente; (iii) facilitam o cálculo do volume das vendas dos produtos contendo a tecnologia licenciada para fins de pagamento de royalties. ${ }^{409}$

Por outro lado, essas cláusulas de exclusividade podem prejudicar a concorrência intertecnologias ao provocar o fechamento do mercado a terceiros titulares de direitos de propriedade intelectual sobre tecnologias alternativas ou substitutas. Podem também aumentar os custos de rivais para o acesso a importantes insumos de produção e distribuição detidos pelos licenciados, reduzindo suas possibilidades de ingresso no mercado, especialmente quando o licenciante estabelecer redes de licenciados exclusivos. $\mathrm{O}$ grau de fechamento do mercado depende do poder de mercado detido pelo licenciante e da presença de barreiras à entrada de outros licenciados capazes de explorar as tecnologias alternativas de terceiros. Esses efeitos de fechamento do mercado e aumento dos custos dos rivais podem ocorrer tanto nos acordos de licenciamento horizontais como nos verticais, na medida em que é a exclusão das tecnologias alternativas ou substitutas que constitui o problema concorrencial. ${ }^{410}$ Contudo, no caso de um acordo de licenças cruzadas entre concorrentes em que as duas partes acordam em não utilizar tecnologias pertencentes a terceiros, o acordo pode facilitar esquemas de colusão no mercado. ${ }^{411}$

Nos Estados Unidos, as cláusulas de exclusividade são analisadas sob a regra da razão, de modo a verificar se eventuais efeitos anticoncorrenciais podem ser compensados por eficiências econômicas. ${ }^{412}$ Dessa forma, deverão ser avaliados fatores como o grau de fechamento do mercado, a duração da obrigação de não concorrência, o nível de concentração do mercado, barreiras à entrada, disponibilidade de canais alternativos de distribuição e produtos ou tecnologias concorrentes, dentre outros. ${ }^{413}$

\footnotetext{
${ }^{409}$ Cf. Diretrizes de 2004, parágrafos 201 e 202.

${ }^{410}$ De acordo com o item 5.4 das Diretrizes de 1995.

${ }^{411}$ Cf. Item 5.4 das Diretrizes de 1995 e Diretrizes de 2004, parágrafos 198-200.

412 Cf. Tampa Electric Co. v. Nashville Coal Co., 365 U.S. 320 (1961) e Beltone Electronics Corp., 100 F.T.C. 68 (1982).

413 De acordo com o item 5.4 das Diretrizes de 1995: "In determining whether an exclusive dealing arrangement is likely to reduce competition in a relevant market, the Agencies will take into account the extent to which the arrangement (1) promotes the exploitation and development of the licensor's technology and (2) anticompetitively forecloses the exploitation and development of, or otherwise constrains competition among, competing technologies. The likelihood that exclusive dealing may have anticompetitive effects is related, inter alia, to the degree of foreclosure in the relevant market, the duration of the exclusive dealing
} 
Ressalte-se que os tribunais norte-americanos exigem a demonstração de fechamento substancial do mercado relevante para a determinação dos efeitos anticoncorrenciais. ${ }^{414} \mathrm{Em}$ geral, os tribunais exigem um percentual de fechamento do mercado superior a $40 \%$ para que seja comprovada a violação da Seção 1 do Sherman Act. ${ }^{415}$

Entretanto, no caso Microsoft III (2001), a Court of Appeals analisou a conduta da Microsoft de impor obrigações de não concorrência em diversos acordos de licenciamento como estratégia de monopolização nos termos da Seção 2 do Sherman Act. ${ }^{416} \mathrm{O}$ tribunal afirmou que, em determinadas circunstância, a utilização de obrigações de não concorrência por um monopolista poderia configurar violação da Seção 2, ainda que os contratos firmados tenham resultado no fechamento de menos de $40 \%$ ou $50 \%$ do mercado, percentuais mínimos exigidos para a comprovação de violação da Seção $1 .^{417}$ Assim, o tribunal afirmou que as obrigações de não concorrência excluíram um percentual substancial das oportunidades disponíveis para a distribuição de softwares de navegação na internet ofertados pelos rivais da Microsoft, aumentando seus custos de distribuição. Essa estratégia de exclusão da Microsoft permitiu a redução do nível de utilização do browser Navigator, desenvolvido pela sua rival Netscape, de modo a impedir que esta e outras concorrentes no mercado de aplicativos de navegação pudessem vir a tornar-se uma ameaça ao seu monopólio no mercado de sistemas operacionais.

Na União Europeia, as obrigações de não concorrência também são analisadas sob a regra da razão, além de poderem beneficiar-se da isenção em bloco nos acordos entre concorrentes e entre não concorrentes nos quais as partes detenham participação não superior a $20 \%$ e $30 \%$, respectivamente, do mercado relevante. No entanto, tais obrigações

arrangement, and other characteristics of the input and output markets, such as concentration, difficulty of entry, and the responsiveness of supply and demand to changes in price in the relevant markets. (...) If the Agencies determine that a particular exclusive dealing arrangement may have an anticompetitive effect, they will evaluate the extent to which the restraint encourages licensees to develop and market the licensed technology (or specialized applications of that technology), increases licensors' incentives to develop or refine the licensed technology, or otherwise increases competition and enhances output in a relevant market".

${ }^{414}$ No caso Omega Environmental v. Gilbarco Inc., o tribunal (9th Cir.) determinou que a participação de mercado de $38 \%$ da empresa defendente seria insuficiente para a demonstração de fechamento substancial do mercado, uma vez que os contratos haviam sido celebrados por prazo muito curto - 1 ano -, além do que muitos deles poderiam ser denunciados mediante aviso prévio de 60 dias.

${ }^{415}$ Cf. Concord Boat Corp. v. Brunswick Corp., 207 F.3d 1039, 1063 (8th Cir.), cert. denied, 531 U.S. 979, 121 S.Ct. 428, 148 L.Ed.2d 436 (2000) e Sewell Plastics, Inc. v. Coca Cola Co., 720 F. Supp. 1196, 1213 (WD.N.C. 1989).

${ }^{416}$ United States v. Microsoft Corp., 253 F.3d 34, 70-1 (D.C. Cir. 2001). 
não podem limitar, direta ou indiretamente, qualquer das partes de conduzir atividades de pesquisa e desenvolvimento, a não ser que a restrição seja indispensável para impedir a divulgação do know-how licenciado para terceiros. ${ }^{418}$

\subsubsection{Licenças casadas e pacotes de licenças}

A venda casada (tying arrangements) é o acordo pelo qual uma das partes se compromete a vender um produto ou a prestar um serviço (produto vinculante ou tying product) sob a condição de que o comprador adquira outro bem ou serviço (produto vinculado ou tied product), ou que pelo menos se comprometa a não adquirir esse produto vinculado de outro fornecedor. ${ }^{419}$ Desse modo, a licença casada pode ser definida como a obrigação pela qual o licenciante condiciona o licenciamento de um direito de propriedade intelectual ou tecnologia à aquisição de um produto ou serviço pelo licenciado. ${ }^{420}$ Caso esse produto/serviço vinculado seja um direito de propriedade intelectual ou tecnologia, a licença casada será um pacote de licenças, definido no item 5.3 das Diretrizes de 1995 como o licenciamento de múltiplos direitos de propriedade intelectual por meio de uma única licença ou de um conjunto de licenças. ${ }^{421}$

Tanto nos Estados Unidos como na União Europeia, a licença casada, assim como a venda casada em geral, pode ser objeto de análise antitruste tanto como cláusula contratual inserida em acordos de licenciamento, nos termos da Seção 1 do Sherman Act e do Artigo 101 do TFUE, como prática de monopolização e abuso de posição dominante, conforme o disposto na Seção 2 do Sherman Act e do Artigo 102 do TFUE, respectivamente. $^{422}$ No contexto dos acordos de licenciamento e transferência de tecnologia, a licença casada pode ser imposta por meio de cláusula contratual (contractual tying) ou de "integração tecnológica", que ocorre quando duas ou mais tecnologias são

417 “(...) a monopolist's use of exclusive contracts, in certain circumstances, may give rise to a 2 violation even though the contracts foreclose less than the roughly $40 \%$ or $50 \%$ share usually required in order to establish a Section 1 violation”. United States v. Microsoft Corp., 253 F.3d 34, 70-1 (D.C. Cir. 2001), p. 70.

${ }^{418}$ Cf. Artigos 5.2 e 4.1(d) do Regulamento de 2004.

${ }^{419}$ Cf. Eastman Kodak Co. v. Image Technical Services, Inc., 504 U.S. 451, 461 (1992).

${ }^{420}$ Para uma análise mais aprofundada sobre o tema, cf. SCHMIDT, Hedvig. Competition Law, Innovation and Antitrust: An Analysis of Tying and Technological Integration. Cheltenham, UK: Edward Elgar, 2009; e RIBAS, Guilherme Favaro Corvo. Direito Antitruste e Propriedade Intelectual: uma abordagem sob a ótica das vendas casadas. São Paulo: Singular, 2011.

${ }^{421}$ Cf. US Philips Corp. v. International Trade Commission, 424 F. 3d. 1189 (Fed. Cir. 2005).

${ }^{422}$ Nos Estados Unidos, a prática de venda casada pode ser analisada tanto nos termos das Seções 1 e 2 do Sherman Act, como também nos termos da Seção 3 do Clayton Act ou Seção 5 do FTC Act. 
integradas fisicamente em um único produto, ou fabricadas de forma a somente serem compatíveis entre si. $^{423}$

As vendas casadas podem ser ilícitas sob a ótica antitruste quando o vendedor detém poder de mercado suficiente no mercado do produto vinculante para forçar o comprador a adquirir o produto vinculado, que ele não desejaria necessariamente comprar. ${ }^{424}$ Como o fornecedor detém elevada participação de mercado no mercado de origem, a montante, mas enfrenta concorrência no mercado alvo, a jusante, poderá empregar uma estratégia de vendas casadas para transferir ou alavancar seu poder de mercado a montante para o mercado a jusante. ${ }^{425}$ Caso a estratégia seja bem sucedida, poderá resultar na exclusão dos concorrentes e fechamento do mercado a jusante, permitindo ao fornecedor aumentar suas vendas nesse mercado.

No caso Jefferson Parish Hospital ${ }^{426}$, julgado pela Suprema Corte norteamericana em 1984, foi estabelecido um teste para a comprovação de uma venda casada como ilícito per se, nos termos da Seção 1 do Sherman Act e Seção 3 do Clayton Act, que passou a ser amplamente utilizado pelos tribunais inferiores. Desse modo, pelo menos três elementos devem ser demonstrados: (i) existência de dois produtos distintos (produto vinculante e produto vinculado); (ii) habilidade especial do vendedor (poder de mercado) para forçar o comprador a adquirir o produto vinculado; e (iii) fechamento de volume substancial do comércio. ${ }^{427}$ Em razão das críticas ao tratamento per se das vendas casadas,

${ }^{423}$ Cf. US DOJ e FTC. Antitrust Enforcement and Intellectual Property Rights: Promoting Innovation and Competition (2007), p. 107.

${ }^{424}$ Nesse contexto, vale citar trecho da famosa decisão da Suprema Corte norte-americana no caso Northern Pacific Railway, que descreve os efeitos anticoncorrenciais da venda casada: "Tying agreements serve hardly any purpose beyond the suppression of competition (...) They deny competitors free access to the market for the tied product, not because the party imposing the tying requirements has a better product or a lower price but because of his power or leverage in another market. At the same time buyers are forced to forgo their free choice between competing products. For these reasons 'tying agreements fare harshly under the laws forbidding restraints of trade' (...) They are unreasonable in and of themselves whenever a party has sufficient economic power with respect to the tying product to appreciably restrain free competition in the market for the tied product and a "not insubstantial' amount of interstate commerce is affected".

${ }^{425}$ De acordo com a chamada "teoria da alavancagem" ("leverage theory"), o agente econômico que detém poder de mercado no mercado relevante de determinado produto poderia, por meio do uso estratégico de vendas casadas, alavancar esse poder para outro mercado, restringindo seu acesso para agentes econômicos rivais. SULLIVAN e GRIMES definem a "teoria da alavancagem" da seguinte forma: "Briefly stated, leverage theory provides that a seller with market power in a tying product could extend that power into another product or line through a tie-in". SULLIVAN, Lawrence A.; GRIMES, Warren S. The Law of Antitrust: An Integrated Handbook. Saint Paul, Minn.: West Group, 2000, p. 384.

${ }^{426}$ Cf. Jefferson Parish Hospital District No. 2 v. Hyde, 466 U.S. 2 (1984).

${ }^{427}$ Nesse caso, quatro juízes opinaram por uma análise mais aprofundada, baseada na regra da razão, mas foram vencidos pela maioria que optou pelo tratamento per se, desde que comprovados os elementos do teste: (i) dois produtos distintos; (ii) poder de mercado/coerção; e (iii) fechamento de volume substancial do 
os tribunais inferiores passaram a exigir, como quarto elemento, a comprovação dos efeitos anticoncorrenciais no mercado do produto vinculado, o que sugere que a análise antitruste das vendas casadas deve ser conduzida com base na regra da razão. ${ }^{428}$

No contexto dos acordos de licenciamento o tema é mais complexo, dificultando a aplicação do teste estabelecido no caso Jefferson Parish. Vimos que nos casos mais antigos de patente misuse, os tribunais norte-americanos costumavam presumir que o titular de uma patente detinha um monopólio que lhe permitiria subordinar seu licenciamento à aquisição de produtos não cobertos pela patente. Todavia, no recente caso Illinois Tools Works, a Suprema Corte refutou expressamente essa hipótese, de modo que o poder de mercado do licenciante não poderá ser presumido, entendimento que também está em linha com as Diretrizes de $1995 .^{429}$

Ademais, a verificação da existência de demanda para dois produtos distintos ("teste da demanda separada") é uma tarefa muitas vezes impossível no contexto dos acordos de licenciamento e transferência de tecnologia. Isso porque muitos produtos possuem diversas tecnologias integradas. Um único smartphone pode possuir dezenas de tecnologias indispensáveis ao seu funcionamento adequado. Muitas vezes, essas tecnologias são licenciadas em conjunto, como um pacote de licenças, possibilitando uma economia de custos de transação. ${ }^{430}$ Em determinadas circunstâncias, os acordos de licenciamento podem incluir a venda de equipamentos ou componentes que, embora não sejam protegidos por direitos de propriedade intelectual, são indispensáveis para utilização das tecnologias licenciadas ou para o funcionamento do produto acabado. Essa integração de tecnologias é na maioria das vezes desejada não apenas pelo licenciado, mas também pelos consumidores finais do produto.

A questão da integração de tecnologias no contexto da licença casada foi analisada no caso Microsoft III (2001), que tratou da prática da Microsoft de integrar o

comércio. GELLHORN e KOVACIC criticam essa decisão e entendem que "the Court's refusal to abandon the per se label constitutes one of the more deliberate missed opportunities in modern antitrust decisionmaking". GELLHORN, Ernest; KOVACIC, William E. Antitrust Law and Economics. 4th ed. Saint Paul, Minn.: West Group, 1994.

${ }^{428}$ Cf. ABA Section of Antitrust Law. Intellectual Property and Antitrust Handbook. ABA Publishing, 2007, p. 194.

${ }^{429}$ Illinois Tool Works Inc. et. al. v. Independent Ink, Inc., 547 U.S. 28 (2006).

${ }^{430}$ Cf. U.S. Philips Corp. v. International Trade Commission, 424 F.3d 1179 (Fed. Cir. 2005), cert. denied sub nom. Princo Corp. v. U.S. Philips Corp., 126 S. Ct. 2899 (2006) 
aplicativo Internet Explorer em seu sistema operacional Windows. ${ }^{431}$ Ao rever a decisão do District Court, que entendeu que a prática seria uma venda casada ilícita per se, a Corte de Apelação (D.C. Circuit) concluiu que o caso deveria ter sido analisado sob a regra da razão, uma vez que a integração de novas funcionalidades em sistemas operacionais seria uma prática comum, além de trazer benefícios à inovação no mercado. ${ }^{432}$ Para o D.C. Circuit, os precedentes da Suprema Corte que tratam da aplicação da regra per se às vendas casadas não levam em consideração tecnologias fisicamente integradas, não podendo, portanto, ser aplicáveis ao caso. ${ }^{433}$

Ademais, a Corte de Apelação acatou os argumentos da Microsoft de que o teste da demanda direta, conforme estabelecido no caso Jefferson Parish, não seria adequado, pois sua aplicação poderia prejudicar a inovação em detrimento dos consumidores, uma vez que os agentes econômicos passariam a ser impedidos de integrar em seus produtos novas funcionalidades que antes eram comercializadas separadamente e, por definição, sujeitas à demanda separada. ${ }^{434}$ Esse caso é um bom exemplo de como considerações de eficiência dinâmicas podem sobrepor-se a critérios de eficiência alocativa (estática) na análise antitruste em casos envolvendo concorrência, inovação e direitos de propriedade intelectual.

\section{O caso U.S. Philips Corp. v. International Trade Commission envolveu uma} interessante discussão sobre a legalidade de um pacote de licenças de tecnologias

\footnotetext{
${ }^{431}$ United States v. Microsoft Corp., 253 F.3d 34 (D.C. Cir. 2001). A Microsoft detinha aproximadamente 95\% do mercado de sistemas operacionais por meio do Windows e passou a integrar o Internet Explorer nessa plataforma, de modo que ambos eram licenciados como um pacote de produtos aos fabricantes de computadores. Para o DOJ, esse pacote não proporcionava eficiências substanciais, podendo, ao contrário, excluir concorrentes inovadores e eficientes do mercado de navegadores de internet (internet browsers), além de possibilitar à Microsoft resguardar seu domínio sobre o mercado de sistemas operacionais.

432 "The integration of new functionality into platform software is a common practice and that wooden application of per se rules in this litigation may cast a cloud over platform innovation for PCs, network computers and information appliances." United States v. Microsoft Corp., 253 F.3d at 77 (D.C. Cir. 2001).

${ }^{433}$ Ao final, a Corte de Apelação acabou não analisando o mérito da questão, limitando-se a afirmar que a análise per se seria inadequada, tendo em vista a ausência de "experiência considerável" sobre o mercado de softwares, o que exigiria uma investigação mais aprofundada com base na regra da razão, levando em consideração possíveis eficiências decorrentes da integração tecnológica. Logo após sua decisão, o caso foi devolvido ao District Court para que fosse realizada uma análise mais aprofundada pela regra da razão. Como não houve apelação à Suprema Corte, o processo acabou sendo arquivado após um acordo entre o DOJ e a Microsoft.

434 "In fact, there is merit to Microsoft's broader argument that Jefferson Parish's consumer demand test would chill innovation to the detriment of consumers by preventing firms from integrating into their products new functionality previously provided by standalone products and hence, by definition, subject to separate consumer demand." United States v. Microsoft Corp., 253 F.3d at 70 (D.C. Cir. 2001).
} 
patenteadas utilizadas na fabricação de $\mathrm{CDs}^{435} \mathrm{O}$ tribunal federal reverteu a decisão administrativa proferida pela International Trade Commission (ITC) que considerou o pacote de licenças como ilícito per se, sob o argumento de que a Philips teria imposto o licenciamento de patentes consideradas não essenciais como condição para o licenciamento das patentes essenciais. ${ }^{436} \mathrm{O}$ tribunal federal enfatizou os benefícios do pacote de licenças, tais como a redução de custos de transação e de custos de administração e monitoramento das patentes, e distinguiu entre licenças que vinculam somente patentes das licenças que vinculam patentes e produtos não protegidos por direitos de propriedade intelectual, de modo que somente estas últimas poderiam ser consideradas ilícitas per se, de acordo com os precedentes da Suprema Corte. ${ }^{437}$ O tribunal também concluiu que não houve coerção, isto é, os licenciados não foram forçados a adquirir as licenças de patentes não essenciais, já que além da aceitação dos termos do acordo de licenciamento, que nada mais era do que uma "simples promessa de não ingressar com ação de infração de patentes", não foram sequer obrigados a empregar essas patentes na fabricação dos CDs e tampouco proibidos de usar tecnologias concorrentes. ${ }^{438}$

Os casos acima mencionados vão ao encontro do entendimento contido nas Diretrizes de 1995, no sentido de que as licenças casadas e pacotes de licenças devem ser analisados sob a regra da razão, isto é, que seja feita a análise de seus eventuais efeitos anticoncorrenciais e a possibilidade de que sejam compensados por significativas eficiências e benefícios pró-competitivos. ${ }^{439}$

Na União Europeia, a abordagem da Comissão para a análise antitruste das licenças casadas e pacotes de licenças, nos termos do Artigo 101, segue a mesma linha

${ }^{435}$ U.S. Philips Corp. v. International Trade Commission, 424 F.3d 1179 (Fed. Cir. 2005), cert. denied sub nom. Princo Corp. v. U.S. Philips Corp., 126 S. Ct. 2899 (2006).

${ }^{436} \mathrm{O}$ pacote de licenças obrigava os licenciados a pagar royalties com base na quantidade de CDs fabricados, independentemente da quantidade de patentes que os licenciados efetivamente utilizavam. Quando diversos licenciados estrangeiros pararam de efetuar o pagamento dos royalties, a Philips ingressou com uma reclamação junto à FTC alegando que os licenciados estavam importando CDs em violação às suas patentes. Os licenciados invocaram a doutrina da patent misuse como defesa, alegando que a Philips teria forçado o licenciamento de patentes que não eram essenciais para a fabricação dos CDs como condição para o licenciamento das patentes essenciais. A ITC então concluiu que o pacote de licenças da Philips constituía ilícito per se, de modo que suas patentes não poderiam ser impostas aos licenciados.

${ }^{437}$ U.S. Philips Corp. v. ITC, 424 F.3d 1187-89.

${ }^{438}$ Ibidem, 1189-90.

${ }^{439}$ De acordo com o item 5.3 das Diretrizes de 1995: "The Agencies would be likely to challenge a tying arrangement if: (1) the seller has market power in the tying product, (2) the arrangement has an adverse effect on competition in the relevant market for the tied product, and (3) efficiency justifications for the arrangement do not outweigh the anticompetitive effects". 
adotada pelas Diretrizes de 1995, levando em consideração os efeitos anticoncorrenciais e possíveis eficiências pró-competitivas que possam justificar a prática restritiva. De fato, as Diretrizes de 2004 reconhecem que uma licença casada pode ser pró-competitiva quando o produto vinculado for necessário para garantir a exploração satisfatória da tecnologia licenciada, ou mesmo para assegurar que a produção, nos termos do acordo de licenciamento, atenda aos padrões de qualidade desejados pelo licenciante. ${ }^{440}$ Assim, quando a restrição recair nas proibições contidas no Parágrafo $1^{\circ}$ do Artigo 101 do TFUE, as condições previstas no Parágrafo $3^{\circ}$ do mesmo dispositivo provavelmente serão atendidas, mesmo que as participações de mercado das partes excedam os limites da isenção em bloco.

A Comissão também pode analisar a venda ou licença casada como abuso de posição dominante, nos termos do Artigo 102 do TFUE, quando a prática resultar no fechamento do mercado e consequente exclusão dos rivais. Nesse caso, a Comissão deverá comprovar os seguintes elementos: (i) domínio do vendedor sobre o mercado do produto vinculante; (ii) existência de um produto vinculado separado do produto vinculante; (iii) coerção, isto é, que os consumidores foram forçados a adquirir o produto vinculado juntamente com o produto vinculante; (iv) efeitos restritivos sobre a concorrência no mercado do produto vinculado; e (v) ausência de justificativas objetivas.

No caso Microsoft, o antigo Tribunal de Primeira Instância (atual Corte Geral), confirmou a decisão da Comissão no sentido de que a Microsoft violou o Artigo 102 do TFUE ao condicionar a venda do sistema operacional Windows à aquisição simultânea do Windows Media Player (WMP), aplicativo de mídia que permite ao usuário transmitir e baixar conteúdos digitais de áudio e vídeo. ${ }^{441}$ Ao aplicar o teste acima mencionado, a Comissão concluiu que: (i) a Microsoft detinha mais de $90 \%$ do mercado relevante de sistemas operacionais para computadores para uso pessoal (PCs); (ii) o Windows e o aplicativo WMP são produtos separados; (iii) a Microsoft negou aos consumidores a opção de adquirir o Windows sem o WMP; (iv) a venda casada eliminou a concorrência no mercado de aplicativos de mídia; e (v) não havia justificativas objetivas para a conduta.

\footnotetext{
${ }^{440}$ Cf. Diretrizes de 2004, parágrafos 194 e 195. Justificativas pró-competitivas nas licenças casadas foram aceitas pela Comissão nos Casos IV/31.208, Rich Products/Jus Rol, OJ 1987 No. L 52, p. 51; IV/31.498, Delta Chemie/DDD, OJ 1988 No. L 309, p. 34; e IV/32.736, Moosehead/Whitbread, OJ 1990 No. L 100, p. 32.

${ }^{441}$ Caso T-201/04 Microsoft v Commission (Julgamento de 17 de setembro de 2007).
} 
O Tribunal de Primeira Instância concordou com a conclusão da Comissão no sentido de que a eliminação da concorrência no mercado relevante de aplicativos de mídia foi facilitada pela presença de externalidades indiretas de redes, permitindo que a Microsoft estabelecesse o WMP como o formato padrão para o desenvolvimento de produtos complementares. Assim, provedores de conteúdo digital e desenvolvedores de softwares seriam incentivados a ofertar produtos complementares compatíveis com o WMP, uma vez que assim alcançariam praticamente todos os usuários de PCs. Em consequência, os consumidores seriam naturalmente atraídos pelo WMP, em razão da maior disponibilidade de conteúdo e softwares complementares para esse produto, dificultando a presença de aplicativos de mídia rivais no mercado. ${ }^{442}$

\subsubsection{Restrições sobre royalties}

Em geral, titulares de direitos de propriedade intelectual possuem ampla liberdade para negociar a base de cálculo de royalties e suas formas de pagamento em acordos de licenciamento. ${ }^{443}$ Royalties são normalmente baseados na quantidade de produtos fabricados pelo licenciado ou nas receitas obtidas com as vendas. Entretanto, autoridades antitruste norte-americanas e europeias poderão intervir em determinadas situações nas quais os royalties são cobrados de forma a restringir a concorrência, o que pode ocorrer em pelo menos dois casos: (i) quando continuam sendo cobrados royalties após a expiração da patente (post-expiration royalties); e (ii) quando a base de cálculo dos royalties inclui a venda total de produtos, independentemente do fato de alguns produtos não serem protegidos por direitos de propriedade intelectual ou não utilizarem a tecnologia licenciada (total-sales royalties).

\footnotetext{
${ }^{442}$ Ao concordar com as conclusões da Comissão sobre o "fenômeno" dos efeitos de rede nesse caso, o Tribunal de Primeira Instância afirmou que: "The Court considers that the Commission was correct to find that such a phenomenon existed in the present case and to find that it was on the basis of the percentages of installation and use of media players that content providers and software developers chose the technology for which they would develop their own products (recital 879 to the contested decision). The Commission correctly stated, first, that those operators tended primarily to use Windows Media Player as that allowed them to reach the very large majority of client PC users in the world and, second, that the transmission of content and applications compatible with a given media player was in itself a significant competitive factor, since it increased the popularity of that media player, and, in turn, favoured the use of the underlying media technology, including codecs, formats (including DRM) and server software (recitals 880 and 881 to the contested decision)". Caso T-201/04 Microsoft v Commission (Julgamento de 17 de setembro de 2007), parágrafo 1062.

443 "A patent empowers the owner to exact royalties as high as he can negotiate with the leverage of that monopoly." Brulotte v. Thys Co., 379 U.S. 29 (1964).
} 
No caso Brulotte v. Thys, Inc., de 1964, a Suprema Corte dos Estados Unidos considerou que a cobrança de royalties após a expiração da patente constitui ilícito per se no contexto da doutrina da patent misuse. ${ }^{444}$ Nesse caso, a Suprema Corte entendeu que essa prática seria uma forma de "alavancar" (leverage) o poder de monopólio para além do período de proteção da patente: "the exaction of royalties for use of a machine after the patent has expired is an assertion of monopoly power in the post-expiration period when (...) the patent has entered the public domain". Após essa decisão, os tribunais inferiores, nas mais diversas circunstâncias, passaram a negar a validade de cláusulas contratuais contendo cobrança de royalties pelo uso de tecnologias cujas patentes já expiraram, quando resultarem na extensão ou "alavancagem" do direito exclusivo para além do prazo legal. $^{445}$

No entanto, esse entendimento sempre foi objeto de críticas por parte de juízes e especialistas. No caso Scheiber v. Dolby Laboratories, Inc. ${ }^{446}$, o Juiz Posner escreveu ao tribunal (Seven Circuit) para expressar discordância com o tratamento per se dado pela Suprema Corte no caso Brulotte ao sugerir que o acordo de licenciamento não poderia estender a exclusividade conferida pela patente para além de seu prazo legal, já que os termos do acordo não seriam oponíveis a terceiros. ${ }^{447}$ Ademais, quanto mais longo for o prazo de amortização dos royalties, menores serão os valores anuais de royalties que o titular da patente poderá cobrar pelo uso da invenção. ${ }^{448}$ De fato, o tribunal concordou com esse entendimento ao afirmar que a duração da patente fixa o limite do poder de seu titular para obter royalties, não importando se cobrará um percentual maior durante um período mais curto ou um percentual menor durante um período mais longo: “(...) charging royalties beyond the term of the patent does not lengthen the patentee's monopoly; it merely alters the timing of royalty payments". ${ }^{49}$ Mesmo assim, o tribunal acabou aplicando a regra contida no caso Brulotte, reconhecendo que somente a Suprema Corte possui a prerrogativa de modificar seus precedentes.

\footnotetext{
${ }^{444}$ Brulotte v. Thys Co., 379 U.S. 29 (1964).

${ }^{445}$ Cf. ABA Section of Antitrust Law. Intellectual Property and Antitrust Handbook. ABA Publishing, 2007, p. 223.

${ }^{446} 393$ F. 3d 1014 (7th Cir. 2002).

${ }^{447}$ Scheiber v. Dolby Laboratories, Inc., 393 F. 3d 1014 (7th Cir. 2002).

448293 F.3d, 1017-18. Posner já havia manifestado essa opinião no caso USM Corp. v. SPS Technologies, 694 F.2d 505, 510-11 (7th Cir. 1982).

${ }^{449} 293$ F.3d, 1017-18.
} 
Por outro lado, a regra estabelecida no caso Brulotte não se aplica quando múltiplas patentes foram licenciadas e ainda resta pelo menos uma patente em vigor após a expiração das demais, desde que as partes tenham concordado mutuamente com os termos do pacote de licenças. ${ }^{450}$ Em casos desse tipo, alguns tribunais norte-americanos já aceitaram estruturas de pagamento de royalties definindo um percentual maior durante a vigência de determinadas patentes, aplicando-se um percentual menor de royalties pósexpiração por conta de patentes ainda em vigor ou know-how e segredos de negócios que tenham sido licenciados simultaneamente. ${ }^{451}$ De qualquer modo, o tema ainda gera muita controvérsia nos tribunais norte-americanos, não sendo claras as situações em que a cobrança de royalties pós-expiração da patente será considerada ilícito per se, de acordo com a regra aplicada no caso Brulotte pela Suprema Corte.

Quanto aos royalties calculados com base na totalidade das vendas dos produtos, independentemente de incluírem produtos não protegidos pela patente licenciada, somente em determinadas circunstâncias essa prática será considerada ilícita no contexto da doutrina da patent misuse. No caso Automatic Radio Manufacturing Co. v. Hazeltine Research, envolvendo um pacote de licenças de patentes para a fabricação de equipamentos de transmissão de rádio, a Suprema Corte norte-americana concluiu que a cobrança de royalties calculados com base em percentual de vendas dos equipamentos, independentemente da utilização das patentes licenciadas, não constitui ilícito per se. ${ }^{452}$

Alguns anos mais tarde, a Suprema Corte acabou esclarecendo seu entendimento ao julgar o caso Zenith Corp. v. Hazeltine Research, que também envolveu um pacote de licenças de patentes e a cobrança de royalties baseados na totalidade das vendas. A Suprema Corte considerou ser abusivo condicionar o licenciamento de patentes ao pagamento de royalties sobre vendas de produtos que não incorporem a invenção

\footnotetext{
450 "If the Rockform decision is taken as holding that a package license, including both important and unimportant patent, is misuse per se when there is no diminution in royalty, or provision for termination, after expiration of an important patent, we respectfully disagree (...) The relative importance of the patents has no significance if a licensee is given the choice to take a patent alone or in combination on reasonable terms. Freedom of choice is the controlling question." Sunrise Med. HHG v. AirSep Corp., 95 F. Supp. 2d 348, 458 (W.D. Pa. 2000). "Brulotte has been inapplicable to package licensing agreements containing expired patents if the licensee was not coerced to enter the arrangement." A.C. Aukerman Co. v. R.L. Chaides Constr., 29 U.S.O.Q.2D (BNA) 1054, 1058 (N.D. Cal. 1993).

${ }^{451}$ Hull v. Brunswick Corp., 704 F.2d 1195 (10 ${ }^{\text {th }}$ Cir. 1983).

452 "We cannot say that payments of royalties according to an agreed percentage of the licensee's sales is unreasonable. Sound business judgments could indicate that such payment represents the most convenient method of fixing the business value of the privileges granted by the licensing agreement." Automatic Radio Manufacturing Co. v. Hazeltine Research, 339 U.S. 827834 (1950).
} 
patenteada. ${ }^{453}$ No entanto, ressaltou que essa base de cálculo de royalties somente será lícita se for estabelecida mediante acordo entre as partes, e não por imposição do titular da patente. $^{454}$ Isso significa que o elemento "coerção" cumpre um papel importante na determinação da ilicitude da conduta.

No caso Microsoft I, o DOJ celebrou acordo judicial com a Microsoft determinando a cessação da prática de licenciar o sistema operacional Windows aos fabricantes de computadores mediante o pagamento de royalties calculados com base na totalidade de computadores vendidos, independentemente de o Windows estar ou não instalado. ${ }^{455}$ Assim, caso o fabricante desejasse vender um computador com outro sistema operacional, teria de pagar royalties duas vezes, uma para a Microsoft e outra para seu concorrente. De acordo com o DOJ, essa prática aumentou os custos dos rivais no mercado de sistemas operacionais, uma vez que os fabricantes preferiam vender computadores com o Windows a pagar royalties duplamente.

Na União Europeia, a Comissão parece adotar uma abordagem menos rigorosa do que os tribunais norte-americanos em casos de royalties cobrados após a expiração da patente. No caso Boussois/Interpane, a Comissão considerou que uma obrigação de pagar royalties pós-expiração não viola o Parágrafo $1^{\circ}$ do Artigo 101 do TFUE. De acordo com a Comissão, essa obrigação seria similar a uma obrigação de pagar uma quantia fixa dividida em diversas parcelas, de modo que algumas poderiam vir a ser pagas após os direitos de propriedade intelectual já terem ingressado em domínio público. Esse entendimento é confirmado pelas Diretrizes de 2004, que acrescentam que, após a expiração do direito de propriedade intelectual, quaisquer terceiros poderão explorar legalmente a tecnologia em questão e concorrer com as partes do acordo de licenciamento, o que elimina a possibilidade de efeitos anticoncorrenciais. ${ }^{456}$

\footnotetext{
453 “ (...) just as the patent's leverage may not be used to extract from the licensee a commitment to purchase, use, or sell other products according to the desires of the patentee, neither can that leverage be used to garner as royalties a percentage share of the licensee's receipts from sales of other products; in either case, the patentee seeks to extend the monopoly of his patent to derive a benefit not attributable to use of the patent's teachings." Zenith Radio Corp. v. Hazeltine Research, Inc., 395 U.S. 100135 (1969).

454 "If convenience of the parties rather than patent power dictates the total-sales royalty provision, there are no misuse of the patents and no forbidden conditions attached to the license." Zenith Radio, 395 U.S. 100135 (1969).

${ }^{455}$ United States v. Microsoft Corp., 56 F. $3 d 1448$ (D.C. Cir. 1995).

${ }^{456}$ As Diretrizes assim estabelecem: "Nowithstanding the fact that the block exemption only applies as long as the technology is valid and in force, the parties can normally agree to extend royalty obligations beyond the period of validity of the licensed intellectual property rights without falling foul of Article 81(1). Once
} 
Quanto aos royalties cobrados com base na totalidade de vendas, a abordagem da Comissão e do TJUE é muito semelhante à adotada no caso Zenith Radio pela Suprema Corte norte-americana. No caso Windsurfing, ao reverter a decisão da Comissão, o TJUE considerou lícita a cobrança de royalties com base no preço líquido de venda de pranchas completas de windsurfing, ainda que somente a estrutura de mastreação fosse protegida por patente e o valor das pranchas fosse muito mais elevado do que o produto patenteado. ${ }^{457} \mathrm{~A}$ Comissão havia concluído que esse método de cálculo de royalties violava o Parágrafo $1^{\circ}$ do Artigo 101 do TFUE, já que permitiria à Windsurfing induzir o licenciado a recusar a venda de pranchas separadas do produto patenteado, de modo a estender seu direito exclusivo a um produto não protegido. O TJUE concluiu que, além de ser difícil calcular o valor da estrutura de mastreação separada da prancha, a forma de cálculo de royalties não teria como objetivo restringir a venda de mastros sem a respectiva prancha, uma vez que a Windsurfing poderia cobrar o mesmo valor de royalties, independentemente do método de cálculo escolhido, bastando estabelecer um percentual mais elevado baseado apenas no valor dos mastros.

Atualmente, a Comissão adota uma postura liberal em matéria de royalties baseados na totalidade das vendas. As Diretrizes de 2004 deixam claro que nos casos em que a tecnologia licenciada for um insumo a ser integrado no produto final, o fato de os royalties serem calculados com base no preço do produto final não dá origem à restrição da concorrência, desde que esse produto incorpore a tecnologia licenciada. ${ }^{458}$

\subsubsection{Grantback}

A cláusula grantback (ou retrolicenciamento) é uma obrigação inserida no acordo de licenciamento para assegurar ao licenciante o direito de explorar os direitos de propriedade intelectual sobre melhorias ou aprimoramentos desenvolvidos pelos licenciados a partir da tecnologia inicialmente licenciada. A cláusula grantback pode impor aos licenciados a obrigação de conferir licenças exclusivas ou não exclusivas sobre essas melhorias ao licenciante, ou mesmo a cessão definitiva do direito de propriedade

these rights expire, third parties can legally exploit the technology in question and compete with the parties to the agreement. Such actual or potential competition will normally suffice to ensure that the obligation in question does not have appreciable anti-competitive effects". Diretrizes de 2004, parágrafo 159.

${ }^{457}$ Windsurfing International Inc. v Commission, [1986] ECR 611, parágrafos 61-67.

${ }^{458}$ Diretrizes de 2004, parágrafo 156. 
intelectual correspondente. ${ }^{459}$ Essas cláusulas podem resultar em efeitos pró-competitivos, principalmente quando não conferirem exclusividade ao licenciante, já que permitem às partes do acordo de licenciamento compartilhar os custos e benefícios de futuras inovações desenvolvidas a partir da contribuição da tecnologia inicial do licenciante e das melhorias realizadas pelo licenciado. Trata-se de importante instrumento de estímulo à inovação e à transferência de tecnologia. ${ }^{460}$ Ademais, como as melhorias desenvolvidas pelos licenciados podem tornar obsoleta a tecnologia inicialmente licenciada, as cláusulas de grantback permitem assegurar que o licenciante não será excluído do mercado. ${ }^{461}$

Preocupações do ponto de vista antitruste podem ocorrer quando a cláusula grantback resulta na redução dos incentivos dos licenciados para investir em atividades de inovação. Se a cláusula grantback obrigar o licenciado a conferir ao licenciante o direito exclusivo de explorar a propriedade intelectual sobre as melhorias realizadas, os incentivos do licenciado para investir em pesquisa e desenvolvimento a partir da tecnologia licenciada poderão ser drasticamente reduzidos ou totalmente eliminados, já que não haverá qualquer retorno desses investimentos. ${ }^{462}$ Além disso, cláusulas de grantback com exclusividade podem estender de forma indevida o poder de mercado do licenciante, permitindo-lhe controlar e acumular todas as melhorias e aprimoramentos desenvolvidos por seus licenciados durante e após a vigência do acordo de licenciamento e dos direitos de propriedade intelectual licenciados. Desse modo, caso o licenciante detenha poder de mercado no mercado relevante do produto ou da tecnologia licenciada, a cláusula de grantback com exclusividade poderá resultar em efeitos adversos sobre a concorrência dinâmica, reduzindo o processo de inovação.

\footnotetext{
${ }^{459}$ Cf. item 5.6 das Diretrizes de 1995.

${ }^{460}$ De acordo com o item 5.6 das Diretrizes de 1995: "Grantbacks can have pro-competitive effects, especially if they are nonexclusive. Such arrangements provide a means for the licensee and the licensor to share risks and reward the licensor for making possible further innovation based on or informed by the licensed technology, and both promote innovation in the first place and promote the subsequent licensing of the results of the innovation".

${ }^{461}$ No caso Transparent-Wrap Machine, a Suprema Corte norte-americana ressaltou que: "An improvement patent may, on expiration of the basic patent, be the key to a whole technology. One who holds it may therefore have a considerable competitive advantage (...) One who uses one patent to acquire another is not extending his patent monopoly to articles governed by the general law and as respects which neither monopolies nor restraints of trade are sanctioned. He is indeed using one legalized monopoly to acquire another legalized monopoly". Transparent-Wrap Machine v. Stokes \& Smith Co., 329 U.S. 637648 (1947).

${ }^{462}$ Cf. HOVENKAMP, Herbert. Federal Antitrust Policy: The Law of Competition and its Practice. 3rd ed. Saint Paul, Minn.: Thomson West, 2005, p. 251.
} 
Em geral, cláusulas de grantback são analisadas sob a regra da razão pelas autoridades antitruste e tribunais norte-americanos. ${ }^{463}$ Ao estabelecer os critérios para análise de cláusulas de grantback sob a regra da razão, as Diretrizes de 1995 demonstram que o foco estará nos potenciais efeitos adversos resultantes da redução dos incentivos à inovação, assim como nos potenciais benefícios pró-competitivos decorrentes do aumento dos incentivos à disseminação da tecnologia:

An important factor in the Agencies' analysis of a grantback will be whether the licensor has market power in a relevant technology or innovation market. If the Agencies determine that a particular grantback provision is likely to reduce significantly licensees' incentives to invest in improving the licensed technology, the Agencies will consider the extent to which the grantback provision has offsetting procompetitive effects, such as (1) promoting dissemination of licensees' improvements to the licensed technology, (2) increasing the licensors' incentives to disseminate the licensed technology, or (3) otherwise increasing competition and output in a relevant technology or innovation market. (...) In addition, the Agencies will consider the extent to which grantback provisions in the relevant markets generally increase licensors' incentives to innovate in the first place. ${ }^{464}$

Na União Europeia, a cláusula de grantback exclusiva (licença ou cessão exclusiva de melhorias) é tratada como restrição excluída, nos termos dos Artigos 5.1(a) e 5.1(b) do Regulamento de 2004, o que significa que não poderá beneficiar-se da isenção em bloco, mas também não será considerada restrição do tipo hard-core. De qualquer modo, a restrição poderá beneficiar-se da isenção nos termos do Parágrafo $3^{\circ}$ do Artigo 101 do TFUE, caso atenda aos requisitos exigidos no dispositivo. ${ }^{465}$ Contudo, essa regra é válida apenas para melhorias consideradas dissociáveis, ou seja, que podem ser utilizadas pelo licenciado sem violar o direito de propriedade intelectual do licenciante. Por outro lado, caso as melhorias sejam indissociáveis, a cláusula de grantback com exclusividade não será considerada restritiva da concorrência nos termos do Parágrafo $1^{\circ}$ do Artigo 101 do TFUE, uma vez que essas melhorias já não poderiam de qualquer forma ser exploradas pelo licenciado sem autorização do licenciante. Assim, cláusulas de grantback exclusivas

\footnotetext{
${ }^{463}$ Cf. Transparent-Wrap Machine v. Stokes \& Smith Co., 329 U.S. 637(1947), p. 648.

${ }^{464}$ Diretrizes de 1995, item 5.6.

${ }^{465}$ Cf. Diretrizes de 2004, parágrafos 109 a 111.
} 
aplicáveis a melhorias indissociáveis poderão beneficiar-se da isenção em bloco, caso as participações de mercado das partes atendam aos limites estabelecidos no Regulamento de $2004 .^{466}$

Ao analisar cláusulas de grantback, alguns fatores deverão ser levados em consideração pelas autoridades e tribunais norte-americanos e europeus: (i) grau do poder de mercado e extensão da concorrência no mercado da tecnologia; (ii) escopo e duração da obrigação; (iii) se as partes são concorrentes; (iv) se há pagamento de royalties em contrapartida ao licenciamento dos direitos sobre as melhorias; (v) se o licenciado retém algum direito decorrente da propriedade intelectual sobre as melhorias; (vi) efeitos da obrigação sobre os incentivos à inovação do licenciado; (vii) possibilidade de cláusulas de grantback inseridas em acordos de licença cruzada e pool de patentes restringirem a concorrência e o processo de inovação; dentre outros fatores. ${ }^{467}$

\subsubsection{Cláusulas de não impugnação ("non-challenge clauses")}

As cláusulas de não impugnação, ou "non-challenge clauses", são aquelas que proíbem o licenciado de questionar a validade de direitos de propriedade intelectual que sejam objeto de acordos de licenciamento, aplicável especialmente a patentes. Essas cláusulas são vistas com desconfiança sob a ótica antitruste, já que podem servir para encobrir patentes inválidas sobre tecnologias que deveriam estar em domínio público, causando prejuízos à concorrência e ao processo de inovação. ${ }^{468}$ Soma-se a essa preocupação, o fato de os licenciados terem normalmente maiores condições para avaliar se os direitos de propriedade intelectual são ou não inválidos, já que efetivamente utilizam esses direitos no desempenho de suas atividades comerciais ou industriais.

Os Estados Unidos e a União Europeia adotam abordagens sensivelmente diferentes em relação ao tema. Antes de 1969, a doutrina do "licensee estoppel" era aplicada pelos tribunais norte-americanos para impedir os licenciados de questionar a validade de um direito de propriedade intelectual licenciado, após terem se aproveitado dos

\footnotetext{
466 Ibid.

${ }^{467}$ Cf. NGUYEN, Tu Thanh. Competition Law, Technology Transfer and the TRIPS Agreement. Cheltenham: Edward Elgar, 2010, p. 91- 92; SOMMER, Evelyn. Antitrust Aspects of Intellectual Property Licensing Arrangements. The Licensing Journal, Apr. 2010, p. 21.

${ }^{468}$ Nesse sentido, as Diretrizes de 2004 estabelecem que: "In the interest of undistorted competition and in conformity with the principles underlying the protection of intellectual property, invalid intellectual property rights should be eliminated. Invalid intellectual property stifles innovation rather than promoting it". Diretrizes de 2004, parágrafo 112.
} 
benefícios da licença. ${ }^{469}$ Desse modo, nos termos dessa doutrina, não era ilícito inserir uma cláusula de não impugnação em acordos de licenciamento. Essa realidade mudou a partir da decisão da Suprema Corte norte-americana no caso Lear, julgado em $1969 .{ }^{470}$ Nesse caso, após ponderar interesses públicos e privados, o Supremo reconsiderou seus precedentes que deram base para a doutrina do "licensee estoppel", concluindo que não seria apropriado proibir o licenciado de impugnar a validade do direito de propriedade intelectual licenciado. Em consequência, após essa decisão, cláusulas de não impugnação passariam a ser consideradas inválidas.

Tribunais inferiores já interpretaram a regra do caso Lear de maneiras diferentes. O Federal Circuit, por exemplo, entendeu que o licenciado não pode se beneficiar da regra contida no caso Lear, a não ser que: (i) efetivamente interrompa o pagamento dos royalties; e (ii) notifique o licenciante para informar que a interrupção dos pagamentos tem como fundamento a invalidade do direito de propriedade intelectual licenciado. Contudo, a Suprema Corte, em recente decisão no caso MedImmune, interpretou a legislação patentária norte-americana no sentido de que o licenciado não precisaria atender a esses pré-requisitos para beneficiar-se da regra do caso Lear. ${ }^{471}$ Nesse sentido, o licenciado pode questionar judicialmente a validade da patente, sem deixar de efetuar os pagamentos ou de cumprir integralmente suas obrigações nos termos do acordo de licenciamento. Caso a ação declaratória de invalidade da patente seja procedente, cessará imediatamente a obrigação de efetuar pagamentos de royalties. Por outro lado, em caso de improcedência da ação, caberá ao licenciado arcar com os custos processuais.

Ainda que as cláusulas de não impugnação sejam consideradas nulas, à luz da regra contida no caso Lear, os tribunais norte-americanos relutam em caracterizá-las como misuse ou ilícito antitruste. ${ }^{472}$ De qualquer modo, sob o prisma concorrencial, essas cláusulas dificilmente seriam consideradas ilícitas per se, sendo provavelmente analisadas sob a regra da razão, tendo em vista a possibilidade de serem justificadas com base em

\footnotetext{
${ }^{469} \mathrm{Em}$ termos gerais, a doutrina do "licensee estoppel" determinava que, ao celebrar um acordo para utilizar uma patente detida pelo licenciante, o licenciante reconhece expressamente a validade dessa propriedade e, por essa razão, está "impedido" ("estopped") de contestar sua validade no futuro. Cf. ABA Section of Antitrust Law. Intellectual Property and Antitrust Handbook. ABA Publishing, 2007, p. 231.

${ }^{470}$ Lear, Inc. v. Adkins, 395 U.S. 653 (1969), p. 670-671.

${ }^{471}$ MedImmune, Inc. v. Genetech, Inc., 127 S.Ct 764 (2007), p. 777.

${ }^{472}$ Cf. Panther Pumps \& Equip. v. Hydrocraft, Inc., 468 F.2d 255 ( $7^{\text {th }}$ Cir. 1972), p. 232; Wallace Clark \& Co. v. Acheson Indus., 401 F. Supp. 637 (S.D.N.Y 1975), aff'd, 532 F.2d 846 (2 ${ }^{\text {nd }}$ Cir. 1976); Congoleum Indus v. Armstrong Cork Co., 366 F. Supp. 220, 233 (E.D. Pa. 1973), aff'd, 510 F.2d 334 (3 ${ }^{\text {rd }}$ Cir. 1975).
} 
critérios de eficiência. Afinal, embora inibam os licenciados a questionarem a validade dos direitos de propriedade intelectual licenciados, essas cláusulas acabam servindo como incentivo para que o licenciante transfira sua tecnologia. Ademais, essas cláusulas podem efetivamente acelerar, ao invés de retardar, questionamentos a direitos de propriedade intelectual inválidos, pois impõem aos potenciais licenciados o dever de avaliar de forma cuidadosa a validade desses direitos antes de celebrarem o acordo de licenciamento. ${ }^{473}$

Na União Europeia, a Comissão já adotou uma postura bem rigorosa no tratamento do tema. Em alguns casos, a Comissão concluiu que a inclusão de uma cláusula de não impugnação seria uma restrição à concorrência por impedir o licenciado de remover "um obstáculo à sua liberdade de ação". ${ }^{474}$ No caso Davidson Rubber, a Comissão determinou a remoção de uma cláusula de não impugnação, reconhecendo que o licenciado tinha as melhores condições para detectar as fragilidades de um direito de propriedade intelectual, não devendo, portanto, ser impedido de questionar sua validade. ${ }^{475}$ No caso Windsurfing, o TJUE confirmou a decisão da Comissão, que considerou ilícita per se uma cláusula de não impugnação, sob o argumento de que o interesse público requer a manutenção de uma concorrência essencialmente livre, com a consequente remoção de um “monopólio" que talvez tenha sido indevidamente concedido ao licenciante. ${ }^{476}$

Todavia, esse posicionamento rígido da Comissão e do TJUE foi sendo aos poucos flexibilizado. Nesse contexto, as autoridades reconhecem que o direito de impugnar pode ser utilizado de forma oportunista por um licenciado, como pretexto para descumprir suas obrigações contratuais concernentes ao pagamento de royalties. ${ }^{477}$ No caso Bayer and Henneke v Süllhöfer, o TJUE entendeu que antes de verificar se uma cláusula de não impugnação deve ser ou não proibida, é necessário levar em consideração o contexto jurídico e econômico do acordo de licenciamento no qual a cláusula foi inserida. ${ }^{478}$

\footnotetext{
${ }^{473}$ Cf. Saturday Evening Post Co. v. Rumbleseat Press, Inc., 816 F.2d 1191 ( $7^{\text {th }}$ Cir. 1987), p. 1200.

${ }^{474}$ Cf. Decision 79/86/EEC, Vassen/Moris, OJ 1979 L 19/32, parágrafo 14.

${ }^{475}$ Cf. Case IV/17.448, Davidson Rubber, OJ 1972 No. L 143, p. 31.

${ }^{476}$ Cf. Case 193/83, Windsurfing International Inc. v Commission, [1986] ECR 611, parágrafos 92-93.

477 Cf. ANDERMAN, Steve. The New EC Competition Law Framework for Technology Transfer and IP Licensing, in: DREXL, Josef (Ed.). Research Handbook on Intellectual Property and Competition Law. Cheltenham: Edward Elgar, 2008, p. 136.

${ }^{478}$ Case 65/86, Bayer AG and Maschinenfabrik Hennecke GmbH v Heinz Süllhöfer, [1988] ECR 5249, parágrafo 21 .
} 
De acordo com o Artigo 5.1(c) do Regulamento de 2004, a cláusula de não impugnação é classificada como "restrição excluída", não podendo, portanto, beneficiar-se da isenção em bloco. ${ }^{479}$ Por outro lado, o dispositivo reconhece expressamente o direito do licenciante de rescindir o acordo de licenciamento, caso o licenciado conteste a validade do direito de propriedade intelectual objeto do acordo. O reconhecimento da prerrogativa do licenciante de rescindir o contrato tem como objetivo evitar impugnações frívolas ou sem causa, decorrentes de comportamentos oportunistas por parte do licenciado. Desse modo, em caso do término do acordo de licenciamento, o licenciado estará na mesma posição em relação a terceiros, ficando por sua conta e risco a utilização do direito de propriedade intelectual impugnado. ${ }^{480}$

\subsection{Licenças cruzadas e pools de patentes}

Licenças cruzadas e pools de patentes (ou compartilhamentos de patentes) são arranjos contratuais entre dois ou mais titulares de diferentes direitos de propriedade intelectual sobre tecnologias, com o objetivo de licenciarem tais direitos entre si ou para terceiros. Embora as licenças cruzadas e pools de patentes recebam tratamento unificado pelas Diretrizes de 1995, o fato é que ambos apresentam características e problemas distintos que devem ser levados em consideração pelas autoridades antitruste. ${ }^{481}$

Por meio de uma licença cruzada típica, dois titulares de patentes conferem licenças recíprocas entre si, de modo a permitir que cada uma das partes utilize individualmente as patentes da outra. ${ }^{482}$ As licenças cruzadas são muito comuns em mercados concentrados, dominados por um pequeno número de agentes econômicos detentores de substanciais portfólios de patentes, como ocorre, por exemplo, em alguns segmentos do mercado de semicondutores. Nesse contexto, patentes detidas por diferentes empresas podem vir a ser essenciais para o desenvolvimento de um novo produto ou

\footnotetext{
${ }^{479}$ Deve-se ressaltar, no entanto, que a Comissão tem uma posição favorável em relação às cláusulas de não impugnação relativas a know-how, já que uma vez divulgado pode ser impossível ou muito difícil recuperar o know-how licenciado. Nesses casos, uma obrigação de não contestação do know-how licenciado pode promover a disseminação de nova tecnologia, em especial, ao permitir que os licenciantes mais fracos concedam licenças a licenciados mais fortes sem temer uma contestação após o licenciado ter absorvido o know-how. Cf. Diretrizes de 2004, parágrafo 112.

${ }^{480}$ Cf. Diretrizes de 2004, parágrafo 113.

${ }^{481}$ ULLRICH, Hans. Patent Pools - Policy and Problems, in: DREXL, Josef (Ed.). Research Handbook on Intellectual Property and Competition Law. Cheltenham: Edward Elgar, 2008, p. 140.

${ }^{482}$ Cf. SPRINGMAN, Christopher Jon. The Intersection of Patents and Antitrust Law, in: ELHAUGE, Einer (Ed.). Research Book on the Economics of Antitrust. Cheltenham: Edward Elgar, 2012, p. 370.
} 
tecnologia. Contudo, essas patentes muitas vezes se sobrepõem, o que ocorre quando a exploração de qualquer uma delas acaba infringindo as demais, situação conhecida como "blocking patents" ou patentes de bloqueio. ${ }^{483}$ Licenças cruzadas entre os diferentes titulares de patentes, permitindo-lhes a exploração de tecnologias complementares, poderá ser a solução para impedir que patentes de bloqueio reduzam a inovação, além de evitar custosas disputas judiciais. $^{484}$

De acordo com as Diretrizes de 1995, licenças cruzadas são na maioria das vezes pró-competitivas, uma vez que permitem a integração de tecnologias complementares, a redução de custos de transação, a eliminação de posições de bloqueio, além de evitar os custos e incertezas de litígios. ${ }^{485}$ Por outro lado, esses acordos podem servir como esquemas de fixação de preços e divisão de mercado entre concorrentes. Para amenizar os riscos de eliminação da concorrência, licenças cruzadas devem ser estabelecidas com isenção de pagamento de royalties entre as partes ou mediante o pagamento de royalties recíprocos com base em uma soma fixa. ${ }^{486}$ Os riscos concorrenciais serão maiores quando os royalties recíprocos forem estabelecidos por unidade vendida, já que podem facilitar esquemas de fixação de preços entre concorrentes no mercado do produto a jusante. ${ }^{487}$

\footnotetext{
${ }^{483}$ Considerando a existência de inovações incrementais ou cumulativas nesses segmentos, a concessão de patentes que resultam em melhorias de tecnologias já patenteadas poderá levar a situações de patentes de bloqueio. Sobre o tema, BRANCHER explica que: "A patente de melhoria pode assim ser considerada subordinada à anterior, chamada dominante. Ambas são consideradas patentes de bloqueio entre si. Explicase: a patente subordinada não pode ser explorada sem infringir a patente dominante. Apesar da concessão das patentes de bloqueio servir como incentivo à inovação (caso contrário apenas o detentor da patente dominante poderia melhorá-la, o que certamente poderia trazer ineficiências ao processo, além de um monopólio legal e possivelmente econômico que duraria o período da concessão), dúvida não há quanto aos problemas legais que dela decorrem". BRANCHER, Paulo. Direito da Concorrência e Propriedade Intelectual: Da Inovação Tecnológica ao Abuso de Poder. São Paulo: Singular, 2010, p. 136.

${ }^{484}$ Cf. MOTTA, Massimo. Competition Policy: Theory and Practice. Cambridge University Press, 2004, p. 206.

${ }^{485}$ Cf. item 5.5. das Diretrizes de 1995.

${ }^{486}$ De acordo com SHAPIRO: "If two patent holders are the only companies realistically capable of manufacturing products that utilize their intellectual property, a royalty-free cross license is ideal from the point of view of competition. But any cross-license is superior to a world in which the patent holders fail to cooperate, since neither could proceed with actual production and sale in that world without infringing on the other's patents". SHAPIRO, Carl. Navigating the Patent Thicket: Cross-License, Patent Pools, and Standard Setting, in: Innovation, Policy and Economy. Cambridge, Mass: National Bureau of Economic Research, 2004, p. 123.

${ }^{487}$ Cf. parágrafo 80 das Diretrizes de 2004, com a seguinte ressalva: “(...) the Commission will only treat cross licenses with reciprocal running royalties as price fixing where the agreement is devoid of any procompetitive purpose and therefore does not constitute a bona fide licensing arrangement. In such cases where the agreement does not create any value and therefore has no valid business justification, the arrangement is a sham and amounts to a cartel".
} 
No caso Line Material, a Suprema Corte norte-americana considerou ilícito per $s e$ um acordo de licenças cruzadas que resultou na fixação de preços entre concorrentes. ${ }^{488}$ Nesse caso, a Southern States Equipment Corporation detinha uma patente sobre certos dispositivos de proteção de circuitos elétricos. Essa patente bloqueava a patente incremental posteriormente obtida pela Line Material, que aprimorava a invenção desenvolvida pela Southern. A Suprema Corte reconheceu que a licença cruzada entre as partes seria necessária para que cada empresa pudesse explorar a tecnologia protegida por ambas as patentes, uma vez que uma bloqueava a outra. Por meio da licença cruzada, a Southern conferiu uma licença exclusiva para a Line Material explorar sua patente, fixando os preços dos dispositivos que incorporavam as patentes. Desse modo, a Suprema Corte concluiu que o acordo em si não seria ilícito, mas sim sua utilização para a fixação de preços entre concorrentes: "It is not the cross-licensing to promote efficient production which is unlawful. (...) The unlawful element is the use of the control that such crosslicensing gives to fix prices". 489

As licenças cruzadas podem incluir diversas cláusulas restritivas ancilares, tais como exclusividade territorial, restrições de campo de aplicação (field-of-use), obrigações de não concorrência, grantback, dentre outras, devendo normalmente ser analisadas sob a regra da razão, tendo em vista seus potenciais efeitos pró-competitivos. Deve-se ressaltar que muitos acordos de licença cruzada resultam de acordos judiciais ou extrajudiciais entre partes em litígio, sobretudo quando envolvem patentes de bloqueio. Mesmo sendo desejáveis, esses acordos podem restringir a concorrência quando as partes estiverem em relação horizontal. $^{490}$

Os pools de patentes, ou compartilhamento de patentes, são arranjos contratuais entre dois ou mais titulares de patentes que lhes permitem a exploração conjunta de seus direitos exclusivos, formando um pacote de licenças a ser ofertado a terceiros interessados. ${ }^{491}$ Esses arranjos contratuais possuem estruturas normalmente mais complexas do que as licenças cruzadas, podendo assumir as mais diversas formas. Em geral, as partes transferem seus direitos de propriedade intelectual para uma joint venture

\footnotetext{
${ }^{488}$ United States v. Line Material Co., 333 U.S. 287 (1948).

489333 U.S. 287 (1948), p. 315.

${ }^{490}$ Cf. United States v. Singer Manufacturing Co., 374 U.S. 174 (1963).

491 Os pools de patentes não devem ser confundidos com joint ventures de pesquisa e desenvolvimento, estruturadas para repartir custos e riscos associados às atividades de pesquisa e desenvolvimento.
} 
ou empresa independente que deverá administrar o portfólio de patentes em nome e por conta das partes, e ofertar licenças a terceiros. Mas não são raros os casos em que esse papel é desempenhado diretamente por uma das partes. Alguns pools podem incluir licenças cruzadas, especialmente quando as partes também atuam nos mercados de produto a jusante, concernentes à fabricação de produtos a partir da tecnologia licenciada pelo pool. $^{492}$

Os pools de patentes são especialmente relevantes quando um grande número de empresas detém diferentes patentes que, embora resultem em situações de bloqueio, são complementares para o desenvolvimento de determinados produtos e tecnologias, tal como ocorre em mercados de biotecnologia, tecnologia da informação e telecomunicações. Qualquer agente econômico que desejar utilizar as patentes para ingressar no mercado com um novo produto ou tecnologia deverá obter licenças individuais junto a cada uma das empresas titulares das patentes, resultando em substanciais custos de transação. A consequência disso é o fenômeno denominado "patent ticket", definido por Carl SHAPIRO como: "a dense web of overlapping intellectual property rights that a company must hack its way through in order to actually commercialize new technology". 493 Esse elevado número de patentes pode ser prejudicial à inovação, já que seus titulares terão condições de cobrar royalties excessivos e discriminatórios, ou recusar negociar licenças com potenciais concorrentes.

Ressalte-se que nessas circunstâncias, isto é, quando as patentes sobre tecnologias complementares estão dispersas entre várias empresas diferentes, as licenças cruzadas passam a ser inviáveis e custosas, além de impedirem o ingresso de terceiros que não detenham direitos de propriedade intelectual para oferecer em troca. Em algumas situações, as tecnologias são tão complexas e fragmentadas, que a identificação de seus respectivos titulares passa a ser uma tarefa quase impossível. ${ }^{494}$ Desse modo, as empresas

\footnotetext{
${ }^{492}$ Cf. ULLRICH, Hans. Patent Pools - Policy and Problems, in: DREXL, Josef (Ed.). Research Handbook on Intellectual Property and Competition Law. Cheltenham: Edward Elgar, 2008, p. 139.

493 SHAPIRO, Carl. Navigating the Patent Thicket: Cross Licenses, Patent Pools, and Standard-Setting, in: JAFFE, Adam B.; LERNER, Josh; STERN, Scott (Ed.). Innovation Policy and the Economy, v. 1. Cambridge, MA: The MIT Press, p. 120.

494 "Pooling arrangements between some or most, possibly even all the holders of complementary technologies are one way to overcome the fragmentation of complex technology, in particular of system technologies. Patents help identify the fragments and their owners, and they allow the owners to pool these fragments on commercial terms while retaining some - broad or narrow - control, just as they generally enable trade in technology markets." ULLRICH, Hans. Patent Pools - Policy and Problems, in: DREXL,
} 
titulares das patentes podem formar um pool para licenciar seus direitos exclusivos num pacote único para terceiros interessados, facilitando o ingresso de novos agentes econômicos inovadores no mercado e ampliando a concorrência dinâmica. Ademais, um pool de patentes complementares servirá também para manter um valor único de royalties pelo pacote como um todo.

É imperioso destacar que pools de patentes também são comuns no contexto da cooperação entre agentes econômicos para a uniformização de padrões tecnológicos, processo normalmente coordenado por entidades de padronização (Standard-Setting Organizations - SSO). ${ }^{495}$ A cooperação entre concorrentes efetivos ou potenciais para a definição de uma tecnologia padrão, como ocorreu nos casos do CD, DVD, protocolos de internet, TV digital, Blue Ray, dentre outros, possibilita a integração entre tecnologias complementares, muitas vezes protegidas por patentes de bloqueio detidas por diferentes empresas. $^{496}$ Uma vez transferidas essas patentes para um pool, quaisquer terceiros interessados em aplicar o padrão tecnológico na fabricação de produtos ou no

Josef (Ed.). Research Handbook on Intellectual Property and Competition Law. Cheltenham: Edward Elgar, 2008, p. 143.

${ }^{495}$ Padrões de indústria podem ser: (i) de jure, quando forem regulamentados por lei ou por organismo público ou privado; ou (ii) de facto, quando o próprio mercado se volta para uma tecnologia, que acaba se tornando dominante na indústria, agregando um elevado número de usuários, tal como ocorre na presença de externalidades de rede. Quando o mercado se volta para determinada tecnologia, criando um padrão de facto, quaisquer tecnologias incompatíveis tendem a desaparecer do mercado, levando a situações de lock-in effect e impondo substanciais custos de troca aos consumidores. A cooperação entre empresas para a definição de um padrão técnico ajuda a evitar esse problema, pois garante a interface e convergência entre tecnologias complementares, reduzindo as incertezas dos consumidores, que terão maiores possibilidades de escolha. Ao comentar os benefícios da cooperação para definição de padrões técnicos, MOTTA afirma que: "The main benefit of common standards is that consumers will belong to the same network. (...) An additional benefit is that consumers do not risk being stranded with a product that turns out to be abandoned later. An standard war can create a lot of uncertainty as to which standard will win, resulting in consumers delaying their purchase for fear of being stuck with the wrong product, and the market not taking off when it could. A common standard also implies fiercer competition, since consumers will face greater choice within the same standard (although smaller choice across standards (...). Instead, if standards were different, consumers would tend to be locked-in with a given product standard, and competition would be reduced". MOTTA, Massimo. Competition Policy: Theory and Practice. Cambridge University Press, 2004, p. 207.

${ }^{496}$ A cooperação para a definição de padrões tecnológicos implica um tradeoff entre a concorrência ex ante e a concorrência ex post. Enquanto a primeira é eliminada, já que as empresas deixarão de competir para estabelecer o padrão dominante, a segunda é intensificada, pois permite que diferentes empresas concorram para desenvolver produtos e tecnologias complementares ao padrão dominante. Em termos de análise antitruste, deve-se indagar como o mercado evoluiria na ausência da cooperação. Uma possibilidade é a de que múltiplos produtos incompatíveis prevaleceriam no mercado. Outra possibilidade seria o mercado voltarse para um determinado produto, criando um padrão de facto, como muitas vezes ocorre. De acordo com SHAPIRO, a cooperação resultaria em significantes eficiências, por evitar incompatibilidades entre produtos, eliminar uma possível "guerra" pela determinação de um padrão dominante de facto, causando incertezas aos usuários, além de permitir a participação de múltiplas empresas, o que seria improvável na ausência da cooperação. SHAPIRO, Carl. Navigating the Patent Thicket: Cross-License, Patent Pools, and Standard Setting, in: Innovation, Policy and Economy. Cambridge, Mass.: National Bureau of Economic Research, 2004, p. 123. 
desenvolvimento de tecnologias complementares poderão ter acesso a um pacote único contendo as licenças necessárias para tanto. ${ }^{497}$

Por outro lado, assim como ocorre com as licenças cruzadas, esses arranjos podem produzir efeitos anticoncorrenciais, como nos casos de fixação coletiva de preços ou restrição coordenada da produção entre os concorrentes que sejam membros do pool. ${ }^{498}$ Ressalte-se que nos Estados Unidos, pools de patentes, assim como as licenças cruzadas, são normalmente analisados ao abrigo da Seção 1 do Sherman Act, sob a regra da razão, muito embora fixações puras de preço e divisão de mercados possam ser tratadas como ilícitos per se ${ }^{499}$ Contudo, há casos em que pools de patente são analisados no contexto da Seção 2 do Sherman Act, o que ocorre quando são formados para a criação ou manutenção de poder de monopólio em determinado mercado relevante, especialmente quando os membros do pool atuam também nos mercados a jusante dos produtos fabricados a partir da tecnologia licenciada. ${ }^{500}$

A União Europeia confere um tratamento diferenciado às licenças cruzadas e pools de patentes. Somente as licenças cruzadas poderão beneficiar-se da isenção em bloco, nos termos do Regulamento de 2004, excluindo-se expressamente os pools de patentes. Por outro lado, as licenças conferidas pelo pool a terceiros interessados podem beneficiar-se da isenção em bloco. Ademais, as Diretrizes de 2004 estabelecem os critérios para aferição da legalidade de pools de patentes, cuja abordagem é muito semelhante à adotada pelos tribunais norte-americanos. Ressalte-se que, tal como ocorre nos Estados Unidos, esses arranjos podem também resultar em abuso de posição dominante, nos termos do Artigo 102 do TFUE.

Pode-se afirmar que a análise antitruste de licenças cruzadas e pools de patentes deve levar em consideração os seguintes fatores: (i) a natureza das tecnologias

\footnotetext{
${ }^{497}$ Para uma análise mais aprofundada sobre a relação entre propriedade intelectual e padronização técnica cf. LEMLEY, Mark A. Intellectual Property Rights and Standard-Setting Organizations (Apr. 1, 2002). California Law Review (online), v. 90, 2002; UC Berkeley Public Law Research Paper n. 84. Disponível em: http://ssrn.com/abstract=310122 ou http://dx.doi.org/10.2139/ssrn.310122; e ZIBETTI, Fabíola Wüst. Relação entre Normalização Técnica e Propriedade Intelectual no Ordenamento Jurídico Internacional, Tese (Doutorado) - Programa de Pós-Graduação em Direito Internacional - Faculdade de Direito da Universidade de São Paulo, São Paulo, 2012.

${ }^{498}$ Cf. Diretrizes de 1995, item 5.5.

${ }^{499}$ Cf. Diretrizes de 1995, item 5.5.

${ }^{500}$ Cf. Rambus, Inc., FTC Docket No. 9302, Opinion of the Commission, Aug. 2, 2006.
} 
agrupadas; (ii) a existência de restrições individuais impostas a terceiros; e (iii) aspectos institucionais de organização do pool. Passamos a examinar esses fatores a seguir.

\subsubsection{Natureza das tecnologias agrupadas}

Assim como as licenças cruzadas, os pools de patentes podem servir para eliminar posições de bloqueio entre diferentes titulares de patente, o que ocorre quando o uso de uma patente necessariamente infringe as demais. No caso Standard Oil Co. v. United States, de 1931, a Suprema Corte examinou um acordo entre diversas companhias de petróleo para formar um pool contendo diferentes patentes que protegiam processos de "craqueamento" de petróleo bruto para extração de gasolina. ${ }^{501}$ As partes fixaram um valor único de royalties para o licenciamento dessas patentes e criaram uma fórmula para a distribuição dos valores arrecadados entre os membros do pool. Ao analisar o caso sob a regra da razão, a Suprema Corte concluiu que o pool serviu para eliminar posições de bloqueio causadas pelas patentes em questão, já que cada membro do pool detinha uma patente de processo de craqueamento de petróleo que necessariamente infringia as demais. Além disso, a Suprema Corte observou que o intercâmbio de patentes, acompanhado da divisão de royalties conforme o valor atribuído por cada parte ao seu direito exclusivo, pode ser necessário para evitar que o progresso tecnológico seja impedido pela ameaça de litígios de infração patentária. ${ }^{502}$

O crucial para a determinação da licitude do acordo foi o fato de que as partes apenas definiram o valor de royalties aplicável ao licenciamento das patentes, mas não fixaram os preços do produto final. Outro aspecto relevante diz respeito ao fato de que as partes não impediram o uso de tecnologias de craqueamento alternativas entre os membros do pool. Por outro lado, a Suprema Corte ressaltou que caso as partes dominassem o mercado e formassem um pool contendo patentes concorrentes, certamente haveria violação das normas antitruste. ${ }^{503}$

\footnotetext{
${ }^{501}$ Standard Oil Co. v. United States, 283 U.S. 163 (1931).

502 "An interchange of patent rights and a division of royalties according to the value attributed by the parties to their respective patent claims is frequently necessary if technical advancement is not to be blocked by threatened litigation. If the available advantages are upon on reasonable terms to all manufacturers desiring to participate, such interchange may promote rather than restrain competition." Standard Oil Co. v. United States, 283 U.S. 163 (1931), p. 171.

503 "Where domination exists, a pooling of competing process patents (...) is beyond the privileges conferred by the patents and constitutes a violation of the Sherman Act." Standard Oil Co. v. United States, 283 U.S. 163 (1931), p. 172.
} 
Desde então, o caso Standard Oil passou a ser referência para as autoridades antitruste e tribunais norte-americanos na análise dos riscos concorrenciais de pools de patentes. Nesse contexto, as chances de que pools de patentes levantem preocupações do ponto de vista antitruste serão menores quando forem constituídos apenas por patentes complementares, em vez de patentes concorrentes ou substitutas.

Patentes de tecnologias complementares são aquelas cuja combinação permite a fabricação de um produto ou a realização de um processo de forma eficiente. Podem ou não resultar em posições de bloqueio, mas jamais serão substitutas entre si. Isso porque as patentes substitutas podem ser utilizadas de forma separada na fabricação de um produto ou realização de um processo, constituindo, portanto, tecnologias concorrentes, ou seja, alternativas disponíveis ao licenciado fora do pool. A preocupação das autoridades antitruste decorre do fato de que, quando as tecnologias agrupadas no pool são substitutas, os royalties serão suscetíveis a se tornar mais elevados, já que a ausência de concorrência entre as tecnologias em questão elimina as possibilidades de escolha dos licenciados. Por outro lado, quando as tecnologias agrupadas são complementares, o acordo reduz os custos de transação, podendo dar origem a royalties mais reduzidos, uma vez que as partes terão condições de fixar um valor único para o conjunto das tecnologias. ${ }^{504}$

O grau de complementaridade entre as patentes agrupadas foi o principal fator levado em consideração pelo DOJ na aprovação das "Business Review Letters" envolvendo pools que continham as patentes necessárias para aplicação dos padrões tecnológicos MPEG-2 (compressor de áudio e vídeo), DVD-ROM e DVD-Vídeo, e tecnologia $3 \mathrm{G}^{505}$ Ao aprovar os pools descritos nessas cartas, o DOJ observou que as partes agruparam apenas patentes complementares que eram consideradas essenciais para o cumprimento dos padrões tecnológicos em questão, excluindo expressamente as patentes consideradas não essenciais. ${ }^{506}$

\footnotetext{
${ }^{504}$ Cf. parágrafos 216 e 217 das Diretrizes de 2004.

${ }^{505}$ Cf. Letter from Joel I. Klein to Gerrard R. Beeney, Esq., June 26, 1997 (MPEG-2); Letter from Joel I. Klein to Gerrard R. Beeney, Esq., Dec. 16, 1998 (DVD-ROM); Business Review Letter issued by Joel I. Klein, June 10, 1999 (DVD-Video); Letter issued by Charles James, Nov. 12, 2002 (3G). Disponíveis em: http://www.usdoj.gov/atr/public/busreview. Acesso em: 15 jun. 2012.

${ }^{506}$ De acordo com as Diretrizes de 2004, há uma sutil diferença entre patentes complementares e essenciais (cf. parágrafo 216). Duas tecnologias são complementares, mas não substitutas entre si, quando ambas são necessárias para fabricar o produto ou realizar o processo a que as tecnologias se aplicam. Inversamente, duas tecnologias são substitutas entre si quando cada uma delas permite ao licenciado fabricar o produto ou realizar o processo a que as tecnologias se aplicam. Uma tecnologia é considerada essencial, em oposição a não essencial, se não houver qualquer substituta para ela entre as tecnologias agrupadas e entre as outras e se
} 
Ressalte-se que a aprovação das "Business Review Letters" pelo DOJ estabeleceu algumas diretrizes para a análise da licitude de pools de patentes. Desse modo, esses arranjos contratuais não deverão resultar em preocupações do ponto de vista antitruste quando estiverem presentes os seguintes elementos: (i) as patentes agrupadas são essenciais para o cumprimento de um padrão tecnológico; (ii) os pacotes de licenças conferidos a terceiros são não exclusivos, isto é, as patentes também podem ser licenciadas por cada um dos respectivos titulares de forma individual; (iii) um especialista independente é nomeado para determinar quais patentes são essenciais; (iv) as licenças são conferidas de forma não discriminatória, de modo que o portfólio de patentes é oferecido de maneira igualitária para quaisquer interessados, evitando-se favorecimentos aos membros do pool que também atuem nos mercados a jusante dos produtos fabricados a partir das tecnologias licenciadas; (v) os licenciados são livres para utilizar ou desenvolver tecnologias alternativas capazes de concorrer com as tecnologias licenciadas pelo pool; e (vi) cláusulas grantback podem ser incluídas apenas para obrigar os membros do pool a conferirem licenças não exclusivas e não discriminatórias de patentes essenciais ou complementares.

É claro que pools de patentes que não cumpram exatamente com todos os elementos acima indicados não serão necessariamente considerados ilícitos do ponto de vista antitruste. Tais elementos constituem meras diretrizes a conferir maior segurança jurídica na estruturação de pools de patentes. A importância dessa ponderação reside no fato de que nem sempre a distinção entre patentes complementares e substitutas pode ser facilmente estabelecida, uma vez que as tecnologias envolvidas podem ser em parte substitutas e em parte complementares. ${ }^{507}$ Em alguns casos, pools podem combinar

a tecnologia em questão constituir uma parte necessária do conjunto das tecnologias agrupadas para fabricar os produtos ou realizar os processos a que o agrupamento se aplica. Uma tecnologia para a qual não há substituto permanece essencial, enquanto a tecnologia for abrangida por pelo menos um direito de propriedade intelectual válido. Desse modo, as patentes essenciais são necessariamente complementares entre si e indispensáveis para a fabricação do produto ou realização do processo. Patentes complementares podem não ser essenciais se não forem indispensáveis para esse fim. No caso $M P E G-2$, patentes essenciais foram definidas da seguinte forma: (i) quando não há alternativas técnicas para cada patente incluída no pool; e (ii) somente podem ser úteis para produtos que contenham a tecnologia quando estiverem agrupadas. Cf. Letter from Joel I. Klein, Acting Assistant Attorney General, Antitrust Division, Department of Justice, to Garrard R. Beeney, Esq. (June 26, 1997). Disponível em: http://www.usdoj.gov/atr/public/busreview/1170.htm. Acesso em: 15 jun. 2012.

507 De acordo com as Diretrizes de 2004, na hipótese de pool envolvendo tecnologias complementares e substitutas, em havendo ganhos de eficiência resultantes da integração das duas tecnologias e os licenciados pretenderem utilizá-los, as tecnologias em questão serão tratadas como complementares, mesmo que sejam parcialmente substituíveis entre si (parágrafo 218). Eventuais riscos anticoncorrenciais nesses casos podem ser minimizados se as patentes também estiverem disponíveis individualmente, fora do pacote de licenças ofertado pelo pool. 
patentes complementares que não sejam essenciais para a fabricação do produto ou até incluir algumas patentes para as quais existam tecnologias substitutas fora do pool. Há também situações em que patentes essenciais incluídas no pool deixam de ser essenciais ao longo do tempo, em razão do desenvolvimento de tecnologias alternativas ou substitutas por terceiros, o que poderá levar ao fechamento do mercado, já que as vantagens dos custos de transação oferecidos pelo pool tendem a atrair os licenciados para o pacote de tecnologias compartilhadas. Esses fatores não apenas aumentam os riscos de efeitos anticoncorrenciais, como tornam mais complexa a análise antitruste desses arranjos contratuais. $^{508}$

Em todo o caso, desde que não se trate de mera colusão para fixação de preços, o que ocorre quando somente tecnologias substitutas são compartilhadas, os pools de patentes deverão ser sempre analisados sob a regra da razão, ponderando-se eventuais efeitos anticoncorrenciais e benefícios pró-competitivos. ${ }^{509}$

Exemplo de pool de patentes considerado ilícito por conter apenas tecnologias substitutas, foi o acordo formado entre a Summit Technology, Inc. e a VISX, Inc., duas concorrentes que fabricavam equipamentos médicos utilizados em cirurgias de correção de visão a laser. ${ }^{510}$ A FTC considerou que a Summit e a VISX agruparam suas patentes sobre tecnologias concorrentes no pool e concederam poderes de veto recíprocos sobre as decisões de licenciar as patentes para quaisquer terceiros, fixando um valor para cada procedimento cirúrgico desempenhado pelas sublicenciadas. De acordo com a FTC, o pool eliminou a concorrência entre as duas participantes nos mercados do produto (equipamentos cirúrgicos) e da tecnologia licenciada, impedindo a entrada de potenciais

\footnotetext{
${ }^{508}$ Para o caso em que um pool contenha algumas patentes não essenciais (aquelas para as quais existem patentes substitutas fora do pool ou que não são necessárias para fabricar um ou vários dos produtos a que $\mathrm{o}$ pool diga respeito ), as Diretrizes de 2004 estabelecem os seguintes critérios de compensação que poderiam servir para justificar um acordo celebrado nessas circunstâncias: (i) existência de razões pró-concorrenciais para incluir tecnologias não essenciais; (ii) os licenciantes mantêm a liberdade de conceder licenças relativas às suas respectivas tecnologias de forma independente; (iii) tecnologias agrupadas que envolvam múltiplas aplicações podem ser disponibilizadas de forma independente com relação a campos de aplicação específicos que estejam fora do escopo do pool; e (iv) quando possível, em vez de oferecer apenas o pacote completo, as tecnologias agrupadas devem ser disponibilizadas também em pacotes menores, mediante redução proporcional do valor dos royalties, o que possibilita a redução do risco de exclusão do mercado de tecnologias pertencentes a terceiros e que não são abrangidas pelo agrupamento (vide parágrafo 222).

${ }^{509}$ De acordo com as Diretrizes de 2004, pools envolvendo apenas tecnologias essenciais (e, por conseguinte, necessariamente complementares) não recaem na proibição do Parágrafo $1^{\circ}$ do Artigo 101 do TFUE, embora as licenças conferidas pelo pool a terceiros possam conter restrições suscetíveis de violar o referido dispositivo (parágrafo 220).

${ }^{510}$ In re Summit Tech., No. 9286, 63 Fed. Reg. 46,453 (Sep. 1, 1998). Disponível em:
} 
rivais, resultando no aumento dos custos para utilização das tecnologias: "Instead of competing with each other, the firms placed their competing patents in a patent pool and share the proceeds each and every time a Summit or VISX laser is used". 511 Após firmarem um acordo com a FTC para colocar fim ao processo, as partes concordaram em eliminar as restrições recíprocas impostas no licenciamento. De acordo com a FTC, o objetivo desse acordo era tornar a Summit e a VISX concorrentes efetivas na venda dos produtos e no licenciamento das respectivas patentes para suas rivais.

\subsubsection{Existência de restrições individuais impostas a terceiros}

Quando os membros de um pool de patentes detêm posição dominante nos mercados da tecnologia licenciada, os riscos de prejuízos à concorrência resultantes de restrições impostas nos acordos de licenciamento celebrados com terceiros serão maiores, especialmente quando os membros do pool também atuam nos mercados a jusante dos produtos fabricados com a tecnologia licenciada. Isso porque o compartilhamento de tecnologias nessas circunstâncias pode servir para criar barreiras à entrada de potenciais concorrentes capazes de desenvolver e ofertar tecnologias alternativas ou substitutas, assim como para impor royalties discriminatórios a determinados licenciados com o objetivo de obter vantagens competitivas nos mercados a jusante. ${ }^{512}$

Diante dos potenciais efeitos restritivos resultantes dos acordos de licenciamento firmados entre o pool e terceiros licenciados, as Diretrizes de 2004 estabelecem critérios que devem ser observados na análise de restrições individuais: (i) quanto mais forte for a posição de mercado dos membros do pool, mais elevados são os riscos de existirem efeitos anticoncorrenciais; (ii) os pools de patente que detenham uma forte posição no mercado devem ser abertos e não discriminatórios; e (iii) os pools de

\footnotetext{
http://www.ftc.gov/os/1998/03/summit.cmp.htm.

${ }^{511}$ Com o pool envolvendo patentes concorrentes ou substitutas, as partes eliminaram a concorrência (no mercado do produto e da tecnologia) que teria havido entre ambas na ausência do acordo. O objetivo do acordo era, então, possibilitar que ambas as empresas dividissem entre si os lucros de monopólio, tal como um cartel de preços.

512 As Diretrizes de 1995 reconhecem que pools formados por agentes econômicos dominantes podem resultar em fechamento do mercado para potenciais concorrentes: "In general, exclusion from a pooling or cross-licensing arrangement among competing technologies is unlikely to have anticompetitive effects unless (1) excluded firms cannot effectively compete in the relevant market for the good incorporating the licensed technologies and (2) the pool participants collectively possess market power in the relevant market. If these circumstances exist, the Agencies will evaluate whether the arrangement's limitations on participation are reasonably related to the efficient development and exploitation of the pooled technologies and will assess the net effect of those limitations in the relevant market" (item 5.5).
} 
patentes não devem excluir indevidamente tecnologias detidas por terceiros e nem limitar a criação de outros acordos de agrupamento. ${ }^{513}$

Conforme já mencionado, quando os membros do pool detêm posição dominante, as práticas restritivas impostas nos acordos de licenciamento celebrados com terceiros poderão também ser consideradas como práticas de monopolização (Seção 2 do Sherman Act) ou abuso de posição dominante (Artigo 102 do TFUE). ${ }^{514}$ Nessas circunstâncias, a imposição de royalties discriminatórios ou a recusa coletiva de licenciar as tecnologias compartilhadas podem resultar no fechamento do mercado e outros efeitos anticoncorrenciais nos mercados a jusante. ${ }^{515}$ Assim, para evitar esse tipo de situação, as Diretrizes de 2004 estabelecem que as licenças devem ser justas, não discriminatórias e não exclusivas, ressalvadas as hipóteses em que diferentes bases de cálculo de royalties são estabelecidas para diferentes usos ou para diferentes mercados de produtos fabricados a partir das tecnologias licenciadas. ${ }^{516}$

Outra preocupação das autoridades antitruste diz respeito aos efeitos de determinadas restrições sobre a inovação. Assim, devem ser evitadas cláusulas de exclusividade ou obrigações de não concorrência que impossibilitem os licenciados de obter licenças individuais diretamente junto aos titulares das patentes compartilhadas, ou mesmo de desenvolver ou explorar tecnologias concorrentes. As Diretrizes de 2004 ressaltam que obrigações de não concorrência impostas aos licenciados aumentam os riscos de exclusão do mercado das tecnologias desenvolvidas por terceiros, além de

\footnotetext{
${ }^{513}$ Diretrizes de 2004, parágrafo 224.

${ }^{514}$ No caso United States v. Krasnov, a Suprema Corte norte-americana entendeu que os membros de um pool de patentes violaram as Seções 1 e 2 do Sherman Act, já que as empresas eram as duas maiores concorrentes no segmento e utilizaram o acordo para controlar preços e excluir a concorrência. $\mathrm{O}$ acordo continha as seguintes restrições: (i) impedia qualquer membro do pool de licenciar terceiros sem o mútuo consentimento dos demais; (ii) alocava consumidores entre os membros do pool; (iii) estabelecia os preços a serem cobrados pelo licenciantes; e (iv) determinava que o licenciantes deveriam propor em conjunto ações de infração de patentes. Cf. United States v. Krasnov, 143 F. Supp. 184 (E.D. Pa. 1956).

515 Por exemplo, no caso Zenith Radio Corp. v. Hazeltine Research, a Suprema Corte norte-americana considerou que os membros de um pool de tecnologias utilizadas na fabricação de televisores e equipamentos de rádio violaram o Sherman Act ao recusarem conferir licenças apenas à Zenith. 395 U.S. 100 (1969).

${ }^{516}$ Cf. parágrafo 216 das Diretrizes de 2004. Ressalte-se que as Diretrizes de 1995 já previam que restrições desse tipo poderiam ser prejudiciais à inovação: "Another possible anticompetitive effect of pooling arrangements may occur if the arrangement deters or discourages participants from engaging in research and development, thus retarding innovation. For example, a pooling arrangement that requires members to grant licenses to each other for current and future technology at minimal cost may reduce the incentives of its members to engage in research and development because members of the pool have to share their successful research and development and each of the members can free ride on the accomplishments of other pool members" (item 5.5).
} 
impedir a criação de soluções tecnológicas concorrentes. ${ }^{517}$ Da mesma forma, cláusulas de grantback devem ser não exclusivas e limitadas aos melhoramentos ou aperfeiçoamentos que sejam indispensáveis ou importantes para a utilização das tecnologias agrupadas no pool, sejam eles desenvolvidos pelos membros do pool ou pelos licenciados. ${ }^{518}$

As Diretrizes de 2004 também abordam a possibilidade de que pools de patentes possam ser utilizados como "escudo" para impedir a contestação de eventuais patentes inválidas que tenham sido compartilhadas juntamente com patentes válidas, o que também poderá provocar efeitos deletérios sobre a inovação. Assim, os direitos de pôr termo a uma licença em caso de contestação pelo licenciado devem ficar limitados à patente cuja validade está sendo discutida, não devendo ser estendidos para as demais patentes de titularidade dos outros membros do pool. ${ }^{519}$

Nota-se que muitos desses elementos presentes nas Diretrizes de 2004 constam da análise das "Business Review Letters" pelo DOJ nos Estados Unidos, o que demonstra a forte influência da política antitruste norte-americana sobre a Comissão no que concerne ao tratamento de licenças cruzadas e pools de patentes.

\subsubsection{Enquadramento institucional que rege o pool de patentes}

De acordo com as Diretrizes de 2004, a forma pela qual um pool de patentes é criado, organizado e operado pode reduzir os riscos de que o acordo venha a restringir a concorrência. Assim, a restrição da concorrência será menos provável quando o processo de criação do pool for aberto a todos os interessados, representando diferentes interesses, em especial nos casos de cooperação para o desenvolvimento de um novo padrão tecnológico. Nessas circunstâncias, será mais provável que as condições de concessão de licenças, incluindo os royalties, sejam abertas e não discriminatórias, de modo a refletir o valor da tecnologia licenciada. ${ }^{520}$

\footnotetext{
${ }^{517}$ As Diretrizes de 2004 acrescentam ainda que quando o agrupamento de tecnologias abrange uma norma industrial de facto e quando as partes estão sujeitas a obrigações de não concorrência, o agrupamento desenvolve um risco específico de impedir a criação de tecnologias e normas novas e melhoradas. Diretrizes de 2004, parágrafo 227.

${ }^{518}$ Cf. Diretrizes de 2004, parágrafo 228.

${ }^{519}$ Cf. Diretrizes de 2004, parágrafo 229.

${ }^{520}$ Quando o pool é controlado apenas por representantes dos licenciantes, serão maiores os riscos de prejuízos à concorrência. Cf. Diretrizes de 2004, parágrafo 231.
} 
O envolvimento de especialistas ou peritos independentes na formação e funcionamento do pool pode ser um fator positivo, especialmente no que concerne à seleção das patentes consideradas essenciais para serem compartilhadas. Vimos que esse fator foi levado em consideração na análise das "Business Review Letters" pelo DOJ nos Estados Unidos. De acordo com as Diretrizes de 2004, as autoridades devem levar em consideração: (i) a forma como os especialistas ou peritos são selecionados e a natureza exata de suas funções; (ii) a independência dos especialistas ou peritos em relação às empresas que constituíram o agrupamento; e (iii) a experiência técnica desses profissionais para o desempenho de suas funções no âmbito do pool, que podem variar desde a análise da validade das patentes até a averiguação de seu caráter essencial para os objetivos do acordo. $^{521}$

As Diretrizes de 2004 também demonstram especial preocupação em evitar que pools de patentes facilitem a troca de informações comerciais sensíveis entre seus membros, tais como dados relativos a preços e custos de produção, o que pode levar a esquemas de colusão entre empresas concorrentes, especialmente em mercados oligopolizados. Desse modo, as autoridades devem levar em consideração a presença de mecanismos para impedir a troca de informações sensíveis entre os membros do pool. ${ }^{52}$

Finalmente, as Diretrizes de 2004 também recomendam que os mecanismos de solução de controvérsias sejam confiados a entidades ou pessoas independentes do pool e de seus membros, de modo a garantir que a resolução de litígios funcione de forma neutra. $^{523}$

\subsection{Condutas unilaterais de exclusão a partir da exploração de direitos de propriedade intelectual}

Condutas unilaterais de exclusão podem ser definidas como estratégias comerciais, praticadas por agentes econômicos dominantes, que têm o objetivo ou o efeito de excluir concorrentes de determinado mercado relevante. Esses abusos tendem a ter um efeito de fechamento no mercado, ou seja, podem limitar o acesso ao mercado de

\footnotetext{
${ }^{521}$ Cf. Diretrizes de 2004, parágrafos 232 e 233.

522 Cf. Diretrizes de 2004, parágrafo 234.

${ }^{523}$ Cf. Diretrizes de 2004, parágrafo 235.
} 
concorrentes existentes e potenciais, prejudicando indiretamente os consumidores. ${ }^{524}$ As condutas unilaterais de exclusão são tratadas no contexto das hipóteses de monopolização e tentativa de monopolização, nos termos da Seção 2 do Sherman Act, bem como hipóteses de abuso de posição dominante, ao abrigo do Artigo 102 do TFUE. ${ }^{525}$

Vimos que a Seção 2 do Sherman Act tem o objetivo de coibir as práticas restritivas unilaterais tendentes à monopolização dos mercados e tentativa de monopolização. ${ }^{526}$ A conduta de monopolização possui dois elementos: (i) a detenção de poder de monopólio em determinado mercado relevante ${ }^{527}$; e (ii) o exercício abusivo desse poder para excluir a concorrência. ${ }^{528}$ Ressalte-se que a obtenção de poder de monopólio não é por si só ilícita, a não ser que acompanhada de alguma conduta anticoncorrencial. ${ }^{529}$ Assim, não há que se falar em intervenção antitruste nas hipóteses em que um agente econômico obteve poder de monopólio por meios lícitos, seja em razão de superioridade

\footnotetext{
${ }^{524}$ Nos termos do Documento de Discussão da Comissão Europeia sobre abusos de exclusão, datado de dezembro de 2005: “(...) exclusionary abuses are behaviors by dominant firms which are likely to have a foreclosure effect on the market, i.e. which are likely to completely or partially deny profitable expansion in or access to a market to actual or potential competitors and which ultimately harms consumers". DG Competition Discussion Paper on the Application of Article 82 of the Treaty to Exclusionary Abuses. Dec. 2005, Brussels. Disponível em:
}

http://ec.europa.eu/comm/competition/antitrust/art82/discpaper2005.pdf.

${ }^{525}$ Ressalte-se que não há um conceito muito claro de práticas restritivas unilaterais de exclusão na literatura antitruste, conforme afirma HoVENKAMP: "Notwithstanding a century of litigation, the scope and meaning of exclusionary conduct under the Sherman Act remain poorly defined. No generalized formulation of unilateral or multilateral exclusionary conduct enjoys anything approaching universal acceptance". HOVENKAMP, Herbert. Exclusion and the Sherman Act, in: University of Chicago Law Review, v. 72, 2005, p. 148.

${ }^{526}$ Nos termos da Seção 2 do Sherman Act: "Every person who shall monopolize, or attempt to monopolize, or combine or conspire with any other person or persons, to monopolize any part of the trade or commerce among the several States, or with foreign nations, shall be deemed guilty of a felony (...)".

${ }^{527}$ Nos Estados Unidos, os termos "poder de monopólio" e "poder de mercado" não são considerados sinônimos. Enquanto o poder de mercado é definido como a capacidade de elevar os preços acima dos níveis que seriam cobrados num mercado competitivo (cf. NCAA v. Bd. of Regents of the Univ. of Okla., 468 U.S. 85, 109 n. 38 (1984)), poder de monopólio é compreendido como o poder de controlar preços e excluir a concorrência, o que requer um grau substancial de poder de mercado (cf. United States v. E. I. du Pont de Nemours \& Co. (Cellophane), 351 U.S. 377, 391 (1956)).

528 Nesse sentido, a Suprema Corte norte-americana identificou os dois elementos da conduta de monopolização como: “(1) the possession of monopoly power in the relevant market and (2) the willful acquisition or maintenance of that power as distinguished from growth or development as a consequence of a superior product, business acumen, or historic accident". Verizon Communications v. Law Offices of Curtis V. Trinko, 540 U.S. 398, 407 (2004); Aspen Skiing Co. v. Highlands Skiing Corp., 472 U.S. 585, 592-96, $602,605 \&$ n.32 (1985).

529 Já a conduta de tentativa de monopolização possui três elementos: (i) o alegado infrator praticou uma conduta anticoncorrencial com (ii) a intenção específica de monopolizar e (iii) com a probabilidade específica de obter poder de monopólio. Cf. Spectrum Sports v. McQuillan, 506 U.S. 447 (1993). Contudo, o requisito da "intenção" tem sido gradualmente abandonado pelos tribunais norte-americanos, que vêm entendendo que bastaria comprovar a probabilidade específica de sucesso. A recente decisão da Suprema Corte no caso Weyerhaeuser reflete a tendência de aplicar a Seção 2 do Sherman Act com base em critérios 
técnica, maior eficiência, ou diferenciação de produtos e serviços. ${ }^{530}$ Os tribunais norteamericanos também reconhecem que a perspectiva de obtenção de poder de monopólio constitui importante incentivo que não pode ser anulado, pois, "tendo sido incitado a concorrer, o concorrente bem-sucedido não deve ser prejudicado quando ganha". ${ }^{531}$

Já o Artigo 102 do TFUE trata das práticas restritivas que constituem abuso de posição dominante, que podem consistir nas seguintes hipóteses previstas no referido dispositivo: (a) imposição, de forma direta ou indireta, de preços de compra ou de venda ou outras condições de transação não equitativas; (b) limitação da produção, da distribuição ou do desenvolvimento técnico em prejuízo dos consumidores; (c) aplicação, relativamente a parceiros comerciais, de condições desiguais no caso de prestações equivalentes, colocando-os em desvantagem na concorrência; e (d) subordinação da celebração de contratos à aceitação, por parte dos outros contratantes, de prestações suplementares que, pela sua natureza ou de acordo com os usos comerciais, não possuem ligação com o objeto desses contratos.

O objetivo do dispositivo é proibir um agente econômico dominante de fortalecer sua posição no mercado recorrendo a meios outros que não aqueles baseados na concorrência por méritos. ${ }^{532}$ De forma semelhante à Seção 2 do Sherman Act, o Artigo 102 do TFUE requer a demonstração de dois elementos: (i) posição dominante no mercado único ou em substancial parte dele; e (ii) abuso dessa posição capaz de impactar o comércio entre os Estados-Membros. ${ }^{533}$ Conforme destacado pelos tribunais da União Europeia, abuso é um conceito objetivo que se refere ao comportamento de um agente

objetivos, com ênfase nos efeitos reais, e não em critérios subjetivos de intenção. Weyerhaeuser Co. v. RossSimmons Hardware Lumber Co., Inc., 127 S.Ct. 1069 (2007).

530 "It is settled law that this offense requires, in addition to the possession of monopoly power in the relevant market, 'the willful acquisition or maintenance of that power as distinguished from growth or development as a consequence of a superior product, business acumen, or historic accident'." Verizon Communications Inc. v. Law Offices of Curtis V. Trinko, LLP, 540 U.S. 398 (2004), p. 407.

531 "The successful competitor, having been urged to compete, must not be turned upon when he wins." United States v. Aluminum Co. of America, 148 F.2d 416 (2d Cir. 1945), p. 430.

${ }^{532}$ Cf. Case T-201/04 Microsoft v Commission, [2007] ECR II - 3601, parágrafo 1070; Case T-229/94, Deutsche Bahn v Commission, [1997] ECR II-1689, parágrafo 78; e Case C-62/86, AKZO v Commission, [1991] ECR I-3359, parágrafos 69-70.

533 O abuso de posição dominante será punido quando não for justificado de forma objetiva. Cf. Caso T201/04, Microsoft v Commission, [2007] ECR II-3601, parágrafo 1070; Caso T-229/94, Deutsche Bahn v Commission, [1997] ECR II-1689, parágrafo 78; e Caso C-62/86, AKZO v Commission, [1991] ECR I-3359, parágrafos 69-70. 
econômico detentor de posição dominante, que tem como finalidade ou efeito eliminar a concorrência. 534

Como se pode observar, as hipóteses de monopolização, nos termos da Seção 2 do Sherman Act, são comparáveis às hipóteses de abuso de posição dominante ao abrigo do Artigo 102 do TFUE. Entretanto, pode-se constatar que nos Estados Unidos apenas práticas unilaterais de exclusão são levadas em consideração, enquanto na União Europeia a Comissão e os tribunais comunitários também consideram condutas unilaterais de exploração, tendo em vista o disposto no Artigo 102(a) do TFUE. Se por um lado abusos de exclusão constituem condutas de agentes dominantes com o objetivo de excluir rivais e fechar o mercado, afetando indiretamente os consumidores, os abusos de exploração são aqueles por meio dos quais firmas dominantes exploram seu poder de mercado diretamente contra os consumidores, como ocorre, por exemplo, nas práticas que resultam na imposição de preços excessivos, muito embora essa forma de abuso tenha sido raramente condenada na União Europeia. ${ }^{535}$

Ademais, há claras diferenças entre as duas jurisdições no que concerne aos critérios e abordagens para a determinação do grau de poder de mercado necessário para a

\footnotetext{
534 “ (...) an abuse is an objective concept referring to the behavior of an undertaking in a dominant position which is such as to influence the structure of a market where, as a result of the very presence of the undertaking in question, the degree of competition is already weakened and which, through recourse to methods different from those governing normal competition in products or services on the basis of the transactions of commercial operators, has the effect of hindering the maintenance of the degree of competition still existing in the market or the growth of that competition." Case T-203/01, Manufacture Française des Pneumatiques Michelin v Commission, [2003] ECR II-4071, parágrafo 54; Case 85/76, Hoffmann-La Roche v Commission [1979] ECR 461, parágrafo 91; Case 322/81, Michelin v Commission [1983] ECR 3461, parágrafo 70; Case C-62/86 AKZO v Commission [1991] ECR I-3359, parágrafo 69; e Case T-228/97 Irish Sugar v Commission [1999] ECR II-2969, parágrafo 111.

${ }^{535}$ No caso United Brands, o TJUE considerou que um preço será excessivo se não tiver relação razoável com o valor econômico do produto. Desse modo, o Tribunal estabeleceu um teste para a configuração de preço excessivo como abuso de posição dominante nos termos do Artigo 102: (i) há uma diferença excessiva entre os custos efetivamente incorridos e o preço efetivamente cobrado; e (ii) o preço efetivamente cobrado é "injusto", tanto por si só, como quando comparado com produtos concorrentes. Case 27/76, United Brands $v$ Commission, [1978] ECR 207, parágrafo 250. Contudo, dadas as dificuldades em avaliar o que seria um preço "justo" e determinar o que seria excessivo, poucos casos de preços excessivos foram analisados pela Comissão. Nesse sentido, ElHAUGE e GERADIN afirmam que: "Because it is extremely difficult in practice to determine when a price is excessive and because the Commission does not want to engage in price control, there has been relatively little examination of high prices and other exploitative behavior by the Commission. The bulk of cases actually brought under Article 102 are for exclusionary abuses rather than exploitative abuses". ELHAUGE, Einer; Damien. Global Competition Law and Economics. 2nd ed. Oxford and Portland: Hart Publishing, 2011, p. 12.
} 
configuração de um ilícito antitruste, bem como para identificar as condutas suscetíveis de causar efeitos danosos sobre a concorrência e bem-estar dos consumidores. ${ }^{536}$

A esse respeito, cumpre ressaltar que uma das maiores dificuldades das autoridades antitruste e tribunais de todo o mundo é distinguir de forma precisa condutas legítimas baseadas na concorrência por méritos, ainda que resultem na exclusão de alguns rivais do mercado, e condutas abusivas de exclusão, cuja finalidade ou efeito é meramente a eliminação da concorrência. ${ }^{537}$ Diante dessas dificuldades, nota-se claramente uma preocupação das autoridades e tribunais norte-americanos em evitar intervir contra condutas de competição agressiva praticadas por monopolistas, que muitas vezes podem assemelhar-se a condutas abusivas de exclusão. ${ }^{538}$ Desse modo, os tribunais costumam ser cautelosos para evitar os riscos de condenações equivocadas de condutas que beneficiam a concorrência e os consumidores, ainda que tenham a aparência de condutas anticoncorrenciais, resultando no chamado erro de "falso positivo". 539

\footnotetext{
${ }^{536}$ É importante esclarecer que tanto nos Estados Unidos como na União Europeia, não há uma definição precisa sobre o grau de participação de mercado necessário para a configuração de poder de monopólio ou de posição dominante. O poder de monopólio foi definido pela Suprema Corte norte-americana como o poder de controlar preços ou excluir a concorrência. Cf. Kodak, 504 U.S., p. 481. A Suprema Corte já indicou que participações de mercado superiores a $65 \%$ seriam suficientes para a comprovação de poder de monopólio, sem especificar claramente limites mínimos. Cf. United States v. Aluminum Co. of America, 148 F.2d 416 (2d Cir. 1945), p. 424. Por outro lado, alguns tribunais inferiores consideraram necessária a presença de participação de pelo menos $50 \%$, de modo que é improvável a configuração de poder de monopólio a patamares inferiores a esse percentual. Na União Europeia, uma participação de mercado entre $40 \%$ e $45 \%$ pode ser suficiente para a determinação de posição dominante, o que indicaria uma abordagem menos rígida em comparação com os Estados Unidos. Cf. Case 27/76, United Brands v Commission, [1978] ECR 207, parágrafos 108-109. Contudo, de acordo com o Guidance Paper sobre as prioridades da Comissão na aplicação do Artigo 102 do TFUE às condutas abusivas de exclusão, a Comissão destaca que participações de mercado constituem apenas um ponto de partida para a análise da estrutura de mercado e a identificação de agentes econômicos dominantes, devendo essas ser interpretadas em conjunto com outros fatores, tais como a dinâmica dos mercados, diferenciação dos produtos, barreiras à expansão e entrada, poder de barganha dos compradores, dentre outros. Cf. Communication from the Commission - Guidance on the Commission's enforcement priorities in applying [Article 82 of the EC Treaty] to abusive exclusionary conduct by dominant undertakings, parágrafos 13-18.

537 "Whether any particular act of a monopolist is exclusionary, rather than merely a form of vigorous competition, can be difficult to discern: the means of illicit exclusion, like the means of legitimate competition, are myriad. The challenge for an antitrust court lies in stating a general rule for distinguishing between exclusionary acts, which reduce social welfare, and competitive acts, which increase it." United States v. Microsoft Corp., 253 F.3d 34 (D.C. Cir. 2001), p. 58.

${ }^{538}$ Nesse sentido, EASTERBROOK afirma que: “Aggressive competitive conduct by any firm, even one with market power, is beneficial to consumers. Courts should prize and encourage it. Aggressive, exclusionary conduct is deleterious to consumers, and courts should condemn it". The big problem lies in this: competitive and exclusionary conduct look alike". EASTERBROOK, Frank H. When Is It Worthwhile to Use Courts to Search for Exclusionary Conduct?, 2003 Colum. Bus. L. Rev. 354, p. 345.

${ }^{539}$ Há dois tipos de riscos de erros em condenações antitruste, riscos de falso positivo (erros de Tipo 1) que ocorrem quando se considera como ilícitos comportamentos que na verdade são lícitos, e riscos de falso negativo (erros de Tipo II), que ocorrem quando comportamentos ilícitos não são condenados quando deveriam ser.
} 
É importante ressaltar que a Suprema Corte já se manifestou sobre as dificuldades em distinguir comportamentos lícitos e ilícitos, bem como sobre os riscos de incorrer em falsos resultados positivos. ${ }^{540}$ De acordo com o posicionamento da Suprema Corte, a intervenção desmedida ou equivocada pode eliminar as possibilidades de ganhos associados a posições monopolistas conquistadas a partir da concorrência por méritos, colocando em risco a estrutura de incentivos promovida pela competição vigorosa nos mercados, que conduz à inovação, ao aumento da qualidade e, em consequência, ao bemestar dos consumidores. ${ }^{541}$

Por outro lado, a Comissão e os tribunais comunitários parecem adotar uma abordagem mais rígida e intervencionista, prevalecendo o entendimento de que agentes econômicos dominantes possuem uma "responsabilidade especial" para evitar que suas condutas venham a prejudicar a livre concorrência. ${ }^{542}$ Essa "responsabilidade especial" significa que os agentes dominantes possuem o ônus de atuar no mercado de forma proporcional aos objetivos que buscam alcançar. Desse modo, condutas que seriam permitidas em situações de concorrência podem vir a ser consideradas abusivas quando praticadas por firmas dominantes. ${ }^{543}$

Assim, nos termos do Artigo 102 do TFUE, qualquer abuso de poder de mercado por um agente econômico dominante será considerado ilegal, enquanto a Seção 2 do Sherman Act proíbe a monopolização e a tentativa de monopolização de um mercado.

\footnotetext{
540 "Against the slight benefits of antitrust intervention here, we must weigh a realistic assessment of its costs. Under the best of circumstances, applying the requirements of $\$ 2$ 'can be difficult' because 'the means of illicit exclusion, like the means of legitimate competition, are myriad.' (...). Mistaken inferences and the resulting false condemnations 'are especially costly, because they chill the very conduct the antitrust laws are designed to protect.' (...). The cost of false positives counsels against an undue expansion of $\$ 2$ liability." Verizon Communications Inc. v. Law Offices of Curtis V. Trinko, LLP, 540 U.S. 398 (2004), p. 407.

${ }^{541}$ Essas características do direito antitruste norte-americano têm origem nas teorias da Escola de Chicago, que buscaram demonstrar que diversas condutas unilaterais, especialmente verticais, podem ser benéficas ao bem-estar dos consumidores. Os economistas neoclássicos da Escola de Chicago também enfatizaram os riscos e custos de condenações de praticas pró-competitivas, além das dificuldades em estabelecer remédios antitruste que sejam fáceis de administrar e mais eficientes do que os mecanismos do mercado. Essa visão pró-mercado e contrária à intervenção governamental teve significativa influência na análise antitruste praticada pelas autoridades e tribunais dos Estados Unidos. Cf. BORK, Robert. The Antitrust Paradox: A Policy at War with Itself, 1978; e HOVENKAMP, Herbert. Post-Chicago Antitrust: A Review and Critique, 2001, Colum. Bus. L. Rev. 257 (2001).

542 "A finding that an undertaking has a dominant position is not itself a recrimination but simply means that, irrespective of the reasons for which it has such a dominant position, the undertaking concerned has a special responsibility not to allow its conduct to impair genuine undistorted competition on the common market." Case 322/81 Michelin v Commission, parágrafo 57.

543 "Undertakings in a dominant position may be deprived of the right to adopt a course of conduct or take measures which are not in themselves abuses and which would even be unobjectionable if adopted or taken by non-dominant undertakings." Commission Decision COMP/A. 37.507/F3 - AstraZeneca, 15 June 2005.
} 
Essa diferença entre os termos utilizados em ambos os dispositivos indica que o Artigo 102 do TFUE tem como finalidade regular o comportamento das firmas dominantes, enquanto a Seção 2 do Sherman Act volta-se apenas aos efeitos exclusionários resultantes desse comportamento. ${ }^{544} \mathrm{Se}$ uma conduta não é exclusionária, não há que se falar em violação das normas antitruste norte-americanas, enquanto essa mesma conduta poderia constituir abuso de posição dominante na União Europeia, uma vez que a Comissão e os tribunais comunitários não exigem prova dos seus efeitos anticoncorrenciais, bastando a constatação da probabilidade de prejuízo à estrutura competitiva do mercado. ${ }^{545}$

Por outro lado, manifestações recentes da Comissão deixaram claro que o Artigo 102 do TFUE tem como objetivo proteger o bem-estar dos consumidores, o que, pelo menos em teoria, parece convergir com o direito antitruste norte-americano. Por meio do Guidance Paper de 2009, a Comissão declara expressamente que, na aplicação do Artigo 102 às estratégias abusivas de exclusão por parte de empresas em posição dominante, deverão ser privilegiados os tipos de conduta mais prejudiciais ao bem-estar dos consumidores, conforme se observa no trecho a seguir: "The aim of the Commission's enforcement activity in relation to exclusionary conduct is to ensure that dominant undertakings do not impair effective competition by foreclosing their competitors in an anti-competitive way, thus having an adverse impact on consumer welfare, whether in the form of higher price levels than would have otherwise prevailed or in some other form such as limiting quality or reducing consumer choice". ${ }^{546}$

\footnotetext{
544 “( ...) the willful acquisition, maintenance, or use of [monopoly] power by anticompetitive or exclusionary means or for anticompetitive or exclusionary purposes." Aspen Skiing Co. v. Aspen Highlands Skiing Corp., 472 U.S. 585 (1985), p. 595-596.

${ }^{545}$ Cf. Case T-219/99 British Airways plc. v Commission [2003], parágrafo 293. Caso confirmado pelo TJUE no caso C-95/04 P British Airways plc. v Commission [2007]. Ao comentar as diferenças entre as duas jurisdições, Eleanor FoX afirma que enquanto a Seção 2 do Sherman Act visa impedir que agentes econômicos adotem comportamentos anticoncorrenciais com o objetivo de aumentar seu poder de monopólio, o Artigo 102 do TFUE seria mais amplo por regular abusos praticados por firmas dominantes, o que incluiria também usos de poder de mercado que não necessariamente resultam em aumento desse poder. Desse modo, firmas dominantes teriam obrigações afirmativas de não excluírem a concorrência a partir de atos que não sejam baseados na concorrência por méritos. Assim, casos potencialmente condenáveis pelos tribunais europeus poderiam ser considerados legítimos pelos tribunais norte-americanos. FOX, Eleanor M. Abuse of Dominance and Monopolization: How to Protect Competition without Protecting Competitors, in: European Competition Law Annual: 2003 What Is an Abuse of Dominant Position? 69, 70 (Claus-Dieter Ehlermann \& Laraine L. Laudati, eds. 2006). Disponível em: http://www.eui.eu/RSCAS/Research/Competition/2003/200306COMP-Fox-sI.pdf

546 Communication from the Commission - Guidance on the Commission's enforcement priorities in applying [Article 82 of the EC Treaty] to abusive exclusionary conduct by dominant undertakings, parágrafo 19.
} 
Ademais, ambas as jurisdições parecem convergir ao privilegiarem uma análise antitruste voltada aos reais efeitos econômicos de condutas unilaterais de exclusão sobre o bem-estar dos consumidores. Essa abordagem, que é similar à regra da razão adotada na análise de acordos horizontais e verticais, abre caminho para que agentes econômicos apresentem justificativas objetivas para determinados comportamentos potencialmente ilícitos, de modo a comprovar que sua conduta foi baseada na concorrência por méritos. Desse modo, caberá às autoridades antitruste e tribunais ponderarem os efeitos anticoncorrenciais e benefícios pró-competitivos da conduta em questão para determinar se os prováveis efeitos líquidos sobre a concorrência e bem-estar dos consumidores são negativos ou positivos. ${ }^{547}$

Em seu Guidance Paper, a Comissão adota essa abordagem mais flexível de ponderação entre efeitos negativos e positivos na análise de condutas unilaterais de exclusão, desde que o comportamento em questão não elimine a concorrência efetiva por meio da supressão de todas ou parte das fontes atuais ou potenciais de concorrência. ${ }^{548}$

Em suma, é possível concluir que as autoridades de defesa da concorrência dos Estados Unidos e da União Europeia vislumbram a intervenção antitruste como instrumento de proteção do bem-estar dos consumidores, além de utilizarem uma abordagem concentrada na análise dos efeitos econômicos. Por outro lado, ambas as jurisdições divergem em relação aos padrões a serem adotados para identificar condutas

\footnotetext{
${ }^{547}$ No caso Microsoft III (2001), o DC Circuit articulou uma "regra geral" contendo quatro passos para averiguar a legalidade de condutas unilaterais ao abrigo da Seção 2: "First, to be condemned as exclusionary, a monopolist's act must have an 'anticompetitive effect.' (...) Second, the plaintiff, on whom the burden of proof of course rests (...) must demonstrate that the monopolist's conduct indeed has the requisite anticompetitive effect. (...) Third, if a plaintiff successfully establishes a prima facie case under 2 by demonstrating anticompetitive effect, then the monopolist may proffer a 'procompetitive justification' for its conduct. (...) If the monopolist asserts a procompetitive justification - a nonpretextual claim that its conduct is indeed a form of competition on the merits because it involves, for example, greater efficiency or enhanced consumer appeal - then the burden shifts back to the plaintiff to rebut that claim. (...) Fourth, if the monopolist's procompetitive justification stands unrebutted, then the plaintiff must demonstrate that the anticompetitive harm of the conduct outweighs the procompetitive benefit". United States v. Microsoft Corp., 253 F.3d 34, 70-1 (D.C. Cir. 2001).

${ }^{548}$ De acordo com o Guidance Paper, a Comissão considera que uma empresa em posição dominante pode justificar uma conduta que leve ao fechamento do mercado aos concorrentes invocando ganhos de eficiência que são suficientes para tornar pouco provável um prejuízo para os consumidores. Neste contexto, a empresa em posição dominante deve normalmente demonstrar, com um grau de probabilidade suficiente e com base em provas verificáveis, que estão preenchidas as seguintes condições cumulativas: (i) os ganhos de eficiência concretizaram-se, ou é provável que se concretizem, em consequência do comportamento; (ii) o comportamento é indispensável para a concretização dos ganhos de eficiência; e (iii) o comportamento não elimina uma concorrência efetiva por meio da supressão de todas ou parte das fontes atuais ou potenciais de concorrência. Cf. Communication from the Commission - Guidance on the Commission's enforcement priorities in applying [Article 82 of the EC Treaty] to abusive exclusionary conduct by dominant undertakings, parágrafo 30 .
} 
abusivas de exclusão, isto é, comportamentos que não sejam baseados na concorrência por méritos. O fato é que essas diferenças ficam ainda mais evidentes quando as condutas em questão envolvem estratégias comerciais consubstanciadas na exploração de direitos de propriedade intelectual.

Se a distinção entre comportamentos de exclusão e comportamentos legítimos não é tarefa simples, as dificuldades são ainda maiores quando esses comportamentos envolvem direitos de propriedade intelectual. Isso porque o direito de excluir constitui elemento essencial do sistema de propriedade intelectual, permitindo que seu titular impeça terceiros de explorar, sem sua autorização, os bens intelectuais protegidos. Desse modo, condutas de exclusão ilegítimas podem muitas vezes ser confundidas com condutas de exclusão legítimas concernentes à mera imposição de direitos de propriedade intelectual contra terceiros, que nada mais é do que o exercício regular desses direitos conforme expressamente autorizado por lei. Os riscos e custos de intervenções antitruste equivocadas tendem a ser maiores nessas situações, pois podem produzir efeitos negativos diretos sobre a estrutura de incentivos criada pelo sistema de propriedade intelectual - especialmente quando o remédio antitruste for a imposição de uma licença compulsória -, prejudicando a inovação nos mercados e, consequentemente, o bem-estar dos consumidores.

Os casos mais complexos envolvem a aplicação das normas antitruste de forma a intervir nas prerrogativas mais básicas conferidas ao titular de direitos de propriedade intelectual, em particular: (i) o direito de recusar o licenciamento de direitos de propriedade intelectual; (ii) o direito de estabelecer unilateralmente o valor de royalties a serem cobrados pelo uso dos bens intelectuais protegidos; e (iii) o direito de adquirir direitos de propriedade intelectual e impor tais direitos contra terceiros que vierem a utilizá-los sem autorização. Distinguir entre as situações em que essas prerrogativas são legítimas e as situações em que essas prerrogativas são utilizadas de forma indevida, como estratégia de exclusão não baseada na concorrência por méritos, é o grande desafio das autoridades de defesa da concorrência, resultando em claras divergências entre autoridades antitruste e tribunais norte-americanos e europeus na análise de condutas de exclusão a partir da exploração de direitos de propriedade intelectual, conforme veremos a seguir. 


\subsubsection{Recusa de licenciar direitos de propriedade intelectual}

O direito de excluir terceiros constitui elemento essencial do sistema de propriedade intelectual. É inegável que o titular de um direito de propriedade intelectual pode licitamente impedir que terceiros explorem o bem objeto de proteção sem sua autorização. Nesse contexto, a imposição de uma licença compulsória como forma de remediar uma recusa de licenciar por parte de um agente econômico dominante constitui uma das maiores controvérsias em matéria de interface entre propriedade intelectual e direito da concorrência, evidenciando muitas vezes situações claras de conflito entre as duas disciplinas.

A teoria econômica que fundamenta a recusa de licenciar como ilícito antitruste tem origem nos casos de recusa de venda e na teoria das "infraestruturas essenciais" ou "insumos essenciais" (essential facilities). ${ }^{549}$ Trata-se de prática restritiva de exclusão, mediante a qual o monopolista, titular de um direito de propriedade intelectual no mercado primário, recusa o licenciamento de seu direito exclusivo a terceiros que desejam utilizá-lo como insumo para o desenvolvimento de novos produtos nos mercados secundários (sejam eles horizontal ou verticalmente relacionados). A racionalidade econômica da conduta reside no fato de que o monopolista deseja atuar também no mercado secundário, de modo que a recusa de licenciar serve como estratégia para excluir seus rivais desse mercado e ampliar seu poder de mercado. ${ }^{550}$

Esse é um dos temas de maior divergência entre os Estados Unidos e a União Europeia. Os tribunais norte-americanos e europeus já afirmaram por diversas vezes que a recusa de licenciar é um direito inerente à propriedade intelectual, podendo ser limitado

\footnotetext{
${ }^{549}$ A doutrina das "infraestruturas essenciais" ou "insumos essenciais" (essential facilities) tem origem na decisão da Suprema Corte norte-americana no caso United States v. Terminal Railroad Association of St. Louis, 224 U.S. 383, 410-411 (1912). Apesar de a Suprema Corte não ter utilizado o termo "essential facilities", diversos tribunais inferiores passaram a interpretar e aplicar os princípios desenvolvidos nesse caso. Conforme se observa no caso MCI Communication Corp. v. AT\&T, 708 F.2d 1081, 1132-1133 (7th Cir. 1983), o tribunal estabeleceu quatro elementos necessários para a aplicação da doutrina das essential facilities: (i) controle de uma infraestrutura essencial pelo monopolista; (ii) inabilidade do concorrente para duplicar a infraestrutura essencial; (iii) recusa do uso da infraestrutura essencial pelo concorrente; e (iv) viabilidade da disponibilização da infraestrutura essencial.

${ }^{550}$ De acordo com MAGGIOLINO: “(...) monopolists' refusal to license may represent exclusionary practices that respond to the logic underpinning both horizontal and vertical foreclosure. As the current leveraging monopoly theory shows, when the holder of an intellectual resource refuses it to its rivals though they would like to use it in their secondary markets - i.e. either horizontally or vertically connected markets - the refusal works as a tool to lessen competitive constraints and, hence, to strengthen market power". MAGGIOLINO, Mariateresa. Intellectual Property and Antitrust: A Comparative Economic Analysis of US and EU Law. Celtenham: Edward Elgar, 2011, p. 143-144.
} 
apenas em "circunstâncias excepcionais". No entanto, inexiste consenso entre as duas jurisdições sobre quais as circunstâncias em que titulares de direitos de propriedade intelectual seriam obrigados a conferir licenças aos seus concorrentes efetivos ou potenciais em mercados adjacentes como forma de remediar os efeitos anticoncorrenciais de uma prática de recusa de licenciar. ${ }^{551}$ Passaremos a tratar a seguir das abordagens adotadas pelas autoridades e tribunais norte-americanos e europeus sobre o tema.

\subsubsection{Estados Unidos}

Nos Estados Unidos, a questão da recusa de licenciar como prática anticoncorrencial reflete a visão tradicional de que o "direito de excluir" constitui a essência da propriedade intelectual, não devendo sofrer intervenção antitruste. Esse posicionamento rígido foi manifestado em 1908 na opinião da Suprema Corte no caso Continental Paper Bag Co. v. Eastern Paper Bag Co., quando afirmou que titulares de patentes possuem o privilégio de optar por explorar ou não a sua propriedade, mesmo que a intenção seja meramente a acumulação de direitos exclusivos com o objetivo de excluir concorrentes. ${ }^{552}$ No mesmo sentido, a Seção 271(d)(4) do Patent Act de 1988 estabelece expressamente que a mera recusa de licenciar ou usar patentes não constitui patent misuse. $^{553}$

Esse entendimento é consistente com a maioria das decisões de tribunais federais norte-americanos, que praticamente conferem imunidade antitruste à prática de recusa de licenciar, embora alguns reconheçam que, em circunstâncias limitadas, a prática

\footnotetext{
${ }^{551}$ Na Europa, vide os casos: Caso 238/87, Volvo, [1988] ECR 6211, parágrafo 8; Casos C-241/91P e C242/91P, RTE and ITP v Commission ("Magill”), [1995] ECR I-743, parágrafo 49; Caso C-418/01, IMS Health, [2004] ECR I-5039, parágrafo 34; Caso T-201/04, Microsoft v Commission. Nos EUA, vide Hartford-Empire Co. v. United States, 323 U.S. 386, 432 (1945) (“o titular da patente não tem obrigação de explorar a patente e nem de autorizar seu uso por terceiros"); Stewart v. Abend, 495 US 207, at 228 (1990) ("titular de direito autoral tem a prerrogativa de arbitrariamente recusar a licença a quem deseja explorar a obra”); In re Independent Service Organizations Antitrust Litigation (CSU v. Xerox), 203 F. 3d 1322, at 1327 (Fed. Cir. 2000), at 1327 and 1329, cert. denied, 121 S. Ct. 1077 (2001) (confirmou que o direito do titular da patente de recusar a venda ou licença de seus direitos de propriedade intelectual é limitado apenas em "certas circunstâncias").

552 "We have no doubt that the complainant stands in the common class of manufacturers who accumulate patents merely for the purpose of protecting their general industries and shutting out competitors. (...) As to the suggestion that competitors were excluded from the use of the new patent, we answer that such exclusion may be said to have been of the very essence of the right conferred by the patent, as it is the privilege of any owner of property to use or not use it, without question of motive." Continental Paper Bag Co. v. Eastern Paper Bag Co., 210 U.S. 405 (1908).

553 Section 271(d): "No patent owner otherwise entitled to relief for infringement or contributory infringement of a patent shall be denied relief or deemed guilty of misuse or illegal extension of the patent
} 
poderia resultar em ilícito antitruste. Mesmo assim, além de não haver consenso entre os tribunais sobre quais seriam essas circunstâncias, nenhum desses casos foram revisados pela Suprema Corte.

No caso Data General Corp. v. Grumman Systems Support Corp., o tribunal (First Circuit) analisou a recusa, pela fabricante de computadores Data General, de licenciar certos direitos autorais sobre software a prestadores de serviços independentes que eram seus concorrentes no mercado de manutenção e reparação de computadores. ${ }^{554} \mathrm{O}$ tribunal afirmou que, enquanto a prática unilateral de exclusão poderia incluir a recusa do monopolista de licenciar direitos autorais, o desejo do autor de impedir que terceiros utilizem o trabalho protegido constitui justificativa comercial presumidamente válida para quaisquer danos imediatos aos consumidores. ${ }^{555}$ Entretanto, reconheceu que essa presunção de legalidade poderia ser reversível apenas em "casos raros" nos quais a intervenção antitruste não prejudique o sistema de incentivos contido na legislação autoral. ${ }^{556}$ Embora o tribunal não tenha explicado quais seriam esses "casos raros", afirmou que a presunção de legalidade da recusa poderia ser revertida na hipótese em que o direito de propriedade intelectual tenha sido adquirido de forma indevida. Contudo, o tribunal reconheceu que os direitos autorais da Data General sobre software eram válidos, de modo que sua recusa de conferir licenças aos seus concorrentes foi considerada lícita. ${ }^{557}$

Alguns anos depois, no caso Kodak, o Ninith Circuit adotou a mesma presunção de legalidade reversível para a recusa de licenciar. ${ }^{558}$ Assim como no caso anterior, o tribunal analisou a conduta da Kodak de recusar licenciar patentes sobre peças de reposição a seus concorrentes, prestadores de serviços independentes, no mercado secundário de manutenção e reparação de equipamentos para extração de cópias

right by reason of his having done one or more of the following: (...) (4) refused to license or use any rights to the patent".

${ }^{554}$ Data General Corp. v. Grumman Systems Support Corp., 36 F.3d 1147 (1 ${ }^{\text {st }}$ Cir. 1994).

555 "While exclusionary conduct can include a monopolist's unilateral refusal to license copyright, an author's desire to exclude others from use of its copyrighted work is a presumptively valid business justification for any immediate harm to consumers." Data General Corp. v. Grumman Systems Support Corp., 36 F.3d 1147 ( $1^{\text {st }}$ Cir. 1994), p. 1187.

556 "In passing the Copyright Act, Congress (...) made an empirical assumption that allowing copyright holders to collect license fees and exclude others from using their works creates a system of incentives that promotes consumer welfare in the long term by encouraging investments in the creation of desirable artistic and functional works of expression." Data General Corp. v. Grumman Systems Support Corp., 36 F.3d 1147 $\left(1^{\text {st }}\right.$ Cir. 1994), p. 1186-87.

${ }^{557}$ Ibid., p. 1188.

${ }^{558}$ Image Technical Service, Inc. v. Eastman Kodak Co., 125 F.3d 1195 (9 $9^{\text {th }}$ Cir. 1997). 
reprográficas, fabricados pela própria Kodak sob sua marca. ${ }^{559} \mathrm{O}$ tribunal reconheceu que a presunção de validade de uma recusa de licenciar poderia ser revertida, nos termos da decisão do First Circuit no caso Data General, mas acrescentou que essa presunção também poderia ser revertida em caso de comprovação de "pretexto" ${ }^{560}$ Para o tribunal, a justificativa apresentada pela Kodak, baseada no desejo de proteger seus direitos de propriedade intelectual, seria apenas um pretexto, já que não seria esse o verdadeiro motivo para sua recusa de conferir licenças aos prestadores de serviços independentes. Isso porque a Kodak recusou a venda de mais de mil peças de reposição, das quais apenas sessenta e cinco eram protegidas por patentes. Além disso, somente ao final do processo, após anos de discussão em juízo, a Kodak invocou seus direitos de propriedade intelectual como justificativa para a recusa. ${ }^{561}$

O caso CSU v. Xerox, julgado em 2000, envolveu fatos semelhantes aos do caso Kodak, mas teve um resultado completamente diferente. ${ }^{562}$ A Xerox, fabricante de copiadoras, instituiu uma política de recusa de venda de peças de reposição aos prestadores de serviços independentes que concorriam com a empresa no mercado secundário. ${ }^{563}$ Ressalte-se que, ao contrário do caso Kodak, todas as peças da Xerox eram protegidas por direitos de propriedade intelectual. Ao analisar a conduta da Xerox, o tribunal entendeu que, apesar de os direitos de propriedade intelectual não conferirem um privilégio para violar as normas antitruste, estas também não negam ao titular de uma patente o direito de "excluir terceiros". Assim, o tribunal concluiu que, na ausência de "situações excepcionais", quais sejam, venda casada ilícita, fraude perante os órgãos de marcas e patentes, ou abuso de direitos processuais (sham litigation), o titular da patente pode impor seu direito de excluir, de modo a impedir terceiros de fabricar, usar ou vender a invenção

\footnotetext{
${ }^{559}$ A alegação era de que a Kodak detinha monopólio no mercado relevante de peças de reposição, de modo que a recusa de fornecer essas peças aos prestadores de serviços independentes lhe possibilitaria estender seu poder de monopólio para o mercado de serviços de manutenção dos equipamentos.

560 "The presumption may also be rebutted by evidence of pretext. Neither the aims of intellectual property law, nor the antitrust laws justify allowing a monopolist to rely upon a pretextual business justification to mask anticompetitive conduct.” Image Technical Service, Inc. v. Eastman Kodak Co., 125 F.3d 1195 (9 ${ }^{\text {th }}$ Cir. 1997), p. 1219.

${ }^{561}$ Ibid., p. 1219-1220.

${ }^{562}$ In re Independent Service Organizations Antitrust Litigation (CSU v. Xerox), 203 F.3d 1322 (Fed. Cir. 2000).

563 Os prestadores de serviços independentes ingressaram com ação alegando que a Xerox havia violado a Seção 2 do Sherman Act ao alavancar seu poder de mercado sobre as peças de reposição para o mercado secundário de serviços de manutenção e reparação dos equipamentos de fotocópia da marca Xerox.
} 
protegida, livre de qualquer responsabilidade sob as normas concorrenciais. ${ }^{564}$ Deve-se ressaltar que o tribunal recusou-se a analisar a motivação subjetiva da recusa de licenciar, afirmando que eventuais efeitos anticoncorrenciais da conduta seriam relevantes apenas se resultassem na extensão indevida da patente para além de seu escopo legal. ${ }^{565}$

Ambas as decisões do caso Kodak e do caso Xerox foram objeto de inúmeras críticas. A decisão do Ninith Circuit no caso Kodak foi muito questionada por ter sido fundamentada em critérios subjetivos de intenção ou motivação da recusa, enquanto a análise antitruste é tradicionalmente concentrada nos aspectos econômicos objetivos de condutas anticoncorrenciais. ${ }^{566}$ A decisão do Federal Circuit no caso Xerox foi bastante criticada, entre outros motivos, por praticamente estabelecer uma imunidade antitruste para a prática de recusa unilateral de licenciar, o que evidenciaria uma rigidez formal que os tribunais norte-americanos costumam evitar. ${ }^{567}$

Pouco tempo depois, ao julgar o caso Trinko em 2004, a Suprema Corte veio a estabelecer seu posicionamento acerca das recusas de contratar em geral, embora o caso

564 "In the absence of any indication of illegal tying, fraud in the Patent and Trademark Office, or sham litigation, the patent holder may enforce the statutory right to exclude others from making, using or selling of the claimed invention free from liability under the antitrust laws." In re Independent Service Organizations Antitrust Litigation (CSU v. Xerox), 203 F.3d 1322 (Fed. Cir. 2000), p. 1327.

565 "We therefore will not inquiry into subjective motivation for exerting his statutory rights, even though his refusal to sell or license his patented invention may have an anticompetitive effect, so long as that anticompetitive effect is not illegally extended beyond the statutory patent grant." In re Independent Service Organizations Antitrust Litigation (CSU v. Xerox), 203 F.3d 1322 (Fed. Cir. 2000), p. 1327-28.

566 De acordo com PATE: 'Introducing a 'pretext' standard into the calculus of determining legitimate business justifications injects subjectivity into what ought to be an objective inquiry into the competitive effects of a business arrangement". PATE, R. Hewitt. Refusals to Deal and Intellectual Property Rights, 10 Geo. Mason L. Rev. 429 (2002), p. 438-41. No mesmo sentido, PATTERSON afirma que: "It is not fruitful to ask if the owner's 'intent' is to exploit its intellectual property; in a subjective sense, it always is". PATTERSON, Mark W. When Is Intellectual Property Intellectual? The Leveraging Problem, 73 S. Cal. L. Rev. 1133 (2000), p. 1157.

${ }^{567}$ Em crítica a essa suposta "imunidade antitruste" e rigidez formal na decisão do caso Xerox, MELAMED e STOEPPELWERTH afirmam que: “(..) the Supreme Court has repeatedly emphasized that "exemptions from the [Sherman Act] are strictly construed and strongly disfavored'. Absent clear evidence that Congress intended to immunize the challenged conduct or that denying immunity could subject the defendants in a particular case to conflicting legal requirements, courts have uniformly rejected such defenses to antitrust liability. The holdings in $C S U$ and other similar cases, however, have either ignored or misapplied these well established principles”. E acrescentam ao final que: “(..) antitrust law has moved away from the rigidities of formalism and legal issues, in favor of a fact-based analysis that applies rigorous economic principles to distinguish anticompetitive from procompetitive conduct. The CSU decision seems oblivious to this development and to the resulting convergence of antitrust and intellectual property law principles. Ironically, therefore, $C S U$ in this respect disserves its own purported objective of protecting a coherent regime for the exploitation of intellectual property rights". MELAMED, A. Douglas; STOEPPELWERTH, Ali M. The CSU Case: Facts, Formalism and the Intersection of Antitrust and Intellectual Property Law, 10 Geo. Mason L. Rev. 407 (2002), p. 410, 412 e 425. 
não envolvesse diretamente direitos de propriedade intelectual. ${ }^{568} \mathrm{O}$ caso tratou da recusa, pela Verizon, monopolista local na prestação de serviços de telefonia, de compartilhar sua rede com sua concorrente AT\&T, o que lhe permitiria prestar serviços de telefonia em concorrência com a Verizon em sua área de atuação. Ressalte-se que, nos termos do Telecommunications Act de 1996, a Verizon tinha a obrigação legal de compartilhar sua rede de telecomunicações com seus concorrentes, tendo sido penalizada pelos órgãos reguladores do setor em razão de sua recusa. Analisando o caso sob a perspectiva antitruste, a Suprema Corte entendeu que forçar um monopolista a compartilhar com seus concorrentes os frutos das vantagens competitivas obtidas a partir de seus próprios investimentos seria contrário aos objetivos da política antitruste, pois poderia reduzir os incentivos dos agentes econômicos para investir e inovar. Afirmou também que admitir essa hipótese levaria os tribunais a atuarem como reguladores da economia, estabelecendo os preços considerados adequados, as quantidades a serem produzidas, bem como outras condições contratuais, desempenhando um papel que não lhes cabe. A Suprema Corte também considerou que forçar negociações entre concorrentes poderia facilitar a colusão, que é o "grande mal" a ser combatido pelas normas antitruste. ${ }^{569}$

No entanto, a Suprema Corte entendeu que apenas sob "certas circunstâncias" a recusa de cooperar com rivais poderia constituir conduta anticoncorrencial em violação da Seção 2 do Sherman Act. ${ }^{570}$ Sem esclarecer quais seriam essas "circunstâncias", a Suprema Corte comparou a recusa de contratar da Verizon com a conduta condenada no caso Aspen Skiing. ${ }^{571}$ Nesse caso, o Supremo estabeleceu o seguinte teste em dois passos para determinar se uma recusa de cooperar com rivais poderia violar a Seção 2 do Sherman Act:

\footnotetext{
${ }^{568}$ Verizon Communications Inc. v. Law Offices of Curtis V. Trinko, LLP, 540 U.S. 398 (2004).

569 "Firms may acquire monopoly power by establishing an infrastructure that renders them uniquely suited to serve their customers. Compelling such firms to share the source of their advantage is in some tension with the underlying purpose of antitrust law, since it may lessen the incentive for the monopolist, the rival, or both to invest in those economically beneficial facilities. Enforced sharing also requires antitrust courts to act as central planners, identifying the proper price, quantity, and other terms of dealing - a role for which they are ill suited. Moreover, compelling negotiation between competitor may facilitate the supreme evil of antitrust: collusion. Thus, as a general matter, the Sherman Act 'does not restrict the long recognized right of [a] trader or manufacturer engaged in an entirely private business, freely to exercise his own independent discretion as to parties with whom he will deal'." Trinko, 540 U.S., p. 407-408.

${ }^{570}$ Trinko, 540 U.S., p. 408.

${ }^{571}$ Aspen Skiing Company v. Aspen Highlands Skiing Corporation, 472 U.S. 585 (1985). Nesse caso, a Aspen Skiing controlava três de quatro montanhas para a prática de esqui em Aspen, Colorado. A empresa Aspen Highlands controlava a quarta montanha. As duas partes ofertavam conjuntamente um ticket completo para as quatro montanhas, mas a Aspen Skiing retirou sua participação na parceria sem justificativas comerciais plausíveis. A Suprema Corte entendeu que a Aspen Skiing violou a Seção 2 do Sherman Act ao recusar cooperar com sua concorrente menor.
} 
(i) há um término unilateral e voluntário de um curso de negociações que é presumidamente lucrativo; e (ii) há um sacrifício em curto prazo para alcançar um objetivo anticoncorrencial em longo prazo, qual seja, a eliminação de um concorrente viável do mercado relevante. Para o Supremo, as condições do caso Aspen Skiing não estavam presentes no caso Trinko, já que não havia negociações em curso entre as concorrentes, além do fato de que a eventual negociação não seria voluntária, mas obrigatória em função do Telecommunications Act de 1996, não havendo, portanto, motivos para inferir que a Verizon havia desistido de um acordo lucrativo ao recusar cooperar com sua concorrente. ${ }^{572} \mathrm{O}$ Supremo ainda acrescentou que sua opinião não seria modificada mesmo se aplicasse ao caso a doutrina das "infraestruturas essenciais", conforme desenvolvida pelos tribunais inferiores, afirmando que não reconheceria e nem repudiaria essa doutrina. $^{573}$

Pelo exposto, pode-se afirmar que a decisão da Suprema Corte no caso Trinko sinaliza uma abordagem de "quase imunidade" para as práticas de recusa de contratar em geral, o que certamente terá reflexos em casos envolvendo recusa de licenciar direitos de propriedade intelectual. ${ }^{574}$ Vale destacar, nesse contexto, trecho do voto do Juiz Scalia, que parece corroborar essa conclusão:

The mere possession of monopoly power, and the concomitant charging of monopoly prices, is not only not unlawful; it is an important element of the free-market system. The opportunity to charge monopoly prices at least for a short period - is what attracts "business acumen" in the first place; it induces risk taking that produces innovation and economic growth. To safeguard the incentive to innovate, the possession of monopoly power will not be found unlawful unless it is accompanied by an element of anticompetitive conduct. ${ }^{575}$

\footnotetext{
572 "Verizon's reluctance to interconnect at the cost-based rate of compensation available under [the 1996 Telecommunications Act] tell us nothing about dreams of monopoly.” Trinko, 540 U.S., p. 409.

${ }^{573}$ Trinko, 540 U.S., p. 409.

${ }^{574}$ De acordo com GALLEGO: "If transposed to the context of IPRs, the Trinko judgment just confirms the 'immunity' of IPRs from the application of antitrust law. Indeed, if there is no duty to deal in cases not involving IPRs, there would be no obligation to share IPRs with competitors, since exclusivity is the primary characteristic of these rights". GALLEGO, Beatriz Conde. Unilateral Refusal to License Indispensable Intellectual Property Rights - US and EU Approaches, in: DREXL, Josef (Ed.). Research Handbook on Intellectual Property and Competition Law. Cheltenham: Edward Elgar, 2008, p. 221.

${ }^{575}$ Trinko, 540 U.S., p. 407.
} 
Como se pode observar, a Suprema Corte entende que a perspectiva de obter poder de monopólio incentiva as empresas a investir em inovação, embora ignore que a concorrência efetiva ou potencial também cumpre papel relevante para esse fim. Jonathan BAKER entende que a afirmação da Suprema Corte é incompleta, pois não leva em consideração a importância da intervenção antitruste para remediar condutas de monopolistas capazes de reduzir os incentivos à inovação agregada no mercado. Para o autor, a probabilidade de inovação em determinados segmentos pode ser prejudicada por condutas de agentes econômicos dominantes capazes de reduzir os incentivos de seus rivais para investir em pesquisa e desenvolvimento. Nesses casos, a intervenção antitruste pode ser necessária para preservar as pressões competitivas no mercado e, consequentemente, os incentivos à inovação da indústria como um todo. ${ }^{576} \mathrm{~A}$ opinião de BAKER está em consonância com a abordagem adotada na União Europeia para a análise de casos de recusa de licenciar, conforme veremos a seguir.

\subsubsection{União Europeia}

Ao contrário da abordagem adotada pela Suprema Corte norte-americana, que praticamente confere imunidade antitruste à prática de recusa de contratar, os tribunais europeus já reconheceram por diversas vezes que a recusa de licenciar direitos de propriedade intelectual, em "circunstâncias excepcionais", pode configurar abuso de posição dominante nos termos do Artigo 102 do TFUE, resultando na imposição de uma obrigação de licenciar.

O famoso caso Commercial Solvents, julgado em 1974, foi o primeiro em que o TJUE aplicou a doutrina dos "insumos essenciais" e impôs uma obrigação de fornecer como forma de remediar uma recusa considerada abusiva. Nesse caso, o TJUE concluiu que um agente econômico abusou de posição dominante ao cessar o fornecimento de um insumo essencial aos seus consumidores com o objetivo de excluí-los do mercado a jusante do produto final, no qual passou a atuar em concorrência com seus antigos

\footnotetext{
${ }^{576}$ De acordo com BAKER, “(...) if a dominant firm finds a way to raise its expected reward from successful innovation, that conduct may increase the dominant firm's incentive to invest in research and development (R\&D). But as a guide to antitrust policy, this preposition is incomplete. Whether total industry R\&D and the aggregate likelihood of innovation success rise depends on the magnitude of the effect and on the extent to which the dominant firm's conduct simultaneously reduces the incentive of rival firms to invest in R\&D. The available empirical evidence resolves the question in favor of competition by showing that as a general rule, greater product market competition strongly encourages innovation and productivity, its close cousin". BAKER, Jonathan B. "Dynamic Competition Does Not Excuse Monopolization" (October 15, 2008), pp. 1011. Disponível em SSRN: http://ssrn.com/abstract=1285223 ou http://dx.doi.org/10.2139/ssrn.1285223
} 
consumidores ${ }^{577}$ Esse entendimento foi confirmado posteriormente no caso Télémarketing, de 1985, no qual o TJUE considerou abusiva a recusa de fornecimento de um serviço indispensável para o desempenho de atividades num mercado secundário sem qualquer justificativa objetiva. ${ }^{578}$

Pouco tempo depois, em 1988, ao julgar os casos Volvo e Renault, o TJUE analisou pela primeira vez a questão da recusa de licenciar direitos de propriedade intelectual como abuso de posição dominante. ${ }^{579}$ Ambos os casos trataram da recusa de licenciar direitos sobre desenhos industriais de peças de reposição de veículos automotores para prestadores de serviços independentes no mercado secundário de reparação e manutenção. ${ }^{580} \mathrm{O}$ TJUE reconheceu que o direito do titular de um registro de desenho industrial de impedir sua exploração por terceiros sem autorização constitui a exata substância de seu direito exclusivo. Diante dessa premissa, o Tribunal concluiu que a recusa de licenciar direitos de propriedade intelectual não constitui por si só abuso de posição dominante e que a limitação ao exercício de um direito exclusivo por seu titular somente será legítima na presença de alguma conduta abusiva, tal como a recusa arbitrária de fornecer peças para prestadores de serviços independentes, a fixação de preços excessivos ou a decisão de não mais fabricar tais peças para um modelo de automóvel específico que ainda esteja em circulação. ${ }^{581}$

577 "An undertaking which has a dominant position in the market of raw material and which, with the object of reserving such raw material for manufacturing its own derivatives, refuses to supply a customer, which is itself a manufacturer of these derivatives, and therefore risks eliminating all competition on the part of customer, is abusing its dominant position within the meaning of Article 86." Istituto Chemioterapico SpA and Commercial Solvents v Commission, [1974] ECR 223, parágrafo 25.

578 “(...) an abuse within the meaning of Article 86 is committed where, without any objective necessity, an undertaking holding a dominant position on a particular market reserves to itself or to an undertaking belonging to the same group an ancillary activity which might be carried out by another undertaking as part of its activities on neighboring but separate market, with the possibility of eliminating all competition from such undertaking." Caso 311/84, Centre belge d'études de marché - Télémarketing (CBEM) v SA Compagnie luxembourgeoise de télédiffusion (CLT) and Information publicité Benelux (IPB), [1985] ECR 3261, parágrafo 27.

${ }^{579}$ Caso C-238/87, Volvo v Veng, [1988] ECR 6211 e Caso C53/87, CICRA v Renault, [1988], ECR 6039.

${ }^{580} \mathrm{O}$ caso Volvo resultou de sua recusa de autorizar a importação, pela Erik Veng no Reino Unido, de peças de reposição fabricadas no exterior. Já o caso Renault resultou de uma ação judicial que tramitou em Milão, na qual a CICRA, associação nacional que congregava a indústria de peças de reposição, reivindicou a declaração de invalidade de registros de desenhos industriais de algumas peças de titularidade da Renault, incluindo uma declaração no sentido de que a fabricação e venda dessas peças por fabricantes independentes não violava as normas nacionais de combate à concorrência desleal.

${ }^{581}$ De acordo com a decisão do TJUE no caso Volvo: "It must be emphasized that the right of the proprietor of a protected design to prevent third parties from manufacturing and selling or importing, without its consent, products incorporating the designs constitute the very subject-matter of his exclusive right. It follows that an obligation imposed upon the proprietor of a protected design to grant to third parties, even in return for a reasonable royalty, a licence for the supply of products incorporating the design would lead to the 
O caso Magill foi o primeiro em que a Comissão e os tribunais europeus impuseram uma obrigação de licenciar direitos de propriedade intelectual para remediar uma conduta abusiva. ${ }^{582}$ Esse caso envolveu a recusa de licenciar direitos autorais sobre programações de TV que permitiriam a publicação, pela Magill, de um novo guia semanal compreensivo e inovador que reuniria as programações das três principais emissoras de TV na Irlanda. Quando a Magill lançou seu guia semanal, as emissoras de TV ingressaram com ação judicial para impedir a publicação, alegando violação de seus direitos autorais. A Magill então ingressou com uma representação perante a Comissão, afirmando que a recusa de licenciar constituía abuso de posição dominante, pois impedia o ingresso de um novo produto que seria desejado pelos consumidores. ${ }^{583}$

Ao analisar o caso, o TJUE veio a confirmar seu entendimento anterior no sentido de que a mera titularidade de um direito de propriedade intelectual não constitui por si só abuso de posição dominante, além de esclarecer de forma mais detalhada as situações em que uma recusa de licenciar poderia resultar em abuso. Desse modo, o Tribunal afirmou que o exercício de um direito exclusivo pelo seu titular pode, em "circunstâncias excepcionais", envolver uma conduta abusiva. O TJUE considerou que essas circunstâncias estavam presentes no caso, já que: (i) a recusa de licenciar referiu-se a um produto (informações de programação das emissoras) cujo fornecimento era indispensável ao exercício de uma atividade específica no mercado secundário (publicação de um guia completo com a programação semanal das emissoras); (ii) a recusa impediu o lançamento de um novo produto (um guia semanal compreensivo que não era ofertado pelas emissoras) para o qual havia demanda potencial dos consumidores; (iii) a recusa não foi justificada de forma objetiva; e (iv) a recusa possibilitou que as emissoras reservassem

proprietor being deprived of the substance of his exclusive right, and that a refusal to grant such a licence cannot in itself constitute an abuse of a dominant position. It must however be noted that the exercise of an exclusive right by the proprietor of a registered design in respect of car body panels may be prohibited by Article 86 if it involves, on the part of an undertaking holding a dominant position, certain abusive conduct such as the arbitrary refusal to supply spare parts to independent repairer, the fixing of prices for spare parts at an unfair level or a decision no longer to produce spare parts for a particular model even though many cars of that model are still in circulation, provided that such conduct is liable to affect trade between Member States”. Caso C-238, parágrafos 8 e 9. Cf. Caso C53/87, CICRA v Renault, parágrafo 11.

${ }^{582}$ Magill, Case C-241 \& 242/91P, RTE, BBC and ITP v Commission [1995] ECR I-743.

583 A Comissão considerou que as emissoras violaram o Artigo 86 do Tratado da Comunidade Europeia [atual Artigo 102 do TFUE], determinando que licenciassem, em condições razoáveis e não discriminatórias, suas respectivas programações semanais. A decisão foi posteriormente confirmada pelo Tribunal de Primeira Instância (atual Tribunal Geral). 
para si o mercado secundário de guias semanais de televisão, eliminando toda a concorrência nesse mercado. ${ }^{584}$

Assim, de acordo com a decisão do TJUE, o licenciamento compulsório serviria para remediar uma situação na qual a recusa de licenciar um direito de propriedade intelectual sobre um insumo indispensável impede o surgimento de um novo produto no mercado secundário, de modo a eliminar a concorrência nesse mercado. ${ }^{585}$

No caso Ladbroke, o Tribunal de Primeira Instância (atual Tribunal Geral) confirmou o entendimento do TJUE no caso Magill, além de esclarecer alguns aspectos do teste das "circunstâncias excepcionais". ${ }^{586}$ Nesse caso, o Tribunal Geral afirmou que a recusa de licenciar não constitui abuso de posição dominante, a não ser que envolva um produto considerado essencial para o exercício da atividade em questão, isto é, para o qual não haja substituto viável, ou um novo produto cuja introdução no mercado seja impedida, apesar da existência de potencial demanda dos consumidores. ${ }^{587} \mathrm{O}$ Tribunal Geral esclareceu que um direito de propriedade intelectual não é indispensável quando os concorrentes do agente econômico dominante forem capazes de desempenhar suas atividades sem ter acesso ao direito exclusivo em questão, ainda que o acesso eventual lhes fosse mais conveniente para concorrer no mercado. ${ }^{588}$

\footnotetext{
${ }^{584}$ Magill, Case C-241 \& 242/91P, RTE, BBC and ITP v Commission [1995] ECR I-743, parágrafo 50.

${ }^{585}$ Embora o TJUE não tenha mencionado em sua decisão a doutrina das "essential facilities" (infraestruturas ou insumos essenciais), alguns autores entendem que essa doutrina foi aplicada no caso Magill e nos demais casos de recusa de licenciar direitos de propriedade intelectual. Sobre o assunto, Forrester e Czapracka entendem que: "Without agreeing that Magill was an essential facility case, we can agree that the situation in Magill presented some analogies with essential facilities case. The protected subject matter was essential Magill could not publish its weekly TV guide without TV listings drawn up each week by the broadcasters. Practical alternatives were not available. A compulsory license substantially improved competition in the market place by increasing innovation - a new product for which there was substantial unmet consumer demand". FORRESTER, Ian S.; CZAPRACKA, Katarzyna A. Compulsory License in European Competition Law: The Power of the Adjective, in: ANDERMAN, Steven; EZRACHI, Ariel. Intellectual Property and Competition Law: New Frontiers. Oxford University Press, 2010, p. 146.

${ }^{586}$ Case T-504/93 Tierce Ladbroke SA v Commission [1995] ECR II-923, [1997] 5 CMLR 309. Ladbroke, uma rede de casa de apostas atuante no mercado belga, alegou que sua concorrente French Tote abusou de sua posição dominante ao recusar licenciar direitos sobre transmissões de corrida de cavalos na França. De acordo com Ladbroke, sem acesso às transmissões televisivas, não poderia concorrer no mercado de apostas de corrida de cavalos.

${ }^{587}$ Ao que parece, dois elementos cumulativos no caso Magill - indispensabilidade e novo produto - seriam alternativos na visão do Tribunal Geral. Contudo, essa nova abordagem não prevaleceu nos casos seguintes.

588 "Even if it were assumed that the presence of the sociétés de courses on the Belgian market in sound and pictures were not, in this case, a decisive factor for the purposes of applying Article 86 of the Treaty, that provision would not be applicable in this case. The refusal to supply the applicant could not fall within the prohibition laid down by Article 86 unless it concerned a product or service which was either essential for the exercise of the activity in question, in that there was no real or potential substitute, or was a new product whose introduction might be prevented, despite specific, constant and regular potential demand on the part of
} 
O caso IMS Health também resultou em modificações e esclarecimentos ao teste das "circunstâncias excepcionais". ${ }^{589}$ O caso tratou da recusa, pela IMS Health, de licenciar direitos autorais sobre um formato geográfico, denominado "1860-brick structure", que acabou se tornando um padrão industrial de facto na Alemanha para apresentação de dados sobre vendas no mercado farmacêutico alemão. ${ }^{590}$ Após reiterar o princípio de que a recusa de licenciar não constitui por si só abuso de posição dominante, o TJUE esclareceu as "circunstâncias excepcionais" em que uma recusa pode violar o Artigo 102 do TFUE. Em primeiro lugar, o Tribunal afirmou que o acesso ao produto protegido por direito de propriedade intelectual deve ser indispensável para conduzir negócios no mercado secundário. ${ }^{591}$ Em sendo esse o caso, três requisitos cumulativos devem ser demonstrados: (i) a recusa deve impedir o surgimento de um novo produto para o qual

consumers (...) In this case, as moreover the Commission and the interveners have pointed out, the televised broadcasting of horse races, although constituting an additional, and indeed suitable, service for bettors, it is not in itself indispensable for the exercise of bookmakers' main activity, namely the taking of bets, as is evidenced by the fact that the applicant is present on the Belgian betting market and occupies a significant position as regards bets on French races. Moreover, transmission is not indispensable, since it takes place after bets are placed, with the result that its absence does not in itself affect the choices made by bettors and, accordingly, cannot prevent bookmakers from pursuing their business". Ladbroke, parágrafos 131 e 132 (grifo nosso).

${ }^{589}$ Case C-418/01 IMS Health GmbH \& Co OHG v NDC Health GmbH \& Co. KG [2004] ECR I-5039.

590 A IMS Health fornecia dados sobre vendas e prescrições de medicamentos no mercado farmacêutico, utilizados por empresas farmacêuticas para mensurar a efetividade de seus esforços promocionais em cada uma das cidades ou regiões em que atuam. No mercado alemão, a IMS Health desenvolveu, com ajuda de seus clientes, um formato geográfico para apresentação desses dados, denominado "1860-brick structure", o que acabou se tornando um padrão de facto para a indústria. Esse formato dividia a Alemanha em 1860 zonas geográficas, baseadas em códigos postais, cada uma contendo pelo menos três empresas farmacêuticas, permitindo a compilação e análise de dados sobre distribuição, vendas, preços e volumes relativos a cada uma das zonas geográficas. Quando uma concorrente, a NDC, ingressou no mercado alemão, a IMS Health invocou perante os tribunais seus direitos autorais sobre o 1860-brick structure para impedir que a empresa fornecesse dados de venda utilizando esse mesmo formato. Ressalte-se que os clientes da NDC deixaram claro que não aceitariam a apresentação de dados de venda em qualquer outro formato que não fosse aquele baseado nas 1860 zonas geográficas. Em consequência, a NDC ingressou com reclamação perante a Comissão alegando que a IMS Health abusou de sua posição dominante ao impedir que a NDC utilizasse o formato 1860-brick structure para apresentar aos seus clientes dados de vendas no mercado farmacêutico.

591 Baseando-se em seu entendimento anterior no caso Oscar Bronner [que não tratou especificamente de direitos de propriedade intelectual], o TJUE afirmou que o acesso ao direito de propriedade intelectual deve ser indispensável para conduzir negócios no mercado secundário, o que deve ser interpretado como absolutamente necessário. Assim, o critério da indispensabilidade não seria satisfeito caso houvesse soluções alternativas ao uso do insumo protegido: "It is clear from paragraphs 43 and 44 of Bronner that, in order to determine whether a product or service is indispensable for enabling an undertaking to carry on business in a particular market, it must be determined whether there are products or services which constitute alternative solutions, even if they are less advantageous, and whether there are technical, legal or economic obstacles capable of making it impossible or at least unreasonably difficult for any undertaking seeking to operate in the market to create, possibly in cooperation with other operators, the alternative products or services. According to paragraph 46 of Bronner, in order to accept the existence of economic obstacles, it must be established, at the very least, that the creation of those products or services is not economically viable for production on a scale comparable to that of the undertaking which controls the existing product or service". IMS Health, parágrafo 28 (grifo nosso). Ressalte-se que essa posição está em linha com o entendimento do Tribunal Geral no caso Ladbroke. 
exista demanda potencial dos consumidores; (ii) a recusa não é justificada de forma objetiva; e (iii) a recusa deve eliminar alguma concorrência no mercado secundário. ${ }^{592}$

Ao analisar o requisito do "novo produto", o TJUE deixou claro que a recusa de licenciar somente será considerada abusiva quando impedir o desenvolvimento do mercado secundário em detrimento dos consumidores. ${ }^{593}$ Para esclarecer seu entendimento, acrescentou que a parte que solicita a licença não deve ter a intenção de meramente duplicar os produtos e serviços que já são ofertados no mercado secundário pelo titular do direito de propriedade intelectual, mas sim desenvolver novos produtos ou serviços que ainda não tenham sido ofertados pelo titular do direito exclusivo e para os quais exista potencial demanda dos consumidores. ${ }^{594}$ A conclusão do TJUE deixa claro que o requisito do "novo produto" tem como objetivo evitar que licenças compulsórias sejam determinadas para favorecer a concorrência pela imitação (estática), o que poderia resultar na fragilização da estrutura de incentivos criada pela propriedade intelectual. Desse modo, o TJUE deixa claro que a recusa de licenciar somente será abusiva quando impedir a concorrência pela substituição ou superação (dinâmica).

Em relação ao terceiro requisito, isto é, se a recusa de licenciar resultou em eliminação da concorrência no mercado secundário, o TJUE afirmou que seria suficiente a identificação de um mercado potencial, ou até mesmo hipotético. Acrescentou, nesse contexto, que seria necessária apenas a identificação de dois diferentes estágios de produção, contanto que o produto "upstream" fosse indispensável ao fornecimento do produto "downstream". 595 Essa conclusão do Tribunal é curiosa e pode dar margem a incertezas, já que a recusa abusiva de contratar ou licenciar normalmente pressupõe a existência de dois mercados distintos, porém relacionados, conforme se observa nos casos anteriores julgados pela Comissão, pelo Tribunal Geral e pelo próprio TJUE. ${ }^{596}$

\footnotetext{
592 IMS Health, parágrafo 38.

593 IMS Health, parágrafo 48.

${ }^{594}$ IMS Health, parágrafo 49.

595 "44. It appears, therefore, as the Advocate General set out in points 56 to 59 of his Opinion, that, for the purposes of the application of the earlier case-law, it is sufficient that a potential market or even hypothetical market can be identified. Such is the case where the products or services are indispensable in order to carry on a particular business and where there is an actual demand for them on the part of undertakings which seek to carry on the business for which they are indispensable. 45. Accordingly, it is determinative that two different stages of production may be identified and that they are interconnected, inasmuch as the upstream product is indispensable for the supply of the downstream product." IMS Health, parágrafos 44 e 45.

${ }^{596}$ Ao criticar essa posição do TJUE, EZRACHI afirma que: “(...) in relation to the third condition, notably that the refusal must be likely to exclude all competition in the secondary market, the Court held that the finding
} 
Ao final, como se tratava apenas de uma decisão preliminar sobre a aplicabilidade do Artigo 102 do TFUE, o TJUE não decidiu se os elementos do teste das “circunstâncias excepcionais" estavam ou não presentes no caso IMS Health, deixando essa incumbência para os tribunais alemães.

O caso Microsoft também resultou em novas interpretações e modificações dos requisitos constantes no teste das "circunstâncias excepcionais", além de refletir a última manifestação dos tribunais europeus acerca do tema da recusa de licenciar. Trata-se de apelação da Microsoft ao Tribunal Geral contra decisão da Comissão, publicada em março de 2004, que entendeu que a empresa abusou de sua posição dominante ao recusar licenciar informações de interoperabilidade, protegidas por direitos de propriedade intelectual, que seriam indispensáveis para que sua concorrente Sun Microsystems, assim como outras rivais, fossem capazes de desenvolver softwares compatíveis com o sistema operacional Windows. De acordo com a Comissão, essas informações permitiriam que outros players concorressem em igualdade de condições com a Microsoft no mercado secundário de softwares de sistemas operacionais de servidores (work group server operating system), utilizados para possibilitar o compartilhamento de softwares, computadores e impressoras entre usuários de uma mesma rede. ${ }^{597}$

A Comissão concluiu que a Microsoft detinha posição dominante no mercado de sistemas operacionais para PCs, pois possuía quase 95\% de participação nesse mercado, o que lhe permitiria impor a arquitetura de domínio Windows como um padrão de facto para o desenvolvimento de servidores. Desse modo, a Comissão entendeu que, ao recusar aos seus concorrentes acesso às informações de interoperabilidade necessárias para o desenvolvimento de servidores capazes de interagir de forma apropriada com a arquitetura padrão Windows, a Microsoft teria como objetivo alavancar sua posição dominante no mercado de sistemas operacionais para o mercado de servidores. Com essa estratégia, os consumidores seriam induzidos a optar pelos servidores da Microsoft, que possuíam plena

of a 'potential or even hypothetical market' would suffice. The finding of a 'fictional' downstream market is significant as it may result in compulsory licensing from a dominant undertaking to its competitor. Arguably, this widening of the breadth of the doctrine, which departed from the upstream downstream model, risks undermining companies' incentive to innovate". EZRACHI, Ariel. Competition Law Enforcement and Refusal to License: The Changing boundaries of Article 102 TFUE, in: ANDERMAN, Steven; EZRACHI, Ariel. Intellectual Property and Competition Law: New Frontiers. Oxford University Press, 2010, p. 98.

${ }^{597}$ Cf. Case COMP/C-3/37.792 - Microsoft [2004]. A decisão também concluiu que a Microsoft abusou de sua posição dominante ao condicionar o licenciamento do sistema operacional Windows para PCs à aquisição simultânea do Windows Media Player (WMP). 
interface com a plataforma Windows, em detrimento aos softwares ofertados pelas concorrentes, uma vez que estes não apresentariam o mesmo nível de interface. ${ }^{598}$

Em sua apelação ao Tribunal de Primeira Instância (atual Tribunal Geral), a Microsoft alegou, entre outras coisas, que informações de interoperabilidade já estavam disponíveis a todos os que desejassem desenvolver softwares compatíveis com o Windows, e que o tipo e a quantidade de informações que a Comissão exigia que fossem disponibilizados permitiriam que seus concorrentes copiassem seus produtos, o que seria prejudicial à inovação. Ademais, a Microsoft alegou que as "circunstâncias excepcionais" que permitiriam o licenciamento compulsório de direitos de propriedade intelectual não estariam presentes no caso.

Em setembro de 2007, o Tribunal Geral publicou sua decisão confirmando as conclusões da Comissão no sentido de que a Microsoft abusou de sua posição dominante ao recusar fornecer informações adequadas de interoperabilidade aos seus concorrentes. Apoiando-se nos casos Volvo, Magill e IMS Health, o Tribunal Geral afirmou que a recusa de licenciar o uso de um produto protegido por direito de propriedade intelectual não pode, por si só, constituir abuso de posição dominante nos termos do Artigo 102 do TFUE, acrescentando que somente em "circunstâncias excepcionais" o exercício do direito exclusivo pelo seu titular pode resultar em tal abuso. Assim, o Tribunal Geral estabeleceu os seguintes requisitos para a configuração dessas circunstâncias: (i) em primeiro lugar, a recusa refere-se a um produto ou serviço indispensável para exercer uma atividade específica num mercado adjacente; (ii) em segundo lugar, a recusa é do tipo que exclui qualquer concorrência efetiva nesse mercado; e (iii) em terceiro lugar, a recusa impede o surgimento de um novo produto para o qual exista potencial demanda dos consumidores. ${ }^{599}$ Por fim, o Tribunal Geral acrescentou que, se essas circunstâncias estiverem presentes, a recusa do agente econômico dominante de conferir uma licença pode violar o Artigo 102 do TFUE, a não ser que seja "objetivamente justificada". 600

Ao analisar o primeiro requisito - indispensabilidade -, o Tribunal Geral parece ter adotado uma abordagem mais ampla do que nos casos anteriores. No caso IMS Health, o TJUE afirmara que o produto ou serviço protegido por direitos de propriedade

\footnotetext{
${ }^{598}$ A Comissão impôs uma multa no valor de €497.196.304 e determinou que a Microsoft colocasse fim ao abuso licenciando as informações de interoperabilidade no prazo de 120 dias.

${ }^{599}$ Case T-201/04 Microsoft v Commission, parágrafo 332.
} 
intelectual seria indispensável apenas quando fosse a única alternativa para que um agente econômico pudesse conduzir negócios e concorrer no mercado. Contudo, o Tribunal Geral, no caso Microsoft, entendeu que o requisito da indispensabilidade seria atendido quando o acesso ao direito de propriedade intelectual em questão fosse necessário para possibilitar que agentes econômicos ingressassem no mercado como "concorrentes viáveis", e não apenas como players marginais. ${ }^{601}$ Com base nesse entendimento, as informações de interoperabilidade foram consideradas indispensáveis para que os servidores desenvolvidos por terceiros fossem capazes de "interagir" com o Windows em igualdade de condições em relação aos servidores da Microsoft. ${ }^{602}$

Quanto ao segundo requisito - eliminação da concorrência no mercado secundário -, o Tribunal Geral também adotou uma abordagem mais ampla em comparação com outros casos. A Microsoft questionou a conclusão da Comissão no sentido de que a recusa de licenciar as informações de interoperabilidade criaria o risco de que toda concorrência efetiva no mercado secundário de servidores fosse eliminada. Em casos anteriores, o Tribunal Geral e o TJUE sempre afirmaram que a recusa de licenciar resultaria em provável eliminação de toda a concorrência. ${ }^{603}$ Nos casos Magill e IMS Health, por exemplo, a recusa de licenciar teve o efeito imediato de forçar os concorrentes para fora do mercado secundário, de modo que a eliminação da concorrência era provável e iminente. ${ }^{604}$ Contudo, a recusa da Microsoft de licenciar as informações de

${ }^{600}$ Case T-201/04 Microsoft v Commission, parágrafo 333.

601 "The Commission analyzed the indispensability criterion (...) and examined whether there were alternative solutions to disclosure of the relevant information that would enable undertakings to compete viably with Microsoft on the work group server operating systems market. (...) The question is whether the information that Microsoft refuses to disclose is indispensable to any competitor seeking to carry on business on the relevant market 'as a viable competitive constraint and not as a de minimis player who has effectively left the market for a 'niche' position." Case T-201/04 Microsoft v Commission, parágrafos 354 e 355.

${ }^{602}$ Ao analisar os argumentos da Microsoft no sentido de que seus concorrentes permaneceram no mercado mesmo após a recusa de licenciar as informações de interoperabilidade e lançamento de seus servidores, o que seria mais uma evidência de que tais informações não eram indispensáveis, o Tribunal Geral afirmou que o fato de a concorrência ser eliminada gradualmente e não imediatamente não contraria o argumento da Comissão de que as informações em questão são indispensáveis. Case T-201/04 Microsoft v Commission, parágrafo 428.

${ }^{603}$ Case T-201/04 Microsoft v Commission, parágrafo 439.

${ }^{604}$ No caso Magill a recusa de licenciar impediu a segunda edição de um guia de programação de TV logo após o lançamento da primeira. Assim, toda a concorrência foi prontamente eliminada como resultado da recusa. No caso IMS Health, a recusa de licenciar, acompanhada de algumas liminares obtidas nos tribunais alemães, impediu a NDC de fornecer dados sobre o mercado farmacêutico no formato que seus clientes desejavam. De novo, a recusa teve o efeito imediato de eliminar a concorrência assim que as liminares foram concedidas. Sobre o assunto, cf. KILLICK, James. IMS and Microsoft Judged in the Cold Light of IMS, in: The Competition Law Review, v. 1, Issue 2, Dec. 2004, p. 39. 
interoperabilidade no máximo colocava seus concorrentes em desvantagem competitiva no mercado de servidores.

Ao analisar a questão, o Tribunal Geral afirmou que o Artigo 102 do TFUE não se aplica apenas quando a concorrência no mercado já foi eliminada, de modo que não caberia à Comissão esperar que os concorrentes fossem eliminados do mercado, ou que a eliminação se tornasse iminente, para então resolver intervir. Se assim agisse, estaria contrariando o objetivo daquele dispositivo, que é justamente preservar a concorrência no mercado relevante. ${ }^{605}$ Adicionalmente, o Tribunal Geral constatou que a presença de externalidades de redes no mercado de servidores tornaria ainda mais provável a eliminação da concorrência, levando a uma situação praticamente irreversível. ${ }^{606}$ Desse modo, sem acesso às informações de interoperabilidade, os rivais da Microsoft concorreriam em extrema desvantagem no mercado de servidores, o que seria suficiente para, em curto prazo, eliminar seus incentivos para investir nesse mercado. ${ }^{607}$

Quanto ao requisito do "novo produto", o Tribunal Geral também desenvolveu uma nova interpretação. A Comissão havia concluído que a recusa da Microsoft de compartilhar as informações de interoperabilidade teve como resultado a redução de inovação no mercado afetado e na diminuição das possibilidades de escolha dos consumidores, já que estes seriam induzidos a optar pela solução homogênea oferecida pela Microsoft (o que seria a consequência do chamado efeito lock-in). Assim, ao contrário dos casos anteriores, a Comissão não identificou nenhum novo produto que os concorrentes da Microsoft teriam desenvolvido a partir das informações de interoperabilidade. $^{608}$

605 “(...) Article [102 TFUE] does not apply only from the time when there is no more competition in the market. If the Commission were required to wait until competitors were eliminated from the market, or until their elimination was sufficiently imminent, before being able to take action under Article 82 EC, that would clearly run counter to the objective of that provision, which is to maintain undistorted competition in the common market and, in particular, to safeguard the competition that still exists in the relevant market." Case T-201/04 Microsoft v Commission, parágrafo 561.

606 "In this case, the Commission had all the more reason to apply Article 82 EC before the elimination of competition on the work group server operating systems market had become a reality because that market is characterized by significant network effects and because the elimination of competition would therefore be difficult to reverse." T-201/04 Microsoft v Commission, parágrafo 562.

${ }^{607}$ Case T-201/04 Microsoft v Commission, parágrafo 593.

${ }^{608}$ No caso IMS Health, o TJUE esclareceu que a recusa de licenciar somente seria abusiva quando um agente econômico reserva o mercado secundário para si, impedindo o surgimento de um novo produto. $\mathrm{O}$ TJUE deixou claro que simples cópias ou imitações dos produtos já vendidos pelo titular dos direitos de propriedade intelectual não seriam suficientes, já que a empresa que solicita uma licença deve ter a intenção 
Ao analisar a questão, o Tribunal Geral afirmou que o requisito do novo produto, conforme estabelecido nos casos Magill e IMS Health, não pode ser o único parâmetro para determinar se uma recusa de licenciar um direito de propriedade intelectual é capaz de causar dano aos consumidores nos termos do Artigo 102 do TFUE. Isso porque, segundo o Tribunal, uma recusa de licenciar pode ser abusiva não apenas quando impedir a produção ou comercialização de um novo produto, mas também quando limitar o desenvolvimento técnico em detrimento dos consumidores, conforme expressamente previsto na alínea "b" do Artigo 102 do TFUE. ${ }^{609}$ Assim, o Tribunal Geral concluiu que, dada a presença de externalidades de redes, um crescente número de consumidores seriam "trancados" (lock-in) na "solução homogênea do Windows", uma vez que os concorrentes da Microsoft não teriam condições de desenvolver soluções alternativas, tendo em vista o grau inferior de interoperabilidade que seus servidores poderiam alcançar com a arquitetura padrão do Windows. ${ }^{610}$

Finalmente, ao analisar as justificativas da Microsoft para sua recusa de licenciar, no sentido de que uma licença compulsória prejudicaria seus incentivos para inovar, o Tribunal Geral afirmou que é comum na indústria de software os operadores disponibilizarem informações técnicas que facilitam a interoperabilidade entre os diferentes produtos e a própria Microsoft disponibilizava essas informações aos seus concorrentes antes de ingressar no mercado de servidores. ${ }^{611}$

Como se pode observar, é inegável que o Tribunal Geral fez uma nova interpretação das "circunstâncias excepcionais" que autorizariam o licenciamento compulsório de direitos de propriedade intelectual como forma de remediar uma recusa abusiva de licenciar. Essa mudança de abordagem, embora possa causar incertezas aos

de ofertar novos produtos e serviços não fabricados pelo titular do direito exclusivo e para os quais haja potencial demanda dos consumidores.

${ }^{609}$ Case T-201/04 Microsoft v Commission, parágrafo 647.

610 “Thus, in the first place, the Commission was correct to observe, at recital 694 to the contested decision, that '[owing] to the lack of interoperability that competing work group server operating system products can achieve with the Windows domain architecture, an increasing number of consumers are locked into a homogeneous Windows solution at the level of work group server operating systems'." Case T-201/04 Microsoft $v$ Commission, parágrafo 650.

611 “ $(\ldots)$ the Court observes that, as the Commission correctly finds at recitals 730 to 734 to the contested decision, it is normal practice for operators in the industry to disclose to third parties the information which will facilitate interoperability with their products and Microsoft itself had followed that practice until it was sufficiently established on the work group server operating systems market. Such disclosure allows the operators concerned to make their own products more attractive and therefore more valuable. In fact, none of the parties has claimed in the present case that such disclosure had had any negative impact on those operators' incentives to innovate." Case T-201/04 Microsoft v Commission, parágrafo 702. 
titulares de direitos de propriedade intelectual, parece confirmar entendimentos anteriores da Comissão e do TJUE no sentido de que os elementos do teste das "circunstâncias excepcionais" não são exaustivos, podendo ser adaptados conforme as circunstâncias dos casos concretos.

De qualquer modo, conforme se observa nas Diretrizes publicadas em 2009 sobre as prioridades da Comissão na aplicação do Artigo 102 do TFUE a comportamentos abusivos de exclusão (Diretrizes de 2009 sobre o Artigo 102), a Comissão eliminou a distinção entre casos de recusa de licenciamento e recusa de fornecimento, não havendo qualquer referência expressa ao requisito do "novo produto". De acordo com essa nova abordagem, a Comissão analisará prioritariamente as práticas de recusa de fornecimento no âmbito da aplicação das regras de concorrência, desde que estejam cumulativamente reunidas as seguintes circunstâncias: (i) a recusa envolve produto ou serviço objetivamente necessário para uma concorrência efetiva no mercado a jusante; (ii) a recusa pode ter como resultado a eliminação da concorrência efetiva no mercado a jusante; e (iii) a recusa é suscetível de causar prejuízo aos consumidores. ${ }^{612}$

Embora o requisito do "novo produto" não tenha sido mencionado expressamente entre as circunstâncias em que uma recusa de fornecimento poderá ser considerada abusiva, a Comissão deixa claro nas Diretrizes de 2009 sobre o Artigo 102 que a análise de eventuais prejuízos aos consumidores levará em consideração a possibilidade de uma recusa de licenciar impedir o surgimento de produtos e serviços inovadores no mercado, prejudicar a inovação cumulativa (follow on innovation), ou impedir o desenvolvimento tecnológico, em detrimento do bem-estar dos consumidores. ${ }^{613}$ Embora o objetivo da Comissão seja preservar a concorrência dinâmica nos mercados, a abordagem contida nas Diretrizes foi criticada por ser superficial e incompleta, não estabelecendo parâmetros claros para intervenção antitruste nesses casos. ${ }^{614}$

\footnotetext{
${ }^{612}$ Cf. parágrafo 81 das Diretrizes de 2009 sobre a aplicação do Artigo 102.

613 "The Commission considers that consumer harm may, for instance, arise where the competitors that the dominant undertaking forecloses are, as a result of the refusal, prevented from bringing innovative goods or services to market and/or where follow-on innovation is likely to be stifled. This may be particularly the case if the undertaking which requests supply does not intend to limit itself essentially to duplicating the goods or services already offered by the dominant undertaking on the downstream market, but intends to produce new or improved goods or services for which there is a potential consumer demand or is likely to contribute to technical development." Cf. parágrafo 87 das Diretrizes de 2009 sobre a aplicação do Artigo 102.

${ }^{614}$ Cf. EZRACHI, Ariel. Competition Law Enforcement and Refusal to License: The Changing boundaries of Article 102 TFUE, in: ANDERMAN, Steven; EZRACHI, Ariel. Intellectual Property and Competition Law: New Frontiers. Oxford University Press, 2010, p. 108.
} 


\subsubsection{Abusos na imposição de direitos de propriedade intelectual}

A imposição de um direito de propriedade intelectual, seja por meios judiciais ou extrajudiciais, nada mais é do que a legítima defesa de um direito exclusivo legitimamente conferido pelo Estado. A propositura de ações judiciais de infração é muitas vezes a única alternativa à disposição de titulares de patentes e direitos autorais para evitar que terceiros, na maioria das vezes concorrentes efetivos ou potenciais, explorem indevidamente seus direitos exclusivos sem autorização. Além disso, o acesso à justiça com o objetivo de preservar direitos ou obter reparação de danos é normalmente assegurado constitucionalmente. ${ }^{615}$ Desse modo, pode-se afirmar que tanto nos Estados Unidos como na União Europeia a imposição de direitos de propriedade intelectual válidos é praticamente imune à intervenção antitruste, ainda que resulte na exclusão de concorrentes do mercado.

Por outro lado, condutas abusivas de exclusão podem resultar da imposição de direitos de propriedade intelectual ilegítimos, como ocorre, por exemplo, nos casos de imposição de patentes inválidas que tenham sido obtidas de forma indevida perante o órgão de patentes. Assim, veremos que quando um direito de propriedade intelectual é obtido de forma ilegítima e utilizado para excluir concorrentes poderá haver violação das normas antitruste. Nesse sentido, HovENKAMP afirma que:

Many claims of unlawful monopolization have been based on the theory that the defendant in the antitrust suit had previously filed an IP infringement suit was improper, meaning that the patent owner knew or should have known that its patent had been obtained by fraud or was unenforceable for other reasons, or perhaps that the product really did not infringe. (...) The Supreme Court recognized such claims in Walker Process, where the antitrust defendant allegedly had obtained a patent by fraud and then filed an infringement suit in order to keep a rival out of this market. The decisions often contrast the patentee's legitimate interest

\footnotetext{
${ }^{615}$ A Primeira Emenda da Constituição norte-americana declara que o Congresso não poderá aprovar leis que restrinjam o direito de peticionar ao governo (incluindo tribunais e órgãos da administração pública) com o objetivo de obter reparação de injustiças. Nesse sentido, a doutrina Noerr-Pennington, conforme desenvolvida pelos tribunais norte-americanos, assegura imunidade antitruste ao direito de peticionar ao governo. Cf. FISHEL, Daniel R. Antitrust Liability for Attempts to Influence Government Action: The Basis and Limits of the Noerr-Pennington Doctrine, 45 U. Chi. L. Rev. 80, 101 (1977). Da mesma forma, o Artigo 47 da Carta de Direitos Fundamentais da União Europeia estabelece que aqueles que sofram violações de direitos ou liberdades garantidos pela legislação comunitária possuem o direito de recorrer aos tribunais, sejam eles judiciais ou administrativos.
} 
in protecting its intellectual property through infringement suits against the competing rights of rivals and the public to be free of monopoly.

\section{$(\ldots)$}

The basic principle is clear: a firm has a legal power to exclude, whether derived from the IP laws or elsewhere, has a right to enforce its power before a court or appropriate regulatory agency. However, it has no right to assert exclusionary powers that it does not have, to assert rights broader than the right that it actually has, or to assert claims against those who are not trespassing on its rights. Recognizing 'Walker Process' claims does not create any conflict with IP rights, because the entire basis of the claim is that the IP "right" being asserted does not exist or is unenforceable.

When a firm asserts such right improperly and should have known better, it is very likely guilty of the tort of malicious prosecution. And when the structural conditions for monopoly are present, it may also have violated antitrust laws. ${ }^{616}$ (grifo nosso)

Assim, conforme ensina HovENKAMP, resta configurada a violação da Seção 2 do Sherman Act, quando um agente econômico dominante tem consciência de que sua patente não deveria ter sido concedida, mas mesmo assim a utiliza para excluir seus concorrentes. $^{617}$

No caso Walker Process, julgado pela Suprema Corte norte-americana em 1965, a Food Machinery \& Chemical Corp. ingressou com ação judicial em face da Walker Process Equipment, Inc., alegando que esta violou sua patente. Em sede de defesa, a Walker Process alegou que não houve violação e que a patente em questão foi obtida de forma fraudulenta, uma vez que a Food Machinery não revelou propositalmente ao US Patent and Trademark Office (USPTO) o uso público anterior da invenção objeto do

\footnotetext{
${ }^{616}$ HOVENKAMP. Herbert. The Antitrust Enterprise: Principle and Execution. Harvard University Press, p. 267-268.

${ }^{617}$ No mesmo sentido, GAVIL, KOVACIC e BAKER afirmam que: “(...) Where a patent in the first instance has been lawfully acquired, a patent holder should be allowed to exercise his patent's exclusionary power even after achieving commercial success; (...) Where, however, the acquisition itself is unlawful, the subsequent exercise of the ordinary lawful exclusionary power inherent in the patent would be a continuing wrong, a continuing unlawful exclusion of potential competitors". GAVIL, Andrew; KOVACIC, William; BAKER, Jonathan. Antitrust law in perspective cases, concepts and problems in competition policy. Thomson West, 2002, p. 1117.
} 
pedido de patente, o que impossibilitaria a concessão da patente por ausência do requisito da novidade. ${ }^{618}$ A Walker Process também argumentou que, nessas circunstâncias, a obtenção e imposição da patente violaria a Seção 2 do Sherman Act. A Suprema Corte concordou com os argumentos da Walker Process, afirmando que a manutenção e imposição de patente obtida por meio de fraude perante o USPTO pode constituir a base de uma ação antitruste, nos termos da Seção 2 do Sherman Act. ${ }^{619}$ Nesse caso, a fraude é definida como apresentação intencional e deliberada de informações falsas ao órgão de registro de patentes. ${ }^{620}$

Em casos mais recentes, o Federal Circuit estabeleceu que uma alegação de fraude com base no caso Walker Process depende da comprovação dos seguintes elementos: (i) o titular da patente detém poder de mercado ou grande probabilidade de obtenção desse poder; (ii) a patente foi obtida por meios fraudulentos, consubstanciados na apresentação de informações enganosas ou omissão propositada, de modo que a patente não teria sido concedida na ausência dessa conduta fraudulenta ${ }^{621}$; (iii) havia intenção de enganar, sendo insuficiente, portanto, a mera negligência ou imperícia (inequitable conduct) na apresentação das informações ao órgão de registro de patentes; e (iv) o titular da patente tinha conhecimento da fraude no momento em que propôs a ação de infração. ${ }^{622}$

Ressalte-se que a mera obtenção da patente por meios fraudulentos, ainda que viole a legislação patentária, é insuficiente para levantar preocupações do ponto de vista antitruste. ${ }^{623}$ Somente a imposição da patente em questão contra rivais é capaz de produzir efeitos sobre o mercado, o que pode se dar não apenas por meio da propositura de ações

\footnotetext{
${ }^{618}$ A Food Machinery havia apresentado ao PTO uma declaração juramentada afirmando que não tinha conhecimento de qualquer uso público da invenção nos Estados Unidos em período anterior aos doze meses que antecederam o depósito do pedido de patente. Entretanto, a Food Machinery estava envolvida nesse uso, o que seria suficiente para invalidar a patente por ausência do requisito da novidade.

${ }^{619}$ Walker Process, 382 U.S. p. 177-8.

${ }^{620}$ Id., ibid.

${ }^{621}$ No caso Nobelpharma, a principal controvérsia não foi a apresentação de informações enganosas, mas sim a omissão deliberada de um fato essencial, o que foi suficiente para uma alegação de fraude com base no Walker Process. O tribunal concluiu que uma omissão fraudulenta pode ser tão repreensível quanto uma afirmação enganosa. O tribunal então concluiu que a Nobelpharma sabia que a patente não teria sido concedida, caso o USPTO tivesse conhecimento da informação omitida no pedido de patente. Nobelpharma Ab v. Implant Innovations, 141 F.3d 1059, (Fed. Cir. 1998), p. 1072.

${ }^{622}$ Cf. C.R. Bard, Inc. v. M3 Sys., Inc., 157 F.3d 1340 (Fed. Cir. 1998), 1365; e Nobelpharma Ab v. Implant Innovations, 141 F.3d 1059 (Fed. Cir. 1998), p. 1071.

623 "Mere procurement of a patent, whatever the conduct of the applicant in the procurement, cannot without more affect the welfare of the consumer and cannot itself violate antitrust laws." FMC Corp. v. Manitwoc Co., 835 F.2d 1411, 1418 \& n. 16 (Fed. Cir. 1987). Cf. HOVENKAMP, Herbert. Federal Antitrust Policy: The Law of Competition and its Practice. 3rd ed. Saint Paul, Minn.: Thomson West, 2005, p. 329.
} 
judiciais, mas também, em determinadas circunstâncias, por meio de ameaças, como ocorre, por exemplo, quando o titular da patente envia notificações solicitando a cessação do uso da patente sob pena da propositura de medidas judiciais. ${ }^{624}$

No caso Handgards, o Ninith Circuit concluiu que uma violação da Seção 2 do Sherman Act pode ocorrer quando um monopolista ingressa com ação de infração sabendo que sua patente é inválida. ${ }^{625} \mathrm{~A}$ patente, no caso, era inválida por não cumprir com o requisito da novidade, uma vez que o produto objeto de proteção havia sido comercializado nos Estados Unidos em período anterior aos doze meses que antecederam o depósito do pedido de patente. Embora a Ethicon, Inc., titular da patente, não soubesse desse fato no momento em que depositou o pedido, acabou tomando conhecimento posteriormente e mesmo assim ingressou com ações de infração em face de sua rival. O tribunal entendeu que o titular de uma patente tem o direito de testar a validade de seu direito exclusivo por intermédio de ações judiciais de infração, mas concluiu que a Ethicon agiu de má-fé ao ingressar com as ações em questão, uma vez que tinha conhecimento de que sua patente era inválida, de modo que seu objetivo era excluir a concorrência no mercado relevante. ${ }^{626}$ O caso Loctite envolveu argumentos e conclusões semelhantes, mas tratou-se da propositura de ação de infração relativa a uma patente que, embora fosse válida, seu titular sabia que não estava sendo infringida. ${ }^{627}$

A imposição de direitos de propriedade intelectual, independentemente de serem válidos ou inválidos, também pode constituir conduta abusiva de exclusão nas hipóteses em que a ação judicial proposta carece de base legal objetiva, prática conhecida como "sham litigation" ou abuso de procedimentos judiciais. A prática de "sham litigation" decorre da propositura de ação sem propósitos legítimos, usada tão somente para aumentar os custos dos rivais, dificultar sua permanência ou intimidá-los a sair do mercado, bem como para inibir a entrada de novos agentes econômicos. A jurisprudência antitruste sobre "sham litigation" foi inicialmente desenvolvida nos EUA, como exceção à doutrina Noerr

${ }^{624}$ Cf. Unitherm Food Sys., Inc. v. Swift-Eckrich, Inc., 375 F.3d 1341, 1357-8 (Fed. Cir. 2004); e MedImmune, Inc. v. Genentech, Inc., 427 F.3d 958, 968 (Fed. Cir. 2005).

${ }^{625}$ Handgards, Inc. v. Ethicon, Inc., 601 F.2d 986 ( $9^{\text {th }}$ Cir. 1979), cert. denied, 444 U.S. 1025 (1980)

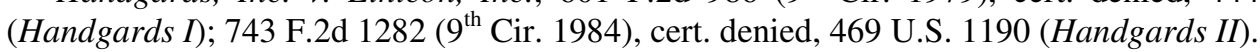

${ }^{626} \mathrm{O}$ tribunal considerou que a boa-fé do titular da patente é presumida, cabendo àquele que alega má-fé apresentar evidências claras e convincentes para sustentar sua alegação. De acordo com o tribunal, essa forte presunção de que a ação de infração foi proposta de boa-fé seria necessária para conferir proteção razoável ao titular de uma patente que recorre à justiça de forma legítima. Handgards I, 601 F.2d, p. 990-996.

${ }^{627}$ Loctite Corp. v. Ultrassel Ltd., 781 F.2d 861 (Fed. Cir. 1985). 
- Pennington, por meio da qual as partes devem ter pleno acesso e direito de petição aos órgãos governamentais mesmo que dele possam decorrer efeitos anticoncorrenciais. ${ }^{628}$

A despeito da doutrina Noerr - Pennington, a Suprema Corte norte-americana passou a punir a prática de "sham litigation", assim entendidas ações que, na realidade, objetivam prejudicar ou limitar a livre concorrência, criando empecilhos e situações meramente protelatórias sem base legal. Assim, entende-se "sham litigation" como litigância predatória ou fraudulenta com objetivo de excluir a concorrência no mercado.

O caso Professional Real Estate Investor (PRE). Inc., et al. v. Columbia Pictures Industries Inc., et al., julgado pela Suprema Corte norte-americana, envolveu uma discussão sobre a prática de "sham litigation" consubstanciada na imposição de direito de propriedade intelectual. Nesse caso, a PRE operava um hotel que alugava aos seus hóspedes filmes da Columbia Pictures protegidos por direitos autorais. A Columbia Pictures alegou que a locação de seus filmes pelo hotel constituiria "execução pública de obra" em violação aos seus direitos de propriedade intelectual. Em sede de defesa, a PRE sustentou que a ação proposta pela autora constituía "sham litigation" e tentativa de monopolização. A interpretação da legislação de copyrights norte-americana feita pela Columbia Pictures acabou revelando-se equivocada, o que a levou à improcedência de sua ação. Contudo, a Suprema Corte rejeitou as alegações de "sham litigation", afirmando que seus elementos não estavam presentes no caso. Para a Corte, há "sham litigation" sempre que estiverem presentes dois requisitos, um objetivo e outro subjetivo, quais sejam: (i) a interposição de uma ação judicial desprovida de qualquer base objetiva (requisito objetivo); e (ii) que represente uma tentativa de interferir diretamente nos negócios de um concorrente em vez de almejar outro resultado de tal processo (requisito subjetivo). ${ }^{629}$

Embora os casos Walker Process e Handgards não tenham sido tratados como casos típicos de "sham litigation", isto é, como exceção à doutrina Noerr-Pennington, é possível sustentar que a tentativa de imposição de patentes fraudulentas ou sabidamente inválidas traduz uma conduta de má-fé capaz de tornar ilegítima e sem base legal objetiva

\footnotetext{
628 A doutrina Noerr-Pennington é derivada de dois casos famosos, a saber, o Eastern R. Presidents Conference v. Noerr Motor Freight Inc. (Noerr) e o caso United Mine Workers of America v. Pennington (Pennington).

${ }^{629}$ Professional Real Estate Investor (PRE). Inc., et al. v. Columbia Pictures Industries Inc., et al., 508 U.S. 49 (1993), p. 65.
} 
qualquer ação judicial de infração, conforme os padrões estabelecidos no caso $P R E{ }^{630}$ Entretanto, o Federal Circuit, no caso Nobelpharma, reconheceu que a imposição de um direito de propriedade intelectual por meio de uma ação judicial frívola ("sham litigation"), constitui tipo de conduta abusiva independente em relação à conduta de impor patentes fraudulentas ou sabidamente inválidas, conforme os casos Walker Process e Handgards. De acordo com o tribunal, haveria dois fundamentos jurídicos distintos capazes de "despir" o titular da patente de sua imunidade antitruste. Assim, o réu de uma ação de infração poderia optar por estabelecer um argumento com base nos critérios mais rígidos contidos no caso $P R E$, recaindo na exceção à imunidade antitruste contida na doutrina NoerrPennington ("sham litigation"), ou estabelecer argumentos com base nos critérios contidos nos casos Walker Process e Handgards, comprovando a má-fé do autor ao tentar impor uma patente obtida por meios fraudulentos (ação ou omissão intencional) ou que sabia ser inválida. Nesse último caso, não haveria a necessidade de comprovar o requisito objetivo contido no caso PRE. ${ }^{631}$

As conclusões do Federal Circuit fazem sentido na medida em que a imposição de uma patente obtida de forma indevida, no contexto dos casos Walker Process e Handgards, pode também decorrer de condutas anticoncorrenciais que não chegam a constituir uma ação judicial propriamente dita, como, por exemplo, ameaças de propositura de medidas judiciais ou até mesmo a recusa de licenciar. Essas condutas são suficientes para inibir a entrada no mercado, principalmente quando os potenciais concorrentes do monopolista presumem que sua patente é válida. ${ }^{632}$ Assim, condutas abusivas de exclusão

${ }^{630}$ Cf. O'DONNEL, S. W. "Unified Theory of Antitrust Counterclaims in Patent Litigation", 9 Virginia Journal of Law \& Technology 1, 14 (2004), p. 3 e 7; e MAGGIOLINO, Mariateresa. Intellectual Property and Antitrust: A Comparative Economic Analysis of US and EU Law. Celtenham: Edward Elgar, 2011, p. 196.

631 "PRE and Walker Process provide alternative legal grounds on which a patentee may be stripped of its immunity from the antitrust laws; both legal theories may be applied to the same conduct. Moreover, we need not find a way to merge these decisions. Each provides its own basis for depriving a patent owner of immunity from the antitrust laws; either or both may be applicable to a particular party's conduct in obtaining and enforcing a patent. The Supreme Court saw no need to merge these separate lines of cases and neither do we. Consequently, if the above-described elements of Walker Process fraud, as well as the other criteria for antitrust liability, are met, such liability can be imposed without the additional sham inquiry required under PRE. That is because Walker Process antitrust liability is based on the knowing assertion of a patent procured by fraud on the PTO, very specific conduct that is clearly reprehensible. On the other hand, irrespective of the patent applicant's conduct before the PTO, an antitrust claim can also be based on a PRE allegation that a suit is baseless; in order to prove that a suit was within Noerr's 'sham' exception to immunity, an antitrust plaintiff must prove that the suit was both objectively baseless and subjectively motivated by a desire to impose collateral, anti-competitive injury rather than to obtain a justifiable legal remedy." Nobelpharma AB v. Implant Innovations, Inc., 141 F.3d 1059 (Fed. Cir. 1998), p. 1070.

${ }^{632}$ Sobre o tema, HovenKAMP afirma que: “(...) certain actions falling short of an infringement suit can be anticompetitive. For example, suppose that a patentee acquires its patent by fraud, misstating facts that are 
consubstanciadas na imposição de patentes fraudulentas ou inválidas, mesmo na ausência de ação judicial, são suscetíveis de produzir efeitos danosos à concorrência e ao bem-estar dos consumidores.

Na União Europeia, casos envolvendo abusos na imposição de direitos de propriedade intelectual são escassos, e a decisão do Tribunal Geral no caso AztraZeneca é considerada a principal referência sobre o tema. ${ }^{633}$ Nesse caso, a Comissão aplicou multa de 60 milhões de euros à AztraZeneca após concluir que a empresa abusou de sua posição dominante ao apresentar informações enganosas em diversos órgãos nacionais de registro de patentes no âmbito da União Europeia entre 1993 e 2000, com o objetivo de obter Certificados de Proteção Suplementar (CPS) para sua patente que protegia o princípio ativo Omeprazol, utilizado na fabricação do medicamento Losec. A conduta visaria prolongar artificialmente a proteção patentária do medicamento de referência e atrasar o ingresso de medicamentos genéricos no mercado, em detrimento dos consumidores. ${ }^{634}$

A Comissão entendeu que a AztraZeneca apresentou informações enganosas perante órgãos de patentes nacionais para obter CPS por período superior ao que teria direito. ${ }^{635}$ Concluiu também que as informações apresentadas pela AztraZeneca permitiram-lhe obter proteção adicional para sua patente em três países onde não teria qualificação para obter CPS. Durante todo o prazo adicional de proteção obtido de forma indevida, empresas fabricantes de genéricos tiveram dificuldades para ingressar no

exclusively within its control. It then refuses to license the patent to another firm, and this firm, assuming the patent's validity, chooses not to enter the market. In that case the patent obtained by fraud has been used anticompetitively by conduct falling short of an infringement suit. Of course, the same story might apply to cases where the patent is invalid for reasons falling short of fraud." HOVENKAMP, Herbert. Federal Antitrust Policy: The Law of Competition and its Practice. 3rd ed. Saint Paul, Minn.: Thomson West, 2005, p. 332.

${ }^{633}$ Case T-321/05 AstraZeneca v Commission..

${ }^{634}$ Os chamados Supplementary Protection Certificates - SPC (Certificados de Proteção Suplementar - CPS) são regulados na União Europeia pelo Regulamento n. ${ }^{\circ}$ 1768/92 e servem para estender por até cinco anos o prazo de proteção de patentes sobre princípios ativos de medicamentos. Esse período adicional de proteção serve para compensar os laboratórios farmacêuticos pelo tempo muitas vezes longo que normalmente levam para obter autorizações regulatórias para a comercialização dos medicamentos após a concessão da patente. Durante o período de proteção adicional, versões genéricas do medicamento de referência não podem ser lançadas no mercado. A duração da proteção adicional conferida por um CPS depende da data da primeira autorização concedida por uma autoridade regulatória nacional para o lançamento do medicamento no mercado. Ressalte-se que os órgãos patentários nacionais concedem CPS com base em informações prestadas pela própria empresa interessada, não havendo qualquer análise aprofundada sobre essas informações.

${ }^{635}$ De acordo com a Comissão, a AstraZeneca havia informado que a data da primeira autorização para comercialização foi em 21 de março de 1988, quando a lista de preços do seu produto foi publicada em Luxemburgo, omitindo propositadamente autorizações concedidas anteriormente na França (em 15 de abril de 1987) e em Luxemburgo (em 16 de novembro de 1987), o que lhe possibilitou obter prazo de proteção 
mercado, pois foram obrigadas a contestar a validade dos CPS detidos pela AztraZeneca perante tribunais e órgãos patentários nacionais. É importante destacar que a Comissão considerou que a aquisição dos CPS por meios fraudulentos constitui violação do Artigo 102, de modo que o ingresso da AztraZeneca perante os tribunais para impor o direito exclusivo ilegítimo nada mais seria do que a continuação lógica de sua conduta abusiva. ${ }^{636}$

Em decisão publicada em julho de 2010, em sede de apelação, o Tribunal Geral concordou com as conclusões da Comissão, sustentando que a natureza enganosa das afirmações feitas a autoridades públicas deve ser analisada com base em fatores objetivos e que a prova da natureza deliberada da conduta e da má-fé do agente econômico dominante não é necessária para identificar um abuso de posição dominante. ${ }^{637}$ Para o Tribunal, a questão sobre se houve ou não apresentação de informações enganosas a autoridades públicas com o objetivo de obter direitos exclusivos de forma indevida, deve ser analisada in concreto, podendo variar de acordo com as circunstâncias específicas de cada caso. Afirmou, então, que a questão objetiva é saber se a conduta levou autoridades públicas a criar obstáculos regulatórios à concorrência por meio da concessão de direitos exclusivos ilegais ao agente econômico dominante. Assim, o Tribunal Geral concordou com a conclusão da Comissão no sentido de que a discricionariedade limitada dos órgãos patentários que concedem o CPS, ou mesmo a ausência de qualquer obrigação de verificar a veracidade das informações prestadas, constituem fatores relevantes a serem levados em

maior para sua patente, além de obter proteção adicional em países nos quais não estava qualificada para tanto. Cf. Commission Decision COMP/A. 37.507/F3 - AstraZeneca, 15 June 2005, parágrafo 182.

636 "The Commission points out, next, that this case only incidentally concerns court proceedings, since the matters at issue in this case are misleading representations to patent agents and patent offices. It refers, in this regard, to recitals 736 to 740 of the contested decision and asserts that AZ's submissions before the courts are the logical continuation of a proactive exclusionary strategy implemented as of 6 May 1993 at the latest and consisting of misleading representations. Accordingly, in so far as the competitors had to bear the costs and suffer the delays associated with legal proceedings, that was a consequence of the SPCs granted as a result of AZ's misleading representations, which obliged them to engage in extensive litigation." Case T-321/05 AstraZeneca v Commission, parágrafo 337.

637 "In the present case, the Court observes that the submission to the public authorities of misleading information liable to lead them into error and therefore to make possible the grant of an exclusive right to which an undertaking is not entitled, or to which it is entitled for a shorter period, constitutes a practice falling outside the scope of competition on the merits which may be particularly restrictive of competition. Such conduct is not in keeping with the special responsibility of an undertaking in a dominant position not to impair, by conduct falling outside the scope of competition on the merits, genuine undistorted competition in the common market (...). It follows from the objective nature of the concept of abuse (...) that the misleading nature of representations made to public authorities must be assessed on the basis of objective factors and that proof of the deliberate nature of the conduct and of the bad faith of the undertaking in a dominant position is not required for the purposes of identifying an abuse of a dominant position." Case T-321/05 AstraZeneca v Commission, parágrafos 355-356. 
consideração ao avaliar se a conduta em questão tem o condão de criar obstáculos regulatórios à concorrência. ${ }^{638}$

Ademais, o Tribunal Geral ponderou que mesmo nas situações em que um agente econômico obtém um direito exclusivo ilegítimo, como resultado de um erro de comunicação com as autoridades públicas, sua "responsabilidade especial" de não prejudicar a concorrência no mercado único exige que informe as autoridades públicas sobre esse fato, de modo a permitir-lhes sanar as irregularidades, o que jamais foi feito pela AztraZeneca. ${ }^{639}$

Interessante observar que o Tribunal Geral rejeitou os argumentos da AztraZeneca no sentido de que a constatação de um abuso de posição dominante nesse caso requer a efetiva imposição do direito exclusivo obtido como resultado da apresentação de informações enganosas. Para o Tribunal, quando um direito de propriedade intelectual é concedido, sua validade é normalmente presumida pelos potenciais concorrentes, que tendem a respeitar o direito exclusivo legalmente protegido. Essa presunção de validade já seria suficiente para restringir a concorrência:

The Court rejects the applicants' argument that a finding of an abuse of a dominant position requires that an exclusive right obtained as a result of misleading representations has been enforced. When granted by a public authority, an intellectual property right is normally assumed to be valid and an undertaking's ownership of that right is assumed to be lawful. The mere possession by an undertaking of an exclusive right normally results in keeping competitors away, since public regulations require them to respect that exclusive right. Furthermore, to the extent that the applicants argue that an intellectual property right must have been exercised in legal proceedings, that argument would tend to make the application of [Article 102 TFEU] conditional on the contravention by competitors of the public regulations by their infringing the exclusive right of an undertaking; that argument must be rejected. Moreover, third parties seldom have information enabling them to know whether an exclusive right has been unlawfully granted. ${ }^{640}$

\footnotetext{
${ }^{638}$ Cf. Case T-321/05 AstraZeneca v Commission, parágrafo 357.

${ }^{639}$ Case T-321/05 AstraZeneca v. Commission, parágrafo 358.

${ }^{640}$ Case T-321/05 AstraZeneca v Commission, parágrafo 362.
} 
Por fim, o Tribunal Geral também concordou com a observação da Comissão no sentido de que o uso indevido do sistema de patentes é capaz de reduzir os incentivos à inovação, uma vez que permite às empresas em posição dominante manter sua exclusividade para além do período previsto pelo legislador. ${ }^{641}$

Por todo o exposto, notam-se claras semelhanças entre os casos Walker Process e AztraZeneca, uma vez que ambos evidenciam o repúdio dos tribunais autoridades antitruste a patentes fraudulentas e indevidas e seus efeitos deletérios sobre a concorrência. Contudo, pelo menos uma diferença deve ser destacada: enquanto a Comissão e o Tribunal Geral consideram que a mera aquisição de direitos de propriedade intelectual por meios fraudulentos já seria suficiente para caracterizar abuso de posição dominante ao abrigo do Artigo 102 do TFUE, os tribunais norte-americanos entendem que somente a tentativa de imposição do direito exclusivo ilegítimo, por meio de medidas judiciais ou extrajudiciais, seria capaz de produzir efeitos anticoncorrenciais nos termos da Seção 2 do Sherman Act.

\subsubsection{Abusos em processos de padronização tecnológica: "patent ambush" e o problema do "hold-up"}

Vimos que os processos de padronização tecnológica no âmbito de organismos de padronização (Standard-Setting Organizations - SSO) promovem a inovação e aumentam a concorrência, especialmente em mercados caracterizados pela presença de externalidades de redes, ao permitir a compatibilidade e interoperabilidade entre as diferentes tecnologias desenvolvidas pelos múltiplos agentes econômicos participantes de determinada SSO, muitas vezes organizada na forma de pool de patentes. Na maioria das vezes, os agentes econômicos envolvidos são concorrentes entre si, seja nos mercados relevantes a montante concernentes às tecnologias licenciadas para aplicação do padrão técnico, seja nos mercados relevantes a jusante, pertinentes aos produtos fabricados a partir da tecnologia padronizada, o que requer cautela por parte das autoridades antitruste, de modo a evitar que a padronização tecnológica sirva para mascarar acordos colusivos para fixação de preços, divisão de mercado e boicotes.

No entanto, a possibilidade de colusão no âmbito de organismos de padronização não é a principal preocupação das autoridades de concorrência norte-

${ }^{641}$ Case T-321/05 AstraZeneca v Commission, parágrafo 367. 
americanas e europeias neste momento. O tema que tem estado no centro do debate tanto nos Estados Unidos como na União Europeia diz respeito ao tratamento antitruste de condutas abusivas unilaterais em processos de padronização tecnológica, particularmente nas questões envolvendo a chamada "patent ambush" e possíveis medidas para evitar o problema do "hold-up". As recentes iniciativas por parte das autoridades antitruste norteamericanas e europeias evidenciam claras diferenças entre as duas jurisdições no que concerne ao tratamento dessas condutas. ${ }^{642}$

A conduta denominada "patent ambush", que pode ser traduzida ao pé da letra como "emboscada de patentes", ocorre quando um agente econômico participante de determinada SSO deixa de informar, propositadamente, que possui direitos de propriedade intelectual que poderiam vir a ser essenciais para o potencial padrão tecnológico a ser adotado. Após o padrão em questão ser implementado pela indústria, aquele agente econômico torna público que detém direitos de propriedade intelectual sobre a tecnologia padronizada e passa a cobrar royalties exorbitantes, além de propor ações judiciais de infração contra a SSO e seus membros. Considerando os elevados custos de mudança para tecnologias alternativas (que foram deixadas de lado durante o processo de padronização) e o consequente efeito "lock-in", a "emboscada" armada pelo titular dos direitos exclusivos acaba lhe conferindo poder de mercado suficiente para cobrar royalties excessivos, deixando a SSO e seus membros como reféns da situação. ${ }^{643} \mathrm{~A}$ imposição de condições abusivas e discriminatórias para o licenciamento - que pode ser compreendida como uma

${ }^{642}$ Cf. HOCKETT, Christopher B.; LIPSCOMB, Rosanna. Best FRANDs Forever? Standard-Setting Antitrust Enforcement in the United States and the European Union, in: Antitrust. American Bar Association, Summer 2009, p. 19.

${ }^{643}$ Antes da adoção de um padrão, uma SSO pode livremente escolher entre uma variedade de tecnologias. Nesse momento, o titular de uma patente sobre qualquer dessas tecnologias não detém poder de mercado para impor os preços que bem entender. No entanto, após a adoção de um padrão, o titular da patente sobre a tecnologia selecionada pode ganhar significante poder de mercado, o que lhe permitiria cobrar royalties exorbitantes para licenciar a tecnologia. Os membros da SSO, diante desses royalties exorbitantes, sequer poderiam migrar para tecnologias alternativas já que, após a adoção do padrão técnico, os participantes da indústria passam a desenhar, testar e produzir bens em conformidade com a tecnologia padronizada, tornando os custos de mudança proibitivos. Nesse sentido, Michael A. CARRIER afirma o seguinte: “(...) these efforts, in learning about a particular technology and investing in equipment and complementary products, typically do not have value if the user switches to an alternative technology. In addition, the industry typically will incur the costs of selecting a new standard. As a result of all these costs, the industry will be locked into the chosen standard". CARRIER, Michael A. Standard Setting Analysis under US Law, in: ANDERMAN, Steven; EZRACHI, Ariel (Ed.). Intellectual Property and Competition Law: New Frontiers. Oxford University Press, 2011, p. 360. 
recusa de licenciar em termos razoáveis -, somada à falta de opções da indústria, dá origem ao denominado "hold-up". 644

Para lidar com esse tipo de problema, as SSOs costumam criar regras institucionais de propriedade intelectual, aplicáveis aos seus membros, exigindo que divulguem com antecedência eventuais patentes registradas ou ainda pendentes de registro, que potencialmente poderiam ser consideradas essenciais para a aplicação do padrão tecnológico a ser definido. É comum também a adoção de regras de licenciamento que determinam os termos pelos quais patentes essenciais devem ser licenciadas, caso sejam adotadas no padrão tecnológico selecionado. Tais regras obrigam os membros a licenciarem seus direitos de propriedade intelectual em termos razoáveis e não discriminatórios, denominados "RAND" (reasonable and non-discriminatory), ou mesmo em termos justos, razoáveis e não discriminatórios, denominados "FRAND" (fair, reasonable and non-discriminatory). ${ }^{645}$ Os membros da SSO podem reservar-se o direito de não aceitar licenciar suas patentes em termos RAND ou FRAND, mas ainda assim são obrigados a divulgar aos demais membros suas patentes registradas ou pendentes. Essas regras institucionais, que possuem natureza contratual, permitem que os participantes de uma SSO tomem decisões de maneira informada, podendo escolher entre as tecnologias disponíveis sabendo de antemão quais são protegidas por direitos de propriedade intelectual e, dentre elas, quais poderão ser licenciadas em termos RAND ou FRAND. ${ }^{646}$

Contudo, essas medidas nem sempre são eficazes para lidar com problemas de "patent ambush" e "hold-up" no âmbito das SSOs, o que tem levado as autoridades de

\footnotetext{
${ }^{644}$ Fabíola ZIBETTI acrescenta que: "Essa posição negociadora vantajosa, por vezes, leva os detentores das tecnologias protegidas a impor termos e condições de licenciamento que dificultam a atuação dos usuários no mercado do produto ou serviço normalizado. Dependendo dos custos exigidos pelo titular da patente, a situação pode levar ao abandono de da norma. Portanto, para os usuários e organizações de normalização, esse panorama converte-se em uma verdadeira 'emboscada' de patentes e de outros direitos de propriedade intelectual”. ZIBETTI, Fabíola Wüst. Relação entre Normalização Técnica e Propriedade Intelectual no Ordenamento Jurídico Internacional, Tese (Doutorado) - Programa de Pós Graduação em Direito Internacional - Faculdade de Direito da Universidade de São Paulo, São Paulo, 2012, p. 130.

${ }^{645}$ De acordo com ANDERMAN e SCHMIDT: "The FRAND obligation is a conditional contract binding members of the patent pool to license their patents on FRAND terms if those patents are chosen as essential for the pool technology. This is a necessary step for a technology pool to provide a one-stop shop product at reasonable price and avoid royalty stacking". ANDERMAN, Steven; SCHMIDT Hedvig. EC Competition Law and Intellectual Property: The Regulation of Innovation. 2nd ed. Oxford University Press, p. 295.

${ }^{646}$ Os termos RAND ou FRAND exigem que os royalties sejam razoáveis, mas não fixam um valor específico, o que pode causar conflitos entre os participantes após a adoção do padrão técnico. Devido a essas possíveis incertezas, algumas SSOs exigem que os membros especifiquem seus termos de licenciamento mais restritivos, definindo de antemão os valores máximos de royalties que pretendem cobrar. CARRIER, Michael A. Standard Setting Analysis under US Law, in: ANDERMAN, Steven; EZRACHI, Ariel (Ed.). Intellectual Property and Competition Law: New Frontiers. Oxford University Press, 2011, p. 360.
} 
defesa da concorrência norte-americanas e europeias - FTC e Comissão - a instaurar processos administrativos para investigar possíveis ilicitudes relacionadas a essas condutas. Nos Estados Unidos, a FTC tem questionado condutas enganosas em processos de padronização com base na Seção 2 do Sherman Act e na Seção 5 do FTC Act, que trata especificamente de práticas de concorrência desleal. ${ }^{647}$

O caso Rambus é, sem dúvida, um dos mais emblemáticos, já que foi o primeiro caso em que uma conduta de "patent ambush" foi tratada como ilícito antitruste à luz da Seção 2 do Sherman Act. ${ }^{648}$ Em 2002, a FTC instaurou um processo administrativo para investigar supostas "condutas enganosas" praticadas pela Rambus no início dos anos 1990, durante um processo de padronização concernente a uma tecnologia de memória eletrônica para computadores, que ficou conhecida como DRAM (dynamics random access memory). Trata-se de tecnologia utilizada para processar informações em computadores, impressoras, câmeras digitais e outros equipamentos. Esse processo de padronização foi coordenado pela Joint Electron Device Engineering Council (JEDEC), uma SSO de engenharia voltada para semicondutores, que agregava diversos fabricantes e adquirentes de tecnologia DRAM, assim como fabricantes de produtos complementares. Após o início das discussões, a Rambus deixou de informar à JEDEC que detinha pedidos de patentes pendentes para tecnologias de memória para computadores, semelhantes

${ }^{647}$ O caso Dell foi um dos primeiros casos em que a FTC fez uso de suas competências definidas na Seção 5 do FTC Act para condenar comportamentos abusivos no âmbito de processos de padronização tecnológica. Nesse caso, a FTC alegou que a Dell havia certificado a uma SSO (Video Electronics Standards Association) que não possuía direitos de propriedade intelectual sobre o padrão para VL-bus, um mecanismo que transfere dados da unidade de processamento central de um computador para seus componentes periféricos, tais como discos rígidos e modems. Após o padrão técnico ter sido adotado pela SSO e passar a ser amplamente utilizado em computadores, a Dell informou que a utilização desse padrão violava suas patentes. Em sua representação, a FTC alegou que a Dell havia praticado concorrência desleal nos termos da Seção 5 do FTC Act, sugerindo também que a empresa poderia ter adquirido poder de monopólio em decorrência de sua conduta abusiva. Em seguida, a FTC firmou acordo com a Dell por meio do qual a empresa comprometeu-se a não opor suas patentes contra aqueles que implementarem o padrão técnico. Cf. Dell Computer Corp., 121 FTC 616 (1996). O caso Unocal também merece ser destacado. Em 2003, a FTC instaurou processo administrativo para questionar "condutas enganosas" praticadas pela Union Oil Company of California (Unocal) em processo de padronização no âmbito da California Air Resources Board, visando a definição de padrões técnicos para a gasolina reformulada de baixa emissão. A Unocal deixou de informar que possuía patentes registradas e pendentes que poderiam conflitar com os padrões que estavam sendo discutidos. Como resultado desse processo, as refinarias californianas gastaram bilhões de dólares para cumprir com os novos padrões. Posteriormente, a Unocal alegou que os novos padrões violavam suas patentes e buscou cobrar royalties que poderiam ter custado aos consumidores mais de US\$ 500 milhões anuais. A FTC, então, impôs uma medida preventiva proibindo a Unocal de impor suas patentes. No final, a Unocal acabou sendo obrigada a aceitar um acordo proposto pela FTC em 2005 como condição para a aprovação de sua fusão com a Chevron Corporation. Cf. Union Oil Co. of Cal., FTC Docket No. 9305, Decision and Order (Aug. 2, 2005). Disponível em: www.ftc.gov/os/adjpro/d9302/06082commissionopinion.pdf. Acesso em: 4 ago. 2012.

${ }^{648}$ Cf. Rambus, Inc., FTC Docket No. 9302, Opinion of the Commission, Aug. 2, 2006. Disponível em: www.ftc.gov/os/adjpro/d9302/060802commissionopinion.pdf. Acesso em: 2 ago. 2012. 
àquelas que estavam sendo discutidas durante o processo. Além disso, à medida que o debate em torno da padronização evoluía no âmbito da JEDEC, a Rambus efetuava modificações nos seus pedidos de patentes, de modo a adequar sua tecnologia ao padrão que estava para ser definido. No início dos anos 2000, após a Rambus obter o registro daquelas patentes e o padrão baseado na tecnologia DRAM já estar em pleno uso pela indústria, a empresa resolveu ingressar com ações judiciais em face da JEDEC e de seus membros, alegando violação de seus direitos de propriedade intelectual. ${ }^{649}$

Embora a política da JEDEC para a divulgação de direitos de propriedade intelectual não fosse suficientemente clara, a FTC concluiu que a Rambus violou a Seção 2 do Sherman Act e a Seção 5 do FTC Act, ao deixar de informar, propositadamente, à JEDEC e seus membros que detinha pedidos de patentes pendentes para a tecnologia DRAM, como parte de uma estratégia visando à monopolização dos mercados relevantes concernentes às tecnologias de memória para computadores, incluídas no padrão tecnológico selecionado. ${ }^{650} \mathrm{Na}$ visão da FTC, se a JEDEC estivesse informada sobre as patentes pendentes da Rambus no início do processo de padronização, um dos seguintes cenários provavelmente teria ocorrido: (i) a JEDEC teria escolhido tecnologias alternativas, que não aquelas cobertas pelos pedidos de patentes da Rambus; ou (ii) os membros da JEDEC teriam negociado ex ante com a Rambus compromissos RAND para o licenciamento de suas patentes. ${ }^{651}$

Como forma de remediar essa suposta "conduta enganosa" de exclusão, a FTC impôs o licenciamento compulsório das patentes detidas pela Rambus, estabelecendo os percentuais máximos de royalties que poderiam ser cobrados das empresas que desejassem implementar os padrões tecnológicos que continham tecnologias protegidas por suas patentes. $^{652}$

\footnotetext{
${ }^{649}$ As tecnologias DRAM representam aproximadamente $95 \%$ do mercado e são utilizadas em praticamente todos os PCs. Em 2008, as vendas mundiais de chips DRAM excederam US\$ 34 bilhões. Cf. Press Release IP/09/1897, da Comissão, referente às investigações das condutas da Rambus na União Europeia. Disponível em: http://europa.eu/rapid/pressReleasesAction.do?reference=IP/09/1897. Acesso em: 04 ago. 2012.

${ }^{650}$ Rambus, Inc., FTC Docket No. 9302, Opinion of the Commission, Aug. 2, 2006. Disponível em: www.ftc.gov/os/adjpro/d9302/060802commissionopinion.pdf. Acesso em: 02 ago. 2012.

${ }^{651}$ Ibid.

${ }^{652}$ Mesmo após a Rambus alegar que os percentuais deveriam variar entre $1 \%$ e 2\%, a FTC determinou que os percentuais não poderiam exceder $0,25 \%$ a $0,5 \%$ durante três anos, sendo zerados após esse período. In the Matter of Rambus Inc., Docket No. 9302, Feb. 5, 2007, "Opinion of the Commission on Remedy", Chairman Deborah Platt Majoras.
} 
No entanto, em sede de apelação, o DC Circuit Court reverteu a decisão da FTC, concluindo que a agência não logrou êxito ao demonstrar o caráter "exclusionário" da conduta da Rambus, conforme exigido pela Seção 2 do Sherman Act. ${ }^{653}$ O tribunal afirmou que uma conduta unilateral de exclusão deve produzir efeitos anticoncorrenciais, isto é, prejudicar o processo competitivo e, consequentemente, os consumidores, não sendo suficientes eventuais danos causados a um ou mais concorrentes. Com base nessa premissa, o DC Circuit Court acrescentou que a comprovação de uma "conduta enganosa" não seria o bastante para a configuração de monopolização, nos termos da Seção 2 do Sherman Act. Nesse contexto, afirmou que mesmo nas hipóteses em que uma conduta enganosa resultasse em preços mais elevados não haveria que se falar em infração antitruste, a não ser que restassem comprovados prejuízos à concorrência. ${ }^{654} \mathrm{Com}$ base nessas premissas, o tribunal concluiu que a JEDEC teria optado pela tecnologia da Rambus mesmo na ausência de qualquer conduta enganosa, dada a superioridade dessa tecnologia em comparação com as alternativas disponíveis. Alegou também que o fato de a JEDEC não ter logrado êxito em obter condições mais favoráveis de licenciamento não poderia, na ausência de outros elementos, constituir ilícito antitruste. ${ }^{655}$

Recentemente, a Suprema Corte norte-americana se negou a apreciar o caso, o que levou a FTC a colocar um fim ao processo que perdurou praticamente sete anos. ${ }^{656}$ As dificuldades em comprovar o elemento "exclusionário" da "conduta enganosa" da Rambus parece ter levado a FTC a concentrar seus esforços nos elementos de concorrência desleal constantes na Seção 5 do FTC Act, para coibir possíveis abusos em processos de

\footnotetext{
${ }^{653}$ Rambus Inc. v. FTC, 522 F.3d 456 (DC Cir. 2008).

654 "Deceptive conduct - like any other kind - must have an anticompetitive effect in order to form the basis of a monopolization claim. (...) Even if deception raises the price secured by a seller, but does so without harming competition, it is beyond the antitrust laws' reach. Cases that recognize deception as exclusionary hinge, therefore, on whether the conduct impaired rivals in a manner tending to bring about or protect a defendant's monopoly power." Rambus Inc. v. FTC, 522 F3d 456, 461 (DC Cir. 2008).

655 “....) if JEDEC, in the world that would have existed but for Rambus's deception, would have standardized the very same technologies, Rambus's alleged deception cannot be said to have had an effect on competition in violation of the antitrust laws; JEDEC's loss of an opportunity to seek favorable licensing terms is not as such an antitrust harm. Yet the Commission did not reject this as being a possible - perhaps even the more probable - effect of Rambus's conduct. We hold, therefore, that the Commission failed to demonstrate that Rambus's conduct was exclusionary, and thus to establish its claim that Rambus unlawfully monopolized the relevant markets." Rambus Inc. v. FTC, 522 F3d 456, (DC Cir. 2008), p. 466-467.

${ }^{656}$ Rambus Inc. v. FTC, 522 F3d 456 (DC Cir. 2008), cert. denied, 129 S. Ct. 1318 (2009).
} 
padronização, deixando de lado, portanto, argumentos com base na Seção 2 do Sherman Act. ${ }^{657}$

O caso Rambus também foi discutido na União Europeia, de modo que a Comissão tem tratado condutas de "patent ambush" como abuso de posição dominante nos termos do Artigo 102 do TFUE. Dado o alcance mundial dos mercados relevantes concernentes à tecnologia DRAM, a Comissão instaurou processo administrativo para investigar as supostas condutas abusivas da Rambus, as quais a FTC falhou em comprovar perante os tribunais norte-americanos. Em agosto de 2007, a Comissão enviou à Rambus suas conclusões preliminares no sentido de que a empresa teria violado o Artigo 102 do TFUE ao cobrar royalties não razoáveis pela utilização de certas patentes relacionadas a tecnologias de memória para computadores. ${ }^{658}$ A Comissão afirmou que a Rambus teria praticado uma forma de "patent ambush" ao não divulgar a existência das patentes que posteriormente alegou serem relevantes para a adoção do padrão. É de se notar que as acusações são praticamente as mesmas analisadas pelo DC Circuit nos Estados Unidos. No entanto, a Comissão acrescentou que, ao pleitear, subsequentemente, royalties não razoáveis pelo uso das patentes relevantes, a Rambus teria violado o Artigo 102 do TFUE. $^{659}$

Em dezembro de 2009, a Comissão aceitou um acordo proposto pela Rambus, colocando fim ao processo. Por meio desse acordo, a Rambus comprometeu-se a estabelecer patamares máximos de royalties para o licenciamento de suas patentes que sejam necessárias para aplicação das tecnologias DRAM, pelo prazo de cinco anos. ${ }^{660} \mathrm{~A}$

657 O caso $N$-Data é um exemplo claro disso. Nesse caso, a FTC instaurou em 2008 um processo administrativo contra a Negotiated Data Solutions (N-Data) por descumprimento dos termos de licenciamento acordados no âmbito do processo de padronização da tecnologia de rede Fast Ethernet, amplamente utilizada em computadores. Esse caso não envolveu qualquer discussão sobre "patent ambush", e nem resultou em qualquer acusação de ilícito antitruste nos termos da Seção 2 do Sherman Act. A cobrança, pela N-Data, de royalties a patamares superiores àqueles acordados nos compromissos firmados durante a padronização, foi considerada prática de concorrência desleal, nos termos da Seção 5 do FTC Act. Ao final, a FTC celebrou um acordo com a N-Data, colocando fim ao processo. Cf. Negotiated Data Solutions LLC, FTC Docked No. C-4234, Complaint (Sept. 22, 2008). Disponível em: www.ftc.gov/os/caselist/0510094/080923ndscomplaint.pdf. Acesso em: 04 ago. 2012.

${ }^{658}$ Cf. Press Release, MEMO/07/330, Commission confirms sending a Statement of Objections to Rambus (Aug. 23, 2007). Disponível em:

http://europa.eu/rapid/pressReleasesAction.do?reference=MEMO/07/330\&format=HTML\&aged=0\&languag e=EN\&guiLanguage $=$ en.

${ }^{659}$ Ibidem.

${ }^{660}$ Dentre os compromissos assumidos, a Rambus concordou em não cobrar royalties para os chips DRAM baseados nos padrões SDR e DDO DRAMs, adotados enquanto a empresa participou da JEDEC. Ademais, a Rambus concordou em fixar em $1,5 \%$ o percentual máximo de royalties para os padrões DRAMs 
determinação de patamares máximos de royalties foi estendida também para as patentes que protegem as tecnologias subsequentes desenvolvidas no âmbito da JEDEC. Na visão da Comissão, essa medida foi considerada necessária e proporcional, tendo em vista a existência de substanciais barreiras à entrada nesse mercado, devido à vinculação de toda a indústria aos padrões desenvolvidos no âmbito da JEDEC. Com o estabelecimento desses tetos, potenciais novos entrantes terão uma perspectiva clara dos custos dos royalties que terão de suportar, facilitando a tomada de decisão sobre possível ingresso no mercado. ${ }^{661}$

\section{Os diferentes resultados do caso Rambus nos Estados Unidos e na União} Europeia constituem mais um exemplo claro das distintas abordagens adotadas nas duas jurisdições para análise antitruste de condutas abusivas unilaterais. Na União Europeia, a imposição de preços excessivos por um agente econômico pode constituir abuso de posição dominante, nos termos do Artigo 102 do TFUE, sem a necessidade de demonstração de efeitos "exclusionários". ${ }^{662}$ Nos Estados Unidos, ao contrário, a imposição de royalties excessivos não tem o condão de constituir ilícito antitruste, a não ser que seja acompanhada de alguma conduta de exclusão. Como bem lembrou o DC Circuit Court ao julgar o caso Rambus: “an otherwise lawful monopolist's use of deception simply to obtain higher prices normally has no particular tendency to exclude rivals and thus to diminish

\footnotetext{
subsequentes, bem inferiores aos 3,5\% que cobrava quando da instauração do processo administrativo. Cf. Case COMP/38.636 - Rambus, Commission decision of 9.12.2009, relating to a proceeding under Article 102 of the Treaty on the Functioning of the European Union and Article 54 of the EEA Agreement, p. 14. Disponível em: http://ec.europa.eu/competition/antitrust/cases/dec_docs/38636/38636_1203_1.pdf. Acesso em: 03 ago. 2012.

661 “(...) there are substantial barriers to entry on the market, which are primarily due to the fact that the industry is locked into the JEDEC standards, and that the effects of the alleged abusive behavior extend to subsequent standards, the fact that Rambus commits to maximum royalty rates for those subsequent standards is adequate and proportionate. The Commitments extend this rate to all market participants and guarantee that industry will not have to pay more than the capped rates. This predictability and certainty has a clear value for business. Potential new entrants will also have a clear perspective of future royalty costs, facilitating a decision to enter the market". Case COMP/38.636 - Rambus, Commission decision of 9.12.2009, relating to a proceeding under Article 102 of the Treaty on the Functioning of the European Union and Article 54 of the EEA Agreement, p. 14. Disponível em: http://ec.europa.eu/competition/antitrust/cases/dec_docs/38636/38636_1203_1.pdf. Acesso em: 03 ago. 2012. ${ }^{662}$ Vimos que a Comissão e os tribunais comunitários levam em consideração tanto condutas unilaterais de exclusão ("exclusionary abuses"), como também condutas unilaterais de exploração ("exploitative abuses"), que normalmente envolvem a imposição de preços excessivos, muito embora esse tipo de conduta tenha perdido espaço ao longo das últimas décadas em razão de seus questionáveis pressupostos econômicos.
} 
competition". ${ }^{663}$ Portanto, na ausência de algum elemento "exclusionário", não há que se falar em violação da Seção 2 do Sherman Act. ${ }^{664}$

Assim, enquanto as condutas de "patent ambush" nos Estados Unidos tendem a ser combatidas pela FTC com base na Seção 5 do FTC Act, que trata tão somente de atos de concorrência desleal (sem a necessidade de preenchimento dos requisitos para a configuração de ilícito antitruste $)^{665}$, as mesmas condutas somente poderão constituir abuso de posição dominante, nos termos do Artigo 102 do TFUE, em caso de imposição de royalties excessivos ou discriminatórios no licenciamento de patentes que sejam essenciais para a aplicação de um padrão tecnológico, especialmente nas hipóteses em que seu titular tenha firmado compromissos FRAND no âmbito de entidades de padronização. ${ }^{666}$

\subsubsection{Aquisição e acumulação de patentes: a supressão unilateral de tecnologias}

A aquisição e acumulação de patentes com vistas à formação de portfólios valiosos de direitos de propriedade intelectual constitui estratégia comercial legítima, além de benéfica à inovação, não havendo, em princípio, qualquer preocupação do ponto de vista antitruste. Contudo, há casos em que a aquisição e acumulação sistemática de todas as patentes referentes a um ramo tecnológico específico pode acabar servindo como estratégia defensiva visando à supressão de todas as tecnologias disponíveis em determinado mercado relevante. Assim, eventuais concorrentes que desejarem ingressar no mercado,

${ }^{663}$ Rambus Inc. v. FTC, 522 F3d 456, (DC Cir. 2008), p. 464.

${ }^{664}$ Cf. HOVENKAMP, Herbert J. Patent Continuations, Patent Deception, and Standard Setting: The Rambus and Broadcom Decisions, 28 University of Iowa Legal Studies Research Paper No. 08-25, May 2008.

665 Conforme apontam HoCKETT e LIPSCOMB: "The United States may move closer to the EU model as antitrust enforcement actions brought by the government in this area increase. In particular, we are likely to see more claims brought under Section 5 of the FTC Act, without Sherman Act violations accompanying them". HOCKETT, Christopher B.; LIPSCOMB, Rosanna. Best FRANDs Forever? Standard-Setting Antitrust Enforcement in the United States and the European Union, in: Antitrust, American Bar Association, Summer 2009, p. 24.

666 Em 2005, as fabricantes de telefone celular Broadcom, Ericsson, NEC, Nokia, Panasonic Mobile Communications e Texas Instruments apresentaram denúncia perante a Comissão, alegando que a Qualcomm, titular de certas patentes essenciais sobre tecnologias contidas no padrão técnico utilizado em telefones celulares, estaria abusando de sua posição dominante, nos termos do Artigo 102 do TFUE, ao recusar licenciar suas patentes em termos FRAND para suas concorrentes no mercado a jusante, em violação aos seus compromissos assumidos perante uma SSO. Os royalties excessivos praticados pela Qualcomm para o licenciamento de suas patentes essenciais inviabilizaria a atuação de suas concorrentes no mercado a jusante. A Comissão instaurou um processo administrativo em 2007 para apurar as denúncias contra a Qualcomm. No entanto, após algumas das denunciantes retirarem suas reclamações em decorrência de acordos diretos celebrados com a Qualcomm, a Comissão anunciou em 2009 o arquivamento do processo. Cf. Antitrust: Commission closes formal proceedings against Qualcomm, Press Release, MEMO/09/516, Brussels, 24th November 2009. Disponível em: http://europa.eu/rapid/press-release_MEMO-09-516_en.htm. 
acabarão sofrendo ações judiciais de infração, ou mesmo podem ser obrigados a aceitar condições desvantajosas de licenciamento para ter acesso às tecnologias protegidas pelas patentes detidas pelo agente econômico dominante, necessárias para a fabricação de seus produtos. $^{667}$

Ressalte-se que, muitas vezes, as patentes adquiridas e acumuladas acabam nem sequer sendo utilizadas pelo seu titular, impedindo que a propriedade intelectual atenda sua função social, já que a coletividade é privada dos benefícios da inovação. É o caso, por exemplo, dos chamados "patent trolls", muito comuns nos Estados Unidos, que são empresas constituídas com o único propósito de adquirir e acumular patentes com o objetivo de ingressar com ações judiciais contra qualquer concorrente que pretenda entrar no mercado, forçando o pagamento de royalties exorbitantes. ${ }^{668}$

Em relatório publicado em março de 2010, a FTC constata a existência de riscos de distorções à concorrência em mercados para patentes que não envolvam transferência de tecnologia, isto é, mercados em que patentes são adquiridas, vendidas e licenciadas como ativos cujo valor é baseado na sua capacidade de extrair royalties vantajosos de empresas que já estejam utilizando a tecnologia patenteada na fabricação de seus produtos e que, portanto, se veem diante de elevados custos de troca e efeitos "lockin" ${ }^{669}$ Desse modo, contrariando os próprios objetivos pelos quais foi idealizado, o sistema

${ }^{667}$ Têm sido frequentes as aquisições de substanciais portfólios de patentes nos mercados de tecnologias utilizadas na fabricação de smartphones. Nesse sentido, de acordo com GoTTS e SCHER: "Under the current marketplace dynamics, for a company to be able to compete in high-tech industries such as operating systems (OS) on mobile devices, it must have a large patent portfolio to defend itself against the inevitable lawsuits that competitors bring to impose a significant tax on - or even ultimately to prevent the entry of - new products on the market. Without the ability to bring about 'mutually assured destruction', a company has no way to defend itself against costly patent litigation. The problem is exacerbated because, as one commenter put it, 'ridiculous, broad, meaningless patents get approved all the time"'. GOTTS, Ilene Knable; SCHER, Scott. The Particular Antitrust Concerns with Patent Acquisitions, in: Competition Law International, August 2012, p. 30. Disponível em: http://www.wsgr.com/publications/PDFSearch/sher-august-12.pdf.

${ }^{668}$ De acordo com POHLMANN e MARIEKE: "A patent troll is a person or entity who acquires ownership of a patent without the intention of actually using it to produce a product and in many cases did not actually engage in developing the technology (...). They are not inventors who pursue their own research, offer it for sale or provide early licenses in the process of innovation. They rather defend their rights against infringements. But, they are entities that - opportunistically or on purpose - profit from payments by companies that inadvertently infringe on the trolls' intellectual property rights (...). There is the fear that these in most cases small entities use the courts as a mechanism to extract economic rents from large companies (...). POHLMANN, Tim Christoph; MARIEKE, Opitz. Typology of the Patent Troll Business (February 27, 2009). Disponível em SSRN: http://ssrn.com/abstract=1711316 ou http://dx.doi.org/10.2139/ssrn.1711316. Acesso em: 18 ago. 2012.

${ }^{669}$ Conforme o relatório da FTC: “(...) we see increasing activity and complexity of business models in markets for patents that do not involve technology transfer. In these markets, patents are bought, sold and licensed as assets whose value is based on their ability to extract rents from manufacturers already using the patented technology. This activity risks distorting competition among technologies and deterring innovation, 
de patentes produz menos concorrência e inovação em consequência dos agressivos litígios que têm sido travados entre detentores de substanciais portfólios de patentes e terceiros que ingressam no mercado sem ter conhecimento de estarem, possivelmente, violando algum daqueles direitos de propriedade intelectual. ${ }^{670}$

Sob a perspectiva antitruste, a aquisição e acumulação de patentes pode constituir conduta abusiva de exclusão em determinadas circunstâncias. Em primeiro lugar, é imperioso distinguir entre as situações em que a aquisição das patentes resulta dos investimentos em pesquisa e desenvolvimento realizados pelo próprio agente econômico dominante, e as situações em que a aquisição se dá por meio de transações no mercado, como ocorre nos casos de cessão definitiva de direitos de propriedade intelectual, ou mesmo na aquisição de licenças. ${ }^{671}$

Quanto à primeira situação, alguns apontam a estratégia denominada de "patent flooding", que consiste no depósito de inúmeros pedidos de patentes contendo pequenas variações ou modificações meramente triviais em relação à tecnologia desenvolvida por seu rival, com o objetivo de impedi-lo de explorar sua própria tecnologia sem o risco de infringir uma daquelas patentes incrementais. Como resultado, nenhuma das partes conseguirá explorar sua patente sem violar a patente da outra parte - situação típica de patentes de bloqueio -, forçando o titular da patente sobre a tecnologia original a aceitar condições desvantajosas de licenciamento para ter acesso às patentes sobre as modificações triviais, sem as quais não poderia atuar no mercado. Muitas vezes essas patentes acabam sendo invalidadas após longas disputas judiciais, custeadas com recursos

especially when driven by poor patent notice and remedies that do not align with the economic value of the patented invention". Federal Trade Commission. The Evolving IP Marketplace, Aligning Patent Notice and Remedies with Competition (2011). Disponível em: www.ftc.gov/os/2011/03/110307patentreport.pdf. Acesso em: 18 ago. 2012.

${ }^{670}$ Vimos que alguns mercados, tais como o de tecnologia da informação e biotecnologia, são marcados pelo fenômeno denominado de "patent ticket", que ocorre quando um grande número de empresas detém diferentes patentes de bloqueio, o que acaba criando situações de incerteza para potenciais concorrentes que desejem ingressar no mercado, já que nunca terão certeza se a utilização de determinada tecnologia poderá violar ou não uma daquelas patentes. De acordo com RUBINFIELD e MANESS: "The patent thicket creates considerable uncertainty for competitors about whether their technology infringes, especially with respect to hidden or submarine patent. Even if a firm is not practicing submarine patents, a patent thicket makes it hard to design and sell products without running the risk of infringing on a competitor's patent". RUBINFIELD, Daniel L.; MANESS, Robert. The Strategic Use of Patents: Implications For Antitrust, in Antitrust, Patents and Copyrights, EU and US Perspectives. Lévêque, F.;Shelanski, H. (Eds), 2005, p. 89.

${ }^{671}$ Conforme Yee Wah CHIN: "The treatment under the antitrust laws of situations involving the acquisition of market power by the accumulation of rights through invention may be contrasted with the approach in situations where market power was obtained through the purposeful acquisition of patent rights". CHIN, Yee Wah. Unilateral Technology Suppression: Appropriate Antitrust and Patent Law Remedies, 66, Antitrust Law Journal, 441 (1998), p. 446. 
valiosos que poderiam ser utilizados em atividades de pesquisa e desenvolvimento de novas tecnologias. ${ }^{672}$

No entanto, é questionável até que ponto essa estratégia poderia ser vislumbrada como ilícito antitruste. A possibilidade de obtenção de patentes de baixa qualidade sobre variações ou modificações meramente triviais sobre a tecnologia disponível no estado da técnica é normalmente o resultado de legislações frágeis de propriedade industrial, que adotam padrões inadequados para a aferição dos requisitos de patenteabilidade, em especial o requisito da atividade inventiva. ${ }^{673}$ Nesse contexto, é importante ressaltar que a intervenção antitruste não deve servir para corrigir eventuais falhas de um sistema patentário, já que o direito da concorrência tem como principal objetivo preservar a competitividade dos mercados. ${ }^{674}$ Por outro lado, a obtenção de patentes incrementais sobre uma dada tecnologia disponível pode significar que a invenção em questão nada mais é do que o resultado de um processo de inovação cumulativa que não apenas cumpre todos os requisitos de patenteabilidade, como também contribui para o desenvolvimento técnico ou científico. ${ }^{675}$ Sob esse prisma, eventual intervenção antitruste teria o risco de incorrer em erro de falso positivo, prejudicando a concorrência dinâmica e o próprio processo de inovação em si. ${ }^{676}$

672 De acordo com RUBINFELD e MANESS: "With patent flooding, a firm files a multitude of patent applications that claim minor variations on a competitor's existing technology. Because its patents surround competitors' key technologies, the firm is in a position to act (through litigation or the threat of litigation) to gain a strategic advantage over its rivals. There is considerable evidence that patent flooding has become more prevalent in recent years". RUBINFIELD, Daniel L.; MANESS, Robert. The Strategic Use of Patents: Implications For Antitrust, in Antitrust, Patents and Copyrights, EU and US Perspectives. Lévêque, F.; Shelanski, H. (Eds), 2005, p. 88.

${ }^{673}$ A não ser que a patente tenha sido adquirida por meio de fraude perante os órgãos competentes, como já mencionado anteriormente.

${ }^{674}$ Sobre o assunto, HovENKAMP afirma com propriedade que: “(...) it is not the purpose of the antitrust to fix defects in other regulatory regimes, particularly when those regimes are federal. Antitrust law was designed as a corrective for private markets. But where intellectual property law leaves questions open, antitrust policy should feel free to seek the most competitive outcomes as long as they do not frustrate the underlaying regulatory regimes". HOVENKAMP, Herbert. Antitrust and Innovation: Where We Are and Where We Should Be Going, in: Antitrust Law Journal, v. 77, Issue 3 (2011), p. 750.

${ }^{675}$ Nesse sentido, conforme relatório da OCDE: “There is at least one plausible argument that patent flooding is not a competition law issue. The argument is that if patent flooding reveals any problem at all, it must be with the patent system's inventive step requirement (specifically that it must be too weak). Either the flooding 'inventions' deserve patent protection or they do not. If they do not, then obviously the patent office should not be granting them and the way to fix the problem is to raise the bar on the inventive step requirement. If they do deserve patent protection, then the so-called flooders must be contributing something new, non-obvious and useful to society and that should be encouraged even if it does cause difficulties for other inventors". ORGANIZATION FOR ECONOMIC COOPERATION AND DEVELOPMENT - OECD, “Competition, Patents and Innovation II", Competition Committee, Cooperation Roundtables, 2009, p. 43.

${ }^{676}$ Segundo MAGGIOLINO: “(...) prosecuting an internally developed patent creates a dangerous risk of false positives that could seriously affect firms' incentives to innovate”. MAGGIOLINO, Mariateresa. Intellectual 
Nesse contexto, é imperioso destacar que as autoridades antitruste e tribunais dos Estados Unidos e da União Europeia não costumam considerar abusivas as aquisições de patentes decorrentes dos esforços de pesquisa e desenvolvimento, a não ser nas situações em que houver fraudes perante os órgãos patentários, conforme já mencionado anteriormente. A Suprema Corte norte-americana já afirmou que a mera acumulação de patentes, não importa quantas, não constitui por si só ilícito. ${ }^{677}$ No caso Berkey Photo $v$. Eastman Kodak, o Second Circuit afirmou que o monopolista é autorizado, e de fato encorajado, pela Seção 2 do Sherman Act, a concorrer agressivamente por méritos, de modo que qualquer sucesso que alcance por meio do processo de invenção e inovação é claramente tolerado pelo direito antitruste. ${ }^{678}$

Conforme apontam Sullivan e GRIMES: "Section 2 does not unseat $R \& D$ winners, even if they fail to exploit and merely stockpile their IP rights". ${ }^{679}$ De fato, a legislação patentária norte-americana, assim como os tribunais daquele país, além de não vedarem a aquisição e acumulação de patentes decorrentes dos esforços de inovação, também não obrigam seus titulares a efetivamente utilizarem a invenção protegida. ${ }^{680} \mathrm{Da}$ mesma forma, não há qualquer dispositivo legal que preveja o licenciamento compulsório

Property and Antitrust: A Comparative Economic Analysis of US and EU Law. Cheltenham: Edward Elgar, 2011, p. 113.

${ }^{677}$ Cf. Automatic Radio Mgs. Co. v. Hazeltine Research, Inc., 339 U.S. 827 (1950).

678 “ $(. .$.$) because (...) a monopolist is permitted, and indeed encouraged, by \S 2$ to compete aggressively on the merits, any success that it may achieve through the process of invention and innovation is clearly tolerated by the antitrust law". Berkey Photo v. Eastman Kodak, 603 F.2d 263 (2nd Circ. 1979).

${ }^{679}$ SULLIVAN, Lawrence A.; GRIMES, Warren S. The Law of Antitrust: An Integrated Handbook. Saint Paul, Minn.: West Group, 2000, p. 836.

${ }^{680}$ No caso Continental Paper Bag Co., a Suprema Corte norte-americana reconheceu que o titular de uma patente não tem qualquer obrigação de usar ou licenciar para terceiros seu direito de propriedade intelectual, mesmo que a intenção seja meramente a acumulação de patentes com o objetivo de excluir concorrentes: "As to the suggestion that competitors were excluded from the use of the new patent, we answer that such exclusion may be said to have been of the very essence of the right conferred by the patent, as it is the privilege of any owner of property to use or not use it, without question of motive”. Continental Paper Bag Co. v. Eastern Paper Bag Co., 210 U.S. 405 (1908). Décadas após essa decisão, no caso Hartford-Empire Co. v. United States, a Suprema Corte confirmou seu entendimento, afirmando que o inventor de uma tecnologia deve ser autorizado a patentear sua invenção, mesmo que não tenha o interesse de utilizá-la ou de licenciá-la para terceiros: "A patent owner is not in the position of a quasi-trustee for the public or under any obligation to see that the public acquires the free right to use the invention. He has no obligation either to use it or to grant its use to others. If he discloses the invention in his application so that it will come into the public domain at the end of the 17 year period of exclusive right he has fulfilled the only obligation imposed by the statute. This has been settled doctrine since at least 1896". 323 U.S. 386, 432-33, clarified, 324 U.S. 570 (1945). 
em caso de não exploração local de uma patente, ao contrário do que ocorre em diversos países. $^{681}$

Na União Europeia, o TJUE conferiu imunidade antitruste à aquisição de patentes decorrente dos esforços internos de inovação, confirmando que a mera existência de direitos de propriedade intelectual não pode ser proibida nos termos do Artigo 102 do TFUE. Ao chegar a essa conclusão, o TJUE invocou o Artigo 345 do TFUE, que estabelece que as instituições da União Europeia não possuem jurisdição sobre matérias relacionadas ao regime da propriedade aplicado nos respectivos Estados-Membros, o que inclui a concessão de patentes e direitos de propriedade intelectual em geral. ${ }^{682}$ Esse entendimento tem origem na famosa distinção feita pelo próprio TJUE no caso Consten \& Grunding v Commission, entre a existência e o exercício de direitos de propriedade intelectual. ${ }^{683}$ Assim, enquanto a mera existência desses direitos não deve sofrer qualquer intervenção antitruste, seu exercício pode resultar em violação do Artigo 102 do TFUE. ${ }^{64}$

Diferente é a situação em que a aquisição e a acumulação de patentes decorrem de transações realizadas por um agente econômico dominante, com o objetivo de suprimir as tecnologias disponíveis em determinado mercado relevante, de modo a aumentar os custos dos rivais e criar barreiras à entrada. Tanto nos Estados Unidos como na União Europeia, essas aquisições podem ser analisadas pelas autoridades de defesa da concorrência no contexto do controle preventivo de atos de concentração empresarial, na qualidade de aquisição de ativos intangíveis, assim como na repressão de comportamentos abusivos de exclusão. ${ }^{685}$ De qualquer modo, é imperioso ressaltar que, em geral, a aquisição de patentes no mercado não apenas constitui mecanismo essencial de retribuição

\footnotetext{
${ }^{681}$ A Seção 271(d)(4) do Patent Act de 1988 estabelece expressamente que a mera recusa de licenciar ou usar patentes não constitui patent misuse. Por outro lado, em diversos países, como o Brasil, a não exploração local da patente pode constituir abuso de direito sujeito ao licenciamento compulsório. Vimos que o Artigo 5(A) da Convenção da União de Paris autoriza os países da União "a adotarem providências legislativas permitindo a concessão de licenças compulsórias para prevenir os abusos que poderiam resultar do exercício do direito exclusivo conferido pela patente, como, por exemplo, a falta de exploração".

${ }^{682}$ Case 24/67, Park, Davis \& Co. v. Probel, Reese, Beintema-Interpharm and Centrafarm, [1968] ECR 55, 72.

${ }^{683}$ Casos 56/84 e 58/64 [1966] ECR 299, [1966] CMLR 418.

${ }^{684}$ Cf. WHISH, Richard. Competition Law. 6th ed. Oxford University Press, 2009, p. 763.

${ }^{685}$ Nos Estados Unidos, é aplicável a Seção 7 do Clayton Act, que proíbe aquisições de ativos produtivos que tenham por efeito a redução substancial da concorrência, além da Seção 1 do Sherman Act, que proíbe fusões ou aquisições que resultem em acordos para restringir o comércio. A Seção 2 do Sherman Act será aplicável quando a aquisição resultar em conduta abusiva de exclusão. Já na União Europeia, são aplicáveis o Artigo 101 do TFUE e o Regulamento do Conselho (EC) No. 139/2004 de 20 de janeiro de 2004 sobre o controle
} 
aos inventores que incorreram nos custos relacionados às atividades de pesquisa e desenvolvimento, como também possibilita uma alocação eficiente de recursos, na medida em que as tecnologias objeto de proteção são transferidas para aqueles que as valorizam mais e que, portanto, terão condições de utilizá-las de maneira mais eficiente.

Nos Estado Unidos, a despeito da aplicabilidade da Seção 7 do Clayton Act, as aquisições de patentes, quando realizadas por agentes econômicos dominantes, são normalmente tratadas como condutas unilaterais de exclusão nos termos da Seção 2 do Sherman Act. Nesses termos, dado o caráter de "bem público" - não rival e não excludente - dos direitos de propriedade intelectual, a aquisição de patentes com o objetivo de suprimir tecnologias somente será abusiva se o agente econômico dominante adquirir direitos exclusivos sobre essas patentes, o que pode ocorrer por meio de cessão definitiva ou mesmo pela obtenção de uma licença exclusiva, de modo a impossibilitar quaisquer terceiros, que não o próprio adquirente, de explorar o objeto protegido. Por outro lado, caso o agente econômico dominante opte pela aquisição de direitos não exclusivos sobre patentes (o que ocorre por meio de licenciamento não exclusivo), não há que se falar em abuso, já que terceiros não serão impedidos de explorar a tecnologia. ${ }^{686}$

Nesse sentido, suponha que um monopolista, que já é titular de patentes sobre uma dada tecnologia, passe a adotar uma estratégia agressiva de aquisição e acumulação de direitos exclusivos sobre patentes que protejam tecnologias substitutas ou alternativas, isto é, que sejam de alguma forma "relacionadas" com aquela tecnologia detida por ele. ${ }^{687}$ Essas aquisições trariam o risco de fechamento do mercado para potenciais concorrentes

das concentrações entre agentes econômicos, EC Merger Regulation, OJ I, 24/1, 29 Jan. 2004. O Artigo 102 do TFUE pode ser aplicável quando a aquisição de patentes decorrer de abuso de posição dominante.

Cf. HOVENKAMP, Herbert; JANIS, Mark D.; LEMLEY, Mark A. IP and Antitrust: An Analysis of Antitrust Principles Applied to Intelectual Property Law, v. I. Aspen Publishers, 2009, capítulo 14: 14-15; 14-16; 14-17; 14-18.

${ }^{687}$ Uma patente "relacionada" pode ser definida como qualquer produto ou processo que seja um substituto ou mesmo uma melhoria em relação ao produto ou processo já utilizado pelo agente econômico dominante. Desse modo, uma patente "relacionada" pode proteger uma tecnologia concorrente que seja equivalente à tecnologia já detida pelo monopolista. De acordo com HOVENKAMP, JANIS e LEMLEY, aquisições realizadas por um agente econômico dominante de direitos exclusivos sobre patentes relacionadas constituem presumidamente conduta unilateral de exclusão, nos termos da Seção 2 do Sherman Act. Entretanto, o monopolista é livre para adquirir direitos exclusivos sobre patentes não relacionadas, ou mesmo adquirir direitos não exclusivos sobre qualquer patente, seja ela relacionada ou não. Contudo, caso o adquirente não domine o mercado no momento em que a aquisição foi realizada, não há que se falar em violação da Seção 2 do Sherman Act, muito embora uma série de aquisições que acabe conferindo poder de monopólio ao agente econômico em questão poderá ser tratada como tentativa ilícita de monopolização. Cf. HOVENKAMP, Herbert; JANIS, Mark D.; LEMLEY, Mark A. IP and Antitrust: An Analysis of Antitrust Principles Applied to Intelectual Property Law, v. I. Aspen Publishers, 2009, capítulo 14: 14-15; 14-16; 14-17; 14-18. 
que poderiam ter acesso àquelas patentes, o que lhes permitiria explorar as tecnologias alternativas no desempenho de suas atividades. ${ }^{688}$ Da mesma forma, a aquisição de direitos exclusivos sobre determinada patente que proteja uma melhoria em relação à patente já detida pelo monopolista poderá ser suficiente para possibilitar a perpetuação de seu poder de monopólio para além do período de vigência de seu direito patentário. ${ }^{689}$

No caso United Shoe Machinery, a Suprema Corte norte-americana afirmou que um agente econômico dominante pode ser responsabilizado nos termos da Seção 2 do Sherman Act nas situações em que adquire licenças exclusivas junto a titulares de patentes, quando poderia, da mesma maneira, ter obtido licenças não exclusivas. A United Shoe havia acumulado mais de duas mil patentes, das quais cinco por cento resultaram da aquisição de licenças exclusivas junto a terceiros, o que impedia o ingresso de potenciais concorrentes no mercado. Como justificativa, a empresa afirmou que as licenças exclusivas foram obtidas no contexto de acordos que colocaram fim a disputas judiciais sobre patentes e que, na ausência dessas aquisições, a empresa teria sido privada da utilização de tecnologias úteis. No entanto, as justificativas foram rejeitadas, já que a aquisição de licenças não exclusivas teria sido suficiente para atender a essas duas finalidades. ${ }^{690}$

Em alguns casos, a não utilização de patentes adquiridas e acumuladas por um agente econômico dominante foi considerada como conduta abusiva unilateral visando à supressão de tecnologias. ${ }^{691}$ No caso Kobe v. Dempsey, o tribunal (Tenth Circuit) concluiu que a aquisição, não uso e proibição de uso por terceiros de todas as patentes importantes sobre um determinado domínio tecnológico com o objetivo de excluir a concorrência constitui violação da Seção 2 do Sherman Act, quando acompanhada de outros elementos. A Kobe havia adquirido e acumulado todas as patentes relevantes sobre tecnologias relacionadas a bombas hidráulicas utilizadas na extração de petróleo, de modo a

\footnotetext{
${ }^{688}$ Nesse sentido, no caso Transparent-Wrap, a Suprema Corte afirmou o seguinte: “As patents are added to patents, a whole industry may be regimented. The owner of a basic patent might thus perpetuate (...) his control over an industry long after the basic patent expired. Competitors might be eliminated, and an industrial monopoly perfected and maintained". Transparent-Wrap v. Stokes \& Smith, 329 U.S. 637 (1947), p. 646-47.

${ }^{689}$ No caso In re Biovail Corp., por exemplo, o agente econômico dominante assumiu perante a FTC o compromisso de não adquirir e impor patentes sobre melhorias em relações aos seus medicamentos patenteados, o que poderia resultar no prolongamento de seu poder de monopólio. In re Biovail Corp., 2002 WL 727033 (FTC No. 011 0094, Apr. 23, 2002).

${ }^{690}$ United States v. United Shoe Machinery Corp., 110 F. Supp. 295, 333 (D.Mass. 153), affirmed per curiam, 347 U.S. 521 (1954).

${ }^{691}$ Sobre o tema, cf. SAUNDERS, Kurt M. Patent Nonuse and the Role of Public Interest as a Deterrent to Technology Suppression, in: Harvard Journal of Law \& Technology, v. 15, No. 2, Spring 2002.
} 
desencorajar potenciais rivais a ingressarem no mercado. Contudo, o tribunal notou que nenhuma bomba hidráulica jamais foi fabricada ou comercializada sob essas patentes adquiridas. Apesar de não utilizar várias dessas patentes, a Kobe ingressava com ações judiciais, ou ameaçava de fazê-lo, contra qualquer agente econômico que tentasse entrar no mercado. De acordo com o tribunal, essa estratégia permitiu que a empresa monopolizasse toda a tecnologia relacionada a bombas hidráulicas. ${ }^{692}$

Na União Europeia, a aquisição de direitos exclusivos sobre patentes também pode constituir abuso de posição dominante nos termos do Artigo 102 do TFUE, conforme se depreende do caso Tetra Pak I - Licença BTG. ${ }^{693}$ A Tetra Pak dominava o mercado relevante de embalagens e equipamentos para embalagem asséptica de alimentos líquidos, com aproximadamente $90 \%$ de market share, e adquiriu uma licença exclusiva sobre uma patente que protegia uma inovação incremental em relação à tecnologia que a empresa já utilizava. A natureza exclusiva dessa licença permitiu que a Tetra Pak impedisse concorrentes efetivos e potenciais de utilizarem aquela patente, permitindo-lhe preservar sua posição dominante. Ao analisar o caso, a Comissão concluiu que a aquisição da licença exclusiva não apenas fortaleceu o domínio considerável da Tetra Pak sobre o mercado, permitindo-lhe dominar uma tecnologia alternativa mais avançada, como também teve o efeito de impedir, ou pelo menos atrasar consideravelmente, a entrada de um novo concorrente num mercado no qual havia pouca, ou quase nenhuma, concorrência. ${ }^{694} \mathrm{O}$ Tribunal Geral confirmou a decisão da Comissão, afirmando que o fator decisivo para considerar abusiva a aquisição da licença exclusiva decorre não apenas da posição da Tetra Pak no mercado relevante, mas também do fato de que, na época da aquisição, a patente em questão era capaz de conferir a um agente econômico os meios necessários para concorrer efetivamente com a Tetra Pak no segmento de embalagem asséptica de alimentos líquidos. $^{695}$

Como se pode observar, tanto nos Estados Unidos como na União Europeia a aquisição de direitos exclusivos sobre patentes por agentes econômicos dominantes, seja

\footnotetext{
${ }^{692}$ Kobe, Inc. v. Dempsey Pump Co., 198 F.2d 416 (10th Cir. 1952).

${ }^{693}$ Tetra Pak I (BTG Licence), 88/501/EC, July 26, 1988 OJ L 272/27.

694 “Tetra abused its dominant position by the acquisition of [the BTG] exclusive licence which had the effect of strengthening its already dominant position, further weakening existing competition and rendering even more difficult the entry of any new competition." Tetra Pak I (BTG Licence), 88/501/EC, July 26, 1988 OJ L 272/27, parágrafo 60 .

${ }^{695}$ Tetra Pak Rausing SA v Commission, Case T-51/89 (10 July 1990), parágrafo 23.
} 
por meio de licença exclusiva ou cessão definitiva, pode constituir conduta abusiva de exclusão, ao abrigo da Seção 2 do Sherman Act e do Artigo 102 do TFUE, tendo em vista a possibilidade de resultar na supressão das tecnologias disponíveis no mercado e, assim, inviabilizar a concorrência efetiva e potencial. Por outro lado, a aquisição de patentes resultante de esforços internos de pesquisa e desenvolvimento é praticamente imune à intervenção antitruste, ainda que o titular do direito exclusivo opte pela sua não utilização. 


\section{A EXPERIÊNCIA BRASILEIRA NA REPRESSÃO AO ABUSO DO PODER ECONÔMICO A PARTIR DA EXPLORAÇÃo DE DIREITOS DE PROPRIEDADE INTELECTUAL}

O tema da interface entre propriedade intelectual e direito da concorrência tem sido tratado no Brasil com menos intensidade e profundidade em comparação com os Estados Unidos e a União Europeia. A ausência de uma jurisprudência sólida sobre a matéria nos órgãos de defesa da concorrência e tribunais brasileiros pode ser explicada pelo fato de a aplicação moderna do direito antitruste e do direito da propriedade intelectual ser relativamente recente no Brasil. ${ }^{696}$ De fato, somente em 1994, com a entrada em vigor da Lei n. ${ }^{\circ}$ 8.884/94, o país passou a adotar uma legislação antitruste em conformidade com os padrões internacionais. Ressalte-se que essa lei foi revogada pela Lei n. ${ }^{\circ}$ 12.529, de 30 de novembro de 2011, a nova Lei Antitruste, que reformulou o Sistema Brasileiro de Defesa da Concorrência (SBDC) e a forma de atuação dos órgãos antitruste, em especial do Conselho Administrativo de Defesa Econômica - CADE. A aprovação de leis modernas de propriedade intelectual ocorreu a partir da segunda metade dos anos 1990, com o objetivo de adaptar o corpo normativo então vigente aos padrões mínimos de proteção estabelecidos pelo Acordo TRIPS/OMC. Nesse contexto, deve-se destacar a Lei n. ${ }^{\circ}$ 9.279/96, que dispõe sobre a proteção da propriedade industrial (marcas, patentes, desenhos industriais, dentre outros), a Lei n. ${ }^{\circ}$ 9.610/98, que disciplina a proteção dos direitos autorais, e a Lei n. ${ }^{\circ}$ 9.609/98, que dispõe sobre a proteção dos programas de computador. $^{697}$

Alguns apontam que a carência de julgados sobre o tema seria uma indicação da pouca importância das patentes como estratégia competitiva relevante e dos baixos investimentos em pesquisa e desenvolvimento no país. ${ }^{698}$ De acordo com relatório da

\footnotetext{
${ }^{696}$ Vale ressaltar que o Brasil já teve leis de defesa da concorrência e de propriedade intelectual antes de 1994 e 1996, respectivamente. Contudo, tais leis não acompanhavam a conotação mais moderna dada às matérias nos países mais industrializados. Cf. ROSEMBERG, Bárbara. Interface entre o Regime de Patentes e o Direito Concorrencial no Setor Farmacêutico, in: Propriedade Intelectual: Estudos em Homenagem à Professora Maristela Basso. Curitiba: Juruá Editora, 2006, p. 169.

${ }^{697}$ Nesse contexto, é importante ressaltar que a entrada em vigor de legislações de defesa da concorrência e de proteção à propriedade intelectual nos anos 1990 acompanhou o movimento de abertura da economia brasileira ao mercado externo, do ingresso do país na OMC, de sua maior inserção nos foros internacionais, das privatizações e da criação das agências reguladoras.

${ }^{698}$ Cf. CUEVA, Ricardo Villas Bôas. A Proteção da Propriedade Intelectual e a Defesa da Concorrência nas Decisões do CADE, in: Revista do IBRAC, v. 16, n. 1, p. 123, 2009.
} 
OCDE publicado em 2007, constatou-se que, embora a legislação de propriedade intelectual brasileira acompanhe os padrões internacionais, o país figurava naquela época na $28^{\mathrm{a}}$ colocação no ranking mundial de patentes concedidas, com $82,2 \%$ das patentes concedidas no Brasil pertencendo a empresas estrangeiras. ${ }^{699}$ Dados recentes indicam que entre 2005 e 2011 os pedidos de patentes cresceram 31\%, com os pedidos de não residentes representando cerca de $75 \%$, contra apenas $25 \%$ dos residentes. $^{700}$ Essa disparidade entre patentes concedidas a residentes e não residentes no Brasil indica que as atividades de inovação no país estão aquém de outros países emergentes, como China, Índia e Rússia. ${ }^{701}$

De qualquer modo, veremos nesta Seção que têm sido crescentes as discussões envolvendo abuso do poder econômico a partir da exploração de direitos de propriedade intelectual nos órgãos brasileiros de defesa da concorrência, o que, de acordo com Marcos Chucralla Moherdaui BLASI, pode ser explicado pelo progressivo amadurecimento e sofisticação do mercado brasileiro, bem como pela nova feição dos órgãos antitruste e do próprio Instituto Brasileiro de Propriedade Industrial - INPI, após o advento da Lei n. ${ }^{\circ}$ 8.884/94 (recentemente revogada pela nova Lei Antitruste) e da Lei n. ${ }^{\circ}$ 9.279/96, que disciplina a proteção da propriedade industrial. ${ }^{702}$ Destarte, discussões complexas envolvendo a relação entre direitos de propriedade intelectual e direito antitruste tendem a assumir um papel cada vez mais relevante no contexto atual, como se tem observado em manifestações recentes proferidas pelos órgãos de defesa da concorrência.

\footnotetext{
699 "Although the legislation seems to be very complete and follows the international standards, Brazil places the 28th on the international ranking of patent concessions, as mentioned. According to INPI, 82,2\% of the patents guaranteed belongs to foreign companies (Annex 1); and among the Brazilian holders, the majority of the protection are granted to the public sector. In 2005, approximately, 20.000 patents were deposited in INPI, against approximately 300.000 in US. Among it, about $70 \%$ are international requests and the other $30 \%$ were presented to companies, universities, research institutes and researchers. As per INPI official data, only $0,2 \%$ of the national deposits came from universities, although this number is growing due to INPI's advocacy initiatives." OECD, Competition, Patents and Innovation, 2006 (Policy Roundtables), DAF/COMP(2007)40. Disponível em:

http://www.oecd.org/competition/abuseofdominanceandmonopolisation/39888509.pdf. Acesso em: 31 ago. 2012.

700 Dados publicados pelo Instituto Nacional de Propriedade Industrial. Disponíveis em: http://www.inpi.gov.br/index.php?option=com_content\&view=article\&id=1361:inpi-divulga-dados-eestimativas-de-patentes-solicitadas-no-brasil\&catid=50:slideshow\&Itemid=146. Acesso em: 31 ago. 2012.

${ }^{701}$ Sobre o tema, cf. reportagem publicada no site da Universidade Federal de Brasília, intitulada "O Brasil é o Lanterninha do BRIC em Patentes": http://www.unb.br/noticias/unbagencia/cpmod.php?id=92149. Acesso em: 31 ago. 2012.

${ }^{702}$ BLASI, Marcos Chucralla Moherdaui. Propriedade Intelectual e Direito da Concorrência: Premissas de Análise e Apontamentos sobre a Jurisprudência Brasileira e Estrangeira. Revista da ABPI, n. 116, p. 52, jan./fev. 2012.
} 
A formulação da legislação brasileira de defesa da concorrência foi fortemente influenciada pelos sistemas antitruste norte-americano e europeu, de modo que há atualmente significativo grau de convergência internacional entre essas diferentes jurisdições no que concerne à aplicação dos conceitos e das teorias fundamentais nessa área. ${ }^{703}$ No que concerne especificamente à interface entre propriedade intelectual e direito antitruste, é possível constatar que os órgãos brasileiros de defesa da concorrência recorrem frequentemente à jurisprudência norte-americana e europeia como referência na análise antitruste de casos semelhantes no Brasil. Nesse contexto, é inegável que a experiência brasileira pode servir de modelo para outros países em desenvolvimento que desejem implementar normas antitruste nacionais para lidar com abusos de direitos de propriedade intelectual, de forma compatível com as regras de concorrência contidas no Acordo TRIPS/OMC.

Feitas as considerações iniciais, passamos a analisar a seguir a relação entre propriedade intelectual e concorrência no contexto do ordenamento jurídico-constitucional brasileiro. Em seguida, serão examinados alguns casos já julgados pelo CADE envolvendo práticas restritivas em acordos de licenciamento e condutas unilaterais de exclusão a partir da exploração de direitos de propriedade intelectual.

\footnotetext{
${ }^{703}$ Sobre a influência do sistema antitruste norte-americano sobre a formação das normas e instituições de defesa da concorrência no Brasil, SCHUARTZ afirma que: "No Brasil, em particular, a teoria antitruste norteamericana foi recebida, especialmente na virada dos anos 1980 e começo dos anos 1990, com o status de 'quase' fonte do direito brasileiro, convertendo-se desde então no principal fornecedor dos insumos intelectuais para a teorização mais abstrata sobre a legislação de defesa da concorrência vigente no país e a sua interpretação". SCHUARTZ, Luiz Fernando. Inovações e defesa da concorrência: em busca de uma política que minimize os custos de decisões equivocadas, in: TIMM, Luciano Benetti; PARANAGUÁ, Pedro. Propriedade Intelectual, Antitruste e Desenvolvimento: caso da transferência de tecnologia e do software. Rio de Janeiro: FGV Direito Rio, 2009, p. 41. No mesmo sentido, ao tratar do "transplante" de sistemas jurídicos estrangeiros no Brasil, especialmente no que concerne a normas de proteção da propriedade intelectual e de defesa da concorrência, Luciano Benetti TıMM afirma que: "O que realmente é novo no transplante jurídico brasileiro é que por quase um século tem sido prolífico no processo de combinação de fontes jurídicas, adotando regras legais de ambas as famílias jurídicas, quais sejam, a romanogermânica e a família da common law. Além disso, recentemente, até mesmo o direito provado brasileiro (e.g., alienação fiduciária em garantia, arrendamento mercantil, franquias, faturização), ou novos ramos jurídicos, têm sido transplantados dos Estados Unidos. Aliás, a nova Lei de Propriedade Industrial (cuja matriz remonta ao Tratado sobre Propriedade Intelectual na Organização Mundial do Comércio) e a Lei Antitruste são fundamentalmente inspiradas na legislação americana (sem falar em farta legislação importada dos Estados Unidos para o Brasil, como a societária, a securitária, a de mercado de ações, a bancária, dentre outras). Este fato apresenta algumas dificuldades em termos de sistematização, vez que as novas regras devem integrar-se ao sistema brasileiro, o qual, originalmente, deriva de fontes jurídicas diferentes". TIMM, Luciano Benetti. Contrato internacional de transferência de tecnologia no Brasil: interseção da propriedade intelectual com o direito antitruste, in: TIMM, Luciano Benetti; PARANAGUÁ, Pedro. Propriedade Intelectual, Antitruste e Desenvolvimento: caso da transferência de tecnologia e do software. Rio de Janeiro: FGV Direito Rio, 2009, p. 66-67.
} 


\subsection{Interface entre propriedade intelectual e concorrência no ordenamento jurídico brasileiro}

Assim como ocorre nos Estados Unidos e na União Europeia, os órgãos brasileiros de defesa da concorrência reconhecem que não existe conflito entre a legislação antitruste e a legislação de propriedade intelectual. Sob esse aspecto, deve-se levar em consideração, primeiramente, que ambas - a proteção da livre concorrência e a tutela dos direitos de propriedade intelectual - encontram fundamento na Constituição Federal. Desse modo, o artigo 170 da nossa Lei Maior dispõe que a ordem econômica, fundada na valorização do trabalho humano e na livre-iniciativa, observará, entre outros, os princípios da função social da propriedade, da livre concorrência e da defesa do consumidor. Já o artigo $173, \S 4^{\circ}$ estabelece que "a lei reprimirá o abuso do poder econômico que vise à dominação dos mercados, à eliminação da concorrência e ao aumento arbitrário nos lucros".

Pode-se afirmar que tanto a livre iniciativa como a livre concorrência estabelecem as regras básicas de funcionamento dos mercados. Nesse sentido, a propriedade intelectual poderia ser vislumbrada como exceção a essas regras básicas, pois estabelece um privilégio temporário em favor dos titulares de direitos imateriais para a exploração do objeto protegido. Essa afirmação poderia ser verdadeira se a proteção dos direitos de propriedade intelectual não estivesse também prevista na própria Constituição Federal.

A proteção da propriedade intelectual encontra seu fundamento no art. $5^{\circ}$ da Carta Magna, que trata dos Direitos Fundamentais. Nesse contexto, o art. 5\% XXVII, determina que "aos autores pertence o direito exclusivo de utilização, publicação ou reprodução de suas obras, transmissível aos herdeiros pelo tempo que a lei fixar". Já o inciso XXIX do mesmo dispositivo confere "aos autores de inventos industriais privilégio temporário para sua utilização, bem como proteção às criações industriais, à propriedade das marcas, aos nomes de empresas e a outros signos distintivos, tendo em vista o interesse social e o desenvolvimento tecnológico e econômico do país". Soma-se a esses dispositivos a limitação constitucional imposta pela função social da propriedade, prevista nos artigos $5^{\circ}$, XXIII, e 170 da nossa Carta Magna. ${ }^{704}$

\footnotetext{
${ }^{704}$ Denis Borges BARBOSA entende que o inciso XXIX do art. $5^{\mathbf{0}}$ da Constituição vincula os direitos de propriedade intelectual de conteúdo essencialmente industrial (e.g. marcas e patentes) à "cláusula finalística"
} 
Nota-se que a Constituição exclui uma interpretação eminentemente privatista dos direitos de propriedade intelectual, pois leva em consideração que tais direitos não são absolutos e devem ser contrabalanceados com outros interesses também tutelados por nosso ordenamento jurídico, tais como a função social da propriedade (arts. $5^{\circ}$, XXIII, e 170, III), a livre iniciativa (art. 170, caput), a livre concorrência (art. 170, IV), dentre outros. Assim, o interesse público nas invenções e nas criações do espírito é o elemento justificador da tutela constitucional da propriedade intelectual.

Dessa forma, a proteção constitucional dos direitos de propriedade intelectual tem como finalidade propiciar o desenvolvimento social, tecnológico e econômico do país, observados os demais princípios constitucionais aplicáveis, tais como a função social da propriedade, a livre iniciativa, a livre concorrência e a defesa dos consumidores. Como bem apontado por Bárbara RosENBERG, a interpretação sistemática da Constituição Federal permite concluir que há uma comunhão de escopos entre os artigos 170, 173 e os incisos XXVII e XXIX do art. $5^{\circ}$ da nossa Carta Magna. ${ }^{705}$

Nesse sentido, é possível constatar que a Constituição Federal vislumbra a propriedade intelectual e o direito da concorrência como instrumentos complementares de promoção de inovação e desenvolvimento econômico, gerando eficiências econômicas -

específica contida no final do texto legal (interesse social e desenvolvimento tecnológico e econômico do país), o que não ocorre com o inciso XXVII do mesmo dispositivo, que trata dos direitos autorais. Contudo, o autor esclarece o seguinte: "Em dispositivo específico, a Constituição brasileira de 1988 sujeita a constituição de tais direitos a condições especialíssimas de funcionalidade (a cláusula finalística), compatíveis com sua importância econômica, estratégica e social. Não é assim que ocorre no que toca aos direitos autorais. Certo é que, no que for objeto de propriedade (ou seja, no alcance dos direitos patrimoniais), o direito autoral também está sujeito às limitações constitucionalmente impostas em favor do bem comum - a função social da propriedade de que fala o Art. $5^{\circ}$, XXIII da Carta de 1988. Note-se, uma vez mais, neste contexto, que a proteção autoral, como propugna boa parte da doutrina, não se esgota na noção de propriedade, em particular pela presença dos direitos de personalidade ou direitos morais em geral. O Art. $5^{\circ}$, XXII, que assegura inequivocamente o direito de propriedade, deve ser sempre contrastado com as restrições do inciso seguinte, a saber, as de que a propriedade atenderá sua função social. Também no Art. 170 a propriedade privada é definida como princípio essencial da ordem econômica, sempre com o condicionante de sua função social". BARbosA, Denis Borges. A Criação de um Ambiente Competitivo no Campo da Propriedade Intelectual: O Caso Sul Americano, in: Centre for Trade and Sustainable Development, nov. de 2005, p. 25.

705 A autora concentra sua análise nas patentes, embora a lição possa estender-se a todas as criações intelectuais protegidas por direitos de propriedade intelectual: “(...) uma interpretação conjunta dos arts. 170, 173 , e do inc. XXIX do art. $5^{\circ}$ da CF, levaria à conclusão de que há uma comunhão de escopos entre ambos os dispositivos. Não obstante o inc. XXIX do art. $5^{\circ}$ garanta os direitos individuais dos inventores resultantes de seu trabalho, o fim último desse dispositivo é garantir o interesse social e promover o bem-estar do consumidor, a livre-iniciativa e a concorrência. No mesmo sentido, conforme comentado, o art. 170 estabelece que são princípios que regem a ordem econômica, fundada na valorização do trabalho humano e na livre-iniciativa, a livre concorrência e a defesa do consumidor. Percebe-se, portanto, que princípios correspondentes regem os distintos artigos”. ROSENBERG, Bárbara. Interface entre o Regime de Patentes e o Direito Concorrencial no Setor Farmacêutico, in: Propriedade Intelectual: Estudos em Homenagem à Professora Maristela Basso. Curitiba: Juruá Editora, 2006, p. 285. 
estáticas e dinâmicas - que resultarão em ganhos de bem-estar social. Conforme já mencionado, a dinâmica da concorrência pela inovação e superação (diferenciação de produtos e serviços) contribui com o progresso técnico e científico, em benefício do bemestar dos consumidores, que terão maiores opções de escolha no mercado.

A despeito dessa relação de complementaridade, é certo que o exercício de direitos de propriedade intelectual não está imune à incidência da Lei Antitruste (Lei n. ${ }^{\circ}$ 12.529/2011), que tem como finalidade a repressão ao abuso do poder econômico. Desse modo, os órgãos brasileiros de defesa da concorrência devem atuar para reprimir práticas restritivas da concorrência a partir do uso abusivo de direitos de propriedade intelectual, o que pode ocorrer por meio de restrições unilaterais de exclusão, cláusulas abusivas inseridas em contratos de licenciamento, licenças cruzadas e pool de patentes capazes de resultar em acordos ilícitos entre concorrentes, dentre outros. ${ }^{706}$

\subsubsection{Enquadramento jurídico das práticas restritivas da concorrência na Lei $\mathbf{n}^{\circ}$}

\subsection{9/2011: especial referência aos direitos de propriedade intelectual}

Conforme já mencionado, a Lei n. ${ }^{\circ}$ 12.529/2011 (Lei Antitruste), que revogou a antiga Lei 8.884/94, estrutura o SBDC e dispõe sobre a prevenção e repressão às infrações à ordem econômica, orientada pelos ditames constitucionais de liberdade de iniciativa, livre concorrência, função social da propriedade, defesa dos consumidores e repressão ao abuso do poder econômico, conforme disposição contida em seu art. $1^{\text {o }}$. Já o parágrafo único do mesmo dispositivo ressalta que "a coletividade é a titular dos bens jurídicos protegidos por esta Lei”. A despeito do debate teórico em torno dos bens jurídicos protegidos pelo direito da concorrência, que não interessa ao escopo desta tese, pode-se afirmar que a Lei Antitruste, em linha com os padrões internacionais, tem como

\footnotetext{
${ }^{706}$ Segundo compreendido no Voto do Conselheiro Carlos RAGAZzo, em decisão do CADE no âmbito da Averiguação Preliminar n. ${ }^{\circ}$ 08012.002673/2007-51: “A propriedade industrial, porém, não é absoluta, nem imune à legislação antitruste. Assim como os direitos de propriedade industrial estão protegidos pela Constituição Federal e pela legislação infraconstitucional, o direito à concorrência também está (arts. 170, IV, e $173, \S 4^{\circ}$, da CF, e da Lei . $^{\circ}$ 8.884/94), e embora seja verdade que esses dois grupos de direitos normalmente se complementam, algumas vezes o exercício de um direito de propriedade industrial pode ferir o direito à concorrência de modo ilegítimo, e tais direitos podem se chocar. Nesse sentido, embora seja certo que o exercício de direitos de propriedade industrial não constitua, de modo algum, uma conduta anticompetitiva per se, e que muitas vezes sequer confira qualquer poder de mercado ao seu detentor, não raro esses direitos surtem efeitos anticompetitivos que, efetivamente, importam uma conduta anticompetitiva ilegal, passível de intervenção da autoridade antitruste, conforme demonstram diversos casos analisados por diferentes jurisdições".
} 
objetivo fundamental a proteção da concorrência e, consequentemente, a liberdade de escolha dos consumidores. $^{707}$

De acordo com a nova estrutura estabelecida pela Lei Antitruste, o SBDC é atualmente composto pelo Conselho Administrativo de Defesa Econômica - CADE, autarquia federal vinculada ao Ministério da Justiça, e pela Secretaria de Acompanhamento Econômico - SEAE, vinculada ao Ministério da Fazenda. ${ }^{708}$ Dentro dessa estrutura, compete ao CADE desempenhar as funções de investigação, instrução processual e tomada de decisões em sede administrativa no que concerne à prevenção e repressão às infrações contra a ordem econômica. ${ }^{709}$ Essas funções são desempenhadas por três órgãos internos do CADE: (i) o Tribunal Administrativo; (ii) a Superintendência-Geral; e (iii) o Departamento de Estudos Econômicos. ${ }^{710} \mathrm{O}$ Tribunal Administrativo é responsável por receber os processos instruídos, realizar instrução adicional, caso seja necessário, e julgar os processos, cabendo revisão apenas na esfera judicial. ${ }^{711}$ Compete à SuperintendênciaGeral a instrução processual, investigação das denúncias recebidas e encaminhamento dos processos devidamente instruídos ao Tribunal Administrativo, com parecer fundamentado indicando a sua recomendação para o julgamento, funções que eram antes desempenhadas pela Secretaria de Direito Econômico (SDE). ${ }^{712}$ Finalmente, o Departamento de Estudos Econômicos é responsável pela elaboração de estudos e pareceres econômicos, de ofício ou quando solicitado. $^{713}$

Feitas essas breves considerações iniciais sobre a estrutura atual do SBDC, passamos a analisar as formas de atuação do CADE no controle das práticas restritivas relacionadas à exploração de direitos de propriedade intelectual. A Lei Antitruste prevê

\footnotetext{
${ }^{707}$ Cf. SALOMÃo FILHO, Calixto. Direito Concorrencial - As Condutas. São Paulo: Malheiros Editores, 2003, p. 81.

${ }^{708}$ Nos termos da lei antitruste anterior (Lei n. ${ }^{\circ} 8.884 / 94$ ), que permaneceu em vigor até 30/05/2012, o SBDC era composto por três órgãos, a Secretaria de Direito Econômico (SDE), o CADE e a SEAE. Atualmente, o CADE absorveu as funções que eram da SDE (investigação e instrução processual), enquanto a SEAE ficou encarregada da "advocacia da concorrência", conforme o disposto no art. 19 da Lei Antitruste, devendo opinar em propostas de atos normativos e projetos de lei, propor a revisão de leis, regulamentos e outros atos normativos, elaborar estudos e pareceres acerca de determinados setores, dentre outros.

${ }^{709}$ Sob o regime anterior da Lei n. $^{\circ} 8.884 / 94$, a SDE tinha funções investigativas e instrutórias no que concerne a condutas anticoncorrenciais e meramente instrutórias em relação aos atos de concentração econômica. Cabia ao CADE exercer uma função judicante, na qualidade de "tribunal administrativo".

${ }^{710}$ Cf. art. $5^{\circ}$ da Lei Antitruste.

${ }^{711}$ Cf. art. $9^{\circ}$ da Lei Antitruste.

${ }^{712}$ Cf. art. 13 da Lei Antitruste.

${ }^{713}$ Cf. art. 17 da Lei Antitruste.
} 
duas formas de atuação nesses casos: (i) de repressão, a partir da fiscalização e imposição de penalidades sobre condutas anticoncorrenciais, sejam elas decorrentes de acordos restritivos horizontais ou verticais, ou mesmo de condutas unilaterais (art. 36); e (ii) de prevenção, a partir do controle ex ante de estruturas de mercado a partir da análise de atos de concentração econômica, horizontais ou verticais, tais como operações de fusão, aquisição, joint venture, dentre outras (art. 90).

A primeira forma de atuação do CADE está prevista no art. 36 da Lei Antitruste, que trata da repressão às infrações à ordem econômica. Diferentemente das leis antitruste norte-americana e europeia, que proíbem separadamente acordos anticoncorrenciais (Seção 1 do Sherman Act e Artigo 101 do TFUE) e condutas abusivas de exclusão (Seção 2 do Sherman Act e Artigo 102 do TFUE), o art. 36 da Lei Antitruste engloba todo tipo de conduta anticoncorrencial, sejam acordos horizontais ou verticais, ou mesmo condutas unilaterais de exclusão. Nesse sentido, o art. 36 dispõe que constituem infração da ordem econômica, independentemente de culpa, os atos sob qualquer forma manifestados, que tenham por objeto ou possam produzir os seguintes efeitos, ainda que não sejam alcançados: (i) limitar, falsear ou de qualquer forma prejudicar a livre concorrência ou a livre iniciativa (inciso I); (ii) dominar mercado relevante de bens ou serviços (inciso II); (iii) aumentar arbitrariamente os lucros (inciso III); e (iv) exercer de forma abusiva posição dominante (inciso IV).

É importante ressaltar que a configuração de qualquer infração à ordem econômica depende da comprovação de que o agente econômico em questão detém posição dominante no mercado relevante, pois somente nessa hipótese os eventuais ilícitos serão capazes de causar efeitos adversos sobre a concorrência. ${ }^{714}$ A exigência de posição dominante para configuração de uma infração à ordem econômica justifica-se pelo fato de que a Lei Antitruste visa à tutela da livre concorrência no mercado, e não necessariamente à proteção dos concorrentes. Ademais, o $\$ 1^{\circ}$ do mesmo art. 36 deixa claro que a conquista de mercado resultante de processo natural fundado em maior eficiência de agente econômico em relação a seus competidores não caracteriza ilícito. Assim, em linha com os padrões internacionais sobre a matéria, a Lei Antitruste não pune o agente econômico que

\footnotetext{
${ }^{714}$ De acordo com o $\S 2^{\circ}$ do art. 36 , a posição dominante será presumida sempre que uma empresa ou grupo de empresas for capaz de alterar unilateral ou coordenadamente as condições de mercado ou quando controlar $20 \%$ ou mais do mercado relevante, podendo esse percentual ser alterado pelo CADE para setores específicos da economia.
} 
conquistou seu poder de mercado de forma lícita, a partir da chamada "concorrência por méritos", não havendo que se falar em intervenção antitruste nesses casos.

Ademais, o $\$ 3^{\circ}$ do mesmo art. 36 apresenta, de forma meramente exemplificativa, certas condutas que podem ser consideradas infração à ordem econômica, desde que configurem qualquer das hipóteses previstas nos incisos I a IV do art. 36, acima citadas. Dessa forma, pode-se afirmar que, em princípio, não há no Brasil ilícito antitruste per se, na medida em que qualquer das condutas listadas no $\S 3^{\circ}$ deve, obrigatoriamente, produzir pelo menos um daqueles efeitos descritos no art. 36. Além disso, eventuais infrações somente serão puníveis na ausência de possíveis eficiências econômicas que as justifiquem. Portanto, o Brasil adota a chamada "regra da razão" como padrão de análise antitruste de condutas anticoncorrenciais. ${ }^{715}$

Dentre as condutas exemplificadas nos incisos do $\$ 3^{\circ}$ do art. 36 diretamente relacionadas à exploração de direitos de propriedade intelectual e tecnologias, destacam-se as seguintes: (i) impedir o acesso de concorrente às fontes de insumo, matérias-primas, equipamentos ou tecnologia, bem como aos canais de distribuição (inciso V); (ii) regular mercados de bens ou serviços, estabelecendo acordos para limitar ou controlar a pesquisa e o desenvolvimento tecnológico, a produção de bens ou prestação de serviços, ou para dificultar investimentos destinados à produção de bens ou serviços ou à sua distribuição (inciso VIII); (iii) açambarcar ou impedir a exploração de direitos de propriedade industrial ou intelectual ou de tecnologia (inciso XIV); e (iv) exercer ou explorar abusivamente direitos de propriedade industrial, intelectual, tecnologia ou marca (inciso XIX). Há outras condutas listadas que também podem constituir ilícitos antitruste relacionados à exploração de direitos de propriedade intelectual, tais como práticas colusivas (incisos I e II), recusa de venda (inciso XI), venda casada (inciso XVIII), dentre outras.

Desse modo, na medida em que estiverem presentes as hipóteses previstas nos incisos I a IV do art. 36, as condutas acima exemplificadas, assim como outras não mencionadas, poderão configurar infração à ordem econômica.

\footnotetext{
${ }^{715}$ Por outro lado, os cartéis têm sido tratados, na prática, como ilícitos per se pelas autoridades de defesa da concorrência brasileiras, seguindo uma tendência mundial de repressão aos chamados "cartéis hard core". Essa tendência se justifica pelo fato de que não seria possível a existência de eficiências econômicas decorrentes desse tipo de prática.
} 
A prática de infração da ordem econômica sujeita as empresas e demais pessoas físicas e jurídicas envolvidas a severas penalidades de multa previstas no art. 37 da Lei Antitruste. ${ }^{716}$ Sem prejuízo das penas de multa, dependendo da gravidade dos fatos ou o interesse público geral, poderão ser impostas outras penalidades previstas no art. 38 do mesmo diploma legal, dentre elas a recomendação aos órgãos públicos competentes para que seja concedida licença compulsória de direitos de propriedade intelectual, conforme veremos adiante.

A outra forma de atuação do CADE em casos envolvendo direitos de propriedade intelectual pode se dar por meio do controle preventivo das estruturas de mercado a partir da análise de atos de concentração, tais como fusões, aquisições, incorporações, ou mesmo operações de joint venture e cooperação empresarial. Nos termos do art. 88 da Lei Antitruste, alterada pela Portaria Interministerial no 994/2012 $2^{717}$, devem ser submetidos ao CADE os atos de concentração nos quais, cumulativamente: (i) pelo menos um dos grupos envolvidos na operação tenha registrado, no último balanço, faturamento bruto anual ou volume de negócios total no território nacional, no ano anterior à operação, equivalente ou superior a $\mathrm{R} \$ 750.000 .000,00$ (setecentos e cinquenta milhões de reais); e (ii) pelo menos um outro grupo envolvido na operação tenha registrado, no último balanço, faturamento bruto anual ou volume de negócios total no País, no ano

716 “Art. 37. A prática de infração da ordem econômica sujeita os responsáveis às seguintes penas:

I - no caso de empresa, multa de 0,1\% (um décimo por cento) a $20 \%$ (vinte por cento) do valor do faturamento bruto da empresa, grupo ou conglomerado obtido, no último exercício anterior à instauração do processo administrativo, no ramo de atividade empresarial em que ocorreu a infração, a qual nunca será inferior à vantagem auferida, quando for possível sua estimação;

II - no caso das demais pessoas físicas ou jurídicas de direito público ou privado, bem como quaisquer associações de entidades ou pessoas constituídas de fato ou de direito, ainda que temporariamente, com ou sem personalidade jurídica, que não exerçam atividade empresarial, não sendo possível utilizar-se o critério do valor do faturamento bruto, a multa será entre $\mathrm{R} \$ 50.000,00$ (cinquenta mil reais) e $\mathrm{R} \$ 2.000 .000 .000,00$ (dois bilhões de reais);

III - no caso de administrador, direta ou indiretamente responsável pela infração cometida, quando comprovada a sua culpa ou dolo, multa de $1 \%$ (um por cento) a $20 \%$ (vinte por cento) daquela aplicada à empresa, no caso previsto no inciso I do caput deste artigo, ou às pessoas jurídicas ou entidades, nos casos previstos no inciso II do caput deste artigo.

$\S 1^{\mathrm{o}}$ Em caso de reincidência, as multas cominadas serão aplicadas em dobro.

$\S 2^{\circ}$ No cálculo do valor da multa de que trata o inciso I do caput deste artigo, o Cade poderá considerar o faturamento total da empresa ou grupo de empresas, quando não dispuser do valor do faturamento no ramo de atividade empresarial em que ocorreu a infração, definido pelo Cade, ou quando este for apresentado de forma incompleta e/ou não demonstrado de forma inequívoca e idônea."

717 A Portaria Interministerial $n^{\circ}$ 994, de 31 de maio de 2012 alterou os valores de faturamento e volume de negócios constantes no texto original do art. 88 da Lei Antitruste. A modificação desses valores tem fundamento no $\S 1^{\circ}$ do mesmo art. 88, que assim dispõe: "os valores mencionados nos incisos I e II do caput deste artigo poderão ser adequados, simultânea ou independentemente, por indicação do Plenário do Cade, por portaria interministerial dos Ministros de Estado da Fazenda e da Justiça". 
anterior à operação, equivalente ou superior a $R$ \$ 75.000.000,00 (setenta e cinco milhões de reais). ${ }^{718}$ É importante destacar que com a entrada em vigor da Lei Antitruste atual o Brasil passou a adotar o sistema de análise prévia de atos de concentração, em linha com as melhores práticas internacionais, de modo que nenhuma operação notificada poderá ser concluída antes de sua aprovação final pelo CADE. ${ }^{719}$

No regime anterior da Lei n. $^{\circ}$ 8.884/94, não havia clareza sobre quais operações poderiam constituir "ato de concentração" para fins de análise antitruste. O art. 54 daquela Lei estabelecia que "os atos, sob qualquer forma manifestados, que possam limitar ou de qualquer forma prejudicar a livre concorrência, ou resultar na dominação de mercados relevantes de bens ou serviços, deverão ser submetidos à apreciação do CADE". Dado o caráter amplo da redação contida no art. 54, caput, que exigia das partes uma análise subjetiva de cada caso concreto e seu potencial lesivo à concorrência, muitos acordos de licenciamento de direitos de propriedade intelectual que continham cláusulas potencialmente restritivas, tais como exclusividade, não concorrência, dentre outras, foram notificados ao SBDC como atos de concentração, mesmo sem guardarem qualquer relação com operações societárias de fusão, incorporação ou constituição conjunta de empresas. ${ }^{720}$

\footnotetext{
${ }^{718}$ Os critérios da revogada Lei n. ${ }^{\text {8 }}$ 8.884/94 para submissão de atos de concentração eram diferentes. Nos termos do art. 54, caput, daquela Lei, "os atos, sob qualquer forma manifestados, que possam limitar ou de qualquer forma prejudicar a livre concorrência, ou resultar na dominação de mercados relevantes de bens ou serviços, deverão ser submetidos à apreciação do CADE”. Já o $\$ 3^{\circ}$ do mesmo art. 54 acrescentava que nos atos mencionados no caput estariam incluídos todos aqueles que visassem a qualquer forma de concentração econômica, seja por meio de fusão ou incorporação de empresas, constituição de sociedade para exercer o controle de empresas ou qualquer forma de agrupamento societário, quando implicassem: (i) participação de empresa ou grupo de empresas resultante em $20 \%$ de um mercado relevante, ou em que qualquer dos participantes tenha registrado faturamento bruto anual no último balanço equivalente a $\mathrm{R} \$ 400.000 .000,00$ (quatrocentos milhões de reais).

${ }^{719}$ Não há dúvida de que o principal avanço promovido pela atual Lei Antitruste foi a instituição do sistema prévio de avaliação das operações de concentração econômica, de modo que nenhuma operação pode ser efetivada antes da aprovação final do CADE (Vide art. $88, \S 2^{\circ}$ e $\S 3^{\circ}$ da Lei Antitruste). Esse novo sistema está em linha com as jurisdições mais avançadas em matéria antitruste. Nos termos do art. 54 da legislação anterior, os atos de concentração deviam ser submetidos previamente ou no prazo máximo de 15 dias úteis de sua realização. Na prática, as empresas notificavam as operações após sua realização, o que comprometia a efetividade das decisões do CADE, além de criar insegurança jurídica para as empresas.

${ }^{720} \mathrm{Na}$ Averiguação Preliminar n. ${ }^{\circ}$ 0800.000518/96-06 (National Medical Care Inc. e Baxter Hospitalar Ltda.), que investigou práticas restritivas territoriais em contratos de franquia, o CADE concluiu que esses contratos deviam ser submetidos ao controle preventivo de atos de concentração, a teor do disposto no art. 54, caput, da Lei n.o 8.884/94, conforme a ementa a seguir transcrita: "AVERIGUAÇÃO PRELIMINAR MERCADO DE SERVIÇO DE DIÁLISE - DENÚNCIA DE PRÁTICA VISANDO LIMITAÇÃO OU FALSEAMENTO DA LIVRE CONCORRÊNCIA MEDIANTE CARTELIZAÇÃO E MONOPOLIZAÇÃO OU DOMINAÇÃO DE MERCADO (...) LEI N. ${ }^{\circ} 8.884 / 94$, ART. 54, §§ $3^{\circ}$ E $5^{\circ}$ (...) [Contratos de venda de equipamentos de diálise] não podem, via contratos de franquia, impor a clínicas de saúde a restrição de não se estabelecer em qualquer parte do território nacional, fato este suficiente a determinar a apresentação dos mesmos contratos, sob as penas da lei, para exame do Cade à luz do art. 54 da Lei n. ${ }^{\circ}$ 8.884/94 (...)".
} 
Com o objetivo de diminuir o grau de subjetividade existente no regime anterior, a legislação atual estabelece uma definição mais clara do que seriam "atos de concentração" para fins do controle preventivo a ser exercido pelo CADE. Nos termos do art. 90 da Lei Antitruste, realiza-se um ato de concentração quando: (i) duas ou mais empresas anteriormente independentes se fundem (inciso I); uma ou mais empresas adquirem, direta ou indiretamente, por compra ou permuta de ações, quotas, títulos ou valores mobiliários conversíveis em ações, ou ativos, tangíveis ou intangíveis, por via contratual ou por qualquer outro meio ou forma, o controle ou partes de uma ou outras empresas (inciso II); (iii) uma ou mais empresas incorporam outra ou outras empresas (inciso III); ou (iv) duas ou mais empresas celebram contrato associativo, consórcio ou joint venture (inciso IV).

Embora o CADE ainda não tenha regulamentado essa questão, é certo que alguns acordos de licenciamento e transferência de tecnologia, incluindo licenças cruzadas e pools de patentes, deverão ser notificados previamente ao CADE, caso atendam aos requisitos legais de submissão previstos no art. 88 da Lei Antitruste, ainda que não sejam realizados no âmbito de operações de fusões e aquisições. Isso porque tais acordos, dependendo de suas características, podem ser considerados como contrato associativo, ou mesmo joint venture, nos termos do art. 90, IV, da Lei Antitruste, na medida em que contenham cláusulas restritivas capazes de alterar as relações entre as partes no mercado, ou entre as partes e terceiros. ${ }^{721}$

Por fim, é imperioso destacar que A Lei Antitruste proíbe os atos de concentração que impliquem eliminação da concorrência em parte substancial de mercado relevante, que possam criar ou reforçar uma posição dominante, ou possam resultar na dominação de mercado relevante de bens ou serviços, ressalvadas as exceções previstas no $\S 6^{\circ}$ do art. 88 da referida Lei. Com base nesse dispositivo, atos de concentração potencialmente lesivos à concorrência poderão ser autorizados caso, cumulada ou alternativamente: (i) aumentem a produtividade ou a competitividade; (ii) melhorem a qualidade de bens ou serviços; (iii) propiciem a eficiência e o desenvolvimento tecnológico ou econômico; e (iv) seja repassada aos consumidores parte relevante dos benefícios

\footnotetext{
${ }^{721}$ Sobre o conceito de contrato associativo, consórcio e joint venture, nos termos do art. 90, IV, da Lei Antitruste, cf. ANDERS, Eduardo Caminati; PAGOTO, Leopoldo; BAGNOLI, Vicente (Coord.). Comentários à Nova Lei de Defesa da Concorrência: Lei n. ${ }^{\circ} 12.529$, de 30 de novembro de 2011. Rio de Janeiro: Forense; São Paulo: Método, 2012, p. 300-302.
} 
decorrentes. ${ }^{722}$ Essas exceções devem ser compreendidas como eficiências econômicas capazes de justificar a aprovação de atos de concentração potencialmente lesivos à concorrência, indicando, portanto, que a análise antitruste desses atos deve ser realizada com base em critérios de razoabilidade ("regra da razão"). ${ }^{723}$

\subsubsection{O licenciamento compulsório de direitos de propriedade intelectual para remediar práticas restritivas da concorrência}

Já tivemos a oportunidade de mencionar ao longo desta tese a importância do licenciamento compulsório de patentes como instrumento complementar de política pública, visando assegurar que a proteção da propriedade industrial atenda ao "interesse social e ao desenvolvimento tecnológico e econômico do país", conforme o disposto no art. $5^{\circ}$ XXIX da Constituição e no art. $2^{\circ}$ da Lei de Propriedade Industrial. Vimos que se trata de uma das mais importantes flexibilidades previstas no Acordo TRIPS (Artigo 31), permitindo aos Membros da OMC que concedam tais licenças a terceiros, sem autorização do titular da patente, em circunstâncias excepcionais, com o objetivo de lidar com situações de emergência nacional e interesse público, bem como para remediar condutas anticoncorrenciais.

A Lei Antitruste prevê em seu art. 38, IV, "a”, o licenciamento compulsório de direitos de propriedade intelectual como uma das penalidades que podem ser impostas em caso de infração à ordem econômica:

Art. 38. Sem prejuízo das penas cominadas no art. 37 desta Lei, quando assim exigir a gravidade dos fatos ou o interesse público geral, poderão ser impostas as seguintes penas, isolada ou cumulativamente:

$(\ldots)$

IV - a recomendação aos órgãos públicos competentes para que:

\footnotetext{
${ }^{722}$ É possível notar claras semelhanças entre o disposto no $\S 6^{\circ}$ do art. 88 da Lei Antitruste e o conteúdo do Parágrafo $3^{\circ}$ do Artigo 101 do TFUE, conforme analisamos na Seção 3.

${ }^{723}$ Nos termos do art. 61 da Lei Antitruste, no julgamento do pedido de aprovação do ato de concentração econômica, o Tribunal Administrativo poderá aprová-lo integralmente, rejeitá-lo ou aprová-lo parcialmente, caso em que determinará as restrições que deverão ser observadas como condição para a validade e eficácia do ato. O Tribunal poderá determinar as restrições cabíveis no sentido de mitigar os eventuais efeitos nocivos do ato de concentração sobre os mercados relevantes afetados. Tais restrições podem incluir: (i) a venda de ativos ou de um conjunto de ativos que constitua uma atividade empresarial; (ii) a cisão de sociedade; (iii) a alienação de controle societário; (iv) a separação contábil ou jurídica de atividades; (v) o licenciamento compulsório de direitos de propriedade intelectual; e (vi) qualquer outro ato ou providência necessários para a eliminação dos efeitos nocivos à ordem econômica (cf. §§ $1^{\circ} \mathrm{e} 2^{\circ}$ do art. 61).
} 
a) seja concedida licença compulsória de direito de propriedade intelectual de titularidade do infrator, quando a infração estiver relacionada ao uso desse direito. (grifo nosso)

A redação da Lei Antitruste atual é bastante semelhante ao disposto no art. 24, IV, "a" da legislação anterior (Lei n. ${ }^{\circ} 8.884 / 94$ ), com a diferença de que no art. 38, IV, "a" da lei atualmente em vigor houve a substituição do termo "patentes" por "direitos de propriedade intelectual”. Essa mudança é elogiável, pois as práticas restritivas relacionadas à exploração abusiva de direitos de propriedade intelectual não se limitam apenas às patentes, podendo envolver outros tipos de direitos de propriedade intelectual. Vimos que diversos casos julgados nos Estados Unidos e na União Europeia envolveram direitos autorais e software, e não apenas patentes. Ainda que o Acordo TRIPS aborde o licenciamento compulsório apenas em relação a patentes, como se observa em seu Artigo 31, é certo que os Membros da OMC podem se valer desse instrumento para remediar condutas anticoncorrenciais envolvendo quaisquer tipos de direitos de propriedade intelectual. Afinal, vimos que o Artigo 8.2 do TRIPS autoriza os Membros a adotarem medidas apropriadas, desde que sejam consistentes com o Acordo, com o objetivo de evitar o abuso dos direitos de propriedade intelectual, ou mesmo práticas que limitem o comércio ou que afetem adversamente a transferência de tecnologia.

É importante destacar que a linguagem contida no caput do art. 38 permite a interpretação de que o licenciamento compulsório é medida extrema que deve ser utilizada em situações excepcionais, isto é, apenas quando assim exigir a gravidade dos fatos ou o interesse público geral. ${ }^{724}$ Essa ressalva inserida no dispositivo permite concluir que a imposição do licenciamento compulsório como sanção deve obedecer a critérios de razoabilidade e proporcionalidade. Sob esse prisma, o disposto em comento está em plena conformidade com os deveres de proporcionalidade e consistência previstos nos Artigos

\footnotetext{
${ }^{724}$ Enquanto o Tribunal Administrativo do CADE tem o poder-dever de impor as penas de multa previstas no art. 37 da Lei Antitruste, sem qualquer condicionalidade, as penas previstas no art. 38 somente deverão ser aplicadas se assim exigir a gravidade dos fatos ou o interesse público. Sob a égide do regime anterior, o CADE já teve a oportunidade de manifestar-se sobre o tema ao emitir seu parecer na Consulta Prévia $n^{\circ}$ 031/99, em 31 de março de 1999. Em seu Voto, o Conselheiro Relator, Mércio FELSKY, esclareceu que: "Pela leitura e interpretação dos dispositivos transcritos, tem-se que o CADE, ao decidir pela caracterização de prática de infração da ordem econômica, tem o poder-dever de aplicar as penas de que trata o art. 23 [atual art. 37 da Lei Antitruste vigente], independentemente de qualquer condição, porquanto o legislador não contemplou qualquer condição que devesse ser observada pelo aplicador da norma quando da imposição dessas penas. Diversamente do art. 23, previu o legislador, como condições necessárias à imposição das penalidades do art. 24 [atual art. 38 da Lei Antitruste vigente], que (a) prática infrativa fosse de tal gravidade que exigisse sua aplicação, ou que (b) o interesse público estivesse a exigi-la. (...) A gravidade da infração é, portanto, a condição que deverá o CADE avaliar com o fim de decidir pela aplicação ou não da penalidade do
} 
8.2 e 40 do TRIPS que, como vimos, constituem as condicionantes para a imposição de medidas objetivando coibir abusos ou práticas restritivas a partir da exploração de direitos de propriedade intelectual.

Ademais, conforme se observa na linguagem utilizada no inciso IV, “a”, do art. 38, cabe ao Tribunal Administrativo do CADE tão somente recomendar aos órgãos públicos competentes para que seja concedida a licença compulsória como forma de remediar uma conduta anticoncorrencial. A autoridade antitruste não possui, portanto, competência para aplicar essa penalidade, mas apenas para recomendar sua efetivação ao órgão público que possui competência para tanto. E o órgão público competente para a efetivação do licenciamento compulsório é o INPI, em conformidade com o procedimento previsto no art. 73 da Lei de Propriedade Industrial. ${ }^{725}$

Por outro lado, enquanto a Lei Antitruste prevê a possibilidade de licenciamento compulsório de quaisquer direitos de propriedade intelectual, a Lei de Propriedade Industrial prevê essa possibilidade apenas para as patentes. Na ausência de previsão expressa de licença compulsória para outros direitos de propriedade industrial, tais como desenhos industriais, marcas e indicações geográficas, a penalidade prevista no art. 38, IV, "a" da Lei Antitruste poderá ter sua eficácia limitada na hipótese de a infração em questão ser relacionada com algum desses direitos. Da mesma forma, não há previsão legal de licenciamento compulsório, quer na Lei de Direitos Autorais, quer na Lei do

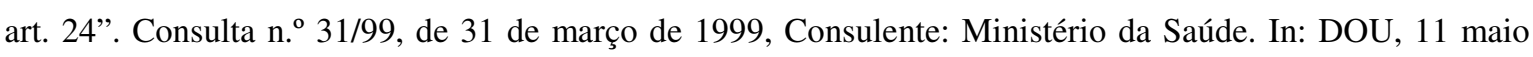
1999.

725 “Art. 73. O pedido de licença compulsória deverá ser formulado mediante indicação das condições oferecidas ao titular da patente.

$\S 1^{\circ}$ Apresentado o pedido de licença, o titular será intimado para manifestar-se no prazo de 60 (sessenta) dias, findo o qual, sem manifestação do titular, será considerada aceita a proposta nas condições oferecidas.

$\S 2^{\circ} \mathrm{O}$ requerente de licença que invocar abuso de direitos patentários ou abuso de poder econômico deverá juntar documentação que o comprove.

$\S 3^{\circ}$ No caso de a licença compulsória ser requerida com fundamento na falta de exploração, caberá ao titular da patente comprovar a exploração.

$\S 4^{\circ}$ Havendo contestação, o INPI poderá realizar as necessárias diligências, bem como designar comissão, que poderá incluir especialistas não integrantes dos quadros da autarquia, visando arbitrar a remuneração que será paga ao titular.

$\S 5^{\circ}$ Os órgãos e entidades da administração pública direta ou indireta, federal, estadual e municipal, prestarão ao INPI as informações solicitadas com o objetivo de subsidiar o arbitramento da remuneração.

$\S 6^{\circ}$ No arbitramento da remuneração, serão consideradas as circunstâncias de cada caso, levando-se em conta, obrigatoriamente, o valor econômico da licença concedida.

$\S 7^{\circ}$ Instruído o processo, o INPI decidirá sobre a concessão e condições da licença compulsória no prazo de 60 (sessenta) dias.

$\S 8^{\circ}$ O recurso da decisão que conceder a licença compulsória não terá efeito suspensivo." 
Software, o que também contribui para reduzir a eficácia da penalidade de licenciamento compulsório, caso a infração esteja relacionada à exploração de direitos autorais ou de software. ${ }^{726}$ Além disso, a proteção de direitos autorais e de software se dá a partir da criação intelectual e independe, portanto, de qualquer registro, não havendo, portanto, órgão público ao qual o Tribunal Administrativo do CADE poderia dirigir sua recomendação em caso de aplicação da penalidade. ${ }^{727}$

A despeito das possíveis limitações à plena eficácia do disposto no art. 38, IV, "a", conforme acima mencionado, é imperioso destacar que a hipótese de licenciamento compulsório de patentes por abuso de direitos ou abuso de poder econômico está bem fundamentada na Lei de Propriedade Industrial. Nos termos do art. 68, "o titular ficará sujeito a ter a patente licenciada compulsoriamente se exercer os direitos dela decorrentes de forma abusiva, ou por meio dela praticar abuso de poder econômico, comprovado nos termos da lei, por decisão administrativa ou judicial". Portanto, o dispositivo prevê o licenciamento compulsório em duas hipóteses, abuso de direito patentes, em linguagem semelhante ao disposto no Artigo 5(A) da Convenção da União de Paris, e abuso de poder econômico a partir da exploração da patente. Nesse último caso, que corresponde à hipótese de licença compulsória prevista no art. 31(k) do Acordo TRIPS, o abuso deve ser comprovado previamente nos termos da Lei Antitruste, por decisão administrativa no âmbito do CADE, ou mesmo por decisão exarada pelo Poder Judiciário. ${ }^{728}$

Já o $\$ 1^{\circ}$ do art. 68 da Lei de Propriedade Industrial prevê o licenciamento compulsório também nas hipóteses de não exploração do objeto da patente, falta de uso integral do processo patenteado, bem como a comercialização que não satisfizer às necessidades do mercado. ${ }^{729}$ A concessão de licença compulsória nesses casos tem como

\footnotetext{
${ }^{726}$ Cf. NETO, Renato Dolabella. A proposta de nova lei de defesa da concorrência e o licenciamento compulsório de direitos de propriedade intelectual. Revista do IBRAC, n. 17, p. 73, jan./jun. 2010.

727 Embora as obras tuteláveis por direitos autorais possam ser registradas na Biblioteca Nacional, esta funciona apenas como órgão registral para quem desejar, no futuro, alegar a anterioridade, já que a proteção independe de registro. Quanto aos softwares, apesar de serem tutelados pelo mesmo regime de proteção conferido às obras literárias pela legislação de direitos autorais, podem ser registrados no INPI, muito embora sua proteção independa de registro.

728 Tendo em vista o controle jurisdicional dos atos administrativos, qualquer decisão do Tribunal Administrativo do CADE impondo licenciamento compulsório de patente como penalidade estará sempre sujeita à revisão judicial.

${ }^{729}$ Nos termos do art. $68, \S 1^{\text {o: }}$ :"Ensejam, igualmente, licença compulsória: I - a não exploração do objeto da patente no território brasileiro por falta de fabricação ou fabricação incompleta do produto, ou, ainda, a falta de uso integral do processo patenteado, ressalvados os casos de inviabilidade econômica, quando será admitida a importação; ou II - a comercialização que não satisfizer às necessidades do mercado. As condicionantes para o licenciamento compulsório em casos de abuso e de não exploração local são as
} 
objetivo assegurar a exploração efetiva da invenção, pelo titular ou por um terceiro licenciado, de modo que a proteção conferida pela patente traga benefícios à sociedade $\mathrm{e}$ não seja utilizada meramente como estratégia defensiva de seu titular ou inibidora de sua utilização adequada, em detrimento de sua função social e do desenvolvimento econômico e tecnológico do país. ${ }^{730}$ Cumpre ressaltar que o disposto no $\S 1^{\circ}$ do art. 68 trata de hipóteses de abuso de direito de patentes, não constituindo, necessariamente, abuso do poder econômico, a não ser que estejam presentes os requisitos contidos no art. 38 da Lei Antitruste para a configuração de uma conduta anticoncorrencial, em especial que o titular da patente detenha poder de mercado suficiente para restringir a concorrência em determinado mercado relevante. ${ }^{731}$

Por fim, é importante destacar que jamais foram concedidas, no Brasil, licenças compulsórias de patentes para remediar práticas que configurem abuso de poder econômico, a teor do art. 68, caput, da Lei de Propriedade Industrial e do art. 24, IV da Lei 8.884/94, derrogada pela atual Lei Antitruste. A ausência de casos práticos de aplicação de licenças compulsórias para remediar a exploração abusiva e anticoncorrencial de direitos de propriedade intelectual, conforme prevista expressamente no art. 31(k) do TRIPS, impossibilita uma análise mais aprofundada desse importante instrumento de política pública.

seguintes: (i) a licença só poderá ser requerida por pessoa com legítimo interesse e que tenha capacidade técnica e econômica para realizar a exploração eficiente do objeto da patente, que deverá destinar-se, predominantemente, ao mercado interno, extinguindo-se nesse caso a excepcionalidade prevista no inciso I do art. 68 (cf. $\$ 2^{\circ}$ ); (ii) no caso de a licença compulsória ser concedida em razão de abuso de poder econômico, ao licenciado, que propõe fabricação local, será garantido o prazo de um ano para proceder à importação do objeto da licença, desde que tenha sido colocado no mercado diretamente pelo titular ou com o seu consentimento (cf. $\S 3^{\circ}$ ); (iii) no caso de importação para exploração de patente e no caso da importação conforme o item anterior, será igualmente admitida a importação por terceiros de produto fabricado de acordo com patente de processo ou de produto, desde que tenha sido colocado no mercado diretamente pelo titular ou com o seu consentimento (cf. $\S 4^{\circ}$ ); (iv) a licença compulsória por falta de exploração local ou exploração insuficiente somente será requerida após decorridos 3 (três) anos da concessão da patente (cf. $\left.\S 5^{\circ}\right)$ ".

${ }^{730}$ MONTEIRO, Renata Pozzato Carneiro. A Função Social da Propriedade na Constituição da República de 1988 e a Propriedade Industrial, in: Revista da ABPI, n. 69, p. 28, mar./abr. 2004.

${ }^{731}$ Importante mencionar, ainda, que a Lei de Propriedade Industrial prevê o licenciamento compulsório de patentes em situações não qualificadas como abuso, tais como no caso dependência de uma patente em relação à outra, a teor do art. 70 da Lei, bem como nas hipóteses previstas no art. 71 - emergência nacional ou interesse público, declarados em ato do Poder Executivo Federal. Vale lembrar que o licenciamento compulsório por emergência nacional ou interesse público tem sido utilizado no âmbito da Política Nacional de AIDS, de modo a conferir maior poder de barganha ao governo brasileiro nas negociações de preços de medicamentos antirretrovirais protegidos por patentes e, assim, possibilitar sua distribuição gratuita e universal aos portadores do HIV. 


\subsection{Análise de casos selecionados julgados pelo CADE}

Conforme já mencionado no início desta Seção, não há uma jurisprudência sólida no Brasil sobre a interface entre propriedade intelectual e concorrência, a maior parte dos casos analisados no âmbito do SBDC dizendo respeito a atos de concentração econômica, tanto no que concerne à cessão de direitos exclusivos no âmbito de operações de fusões e aquisições, como no exame de cláusulas restritivas em acordos de licenciamento e de franquia. ${ }^{732}$ No entanto, veremos que têm sido cada vez mais frequentes os casos de infrações à ordem econômica envolvendo a exploração abusiva de direitos de propriedade intelectual.

O que se percebe da análise dos poucos casos ligados ao tema, é que as autoridades brasileiras de defesa da concorrência parecem estar alinhadas com as autoridades dos EUA e da União Europeia. A verificação da ilicitude de uma prática potencialmente anticoncorrencial nesses casos tem sido sempre baseada em critérios de razoabilidade ("regra da razão"), de modo que as autoridades antitruste brasileiras reconhecem os benefícios da proteção conferida aos direitos de propriedade intelectual para a inovação tecnológica e para a concorrência. Nesse contexto, veremos que os critérios tradicionais de eficiência alocativa (estática) têm dado lugar a uma abordagem mais moderna concentrada na eficiência dinâmica, consubstanciada na proteção dos incentivos à inovação, seguindo a mesma tendência já manifestada nas guidelines norteamericana e europeia.

Analisamos a seguir alguns casos que merecem destaque, envolvendo práticas restritivas em acordos licenciamento e transferência de tecnologia, incluindo pool de patentes, bem como condutas unilaterais de exclusão a partir da exploração de direitos de propriedade intelectual. Embora existam importantes casos atualmente em discussão no âmbito do SBDC, nossa análise será concentrada nos casos já julgados pelo CADE. ${ }^{733}$

\footnotetext{
${ }^{732}$ Em interessante estudo sobre o tema, Denis Borges BARBosA descreve a jurisprudência do CADE envolvendo propriedade intelectual entre 1962 e 2005. Cf. BARBOSA, Denis Borges. Jurisprudência de PI do CADE, 2005. Disponível em: denisbarbosa.addr.com/picade.doc. Acesso em: 25 ago. 2012.

${ }^{733}$ Dentre os casos ainda pendentes, vale mencionar a Averiguação Preliminar n. ${ }^{\circ}$ 08012.002673/2007-51, originada de Representação protocolada pela Associação de Fabricantes de Autopeças - ANFAPE, por meio da qual traz denúncia de suposto abuso de poder econômico por parte das principais montadoras do país, a Ford Motor Company Brasil Ltda., Fiat Automóveis S.A. e Volkswagen do Brasil Indústria de Veículos Automotores Ltda. A alegada conduta seria o abuso de poder econômico decorrente do exercício, por parte das montadoras, de direito de propriedade sobre desenhos industriais de peças de reposição, registrados no INPI. Embora a SDE tenha concluído que a suposta conduta decorria do legítimo exercício de direitos de
} 


\subsubsection{Licenciamento de direitos de propriedade intelectual}

Inicialmente, é importante esclarecer que, no Brasil, os acordos de licenciamento constituem modalidades de "transferência de tecnologia", termo utilizado pelo INPI para designar os seguintes contratos: (i) licença de direitos (exploração de patentes ou de uso de marcas); (ii) aquisição de conhecimentos tecnológicos (fornecimento de tecnologia e prestação de serviços de assistência técnica e científica); e (iii) franquia. ${ }^{734}$ Tais contratos devem ser averbados ou registrados no INPI para produzirem efeitos perante terceiros, conforme o disposto no art. 211 da Lei de Propriedade Industrial e item 2 do Ato Normativo n. ${ }^{\circ} 135 / 1997 .{ }^{735}$

Cumpre ressaltar que o Brasil possui um histórico de intensa intervenção estatal nos contratos de transferência de tecnologia, que teve início a partir de 1945, mas que foi intensificada na década de 1970 com a promulgação do antigo Código de Propriedade Industrial ("Lei n. ${ }^{\text {o }} 5.772 / 71$ "), que atribuiu ao INPI o poder de "adotar medidas capazes de acelerar e regular a transferência de tecnologia e de estabelecer melhores condições de negociação e utilização de patentes". ${ }^{736}$ Com base nesse dispositivo, o INPI passou a implementar uma série de atos normativos que limitavam a autonomia da vontade das partes na negociação de contratos de transferência de tecnologia sujeitos à aprovação e averbação, além de proibirem algumas cláusulas consideradas abusivas. ${ }^{737}$ A mais emblemática dessas normas foi o Ato Normativo n. ${ }^{\circ} 15$, de 11 de setembro de 1975, que autorizava o INPI a restringir os valores de royalties devidos pelo receptor da tecnologia, além de indicar as cláusulas obrigatórias e as cláusulas proibidas

propriedade intelectual, recomendando o arquivamento do caso, o CADE, em sede de recurso de ofício, acabou determinando em 15/12/2010 a instauração de processo administrativo pela SDE com o objetivo de aprofundar as investigações.

${ }^{734}$ Cf. item 2 do Ato Normativo n. ${ }^{\circ}$ 135/1997 do INPI.

735 “Art. 211. O INPI fará o registro dos contratos que impliquem transferência de tecnologia, contratos de franquia e similares para produzirem efeitos em relação a terceiros."

${ }^{736}$ Cf. art. $2^{\circ}$, parágrafo único, da Lei n. ${ }^{\circ} 5.722 / 71$.

${ }^{737}$ Em substancioso estudo sobre o tema, Juliana L. B. VIEGAS explica que: “A política implementada pelo INPI na década de 1970 (e até meados de 1980), com relação à aprovação e averbação desses contratos, refletia nitidamente a política geral do governo federal, no sentido de (a) estimular a substituição de importações mediante a capacitação nacional, isto é, estimular a geração autóctone de tecnologia nacional mediante esforço de pesquisa e desenvolvimento, (b) exigir que a adquirente de tecnologia obtivesse o controle da tecnologia adquirida e (c) regular - e na medida do possível, coibir - as remessas de royalties ou remunerações por fornecimento de tecnologia ao exterior, que eram consideradas 'evasão de divisas"'. VIEGAS, Juliana L. B. Contratos Típicos de Propriedade Industrial: Contratos de Cessão e de Licenciamento de Marcas e Patentes; Licenças Compulsórias, in: PEREIRA DOS SANTOS, Manoel J.; JABUR, Wilson Pinheiro. Contratos de Propriedade Industrial e Novas Tecnologias. São Paulo: Saraiva, 2007 (Série GVlaw), p. 66. 
nesses contratos, seguindo a mesma abordagem intervencionista e desenvolvimentista do já mencionado projeto de Código Internacional de Conduta para a Transferência de Tecnologia no âmbito da UNCTAD, cujas negociações tiveram início em 1976, até serem definitivamente suspensas em meados de $1985 .^{738}$

Dados os resultados negativos dessa política intervencionista, que afugentou investidores estrangeiros e impediu as empresas brasileiras de se beneficiarem de tecnologia de ponta desenvolvida no exterior, o INPI passou a flexibilizar o processo de averbação e registro de contratos de transferência de tecnologia já em meados dos anos 1980, culminando em total liberalização a partir do início dos anos 1990, como consequência da abertura econômica e da maior inserção do país no comércio internacional. ${ }^{739}$ A grande mudança adveio com publicação do Ato Normativo n. ${ }^{\circ}$ 120, de 17 de dezembro de 1993, por meio do qual o INPI passou a averbar e registrar contratos de transferência de tecnologia, sem intervir na liberdade contratual das partes, que passaram a ter autonomia para negociar os termos e cláusulas, sobretudo no que diz respeito ao preço, condições de pagamento, prazos contratuais, limitações de uso dos direitos exclusivos, dentre outros. Essa abordagem liberal foi posteriormente confirmada pela Lei n. ${ }^{\circ}$ 9.279/96, a nova Lei de Propriedade Industrial, que retirou definitivamente o poder do INPI de intervir no mérito dos contratos de transferência de tecnologia. ${ }^{740}$

\footnotetext{
${ }^{738}$ Ao comentar os impactos do Ato Normativo n. ${ }^{\circ}$ 15/75, Luciano Benetti Timm esclarece que: "O Ato Normativo n. ${ }^{\circ} 15$ continha disposição autorizando a rejeição de formulários de registro para os contratos que apresentassem quaisquer das aludidas cláusulas ilegais. Em consequência disso, cláusulas que, de acordo com a interpretação dada pelo Inpi, fossem consideradas contra as disposições do citado ato normativo, deveriam ser consideradas nulas e ineficazes, dando margem à negativa do registro do contrato. $\mathrm{O}$ escopo disso era proteger e aprimorar a tecnologia local. Essas regras foram criadas na tentativa de fortalecer o poder de barganha dos adquirentes domésticos de tecnologia. O governo acreditou que os mercados internacionais de tecnologia eram altamente imperfeitos, o que capacitava os fornecedores a obter larga vantagem sobre as companhias nacionais menores, em razão da grande lacuna tecnológica existente. Era uma maneira de, da mesma forma, proteger a balança de pagamentos do país de destino. O objetivo era, também, fornecer informação, de modo a equilibrar a relação entre exportadores e importadores, e aperfeiçoar a qualidade e a assimilação da tecnologia transferida, estimulando, assim, a inovação local”. TIMM, Luciano Benetti. Contrato internacional de transferência de tecnologia no Brasil: interseção da propriedade intelectual com o direito antitruste, in: TIMM, Luciano Benetti; PARANAGUÁ, Pedro. Propriedade Intelectual, Antitruste e Desenvolvimento: caso da transferência de tecnologia e do software. Rio de Janeiro: FGV Direito Rio, 2009, p. 80.

${ }^{739}$ A Resolução n. ${ }^{\circ}$ 22/1991 emitida pelo INPI deu início ao processo de liberalização, cancelando o Ato Normativo n. ${ }^{\circ}$ 15/1975, assim como outros atos normativos de caráter restritivo, e simplificando os procedimentos de averbação e registro.

${ }^{740}$ Cf. TIMM, Luciano Benetti. Contrato internacional de transferência de tecnologia no Brasil: interseção da propriedade intelectual com o direito antitruste, in: TIMM, Luciano Benetti; PARANAGUÁ, Pedro. Propriedade Intelectual, Antitruste e Desenvolvimento: caso da transferência de tecnologia e do software. Rio de Janeiro: FGV Direito Rio, 2009, p. 81.
} 
Sob a égide da Lei de Propriedade Industrial, o INPI aprovou o Ato Normativo

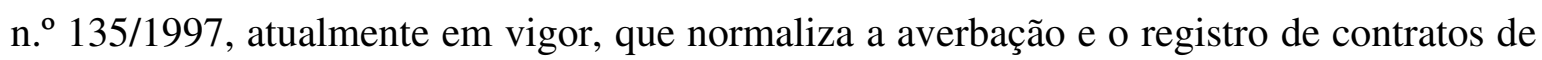
transferência de tecnologia e franquia. De acordo com VIEGAS, muito embora esse ato normativo não estabeleça qualquer intervenção na liberdade contratual das partes, permite ao INPI o retorno ao passado intervencionista ao estabelecer que este órgão deverá proceder à averbação e registro de contratos de transferência de tecnologia, na forma da Lei de Propriedade Industrial, e de outras leis, entre elas a então vigente Lei n. ${ }^{\circ}$ 8.884/94 (que foi recentemente revogada pela nova Lei Antitruste). ${ }^{741}$

A despeito da referência à legislação de defesa da concorrência no Ato Normativo n. ${ }^{\circ}$ 135/1997, o INPI não possui competência para recusar a averbação ou registro de contratos de transferência de tecnologia que contenham cláusulas potencialmente lesivas à concorrência. Nos termos do art. $2^{\circ}$ da Lei n. ${ }^{\circ}$ 5.648/70, com redação alterada pelo art. 240 da Lei de Propriedade Industrial, "o INPI tem por finalidade principal executar, no âmbito nacional, as normas que regulam a propriedade industrial, tendo em vista a sua função social, econômica, jurídica e técnica, bem como pronunciar-se quanto à conveniência de assinatura, ratificação e denúncia de convenções, tratados, convênios e acordos sobre propriedade industrial'. Nota-se, portanto, que não cabe ao INPI analisar aspectos concorrenciais de contratos de transferência de tecnologia. Essa atribuição é exclusiva dos órgãos brasileiros de defesa da concorrência, nos termos da Lei Antitruste, seja no que concerne à sua atuação preventiva na análise de atos de concentração econômica, seja por meio de sua atuação repressiva na investigação de condutas anticoncorrenciais. $^{742}$

Essa abordagem liberal que passou a prevalecer a partir do início dos anos 1990 também se estendeu ao controle antitruste de contratos de licenciamento e transferência de tecnologia pelos órgãos de defesa da concorrência. Não havia na Lei 8.884/94 (assim como não há na Lei Antitruste vigente) qualquer indicação de cláusulas contratuais que devessem ser consideradas ilícitas per se. Afinal, sob a perspectiva

741 VIEGAS, Juliana L. B. Contratos Típicos de Propriedade Industrial: Contratos de Cessão e de Licenciamento de Marcas e Patentes; Licenças Compulsórias, in: PEREIRA DOS SANTOS, Manoel J.; JABUR, Wilson Pinheiro. Contratos de Propriedade Industrial e Novas Tecnologias. São Paulo: Saraiva, 2007 (Série GVlaw), p. 73.

742 Nesse sentido, de acordo com BRANCHER: “Ao INPI compete executar as normas que regulam a propriedade industrial, mas nada além. Não cabe ao órgão estender tal competência para dispor sobre aspectos concorrenciais em relação aos contratos privados que analisa". BRANCHER, Paulo. Direito da 
antitruste, é certo que os acordos de licenciamento são benéficos à concorrência, uma vez que conduzem à difusão de tecnologias e promoção da inovação, possibilitando a integração de tecnologias complementares para o desenvolvimento de novos produtos em benefício dos consumidores. Mesmo os acordos de licença que contenham cláusulas restritivas podem resultar em ganhos de eficiência dinâmicas e estáticas favoráveis à concorrência, devendo sempre ser analisadas com base em critérios de razoabilidade, já que seus eventuais efeitos negativos podem vir a ser compensados por efeitos positivos.

Discussões sobre cláusulas restritivas em acordos de licenciamento e transferência de tecnologia já foram tratadas pelo CADE em diversos casos envolvendo mercados de biotecnologia. No ato de concentração envolvendo a Monsanto do Brasil Ltda. e a Syngenta Seeds Ltda., por exemplo, o CADE analisou o acordo de licenciamento firmado entre essas duas empresas, que continha cláusula de exclusividade proibindo a Syngenta de produzir e comercializar sementes de soja com tolerância ao glifosato que não contivessem a tecnologia desenvolvida pela Monsanto. ${ }^{743}$ Em seu voto condutor, o Conselheiro Abraham SICSÚ concluiu que a referida restrição não produziria efeitos anticoncorrenciais no mercado do produto (sementes), mas sim no mercado de inovação (pesquisa e desenvolvimento). Nesse sentido, o Conselheiro então afirmou o seguinte:

As análises antitruste devem focar-se então no conceito de mercados de inovação (innovation markets), o qual foi desenvolvido para lidar com questões antitruste focadas em $\mathrm{P} \& \mathrm{D}$, na qual a definição de produto não era aplicável. A discussão antitruste se desloca da capacidade de as empresas manipularem preço para o incentivo do monopolista hipotético de retardar o andamento de pesquisa e desenvolvimento e assim deixar de difundir o avanço tecnológico. ${ }^{744}$

Ao analisar o caso com base na regra da razão, o Conselheiro Sicsú afirmou que operações envolvendo licenciamento de tecnologia ao desenvolvimento, produção e comercialização de sementes, em geral, não têm o condão de gerar danos à concorrência, uma vez que possibilitam a uma empresa ter acesso à "tecnologia-chave" para a produção de produto (sementes), o que não seria possível dada a existência de monopólio dessa

Concorrência e Propriedade Intelectual: Da Inovação Tecnológica ao Abuso de Poder. São Paulo: Singular, 2010, p. 237.

${ }^{743}$ Ato de Concentração n. ${ }^{\circ}$ 08012.000311/2007-26.

${ }^{744}$ Ato de Concentração n. ${ }^{\circ}$ 08012.000311/2007-26. Voto-vogal do Conselheiro Abraham Sicsú, p. 03. 
tecnologia por parte de outra empresa atuante no mercado. O Conselheiro acrescentou, então, que "o pleno benefício social da tecnologia se dá por sua difusão". 745

Após estabelecer essa importante premissa, Sicsú afirmou que cláusulas de exclusividade em acordos de licenciamento poderiam levantar duas preocupações. A primeira seria a possibilidade de ocorrência de fechamento progressivo do mercado de tecnologia para sementes de soja resistentes ao glifosato, ocasionada pela vinculação de exclusividade no fornecimento de inovação. Essas obrigações de exclusividade poderiam tornar os licenciados dependentes de apenas uma tecnologia, já que estariam impedidos de ter acesso a tecnologias alternativas que, com o tempo, poderiam vir a ser mais eficientes. A segunda preocupação, que também foi apontada no Voto do Relator, seria o fato de que essas cláusulas poderiam permitir à Monsanto estender o poder de mercado detido na produção de soja geneticamente modificada resistente ao glifosato (resultante do monopólio viabilizado por sua patente) ao segmento de produção de herbicidas à base de glifosato. No entanto, o Conselheiro ressaltou que não havia nenhuma cláusula no acordo que fundamentasse essa última preocupação. Assim, o único risco levado em consideração foi o da exclusividade, razão pela qual o ato de concentração foi aprovado com a restrição de exclusão de referida cláusula, de modo a possibilitar que a licenciada não fosse impedida de produzir ou comercializar sementes utilizando-se de tecnologias alternativas.

Questão semelhante foi analisada no ato de concentração entre Monsanto e Brasmax Genética Ltda., no qual o CADE analisou cláusulas restritivas constantes do acordo comercial celebrado entre as duas empresas, que estabelecia os termos e condições para que a Brasmax explorasse comercialmente a tecnologia da Monsanto no Brasil, mediante a produção e comercialização de sementes próprias a partir dessa tecnologia. ${ }^{746}$ Para tanto, a Monsanto concedeu à Brasmax licença não exclusiva e intransferível para utilização da tecnologia, além do know-how necessário para o desenvolvimento de cultivares a partir dessa tecnologia e a respectiva produção de sementes, incluindo as inovações e aperfeiçoamentos porventura desenvolvidos. Enquanto a Monsanto atuava fundamentalmente no mercado relevante de desenvolvimento da tecnologia, a Brasmax operava em mercados verticalmente relacionados, concernentes à incorporação da

\footnotetext{
${ }^{745}$ Ibid., p. 04.

${ }^{746}$ Ato de Concentração n. ${ }^{\circ}$ 08012.003296/2007-78.
} 
tecnologia às diferentes variedades de soja existentes (melhoramentos), multiplicação e comercialização de sementes. ${ }^{747}$

Assim como em outros casos semelhantes, o problema era a exclusividade no mercado da tecnologia licenciada. Uma das cláusulas impedia que a Brasmax explorasse comercialmente variedades de soja tolerantes ao glifosato que não tivessem sido obtidas a partir da tecnologia desenvolvida pela Monsanto. Além disso, a Brasmax também não poderia introduzir nos cultivares desenvolvidos a partir da tecnologia Monsanto qualquer outra tecnologia alternativa sem a prévia concordância da licenciante. Uma segunda cláusula considerada problemática autorizava a Monsanto a deixar de licenciar sua tecnologia, ou rescindir o contrato, caso a Brasmax produzisse ou comercializasse sementes de soja com tolerância ao glifosato que não contivessem a tecnologia licenciada. A preocupação era com os efeitos de fechamento progressivo do mercado de melhoramento de sementes de soja resistentes ao glifosato. Em consequência, ponderou o Conselheiro Relator, os detentores brasileiros de banco de germoplasma ficariam vinculados apenas ao produto da Monsanto, impedindo a entrada de outros agentes econômicos nos mercados de biotecnologia.

Contudo, por razões técnicas, admitiu-se, nesse caso, que a licenciada fosse proibida de introduzir nos cultivares desenvolvidos com a tecnologia da Monsanto outras tecnologias que não a da licenciante, sobretudo para evitar a polinização não controlada das sementes, o que poderia trazer impactos ambientais não planejados, resultantes da miscigenação de tecnologias. Como a polinização e o possível cruzamento não controlado de variedades transgênicas ocorrem somente quando são desenvolvidos os produtos no mesmo campo experimental, foi determinada alteração da cláusula para fazer constar a ressalva de que essa vedação não impede a licenciada de pesquisar, desenvolver, produzir e comercializar sementes de soja tolerantes ao glifosato com tecnologias outras que não aquela desenvolvida pela Monsanto. ${ }^{748}$

\footnotetext{
${ }^{747}$ Conforme se observa no Voto do ConselheiroRelator, o processo produtivo das sementes de soja com essa tecnologia se compõe das seguintes etapas: (i) desenvolvimento da tecnologia; (ii) incorporação da tecnologia às diferentes variedades de soja existentes (melhoramentos); (iii) multiplicação de sementes e (iv) comercialização de sementes. Enquanto a Monsanto atuava no mercado do desenvolvimento da tecnologia, englobando o licenciamento de patentes e know-how necessários ao desenvolvimento de linhagens e cultivares de soja tolerantes ao glifosato, a Brasmax operava nos segmentos de melhoramentos, multiplicação de sementes e comercialização. Havia, portanto, relação vertical entre as partes.

${ }^{748}$ Ato de Concentração n. ${ }^{\circ}$ 08012.003296/2007-78. Voto do relator, p. 04.
} 
A outra cláusula problemática também foi alterada com vistas a eliminar a possibilidade de fechamento do mercado de melhoramento de sementes de soja resistentes ao glifosato. Assim, a Monsanto somente poderia deixar de licenciar sua tecnologia, ou rescindir o contrato, nas seguintes hipóteses: (i) se o licenciado produzisse e/ou comercializasse sementes de soja tolerantes ao glifosato que não contivessem sua tecnologia sem a comprovação de que a instalação e gestão dos campos experimentais de melhoramento, multiplicação e produção, bem como a embalagem, armazenamento e comercialização de tais sementes seriam realizados de forma segregada, separada e diferenciada dos procedimentos relativos às sementes com a tecnologia Monsanto; ou (ii) quando demonstrasse que não possuía viabilidade técnica e/ou econômica para realizar tal segregação. ${ }^{749}$ Desse modo, o CADE aprovou o ato de concentração, com a restrição de modificação das cláusulas, nos termos acima mencionados. Ressalte-se que essas alterações possibilitaram a redução do possível dano ambiental que as cláusulas originais visavam impedir, além de evitarem o fechamento do mercado provocado pela exclusividade.

Discussão interessante também ocorreu no ato de concentração n. ${ }^{\circ}$ 08012.008810/2009-23, que tratou de operação de constituição de um pool de patentes entre as empresas Sony, Philips, Panasonic, Hitachi, Samsung e Cyberlink e da aquisição de participações societárias em futura companhia de licenciamento mundial de patentes essenciais para a fabricação de produtos de Blu-ray Disc com padrões compatíveis. O objetivo dessas empresas era a criação de pool de patentes essenciais para leitura e reprodução de discos Blu-ray, bem como dos formatos DVD e CD em aparelhos de Bluray, oferecendo um pacote básico de licenças em forma de produto.

Vimos na Seção anterior que os pools de patentes são comuns no contexto da cooperação entre agentes econômicos para a padronização tecnológica, possibilitando a integração entre tecnologias complementares, muitas vezes protegidas por patentes de bloqueio detidas por diferentes empresas. Uma vez que essas patentes são transferidas para um pool, quaisquer terceiros interessados em aplicar o padrão tecnológico na fabricação de produtos ou no desenvolvimento de tecnologias complementares poderão ter acesso a um pacote de licenças único contendo as patentes essenciais para a fabricação de produtos com a tecnologia padronizada.

${ }^{749}$ Id., ibid. 
O ato de concentração em comento envolveu exatamente essa questão, já que o pool seria administrado por uma empresa independente - a Companhia de Licenciamento , que teria a responsabilidade de impedir a troca de informações confidenciais entre os membros do pool e de ofertar o pacote de licenças a possíveis interessados, sem qualquer discriminação. Muito embora todas as empresas participantes concorressem no mercado de aparelhos de reprodução e/ou gravação de Blu-ray, o mercado relevante da operação foi definido como o de serviços de licenciamento de pool de patentes, estando aquele à jusante deste. Ademais, o pool seria limitado às patentes essenciais, não havendo qualquer sobreposição horizontal, de modo que os licenciantes permaneceriam livres para licenciar suas patentes essenciais de forma independente do pool, inclusive para usos fora do formato Blu-ray.

Ao analisar a operação, o Conselheiro Relator citou as disposições relevantes das "Diretrizes Antitruste para o Licenciamento de Propriedade Intelectual", elaboradas pelo DOJ e pela FTC, que tratam de licenciamento cruzado e pool de patentes. Nesse sentido, mencionou os benefícios do pool de patentes para a dinâmica concorrencial, desde que reduza custos de transação, resulte em economia de escala, desobstrua patentes de bloqueio, evite custos judiciais, promova a disseminação da tecnologia, não interfira na concorrência dos mercados relevantes envolvidos, não constitua um acordo fechado e/ou exclusivo, e que estimule a pesquisa e o desenvolvimento, evitando prejuízos à inovação. $^{750}$

Em seguida, o Conselheiro Relator concluiu que o ato de concentração sob análise atendia a todas essas recomendações do Guia americano, já que:

Como visto, o pool (i) não gera sobreposição horizontal, já que receberá apenas patentes válidas e essenciais, ou seja, complementares, (ii) não afeta a inovação, já que engloba apenas patentes essenciais, ou seja, sem substitutos, considerando ainda que as licenciadoras terão acesso a tecnologias concorrentes, produtos concorrentes em desenvolvimento, inclusive podendo participar desse desenvolvimento, (iii) não diminui a concorrência nos mercados finais, haja vista que promove o acesso às patentes essenciais, ao invés de limitá-lo, impõe o licenciamento não discriminatório e impede o acesso e a troca de informações

${ }^{750}$ Ato de Concentração n. ${ }^{\circ}$ 08012.008810/2009-23. Voto do relator, p. 07. 
concorrencialmente sensíveis e (iv) exige baixos investimentos na presente operação e (v) impede que qualquer dos sócios do pool influencie nas suas decisões mercadológicas.

Em vista de seus efeitos pró-competitivos, o ato de concentração foi aprovado sem qualquer restrição. Esse caso é mais um exemplo da grande influência do direito antitruste norte-americano na formação da convicção das autoridades brasileiras de defesa da concorrência. Muito embora não existam no Brasil diretrizes semelhantes àquelas publicadas pelas autoridades antitruste norte-americanas e europeias, esses guias de análise estrangeiros são muitas vezes citados em casos julgados pelo CADE, como ocorreu no ato de concentração em comento.

Em conclusão, é possível constatar que o CADE utiliza uma abordagem muito semelhante à das autoridades de defesa da concorrência dos Estados Unidos e da União Europeia na análise antitruste de acordos de licenciamento e transferência de tecnologia, valendo-se de critérios de razoabilidade e proporcionalidade, de modo a intervir o mínimo necessário, quando for o caso, para salvaguardar a concorrência, sem prejudicar os incentivos à inovação dos agentes econômicos detentores de direitos de propriedade intelectual e tecnologias. ${ }^{751}$ Sob esse prisma, é certo que a abordagem adotada pelo CADE também está em plena convergência com os deveres de consistência e proporcionalidade contidos nos Artigos 8.2 e 40.2 do Acordo TRIPS.

\subsubsection{Condutas unilaterais de exclusão na exploração de direitos de propriedade intelectual}

Na Seção 3, ao tratamos das condutas unilaterais de exclusão, afirmamos que um dos maiores desafios das autoridades antitruste é distinguir de forma precisa condutas legítimas baseadas na concorrência por méritos, ainda que resultem na exclusão de alguns rivais do mercado, e condutas abusivas de exclusão, cuja finalidade ou efeito é meramente a eliminação da concorrência. Essas dificuldades são ainda maiores quando esses comportamentos envolvem direitos de propriedade intelectual, já que o direito de excluir constitui elemento essencial do sistema de propriedade intelectual, permitindo que seu titular impeça terceiros de explorar, sem sua autorização, os bens intelectuais protegidos.

\footnotetext{
${ }^{751}$ Cf. CUEVA, Ricardo Villas Bôas. A Proteção da Propriedade Intelectual e a Defesa da Concorrência nas Decisões do CADE, in: Revista do IBRAC, v. 16, n. 1, p. 140, 2009.
} 
Vimos que os casos mais complexos envolvem a aplicação das normas antitruste de modo a intervir nas prerrogativas mais fundamentais do titular de direitos de propriedade intelectual, como o direito de recusar o licenciamento de direitos de propriedade intelectual, de estabelecer unilateralmente o valor de royalties a serem cobrados e o direito de adquirir e impor tais direitos contra terceiros que vierem a utilizálos sem autorização. Qualquer intervenção antitruste exagerada ou desmedida pode ser prejudicial ao esquema de incentivos estabelecido pelo sistema de propriedade intelectual, afetando adversamente a inovação, a concorrência e o bem-estar dos consumidores.

É por essa razão que as autoridades antitruste e os tribunais norte-americanos e europeus costumam ser cautelosos para evitar os riscos de condenações equivocadas de condutas que beneficiam a concorrência dinâmica e os consumidores, ainda que tenham a aparência de condutas anticoncorrenciais. Os órgãos brasileiros de defesa da concorrência parecem adotar essa mesma abordagem cautelosa, conforme se pode observar nos casos analisados a seguir, que demonstram claramente as preocupações do CADE em evitar intervenções desmedidas e desarrazoadas, sem deixar de punir aquelas condutas de exclusão que são comprovadamente ilegítimas e prejudiciais à concorrência.

\subsubsection{O caso Philips - DVD}

Um caso que envolveu interessante discussão sobre exploração abusiva de direitos de propriedade intelectual foi a Averiguação Preliminar n. ${ }^{\circ}$ 08012.001315/2007-21 instaurada pela SDE para apurar denúncia apresentada pelas empresas Gradiente Eletrônica S.A. (Gradiente) e Cemaz Indústria Eletrônica da Amazônia (CCE). De acordo com essas empresas, as Representadas, quais sejam, Koninklijke Philips Eletronics N.V. (Philips) e Philips do Brasil Ltda. (Philips do Brasil), estariam praticando infração à ordem econômica nos mercados verticalmente relacionados de tecnologia para a produção de hardware leitor e reprodutor de digital video discs (DVD), e de aparelhos de DVD, com o intuito de alavancar, por meio da exclusão de rivais, sua participação no mercado à jusante nas cadeias de produção e comercialização dos referidos aparelhos.

Dentre as condutas que foram imputadas às Representadas, incluem-se: (i) abuso de posição dominante mediante a imposição de propriedade intelectual contra clientes, fornecedores, distribuidores de aparelhos de DVD fabricados pela Gradiente e CCE; (ii) inclusão, no pool de patentes, de tecnologias que não seriam de sua titularidade; 
(iii) cobrança de royalties excessivos e em duplicidade pelo licenciamento de suas tecnologias; (iv) dificultar acesso a uma infraestrutura essencial; e (v) discriminação de produtores de alguns países da América do Sul, como as Representantes, uma vez que as Representadas sequer depositaram suas patentes em todos os países da região.

Ao longo do processo, constatou-se que a tecnologia de leitura e reprodução de DVD engloba trinta e nove invenções, dezoito das quais protegidas por patentes concedidas pelo INPI. As empresas titulares dos direitos patentários estavam reunidas em dois pools, denominados Grupos 3C e 6C, responsáveis por licenciar conjuntos distintos e complementares de tecnologias, mediante o pagamento de royalties, sendo necessário obter licenças referentes às patentes de ambos os grupos para a fabricação de aparelhos de DVD. ${ }^{752}$ As Representadas estavam incluídas apenas no Grupo $3 \mathrm{C}$, cabendo à Philips do Brasil, como representante do pool, negociar os contratos de licenciamento das respectivas tecnologias no território nacional. Ademais, importante ressaltar que os pacotes de licenças ofertados pelo pool não eram exclusivos, o que significa que as patentes poderiam ser licenciadas de forma individual, por cada um dos seus respectivos titulares, a critério do interessado em obter as licenças.

Após concluir a investigação da denúncia em sede de averiguação preliminar, a SDE atestou que não foram confirmados os indícios de infração à ordem econômica presentes na instauração do procedimento administrativo, razão pela qual recomendou ao CADE seu arquivamento. Ao analisar o caso, em voto proferido na sessão pública de julgamento de 13 de maio de 2009, o Conselheiro Relator, Olavo Zago CHINAGLIA, atestou

\footnotetext{
752 O parecer econômico intitulado "Concorrência no Mercado de Equipamentos Leitores de DVD", que instruiu os autos, narra como se deu o desenvolvimento dessas tecnologias e como foram formados esses dois grupos: "No início da década de 90, dois tipos de discos ópticos de alta capacidade estavam em desenvolvimento: o MultiMedia Compact Disc (MMCD), da Philips e Sony, e o Super Density Disc (SD), da Toshiba, Time-Warner, Matsushita Electric, Hitachi, Mitsubishi, Pioneer, Thomson e JVC. Antecipando a repetição dos problemas ocorridos na década de $80 \mathrm{com}$ os videocassetes formatos VHS e Betamax, as empresas procuraram unificar os dois sistemas. Dessa forma, em 1996 a Panasonic, Toshiba, Mitsubishi, AOL, JVC, Hitachi, Thomson, Philips, Sony e Pioneer reuniram-se e formaram o 'Consórcio DVD', para desenvolver especificações técnicas para a fabricação de equipamentos capazes de realizar a leitura de discos ópticos e converter suas informações em imagens acompanhadas de áudio. Assim, o formato MMCD foi abandonado pela Philips e Sony, que adotaram o formato da Toshiba com duas modificações da tecnologia escolhida. A primeira foi a capacidade de pular faixas, tecnologia desenvolvida pela Philips/Sony. A segunda foi a adoção do sistema Philips EFMPlus que apresentava grande resistência a intempéries, apesar da capacidade ligeiramente inferior ao sistema SD. Tais especificações técnicas deram origem ao aparelho DVD. Em 1997, o Consórcio DVD tornou-se Fórum DVD, aberto a todas as companhias. Existem dois acordos horizontais que caracterizam 'pool' de patentes. Grupo 3C e Grupo C, que certificaram e licenciaram diferentes patentes essenciais do DVD. Em 1998, formou-se o Grupo 3C (Philips, Sony e Pioneer) para licenciamento do conjunto de patentes relacionados à tecnologia DVD da titularidade das três empresas. Em
} 
que as Representadas são detentoras de posição dominante no mercado à montante de tecnologia para produção de DVDs e que haveria condições estruturais para adoção de condutas anticompetitivas verticais, com o objetivo de alavancar sua posição dominante para o mercado à jusante de produção e comercialização dos aparelhos. No entanto, constatou a inexistência de elementos suficientes que permitissem concluir que as condutas investigadas prejudicavam a concorrência.

Em seguida, o relator ressaltou que todas as condutas alegadas tinham em comum a lógica de exclusão dos rivais, ou pelo menos de criação de dificuldades ao seu funcionamento, de modo a mitigar as pressões competitivas que esses concorrentes poderiam exercer no mercado de fabricação e comercialização de aparelhos de DVD. A questão central da denúncia tratava, basicamente, da suposta imposição indevida de direitos de propriedade intelectual, como resultado da inclusão de patentes não essenciais no pacote de licenças ofertado pelo pool, ou mesmo em razão da alegada invalidade desses direitos exclusivos, bem como do possível abuso na cobrança de royalties cobrados pelos titulares das patentes, o que poderia resultar no aumento dos custos dos rivais a ponto de impossibilitar que concorressem de forma efetiva no mercado. Nesse sentido, o relator afirmou que:

Tal conduta seria manifestada não apenas nos valores "abusivos" dos royalties, mas também na sua cobrança "em duplicidade", na discriminação de preços entre diferentes concorrentes e, ainda, na adoção de medidas visando à proteção ilegítima de direitos de propriedade intelectual, seja porque não seriam essenciais à produção dos aparelhos reprodutores de DVDs - e, desse modo, estavam sendo indevidamente incluídos no pool de patentes licenciadas -, seja porque teriam sido concedidos em violação aos preceitos legais que regem a matéria. ${ }^{753}$

Com relação à suposta invalidade das patentes ou imposição indevida de direitos de propriedade intelectual, o Conselheiro Relator confirmou entendimentos anteriores manifestados pelo $\mathrm{CADE}$ no sentido de que não possui competência para invalidar um direito de propriedade intelectual, de modo que, na ausência de decisão administrativa ou judicial tomada por autoridade competente, o exercício de tais direitos 
pode se dar de forma plena, o que inclui sua oposição contra terceiros mediante a adoção das medidas legais cabíveis, tais como envio de correspondências e notificações, propositura de ações judiciais, dentre outras. ${ }^{754}$ Além disso, o relator constatou que os documentos juntados pelas Representadas evidenciam que a autoridade antitruste norteamericana, DOJ, ao analisar a operação notificada nos Estados Unidos, concluiu que todas as patentes incluídas no pool eram, de fato, essenciais, ou seja, necessárias para o cumprimento dos padrões tecnológicos do DVD. ${ }^{755}$

E se os direitos de propriedade intelectual são, em princípio, válidos e essenciais para a fabricação dos aparelhos de DVD, seus titulares têm a prerrogativa básica e fundamental de fixar o valor a ser pago a título de royalties em contrapartida ao licenciamento, não havendo que se falar em abuso nessa cobrança, a não ser que o acesso ao direito exclusivo fosse indispensável para o funcionamento de toda a cadeia de produção. ${ }^{756}$ No caso em discussão, é inegável que o acesso às patentes essenciais disponíveis no pool pode ser considerado indispensável para a fabricação de aparelhos de DVD no mercado a jusante, de modo que a eventual recusa de licenciamento poderia ter o condão de prejudicar a concorrência. No entanto, conforme ressaltado pelo relator, o caso não tratava de recusa de licenciar, não havendo qualquer evidência de que os preços

${ }^{753}$ Averiguação Preliminar n. ${ }^{\circ}$ 08012.001315/2007-21. Voto do Relator, Conselheiro Olavo Zago Chinaglia, p. 10.

754 As Representadas foram acusadas de terem abusado de sua posição dominante ao abordar, por meio de correspondência, clientes, distribuidores, fornecedores e revendedores dos aparelhos comercializados pelas Representantes, inibindo novas compras de aparelhos das marcas Gradiente e CCE. O relator constatou que as correspondências juntadas nos autos continham apenas a informação de que a comercialização de aparelhos de DVD sem a comprovação do prévio pagamento de royalties por parte dos fabricantes poderia ensejar medidas legais cabíveis, o que é absolutamente compatível com as disposições que regem a matéria, em especial o art. 42 da Lei de Propriedade Industrial, e com os princípios que regem a legislação processual civil. Para o relator, os contatos feitos pela Philips estão dentro do rol dos direitos de que dispõem os titulares de direitos de propriedade intelectual para resguardá-los. Medidas preventivas de resguardo desses direitos são fundamentais para que exista alguma eficácia na proteção do conhecimento, das marcas envolvidas, seja qual for o objeto sobre o qual recaia o direito de propriedade intelectual.

${ }^{755} \mathrm{O}$ relator acrescentou que o valor dos royalties contratados entre Representantes e Representadas era fixo e independia da quantidade de patentes disponíveis no pool. Desse modo, ainda que se admitisse que havia patentes não essenciais incluídas no pool, seria bastante limitado o espaço para intervenção das autoridades antitruste, pois as Representadas poderiam, simplesmente, elevar o preço para licenciar as patentes remanescentes (e efetivamente indispensáveis para a fabricação dos aparelhos de DVD).

${ }^{756}$ De acordo com o Conselheiro Relator: "De fato, dentre todas as prerrogativas de que gozam os titulares de direitos de propriedade intelectual, a principal é, indubitavelmente, a de fixar o montante a ser pago pelas respectivas licenças, sendo certo, ademais, que até mesmo o preço infinito - expressão econômica da recusa de venda - estaria, em princípio, amparado pela legislação específica. Em termos prosaicos, o titular de direitos de propriedade intelectual cobra o quanto quiser de terceiros que pretendam utilizá-los em sua própria atividade, a não ser que se trate de uma situação muito específica, em que o acesso a este conhecimento ou este insumo se revele indispensável para o funcionamento de toda a cadeia de produção". Averiguação Preliminar n. ${ }^{\circ}$ 08012.001315/2007-21. Voto do Relator, Conselheiro Olavo Zago Chinaglia, p. 14. 
cobrados a título de royalties fossem capazes de impedir o acesso dos concorrentes às tecnologias patenteadas.

Ao concluir seu raciocínio, o Conselheiro Relator ponderou que o eventual licenciamento compulsório seria, em qualquer hipótese, medida extrema a ser sopesada com os próprios princípios que justificam a proteção dos direitos de propriedade intelectual:

Se a Constituição Federal e a lei conferem o direito temporário de uso exclusivo de determinada tecnologia ao seu inventor, como forma de incentivo à pesquisa e ao desenvolvimento tecnológico; e se (...) tal proteção exerce uma função social de estímulo à competição via diferenciação, real ou percebida, a intervenção da autoridade antitruste no sentido de limitar esse direito seria, no mínimo, bastante questionável. ${ }^{757}$

Finalmente, na ausência de comprovação dos supostos indícios de infração à ordem econômica, o CADE determinou o arquivamento em definitivo da Averiguação Preliminar. Esse caso demonstra que o CADE adota extrema cautela para evitar que a intervenção antitruste venha a prejudicar a conquista de poder de mercado dentro das regras de mercado, como é o caso do legítimo exercício de direitos de propriedade intelectual. Como se pode observar, essa abordagem é muito similar àquela adotada pelos tribunais norte-americanos, no sentido de preservar a concorrência por méritos e evitar os riscos de condenação de práticas comerciais legítimas que favorecem a concorrência dinâmica.

\subsubsection{2. $\quad$ O caso Box 3 (Shop Tour)}

O caso Box 3 (Shop Tour) traz interessante discussão sobre a prática de sham litigation que, como vimos na Seção 3, decorre da propositura de ações sem propósitos legítimos, ou mesmo do abuso de procedimentos judiciais ou administrativos, com o objetivo de aumentar os custos dos rivais, dificultar sua permanência ou intimidá-los A discussão envolveu a propositura ilegítima de diversas ações judiciais de infração de direitos autorais, que careciam de qualquer fundamentação legal, com o objetivo de excluir concorrentes do mercado. Trata-se do Processo Administrativo n. ${ }^{\circ}$ 08012.004283/2000-40, instaurado em 2000 contra a Box 3 Vídeo e Publicidade Ltda. (Box 3) e Léo Produções e

${ }^{757}$ Ibid., p. 15. 
Publicidade Ltda. (Léo Produções), produtoras do programa de TV Shop Tour, a partir de Representação apresentada à SDE pela Comissão de Defesa dos Consumidores, Meio Ambiente e Minorias da Câmara dos Deputados, motivada por denúncias encaminhadas pelas empresas 3 A Negócios Publicitários e Marketing Ltda. (produtora do programa Telemídia Ofertas), General Marketing do Brasil (produtora do programa Shop \& Lazer) e Fundação Casper Líbero - TV Gazeta e Vídeo In Comunicações Ltda. (produtoras do programa Liquida Mix).

Essas denúncias indicariam que as Representadas Box 3 e Léo Produções estariam praticando atos restritivos à concorrência de forma a retirar do mercado de vendas por meio de programas de televisão as empresas denunciantes, tentando, por meio de ações judiciais descabidas, dominar esse mercado. De acordo com as denunciantes, as Representadas ajuizaram uma série de medidas judiciais com pedidos de liminares objetivando tirar do ar os programas de vendas das denunciantes, com fundamento em um suposto registro de direito autoral do roteiro do programa Shop Tour, concedido pela Biblioteca Nacional, que lhes conferiria exclusividade sobre o formato desses programas, nos termos do art. 5 , XXVIII, da Constituição Federal, e do art. $7^{\circ}$ da Lei de Direitos Autorais. A quantidade de ações judiciais baseadas no mesmo argumento desprovido de razoabilidade constituía claro indício de exercício abusivo do direito de petição com o objetivo de eliminar a concorrência.

A SDE opinou pelo arquivamento do processo administrativo, entendendo que a Box 3 havia apenas exercido o seu direito de ação regular assegurado pela Constituição Federal (art. $5^{\circ}$, XXXIV, $a$, e XXXV), destacando também que a empresa obteve alguns provimentos positivos junto ao Judiciário. A opinião da SDE foi acompanhada pelo Ministério Público e pela Procuradoria do CADE. Contudo, o caso acabou sendo analisado com maior profundidade no CADE, tendo o Conselheiro Relator, Vinícius Marques de CARVALHO, realizado instrução complementar para avaliar o histórico das ações judiciais e seu fundamento, na qual constatou que todas as decisões favoráveis mencionadas pela Box 3 em sua defesa acabaram sendo revertidas pelo Poder Judiciário após análise do mérito dessas ações. Vale destacar que o caso foi julgado pelo CADE em 15 de dezembro de 2010, praticamente dez anos após sua instauração.

O relator iniciou seu voto indagando se haveria ou não possibilidade de utilização do Poder Judiciário para fins anticompetitivos ou se o direito de petição é 
absoluto, hipótese que impediria qualquer intervenção pelo CADE. Para tanto, valeu-se de precedentes de sham litigation nos Estados Unidos, na União Europeia e no próprio CADE. Afirmou que nos Estados Unidos a prática de sham litigation é analisada como exceção à doutrina Noerr - Pennington (que garante e direito de peticionar e ter acesso aos órgãos governamentais sem qualquer punição antitruste), já que a Suprema Corte daquele país não mais vislumbra o direito de petição como absoluto, entendendo que a litigância predatória ou fraudulenta com efeitos anticoncorrenciais deve ser coibida. Fez então referência ao caso Professional Real Estate Investor (PRE), no qual a Suprema Corte norte-americana estabeleceu os requisitos para a configuração de sham litigation, quais sejam: a propositura de ações sem qualquer fundamento razoável (requisito objetivo) e a tentativa de intervir diretamente nos negócios de um concorrente (requisito subjetivo). ${ }^{758}$

Além de mencionar outros casos norte-americanos, o relator citou também o caso AztraZeneca, no qual o TJUE confirmou as conclusões da Comissão Europeia, condenando a empresa com multa de 60 milhões de euros por utilizar de modo fraudulento procedimentos para estender a proteção da patente de seu medicamento Losec, com o objetivo de retardar o ingresso de versões genéricas desse produto no mercado. Ademais, o relator recorreu aos próprios precedentes do CADE sobre o assunto para sustentar que o direito de petição não é absoluto e, portanto, não pode servir de justificativa para eximir as partes de sua responsabilidade concorrencial. ${ }^{759}$

A esse respeito, cumpre ressaltar que o CADE já admitiu expressamente que o acesso ao Poder Judiciário pode ser utilizado para excluir concorrentes, como se observa no voto do Conselheiro Fernando Furlan no Processo Administrativo n. ${ }^{\circ}$ 08012.004484/200-51:

(...) o recurso ao Judiciário pode ser empregado como instrumento para a realização de infração contra a ordem econômica. Surge daí a necessidade de ação estatal voltada a evitar que o direito de acesso ao Judiciário seja empregado para a consecução de fim ilícito, capaz de prejudicar o mercado como um todo.

\footnotetext{
${ }^{758}$ Cf. Professional Real Estate Investor (PRE). Inc., et al. v. Columbia Pictures Industries Inc., et al., 508 U.S. 49 (1993), p. 65.

${ }^{759}$ Os precedentes do CADE citados foram: (i) Averiguação Preliminar n. ${ }^{\circ}$ 08012.005610/2000-81; (ii) Averiguação Preliminar n. ${ }^{\circ}$ 08012.006076/2003-72 (caso Baterias Moura); (iii) Averiguação Preliminar 0812.005727/2006 (caso Alcoa - perfis de alumínio); e (iv) Processo Administrativo n. ${ }^{\circ} 08012.004484 / 2005$ 51 (caso dos tacógrafos).
} 
Também surge daí a competência do CADE para a matéria. Não se sustenta a tese da representada de que o Poder Judiciário seria a instância responsável por apontar e punir ações judiciais que visassem a restringir ilicitamente a concorrência. Este argumento se sustenta em bases que disfarçam a real natureza do ilícito e a adequada análise de sua ocorrência.

O ponto fucral para a caracterização da conduta ilícita em questão pode ser entendido como a promoção de fim anticompetitivo espúrio com base em ação desnecessária para a proteção de direito legítimo da parte. Tratase essencialmente de uma questão de proporcionalidade entre os interesses econômicos defendidos pela demanda ajuizada, os mecanismos empregados para a promoção de tais interesses e o efeito negativo sobre a competição gerado pelo ajuizamento. ${ }^{760}$

Em seguida, o relator afirmou que as ações intentadas pela Representada Box 3 careciam de fundamentação legal razoável, já que nem mesmo sob o prisma teórico seria possível esperar que essas demandas pudessem prosperar. Isso porque o fundamento para o ajuizamento dessas medidas judiciais era a existência de um suposto direito autoral do roteiro do programa Shop Tour, que seria amparado por um registro na Biblioteca Nacional. Tal registro informava que na mencionada série televisiva apresentadores promovem televendas, esclarecendo as características de uma série de produtos, suas formas de pagamento, em um ambiente informal.

No entanto, um registro de direito autoral é providência meramente facultativa e não constitutiva de direitos, ao contrário da propriedade industrial, cuja proteção depende da concessão de registro pelo INPI. Uma obra passível de registro é toda a criação intelectual, literária, artística ou científica original expressa por qualquer meio ou fixada em suporte mecânico. O registro na Biblioteca Nacional visa apenas garantir anterioridade ao texto ou vídeo depositado, não afetando outras obras intelectuais que porventura não tenham sido registradas. ${ }^{761} \mathrm{O}$ relator constatou que, embora um registro dê a aparência de

\footnotetext{
${ }^{760}$ Processo Administrativo n. ${ }^{\circ}$ 08012.004484/2005-51. Voto proferido pelo Conselheiro Fernando FuRLAN, em 09 de dezembro de 2009.

${ }^{761}$ De acordo com o parecer de Eliane Y. ABRÃO acostado aos autos: "O registro alcança tão somente o texto ou o audiovisual individualmente depositado. E a prova de anterioridade funciona apenas contra reproduções comerciais daquele escrito ou daquele audiovisual depositado. A presunção não se irradia a nenhum outro roteiro - de outro programa - ou a nenhuma outra obra. A regra vale tanto para obras protegidas como para as não protegidas, posto que a Biblioteca Nacional funciona apenas como receptáculo para quem desejar, no
} 
lastro em direito subjetivo, somente haveria infração ao suposto direito autoral em caso de reprodução ipsis litteris do programa arquivado na Biblioteca Nacional. Ademais, constatou que o roteiro do Shop Tour não preenchia os requisitos mínimos para a proteção autoral, uma vez que não possuía qualquer característica literária, artística ou científica e tampouco era dotado de originalidade, já que comerciais e vendas de produtos em programas existem desde os primórdios da televisão. Além disso, a própria Lei de Direitos Autorais, em seu art. $8^{\circ}$, veda expressamente a proteção autoral às ideias e esquemas de negócios, o que constitui mais um motivo pelo qual o programa Shop Tour, como gênero televisivo, não merece proteção. ${ }^{762}$

Assim, o relator constatou que a Box 3 agiu de má-fé por deduzir pretensão contra texto expresso da Lei de Direitos Autorais, conforme art. 17, I, do Código de Processo Civil. ${ }^{763}$ E mais, a Representada não se ateve apenas a oferecer uma ou outra ação esporádica, mas uma série de ações seguidas e repetidas, contra texto expresso de lei e com o mesmo argumento. Além disso, em todas as ações houve pedidos de liminares com pretensões que a Representada sabia de antemão que eram precárias, dadas as diversas manifestações do Judiciário no sentido contrário. Assim, conforme ressaltado pelo relator, ao ocultar e omitir todos os precedentes contrários à sua pretensão, a Box 3 procedeu de modo temerário, sabendo que estava provocando incidentes manifestamente infundados, ao teor do art. 17, IV, do Código de Processo Civil. ${ }^{764}$ Ademais, a retirada precoce de

futuro, alegar a anterioridade. A anterioridade sem originalidade, como se verá, nenhum significado possui. Entretanto, o registro, por sinal também exibido pelas demandadas, não tem senão o condão de declarar o direito que cada parte possui àquele roteiro depositado na fundação Federal. Querer com isso pretender que demais roteiros não depositados funcionem como garantia de monopólio é abusar do direito que possuem (...). O que, na verdade, pretendem os demandantes é, baseados numa formalidade não essencial, meramente facultativa e declaratória, transformar o direito particular e estreito que possuem às suas produções de caráter comercial em direito monopolista de caráter cultural (...) impedindo que quaisquer outros concorrentes tenham acesso à mídia eletrônica para seus serviços".

762 Quanto à possibilidade de se monopolizar um gênero televisivo, o relator mencionou a existência de uma série de decisões que demonstram a fragilidade dessa pretensão. Mencionou primeiramente, como exemplo, o caso em que a TV Globo alegou plágio do programa Você Decide, em relação ao programa O Povo é o Juiz, sendo que o Judiciário considerou não ser possível reclamar a propriedade de ideias a respeito de um gênero televisivo (Apelação Cível 5731/95 - 6 ${ }^{\text {a }}$ Câmara Cível do TJRJ - unânime - Des. Rel. Itamar Barballo). No caso de reality shows, o relator fez menção ao caso em que os donos do programa Big Brother acusaram de plágio os responsáveis pelo programa A Casa dos Artistas, solicitando medida cautelar para retirar esse programa do ar, sendo que a decisão foi clara no sentido de que um método de programação não goza da proteção legal da Lei de Direitos Autorais por não se tratar de assunto ou argumento literário (Agravo Regimental n. ${ }^{\circ}$ 255.882.4/1-01, $5^{\text {a }}$ Câmara de Direito Privado do TJSP, Des. Rel. Marcus Vinícius dos Santos Andrade).

763 “Art. 17. Reputa-se litigante de má-fé aquele que: I - deduzir pretensão ou defesa contra texto expresso de lei ou fato incontroverso."

764 “Art. 17. Reputa-se litigante de má-fé aquele que: (...) VI - provocar incidentes manifestamente infundados." 
concorrentes do mercado, com base em liminares, sem ao menos discutir o mérito da questão, fundada em suposto registro de direito autoral, acaba confundindo os magistrados, que confiam na boa-fé da parte que pleiteou a tutela de urgência.

O relator então citou como exemplo uma patente válida, que permite uma contrapartida social, já que seu titular obtém um monopólio legal por determinado período de tempo, como forma de retribuição pelos seus esforços inventivos e contribuição ao patrimônio científico e tecnológico, resultando em ganho social decorrente da própria inovação. No caso em comento, o autor da ação não desenvolveu nenhuma inovação, não contribuiu para a sociedade com trabalho original a enriquecer o domínio literário, artístico ou científico, não fazendo jus, portanto, a qualquer forma de proteção autoral. Além disso, acabou simulando um direito que não possuía com o objetivo de ludibriar o Poder Judiciário, assumindo, assim, uma conduta de risco que pode levar ao monopólio, considerando os custos processuais existentes.

Desse modo, o relator constatou que as ações ajuizadas pela Representada desrespeitam o princípio concorrencial em diversos âmbitos, em variadas esferas:

No nível mais externo, há o risco da eliminação de concorrentes no mercado televisivo, sem qualquer contrapartida oferecida socialmente.

No nível intermediário, haverá menos concorrência no que diz respeito à negociação com anunciantes, o que pode acarretar um preço maior aos consumidores.

Ademais, o presente tipo de ação não busca atingir uma ideia de um programa qualquer, como programas de auditórios ou de entrevistas, mas, sim, um programa de propagandas. Assim, tal prática, no nível mais profundo, acaba por atingir a própria ideia de concorrência, já que o que a parte solicita acaba tendo um efeito semelhante a uma patente sobre a "ideia" de compra e venda pela televisão. Qualquer canal que coloque uma pessoa falando, de forma descontraída, as características dos produtos a serem oferecidos, está buscando fazer nada mais nada menos do que uma oferta de compra e venda. Assim, chamar para si o direito de realizar esse tipo de oferta, de forma monopolística, significa acabar com a possibilidade dos consumidores perceberem a diferença de preço e de qualidade dos produtos existentes e disponíveis no mercado. 
Assim, o relator afirmou que a proteção buscada por meio das liminares é contrária à própria noção de concorrência. A Representada agiu, portanto, de forma extremamente arriscada, tendo o potencial de retirar concorrentes do mercado com base em alegações frívolas, o que permite constatar que houve infração à ordem econômica. Isso porque a Box 3 tinha plena noção do que estava fazendo, considerando sua má-fé, e que estava pleiteando no Judiciário causas desprovidas de qualquer fundamentação legal. O relator então analisou todas as nove ações judiciais propostas pela Representada em face de grandes e relevantes concorrentes no mercado e constatou que mesmo tendo uma série de decisões contrárias à sua pretensão transitadas em julgado, que explicitamente mencionavam a ausência de originalidade, a precariedade do título registrado na Biblioteca Nacional e a impossibilidade de se patentear um gênero televisivo, ainda assim a Box 3 continuou litigando no Judiciário, por meio de novas ações contra seus concorrentes e com o mesmo fundamento. Diante desse cenário, o relator constatou que é difícil argumentar que a Representada estava de boa-fé, que não sabia o que estava fazendo, ou mesmo que apenas buscava defender direitos que acreditava ter.

Após analisar as ações, sua fundamentação e decisões, o relator concluiu que a conduta da Representada resultou em danos efetivos à concorrência, devido à eliminação de concorrentes por diversos períodos e lapsos de tempo, como resultado das liminares inicialmente obtidas, que foram posteriormente revertidas. Concluiu pela existência de prática de litigância predatória ou fraudulenta com efeitos anticoncorrenciais por parte da Box 3, determinando o pagamento de multa de $5 \%$ de seu faturamento do ano anterior à abertura do processo administrativo. Os demais Conselheiros acompanharam o relator, de modo que a votação do Plenário do CADE foi unânime pela condenação.

\subsubsection{O caso Alcoa - perfis de alumínio}

O caso Alcoa - perfis de alumínio também tratou da prática de sham litigation. Trata-se da Averiguação Preliminar n. ${ }^{\circ}$ 08012.005727/2006-50, instaurada após representação feita pelo Ministério Público Federal, protocolada na SDE em 30 de maio de 2006, a partir de denúncia contra a Alcoa Alumínio S.A. (Alcoa). De acordo com a representação, a Alcoa estaria praticando abuso do poder econômico, mediante o requerimento, junto ao INPI, de desenhos industriais e patentes de modelos de perfis de alumínio pertencentes ao domínio público, seguido de ações judiciais propostas em face de possíveis violadores desses direitos de propriedade intelectual. Além disso, a Representada 
teria distribuído um comunicado ao mercado, induzindo os consumidores e concorrentes em erro, ao sugerir que detinha a propriedade intelectual de perfis que não seriam de fato registrados. Finalmente, a Alcoa estaria se negando a vender seus produtos para os pequenos e médios revendedores de alumínio.

Além disso, conforme a representação, os pedidos de registros de desenho industrial e de patentes de modelo de utilidade impugnados referiam-se a perfis de alumínio já comercializados no mercado, além de o pedido de registro de desenho industrial extrapolar os aspectos ornamentais, âmbito e abrangência regular desse tipo de proteção. ${ }^{765}$ A Representada estaria se valendo de uma brecha no procedimento adotado pelo INPI para obter o direito de exploração exclusiva desses produtos já encontrados no mercado, uma vez que os registros são concedidos de forma automática, não havendo qualquer análise de mérito, a não ser mediante requerimento do depositante, ou impugnação de terceiros. Valendo-se desses registros, a Representada estaria ingressando com ações judiciais, induzindo os magistrados em erro, pois, por desconhecimento da matéria, concediam liminares tanto para impedir a fabricação de produtos pelos concorrentes, como para apreender equipamentos utilizados em sua fabricação.

Após investigar as denúncias, a SDE opinou pelo arquivamento da averiguação preliminar, enquanto a Procuradoria do CADE e o Ministério Público Federal opinaram pela instauração do processo administrativo. Ao analisar o caso em sede de recurso de ofício ao CADE, na sessão de julgamento realizada em 13 de maio de 2009, o Conselheiro Relator César MATTOS analisou se seria o caso de arquivamento da averiguação preliminar ou se a SDE deveria instaurar processo administrativo para investigar as acusações. $\mathrm{O}$ relator iniciou seu voto descrevendo as condutas supostamente praticadas pela Alcoa e afirmou que a prática em questão se enquadraria no conceito de sham litigation, que, embora seja oriunda da comunidade jurídica norte-americana, encontra sua configuração no arcabouço jurídico brasileiro, na figura do abuso de direito do Código Civil, em seu art. 187, combinado com a então vigente Lei n. ${ }^{\circ} 8.884 / 94$ (arts. 20, caput, e inciso II e art. 21, incisos IV e V). De acordo com o relator, ao peticionar com base em direito que supostamente não lhe é legítimo, a Representada estaria abusando do direito de acesso ao Poder Judiciário, de modo a extrapolar o fim social e econômico no caso concreto, uma

\footnotetext{
${ }^{765}$ Nos termos do art. 95 da Lei de Propriedade Industrial: "Considera-se desenho industrial a forma plástica ornamental de um objeto ou o conjunto ornamental de linhas e cores que possa ser aplicado a um produto,
} 
vez que o direito patentário não serve para acobertar patentes fraudulentas, nem tampouco deve ser utilizado como instrumento anticompetitivo para defender direitos ilegítimos perante os tribunais.

Em seguida, o relator afirmou que a SDE delimitou o mercado relevante como sendo o mercado nacional de perfil de alumínio em geral, incluindo o destinado à construção civil e à indústria. A despeito da existência de outros materiais possíveis para a fabricação de perfis, tais como madeira, aço e plástico, para a construção civil, e aço, latão e cobre, para o segmento industrial, a SDE justificou sua exclusão como substitutos suficientemente próximos por não apresentarem as características do alumínio, como resistência à umidade e corrosão. Já no que concerne à inclusão dos perfis destinados ao segmento industrial e aqueles destinados à construção civil no mesmo mercado, a SDE afirmou que isso se justifica em razão da substituibilidade pelo lado da oferta, pois ambos os segmentos de perfis requerem o mesmo processo tecnológico e equipamento produtivo. $^{766}$

Ao analisar a conduta, o relator ressaltou de pronto a incompetência do CADE para verificar a procedência da concessão das patentes de modelo de utilidade, uma vez que o procedimento concessório envolve análise de mérito realizada pelo órgão competente, que no caso é o INPI, não podendo o CADE invadir essa competência. O mesmo entendimento se aplica em relação à denúncia sobre a suposta precariedade do INPI na análise do mérito dos registros de desenho industrial. De acordo com o relator, ambas as denúncias devem ser examinadas em foro judicial, que é competente para a tutela dos direitos subjetivos em face dos atos da administração supostamente eivados de vício. De qualquer modo, afirmou que direitos de propriedade intelectual ilegítimos poderiam, em tese, constituir barreira artificial à entrada, especialmente se a definição do mercado relevante fosse restringida para o mercado de perfis de alumínio para portas e janelas. ${ }^{767}$

proporcionando resultado visual novo e original na sua configuração externa e que possa servir de tipo de fabricação industrial".

766 A SDE observou que essa definição de mercado relevante seguiu a jurisprudência do CADE no ato de concentração n. ${ }^{\circ}$ 08012.0465/202-11, que tratava da aquisição da totalidade do capital social da VAW Alumínio AG pela Hydro Aluminium Holding Deutschland GmbH.

${ }^{767}$ Ressalte-se que tanto a Procuradoria do CADE como o Ministério Público Federal entenderam o mercado relevante como o de perfis de alumínio para portas e janelas, em razão de ser esse o segmento em que os pedidos de registro de desenho industrial objeto do processo estariam posicionados. 
Por outro lado, o relator constatou que houve exame de mérito dos registros de desenho industrial pelo INPI, a pedido da própria Representada. Desse exame, constatou-se que seis registros foram mantidos e três estavam sendo examinados, e que entre os registros mantidos quatro tiveram o pedido de mérito requerido em 2003, antes mesmo da representação formulada pelo Ministério Público. Ademais, ponderou que como houve exames de mérito dos registros em questão, tal fato enfraquece a denúncia de que a Representada estaria se aproveitando de brecha nos procedimentos do INPI.

Quanto ao comunicado emitido para o mercado, o relator afirmou que este poderia, em tese, sinalizar uma ameaça crível, por parte da Representada, de que qualquer empresa e consumidor que ofertasse ou consumisse os produtos mencionados sofreria as consequências de uma ação judicial. Contudo, constatou que houve um mal-entendido em relação ao teor desse comunicado, já que em nenhum momento a Representada advertiu que os consumidores não poderiam adquirir, junto a terceiros, perfis semelhantes aos encontrados em sua linha de produtos. Ao contrário, essa advertência era no sentido de que os consumidores deveriam adquirir os produtos sob as marcas pertencentes à Alcoa diretamente da própria Alcoa ou de seus distribuidores autorizados, como garantia de qualidade. A finalidade do comunicado era alertar o consumidor para que tivesse a segurança de que estava adquirindo um produto Alcoa, independentemente do fato de ser um perfil registrado ou não no INPI.

Finalmente, o relator constatou que apenas uma minoria de perfis sob a marca Alcoa era protegida pelos registros de desenho industrial e patentes de modelo de utilidade. De fato, de 641 tipos de perfis nas linhas da Alcoa, apenas $35(5,4 \%)$ possuíam registro de desenho industrial. Se esses poucos perfis protegidos por registro de desenho industrial fossem os líderes de venda no segmento, poder-se-ia admitir a possibilidade de prejuízos à concorrência, caso tivessem sido obtidos de forma indevida, aproveitando-se da ausência de análise de mérito pelo INPI para a concessão desses registros. No entanto, como houve análise de mérito e a maioria dos registros foi aprovada pelo INPI, mesmo que esses registros se concentrassem naqueles perfis considerados líderes de mercado, tal fato seria apenas uma consequência do próprio mérito da Alcoa na criação de produtos mais aceitos e valorizados pelos consumidores. Sobre esse aspecto, o relator afirmou que: 
Questionar a proteção desses produtos seria questionar a legítima busca da empresa por uma maior qualidade percebida pelos consumidores, o que constitui a essência do próprio processo concorrencial.

Se a Alcoa introduzisse um conjunto qualquer de perfis novos, com proteção de propriedade industrial, que acabassem por se tornar os preferidos dos consumidores, gerando participações de mercado elevadas, teríamos o caso da conquista de posição dominante fundada na maior eficiência do agente econômico, o que é expressamente protegido no $\S 1^{\circ}$ do art. 20 da Lei 8.884/94 [equivalente ao atual $\S 1^{\circ}$ do art. 36 da Lei Antitruste].

De qualquer modo, o relator constatou que o grau de sucesso da Alcoa não chegou a tanto, já que a participação de mercado da empresa em extrudados de alumínio manteve-se na faixa de 30\% entre 2003 e 2010. No segmento de extrudados de alumínio para construção civil, a participação de mercado variou em patamar ligeiramente mais elevado, em torno de 32,57\%. Ainda que se restringisse a definição do mercado relevante, considerando apenas o mercado de extrudados de alumínio para portas e janelas, a participação da Representada ficaria em torno de $21 \%$ em 2009 contra 30\% para extrudados em geral, uma vez que a empresa não ofertava extrudados de alumínio para fachadas.

Dessa forma, mesmo entrando nas considerações sobre os efeitos da conduta imputada à Representada, esta não detinha domínio suficiente sobre o mercado a ponto de impedir a entrada de outros agentes econômicos. Diante desses fatos, o relator afastou a acusação de sham litigation, mantendo o arquivamento da averiguação preliminar. Os demais Conselheiros do CADE acompanharam o voto do relator. 


\section{AS DIRETRIZES DO TRIPS SOBRE CONCORRÊNCIA NO CONTEXTO GLOBAL E SUAS IMPLICAÇÕES PARA OS PAÍSES EM DESENVOLVIMENTO}

Vimos que as normas do Acordo TRIPS sobre concorrência, embora constituam uma concessão dos países desenvolvidos aos países em desenvolvimento, não oferecem a estes diretrizes suficientes para a formulação de sistemas antitruste nacionais capazes de lidar com as complexas questões que envolvem a exploração abusiva e anticoncorrencial de direitos de propriedade intelectual. A redação aberta e flexível constante nos Artigos 8.2 e 40 do TRIPS sugere que esses dispositivos foram pensados mais como regras de contenção para a política nacional de concorrência dos Membros da OMC - consubstanciadas nas exigências de proporcionalidade e consistência -, do que como obrigações afirmativas para o desenvolvimento apropriado de tal política. ${ }^{768}$ Afinal, o Acordo TRIPS é um tratado internacional que trata de direitos de propriedade intelectual, e não de concorrência. ${ }^{769}$ Conforme bem ressaltado por Robert D. ANDERSON, ainda que seja desejável fornecer diretrizes adicionais para os membros da OMC em relação ao tema da interface entre propriedade intelectual e concorrência, é muito difícil que no curto prazo seja possível estabelecer padrões apropriados para reger todas as práticas restritivas em todas as situações. ${ }^{770}$

Nesse contexto, a análise da experiência dos tribunais e autoridades antitruste dos EUA e União Europeia e Brasil nessa área revelou-se fundamental para conferir aplicação prática às normas do TRIPS sobre concorrência, permitindo a formulação de diretrizes que poderiam ser utilizadas pelos países em desenvolvimento na implementação

\footnotetext{
${ }^{768}$ Nesse sentido, Eleanor FOX afirma que: "TRIPS implicitly acknowledges that there may be a clash between TRIPS protection and competition law. Since aggressive antitrust law or enforcement could impair the intellectual property protection that TRIPS assures, drawing the line beyond which competition law (as well as unfair competition law) may not go is an enterprise special to TRIPS. This enterprise concerns setting the limits on competition laws, not affirmative formulation and enforcement of competition law. It is an exercise that nations that have both antitrust and IP traditions have undertaken and resolved - however uncertainly - for themselves". FOX, Eleanor M. Trade, Competition, and Intellectual Property - TRIPS and its Antitrust Counterparts, in: 29 Vand. J. Transnat'1 L. 481, 1996, p. 486-487.

${ }^{769}$ Cf. ULLRICH, Hans. Expansionist Intellectual Property Protection and Reductionist Competition Rules: A TRIPS Perspective, in: MASKUS, Keith E.; REICHMAN, Jerome H. (Ed.). International Public Goods and Technology Transfer Under a Globalized Intellectual Property Regime. Cambridge University Press, 2005 , p. 414.
} 
de políticas públicas voltadas ao controle das práticas restritivas a partir da exploração de direitos de propriedade intelectual. Por outro lado, muito embora as abordagens sobre o tema nas jurisdições mais desenvolvidas tenham chegado a um grau de convergência ao longo dos últimos anos, vimos que ainda restam importantes diferenças mesmo entre os EUA e a União Europeia. No passado, havia divergências ainda maiores entre países desenvolvidos e em desenvolvimento em relação a questões envolvendo acordos de licenciamento e transferência de tecnologia. De qualquer modo, ainda que não seja possível concordar em padrões comuns para reger todas as práticas anticoncorrenciais relacionadas à propriedade intelectual, é inegável que os países em desenvolvimento podem beneficiar-se das trocas de experiências sobre o tema entre os diferentes membros da OMC.

O objetivo desta Seção é propor diretrizes globais para a implementação de políticas públicas para lidar com complexas questões envolvendo a interface entre propriedade intelectual e concorrência, a partir da experiência das jurisdições mais avançadas nessa área. Não se trata do estabelecimento de uma vertente específica que os países em desenvolvimento deveriam seguir ou mesmo de um modelo único a ser aplicado em todo e qualquer caso, o que, como vimos, seria inadequado diante das assimetrias econômicas e diferenças de cultura de concorrência existentes entre os diversos países. ${ }^{771}$ A ideia é tão somente analisar as possíveis abordagens que poderiam ser utilizadas na implementação de uma política de concorrência eficaz, compatível e consistente com os padrões mínimos de proteção da propriedade intelectual estabelecidos pelo TRIPS, que favoreça a concorrência dinâmica e a manutenção de mercados abertos ao ingresso de agentes econômicos inovadores, em benefício do bem-estar econômico e social.

\subsection{Possíveis abordagens para a implementação de normas de concorrência compatíveis com as disposições do Acordo TRIPS}

Os Artigos 8.2, 40 e 31(k) do Acordo TRIPS foram concebidos como instrumentos para salvaguardar o funcionamento adequado do sistema de propriedade

\footnotetext{
770 ANDERSON, Robert D. Competition Policy and Intellectual Property in the WTO: More Guidance Needed?, in: DREXL, Josef (Ed.). Research Handbook on Intellectual Property and Competition Law. Cheltenham: Edward Elgar, 2008, p. 453.

771 De acordo com NGUYEN: "There is no one-size-fits-all model of competition law. (...) A common technology transfer-related competition law approach to all developing countries is neither desirable nor feasible". NGUYEN, Tu Thanh. Competition Law, Technology Transfer and the TRIPS Agreement. Cheltenham: Edward Elgar, 2010, p. 288.
} 
intelectual, possibilitando que a proteção dos direitos exclusivos contribua para a "promoção da inovação e para a transferência e difusão de tecnologia, em benefício mútuo de produtores e usuários de conhecimento tecnológico e de uma forma conducente ao bem-estar social e econômico e a um equilíbrio entre direitos e obrigações", conforme preconiza o Artigo 7 do Acordo. Nessa perspectiva, é possível afirmar que as disposições do TRIPS sobre concorrência foram vislumbradas como elementos de equilíbrio a evitar que os excessos ou abusos na exploração de direitos de propriedade intelectual venham a constituir entraves não apenas à inovação tecnológica, como também à transferência e disseminação de tecnologia. Desse modo, considerando que os bens intelectuais e tecnologias são importantes insumos para a produção do conhecimento, a tutela da concorrência acaba sendo tão fundamental quanto a tutela da propriedade intelectual para a promoção da inovação, uma vez que possibilita a manutenção de mercados abertos ao ingresso de atuais "usuários de conhecimento tecnológico", que de certo modo são potenciais inovadores capazes de produzir as próximas gerações de tecnologia, tendo em vista o caráter cumulativo e incremental do processo de inovação. ${ }^{772}$

Nesse contexto, como os "usuários de conhecimento tecnológico" precisam obter licenças junto aos titulares de direitos de propriedade intelectual para ter acesso aos mercados de inovação e tecnologia, e assim possibilitar sua atuação em mercados horizontal e verticalmente relacionados, a preocupação com possíveis cláusulas restritivas em acordos de licenciamento, ou mesmo condutas unilaterais como a recusa de licenciar, assume importância vital na formulação de políticas públicas nessa área. ${ }^{773}$ Diante desse quadro, uma política antitruste excessivamente intervencionista, que estabeleça proibições genéricas a determinadas cláusulas restritivas ou mesmo que recorra frequentemente ao

${ }^{772}$ Cf. RICOLFI, Marco. Is there an Antitrust Antidote against IP Overprotection within TRIPS?, in: Marquette Intellectual Property L. Rev. 10, 305, 2006, p. 328. Disponível em: http://scholarship.law.marquette.edu/iplr/vol10/iss2/6.

${ }^{773}$ Sob esse prisma, UlLRICH menciona os dilemas da inovação vertical e da inovação horizontal como obstáculos à inovação cumulativa: "Reliance on exclusive intellectual property rights to stimulate investment in new technology poses a twofold economic dilemma. First, the exclusive rights, which provide incentives to innovate in order to reap the market-induced rewards, may also block the development of improved, related or complementary technology. This is known as the vertical innovation dilemma. Second, exclusivity may impede optimal exploitation of protected technology, since by definition, optimal exploitation will occur only under conditions of full intra-brand competition, at least if inter-brand competition is not perfect. This is known as the horizontal diffusion dilemma". ULLRICH, Hans. Expansionist Intellectual Property Protection and Reductionist Competition Rules: A TRIPS Perspective, in: MASKUS, Keith E.; REICHMAN, Jerome H. (Ed.). International Public Goods and Technology Transfer Under a Globalized Intellectual Property Regime. Cambridge University Press, 2005, p. 412. 
licenciamento compulsório, pode acabar subvertendo os incentivos à inovação e à disseminação e transferência de tecnologia.

Por outro lado, uma política de concorrência excessivamente leniente ou tolerante com determinadas práticas potencialmente restritivas, pode acabar dando abertura para utilização estratégica de direitos de propriedade intelectual com vistas ao fechamento dos mercados ao ingresso de agentes econômicos potencialmente inovadores, causando entraves ao desenvolvimento de novos produtos ou tecnologias complementares. A extensão dos efeitos negativos dessas condutas sobre a concorrência é proporcional ao grau de poder de mercado detido pelo agente econômico titular dos direitos exclusivos e da presença de barreiras à entrada nos mercados relevantes afetados por essas estratégias, especialmente nos segmentos de tecnologia da informação que, como vimos, são muitas vezes caracterizados pela presença de externalidades de redes e efeitos lock-in.

Diante dessas considerações, indaga-se quão intervencionista deveria ser a política antitruste nacional para coibir práticas anticoncorrenciais decorrentes da exploração de direitos de propriedade intelectual? A resposta a esta questão depende das preferências e escolhas políticas feitas por cada Estado soberano, a depender de diversas variáveis, tais como sua realidade econômica, social e cultural, seu estágio de desenvolvimento, suas prioridades de política pública, dentre outros. Dependendo dessas variáveis, as escolhas de política pública podem pender para a maior ampliação da competitividade dos mercados e redução dos preços, em detrimento da proteção da propriedade intelectual (abordagem estática), ou pelo fortalecimento e ampliação da proteção da propriedade intelectual com vistas a estimular mais investimentos em inovação, ainda que a consequência seja a redução da concorrência e o aumento dos preços (abordagem dinâmica). ${ }^{774}$

Maristela BASSO sintetiza bem as diferentes abordagens que refletem os interesses opostos de países desenvolvidos e países em desenvolvimento:

\footnotetext{
${ }^{774}$ Nesse contexto, a política de concorrência poderia ser mais intervencionista em relação às estratégias de licenciamento e exploração de direitos de propriedade intelectual, possibilitando maiores condições de acesso por terceiros a preços menores, de modo a ampliar a concorrência e possibilitar maior eficiência alocativa e produtiva (estática). Alternativamente, essa política poderia ser menos intervencionista em relação a essas estratégias, conferindo maior importância à proteção da propriedade intelectual e aos incentivos à inovação, de modo a estimular a concorrência dinâmica.
} 
Os países que investem em pesquisa e desenvolvimento e que possuem grande quantidade de direitos de propriedade intelectual (países desenvolvidos e exportadores) preferem um sistema rigoroso de proteção desses direitos no mundo, uma vez que levam em conta apenas os benefícios que isso traz para os seus produtores locais ignorando, por outro lado, os benefícios que os consumidores estrangeiros conseguiriam por meio de um sistema menos rigoroso devido ao aumento do acesso à inovação.

Por outro lado, os países importadores de direitos de propriedade intelectual (países em desenvolvimento) preferem um sistema com menor nível de proteção, que conferiria aos seus residentes maior acesso às novas tecnologias, ignorando os interesses dos produtores estrangeiros de propriedade intelectual. ${ }^{775}$

A opção por uma ou outra abordagem varia não apenas entre os diferentes países, mas também dentro de um único país ao longo do tempo, dependendo de seu momento histórico. ${ }^{776}$ Vimos que o desenvolvimento da interface entre propriedade intelectual e política de concorrência nos Estados Unidos e na União Europeia foi marcado por ciclos de maior ou menor intervenção antitruste. ${ }^{777}$ Após uma maior predominância do direito da concorrência sobre a propriedade intelectual no passado, é possível constatar que prevalece atualmente uma abordagem mais liberal, ou seja, menos intervencionista, sobre a exploração de direitos exclusivos, especialmente no que concerne às práticas restritivas em acordos de licenciamento e transferência de tecnologia, a despeito de ainda haver

${ }^{775}$ BASSO, Maristela. Propriedade Intelectual e Importação Paralela. São Paulo: Atlas, 2011, p. 212.

${ }^{776}$ Sobre o assunto, Eleanor Fox esclarece o seguinte: “(...) we see a set of interface problems and a diversity of perspectives regarding them. The solutions differ in view of different preferences regarding the weight to be given to the protection of intellectual property holders' rights to exclusive enjoyment of their intellectual property and the perceived or presumed effect of such preferences in increasing incentives to invent. Whether the tension is resolved in favor of the IP right or the competition value varies not only from country to country but also within one country over time, as reflected by the marked swing in the U.S. position over the last quarter century. When the United States was less industrialized, less challenged by foreign competitors, and not a net exporter, it preferred more competition to more protection of intellectual property rights". FOX, Eleanor M. Trade, Competition, and Intellectual Property - TRIPS and its Antitrust Counterparts, in: 29 Vand. J. Transnat'1 L. 481, 1996, p. 490.

777 De acordo com LEMLEY, esses ciclos de maior e menor intervenção antitruste sobre a propriedade intelectual nos Estados Unidos impediu um maior equilíbrio entre esses dois campos do direito: “(...) the history of the intersection has been characterized by cycles of over- and under-enforcement, which first antitrust and then IP is on the ascendancy while the other recedes into the background. This cyclical history has kept the two laws from settling into a healthy balance". LEMLEY, Mark A. A New Balance Between IP and Antitrust. John M. Olin Program in Law and Economics Stanford Law School. Working Paper n. 340, April, 2007, p. 15. Disponível no website da Social Science Research Network Electronic Paper Collection: http://ssrn.com/abstract=980045. Acesso em: 24 out. 2009. 
diferenças relevantes nos dois lados do Atlântico em relação ao tratamento das condutas unilaterais de exclusão.

Sob a perspectiva do Acordo TRIPS, é inegável que os membros da OMC, em especial os países em desenvolvimento, possuem ampla discricionariedade para optar por abordagens mais intervencionistas ou mais liberais, dado o caráter flexível das disposições contidas nos Artigos 8.2 e 40, muito embora essa opção acabe sendo ponderada (ou limitada) pelas exigências de consistência e proporcionalidade contidas nesses dispositivos. Assim, desde que as políticas nacionais de concorrência implementadas não sirvam para esvaziar os padrões mínimos de proteção ou contrariar as demais normas constantes no Acordo (exigência de consistência), e nem resultem na aplicação de remédios excessivos ou incompatíveis em relação aos fins a serem alcançados (exigência de proporcionalidade), os membros da OMC são livres para optar pela abordagem que melhor atenda aos seus interesses e necessidades.

Nesse contexto, duas abordagens aparentemente opostas costumam ser apontadas como alternativas disponíveis aos países em desenvolvimento para a formulação de políticas de concorrência nacionais nessa área, quais sejam: (i) abordagem orientada pela disseminação e transferência de tecnologia, em resposta aos anseios dos países em desenvolvimento por maior acesso aos bens e tecnologias protegidos por direitos de propriedade intelectual; e (ii) abordagem orientada pela inovação e concorrência dinâmica, que atualmente predomina nos países desenvolvidos, em especial nos Estados Unidos e na União Europeia, bem como em países em desenvolvimento que alcançaram maiores níveis de industrialização, como o Brasil.

Passamos a tratar essas duas abordagens a seguir.

\subsubsection{Abordagem orientada pela disseminação e transferência de tecnologia}

As normas do TRIPS sobre concorrência tratam de práticas restritivas a partir da exploração de direitos de propriedade intelectual, especificamente no que concerne às práticas anticoncorrenciais em acordos de licenciamento. Dada a linguagem constante em seus dispositivos, o enfoque parece estar muito mais na "transferência e disseminação de tecnologia", isto é, a propagação ou difusão de conhecimentos tecnológicos, do que no reforço ao processo de inovação orientado por atividades de pesquisa e desenvolvimento ou pelo licenciamento ampliado de invenções. De fato, tanto o histórico das negociações 
do Acordo TRIPS quanto sua estrutura sugerem a existência de uma tensão subjacente entre o objetivo de promover a inovação, por meio da elevação dos padrões universais de proteção da propriedade intelectual ao nível que os países desenvolvidos consideram apropriado $^{778}$, e o objetivo de salvaguardar a transferência e disseminação de tecnologia em termos favoráveis aos países em desenvolvimento, por intermédio de algumas regras de concorrência vagamente definidas, que acabaram sendo concedidas com relutância pelos países mais industrializados. ${ }^{779}$

Conforme já mencionado, a inclusão das disposições constantes nos Artigos 8.2 e 40 no Acordo TRIPS tem origem nas discussões do projeto de Código de Conduta para Transferência de Tecnologia no âmbito da UNCTAD, que tinham um foco natural nos anseios dos países em desenvolvimento em garantir maior acesso a conhecimentos tecnológicos protegidos por direitos de propriedade intelectual de titularidade de empresas multinacionais. Desse modo, as disposições do TRIPS sobre concorrência possuem uma clara orientação voltada para a disseminação e transferência de tecnologias, explicada pelas suas próprias origens históricas. Sob esse prisma, a política de concorrência seria imprescindível aos países em desenvolvimento, pois serviria para coibir práticas abusivas por titulares de direitos de propriedade intelectual, incluindo cláusulas restritivas em acordos de licenciamento capazes de restringir o acesso a tecnologias e bens protegidos por direitos exclusivos.

Com base nessa orientação "disseminadora", as autoridades de defesa da concorrência dos países em desenvolvimento podem ser levadas a utilizar critérios estáticos na análise antitruste de certas condutas, tais como preço, quantidade e produção, dando menor ênfase a aspectos dinâmicos concernentes à preservação dos incentivos à inovação. A lógica dessa abordagem mais intervencionista, concentrada em elementos de eficiência alocativa (estática), pode ser explicada pelo fato de que a maioria das tecnologias protegidas por direitos de propriedade intelectual, em especial por patentes, pertence a empresas multinacionais, o que pode acabar restringindo a atuação de empresas nacionais, que muitas vezes dependem dessas tecnologias para concorrerem no mercado,

\footnotetext{
${ }^{778}$ Cf. ReICHMAN, J. H. Universal Minimum Standards of Intellectual Property Protection under the TRIPS Component of the WTO Agreement, in: Intellectual Property and International Trade - the TRIPS Agreement (1998), p. 24-26.

${ }^{779}$ Cf. Ullrich, Hans. Expansionist Intellectual Property Protection and Reductionist Competition Rules: A TRIPS Perspective, in: MASKUS, Keith E.; REICHMAN, Jerome H. (Ed.). International Public Goods and
} 
ou mesmo para desempenharem suas atividades em outros segmentos. ${ }^{780}$ Ademais, alguns autores apontam que a cautela adotada pelas autoridades antitruste dos países desenvolvidos - de proteger a concorrência estática sem prejudicar os incentivos à inovação - teria menor relevância para os países menos desenvolvidos, considerando a necessidade desses países de manter preços acessíveis aos consumidores, além do impacto limitado de eventual intervenção dos órgãos de concorrência locais sobre os incentivos à inovação das empresas estrangeiras titulares de direitos de propriedade intelectual. ${ }^{781}$

Partindo-se dessas premissas, a política de concorrência adotada pelos países em desenvolvimento poderia estabelecer proibições per se a cláusulas potencialmente restritivas em acordos de licenciamento e transferência de tecnologia. Da mesma forma, as autoridades antitruste desses países poderiam estabelecer como prioridades de política pública não apenas a repressão a condutas unilaterais de exclusão na exploração de direitos de propriedade intelectual, como também as chamadas "condutas de exploração", tais como a cobrança de royalties excessivos em contrapartida ao acesso a tecnologias protegidas, assim como a imposição de preços considerados abusivos para a aquisição de produtos contendo direitos exclusivos. Além disso, a atenção dos órgãos de defesa da concorrência nesses casos poderia voltar-se para setores sensíveis aos interesses dos países em desenvolvimento, como o de saúde pública, o que possibilitaria, por exemplo, a imposição de licenças compulsórias de patentes detidas por empresas farmacêuticas

Technology Transfer Under a Globalized Intellectual Property Regime. Cambridge University Press, 2005, p. 412-413.

${ }^{780}$ De acordo com KHOR: "The overwhelming share of patents in developing countries are held by foreigners, and thus most of the commercial benefits of IP accrue to these foreign institutions. There are large and growing patent rents transferred from developing to developed countries. Since the patents are owned by foreigners, local researchers and enterprises are blocked or restricted in their use of the patented materials. Local industries will also find it difficult or impossible to produce similar products as those patented. In terms of effect on competition, the situation confers monopoly rights on foreigners, and local enterprises are placed in a situation in which they face high or even insurmountable obstacles to compete". KHOR, Martin. Intellectual Property, Competition and Development, in: Third World Network, June 2005, p. 04. Disponível em: http://www.wipo.int/edocs/mdocs/mdocs/en/isipd_05/isipd_05_www_103984.pdf.

${ }^{781}$ É nesse sentido que GALEGO afirma que: “(...) it should be remembered that intellectual property protection in developing countries very often leads to higher prices for protected goods without substantially contributing to domestic innovation. The dilemma faced by the legislator and the competition law enforcer in developed countries of promoting static competition without chilling innovation does not arise, or at least not in the same terms, in developing countries. Moreover, even if considered from a global perspective, given the limited willingness and capacity to pay in low-income countries, the decision of a developing country to focus rather on the goal of keeping prices down and increasing consumers' choice would in a vast number of cases have only little impact on the innovation incentives of right holders in the developed world". GALLEGO, Beatriz Conde. Intellectual Property Rights and Competition Policy, in: CORREA, Carlos (Ed.). Research Handbook on the Protection of Intellectual Property under WTO Rules. Intellectual Property in the WTO, v. I, Edward Elgar, 2010, p. 256. 
multinacionais, com o objetivo de remediar práticas de preços excessivos na comercialização de medicamentos essenciais para a população. ${ }^{782}$

No entanto, ainda que seja, em princípio, compatível com o Acordo TRIPS, essa abordagem tem perdido espaço diante da influência cada vez maior da teoria econômica sobre a análise antitruste, especialmente no que concerne aos modelos de organização industrial, além do reconhecimento praticamente unânime das autoridades de concorrência da maioria das jurisdições sobre os benefícios pró-competitivos de determinadas restrições contidas em acordos de licenciamento. Senão vejamos.

Apoiadas em pressupostos econômicos, as autoridades antitruste dos países mais industrializados têm deixado de reconhecer a prática de preços excessivos como conduta anticoncorrencial autônoma, ou seja, desvinculada de outros ilícitos, tais como cartelização e abusos unilaterais de exclusão. ${ }^{783}$ De fato, admitir a possibilidade de que a prática de preços excessivos constitui, por si só, ilícito antitruste, poderia levar as autoridades da concorrência a assumir um papel que não lhes cabe de reguladores de mercado ou controladores de preços, o que certamente resultaria em punições arbitrárias e injustas contra empresas que conquistaram posições de mercado de forma legítima, por meio de investimentos em qualidade e inovação. ${ }^{784}$ Uma política de concorrência que negue a realização de lucros decorrentes de posições legitimamente alcançadas resultaria em desincentivos para que outras empresas também investissem em qualidade e inovação,

\footnotetext{
${ }^{782}$ Exemplo disso ocorreu na África do Sul. Em 2002, algumas organizações da sociedade civil protocolaram junto à Comissão de Concorrência uma reclamação contra dois laboratórios farmacêuticos multinacionais, a GlaxoSmithKleine e a Boehringer Ingelheim, alegando que teriam violado a Lei de Concorrência da África do Sul ao abusarem de sua posição dominante no mercado para cobrarem preços excessivos pelos seus medicamentos antirretrovirais, que eram protegidos por patentes. Após mais de um ano de investigações, a Comissão de Concorrência concluiu que as evidências seriam suficientes para sustentar as acusações. Cf. Competition Commission Finds GSK and BI in Contravention of the Competition Act, 16 Oct., 2003. Disponível em: http://www.cptech.org/ip/health/sa/cc10162003.html. Acesso em: 16 nov. 2012.

783 Embora o Artigo 102(a) do TFUE reconheça que o abuso de posição dominante pode decorrer da imposição, de forma direta ou indireta, de preços de compra ou de venda ou outras condições de transacção não equitativas, essa forma de abuso foi raramente condenada na União Europeia.

${ }^{784}$ Vimos que a Lei Antitruste brasileira prevê expressamente em seu art. $36, \S 1^{\circ}$ que a conquista de mercado resultante de processo natural fundado na maior eficiência de agente econômico em relação a seus competidores não caracteriza ilícito antitruste. Nessa linha, não há registro no Brasil de condenação por prática de preço excessivo, muito embora diversas denúncias tenham sido apresentadas ao SBDC. De acordo com RAGAZZO: "O alto número de casos de preço excessivo acabou por gerar um esforço jurisprudencial que vem se tornando complexo ao longo dos anos. No entanto, até recentemente, o discurso era dominado por economistas, que se dividiam em duas posições históricas no Cade, definindo preço abusivo como: (a) aquele que decorre de alguma conduta ilícita (e o exemplo mais frequente seria o cartel); e (b) uma verdadeira conduta autônoma, desde que tenha um caráter exclusionário como efeito. RAGAZZO, Carlos Emmanuel Joppert. Preço Abusivo, Eficácia Jurídica e Análise Econômica: Afinal, onde está a cabeça de bacalhau?, in: Revista do IBRAC, Ano 18, v. 19, p. 23, jan./jun. 2011.
} 
subvertendo a própria lógica do sistema de propriedade intelectual, que traduz o reconhecimento do Estado sobre a necessidade de estimular as criações intelectuais. É por esses motivos que a intervenção antitruste somente deve ocorrer naquelas situações em que os preços excessivos estão associados a alguma conduta ilícita, como um cartel, ou mesmo quando o aumento de preços é praticado por agente econômico dominante com o objetivo de excluir seus rivais do mercado. ${ }^{785}$

Da mesma forma, as autoridades antitruste da maioria das jurisdições reconhecem atualmente que cláusulas restritivas contidas em acordos de licenciamento podem servir a propósitos legítimos pró-concorrenciais. Desse modo, as proibições per se têm perdido espaço para uma análise antitruste fundada em critérios econômicos e de razoabilidade, levando em consideração os reais efeitos dessas restrições sobre a concorrência em determinado mercado relevante (de inovação, tecnologia ou de produto). ${ }^{786}$ Vimos que muitas das cláusulas consideradas restritivas podem ser justificadas com base em critérios de eficiência, uma vez que possibilitam a integração da propriedade licenciada com fatores complementares de produção, conduzindo a uma exploração mais eficiente dos direitos de propriedade intelectual, além de promover a inovação e a transferência de tecnologia, em benefício de produtores e usuários de conhecimentos tecnológicos, além dos consumidores, por meio da redução de custos e introdução de novos produtos no mercado. ${ }^{787}$

${ }^{785}$ Cf. MOTTA, Massimo. Competition Policy: Theory and Practice. Cambridge University Press, 2004, p. 69-70.

${ }^{786}$ Nesse sentido, BASSO afirma que: “(...) do ponto de vista concorrencial, o abuso de direitos de propriedade intelectual ocorre quando efetivamente combinado com condutas empresariais cujos efeitos restritivos intensificam-se nos mercados relevantes analisados, como, por exemplo, fixação de preços em licenciamento cruzado de marcas, fixação de preços de bens protegidos por patentes, acordos restritivos entre concorrentes relativos à fabricação e comercialização de bens objeto de proteção marcaria ou patentária. $\mathrm{O}$ abuso de direitos de propriedade intelectual, portanto, não poderia constituir per se conduta anticoncorrencial passível de sanção pelo direito antitruste, nem muito menos as ações do titular do direito visando zelar por ele. Conclui-se, portanto, que o teste jurisprudencial a ser minimamente observado nos casos relativos ao abuso de direitos de propriedade intelectual deve: (i) identificar (individualizar) se a prática levada a cabo pelo titular do direito é ilícita per se ou não, e (ii) demonstrar que os efeitos globais da conduta examinada (e.g., um contrato de licenciamento de marcas cruzadas) tendem à dominação dos mercados relevantes adequadamente definidos, resultando em restrições significativas à concorrência". BASSO, Maristela. Importação Paralela: Efeitos no Comércio Internacional e nos Direitos de Propriedade Intelectual. São Paulo: Atlas, 2011, p. 211.

${ }^{787}$ Conforme já mencionado, o Regulamento de 2004 sobre transferência de tecnologia, adotado pela Comissão Europeia, representou uma clara mudança de uma abordagem essencialmente formalista, baseada em listas de cláusulas proibidas, para uma abordagem mais flexível, consubstanciada na análise dos efeitos econômicos dos acordos de licenciamento e transferência de tecnologia, mais alinhada com as Diretrizes de 1995 adotadas pelo DOJ e pela FTC nos Estados Unidos. 
Diante dessa conjuntura atual, ainda que uma política de concorrência favorável a proibições per se possa ser, em princípio, compatível com o Acordo TRIPS ${ }^{788}$, é inegável que essa abordagem mais intervencionista seria prejudicial às próprias economias dos países em desenvolvimento, tendo em vista a possibilidade de afugentar investimentos estrangeiros ou mesmo de desencorajar a transferência internacional de tecnologias. ${ }^{789}$ Ademais, a aplicação de uma política nacional de concorrência que insista em recusar a validade de cláusulas restritivas, tais como licenças casadas, exclusividade, grantback, restrições territoriais, dentre outras, teria efeitos práticos limitados, na medida em que os licenciantes poderiam deslocar seus investimentos para outros países que permitem tais restrições. Afinal, os licenciantes podem escolher livremente seus licenciados. Além disso, a aplicação de medidas proibindo quaisquer dessas cláusulas somente teria efeitos sobre aqueles direitos de propriedade intelectual que tenham sido concedidos sob as leis do Estado responsável por essas medidas, não afetando os direitos concedidos em outros países, ainda que estejam cobertos por uma licença internacional. ${ }^{790}$

\footnotetext{
${ }^{788}$ Vimos que a expressão "em determinados casos" contida na redação do Artigo 40.2 do TRIPS parece refletir a intenção dos Membros de que práticas restritivas em acordos de licenciamento sejam analisadas pelas autoridades nacionais de defesa da concorrência com base em critérios de razoabilidade, o que não impede que determinados tipos de práticas sejam consideradas ilícitas per se. O objetivo desse dispositivo é assegurar que os Membros não especifiquem práticas ou condições restritivas da concorrência em acordos de licenciamento de modo genérico ou abstrato, mas com base nas circunstâncias de cada caso concreto, examinando seus reais efeitos sobre a concorrência nos respectivos mercados relevantes.

${ }^{789}$ Nesse sentido, RICOLFI afirma que: “(...) it is quite possible that some of the measures considered TRIPScompliant may eventually backfire on the economies of the Members that adopt them. Indeed, licensing by Northern firms to Southern businesses may end up being discouraged rather than promoted by overly restrictive legislation. This simple rules applies across-the-board: to exchange control and profit repatriation restrictions as well as to antitrust intervention aiming to forbid 'unfair' contractual arrangements. Just to mention an IP-specific situation, it has been often argued that outlawing clauses that prevent licensees from exporting licensed products either to the country of the licensor or to those of other licensees may in actual practice have an adverse impact on technology flows, thereby inducing a would-be licensor to give up the idea of licensing in the first place". RICOLFI, Marco. Is there an Antitrust Antidote against IP Overprotection within TRIPS?, in: Marquette Intellectual Property L. Rev. 10, 305, 2006, p. 336. Disponível em: http://scholarship.law.marquette.edu/iplr/vol10/iss2/6.

${ }^{790}$ ULLRICH aponta que uma política antitruste que negasse sistematicamente a validade de certas cláusulas teria efeitos apenas no mercado doméstico e poderia comprometer a competitividade internacional do licenciado, de modo que a tendência, ao longo do tempo, seria o abandono dessa abordagem intervencionista em favor de uma abordagem mais em linha com aquela adotada pelos países mais industrializados: "At best, therefore, a technology-transfer oriented competition policy would be effective only at the local level. When assessed in the context of other adverse competition policies, it would most likely fail to promote the larger goal of enhancing the licensee's international competitiveness. (...) Over time, moreover, the systemic operation and constraints of this innovation-efficiency approach to competition policy are likely to limit the scope of sovereign policy decisions by technologically less advanced countries". ULLRICH, Hans. Expansionist Intellectual Property Protection and Reductionist Competition Rules: A TRIPS Perspective, in: MASKUS, Keith E.; REICHMAN, Jerome H. (Ed.). International Public Goods and Technology Transfer Under a Globalized Intellectual Property Regime. Cambridge University Press, 2005, p. 426.
} 
Foram esses os motivos que levaram o Brasil a abandonar a política intervencionista adotada pelo INPI entre os anos 1970 e 80, que afugentou investidores estrangeiros e impediu as empresas brasileiras de se beneficiarem de tecnologia de ponta desenvolvida no exterior. Vimos que a partir dos anos 1990, após a abertura econômica, o INPI passou a flexibilizar o processo de averbação e registro de contratos de licenciamento e transferência de tecnologia, em linha com a maior inserção do país no comércio internacional. Desde então, cabe apenas aos órgãos brasileiros de defesa da concorrência, se for o caso, examinar cláusulas restritivas inseridas nesses acordos, sempre com base em critérios econômicos e de razoabilidade, ponderando-se as eficiências econômicas e seus eventuais efeitos anticoncorrenciais, já que, como vimos, não há ilícito antitruste per se no Brasil.

Diante do exposto, conclui-se que essa abordagem estática, orientada pela disseminação e transferência de tecnologia, tem perdido espaço para uma política de concorrência adotada atualmente nos países mais industrializados, política esta fortemente influenciada pela teoria econômica e orientada pela necessidade de se preservar os incentivos à inovação e promover a concorrência dinâmica nos mercados.

Isso não significa que os países em desenvolvimento não possuam outros meios, que não o direito da concorrência, para incentivar a transferência de tecnologia e promover o acesso da população a bens essenciais protegidos por direitos de propriedade intelectual. As flexibilidades constantes no Acordo TRIPS autorizam os países em desenvolvimento e menos desenvolvidos a adotar políticas socioeconômicas voltadas para setores de vital importância, tais como o de saúde pública e nutrição, de acordo com o disposto no Artigo 8.1 do TRIPS. $^{791}$ Esses países podem inclusive recorrer ao licenciamento compulsório de patentes nas hipóteses em que os preços de medicamentos essenciais impedirem seu acesso pela população, conforme expressamente reconhecido pela Declaração sobre TRIPS e Saúde Pública, adotada na Conferência Ministerial de Doha em 2001. ${ }^{792}$ Além disso, os países em desenvolvimento podem fortalecer os filtros

\footnotetext{
${ }^{791}$ Nos termos do Artigo 8.1 do TRIPS: “Os Membros, ao formular ou emendar suas leis e regulamentos, podem adotar medidas necessárias para proteger a saúde e nutrição públicas e para promover o interesse público em setores de importância vital para seu desenvolvimento socioeconômico e tecnológico, desde que estas medidas sejam compatíveis com o disposto neste Acordo".

792 A Declaração de Doha sobre TRIPS e Saúde Pública reconheceu que cada Membro tem o direito de conceder licenças compulsórias, possuindo total liberdade para determinar as bases para a determinação dessa medida (Declaração de Doha, Parágrafo 6). Vale ressaltar que a licença compulsória de patentes tem sido utilizada com sucesso pelo Brasil no âmbito de sua Política Nacional de AIDS, conferindo maior poder
} 
internos do sistema de propriedade intelectual, ampliando as limitações e exceções à exploração de direitos exclusivos. Esse tipo de medida poderia garantir melhores condições de acesso aos bens intelectuais e tecnologias, ampliando a liberdade de atuação de terceiros ("usuários de conhecimento tecnológico") sem prejudicar os legítimos interesses dos titulares de direitos exclusivos, além de conferir maior segurança e previsibilidade em relação aos direitos e obrigações de todas as partes interessadas.

\subsubsection{Abordagem orientada pela inovação}

Vimos que a premissa comum das orientações da maioria das jurisdições com experiência nessa área é a de que, em princípio, a propriedade intelectual não é conflitante com os objetivos da política de concorrência. Pelo contrário, se bem estruturada e administrada, a proteção aos direitos de propriedade intelectual fortalece a concorrência ao promover os incentivos necessários para o desenvolvimento de novos produtos, processos e serviços, além de facilitar a transferência de tecnologia. Essa relação de complementaridade entre a propriedade intelectual e o direito antitruste é consubstanciada por uma política de concorrência orientada pela inovação. Sob essa perspectiva, a análise antitruste de práticas restritivas a partir da exploração de direitos de propriedade intelectual - sejam restrições impostas em acordos de licenciamento ou condutas unilaterais de exclusão -, deve não apenas ponderar seus efeitos pró-competitivos (e pró-inovação) vis-àvis seus potenciais efeitos anticoncorrenciais, mas também levar em consideração os eventuais impactos negativos da intervenção das autoridades da concorrência sobre a estrutura de incentivos estabelecida pelo sistema de propriedade intelectual. ${ }^{793}$

de barganha ao governo federal nas negociações de preços de medicamentos antirretrovirais protegidos por patentes junto a laboratórios farmacêuticos multinacionais, possibilitando a distribuição gratuita e universal desses produtos no âmbito do Sistema Único de Saúde aos portadores do vírus HIV. Além disso, a regulação do setor farmacêutico também serviu para impor limitações aos preços de medicamentos comercializados no país. Nos termos da Lei n. ${ }^{\circ}$ 10.742, de 06 de abril de 2003, que criou a Câmara de Regulação do Mercado de Medicamentos - CMED, formada por representantes dos Ministérios da Saúde, Justiça, Fazenda e Casa Civil, foram estabelecidas normas de regulação do setor farmacêutico, com a finalidade de promover a assistência farmacêutica à população, por meio de mecanismos que estimulem a oferta de medicamentos e a competitividade do setor. Dessa forma, tendo em vista que o setor farmacêutico é altamente regulado, a imposição de preços de medicamentos novos, protegidos por patentes, não depende apenas da vontade do fabricante ou titular da patente, mas de critérios econômicos objetivos, adotados pela CMED, para o estabelecimento dos preços máximos que poderão ser praticados no mercado e de seus reajustes anuais.

793 Sobre a necessidade de se levar em consideração os incentivos à inovação na intervenção antitruste, as autoridades da concorrência norte-americanas, DOJ e FTC, afirmaram que: “(...) the Agencies must apply antitrust principles to identify illegal collusive or exclusionary conduct while at the same time supporting the incentives to innovate created by intellectual property rights. Condemning efficient activity involving intellectual property rights could undermine that incentive to innovate, and thus slow the engine that drives much economic growth in the United States". U.S. Dep't of Justice \& Fed. Trade Comm'n. Antitrust Enforcement and Intellectual Property Rights: Promoting Innovation and Competition, 2007, p. 02. No 
Nesse contexto, Hans ULLRICH afirma que as normas do Acordo TRIPS sobre concorrência seguem um modelo de política antitruste que se tornou obsoleto, concentrado em mercados de produtos e transferências de tecnologia pós-inovação por meio de acordos bilaterais de licenciamento celebrados entre empresas multinacionais, exportadoras de tecnologias, e empresas sediadas em países em desenvolvimento, que dependem dessas tecnologias para desempenharem suas atividades. Segundo o autor, essas áreas têm sido marginalizadas na medida em que a propriedade intelectual tem dado menor importância para a proteção das "corporificações materiais tangíveis", tais como equipamentos mecânicos e produtos farmacêuticos, para se concentrar em "objetos de proteção não corporificados", como softwares, bases de dados e insumos biotecnológicos, de modo que a tecnologia tem se tornado cada vez mais o "produto" a ser comercializado no mercado. ${ }^{794}$ Além disso, o equilíbrio entre estimular a inovação e promover a disseminação de tecnologia pode inclinar-se para o primeiro, na medida em que pools de patentes e licenças cruzadas têm sido tolerados pelas autoridades antitruste como arranjos contratuais voltados para a inovação, e não necessariamente como sistemas de disseminação de tecnologia. Esses acordos são arquitetados sobre o sistema de propriedade intelectual, mas, pelo menos em parte, modificam seu estímulo lógico fundamental, deixando de lado sua orientação individualista consubstanciada na exclusividade, para concentrar na inovação em grupo e no acesso às tecnologias mediante o licenciamento cruzado entre diferentes titulares de

mesmo sentido, as Diretrizes da Comissão Europeia sobre a aplicação do Artigo 102 aos abusos de exclusão, ao tratarem especificamente da recusa de venda (e de licenciar), também deixaram clara a importância de se levar em consideração os incentivos à inovação dos agentes econômicos dominantes antes de impor uma licença compulsória: "The Commission will consider claims by the dominant undertaking that a refusal to supply is necessary to allow the dominant undertaking to realize an adequate return on the investments required to develop its input business, thus generating incentives to continue to invest in the future, taking the risk of failed projects into account. The Commission will also consider claims by the dominant undertaking that its own innovation will be negatively affected by the obligation to supply, or by the structural changes in the market conditions that imposing such an obligation will bring about, including the development of follow-on innovation by competitors". Cf. Communication from the Commission - Guidance on the Commission's enforcement priorities in applying [Article 82 of the EC Treaty] to abusive exclusionary conduct by dominant undertakings, parágrafo 89.

${ }^{794}$ Nas palavras do autor: "The disembodied technological subject matter itself - rather than some particular embodiments of it - this increasingly became the product that was directly sold on the market. This is true, for exemple, in biotechnology to the extent that inventions are not transformed into goods, but are exploited as research tools of directly applied as a technology. It is particularly true of computer software and databases when licensed (as they normally are) as services rather than distributed as physical products. In all these cases, use of the protected matter is subject to strict contractual limitations and direct quantitative control; and there is no possibility of freeing trade from these constraints and promoting intra-brand competition by resorting to the doctrines of exhaustion. On the contrary, any potential network effects - though dependent in scope on the functional properties of the subject matter at issue - may become fully internalized, to the benefit of proprietors". ULLRICH, Hans. Expansionist Intellectual Property Protection and Reductionist Competition Rules: A TRIPS Perspective, in: MASKUS, Keith E.; REICHMAN, Jerome H. (Ed.). International Public Goods and Technology Transfer Under a Globalized Intellectual Property Regime. Cambridge University Press, 2005, p. 416. 
direitos exclusivos, com vistas à redução de custos de transação e eliminação de posições de bloqueio, aspectos que, segundo ULLRICH, vão além do alcance do Acordo TRIPS. ${ }^{795}$

De acordo com o autor, a perspectiva é a da concorrência como um processo dinâmico, com o poder de mercado visto como efêmero e necessário para estimular a inovação, de modo que a conduta que restringe a concorrência tem se tornado parte do processo de inovação. Nesse contexto, a lei antitruste serviria para promover a inovação, mais do que a concorrência em si, ainda que fosse possível supor que a inovação deveria ser considerada como consequência da concorrência. ${ }^{796}$ Segundo Hans UlLRICH, essa abordagem orientada pela inovação não estaria em linha com a ideia de equilíbrio consubstanciado no Artigo 7 do Acordo TRIPS, além de contrariar a própria orientação “disseminadora" contida nos Artigos 8.2 e 40, vislumbrada como um contrapeso ao fortalecimento dos padrões mínimos de proteção da propriedade intelectual, conforme explica a seguir:

Whatever the merits of this policy orientation may be, from a TRIPS perspective it implies much more than merely extending IPR-related competition policy beyond the licensing restrictions that the Agreement embraces. Here we are faced with a concerted effort in major markets to allow restrictive licensing agreements to reinforce the IPR-based protection of innovation opportunities and profits, with a view to enhancing the productive and innovative capacity of the IPR owner and to spurring the licensee to join in and cooperate with the former's project.

The end result tends to undermine the political balance that was struck by the TRIPS negotiations. Competition law rightly or wrongly, had been looked upon as a counterweight, and as a means of enabling third parties to participate in the benefits of 'adequate' intellectual property protection, in objective set out in Article 7 of the Agreement. Suddenly, under the new dispensation, competition law turns out to support the exploitation of exclusive rights and innovation in general. The technological and

\footnotetext{
${ }^{795}$ De acordo com ULLRICH: “(...) the supposed defects of the intellectual property system or, more precisely, of its individualistic orientation and its emphasis on single proprietors is overcome by institutional arrangements, which may or may not be market-driven, and these are used to support innovation. Whether this approach also implies group innovation or not will depend on whether a given pool is built around convergent, component, or complementary technologies. At the very least it certainly means that the incentives are shifted away from exclusivity to group access, if not membership". Ibid., p. 418-419.

${ }^{796}$ Ibid., p. 424.
} 
competitive position of right holders; the bulk of which reside in industrialized countries is accordingly strengthened.

Sem contestar o fato de que a política de concorrência atualmente adotada nos países industrializados tem dado maior ênfase à proteção aos incentivos à inovação, a abordagem proposta por ULLRICH merece algumas ressalvas. Em primeiro lugar, ainda que os incentivos à inovação dos titulares de direitos de propriedade intelectual possam ser levados em consideração na análise antitruste de práticas supostamente restritivas, as autoridades devem ter cautela para não perder de vista o objetivo primordial da política de concorrência, qual seja, o de proteger o processo competitivo nos mercados, que ao final conduz à inovação e à eficiência dinâmica. Se por um lado as autoridades da concorrência têm adotado uma abordagem mais tolerante com cláusulas restritivas em acordos de licenciamento, por outro, persistem preocupações com determinadas restrições capazes de estender o poder de mercado detido pelo licenciante em mercados de tecnologia para mercados de produtos verticalmente relacionados, como poderia ocorrer, por exemplo, com a inclusão de cláusulas de exclusividade, licenças casadas ou grantbacks exclusivos nesses acordos. ${ }^{797}$ Ainda que tais restrições devam ser analisadas sob a regra da razão, poderão vir a ser coibidas pelas autoridades antitruste na medida em que resultarem no fechamento do mercado para concorrentes efetivos ou potenciais, causando efeitos danosos sobre a inovação e a concorrência dinâmica.

O mesmo raciocínio se aplica aos pools de patentes que, como bem ressaltado por ULLRICH, têm sido cada vez mais tolerados pelas autoridades antitruste como arranjos

\footnotetext{
797 Vimos que as cláusulas de exclusividade (ou não concorrência), quando impostas por licenciantes que detenham poder de mercado substancial, podem prejudicar a concorrência intertecnologias ao provocar o fechamento do mercado a terceiros titulares de direitos de propriedade intelectual sobre tecnologias alternativas ou substitutas. As licenças casadas, assim como a venda casada em geral, podem ser prejudiciais à concorrência quando o licenciante detém poder de mercado suficiente no mercado da tecnologia licenciada, a montante, para forçar o licenciado a adquirir outro produto ou tecnologia que não deseja, e que muitas vezes sequer é protegido por direitos de propriedade intelectual. Caso a estratégia seja bem sucedida, poderá possibilitar que o licenciante alavanque seu poder de mercado para o mercado a jusante, resultando no fechamento desse mercado para possíveis concorrentes. Finalmente, a cláusula grantback com exclusividade pode ser diretamente prejudicial à inovação. Se a cláusula grantback obrigar o licenciado a conferir ao licenciante o direito exclusivo de explorar a propriedade intelectual sobre as melhorias realizadas, os incentivos do licenciado para investir em pesquisa e desenvolvimento a partir da tecnologia licenciada poderão ser drasticamente reduzidos ou totalmente eliminados, já que não haverá qualquer retorno desses investimentos. Além disso, cláusulas de grantback com exclusividade podem estender de forma indevida o poder de mercado do licenciante, permitindo-lhe controlar e acumular todas as melhorias e aprimoramentos desenvolvidos por seus licenciados durante e após a vigência do acordo de licenciamento e dos direitos de propriedade intelectual licenciados. Assim, caso o licenciante detenha poder de mercado no mercado relevante do produto ou da tecnologia licenciada, a cláusula de grantback com exclusividade poderá resultar em efeitos adversos sobre a concorrência dinâmica, reduzindo o processo de inovação.
} 
institucionais voltados para a inovação, redução de custos de transação e eliminação de posições de bloqueio. Vimos que essa tolerância depende da forma pela qual esses arranjos são estruturados, ou seja, se admitem apenas a inclusão de patentes complementares e/ou essenciais, se os pacotes de licenças ofertados para terceiros não são exclusivos, se os royalties a serem cobrados não são discriminatórios, dentre outras condicionantes. As preocupações das autoridades antitruste nesses casos se justificam em razão da possibilidade desses pools de patentes servirem para encobrir esquemas de colusão para fixação coletiva de preços, divisão de mercados e boicotes contra potenciais rivais. Além disso, há também preocupações com os riscos de prejuízos à concorrência resultantes de restrições impostas nos pacotes de licenças ofertados a terceiros, especialmente quando os membros do pool também atuam nos mercados a jusante dos produtos fabricados com a tecnologia licenciada. Nessas circunstâncias, a imposição de royalties discriminatórios ou a recusa coletiva de licenciar as tecnologias compartilhadas podem resultar no fechamento desses mercados a potenciais concorrentes capazes de desenvolver e ofertar tecnologias alternativas ou substitutas.

No que concerne aos abusos decorrentes do exercício unilateral de direitos de propriedade intelectual, vimos que as autoridades antitruste costumam ser cautelosas tendo em vista as dificuldades em distinguir claramente entre condutas abusivas de exclusão e condutas de competição agressiva por méritos, além dos consequentes riscos de condenações equivocadas que poderiam resultar em desincentivos à inovação e efeitos adversos ao processo competitivo nos mercados. ${ }^{798}$ No entanto, mesmo nesses casos é possível constatar que as autoridades antitruste podem optar por intervir quando o exercício desses direitos exclusivos servir de entrave à inovação e à concorrência dinâmica em mercados adjacentes. A recusa de licenciar é um exemplo muito claro desse tipo de intervenção. Vimos que a Comissão e os Tribunais da União Europeia têm admitido a imposição de licenciamento compulsório em "circunstâncias excepcionais", com o objetivo de remediar recusas abusivas de licenciar. Essas circunstâncias são definidas como aquelas raras situações em que agentes econômicos dominantes recusam licenciar direitos

\footnotetext{
798 Essa cautela tem justificativa quando as condutas investigadas envolvem direitos de propriedade intelectual válidos. Por outro lado, as autoridades antitruste tendem a repudiar com veemência condutas praticadas por agentes econômicos dominantes, consubstanciadas na imposição abusiva e deliberada de patentes inválidas, obtidas por meio de fraude junto aos órgãos patentários, ou mesmo na propositura de ações de infração que careçam de base legal, com o único objetivo de impedir o ingresso no mercado de novos concorrentes. Em termos de prejuízos à inovação, tais condutas podem resultar na exclusão de concorrentes capazes de desenvolver e ofertar produtos alternativos ou substitutos mais inovadores do que o produto ofertado pelo agente econômico dominante.
} 
exclusivos que sejam indispensáveis para o desenvolvimento de novos produtos, serviços e tecnologias, prejudicando inovação cumulativa (follow on innovation) e, consequentemente, a concorrência dinâmica. Os prejuízos tendem a ser ainda maiores em mercados de tecnologia da informação, caracterizados pela presença de externalidades de redes e efeitos lock-in, uma vez que potenciais inovadores não terão condições de ingressar em mercados secundários com tecnologias complementares sem ter acesso à tecnologia dominante protegida por direitos de propriedade intelectual. ${ }^{799}$

Em todos esses exemplos, a intervenção antitruste passa a ser necessária para proteger o processo competitivo, conduzindo à maior abertura dos mercados e, consequentemente, a condições mais propícias à inovação. Nesse contexto, as autoridades da concorrência não devem apenas se preocupar com os incentivos à inovação dos titulares de direitos de propriedade intelectual que venham a praticar condutas supostamente abusivas, mas também com os incentivos à inovação de concorrentes efetivos ou potenciais, os quais podem acabar sendo impedidos de lançar produtos inovadores no mercado em decorrência dessas condutas. Sob esse prisma, é inegável que as práticas abusivas que restringem a inovação tendem a ser mais danosas do que outras condutas anticoncorrenciais mais tradicionais, como os cartéis de preço. Isso porque as restrições sobre a inovação podem produzir efeitos adversos não apenas sobre a concorrência num dado mercado relevante, mas principalmente sobre o crescimento econômico e o progresso científico e tecnológico, provocando imensas perdas de bem-estar social. ${ }^{800}$

Desse modo, é possível concluir que uma política de concorrência orientada pela inovação deve permitir que o sistema de propriedade intelectual cumpra sua função essencial de impedir concorrência pela imitação, permitindo que as autoridades antitruste concentrem seus esforços na proteção da concorrência dinâmica, ou seja, pela superação ou substituição, mantendo na medida do possível os mercados abertos ao ingresso de agentes

\footnotetext{
799 Vimos que, nessas circunstâncias, a recusa de licenciar pode ser utilizada como estratégia para criar incompatibilidades entre a tecnologia dominante ("padrão de fato"), protegida por direitos exclusivos, e tecnologias complementares desenvolvidas por concorrentes em mercados secundários.

${ }^{800}$ Nesse sentido, Herbert HovENKAMP afirma que: “(...) if innovation contributes so much more than competition to economic growth, then restraints on innovation very likely produce a far greater amount of economic harm than classical restraints on competition. As a result, antitrust, with its heavy concern that prices be kept as close as possible toward cost, is often shooting at the wrong target. Restraints on innovation are very likely even more harmful than traditional price cartels, which we usually consider to be the most harmful anticompetitive practice. Innovation restraints are almost certainly more harmful than a great many of the exclusionary practices that antitrust has condemned, often without fully understanding them". HOVENKAMP, Herbert. Restraints on Innovation (December 23, 2007). Cardozo Law Review, v. 27, n.1, 2007, p. 248. Disponível em SSRN: http://ssrn.com/abstract=1438117.
} 
econômicos capazes de ofertar novos produtos e serviços alternativos aos já existentes e, assim, ampliar as possibilidades de escolha dos consumidores. ${ }^{801}$ Nessa perspectiva, a intervenção antitruste seria cabível sempre que agentes econômicos abusassem de seus direitos de propriedade intelectual para inviabilizar essa concorrência dinâmica, seja por meio do fechamento do mercado para novos entrantes potencialmente inovadores, ou mesmo pela exclusão de rivais efetivos capazes de desenvolver produtos mais inovadores.

Portanto, não há nada de incompatível nas disposições do TRIPS sobre concorrência com essa abordagem orientada pela inovação, já que as restrições pósinovação em mercados de tecnologia e de produto continuam sendo objeto de preocupação por parte das autoridades antitruste da maioria das jurisdições, sobretudo quando tais restrições produzem efeitos adversos sobre a concorrência dinâmica, impedindo o processo de inovação cumulativa conducente ao crescimento econômico, ao progresso técnico e ao bem-estar dos consumidores.

\subsection{Limites da intervenção antitruste e a importância dos princípios concorrenciais na formulação das leis de propriedade intelectual}

É inegável que a propriedade intelectual e o direito antitruste constituem instrumentos complementares de incentivo à inovação, muito embora busquem esse objetivo de forma distinta. Enquanto as leis antitruste visam à proteção do processo competitivo nos mercados, em benefício da inovação e do bem-estar dos consumidores, as leis de propriedade intelectual têm como objetivo principal a promoção da inovação, estabelecendo condições favoráveis para que autores e inventores recuperem os investimentos incorridos nas atividades de criação intelectual.

Por outro lado, tanto a propriedade intelectual como o direito antitruste, se mal administrados ou fundados em premissas equivocadas, podem ser prejudiciais à inovação e à concorrência dinâmica. As leis de propriedade intelectual podem desestimular o processo criativo ao conferir proteções excessivas a patentes e direitos autorais, muito além do que seria necessário para criar os incentivos adequados à inovação. Já o direito antitruste pode ser prejudicial à concorrência dinâmica na medida em que coibir ou penalizar formas legítimas de exploração de direitos de propriedade intelectual, com o objetivo de proteger

${ }^{801}$ Cf. DREXL, Josef. Is there a "More Economic Approach" to Intellectual Property and Competition Law?, in: DREXL, Josef (Ed.). Research Handbook on Intellectual Property and Competition Law. Cheltenham: Edward Elgar, 2008, p. 47. 
agentes econômicos menos eficientes que muitas vezes dependem da cópia ou imitação para concorrer no mercado. Desse modo, as eventuais situações de conflito entre propriedade intelectual e direito antitruste são muitas vezes o resultado de escolhas equivocadas de política pública e falhas legislativas, que impedem a desejada convergência entre os dois sistemas em benefício do desenvolvimento econômico e social, e do progresso técnico, científico, literário e artístico. ${ }^{802}$

Muitos casos que envolvem discussões de propriedade intelectual e antitruste decorrem de imperfeições existentes na própria legislação nacional de propriedade intelectual, que muitas vezes falha ao conferir proteções excessivas e amplas e, sobretudo, ao não definir com clareza os limites e exceções à exploração de direitos exclusivos, o que pode ser prejudicial à concorrência dinâmica e ao processo de inovação cumulativa. Nesse sentido, Hans ULLRICH afirma que: “(...) because legislators often fail to properly define the limits of exclusive property rights, the exercise of these rights in new situations, and especially with regard to new technologies, attracts scrutiny under competition law, with a view to preventing anticompetitive market foreclosure". ${ }^{803}$ Vale mencionar como exemplo os já comentados casos Magill e IMS Health, julgados pelo Tribunal de Justiça da União Europeia. Alguns autores entendem que os problemas concorrenciais nesses casos decorreram de direitos autorais definidos de maneira excessivamente abrangente pelas respectivas leis nacionais, o que acabou sendo determinante para que o Tribunal concluísse pela abusividade da recusa de licenciar esses direitos. ${ }^{804}$

\footnotetext{
${ }^{802}$ Nesse sentido, LEMLEY esclarece que: "The goal of both IP and antitrust as regulatory policy should be to balance the need for incentives to innovate against the need for robust competition. We need both innovation and competition to achieve dynamic efficiency. IP laws should ideally encourage innovation up to the optimal level, but no further, because overly strong IP laws unduly interfere with competition and therefore reduce welfare unnecessarily. The same is true in reverse: overly aggressive competition law sometimes privileges static efficiency over innovation and therefore reduces long-term welfare. To this balance we must add another: too much emphasis on IP to encourage innovation may have the opposite effect, impeding innovation, while too much emphasis on competition in an effort to spur innovation may also prove counterproductive". LEMLEY, Mark A. A New Balance Between IP and Antitrust (April 1, 2007). Southwestern Journal of Law and Trade in the Americas, v. 13, p. 18, 2007; Stanford Law and Economics Olin Working Paper n. 340. Disponível em SSRN: http://ssrn.com/abstract=980045

${ }^{803}$ ULLRICH, Hans. Expansionist Intellectual Property Protection and Reductionist Competition Rules: A TRIPS Perspective, in: MASKUS, Keith E.; REICHMAN, Jerome H. (Ed.). International Public Goods and Technology Transfer Under a Globalized Intellectual Property Regime. Cambridge University Press, 2005, p. 401.

${ }^{804}$ No caso Magill, os direitos autorais previstos na legislação inglesa e irlandesa foram considerados excessivamente amplos por conferirem às companhias de TV o controle total sobre as informações referentes às listas de programação televisiva (informações estas que eram enviadas diariamente aos jornais de forma gratuita), em vez de limitar-se apenas a uma expressão original dessas informações. De forma semelhante, no caso IMS Health também foi questionada a proteção autoral sobre um formato geográfico ("1860-brick structure") que se tornou um padrão industrial de facto para apresentação de dados sobre
} 
Diante de casos como esses, as autoridades antitruste acabam tendo de intervir muito mais para corrigir as falhas das leis de propriedade intelectual do que para promover a concorrência nos mercados, aumentando a probabilidade de decisões equivocadas e gerando incertezas aos titulares de direitos exclusivos e a terceiros interessados quanto aos limites legais para a exploração desses direitos. Como se sabe, o direito da concorrência não tem como objetivo corrigir defeitos de regimes legais e regulatórios, ou mesmo resolver problemas estruturais que decorram da própria existência de um direito de propriedade intelectual, já que essa é uma função que cabe ao Poder Legislativo, como bem ressaltado por Annette KUR:

A general, fundamental division of tasks must be observed between the legislature promulgating intellectual law provisions, on the one hand, and competition authorities acting on the basis of competition law, on the other. Competition rules are charged with addressing conflicts arising out of the individual circumstances in a specific situation; they are not an appropriate instrument to solve structural problems ensuing from the very existence of an intellectual property right. If a serious problem of the latter type arises, it is therefore primarily a task for the legislature, and not for competition authorities, to react. ${ }^{805}$

Assim, é possível afirmar que não cabe às autoridades da concorrência intervir na "exploração normal" dos direitos de propriedade intelectual (utilizando a expressão contida no Artigo 30 do TRIPS) ${ }^{806}$, consubstanciada no direito de excluir terceiros não

vendas no mercado farmacêutico da Alemanha. Ainda que o mérito dos direitos autorais não tenha sido levado em consideração pelo TJUE, alguns autores consideram que o caráter amplo desses direitos acabou influenciando o resultado final do caso. É o que explicam FORRESTER e CZAPRACKA: "Both in Magill and $I M S$, the IP in question was controversial and the copyrighted work was distributed free of charge to commercial partners or intermediaries. In both cases, there was said to be an imbalance between the creative effort of the right holder and the economic advantages flowing from its exercise of the right. In Magill, the challenged copyrights were criticized as an anomaly, as they granted TV companies control over information (channel, day, time, and title of programmes) and not just the way in which that information was expressed. Similarly, in IMS, the scope of the copyright in question as well as entitlement to the copyright were debated, a debate which is still unresolved today years later. Although the merits of extending copyright protection were not directly considered in Magill or in IMS, they had significance for the final outcome of each case". FORRESTER, Ian S.; CZAPRACKA, Katarzyna A. Compulsory License in European Competition Law: The Power of the Adjective, in: ANDERMAN, Steven; EZRACHI, Ariel. Intellectual Property and Competition Law: New Frontiers. Oxford University Press, 2010, p. 157-158.

${ }^{805}$ KUR, Annette. Limiting IP Protection for Competition Policy Reasons - a case study based on the EU spare-parts-design discussions, in: DREXL, Josef. Research Handbook on Intellectual Property and Competition Law. Cheltenham, UK: Edward Elgar, 2008, p. 327.

${ }^{806}$ O significado do termo "exploração normal" constante no Artigo 30 do TRIPS, que dispõe sobre as limitações e exceções à exploração de patentes, já foi discutido por um Painel instaurado no âmbito do Órgão de Solução de Controvérsias da OMC, no caso Canada - Pharmaceutical Patents. Nesse caso, o Painel 
autorizados e de impedir a concorrência pela cópia ou imitação. ${ }^{807}$ Essa intervenção somente seria desejável quando a exploração de direitos exclusivos extrapolasse os limites previstos em lei, o que poderia se dar por meio de condutas voltadas para a ampliação indevida do escopo de proteção desses direitos, em decorrência do exercício abusivo de poder de mercado. ${ }^{808}$ Por outro lado, se a legislação é falha em relação à definição dos limites e da extensão da "exploração normal" de direitos de propriedade intelectual, caberia ao Poder Legislativo, e não ao direito antitruste, intervir para estabelecer as devidas correções legais e regulatórias, podendo inclusive valer-se dos parâmetros do Acordo TRIPS em relação aos limites e exceções estruturados a partir da chamada "regra dos três passos". 809 Quando muito, a "exploração normal" poderia ser limitada pelo direito antitruste apenas em "circunstâncias excepcionais" nas quais uma recusa de licenciar por parte de um agente econômico detentor de posição dominante viesse a prejudicar a

considerou que a exploração normal de uma patente, assim como de qualquer direito de propriedade intelectual, deve ser definida como aquela que permite ao seu titular excluir todas as formas de concorrência que poderiam depreciar significativamente os retornos econômicos decorrentes de seu direito de exclusividade, como forma de estimular a inovação, como se pode observar no trecho a seguir: "The normal practice of exploitation by patent owners, as with owners of any other intellectual property right, is to exclude all forms of competition that could detract significantly from the economic returns anticipated from a patent's grant of market exclusivity. The specific forms of patent exploitation are not static, of course, for to be effective exploitation must adapt to changing forms of competition due to technological development and the evolution of marketing practices. Protection of all normal exploitation practices is a key element of the policy reflected in all patent laws. Patent laws establish a carefully defined period of market exclusivity as an inducement to innovation, and the policy of those laws cannot be achieved unless patent owners are permitted to take effective advantage of that inducement once it has been defined". Cf. Panel Report on Canada - Pharmaceutical Patents, WT/DS114/R, 17 March 2000, parágrafos 7.54-7.55.

${ }^{807}$ Sobre o assunto, GHIDINI esclarece que: “(...) the exercise of the power to exclude unauthorized third parties, even if implemented in contractual forms, reflected the essential function of IPRs and hence also that untouchable normal exercise of the rights themselves as distinct from other anti-competitive behavior by IPRs holders aimed at exploiting their position of strength on the market in their dealings with third parties, and the consequent generation of further anti-competitive effects. Thus, only those further contractual exercises whereby IPRs are used as a lever to expand market power beyond their (normal) anti-free-riding function would be restricted by antitrust law. In other words, that perspective did not challenge the sanctuary of IPRs owners' absolute power to exclude unauthorized third parties seeking access to the use of the IPRprotected innovation/creation". GHIDINI, Gustavo. Innovation, Competition and Consumer Welfare in Intellectual Property Law. UK: Edward Elgar, 2010, p. 217.

${ }^{808}$ Nesse sentido, HoVENKAMP esclarece que não cabe às autoridades antitruste estabelecer limitações de escopo e duração dos direitos exclusivos, mas tão somente intervir quando condutas anticoncorrenciais extrapolarem o escopo de proteção definido em lei: "Practices that reach beyond the scope of protection given by an IP right can violate the antitrust laws. Such issues arise, for example, when a patent license calls for price-fixing or some kind of exclusion that the relevant IP provision does not authorize, or when a dominant firm files an infringement suit based on a claim that is broader than its patent actually creates. Practices such as these can be both anticompetitive and antitrust violations. But they are so only when the IP right holder exceeds the scope of its IP right, and making that determination depends on the relevant IP provision, not on antitrust. Notably, there is no antitrust law that defines the scope of patent claims, or the breadth of copyright 'fair use', or whether a competing product infringe a trademark". HOVENKAMP, Herbert. The Antitrust Enterprise: Principle and Execution, Harvard University Press, p. 255-257.

${ }^{809}$ Conforme já mencionado anteriormente, a "regra dos três passos" prevista no Acordo TRIPS estabelece as balizas para a definição de limites e exceções legais à exploração de direitos de propriedade intelectual e o alcance da atuação legítima de terceiros interessados. 
concorrência dinâmica no mercado, em detrimento do processo de inovação cumulativa, muito embora a maioria desses casos seja consequência de imperfeições do próprio sistema de propriedade intelectual.

Diante dessas considerações, é possível concluir que muitos dos problemas concorrenciais decorrentes da exploração de direitos exclusivos poderiam ser solucionados por meio de intervenções estruturais nas próprias leis de propriedade intelectual, com o objetivo de definir claramente o escopo da proteção desses direitos e as respectivas limitações e exceções ao seu exercício. Sob a perspectiva do Acordo TRIPS, é possível sustentar que suas normas sobre concorrência - considerando a ampla autonomia que conferem aos Membros da OMC - não são limitadas à persecução de políticas nacionais de concorrência fundadas na intervenção antitruste ex post, podendo também ser vislumbradas como instrumentos de política pública ex ante, concernentes à incorporação de elementos pró-competitivos na formulação das leis de propriedade intelectual. Essa constatação está inerente na linguagem ampla contida no Artigo 8.2 do Acordo TRIPS, ao reconhecer que “medidas apropriadas" poderão ser necessárias para coibir abusos e práticas restritivas, não havendo qualquer impedimento para que tais medidas sejam implementadas a partir de esforços legislativos voltados para a incorporação de princípios concorrenciais na estruturação de sistemas nacionais de propriedade intelectual. ${ }^{810}$

Nesse sentido, RICOLFI afirma que o desejado equilíbrio concorrencial entre "produtores e usuários de conhecimento tecnológico" pode ser alcançado de maneira mais eficiente por meio do aperfeiçoamento dos regimes de propriedade intelectual do que pela intervenção antitruste ex post. ${ }^{811}$ Para ele, a incorporação de princípios concorrenciais na estruturação do sistema de propriedade intelectual possibilita resultados mais previsíveis por se tratar de medida adotada ex ante, conferindo maior grau de certeza aos agentes econômicos atuantes no mercado no momento de investirem em inovação. Em contrapartida, a intervenção antitruste ex post pode resultar em longas e custosas investigações com desfechos imprevisíveis, sem contar os riscos de decisões equivocadas capazes de prejudicar a própria concorrência e a estrutura de incentivos vislumbrada pela propriedade intelectual.

\footnotetext{
${ }^{810}$ Desde que tais medidas sejam coerentes com as disposições do Acordo TRIPS e não interfiram nos padrões mínimos de proteção nele estabelecidos.
} 
A conotação ampla da política de concorrência pressupõe a possibilidade da edição de normas em abstrato que tenham impacto sobre mercados livres ou regulados. ${ }^{812}$ É desejável, portanto, que as normas que disciplinam as criações intelectuais e industriais sejam influenciadas pela política concorrencial, com vistas ao fortalecimento da relação de complementaridade (e a coerência) entre a legislação de propriedade intelectual e a legislação antitruste, considerando o objetivo fundamental de se criar condições favoráveis à inovação nos mercados, em benefício do bem-estar econômico e social. É nesse contexto que o Professor Calixto SALOMÃo FILHO afirma que: "ao contrário do que normalmente se acredita, a compreensão do direito industrial dentro da lógica institucional do direito concorrencial é a única capaz de dar ao primeiro a conotação publicística de que este necessita". ${ }^{813}$ Diante dessa relação de complementaridade, é inegável que as normas de propriedade intelectual podem e devem ser estruturadas sob a influência de princípios concorrenciais, seja no que concerne à determinação dos limites de escopo e duração dos direitos exclusivos, ou mesmo na definição das limitações e exceções ao exercícios desses direitos, levando-se em consideração os interesses legítimos dos "produtores e usuários de conhecimento tecnológico".

Sob essa perspectiva, a coerência entre as normas de propriedade intelectual e as normas antitruste é medida necessária para impedir que os direitos exclusivos constituam instrumentos de domínio sobre os mercados e entraves à inovação e à disseminação do conhecimento. ${ }^{814}$ Da mesma forma, essa coerência exigiria que as autoridades antitruste aprimorassem seus conhecimentos sobre propriedade intelectual, de modo a reduzir os riscos de decisões equivocadas consubstanciadas em proibições

${ }^{811}$ Cf. RICOLFI, Marco. Is there an Antitrust Antidote against IP Overprotection within TRIPS?, in: Marquette Intellectual Property L. Rev. 10, 305, 2006, p. 329. Disponível em: http://scholarship.law.marquette.edu/iplr/vol10/iss $2 / 6$.

${ }^{812}$ Cf. Goldberg, Daniel. Poder de Compra e Política Antitruste. São Paulo: Singular, 2006, p. 28.

${ }^{813}$ Salomão Filho, Calixto. Direito Industrial, Direito Concorrencial e Interesse Público, in: Revista de Direito Público da Economia, Belo Horizonte, ano 2, n. 7, p. 33, jul./set. 2004.

${ }^{814}$ Nesse sentido, REMÉDIO MARQUES, afirma que "É sob o princípio-matriz da liberdade de concorrência que devemos, outrossim, extrair o sentido e o alcance do conteúdo das concretas políticas legislativas em sede de direitos de exclusivos e do conteúdo das normas aí existentes, sob pena de o sub-sistema da propriedade intelectual 'sucumbir sob o seu próprio peso super-proteccionista', e de os seus instrumentos jurídicos passarem a desempenhar a função protecionista em favor das empresas dominantes. Que o mesmo é dizer que a propriedade intelectual passaria a ser um fator de restrição da oferta (de conhecimento e de cultura) e um travão à inovação tecnológica. Risco tanto mais actual quanto a actual tendência de os mercados (v.g., das telecomunicações, da indústria de conteúdos fornecidos em linha, da indústria biotecnológica, da indústria do design) se transformarem em mercados oligopolistas". REMÉDIO MARQUES, J.P. Propriedade Intelectual e Interesse Público, in: Boletim da Faculdade de Direito da Universidade de Coimbra, n. 79, p. 350, 2003. 
genéricas a formas de "exploração normal" de direitos exclusivos, o que também pode ser prejudicial à própria concorrência dinâmica e ao processo de inovação, além de causar incertezas quanto à determinação da fronteira entre condutas lícitas e ilícitas. ${ }^{815}$ Nesse contexto, é de extrema valia a celebração de convênios ou acordos de cooperação técnica entre as autoridades da concorrência e as autoridades responsáveis pela concessão de direitos exclusivos, de modo a possibilitar a troca de experiências e conhecimentos técnicos em matéria de direito antitruste e de propriedade intelectual. O acordo de cooperação técnica celebrado entre o CADE e o INPI é um bom exemplo que poderia ser seguido por outros países em desenvolvimento. ${ }^{816}$

Experiências recentes também sublinham a importância da advocacia da concorrência por parte das autoridades antitruste com o objetivo de assegurar que as patentes e outras formas de direitos de propriedade intelectual não sejam concedidas desnecessariamente ou expressas em termos excessivamente amplos. Tais atividades podem incluir aquelas ligadas à educação pública, estudos e pesquisas realizados para documentar a necessidade de medidas visando à abertura de mercados, apresentações formais perante comitês legislativos ou outros órgãos governamentais, dentre outras. ${ }^{817}$

Um exemplo pertinente e muito importante da atividade da advocacia da concorrência na área da propriedade intelectual diz respeito ao relatório publicado em 2003

\footnotetext{
${ }^{815}$ Sobre essa questão, SCHUARTZ esclarece com propriedade que: “A clareza na distinção entre o lícito e o ilícito, de que depende a segurança jurídica dos agentes econômicos e a preservação dos incentivos adequados para a promoção da concorrência, requer que tal distinção não se sustente exclusivamente em uma aposta do agente quanto aos resultados de um cálculo, sempre imperfeito e incompleto, de custos e benefícios sociais pela autoridade antitruste. Se o direito de defesa da concorrência deve ser usado não para subverter, mas para promover a competição, então é necessário que os agentes não sejam dissuadidos de competir agressivamente uns contra os outros, seja por não terem como prever, com um mínimo grau de certeza, como as autoridades julgarão as suas condutas e estratégias, seja ainda por temor de que as suas condutas venham a ser equivocadamente consideradas ilícitas pelas autoridades". SCHUARTZ, Luis Fernando. Inovações e defesa da concorrência: em busca de uma política que minimize os custos de decisões equivocadas, in: TIMM, Luciano Benetti; PARANAGUÁ, Pedro. Propriedade Intelectual, Antitruste e Desenvolvimento: caso da transferência de tecnologia e do software. Rio de Janeiro: FGV Direito Rio, 2009, p. 48.

${ }^{816}$ Nos termos do acordo de cooperação técnica entre CADE e INPI, poderão os partícipes prestar consultoria mútua sobre direito da concorrência e propriedade intelectual, realizar estudos em conjunto e participar de seminários sobre o tema, bem como trocar informações técnicas. Ademais, o CADE poderá solicitar o auxílio do INPI em investigações de condutas anticoncorrenciais que envolvam direitos de propriedade industrial, da mesma forma que o INPI, quando do exercício de suas atribuições legais, poderá encaminhar ao CADE informações sobre possíveis infrações à ordem econômica. Cf. Acordo de Cooperação Técnica celebrado entre o INPI, a União, por intermédio da SDE, e o CADE, em 07 de junho de 2010. Disponível em: http://www.cade.gov.br/upload/Acorco\%20de\%20Coopera\%C3\%A7\%C3\%A30\%20CADE_SDE_INPI.pdf. Acesso em: 25 nov. 2012.

${ }^{817}$ Cf. ANDERSON, Robert D. Competition Policy and Intellectual Property in the WTO: More Guidance Needed?, in: DREXL, Josef (Ed.). Research Handbook on Intellectual Property and Competition Law. Cheltenham: Edward Elgar, 2008, p. 468.
} 
pela FTC, o qual traz uma profunda discussão sobre os efeitos prejudiciais sobre a concorrência que podem advir da concessão de patentes indevidas ou expressas em termos excessivamente amplos, além de apresentar uma série de propostas para tratar do problema. $^{818}$ Em março de 2010, a mesma FTC publicou novo relatório sugerindo modificações para aprimorar o sistema de patentes, de modo a promover a concorrência e a inovação em benefício dos consumidores. ${ }^{819}$ Conforme bem ressaltado por Edith RAMIREZ, Comissária da FTC, ao comentar o relatório: "When the patent system incorporates the principles of competition policy, the patent and antitrust laws work together to achieve their common goal. The recommended changes would benefit consumers by encouraging investments in innovation and promoting competition among patented technologies". 820

As implicações dessas considerações para os países em desenvolvimento são claras: quanto mais extensivamente os direitos de propriedade intelectual são definidos pela legislação, mais provável a configuração de poder de mercado e de seu exercício abusivo por parte dos titulares desses direitos, exigindo a intervenção das autoridades antitruste. $^{821}$ Em contrapartida, quanto mais equilibrado o sistema de propriedade intelectual, menos prováveis serão as situações de conflito com o sistema concorrencial e, por conseguinte, menores os custos e riscos de decisões equivocadas capazes de trazer incertezas ao mercado. De qualquer modo, mesmo com o aperfeiçoamento das leis de propriedade intelectual, sempre haverá a possibilidade de abusos, tendo em vista a complexidade de determinadas estratégias e práticas restritivas a partir da exploração de direitos exclusivos, o que requer a atuação vigilante das autoridades antitruste. Sejam quais forem as circunstâncias, o desafio será sempre o mesmo: buscar fortalecer a relação de complementaridade entre a propriedade intelectual e a política de concorrência com vistas à criação de incentivos à inovação e à promoção da concorrência dinâmica nos mercados.

\footnotetext{
${ }^{818}$ Cf. Federal Trade Commission. To Promote Innovation: The Proper Balance of Competition and Patent Law and Policy, October 2003. Disponível em: http://www.ftc.gov/os/2003/10/innovationrpt.pdf. Acesso em: 26 nov. 2012.

${ }^{819}$ Cf. Federal Trade Commission, The Evolving IP Marketplace, Aligning Patent Notice and Remedies with Competition (2011). Disponível em: www.ftc.gov/os/2011/03/110307patentreport.pdf. Acesso em: 26 nov. 2012.

${ }^{820}$ FTC Report Recommends Improvements in Patent System to Promote Innovation and Benefit Consumers. Press Release published on 03/07/2011. Disponível em: http://www.ftc.gov/opa/2011/03/patentreport.shtm. Acesso em: 26 nov. 2012.

${ }^{821}$ Cf. HEINEMANN, Andrea. Antitruste Internacional e Propriedade Intelectual, in: RODRIGUES JR., Edson Beas; POLIDO, Fabrício (Orgs.). Propriedade Intelectual: Novos Paradigmas Internacionais, Conflitos e Desafios. Rio de Janeiro: Elsevier, 2007, p. 451.
} 


\title{
CONCLUSÕES
}

\begin{abstract}
Durante as negociações do Acordo TRIPS/OMC, os países em desenvolvimento manifestaram preocupação com o fato de que o fortalecimento dos padrões internacionais para a proteção da propriedade intelectual poderia resultar no aumento da incidência de práticas restritivas capazes de prejudicar o comércio e a transferência internacional de tecnologia. A despeito da falta de interesse dos países desenvolvidos em relação ao tema, normas sobre concorrência acabaram sendo incluídas no TRIPS como resultado de concessões feitas aos países em desenvolvimento em troca do fortalecimento da proteção da propriedade intelectual. As disposições relevantes sobre concorrência foram incluídas no Artigo 8.2, que autoriza os Membros a adotarem medidas apropriadas para evitar abusos dos direitos de propriedade intelectual e práticas que restrinjam o comércio e a transferência internacional de tecnologia, no Artigo 40, que dispõe sobre o controle das práticas restritivas em acordos de licenciamento de direitos de propriedade intelectual, e no Artigo 31(k), que trata do licenciamento compulsório de patentes para remediar práticas anticoncorrenciais.
\end{abstract}

No entanto, as disposições do TRIPS sobre concorrência, embora representem um elemento essencial de equilíbrio constante no Acordo, também deixaram importantes questões sem resposta. De fato, essas normas, da forma como estão redigidas, são vagas e não fornecem diretrizes adequadas para que os países em desenvolvimento possam implementar políticas públicas nacionais a fim de coibir práticas restritivas da concorrência relacionadas à exploração de direitos de propriedade intelectual. A redação aberta e flexível constante nos Artigos 8.2 e 40 do TRIPS permite concluir que esses dispositivos foram vislumbrados meramente como regras de contenção para as políticas nacionais de concorrência, consubstanciadas nas exigências de proporcionalidade e consistência, e não como obrigações afirmativas capazes de orientar o desenvolvimento apropriado do tema nos ordenamentos jurídicos internos dos Membros da OMC.

Diante da experiência limitada dos países em desenvolvimento e de menor desenvolvimento relativo para lidar com complexas questões envolvendo a interface entre propriedade intelectual e direito antitruste, é inegável que a troca de experiências sobre o tema entre os diferentes Membros da OMC pode ser extremamente proveitosa. Nesse contexto, a experiência das duas jurisdições mais avançadas nessa área - Estados Unidos e União Europeia - pode servir como referência para que os países em desenvolvimento 
sejam capazes de implementar normas e instituições de concorrência adaptadas às suas próprias realidades, necessidades e prioridades de política pública.

O desenvolvimento da interface entre propriedade intelectual e política de concorrência nos Estados Unidos e na União Europeia foi marcado por ciclos de maior ou menor intervenção antitruste. Após um período de maior predominância do direito da concorrência sobre a propriedade intelectual, as autoridades antitruste e tribunais norteamericanos e europeus passaram a compartilhar o entendimento de que a propriedade intelectual e o direito antitruste são instrumentos complementares de promoção da inovação e do bem-estar dos consumidores. Nesse contexto, prevalece atualmente uma abordagem menos intervencionista sobre a exploração de direitos exclusivos, especialmente no que concerne às práticas restritivas em acordos de licenciamento e transferência de tecnologia, a despeito de ainda haver diferenças relevantes entre as duas jurisdições em relação ao tratamento das condutas unilaterais de exclusão.

Em relação ao tratamento das cláusulas restritivas em acordos de licenciamento, é possível constatar o gradual abandono de uma abordagem essencialmente formalista, consubstanciada em proibições per se a determinadas cláusulas previamente definidas, para a adoção de uma abordagem baseada em critérios de razoabilidade, concentrada no exame caso a caso dos reais efeitos econômicos dessas condutas em determinado mercado relevante (de inovação, tecnologia, ou de produto), de modo a verificar se os eventuais efeitos negativos podem ser compensados por eficiências econômicas. Essa mudança de posicionamento decorreu do reconhecimento dos benefícios econômicos desses acordos, não apenas por conduzirem à disseminação de tecnologias e promoção da inovação, mas também por possibilitar a integração de tecnologias complementares para o desenvolvimento de novos produtos em benefício dos consumidores. Nesse contexto, considera-se que determinadas cláusulas potencialmente restritivas, tais como licenças casadas, exclusividade e grantback, podem resultar em ganhos de eficiência dinâmica e estática favoráveis à concorrência.

No que concerne aos padrões de análise antitruste de condutas unilaterais de exclusão relacionadas à exploração de direitos de propriedade intelectual, ainda pairam divergências entre as duas jurisdições, como se observa claramente nos casos de recusa de licenciar. Enquanto as autoridades e tribunais norte-americanos adotam uma abordagem mais liberal e, portanto, menos intervencionista em relação à exploração unilateral de 
direitos exclusivos, a Comissão e os tribunais da União Europeia tendem a ser mais hostis nesses casos, sendo comum o recurso ao licenciamento compulsório em circunstâncias excepcionais nas quais uma recusa de licenciar por parte de um agente econômico dominante impede o desenvolvimento de novos produtos por seus concorrentes em mercados secundários. A despeito dessas divergências culturais em matéria de política de concorrência, é possível constatar que as autoridades antitruste e os tribunais norteamericanos e europeus costumam ser cautelosos para evitar o risco de condenações equivocadas de condutas legítimas baseadas na concorrência por méritos, que beneficiam a concorrência dinâmica e os consumidores, ainda que tenham a aparência de condutas anticoncorrenciais.

A partir do exame da experiência dos Estados Unidos e da União Europeia no controle de práticas restritivas relacionadas à exploração de direitos de propriedade intelectual, é possível concluir que a política antitruste atualmente adotada nessas duas jurisdições possui uma abordagem claramente orientada pela inovação. Sob essa perspectiva, a análise antitruste dessas condutas - sejam restrições impostas em acordos de licenciamento ou condutas unilaterais de exclusão - deve não apenas ponderar seus efeitos pró-competitivos (e pró-inovação) vis-à-vis seus potenciais efeitos anticoncorrenciais, mas também levar em consideração os eventuais impactos negativos da intervenção das autoridades da concorrência sobre a estrutura de incentivos estabelecida pelo sistema de propriedade intelectual.

Nessa linha, poder-se-ia afirmar que haveria um conflito entre essa abordagem orientada pela inovação, conforme desenvolvida nos países mais industrializados, e uma abordagem orientada pela disseminação e transferência de tecnologia, que teria a preferência dos países em desenvolvimento. De fato, as negociações das disposições sobre concorrência no Acordo TRIPS tomaram como base as discussões inacabadas do projeto de Código de Conduta para Transferência de Tecnologia da UNCTAD, que refletiam os anseios dos países em desenvolvimento em garantir maior acesso a conhecimentos tecnológicos protegidos por direitos de propriedade intelectual de titularidade de empresas multinacionais. Uma leitura superficial das disposições do TRIPS sobre concorrência pode sugerir que estas possuem uma linguagem aparentemente mais voltada para a disseminação e transferência de tecnologias do que para a inovação propriamente dita. 
Sob esse prisma, dada a dependência tecnológica dos países em desenvolvimento e de menor desenvolvimento relativo, a política de concorrência nacional a ser implementada nesses países tenderia a ser mais intervencionista, abrindo caminho para a imposição de proibições per se a cláusulas restritivas em acordos de licenciamento, repressão a preços excessivos por agentes econômicos dominantes, dentre outras medidas que visariam garantir maiores condições de acesso a bens e tecnologias protegidos por direitos exclusivos. Desde que tais medidas fossem consideradas apropriadas e consistentes com as disposições do Acordo TRIPS, não haveria, em princípio, qualquer impedimento para sua implementação.

Todavia, é possível constatar que essa abordagem mais intervencionista tem perdido espaço para a política de concorrência orientada pela inovação, conforme aplicada nos Estados Unidos e na União Europeia, que, além de ser fortemente influenciada pela teoria econômica, baseia-se no pressuposto de que o direito da concorrência deve intervir para preservar a competitividade dos mercados, sem prejudicar a estrutura de incentivos da propriedade intelectual. Isso não significa que as autoridades de defesa da concorrência devam adotar uma postura leniente diante de determinadas práticas anticoncorrenciais, ou preocupar-se apenas com os incentivos à inovação dos titulares de direitos de propriedade intelectual que estejam sendo investigados. Afinal, determinadas condutas anticoncorrenciais relacionadas à exploração de direitos exclusivos podem causar efeitos adversos não apenas à concorrência, mas também à inovação, resultando em perdas substanciais de bem-estar social.

Diante dessas constatações, conclui-se que a política de concorrência deve permitir que o sistema de propriedade intelectual cumpra sua função essencial de impedir concorrência pela cópia ou imitação, levando às autoridades antitruste a concentrarem seus esforços na proteção da concorrência dinâmica - pela superação ou substituição - movida pelo processo de inovação. Para tanto, é indispensável a preservação das pressões competitivas do mercado capazes de impulsionar os agentes econômicos a investir em inovação e desenvolver novos produtos e serviços, ampliando as possibilidades de escolha dos consumidores. Nesse contexto, a intervenção antitruste seria indispensável para coibir abusos de direitos de propriedade intelectual capazes de restringir a concorrência dinâmica, seja por meio do fechamento do mercado para novos entrantes potencialmente inovadores, ou mesmo pela exclusão de rivais efetivos capazes de desenvolver produtos mais inovadores. 
É importante ressaltar que essa abordagem está em plena consonância com as disposições do TRIPS sobre concorrência. Essas normas foram vislumbradas como elemento de equilíbrio para evitar que os excessos ou abusos na exploração de direitos de propriedade intelectual venham a constituir entraves não apenas à transferência e disseminação de tecnologia, mas também, e sobretudo, à inovação tecnológica, que é a mola propulsora do crescimento econômico e do progresso tecnológico e científico.

O Brasil é um bom exemplo de país em desenvolvimento que deixou de lado essa abordagem mais intervencionista, consubstanciada em proibições per se de cláusulas restritivas em acordos de licenciamento, para implementar uma abordagem orientada pela inovação, tendo em vista a forte influência dos sistemas antitruste norte-americano e europeu na formulação das normas antitruste nacionais. Na esteira da abertura econômica a partir do início dos anos 1990, o país aprovou modernas legislações de propriedade intelectual e de defesa da concorrência, reduzindo os poderes do INPI para intervir na liberdade contratual das partes. Desse modo, a análise antitruste de restrições em acordos de licenciamento, assim como de outras condutas anticoncorrenciais, é conduzida pelas autoridades da concorrência com base em critérios de razoabilidade, ponderando-se as eficiências econômicas e seus eventuais efeitos anticoncorrenciais, em consonância com os padrões antitruste adotados nas principais jurisdições.

Finalmente, é imperioso destacar que muitas práticas restritivas relacionadas à exploração de direitos de propriedade intelectual decorrem de falhas constantes na própria legislação de propriedade intelectual. Na medida em que os direitos exclusivos são definidos extensivamente, sem uma determinação precisa das limitações e exceções ao seu exercício, maiores são as possibilidades para a configuração de poder de mercado e de seu exercício abusivo por parte dos titulares desses direitos. Nessas circunstâncias, as autoridades antitruste acabam sendo levadas a atuar muito mais para corrigir essas falhas do que para efetivamente promover a concorrência, aumentando a probabilidade de decisões equivocadas e trazendo incerteza quanto aos limites legais da exploração de direitos exclusivos.

Para evitar esse tipo de situação, é recomendável a incorporação de princípios concorrenciais na estruturação do sistema de propriedade intelectual, seja no que concerne a uma determinação mais adequada dos limites de escopo e duração dos direitos exclusivos, ou mesmo em relação à definição das limitações e exceções ao exercício desses 
direitos, o que, inclusive, está em plena consonância com o Acordo TRIPS. Nessa perspectiva, quanto mais equilibrado o sistema de propriedade intelectual, menos necessária poderá ser a intervenção antitruste e, consequentemente, menores os custos e riscos de condenações equivocadas, consubstanciadas em proibições a formas legítimas de exploração de direitos exclusivos, capazes de prejudicar a própria concorrência dinâmica e a estrutura de incentivos visada pela propriedade intelectual.

É inegável que a desejada relação de complementaridade entre a propriedade intelectual e o direito da concorrência depende da coerência na formulação das normas que as disciplinam. As leis de propriedade intelectual podem desestimular, ao invés de incentivar, a inovação, caso estabeleçam proteções excessivas ou exageradas. Da mesma forma, o direito antitruste pode ser prejudicial à concorrência na medida em que coíbe ou penaliza formas legítimas de exploração de direitos de propriedade intelectual. Assim, as eventuais situações de conflito entre propriedade intelectual e concorrência são muitas vezes o resultado de escolhas equivocadas de política pública e falhas legislativas que impedem a desejada convergência entre os dois sistemas.

Nesse contexto, vale destacar a opinião de HovENKAMP sobre a questão, muito oportuna para encerrar este trabalho: “(...) as leis antitruste e as leis de propriedade intelectual estão em conflito no sentido muito geral de que, quando as duas áreas do direito se comportam de forma míope, o direito antitruste sempre quer mais concorrência e o direito da propriedade intelectual quer mais proteção ao direito de excluir. Mas esse conflito é em grande parte ilusório, pois quando a política legislativa não se comporta de forma míope, então todos devem desejar a mesma coisa, ou seja, o equilíbrio ideal entre a concorrência e a proteção da inovação". 822

\footnotetext{
${ }^{822}$ Tradução livre de: “(...) the antitrust laws and the IP laws are in conflict in the very general sense that when the two bodies of law behave myopically, antitrust always want more competition and IP law wants more protection for the right to exclude. But this conflict is largely illusory because when legal policy is not behaving myopically, then everyone should want the same thing, namely, the optimal balance between competition and protection for innovation. HOVENKAMP, Herbert. The Antitrust Enterprise: Principle and Execution. Harvard University Press, p. 251.
} 


\section{BIBLIOGRAFIA}

ABA Section of Antitrust Law. Intellectual Property and Antitrust Handbook. ABA Publishing, 2007.

ABBOTT, Alden F. Intellectual Property Licensing and Antitrust Policy: A Comparative Perspective. Law and Policy International Business, v. 34, n. ${ }^{\circ}$ 4, 2003.

ABBOTT, Frederick M. "Are the Competition Rules in the WTO Agreement on TradeRelated Aspects of Intellectual Property Rights Adequate?", in: PETERSMAN, ErnstUlrich (ed.). Reforming the World Trading System: Legitimacy, Efficiency, and Democratic Governance. Oxford: OUP, 2005.

Innovation and Technology Transfer to Address Climate Change: Lessons from the Global Debate on Intellectual Property and Public Health, ICTSD's Programme on IPRs and Sustainable Development Program Issue Paper No. 24, International Centre for Trade and Sustainable Development, Geneva, Switzerland, 2009AGHION, Philippe and GRIFFITH, Rachel. Competition and Growth: Reconciling Theory and Evidence, The MIT Press, 2005.

AHLBORN, Christian, EVANS, David S. e PADILLA, Jorge. "The Antitrust Economics of Tying: A Farewell to Per Se Illegality", in: AEI-Brookings Joint Center for Regulatory Studies, 2004.

AMARAL, Francisco. Direito Civil: Introdução, 7. ed. Rio de Janeiro: Renovar, 2008.

ANDERMAN, Steven D. The New EC Competition Law Framework for Technology Transfer and IP Licensing, in: DREXL, Josef (Ed.). Research Handbook on Intellectual Property and Competition Law. Cheltenham: Edward Elgar, 2008.

; EZRACHI, Ariel (Ed.). Intellectual Property and Competition Law: New Frontiers. Oxford University Press, 2011.

; HEDVIG, Schmidt. EC Competition Policy and Intellectual Property Rights: The Regulation of Innovation, 2nd Ed., Cambridge University Press, 2011. 
; KALLAUGHER, John. Technology Transfer and the New EU

Competition Rules - Intellectual Property Licensing after Modernization, Oxford University Press, 2006.

ANDERS, Eduardo Caminati; PAGOTO, Leopoldo; BAGNOLI, Vicente (Coord.). Comentários à Nova Lei de Defesa da Concorrência: Lei $n^{\circ}{ }^{\circ} 12.529$, de 30 de novembro de 2011. Rio de Janeiro: Forense; São Paulo: Método, 2012.

ANDERSON, Robert D. Competition Policy and Intellectual Property in the WTO: More Guidance Needed?, in: DREXL, Josef (Ed.). Research Handbook on Intellectual Property and Competition Law. Cheltenham: Edward Elgar, 2008.

The Interface Between Competition Policy and Intellectual Property in the Context of the International Trading System, in: Journal of International Economic Law, Vol. 1, Issue 4, 1998.

; HOLMES, Peter. Competition Policy and the Future of The Multilateral Trading System, in: Journal of International Economic Law (2002) pp. 531-563.

; JENNY, Frédéric. Competition Policy, Economic Development and the Multilateral Trading System: Overview of the Linkages and Current Proposals for an Agreement in the WTO, Integrated Framework Seminar on the Policy Relevance of Mainstreaming Trade into Country Development Strategies, held at WTO on 29-30 January of 2002.

ANDRADE, Gustavo Piva de. A Interface entre a Propriedade Intelectual e o Direito Antitruste, in: Revista da Associação Brasileira de Propriedade Intelectual - ABPI, n. 91, nov./dez., 2007.

AREEDA, Phillip; KAPLOW, Louis; EDLIN, Aaron. Antitrust Analysis, 6. ed. New York: Aspen, 2004.

ARROW, Kenneth J., Economic Welfare and the Allocation of Resources for Invention. California: The Rand Corporation, 1959. Disponível em: http://www.rand.org/content/dam/rand/pubs/papers/2006/P1856.pdf.

ASCENSÃO, José de Oliveira. Direito Autoral, $2^{\circ}$ edição, Rio de Janeiro: Renovar, 2007. 
BAKER, Jonathan B. Beyond Schumpeter vs. Arrow: How Antitrust Fosters Innovation (2007), p. 6-10. Disponível em SSRN: http://ssrn.com/abstract=962261 ou http://dx.doi.org/10.2139/ssrn.962261. . “Dynamic Competition Does Not Excuse Monopolization” (October 15, 2008). Disponível em $\quad$ SSRN: $\underline{\text { http://ssrn.com/abstract=1285223 }}$ ou http://dx.doi.org/10.2139/ssrn.1285223.

BARBOSA, Cláudio R. Propriedade Intelectual: Introdução à Propriedade Intelectual como Informação. Rio de Janeiro: Campus Jurídico, 2008.

BARBOSA, Denis Borges. A Criação de Um Ambiente Competitivo no Campo da Propriedade Intelectual: O Caso Sul Americano. Geneva, Switzerland: Centre for Trade and Sustainable Development - ICTSD, 2005. Disponível em: http://www.iprsonline.org/unctadictsd/docs/Barbosa\%20FINAL\%20formatado.pdf

. Bases Constitucionais da Propriedade Intelectual, Revista da Associação Brasileira de Propriedade Intelectual - ABPI, Agosto de 2002.

"Contratos em Propriedade Intelectual". Disponível em: http://www.denisbarbosa.addr.com/arquivos/apostilas/ufrj/contratos_propriedade_intelectu al.pdf.

Jurisprudência de PI do CADE, 2005. Disponível em: denisbarbosa.addr.com/picade.doc.

. Propriedade Intelectual: A Aplicação do Acordo TRIPS. Rio de Janeiro: Lúmen Juris, 2003.

Tratado da Propriedade Intelectual, Tomo I. Rio de Janeiro: Lumen Juris Editora, 2010.

BASSO, Maristela. As Exceções e Limitações aos Direitos de Autor e a Observância da Regra dos Três Passos (Three Step Test), in: Eduardo Salles Pimenta (Coord.). Direitos Autorais: Estudos em Homenagem a Afonso dos Santos, São Paulo: Revista dos Tribunais, 2008 . 
. A Propriedade Intelectual na Era Pós-OMC-TRIPS, Porto Alegre: Livraria do Advogado Editora, 2005.

. O Direito Internacional da Propriedade Intelectual. Porto Alegre: Livraria do Advogado, 2000.

. Propriedade Intelectual e Importação Paralela. São Paulo: Atlas, 2011.

- O Regime Internacional de Proteção da Propriedade Intelectual da OMC/Trips, in: JÚNIOR, Alberto do Amaral (Coord.). OMC e o Comércio Internacional, São Paulo: Aduaneiras, 2002.

BAULMOL, William J. The Free-Market Innovation Machine: Analyzing the Growth Miracle of Capitalism. Princeton University Press, 2002.

BENSEN, Stanley M. e RASKIND, Leo J. "An Introduction to the Law and Economics of Intellectual Property”, in: Journal of Economic Perspectives, Vol. 5, No. 1, 1991.

BLAIR, Roger D.; COTTER, Thomas F. Intellectual Property: Economics and legal Dimensions of Rights and Remedies. Cambridge, UK: Cambridge University Press, 2005.

BLASI, Marcos Chucralla Moherdaui. Propriedade Intelectual e Direito da Concorrência: Premissas de Análise e Apontamentos sobre a Jurisprudência Brasileira e Estrangeira. Revista da ABPI, n. 116, p. 52, jan./fev. 2012.

BORK, Robert H. BORK. The Antitrust Paradox: A Policy at War with Itself, New York: The Free Press, 1993.

BRADFORD, Anu. International Antitrust Regime, TRIPs and Different Paths to Regulatory Convergence, in: PIPES: The Program on International Politics, Economics, and Security, 2009.

BRANCHER, Paulo. Direito da Concorrência e Propriedade Intelectual: Da Inovação Tecnológica ao Abuso de Poder. São Paulo: Singular, 2010.

BRUNA, Sérgio Varella. O Poder Econômico e a Conceituação do Abuso em seu Exercício, São Paulo: Editora Revista dos Tribunais, 1997. 
BUCHANAN, James M. "Rent Seeking and Profit Seeking", in: TOLLISON, Robert D.; CONGLETON, Roger D. (Ed.). The Economic Analysis of Rent Seeking. Aldershoot, England: Edward Elgar Publishing Ltd., 1995.

CARVALHO, Patrícia Luciane. "Do Licenciamento Compulsório. Uma Abordagem do Direito Internacional e do Direito Administrativo", in: Revista de Informação Legislativa, v. 46, p. 137-153, 2009.

CAMPELO, Dyle. O Direito da Concorrência no Direito Comunitário Europeu: Uma Contribuição ao Mercosul, Rio de Janeiro: Renovar, 2001.

CAMPILONGO, Celso Fernandes. "Política de Patentes e o Direito da Concorrência". In: PICARELLI, Márcia Flévia Santini e ARANHA, Márcio Iorio (Organizadores). Política de Patentes em Saúde Humana. São Paulo: Atlas, 2001.

CAPP, Débora Andrade. “A Função Social da Propriedade Intelectual”. In: FONSECA, Antonio (Organizador). Limites Jurídicos da Regulação e Defesa da Concorrência. Porto Alegre: Sergio Antonio Fabris Editor, 2003.

CARRIER, Michael A. Innovation for the 21st Centure: Harnessing the Power of Intellectual Property and Antitrust Law, Oxford University Press, 2009.

- Standard Setting Analysis under US Law, in: ANDERMAN, Steven; EZRACHI, Ariel (Ed.). Intellectual Property and Competition Law: New Frontiers. Oxford University Press, 2011.

CARVALHO, Nuno Pires. The TRIPS Regime of Antitrust and Undisclosed Information, Kluwer Law International, The Hague, 2008.

CELLI JÚNIOR, Umberto. Regras de Concorrência no Direito Internacional Moderno. Porto Alegre: Livraria do Advogado, 1999.

CHIN, Yee Wah. Unilateral Technology Suppression: Appropriate Antitrust and Patent Law Remedies, 66, Antitrust Law Journal, 441, 1998.

COASE, Ronald. The Problem of Social Cost. The Journal of Law and Economics, 3: 1 44, 1960. 
COOTER, Robert; ULEN, Thomas. Law and Economics, Addison Wesley, 5th ed., 2008.

CORDOVIL, Leonor; CARVALHO, Vinícius Marques de.; ANDERS, Eduardo Caminati. Nova Lei de Defesa da Concorrência Comentada - Lei n. ${ }^{\circ}$ 12.529, de 30 de novembro de 2011, São Paulo: Revista dos Tribunais, 2011.

CORREA, Carlos M. Intellectual Property and Competition Law: Exploring Some Issues of Relevance to Developing Countries, ICTSD IPRs and Sustainable Development Program Issue Paper No. 21, International Centre for Trade and Sustainable Development, Geneva, Switzerland, 2007.

Intellectual Property Rights, the WTO and Developing Countries: The TRIPS Agreement and Policy Options, London: Zed Books / Penang, Malaysia: Third World Network, 2000.

Trade Related Aspects of Intellectual Property: A Commentary on the TRIPS Agreement. Oxford University Press, 2007.

CORRÊA, Mariana Villela. Exclusividade e Direito da Concorrência, Dissertação de Mestrado Apresentada ao Departamento de Direito Comercial da Universidade de São Paulo, 2008.

COSTA, Lígia Maura. OMC: Manual Prático da Rodada Uruguai. São Paulo: Saraiva, 1996.

COTTIER, Thomas; FOLTEA, Marina. Global Governance in Intellectual Property Protection, NCCR Trade Regulation, Working Paper n. 2011/45, June 2011.

; MEITINGER, Ingo. The Trips Agreement without a Competition Agreement?, Fondazione Eni Enrico Mattei. Trade and Competition in the WTO and Beyond, Venice, December 4th-5th, 1998.

CUEVA, Ricardo Villas Bôas. A Proteção da Propriedade Intelectual e a Defesa da Concorrência nas Decisões do CADE, in: Revista do IBRAC, v. 16, n. 1, p. 123, 2009.

CZAPRACKA, Katarzyna. Intellectual Property and the Limits of Antitrust: A Comparative Study of US and EU Approaches, Cheltenham, UK: Edward Elgar, 2009. 
DEMETZ, Harold. Toward a Theory of Property Rights. American Economic Review Papers \& Proc., v. 57, p. 347-348, 1967.

DIAS, José Carlos Vaz e. Licença Compulsória de Patentes e o Direito Antitruste, in: Revista da ABPI n. 54, São Paulo: ABPI, p. 03, 2001.

DREXL Josef. "Deceptive Conduct in the Patent World", in: WALDECK AND PYRMONT, Wolrad Prinz zu, ADELMAN, Martin J., BRAUNEIS, Robert, DREXL, Josef and NACK, Ralph (Editor). Patents and Technological Progress in a Globalized World, Liber Amicorum Joseph Straus, Springer-Verlag Berlin Heidelberg, 2009.

DREXL, Josef. Is there a "More Economic Approach" to Intellectual Property and Competition Law ?, in: DREXL, Josef (Ed.), Research Handbook on Intellectual Property and Competition Law. Cheltenham: Edward Elgar, 2008.

EASTERBROOK, Frank H. When Is It Worthwhile to Use Courts to Search for Exclusionary Conduct?, Colum. Bus. L. Rev. 354, 2003.

ELHAUGE, Einer. United States Antitrust Law and Economics, 2nd ed., New York: Thomson Reuters/Foundation Press, 2011.

; GERADIN, Damien. Global Competition Law and Economics. 2nd ed. Oxford and Portland: Hart Publishing, 2011.

EUROPEAN COMMISSION. Commission Notice: Guidelines on the Application of Article 81 of the EC Treaty to Technology Transfer Agreements (OJ C 101, 27.4.2004). Disponivel em: http://eurlex.europa.eu/LexUriServ/LexUriServ.do?uri=OJ:C:2004:101:0002:0042:EN:PDF.

EUROPEAN COMMISSION. Communication from the Commission - Guidance on the Commission's enforcement priorities in applying [Article 82 of the EC Treaty] to abusive exclusionary conduct by dominant undertakings (2009/C 45/02). Disponível em: http://eurlex.europa.eu/LexUriServ/LexUriServ.do?uri=OJ:C:2009:045:0007:0020:EN:PDF

EVANS, David S.; PADILLA, A. Jorge. Designing Antitrust Rules for Assessing Unilateral Practices: A Neo-Chicago Approach, in: University of Chicago Law Review Vol. 72, 2005. Disponível em SSRN: http://ssrn.com/abstract=580882. 
EVANS, David S.; SCHMALENSEE, Richard. Some Economic Aspects of Antitrust Analysis in Dynamically Competitive Industries, in: National Bureau of Economic Research, Working Paper 86268, issued on May 2001. Disponível em: http://www.nber.org/chapters/c10784.pdf.

EZRACHI, Ariel. Competition Law Enforcement and Refusal to License: The Changing boundaries of Article 102 TFUE, in: ANDERMAN, Steven; EZRACHI, Ariel. Intellectual Property and Competition Law: New Frontiers. Oxford University Press, 2010.

FAGUNDES, Jorge. Concorrência, Eficiência Dinâmica e Análise Antitruste. Revista do IBRAC, v. 11, n. 4, 2004.

Fundamentos Econômicos das Políticas de Defesa da Concorrência: Eficiência Econômica e Distribuição de Renda em Análises Antitruste. São Paulo: Singular, 2003.

; PONDÉ, João Luiz. Economia Institucional: Custos de Transação e Impactos sobre a Política de Defesa da Concorrência, in: POSSAS, Mário (coordenador). Ensaios sobre Economia e Direito da Concorrência, São Paulo: Singular, 2002.

FARINA, Elizabeth Maria Mercier Querido. Desregulamentação e o Controle do Abuso do Poder Econômico: Teoria e Prática. Revista de Economia Política, vol. 14, n. 3 (55), 1994.

FEDERAL TRADE COMMISSION. The Evolving IP Marketplace, Aligning Patent Notice and Remedies with Competition, 2011. Disponível em: www.ftc.gov/os/2011/03/110307patentreport.pdf.

FEDERAL TRADE COMMISSION. To Promote Innovation: The Proper Balance of Competition and Patent Law and Policy, 2003, disponível em: http://www.ftc.gov/os/2003/10/innovationrpt.pdf.

FEKETE, Elisabeth Kasznar. O Regime Jurídico do Segredo de Indústria e Comércio no Direito Brasileiro. Rio de Janeiro: Forense, 2003.

FERRAZ Jr., Tércio Sampaio. "Propriedade Industrial e Defesa da Concorrência". In: Estudos em Homenagem a Irineu Strenger. Direito e Comércio Internacional: Tendências e Perspectivas. São Paulo: LTr, 1994. 
FISHEL, Daniel R. Antitrust Liability for Attempts to Influence Government Action: The Basis and Limits of the Noerr-Pennington Doctrine, 45 U. Chi. L. Rev. 80, 101, 1977.

FISHER, Matthew. Fundamentals of Patent Law: Interpretation and Scope of Protection. Oxford: Hart Publishing, 2007.

FONSECA, Antonio. Concorrência e Propriedade Intelectual. Revista da Associação Brasileira da Propriedade Intelectual, n. 36, set-out. 1998.

FORRESTER, Ian S.; CZAPRACKA, Katarzyna A. Compulsory License in European Competition Law: The Power of the Adjective, in: ANDERMAN, Steven; EZRACHI, Ariel. Intellectual Property and Competition Law: New Frontiers. Oxford University Press, 2010.

FOX, Eleanor M. Abuse of Dominance and Monopolization: How to Protect Competition without Protecting Competitors, in: European Competition Law Annual: 2003 What Is an Abuse of Dominant Position? 69, 70 (Claus-Dieter Ehlermann \& Laraine L. Laudati, eds. 2006). Disponível em: http://www.eui.eu/RSCAS/Research/Competition/2003/200306COMP-Fox-sI.pdf. . Can Antitrust Policy Protect the Global Commons From the Excess of IPRs?, in: MASKUS, Keith E. and REICHMAN, Jerome H. (Editors). International Public Goods and Technology Transfer Under a Globalized Intellectual Property Regime, Cambridge University Press, 2005.

. International Antitrust and the Doha Dome. Virginia Journal of International Law, v. 43, n. ${ }^{\circ}$ 4, 2003.

. Trade, Competition, and Intellectual Property - TRIPS and its Antitrust Counterparts, in: 29 Vand. J. Transnat'l L. 481, 1996.

What is Harm to Competition? Exclusionary Practices and Anticompetitive Effect, in: Antitrust Law Journal, n. 70, 2002.

; SULLIVAN, Lawrence A. e PERITZ, Rudolph J.R. Cases and Materials on U.S. Antitrust in Global Context, $2^{\text {nd }}$ Edition, United States of America: West Publishing Co., 2004. 
FRAGOSO, João Henrique da Rocha. Direito Autoral: Da Antigüidade à Internet, São Paulo: Quartier Latin, 2009.

FRIEDMAN, David D. Law's Order: What Economics has to do with Law and what it matters, Princeton University Press, 2000.

GALLEGO, Beatriz Conde. Intellectual Property Rights and Competition Policy, in: CORREA, Carlos (Ed.). Research Handbook on the Protection of Intellectual Property under WTO Rules. Intellectual Property in the WTO v. I, Edward Elgar, 2010.

. Unilateral Refusal to License Indispensable Intellectual Property Rights US and EU Approaches, in: DREXL, Josef (Ed.). Research Handbook on Intellectual Property and Competition Law. Cheltenham, UK: Edward Elgar, 2008.

GAMA CERQUEIRA. Tratado da Propriedade Industrial, Vol. I, Rio de Janeiro: Forense, 1946.

GAVIL, Andrew; KOVACIC, William; BAKER, Jonathan. Antitrust law in perspective cases, concepts and problems in competition policy. Thomson West, 2002.

GELLHORN, Ernest e KOVACIC, Willian E. Antitrust Law and Economics, $4^{\text {th }}$ edition, St Paul, Minn.: West Group, 1994.

GERADIN, Damien; AHLBORN, Christian; DENICOLÓ, Vincenzo; PADILLA, A. Jorge. DG Comp's Discussion Paper on Article 82: Implications of the Proposed Framework and Antitrust Rules for Dynamic Competitive Industries, 2006. Disponível em: http://papers.ssrn.com/sol3/papers.cfm?abstract_id=894466.

GHIDINI, Gustavo. Innovation, Competition and Consumer Welfare in Intellectual Property Law. UK: Edward Elgar, 2010.

GILBERT, Richard J. Antitrust for Patent Pools: A Century of Policy Evolution, 2004, Stanford Technology L. Rev. 3, disponível em: http://stlr.stanford.edu/pdf/gilbert-patentpools.pdf, acesso em 02 de novembro de 2009.

Converging Doctrines? US and EU Antitrust Policy for the Licensing of Intellectual Property (February 2004). University of California, Berkeley, Competition 
Policy Working Paper. Disponível em SSRN: http://ssrn.com/abstract=527762 ou http://dx.doi.org/10.2139/ssrn.527762.

- Looking for Mr. Schumpeter: Where Are We in the CompetitionInnovation Debate?, in: 6 Innovation Policy and the Economy, 2006.

; NEWBERRY, David M.G. Preemptive Patenting and the Persistence of Monopoly, in: 75 American Economic Review, 1982.

; SHAPIRO, Carl. "Optimal Patent Lenght and Breadth", in: The RAND Journal of Economics, vol. 21, n. ${ }^{\circ}$ 1, 1990.

GLADER, Marcus. Innovation Markets and Competition Analysis: EU Competition Law and US Antitrust Law, Edward Elgar Publishing, 2009.

GOLDBERG, Daniel. Poder de Compra e Política Antitruste, São Paulo: Singular, 2006.

GONÇALVES, Luís, M. Couto. Manual de Direito Industrial, $2^{\mathrm{a}}$ edição, Coimbra: Almedina, 2008.

GOTTS, Ilene Knable; SCHER, Scott. The Particular Antitrust Concerns with Patent Acquisitions, in: Competition Law International, August 2012. Disponível em: http://www.wsgr.com/publications/PDFSearch/sher-august-12.pdf.

GREENSTEIN, Shane; RAMEY, Garey. Market Structure, Innovation, and Vertical Product Differentiation, in: 16 International Journal of Industrial Organization, 1988.

GUZMAN, Andrew T. International Antitrust and the WTO: the lesson from intellectual property. Berkeley Program in Law \& Economics. 43 Va. J. Int'l L. 933, 2002. Disponível em: http://scholarship.law.berkeley.edu/facpubs/994.

. The Case for International Antitrust, in: EPSTEIN Richard A.; GREVE, M.S. (Ed.). Competition Laws in Conflict: Antitrust Jurisdiction in the Global Economy, Washington DC: AEI Press, 2004.

HARDIN, Garrett. The Tragedy of the Commons. Science, New Series, v. 162, Dec., 1968. 
HEINEMANN, Andrea. "Antitruste Internacional e Propriedade Intelectual”, in: RODRIGUES JR., Edson Beas; POLIDO, Fabrício (orgs.). Propriedade Intelectual: Novos Paradigmas Internacionais, Conflitos e Desafios. Rio de Janeiro: Elsevier, 2007.

- The Contestability of IP-Protected Markets, in: DREXL, Josef (Ed.). Research Handbook on Intellectual Property and Competition Law. Cheltenham, UK: Edward Elgar, 2008.

HETTINGER, Edwin C. Justifying Intellectual Property, in: Philosophy and Public Affairs, v. 18, n. 1, 1989.

HICKS, John R. Annual Survey of Economic Theory: The Theory of Monopoly. Econometrica 3, 1-8, 1955.

HOCKETT, Christopher B.; LIPSCOMB, Rosanna. Best FRANDs Forever? StandardSetting Antitrust Enforcement in the United States and the European Union, in: Antitrust. American Bar Association, Summer 2009.

HOVENKAMP, Herbert J. Antitrust and Innovation: Where We Are and Where We Should Be Going, in: Antitrust Law Journal, v. 77, Issue 3, 2011.

. Federal Antitrust Policy: The Law of Competition and its Practice, Third Edition, Saint Paul, Minn.: Thomson West, 2005.

Innovation and the Domain of Competition Policy, University of Iowa Legal Studies Research Paper, number 08-07, March 2008. Disponível Disponível em SSRN: http://ssrn.com/abstract=1091488.

. Patent Continuations, Patent Deception, and Standard Setting: The Rambus and Broadcom Decisions, 28 University of Iowa Legal Studies Research Paper No. 08-25, May 2008.

. Post-Chicago Antitrust: A Review and Critique, 2001, Colum. Bus. L. Rev. 257, 2001.

Schumpeterian Competition and Antitrust (October 01, 2008), in: University of Iowa Legal Studies Research Paper n. 08-43. Disponível em SSRN: $\underline{\text { http://ssrn.com/abstract=1275986 ou http://dx.doi.org/10.2139/ssrn.1275986 }}$ 
The Antitrust Enterprise: Principle and Execution. Harvard University

Press, 2005.

; JANIS, Mark D.; LEMLEY, Mark A. IP and Antitrust: An Analysis of Antitrust Principles Applied to Intellectual Property Law, vols. 1 and 2, Aspen Publishers, 2009 Supplement.

KAPLOW, Louis. A Note on Antitrust Issues in the Licensing of Intellectual Property. Harvard Law School John M. Olin Center for Law, Economics and Business Discussion Paper Series. Paper 217, 1997. Disponível em Harvard Law School at NELLCO Legal Scholarship Repository:

http://lsr.nellco.org/cgi/viewcontent.cgi?article=1005\&context=harvard_olin.

KATZ, Michael L.; SCHAPIRO, Carl. Network Externalities, Competition, and Compatibility, in American Economics Review, 1985.

; SHELANSKI, Howard A. "Schumpeterian" Competition and Antitrust Policy in High-Tech Markets, 2005. Disponível em SSRN: http://ssrn.com/abstract $=925707$.

KHOR, Martin. Intellectual Property, Competition and Development, in: Third World Network, June 2005, Disponível em: http://www.wipo.int/edocs/mdocs/mdocs/en/isipd_05/isipd_05_www_103984.pdf

KITCH, Edmund W. Patents: Monopolies or Property Rights?. Research in Law and Economics, v. 8, 1986.

KLEMPERER, Paul. "How Broad Should the Scope of Patent Protection Be?", in: The RAND Journal of Economics, vol. 21, n. ${ }^{\text {1 }}$ (Spring, 1990), pp. 113-130.

KORT, Michael. Intellectual Property and Article 82 EC, in: WALDECK AND PYRMONT, Wolrad Prinz zu, ADELMAN, Martin J., BRAUNEIS, Robert, DREXL, Josef and NACK, Ralph (Editor). Patents and Technological Progress in a Globalized World, Liber Amicorum Joseph Straus, Springer-Verlag Berlin Heidelberg, 2009.

KRATTENMAKER, Thomas e SALOP, Steven. "Anticompetitive Exclusion: Raising Rivals' Costs to Achieve Market Power over Price”, Yale Law Journal, no 96. 
KUBRUSLY, Claudia Tosin. Direito Antitruste e Propriedade Intelectual: Análise Concorrencial dos Acordos de Licença e da Recusa de Licenciar, 2008, Dissertação de Mestrado - Faculdade de Direito da Universidade de São Paulo, São Paulo, 2008.

KUR, Annette. Limiting IP Protection for Competition Policy Reasons - a case study based on the EU spare-parts-design discussions, in: DREXL, Josef. Research Handbook on Intellectual Property and Competition Law. Cheltenham, UK: Edward Elgar, 2008.

LABRUNIE, Jacques. Direito de Patentes: Condições Legais de Obtenção de Nulidades, São Paulo: Manole, 2006.

LANDES, William M. and POSNER, Richard A. The Economic Structure of Intellectual Property Law, The Belknap Press of Harvard University Press, Cambridge, Massachusetts, and London, 2003.

LANG, J. "The Application of the Essential Facility Doctrine to Intellectual Property Rights under European Competition Law", in: Antitrust, Patents and Copyright, EU and US Perspectives, Lévêque, F. and Shelanski, H. (Edi.), 2005.

LEMLEY, Mark A. A New Balance Between IP and Antitrust. John M. Olin Program in Law and Economics Stanford Law School. Working Paper n. 340, April, 2007, disponível no website da Social Science Research Network Eletronic Paper Collection: http://ssrn.com/abstract=980045, acesso em 24 de outubro de 2009.

. Ex Ante versus Ex Post Justifications for Intellectual Property. University of Chicago Law Rervew, vol. 71, 2004; UC Berkeley Public Law Research Paper No. 144. Disponível em $\quad$ SSRN: $\quad$ http://ssrn.com/abstract=494424 http://dx.doi.org/10.2139/ssrn.494424.

Intellectual Property Rights and Standard-Setting Organizations (April 1, 2002). California Law Review (online), vol. 90, 2002; UC Berkeley Public Law Research Paper No. 84. Disponível em: $\underline{\text { http://ssrn.com/abstract=310122 }}$ ou http://dx.doi.org/10.2139/ssrn.310122.

. Property, Intellectual Property, and Free Riding. Stanford Law School, John M. Olin Program in Law and Economics, Working Paper n. 291, August 2004. 
LESLIE, Christopher R. Antitrust Law and Intellectual Property Rights: Cases and Materials, Oxford University Press, 2010.

MACKENRODT, Mark-Oliver. Assessing the Effects of Intellectual Property Rights in Network Standards, in: DREXL, Josef (Ed.). Research Handbook on Intellectual Property and Competition Law. Cheltenham: Edward Elgar, 2008.

MAGGiOLINO, Mariateresa. Intellectual Property and Antitrust: A Comparative Economic Analysis of US and EU Law. Celtenham: Edward Elgar, 2011.

- The Economics of Antitrust and Intellectual Property Rights, in: ANDERMAN, Steven; EZRACHI, Ariel. Intellectual Property and Competition Law: New Frontiers, Oxford University Press, 2010.

MARSDEN, Philip. A Competition Policy for the WTO, London: Cameron May Ltd., 2003.

MARSHALL, Richard H. Patent, Antitrust and the WTO/GATT: Using TRIPS as a vehicle for antitrust harmonization, in: Law \& Policy International Business, v. 28, p. 1190 e ss., 1997.

MASKUS, Keith E. Intellectual property Rigths in the Global Economy, Washington: Institute for International Economics, 2000.

MATSUSHITA, Mitsuo; SCHOENBAUM, Thomas J.; MAVROIDIS, Petros. The World Trade Organization: Law, Practice and Policy, Oxford Press University, 2006.

MELAMED, A. Douglas; STOEPPELWERTH, Ali M. The CSU Case: Facts, Formalism and the Intersection of Antitrust and Intellectual Property Law, 10 Geo. Mason L. Rev. 407, 2002.

MERGES, Robert P.; MENELL, Peter S.; LEMLEY, Mark A. Intellectual Property in the New Technological Age, 4th ed. New York: Aspen Publishers, 2006.

MONTEIRO, Renata Pozzato Carneiro. A Função Social da Propriedade na Constituição da República de 1988 e a Propriedade Industrial, in: Revista da Associação Brasileira de Propriedade Intelectual-ABPI, n. 69, p. 28, mar./abr. 2004. 
MONTI, Mario. EC Antitrust Policy in the Pharmaceutical Sector. Alliance Unichem Conference, Brussels, 2001.

MONTINI, Massimiliano. "Globalization and International Antitrust Cooperation". International Conference - Trade and Competition in the WTO and Beyond - Veneza, 4 e 5 de dezembro de 1998.

MOTTA, Massimo. Competition Policy: Theory and Practice, Cambridge University Press, 2004.

MOURA E SILVA, Miguel. Inovação, Transferência de Tecnologia e Concorrência: Estudo Comparado dos Direito da Concorrência dos Estados Unidos e da União Européia, Coimbra: Almedina, 2003.

MOURA, Mauro Hiane de. A Teoria do Abuso de Direito: Uma Alternativa para Interpretar a Jurisprudência Americana sobre Refusals to Deal. Revista do IBRAC, v. 14, n. ${ }^{\circ} 6,2007$.

MYERS, Gary. The Intersection of Antitrust and Intellectual Property Rights - Cases and Materials, Thomson West, American Casebook Series, 2007.

NETO, Renato Dolabella. A proposta de nova lei de defesa da concorrência e o licenciamento compulsório de direitos de propriedade intelectual. Revista do IBRAC, n. 17, jan./jun. 2010.

NEWBERRY, David M.G. Preemptive Patenting and the Persistence of Monopoly, in: 75 American Economic Review, 1982.

NGUYEN, Tu Thanh. Competition Law, Technology Transfer and the TRIPS Agreement. Cheltenham, UK: Edward Elgar, 2010.

O’DONNEL, S. W. "Unified Theory of Antitrust Counterclaims in Patent Litigation", 9 Virginia Journal of Law \& Technology 1, 14, 2004.

OECD - ORGANIZATION FOR ECONOMIC COOPERATION AND DEVELOPMENT. Competition, Patents and Innovation II, 2009, Competition Committee, Cooperation Roundtables, DAF/COMP(2009)22. Disponível em: http://www.oecd.org/daf/competition/45019987.pdf. 
. Competition, Patents and Innovation, 2006 (Policy Roundtables), DAF/COMP(2007)40. Disponível em: http://www.oecd.org/competition/abuseofdominanceandmonopolisation/39888509.pdf . Committee on Competition Law and Policy (1998). Competition Policy and Intellectual Property Rights, DAFFE/CLP(98)18. Disponível em: http://www.oecd.org/dataoecd/34/57/1920398.pdf.

OLIVEIRA, Gesner e RODAS, João Grandino. Direito e Economia da Concorrência, Rio de Janeiro: Renovar, 2004.

OLIVEIRA. Viviane Perez de. Exploração Patentária e Infração à Ordem Econômica. Revista de Direito Público Econômico, ano 1, nº 1, 2003, pp. 261-279.

PADILHA, Alexandre Garcia. A Influência do Direito da Concorrência na Proteção Internacional dos Direitos de Propriedade Intelectual: Especial Referência aos Artigos 8.2 e 40 do Acordo TRIPS, Dissertação de Mestrado - Faculdade de Direito da Universidade de São Paulo, São Paulo, 2012.

PAGE, Willian H.; LOPATKA, John. The Microsoft Case: Antitrust, High Technology, and Consumer Welfare. The University of Chicago Press, 2007.

PATE, R. Hewitt. Refusals to Deal and Intellectual Property Rights, 10 George Mason Law Review, 429, 2002.

PATTERSON, Mark W. When Is Intellectual Property Intellectual? The Leveraging Problem, 73 S. Cal. L. Rev. 1133 (2000).

PERITZ, Rudolph J. R. Competition Policy and Its Implications for Intellectual Property in the United States, in: ANDERMAN, Steven D. (Ed.). The Interface Between Intellectual Property and Competition Policy, Cambridge University Press, 2007.

PINHEIRO, Armando Castelar; SADDI, Jairo. Direito, Economia e Mercados. Rio de Janeiro: Elsevier, 2005.

PITOFSKI, Robert. Antitrust and Intellectual Property: Unresolved Issues at the Heart of the New Economy, 16 Berkeley Tech. L.J. 535-559, 2001. Disponível em: http://scholarship.law.georgetown.edu/facpub/315. 
; PATTERSON, Donna; HOOKS, Jonathan. The Essential Facilities

Doctrine Under the U.S. Antitrust Law. Antitrust Law Journal, v. 70, n. 2, 2002.

POHLMANN, Tim Christoph; MARIEKE, Opitz. Typology of the Patent Troll Business (February 27, 2009). Disponível em SSRN: http://ssrn.com/abstract=1711316 ou http://dx.doi.org/10.2139/ssrn.1711316.

POSNER, Richard A. Antitrust in the New Economy, 68 Antitrust Law Journal, 952, 2001 . Intellectual Property: The Law and Economics Approach, in: Journal of Economic Perspectives - v. 19, n. 2, 2005.

. Antitrust Law, Second Edition, Chicago: The University of Chicago Press, 2001.

POSSAS, Mário Luiz. Concorrência Schumpteriana, in: KUPFER, David; HASENCLEVER, Lia. Economia Industrial: Fundamentos Teóricos e Práticos no Brasil. Rio de Janeiro: Elsevier, 2002.

. Os Conceitos de Mercado Relevante e de Poder de Mercado no Âmbito da Defesa da Concorrência, in: POSSAS, Mário (coordenador). Ensaios sobre Economia e Direito da Concorrência, São Paulo: Singular, 2002.

; FAGUNDES, Jorge e PONDÉ, João Luiz. Política Antitruste: Um Enfoque Schumpteriano, in: POSSAS, Mário (coordenador). Ensaios sobre Economia e Direito da Concorrência, São Paulo: Singular, 2002.

PRETNAR, Bojan. Patents and the Economic Incentive to Invent, in: WALDECK AND PYRMONT, Wolrad Prinz zu, ADELMAN, Martin J., BRAUNEIS, Robert, DREXL, Josef and NACK, Ralph (Editor). Patents and Technological Progress in a Globalized World, Liber Amicorum Joseph Straus, Springer-Verlag Berlin Heidelberg, 2009.

RAHNASTO, Ilkka. Intellectual Property Rights, External Effects, and Anti-Trust Law: Leveraging in the Communication Industry, Oxford University Press, 2005.

RÉGIBEAU, Pierre and ROCKETT, Katharine. The Relationship Between Intellectual Property Law and Competition Law: An Economic Approach, in: ANDERMAN, Steven 
D. (Editor). The Interface Between Intellectual Property and Competition Policy, Cambridge University Press, 2007.

REICHMAN, J. H. Universal Minimum Standards of Intellectual Property Protection under the TRIPS Component of the WTO Agreement, in: CORREA, Carlos M.; YUSUF, Abdulqawi A. (Ed.). Intellectual Property and International Trade: The Trips Agreement. 2nd ed. Wolters Kluwer, 2008.

REMÉDIO MARQUES, J. P. Propriedade Intelectual e Interesse Público, in: Boletim da Faculdade de Direito da Universidade de Coimbra, n. ${ }^{\circ}$ 79, 2003.

RIBAS, Guilherme Favaro Corvo. Direito Antitruste e Propriedade Intelectual: uma abordagem sob a ótica d as vendas casadas, São Paulo: Singular, 2011.

RICOLFI, Marco. Is there an Antitrust Antidote against IP Overprotection within TRIPS?, in: Marquette Intellectual Property L. Rev. 10, 305, 2006. Disponível em: http://scholarship.law.marquette.edu/iplr/vol10/iss2/6.

ROFFE, Pedro; SPENNEMANN, Christoph. Control of Anti-competitive Practices in Contractual Licenses under the TRIPS Agreement, in: CORREA, Carlos M.; YUSUF, Abdulqawi A. (Ed.). Intellectual Property and International Trade: The Trips Agreement. 2nd ed. Wolters Kluwer, 2008.

ROOIJEN, Ashwin van. The Software Interface Between Copyright and Competition Law: A Legal Analysis of Interoperability in Computer Programs, New York: Wolters Kluwer, 2010.

ROSCH, Thomas. Antitrust Regulation of Innovation Markets, in: "ABA Antitrust Intellectual Property Conference”, Berkeley, CA (February 5, 2002).

ROSEMBERG, Bárbara. "Considerações sobre Direito da Concorrência e os Direitos de Propriedade Intelectual”, in: ZANOtTA, Pedro e Brancher, Paulo. Desafios Atuais do Direito da Concorrência, São Paulo: Singular, 2008.

Interface entre o Regime de Patentes e o Direito Concorrencial no Setor Farmacêutico, in: Propriedade Intelectual: Estudos em Homenagem à Professora Maristela Basso, Curitiba: Juruá Editora, 2006. ROSEMBERG, Bárbara. 
Patentes de Medicamentos e Comércio Internacional: Os Parâmetros do TRIPS e do Direito Concorrencial para a Outorga de Licenças Compulsóriaas, Tese de Doutorado - Faculdade de Direito da Universidade de São Paulo, São Paulo, 2004.

RUBINFIELD, Daniel L.; MANESS, Robert. The Strategic Use of Patents: Implications For Antitrust, in Antitrust, Patents and Copyrights, EU and US Perspectives. Lévêque, F.;Shelanski, H. (Eds), 2005.

SAITO, Leandro. A propriedade intelectual como barreira à entrada de novos players no mercado de softwares. São Paulo: Ibpi - Instituto Brasileiro de Propriedade Intelectual, 2012.

SALOMÃO FILHO, Calixto. Direito Concorrencial: As Condutas, São Paulo: Malheiros Editores, 2003.

. Direito Concorrencial: As Estruturas. 2 ed., São Paulo: Malheiros, 2002.

Direito Industrial, Direito Concorrencial e Interesse Público, in: Revista de Direito Público da Economia, Belo Horizonte, ano 2, n. ${ }^{\text {o }}$ 7, jul./set. 2004.

- Histoire Critique des Monopoles: Une Perspective Juridique et Économique, LGDJ, Collection Droit \& Économie, 2010.

SAUNDERS, Kurt M. Patent Nonuse and the Role of Public Interest as a Deterrent to Technology Suppression, in: Harvard Journal of Law \& Technology, v. 15, No. 2, Spring 2002.

SCOTCHEMER, Suzanne. Innovation and Incentives, Cambridge, Mass: MIT Press, 2006.

SCHERER, Frederick M. Market Structure and the Employment of Scientists and Engineers, in: 57 American Economic Review, 1967.

; ROSS, David. Industrial Market Structure and Economic Performance, $3^{\text {rd }}$ ed., Boston: Houghton Mifflin, 1990.

SCHMIDT, Hedvig. Competition Law, Innovation and Antitrust: An Analysis of Tying and Technological Integration. Cheltenham, UK: Edward Elgar, 2009. 
SCHUARTZ, Luiz Fernando. Ilícito Antitruste e Acordos entre Concorrentes, in: POSSAS, Mário (Coord.). Ensaios sobre Economia e Direito da Concorrência, São Paulo: Singular, 2002. . Inovações e defesa da concorrência: em busca de uma política que minimize os custos de decisões equivocadas, in: TIMM, Luciano Benetti; PARANAGUÁ, Pedro. Propriedade Intelectual, Antitruste e Desenvolvimento: caso da transferência de tecnologia e do software. Rio de Janeiro: FGV Direito Rio, 2009.

SCHUMPETER, Joseph A. Capitalism, Socialism and Democracy, New York: Harper Perennial Modern Thought, nova edição publicada em 2008.

SHAPIRO, Carl. Navigating the Patent Thicket: Cross Licenses, Patent Pools, and Standard-Setting, in: JAFFE, Adam B.; LERNER, Josh; STERN, Scott (Ed.). Innovation Policy and the Economy, v. 1. Cambridge, MA: The MIT Press, 2001.

SHAVEL, Steven. Foundations of Economic Analysis of Law. Cambridge, Massachusetts: Harvard University Press, 2004.

SHAVER, Lea (Ed). Access to Knowledge in Brazil, Information Society Project, 2008.

SILVEIRA, Newton. Propriedade Intelectual: propriedade industrial, direito de autor, software, cultivares, nome empresarial, $4^{\mathrm{a}}$ Ed., São Paulo: Manole, 2011.

SPRINGMAN, Christopher Jon. The Intersection of Patents and Antitrust Law, in: ELHAUGE, Einer (Ed.). Research Book on the Economics of Antitrust. Cheltenham: Edward Elgar, 2012.

STIGLITZ, Joseph E. Economic Foundations of Intellectual Rights. Duke Law Journal, Durham, v. 57, n. 6, p. 1693-1724, abr. 2008.

. Knowledge as a Global Public Good, in: KAUL, Inge; GRUNBERG, Isabelle; STERN, Marc A. (Coord.). Global Public Goods: International Cooperation in the 21st Century, United Nations Development Program (UNDP), Oxford University Press, 1999.

SULLIVAN, Lawrence A. e GRIMES, Warren S. The Law of Antitrust: An Integrated Handbook, Saint Paul, Minn.: West Group, 2000. 
SWANSON, Daniel G., and BAUMOL, Willian J. Reasonable and Nondiscriminatory (RAND) Royalties, Standards Selection, and Control of Market Power, 73 Antitrust L. J. 1, 2005.

SZTAJN Rachel. Economia dos Direitos de Propriedade. Capítulo 5 de Direito \& Economia. Análise Econômica do Direito e das Organizações. Organização Decio Zylbersztajn e Rachel Sztajn. São Paulo: Campus, 2005.

Externalidades e Custos de Transação: A Redistribuição de Direitos no Código Civil, in: Revista de Direito Privado, n. 22, abr./jun. 2005.

THORSTENSEN, Vera. OMC - As Regras do Comércio Internacional e a Nova Rodada de Negociações Multilaterais, São Paulo: Aduaneiras, 2ª edição, 2001.

TIMM, Luciano Benetti e CAOVILLA, Renato. “As Teorias Rivais sobre Propriedade Intelectual no Brasil”, in: Economic Analysis of Law Review, V. 01, n. ${ }^{\circ} 01$, pp. 47-74, janjun, 2010.

. Contrato internacional de transferência de tecnologia no Brasil: interseção da propriedade intelectual com o direito antitruste, in: TIMM, Luciano Benetti; PARANAGUÁ, Pedro. Propriedade Intelectual, Antitruste e Desenvolvimento: caso da transferência de tecnologia e do software. Rio de Janeiro: FGV Direito Rio, 2009.

TOLLISON, Robert D. Rent-Seeking: a Survey, in: TOLLISON, Robert D.; CONGLETON, Roger D. (Ed.). The Economic Analysis of Rent Seeking. Aldershoot, England: Edward Elgar Publishing Ltd, 1995

ULLRICH, Hans. Expansionist Intellectual Property Protection and Reductionist Competition Rules: A TRIPS Perspective, in: MASKUS, Keith E.; REICHMAN, Jerome H. (Ed.). International Public Goods and Technology Transfer Under a Globalized Intellectual Property Regime. Cambridge University Press, 2005.

ULLRICH, Hans. "Patent Pools - Policy and Problems", in: DREXL, Josef (Ed.). Research Handbook on Intellectual Property and Competition Law. Cheltenham: Edward Elgar, 2008. 
UNCTAD \& ICTSD. Resource Book on TRIPS and Development, Part Three: Intellectual Property Rights and Competition, Cambridge University Press, 2005.

UNCTAD - UNITED NATIONS CONFERENCE ON TRADE AND DEVELOPMENT. "Draft International Code of Conduct on the Transfer of Technology as of 5 June 1985's (TD/CODE/TOT/47), 1985.

- Intergovernmental Group of Experts on Competition Law and Policy, Competition Policy and the Exercise of Intellectual Property Rights, TD/B/COM.2/CLP/22/Rev.1. Disponível em: http://unctad.org/en/docs/c2clp22r1.en.pdf.

The Basic Objectives and Main Provisions of Competition Laws and Policies, (UNCTAD/ITD/15), 11 October 1995.

- Series on Issues in International Investment Agreements. "Transfer of Technology”. UNCTAD/ITE/IIT/28, United Nations, New York and Geneva, 2001.

U.S. DEPARTMENT OF JUSTICE \& FEDERAL TRADE COMMISSION. Antitrust Enforcement and Intellectual Property Rights: Promoting Innovation and Competition, 2007.

U.S. DEPARTMENT OF JUSTICE \& FEDERAL TRADE COMMISSION. Antitrust Guidelines for the Licensing of Intellectual Property, 1995.

VENOSA, Silvio de Salvo. Direito Civil: Parte Geral, 10. ed. São Paulo: Atlas, 2010.

VIEGAS, Juliana L. B. Aspectos Legais de Contratação na Área da Propriedade Industrial, in: PEREIRA DOS SANTOS, Manoel J.; JABUR, Wilson Pinheiro. Contratos de Propriedade Industrial e Novas Tecnologias. São Paulo: Saraiva, 2007 (Série GVlaw).

VIEGAS, Juliana L. B. Contratos Típicos de Propriedade Industrial: Contratos de Cessão e de Licenciamento de Marcas e Patentes; Licenças Compulsórias, in: PEREIRA DOS SANTOS, Manoel J.; JABUR, Wilson Pinheiro. Contratos de Propriedade Industrial e Novas Tecnologias. São Paulo: Saraiva, 2007 (Série GVlaw).

WHISH, Richard. Competition Law, Sixth Edition, Oxford University Press, 2009. 
WRIGHT, Joshua D. Antitrust, Multi-Dimensional Competition, and Innovation: Do We Have an Antitrust-Relevant Theory of Competition Now? (August 28, 2009). George Mason Law \& Economics Research Paper n. 09-44. Disponível em SSRN: http://ssrn.com/abstract=1463732.

WORLD TRADE ORGANIZATION - WTO. Report of the WTO Working Group on the Interaction between Trade and Competition Policy (WGTCP), WT/WGTCP/M/6, November 16, 1998.

. Working Group on the Interface between Trade and Competition Policy (WGTCP) Annual Report of 2003, WTO document WT/WGTCP/7.

WTO - Trade Related Aspects of Intellectual Property Rights (Max Planck Commentaries on World Trade Law). Editado por Peter-Tobias Stoll, Jan Busche e Katrin Arend. Max Planck Institute for Comparative Public Law and International Law, 2009.

ZIBETTI, Fabíola Wüst. Relação entre Normalização Técnica e Propriedade Intelectual no Ordenamento Jurídico Internacional, Tese (Doutorado) - Programa de Pós Graduação em Direito Internacional - Faculdade de Direito da Universidade de São Paulo, São Paulo, 2012. 